


\title{
Developing a Holocene Tephrostratigraphy for Ethiopia
}

\section{Catherine Mariel Martin-Jones}

\author{
BSc, MPhil (Aberystwyth)
}

Thesis submitted in fulfilment of the requirements for the degree of Doctor of Philosophy Aberystwyth University 


\begin{abstract}
Explosive eruptions occurred throughout the Ethiopian Rift Valley during the Quaternary, depositing tephras that have provided crucial chronology for archaeological sites in eastern Africa. However, Holocene tephras are largely unstudied and the recent volcanic history of Ethiopia remains poorly constrained.

The first $<17$ ka regional tephrostratigraphy is presented here, constructed using sediments from seven Ethiopian lakes: Ashenge and Hayk (Ethiopian Highlands), Dendi and Hora (Yerer-Tullu Wellel Volcano Tectonic Lineament, YTVL) and Awassa, Tilo and Chamo (central Main Ethiopian Rift, CMER). A database of $\sim 2100$ major and trace element single grain glass analyses will aid the future identification of these tephras at proximal and distal locations.

Peralkaline rhyolitic tephras are dominant throughout the Ethiopian Rift. Tephras are more differentiated in the central Main Ethiopian Rift than those deposited in northern Ethiopia. The uniquely phonolitic-trachytic Dendi tephras are derived from volcanoes on the rift shoulders, where magma evolved under high pressure.

Archives from the Ethiopian Highlands record $<17$ ka distal volcanism from seven unknown volcanic centres in the Afar Rift. Eruptions occurred every $<1000$ years between 15.3 - 1.6 cal. ka BP. Different tephras were deposited in lakes Ashenge and Hayk, and they were not dispersed towards lakes further south.

Tephras erupted from centres in the CMER are recorded in the Awassa, Tilo and Chamo archives. Glass compositions are indistinguishable from recent Corbetti eruptives. During $<10 \mathrm{ka}$, eruptions from Corbetti occurred every $<800$ years and 6 eruptions were highly explosive. Two tephras are correlated between Tilo and Chamo (170 km SW of Tilo). However, eruptions from Corbetti are not recorded in archives from Ashenge, Hayk and Dendi.

These findings demonstrate the potential for further study to construct a comprehensive tephra framework, enabling assessment of regional volcanic hazards. Further geochemical characterisation of regional volcanoes will constrain the sources of these tephras and their petrogenesis.
\end{abstract}



WORD COUNT: 42,627

\section{DECLARATION}

This work has not previously been accepted in substance for any degree and is not being concurrently submitted in candidature for any degree.

Signed: (candidate)

Date:

\section{STATEMENT 1}

This thesis is the result of my own investigations, except where otherwise stated. Where *correction services have been used, the extent and nature of the correction is clearly marked in a footnote(s).

Other sources are acknowledged by footnotes giving explicit references. A bibliography is appended.

Signed: (candidate)

Date:

[*this refers to the extent to which the text has been corrected by others]

\section{STATEMENT 2}

I hereby give consent for my thesis, if accepted, to be available for photocopying and for inter-library loan, and for the title and summary to be made available to outside organisations.

Signed: (candidate)

Date: 



\section{Acknowledgements}

This research was funded by a NERC algorithm studentship. This work would not have been possible without the assistance and insight provided by a multitude of people.

Most importantly, I thank my supervisors, Prof. Henry Lamb, Prof. Nick Pearce and Dr Christine Lane (University of Manchester), who have provided support, encouragement and constructive criticism throughout my research.

I thank Prof. Frank Schaebitz (University of Cologne) and the Hominin Sites and Palaeolakes Drilling Project for inviting me to participate in fieldwork in Ethiopia, providing me with an unforgettable experience.

Numerous people have assisted me during my never-ending quest for Ethiopian lake sediment cores and tephra deposits. Prof. Frank Schaebitz and Dr. Verena Foerster (University of Cologne) provided me with access to core sediments and helped me with shipping them. Dr Keith Haylock devoted days to helping me catalogue forgotten lake archives in the depths of the cold store. Dr. Giday WoldeGabriel (Los Alamos National Laboratory) and Prof. Clive Oppenheimer (University of Cambridge) supplied proximal tephra samples from Ethiopia.

Drs. Katie Loakes (Loughborough University), Helene Ducrotoy (Aberystwyth University) and Tsige Kassa and Bernd Wagner (University of Cologne) provided unpublished radiocarbon dates. Prof. Christopher Bronk Ramsey (University of Oxford) and the OxCal Google Group assisted me with Bayesian age modelling.

Analytical costs at LacCore were supported by the Visiting Graduate Student Travel Grant Program (University of Minnesota). Lorraine Morrison and Hollie Wynne helped me with cryptotephra sample processing. Tommy Ridway is thanked for helping mount tephra samples for analysis. Prof. John Westgate (University of Toronto) assisted me with polishing epoxy mounts and offered advice on geochemical analysis. Dr Victoria Smith (University of Oxford) assisted me greatly with EPMA glass analysis. Dr Bill Perkins and Andy Brown helped me with the LA-ICP-MS analysis at Aberystwyth University.

I thank Dr Asfawossen Asrat and Bahru Adugna (Addis Ababa University). Their wealth of knowledge on Ethiopian geology provided a wider perspective to my research findings. Dr Giacomo Corti (National Research Council of Italy) provided DEM data files for Ethiopia.

Thank you to Drs Ian Saunders, Jo Matthews, Marrie-Jeanne Royer and Keith Haylock and Vicky Mann, Alice Court and Alun James for supporting me and never failing to make me laugh. Drs Jo Matthews, Melissa Chapot and Sara Rassner have helped me so much with typesetting my thesis. I will greatly miss the excellent company and stories at tea time in the L floor common room.

A special thank you to Huw, who has been my rock. I thank Kayleigh and Amy, for always being there when I need them. Finally, I am hugely grateful for the support of my family, and to my Mum - who's rock collections inspired me as a child. 



\section{Contents}

Contents vii

List of Figures $\quad$ xi

List of Tables $\quad$ Xv

1 Context and aims 1

1.1 Research context . . . . . . . . . . . . . . . . 1

1.2 Research aims . . . . . . . . . . . . . . . 4

1.3 Thesis outline .................. 5

2 Tephrochronology and its application $\quad 7$

2.1 Principles of tephrochronology . . . . . . . . . . . . 7

2.2 Characteristics of tephra . . . . . . . . . . 8

2.2.1 Macroscopic tephra . . . . . . . . . . 8

2.2.2 Microscopic tephra . . . . . . . . . . . . 9

2.3 Tephra records as dossiers of past eruptions . . . . . . . . . . 12

2.4 Tephras in lake sediments . . . . . . . . . . . . . 15

2.4.1 Factors impacting tephra deposition and preservation in

lake sediments . . . . . . . . . . . 16

2.4.2 Identifying cryptotephras in lake sediments . . . . . . 19

2.5 Tephra fingerprinting . . . . . . . . . . . . 23

2.5.1 Glass shard morphology .................. 23

2.5.2 Mineral assemblages ................. 25

2.5 .3 Glass chemistry . . . . . . . . . . . 26

2.5.4 Fe-Ti oxide and silicate mineral chemistry . . . . . . . 31

2.6 Geochemical data . . . . . . . . . . . . . . . . . . 34

2.6.1 Rock classification . . . . . . . . . . . . 34

2.6.2 Magmatic differentiation . . . . . . . . . . . . 39

2.6.3 The use of bi-variate plots . . . . . . . . . . . . 47

2.6.4 Principal component analysis . . . . . . . . . 51

2.7 Dating tephras . . . . . . . . . . . . . . 52

2.8 Summary . . . . . . . . . . . . . . 56 
3 East African tephra studies $\mathbf{5 9}$

3.1 Geological setting . . . . . . . . . . . . . . . . . . 59

3.1.1 EARS 1: Oligocene - mid Miocene . . . . . . . 61

3.1.2 EARS 2: Mid Miocene - Recent . . . . . . . . . . 62

3.2 Ethiopian tephra deposits . . . . . . . . . . . . . 62

3.2.1 The Afar Rift . . . . . . . . . . . . . . . . . . . . 64

3.2.2 The Main Ethiopian Rift . . . . . . . . . . . . 67

3.2.3 Quaternary tephras from further afield . . . . . . . 72

3.3 Quaternary tephra studies . . . . . . . . . . . 75

3.3.1 The Middle Awash . . . . . . . . . . . . . 79

3.4 Holocene tephra studies . . . . . . . . . . . . . . . 81

3.4.1 Volcanic hazards in Ethiopia . . . . . . . . . . . . 85

3.5 Summary . . . . . . . . . . . . . . . 90

4 Research design and methods 91

4.1 Research design . . . . . . . . . . . . . . . . . . . 91

4.2 Lake core sites . . . . . . . . . . . . . . . . . 96

4.2.1 Lake core sites in the Ethiopian Highlands: Ashenge and Hayk . . . . . . . . . . . . . . 96

4.2.2 Lake core sites on the Yerer-Tullu Wellel Volcano Tectonic Lineament: Dendi and Hora . . . . . . . . . . 100

4.2.3 Lake core sites in the Main Ethiopian Rift: Awassa, Tilo \& Chamo . . . . . . . . . . . . . . . 104

4.2.4 Proximal tephra samples . . . . . . . . . . 110

4.3 Chronology . . . . . . . . . . . . . . . . 122

4.3 .1 Lake cores . . . . . . . . . . . . . . 122

4.3.2 Proximal tephras . . . . . . . . . . . . . 123

4.4 Tephra identification and analysis . . . . . . . . . . 126

4.4.1 Tephra sampling and laboratory processing . . . . . . 126

4.4.2 Preparation of samples for geochemical analysis . . . . 129

4.4.3 Electron microprobe analysis of glass shards . . . . . 130

4.4.4 Laser ablation inductively coupled plasma-mass spectrometry geochemical analysis . . . . . . . . . . 133

4.4.5 Major and trace element data interpretation . . . . . . 138

5 Characteristics and composition of Holocene Ethiopian tephras 141

5.1 Tephras from the Ethiopian Highlands . . . . . . . . . . . . 142

5.1 .1 Lake Ashenge tephras . . . . . . . . . . . . 142

5.1.2 Lake Hayk tephras . . . . . . . . . . . . . . . . 146

5.2 Tephras from the YTVL . . . . . . . . . . . . . . . . 148

5.2.1 Lake Dendi tephras . . . . . . . . . . . . . . . . . . . 148

5.2 .2 Lake Hora tephras . . . . . . . . . . . . . 150

5.3 Tephras from the CMER . . . . . . . . . . . . . 150 
$5.3 .1 \quad$ Lake Tilo . . . . . . . . . . . . . . . . . . . 150

5.3 .2 Lake Awassa . . . . . . . . . . . . . . . . . 151

5.3 .3 Lake Chamo . . . . . . . . . . . . . . . . 156

5.4 Holocene tephra composition . . . . . . . . . . . . . 158

5.4.1 Petrogenesis and spatial variations in the composition of

Holocene tephras from Ethiopia . . . . . . . . . 158

5.4.2 Potential tephra correlations . . . . . . . . . . 170

5.5 Conclusions . . . . . . . . . . . . . . 175

6 The timing and composition of post-17 ka distal volcanism from the Afar recorded in Lakes Ashenge and Hayk 177

6.1 Introduction . . . . . . . . . . . . . . . . . . . . . 177

6.2 Glass compositions . . . . . . . . . . . . . . . . . 178

6.2.1 The Ashenge tephras . . . . . . . . . . . . . . . 178

6.2.2 The Hayk tephras . . . . . . . . . . . . . . . . . . . . . 182

6.3 Discussion . . . . . . . . . . . . . . . . . . . . . . . 187

6.3.1 Tephra correlations . . . . . . . . . . . . . . . 187

6.3.2 Eruption tempo and characteristics . . . . . . . . . . 196

6.3.3 Provenance of the Holocene Lake Ashenge and Hayk

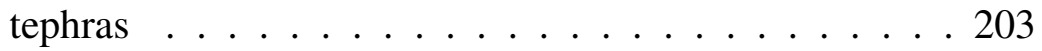

6.4 Conclusions . . . . . . . . . . . . . . . . . . . . . . 207

7 The composition, timing and characteristics of post $\sim 10 \mathrm{ka}$ eruptions from Corbetti recorded in lakes Awassa, Tilo and Chamo 211

7.1 Introduction . . . . . . . . . . . . . . 211

7.2 Glass compositions . . . . . . . . . . . . . . . . . . 212

7.2 .1 The Tilo tephras . . . . . . . . . . . . . . . . 212

7.2.2 Composition of the Awassa tephras . . . . . . . . . 216

7.2.3 Composition of the Chamo tephras . . . . . . . . . 221

7.3 Discussion . . . . . . . . . . . . . . . . . . . . . 224

7.3.1 Potential tephra correlations . . . . . . . . . . . . 224

7.3.2 Provenance of tephras deposited in central MER lakes . 235

7.3.3 The tempo, petrogenesis and characteristics of $<10 \mathrm{ka}$ Corbetti eruptions . . . . . . . . . . . 241

7.4 Conclusions . . . . . . . . . . . . . . . . 250

8 Conclusions 253

8.1 Context . . . . . . . . . . . . . . . . . 253

$8.2<17$ ka Ethiopian tephra record . . . . . . . . . 256

8.2.1 Lakes sediment records of past volcanism . . . . . . . 256

8.2.2 Spatial variations in tephra composition . . . . . . . . 260

8.2 .3 Tephra correlations . . . . . . . . . . . . . . . . 262

8.2.4 Sources and frequency of eruptions . . . . . . . . 264

8.3 Further work . . . . . . . . . . . . . . . 266 
References

Appendices

.1 Sample details . . . . . . . . . . . . . . . . . 313

.2 Crypotephra glass shard counts . . . . . . . . . . . . 317

.3 Tephras from the Ethiopian Highlands . . . . . . . . . . . . . 327

.3.1 Major and trace element glass compositions . . . . . . . 327

.3.2 Bayesian age models . . . . . . . . . . . . 340

.4 Tephras from the YTVL . . . . . . . . . . . . . . 343

.4.1 Major and trace element glass compositions . . . . . . . 343

.4.2 Bayesian age models . . . . . . . . . . . . 352

.5 Tephras from the central MER . . . . . . . . . . . . . 352

.5.1 Major and trace element glass compositions . . . . . . . 353

.5 .2 Bayesian age models . . . . . . . . . . 383

.6 Other outcrop samples . . . . . . . . . . . . . . . . . . . . . . . 387

.7 Reference materials . . . . . . . . . . . . . . . . 398

.7.1 EPMA reference materials . . . . . . . . . . 398

.7 .2 EPMA lower limits of detection ......... . . 401

.7 .3 LA-ICP-MS reference materials . . . . . . . . 402

.7.4 LA-ICP-MS lower limits of detection . . . . . . . . . 407

$.8 \quad$ Calculations . . . . . . . . . . . . . . . . . . . . 411

.8.1 Calculation of Q Ab Or normative positions in the Haplogranite System . . . . . . . . . . . . 411

.8.2 Calculation of $\mathrm{Q} \mathrm{Ne} \mathrm{Ks}$ normative positions in Petrogeny's Residua Sytem . . . . . . . . . . . . . 412 


\section{List of Figures}

2.1 Tephra production and deposition . . . . . . . . . 10

2.2 YTT cryptotephra in Lake Malawi, eastern Africa, $\sim 7000 \mathrm{~km}$ to the west . . . . . . . . . . . . . . 13

2.3 Map of Ethiopia showing seasonal wind directions . . . . . . 18

2.4 Cryptotephra detection using XRF core scanning . . . . . . . 22

2.5 Glass shard morphologies . . . . . . . . . . . . . . . 25

2.6 Trace element composition of the YTT . . . . . . . . . . . . 29

2.7 LA-ICP-MS craters . . . . . . . . . . . . . . . 31

2.8 YTT biotite composition . . . . . . . . . . . . . . . 32

2.9 Chemical classification of volcanic rocks using TAS . . . . . . 35

2.10 Phase relations in Petrogeny's residua system . . . . . . . . . . 38

2.11 The haplogranite Q-Ab-Or system . . . . . . . . . . . . . 40

2.12 Bowen's Reaction Series . . . . . . . . . . . . . . 43

2.13 Bowen's Reaction Series . . . . . . . . . . . . . . . . . 44

2.14 Spiderdiagram showing compositions of tephras from Chefe Donsa, Ethiopia . . . . . . . . . . . . . . . . 45

$2.15 \mathrm{Ba} / \mathrm{Rb}$ vs. $\mathrm{Rb} / \mathrm{Nb}$ diagram for basaltic rocks from the Ethiopian Rift ..................... . 46

2.16 Using major element data to distinguish between tephras . . . . 49

2.17 Using trace element data to distinguish between tephras . . . . . 50

$2.18 \mathrm{Bi}$-variate plot of $\mathrm{Th} / \mathrm{Ta} \mathrm{vs}$. Th/Tb for basalts . . . . . . . . 51

3.1 The East African Rift System . . . . . . . . . . . . . . . . . 60

3.2 Map showing volcanoes and rift sections in Ethiopia . . . . . . 63

3.3 Quaternary tephra sources in Africa, the Mediterranean, Middle East and Atlantic . . . . . . . . . . . . . . . . . . . . 72

3.4 Ethiopian archaeological sites . . . . . . . . . . . 76

3.5 Correlation of the SHT at the Middle Awash archaeological sites 80

3.6 The Dubbi volcanoand 1861 tephra deposits . . . . . . . . . . . 83

3.7 Map showing volcanoes which have erupted recently . . . . . . 84

3.8 Dabbahu and Nabro eruptions . . . . . . . . . . . . . 89

4.1 Locations of Ethiopian lake sediment cores . . . . . . . . . . 94

4.2 Location of the Ashenge 2003 core site . . . . . . . . . . . 97 
4.3 Location of the Hayk 2003 core site . . . . . . . . . . . . . . 98

4.4 Photos of the Lakes Ashenge and Hayk . . . . . . . . . . . . . 99

4.5 Location of the Dendi 2012 core site . . . . . . . . . . . . . 101

4.6 Location of the Hora 2001 core site . . . . . . . . . . . . . 102

4.7 Photos of the the volcanic lake, Wenchi and Lake Bishoftu . . . 103

4.8 Location of the Awassa 1994 core site . . . . . . . . . . . . . . 105

4.9 Location of the Tilo 1997 coring site . . . . . . . . . . . . . 107

4.10 Photos of the Corbetti caldera and Lake Tilo . . . . . . . . . . . 108

4.11 Location of the Chamo 2010 core site . . . . . . . . . . . . . . 109

4.12 Photos of the Tosa Sucha volcanic chain . . . . . . . . . . 111

4.13 Locations of outcrop samples collected from the Dubbi Volcano 113

4.14 Locations of outcrop samples collected from the Ayelu volcano . 115

4.15 Locations of outcrop samples collected from the Tilo, Awassa,

Tora Abaya and Mochena Borago areas . . . . . . . . . . 116

4.16 Locations of tephra samples collected from the Lake Awassa area 118

4.17 Locations of tephra samples collected from the Lake Tilo shores 119

4.18 Tephra samples from Mochena Borago Rockshelter and Bisare . 121

4.19 Cryptotephra sampling procedure . . . . . . . . . . . . 127

4.20 Mounting tephras for geochemical analysis . . . . . . . . . 131

4.21 Mineral inclusions in glass . . . . . . . . . . . . . . . 138

5.1 Images of tephras recorded in lake sediments from the Highlands 144

5.2 Cryptotephra shard counts through the Ashenge stratigraphy . . 145

5.3 Cryptotephra shard counts through the Hayk stratigraphy . . . . 147

5.4 Modelled age, lithology and occurrence of visible tephras in the Dendi sediments . . . . . . . . . . . . . . . . . . 149

5.5 Photos of the Tilo tephras . . . . . . . . . . . . . . . . 152

5.6 Age, lithology and occurrence of visible tephras in the Tilo

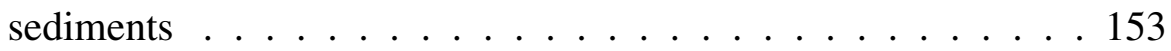

5.7 Age, lithology and occurrence of visible tephras in the Awassa sediments ..................... . . 155

5.8 Age, lithology and occurrence of visible tephras in the Chamo sediments . . . . . . . . . . . . . . . 157

5.9 Major element composition of glass shards from Holocene Ethiopian

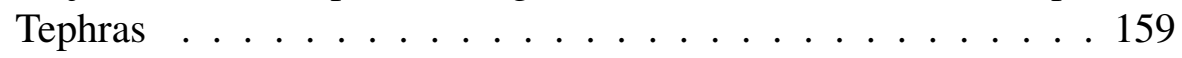

5.10 Bi-plots of selected trace elements in glass shards from the Holocene Ethiopian Tephras . . . . . . . . . . . . . 160

5.11 Average chondrite normalised element concentrations in rhyolitic tephra glass shards from all lake sediments . . . . . . . . . 162

5.12 Projection of glass composition from rhyolitic tephras recorded in Ethiopian lake sediments onto a Qz-Ab-Or ternary . . . . . . 163

5.13 Major and trace element composition of all tephras versus the latitude of the lake they are recorded in . . . . . . . . . . 164 
$5.14 \mathrm{Rb} / \mathrm{Nb}$ versus $\mathrm{Ba} / \mathrm{Nb}$ in glass shards from tephras recorded in all lake sediments . . . . . . . . . . . . . . . . 165

5.15 Average chondrite normalised element concentrations in tephra glass shards from all lake sediments . . . . . . . . . . . 167

5.16 Average composition of the Dendi phonolitic-trachytic tephra plotted onto Petrogeny's residua system . . . . . . . . . . 168

5.17 Schematic cross section showing possible model for distribution of magmatic types across the northern MER . . . . . . . . 169

5.18 Comparison of the composition of tephras from lake archives in the Ethiopian Highlands and CMER . . . . . . . . . . . 172

5.19 Comparison of the composition of tephras from lake archives in the YTVL and CMER . . . . . . . . . . . . . . . 173

5.20 Comparison of the composition of tephras from lake archives in the Ethiopian Highlands and YTVL . . . . . . . . . . 174

6.1 Bi-plots of selected major and trace elements in the Ashenge glass shards . . . . . . . . . . . . . . . 180

6.2 Bi-plots of selected major and trace elements in the Hayk glass shards ....................... 186

6.3 Bi-plots comparing the major and trace element composition of Ashenge and Hayk tephras . . . . . . . . . . . . . . 189

6.4 Major and trace element bi-plots comparing the composition of HT-7 with Ashenge Group II tephras . . . . . . . . . . . . 190

6.5 Bi-plots comparing the major and trace element compositions of AST-3 and HT-7 . . . . . . . . . . . . . . . . 191

6.6 Map of northern Ethiopia showing lakes volcanoes and wind data 194

6.7 3D elevation model of the areas surrounding lakes Ashenge and Hayk . . . . . . . . . . . . . . . . . 195

6.8 Major and trace element compositions of the Ashenge and Hayk tephras against their ages . . . . . . . . . . . . . 199

6.9 Modelled fractional crystallisation between AST-3 and HT-7 . . 200

6.10 Modelled fractional crystallisation between the Hayk Group I tephras . . . . . . . . . . . . . . . . 201

6.11 Modelled fractional crystallisation between the Hayk Group V tephras . . . . . . . . . . . . . . . 202

6.12 Comparision of Ashenge \& Hayk tephras with the composition of Dabbahu and Dubbi volcano proximal deposits . . . . . . . 205

6.13 PCA of tephras from Ashenge, Hayk, Dabbahu and Dubbi . . . 206

7.1 Major and trace element compositions of the Tilo tephra glass shards. . . . . . . . . . . . . . . . 215

7.2 Ratios of $\mathrm{Y} / \mathrm{Zr}, \mathrm{Zr} / \mathrm{Th}$ and $\mathrm{Ba} / \mathrm{Th}$ in the Tilo Group II glass shards 217

7.3 Major and trace element compositions of the Awassa tephra glass shards. . . . . . . . . . . . . . . 220 
7.4 Major and trace element compositions of the Chamo tephra glass shards. . . . . . . . . . . . . . . . 223

7.5 Major and trace element compositions of the Awassa, Tilo and Chamo tephra glass shards . . . . . . . . . . . . 225

7.6 Bi-plots showing the composition of CHT-1, TT-1;2;4 and TT-5 227

7.7 PCA comparing the composition of CHT-1, TT-1; 2; 4 and TT-5 228

7.8 Bi-plots showing the composition of CHT-1, TT-11;12;13 and TT-14 . . . . . . . . . . . . . . . . . 229

7.9 PCA comparing the composition of CHT-2 and TT-11;12;13 . . 230

7.10 Bi-plots showing the composition of AWT-2, AWT-4, and TT$7 ; 8 ; 9$ and TT-10 . . . . . . . . . . . . . . . 232

7.11 PCA comparing the composition of AWT-2, AWT-4, and TT$7 ; 8 ; 9$ and TT-10 . . . . . . . . . . . . . . . . 233

7.12 Correlations between Tilo, Awassa and Chamo archives . . . . . 234

7.13 Map of the Corbetti caldera . . . . . . . . . . . . . 238

7.14 Comparison of tephras from CMER lakes with the composition of outcrop samples . . . . . . . . . . . . . . . . . 239

7.15 Bi-plots comparing the compositions of ST-NW1, CHT-1, TT$1 ; 2 ; 4$ and TT-5 . . . . . . . . . . . . . . . 242

7.16 PCA comparing the composition of ST-NW1, CHT-1, TT-1;2;4 and TT-5 . . . . . . . . . . . . . . . 243

7.17 Selected trace element ratios in the Tilo Group II tephra glass shards plotted against their age ranges, modelled at the 95.4 $\%$ confidence interval. Groups of tephras which have similar compositions and ages are indicated in the same colour. . . . . . 245

7.18 Modelled AFC in the Tilo tephras . . . . . . . . . . . . 249

8.1 Map summarising the key findings of this study . . . . . . . 258 


\section{List of Tables}

2.1 Summary of analytical methods used for characterising tephras. 24

2.2 Methods of dating tephras. . . . . . . . . . . . 55

3.1 Regional tephras in East Africa. . . . . . . . . . . . . 78

3.2 List of volcanoes in Ethiopia which may have been active during the Holocene . . . . . . . . . . . . . . . . . 88

4.1 Details of Ethiopian lake sediment cores used in this study. . . . 95

4.2 Outcrop samples from the Afar Rift . . . . . . . . . . . . 112

4.3 Outcrop samples from the CMER . . . . . . . . . . . . . 117

4.4 AMS ${ }^{14} \mathrm{C}$ measurements for the Ashenge and Hayk lake sediment cores . . . . . . . . . . . . . . . . . . . 124

4.5 Conventional AMS ${ }^{14} \mathrm{C}$ measurements for the Awassa, Tilo and Chamo lake sediment cores . . . . . . . . . . . . . 125

4.6 EPMA analytical operating conditions. . . . . . . . . . . . 133

4.7 Major element secondary standard analyses . . . . . . . . . . 134

4.8 LA-ICP-MS operating conditions. . . . . . . . . . . . . . 135

4.9 LA-ICP-MS analytical considerations. Median lower limits of detection (LLD), calculated from all analytical sessions. Average trace element concentrations measured in the ATHO-G reference material throughout all analytical sessions. Two standard deviation on the ATHO-G analyses, and published concentrations from the GeoReM database (Jochum et al., 2006) are shown. All concentrations are in ppm. . . . . . . . . . 136

5.1 Characteristics of tephras recorded in sediments from Lake Ashenge and Lake Hayk . . . . . . . . . . . . . . . . 143

5.2 Characteristics of tephras recorded in sediments from Lake Dendi 148

5.3 Characteristics of tephras recorded in sediments from Lake Tilo 151

6.1 Major and trace element composition of the Ashenge tephra glass shards . . . . . . . . . . . . . . . . . 179

6.2 Major and trace element composition of the Hayk tephra glass shards ..................... 185 
7.1 Major and trace element concentrations of glass shards in the Tilo shards . . . . . . . . . . . . . . . . . 212

7.3 Major and trace element concentrations of glass shards in the Awassa tephras . . . . . . . . . . . . . . . . 219

7.4 Major and trace element concentrations of glass shards in the

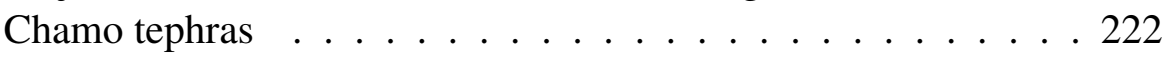

7.5 Outcrop samples from the CMER . . . . . . . . . 237 


\section{Chapter 1}

\section{Context and aims}

\subsection{Research context}

The Ethiopian Rift is one of the few locations worldwide where active continental rifting can be observed (Macgregor, 2015). The rift extends from the intersection of the Red Sea and Gulf of Aden oceanic rifts through to southern Ethiopia in a south-west direction.

Whilst geologically intriguing, magmatic and tectonic processes of the Ethiopian Rift remain poorly understood (Macgregor, 2015). The early stage of regional geological studies is partly associated with the logistical difficulties of undertaking field work; e.g. the remote Afar region of northern Ethiopia is regarded as one of the hottest and most inhospitable areas of the world (Oppenheimer and Francis, 1997).

Explosive volcanic eruptions occurred throughout the Ethiopian Rift Valley during the Quaternary and into the Holocene (Pyle, 1999; Siebert et al., 2011). Volcanic ash (tephra) produced by explosive eruptions is typically dispersed and deposited over hundreds to thousands of kilometres (e.g. Jensen et al., 2014) 
within a geologically instantaneous time frame (e.g. Rose and Durant, 2009). Due to this rapid dispersal and deposition, tephra layers record a 'moment in time' and can therefore be used as chronostratigraphic markers. Distal tephra records provide a dossier of past eruptions from multiple sources and an insight into eruption tempo and magnitude (e.g. Smith et al., 2011a, 2013). Furthermore, the temporal and spatial precision of tephrochronology has been exploited by Quaternary researchers in order to corroborate other dating techniques and synchronize palaeoenvironmental proxy data, providing invaluable information on the leads and lags of palaeoclimate change (e.g. Lane et al., 2013a,b).

Early Pliocene to late Pleistocene tephra deposits preserved in sedimentary archives throughout eastern Africa provide chronological control on hominin fossil sites in Ethiopia and Kenya (e.g. Clark et al., 2003; WoldeGabriel and Hart, 2005; Brown et al., 2006). The region is regarded as the crucible of human evolution and, since the discovery of the first hominid remains at Olduvai Gorge, Tanzania (Leakey et al., 1961), has been a magnet for interdisciplinary research. Tephra studies have provided important temporal and spatial control on geological, archaeological and palaeoclimatic records from the region and have therefore been crucial in understanding the context of hominin evolution (WoldeGabriel and Hart, 2005). Stratigraphic controversies at numerous archaeological sites throughout eastern Africa have been resolved using tephrochronology (e.g. McDougall, 1985; Renne et al., 1999; WoldeGabriel, 1994). The controversial age of the famous 'Lucy' (Australopithecus afarensis) fossil remains were corroborated through tephra correlations (Brown and Cerling, 1982).

However, younger Holocene tephras remain unstudied in Ethiopia. Ethiopia has 65 volcanoes of suspected Holocene age, only 14 of which have recorded historic eruptions (Siebert et al., 2011). The historic record of volcanism is 
sparse, and $85 \%$ of Africa's 155 recent eruptions recorded since 1870. The main historical record of volcanism followed the construction of the Suez Canal in 1869 and subsequent exploration of Africa. Those historic eruptions recorded are typically VEI $<4$ (Newhall and Self, 1982), due to the typically milder nature of rift volcanism. However, the rift volcanism is bimodal and large volume explosive eruptions are suspected to have occurred during the late Pleistocene to early Holocene (Siebert et al., 2011).

Africa ranks within the top five volcanic regions in terms of people living close to volcanoes, and high population densities live in the vicinity of silicic volcanoes and calderas in the Ethiopian Rift Valley (Siebert et al., 2011). Currently 12 volcanoes throughout eastern Africa are known to be actively deforming; 4 of which are within the Main Ethiopian Rift (Alutu, Corbetti, Bora and Haledebi) and many are undergoing fumarolic activity (Biggs et al., 2009, 2011; Lenhardt and Oppenheimer, 2014). Despite this, the hazards remain underestimated (Lenhardt and Oppenheimer, 2014). The Main Ethiopian Rift volcanoes are listed by the World Bank report of volcanic hazards at a zero level of monitoring and the highest level of uncertainty in terms hazard and risk (Biggs et al., 2011).

The potential for volcanoes in East Africa to erupt suddenly is demonstrated by the 2011 eruption of Nabro (Eritrea). Eritrea had no volcano monitoring network at this time and, until further inspection of higher spatial resolution satellite data, Dubbi (a volcano $25 \mathrm{~km}$ to the NE) was initially thought to be the source (Lenhardt and Oppenheimer, 2014). A lack of seismometers in Eritrea meant that seismic unrest during the weeks before was not interpreted as a precursor to an eruption. The eruption displaced thousands of people and the ash plume caused widespread disruption to international air-traffic (Lenhardt and 
Oppenheimer, 2014). The Nabro eruption is believed to have caused the largest aerosol perturbation since the 1991 Pinatubo eruption (Sawamura et al., 2012).

The Holocene record of volcanism in Ethiopia is therefore poorly documented. In order to prepare for hazards posed by future volcanic eruptions, it is important to understand how frequently they occur and their magnitude.

\subsection{Research aims}

The principal aim of this study is to construct a Holocene tephra framework for Ethiopia, the first tephrostratigraphy to cover this temporal and spatial range. To achieve this, tephras in $<17 \mathrm{ka}$ lake sediment cores from seven lakes throughout the Ethiopian Rift are studied. A selection of samples from potential source volcanoes are also studied to test the provenance of these tephras. This study focusses on lake sediments because they often contain a more comprehensive and accessible record of distal tephras from multiple volcanic sources than proximal tephra deposits (Lowe, 2011). Linking tephras between different archives in Ethiopia will provide an insight into the dispersal of the tephras and their potential volcanic sources. Modelled radiocarbon ages for the tephras will give information on the tempo of past eruptions. Furthermore, this record of previous eruptions can also be used to mitigate against hazards of future events (Swindles et al., 2011).

This study addresses the following specific research questions:

1. Do the lake sediment cores available to the study contain tephra layers (including visible and microscopic tephras)?

2. If so, what are their approximate ages, and can any of these layers be correlated from lake to lake? 
3. Can any tephras be attributed to known deposits on land, particular volcanoes, or particular eruptive events of known volcanoes? Where exact matches cannot be made, can affinities nevertheless be established through modelling of geochemical trends?

4. Based on the ages and characteristics of discrete ash layers, what if anything can be said about rates of volcanism in the Ethiopian Rift and adjacent Rift Shoulders?

\subsection{Thesis outline}

This thesis is divided into eight chapters. This chapter has discussed the context and rationale behind the research and set out the aims of the study. Chapter 2 describes the principles of tephrochronology and the methods involved in this geochronological technique. Chapter 3 discusses Quaternary tephra deposits in eastern Africa and their importance in providing chronologies for fossil sites. Importantly, Chapter 3 outlines the lack of Holocene tephra studies in Ethiopia and the necessity for further investigation of these deposits. The methodological rationale is detailed in Chapter 4, which outlines the research design, gives site descriptions and provides information on the analytical methods employed to identify and characterise the tephras. Chapter 5 presents the tephrochronology of each archive and the major and trace element composition of the tephras. Chapter 5 goes on to investigate whether the composition of tephras varies spatially and if there is potential for tephra correlation between archives. The record of volcanism preserved in archives from the Ethiopian Highlands is presented in Chapter 6. Chapter 7 discusses the composition and timing of eruptions in the central Main Ethiopian Rift. Chapter 8 presents the conclusions of this study. 



\section{Chapter 2}

\section{Tephrochronology and its}

\section{application}

In this chapter, tephrochronology is discussed with specific reference to the fundamentals of this stratigraphic linking and dating technique, its applications and utility for providing records of past volcanism. The methodological approaches used in tephrochronology and analytical advances which have extended its geographical scope are later described.

\subsection{Principles of tephrochronology}

Tephra (originating from the Greek 'ashes') describes the loose fragmental material ejected by explosive volcanic eruptions and may range in grainsize from volcanic ash to volcanic blocks (Walker, 1971; Heiken, 1972; Fisher and Schminke, 1984). Explosive volcanic eruptions generate large volumes of tephra which is transported over thousands of kilometres (Jensen et al., 2014) and deposited in sedimentary sequences over a geologically instantaneous time frame (Rose and Durant, 2009). Therefore a tephra layer represents a plane of equal 
age in the host sediments which may be used to link archives over a wide geographic area (Lowe, 2011). A tephra layer from the same eruption has a unique geochemical fingerprint, allowing it to be identified and correlated across the fallout zone (Alloway et al., 2007; Lowe, 2011). Tephrochronology can be used to test whether past events were synchronous or time-transgressive, the technique has been used in Quaternary science, with applications to hominin evolution (WoldeGabriel et al., 2013), the hominin genetic bottleneck (Lane et al., 2013b), the Neanderthal extinction (Lowe et al., 2012) and the asynchronicity of climatic changes associated with the Younger Dryas in northern Europe (Lane et al., 2013a).

\subsection{Characteristics of tephra}

\subsubsection{Macroscopic tephra}

Volcanic ash clouds are generally produced either by Plinian eruption columns or are elutriated from pyroclastic clouds formed by column collapse (Sparks and Walker, 1977; Woods and Wohletz, 1991; Sparks et al., 1997) (see Fig. 2.1). The dispersal of tephra depends on a number of factors, including, column height, wind direction and speed and the grain size distribution of the ejecta (Sparks et al., 1992). More powerful eruptions producing higher volumes of finer grained ejecta are likely to disperse tephra over greater spatial areas (Walker, 1973).

Tephra particles from within the ash plume are typically deposited rapidly, within minutes to days (Lowe, 2011). Tephra particles are deposited on the lake bed rapidly, although secondary transportation processes (e.g. turbidity currents) and depositional processes (e.g. settling of tephra particles through lake sediments) may compromise the stratigraphic position of the tephra layer 
(Boygle, 1999; White and Riggs, 2001). Tephra particles sink rapidly in still lake waters and, assuming a particle size of fine sand, the fall velocity can exceed $40 \mathrm{~m} \mathrm{~h}^{-1}$ (Julien, 1995). Once saturated, even pumice will sink to the lake bed rapidly (Manville et al., 2002).

Tephras typically become exponentially thinner with distance from the volcanic source, ranging in thickness from metres at proximal locations to sub-millimetres at distal locations (Pyle, 1989). Proximal deposits typically blanket the existing topography and contain a greater range of components, including heavier lithics and loose crystals, than their distal counterparts (Lowe, 2011). Proximal tephras can be traced locally between outcrops on the basis of stratigraphic relationships and physical characteristics, including, colour, bedding, pumice density or colour, the presence of accretionary lapilli or unique mineral assemblages (e.g. Brown, 1969; Brown et al., 1970). Further stratigraphic information, such as palaeoenvironmental and archaeological associations, may also enable correlation of tephras (Feibel, 1999).

Tephras are generally better preserved in subaqueous settings as opposed to subaerial settings (Köninger and Stollhofen, 2001). Proximal deposits in subaerial settings are prone to erosion, local reworking and burial and therefore tracing these deposits over wide geographic areas becomes more challenging (Lowe, 2011). Distal tephra records, preserving tephras from multiple volcanic sources, therefore provide a more comprehensive record of past volcanism (Lowe, 2011).

\subsubsection{Microscopic tephra}

Cryptotephra (from the Greek, 'kryptein' to hide) are 'non-visible' tephras and are typically far-travelled 'distal' deposits. They are commonly constituted of 

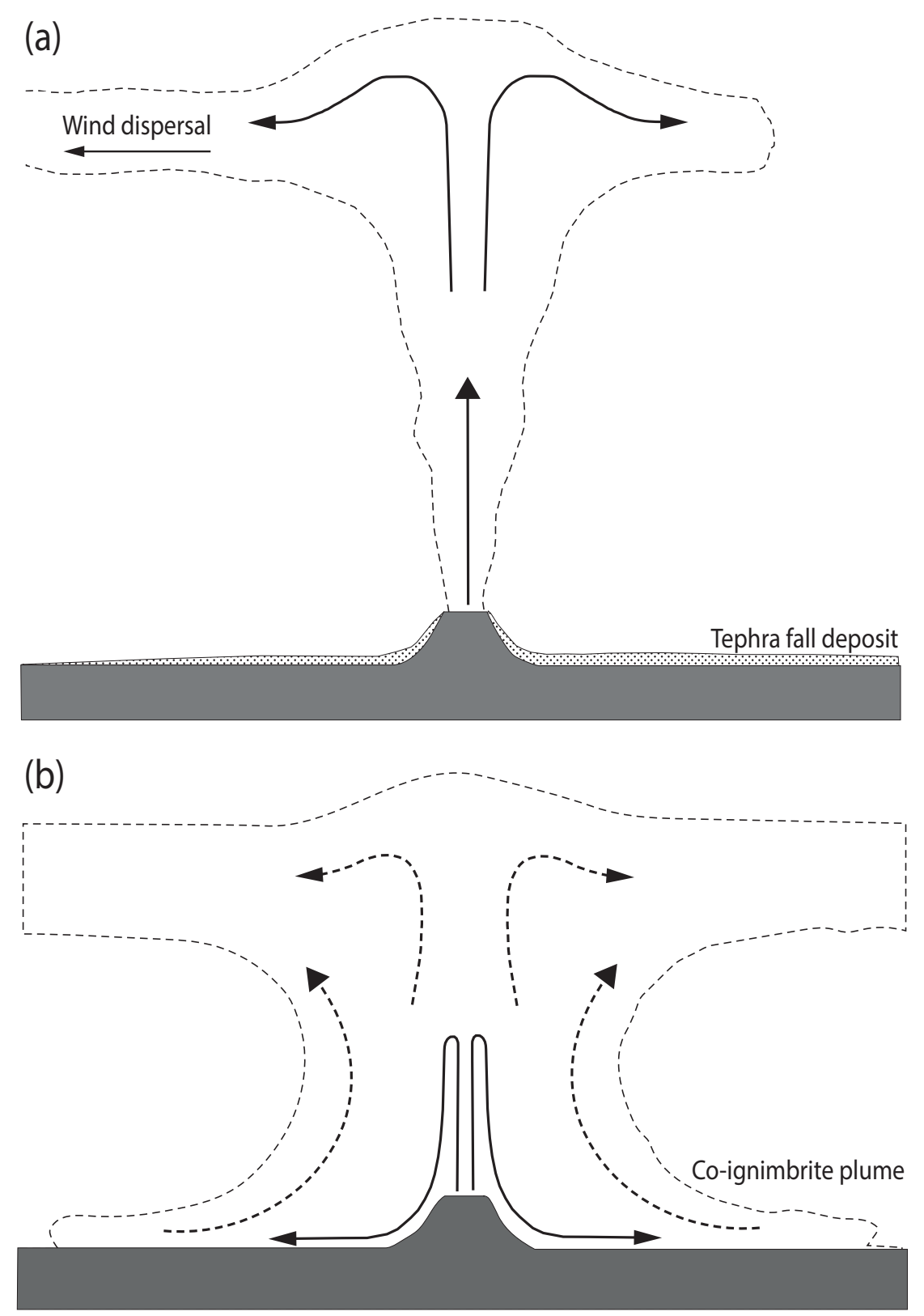

Figure 2.1: Tephra dispersal and deposition. Two mechanisms produce a widely dispersed tephra: (a) Tephra fall out from volcanic ash cloud generated by Plinianstyle eruption (b) Tephra elutriated from extensive pyroclastic flows and forming co-ignimbrite plumes. Figure adapted from Dartevelle et al. (2002). 
fine grained ( typically $<125 \mu \mathrm{m}$ ) glass shards present at dilute concentrations and are difficult to distinguish from host sediments which may have a similar grain size and colour (Lane et al., 2014; Davies, 2015).

Cryptotephras were first studied by Christer Persson, who described microscopic Icelandic tephra layers occurring in peat bogs in Sweden (Persson, 1966; Wastegård, 2005). Dugmore (1989) documented the first occurrence of an Icelandic cryptotephra in the UK (in a Scottish peat bog) and kick-started the search for cryptotephra in Holocene deposits across Europe. Dugmore (1989) used an acid digestion technique to remove organic material and identify a cryptotephra which was correlated to the Hekla 4 eruption of $\sim 4 \mathrm{ka}$ on the basis of the unique geochemical fingerprint of its glass shards.

Less destructive methods of cryptotephra identification have since been developed, for example, the density separation procedures of Turney (1998) and Blockley et al. (2005) which were designed to isolate glass shards from host sediments.

Applications of cryptotephrochronology have now been undertaken in more than 24 countries, where sub-millimetre tephra have been traced over hundreds to thousands of kilometres (Lowe, 2011). Cryptotephras have greatly extended the scope of tephrochronology, allowing correlation over much greater areas and leading to the discovery of new tephras (Blockley et al., 2005).

The fallout distribution of cryptotephra is exemplified by recent and historic eruptions. The AD $833-850$ Alasksan White River Ash, erupted from the Bona-Churchill massif, south-eastern Alaska, forms a prominent visible marker for $1000 \mathrm{~km}$ to the east. Recently the Alaskan White River Ash has been found to correlate to the 'AD860B' cryptotephra (AD 846 - 848) occurring in Greenland and northern Europe, $7000 \mathrm{~km}$ to the east (Jensen et al., 2014). The eruption had 
an explositivity of VEI=6 (an order of magnitude greater than Pinatubo 1991), which illustrates how even moderate size eruptions can disperse tephra over greater geographical distances than previously thought (Jensen et al., 2014).

Recent applications of cryptotephrochronology include the discovery of tephra from the most explosive eruption of the Quaternary, the $\sim 75$ ka Younger Toba Tuff (YTT), in Lake Malawi sediments (East Africa), > 7,000 km to the west of the source volcano (Lane et al., 2013b) (Fig. 2.2). Numerous studies have linked a supposed human genetic bottleneck with a dramatic climatic shift in eastern Africa resulting from the YTT supereruption (Gibbons, 1993; Ambrose, 1998; Hewlitt, 2000; Rampino and Ambrose, 2000). The identification of the YTT in the Lake Malawi sediments is significant because the sediments record no climatic changes at the position of the cryptotephra. This demonstrates that the eruption did not impact the East African climate significantly and may not have been responsible for a human genetic bottleneck (Lane et al., 2013b). This is reiterated by Jackson et al. (2015) who observed no palaeoecological changes recorded in the Lake Malawi sediments before, during and after the deposition of the YTT.

\subsection{Tephra records as dossiers of past eruptions}

Tephras preserved in East African sedimentary archives have been used to elucidate the frequency, magnitude and style of past eruptions and also provide information on tectonic processes and petrogenesis (WoldeGabriel et al., 1990, 1999, 2005; Ukstins Peate et al., 2003; Feakins et al., 2007). For instance, Feakins et al. (2007) identified 155 cryptotephras in the DSDP Site 231 Gulf of Aden marine core. The cryptotephras were geochemically linked to East African 


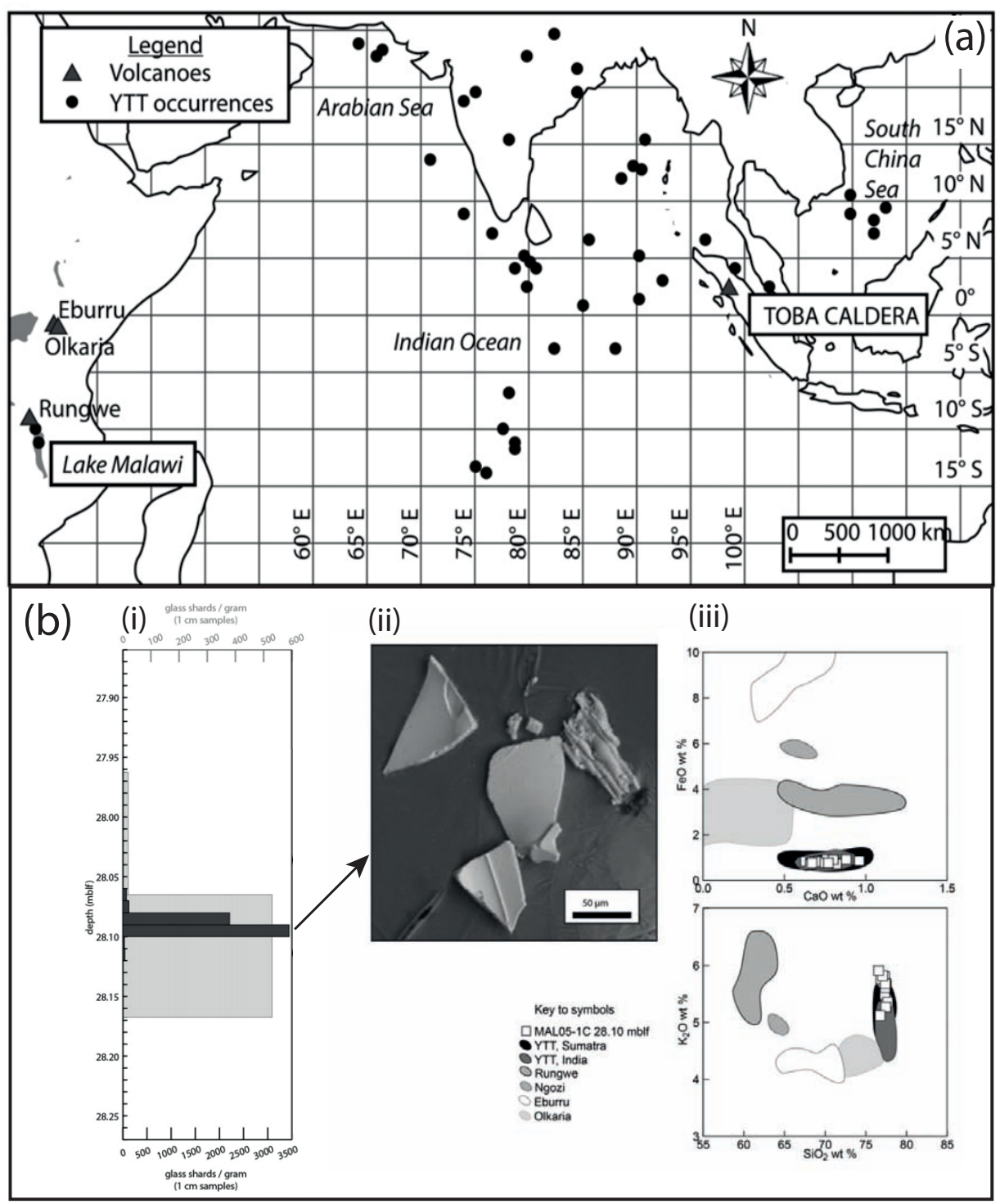

Figure 2.2: Cryptotephra from the Youngest Toba Tuff ( $\sim 75 \mathrm{ka})$ found in Lake Malawi, eastern Africa; (a) Map showing the Toba caldera (Sumatra) and distribution of the YTT (b) the position of the YTT cryptotephra in sediments from Lake Malawi; (i) Glass shard counts in the Malawi lake sediments, the peak indicates the isochron position, (ii) SEM image of glass shards in the Malawi sediments, (iii) Glass shards from the Malawi cryptotephra have an identical composition to the YTT tephra. Figures from Lane et al. (2013b). 
tephras and reveal three main volcanic episodes; at $\sim 4.0-3.2 \mathrm{Ma}, 2.4 \mathrm{Ma}$ and 1.7 - 1.3 Ma. Larger volume eruptions between 4.0 - 3.2 Ma were inferred from the generally thicker tephras deposited in the Gulf of Aden during this time interval.

The tephra record has important implications for hazard assessments, giving insight into the tempo and magnitude of eruptions from multiple volcanic centres (Lowe, 2011). Tephra records have been used in numerous studies to provide information on past eruptive frequencies and therefore future hazards (Shane and Hoverd, 2002; Hurst and Smith, 2004; Jenkins et al., 2007; Turner et al., 2009). The Eyjafjallajökull 2010 eruption (Davies et al., 2010) and Grímsvötn 2011 Icelandic eruptions and subsequent disruption to air-traffic demonstrated the importance of studying previous eruptive deposits and their dispersal. These eruptions prompted Swindles et al. (2011) to compile information on the tephra deposits sourced from Icelandic volcanoes over the past 7000 years. Swindles et al. (2011) demonstrated that within any decade over the past millennium there was a $16 \%$ probability of an eruption from Iceland producing a visible tephra deposit in northern Europe. Through understanding the past and therefore future eruptions from Iceland the impact on aviation, public health and economy can be lessened (Lawson et al., 2012).

The lack of documented Holocene eruptions and their tephra deposits in eastern Africa, coupled with the absence of a volcano monitoring network, meant that the Nabro 2011 (Eritrea) eruption occurred unexpectedly. Although tephra studies have been used for hazard mitigation to great effect elsewhere, this approach is yet to be used in eastern Africa. In order to prevent future disruption to the aviation industry and the displacement of thousands of people, 
it is crucial that previous eruptions from regional volcanoes and their deposits are investigated.

\subsection{Lakes as tephrostratigraphic repositories}

Subaerial tephras may be obscured by dense vegetation, buried and extensively eroded. For instance the subaerial Dubbi (Eritrea) 1861 tephra deposit has been eroded since its deposition (Lenhardt and Oppenheimer, 2014). The most complete records of volcanism therefore occur where tephras are deposited in aggrading sediment records, rather than eroding systems (White and Riggs, 2001).

Sediments from Ethiopian Rift lakes provide records of past volcanism, and an archive of core material is held at Aberystwyth University. The accessibility of these tephra records is crucial in a region where fieldwork is regarded as logistically challenging and where proximal tephra deposits at volcanoes may be poorly exposed, buried or eroded (Wiart and Oppenheimer, 2004). This study uses Holocene Ethiopian lake sediment cores as dossiers of past regional volcanic activity.

Lake sediments provide ideal records of past volcanic activity because:

1. Lakes are low energy depositional environments that may record near continuous sedimentation, allowing high resolution tephra records to be preserved (White and Riggs, 2001).

2. Tephra particles fall rapidly to the lake bed and their deposition is typically geologically instantaneous (Julien, 1995; Manville et al., 2002). 
3. Lacustrine sediments contain age-diagnostic material which is useful for chronostratigraphic correlation (White and Riggs, 2001).

4. Tephras from multiple volcanic sources are preserved, enabling interrelationships between different centres to be investigated (Smith et al., 2013).

\subsubsection{Factors impacting tephra deposition and preservation in lake sediments}

Prior to investigating tephra records preserved in Ethiopian lake sediments, it is important to consider factors that may determine the distribution of tephras and their subsequent preservation in disparate lake sediments. These factors may determine the potential for tephra correlations between lake archives and have implications for interpretations of past eruption frequency.

As discussed above, the physical characteristics of a volcanic eruption, including the volcanic explosivity, column height and grain size directly determine the spatial distribution of tephra deposits (Sparks et al., 1997). Furthermore, differences in tephra occurrence in lake sediments are related to meteorological conditions, and their deposition in precipitation bearing systems may cause sporadic fall out patterns (Boygle, 1999). Importantly, tephra dispersal is dependant on wind direction and speed (Carey and Bursik, 2015). Figure 2.3 shows recent wind regimes during summer and winter, averaged over Ethiopia. Wind directions vary seasonally over Ethiopia, and this will determine the spatial distribution of tephras over time. During the wet season westerly winds predominate, potentially dispersing tephra away from Ethiopia towards the east. However, during the dry season months, the wind directions reverse causing 
tephras to be dispersed towards the west. It is therefore apparent that the preservation of tephras in lake sediments may be governed in part by variations in wind direction. However, these are recent wind regimes, which may have varied throughout the Holocene.

Processes including sediment focussing, slumping, turbidity currents, bioturbation and tectonic movement may also compromise the stratigraphic position of a tephra (Boygle, 1999; White and Riggs, 2001; Payne et al., 2005). Tephra particles may also migrate vertically through lake sediments; typically causing the tephra to appear older (Anderson et al., 1985; Payne et al., 2005). Furthermore, the fragmental nature of tephra deposit means that they can be redistributed throughout the lake catchment by aeolian and fluvial processes (Boygle, 1999).

The controls on the deposition and preservation of tephras therefore varies between sites and these factors need to be considered when constructing a tephra framework. Nevertheless, lake sediments frequently provide more complete tephra records than those proximal to volcanic centres. 


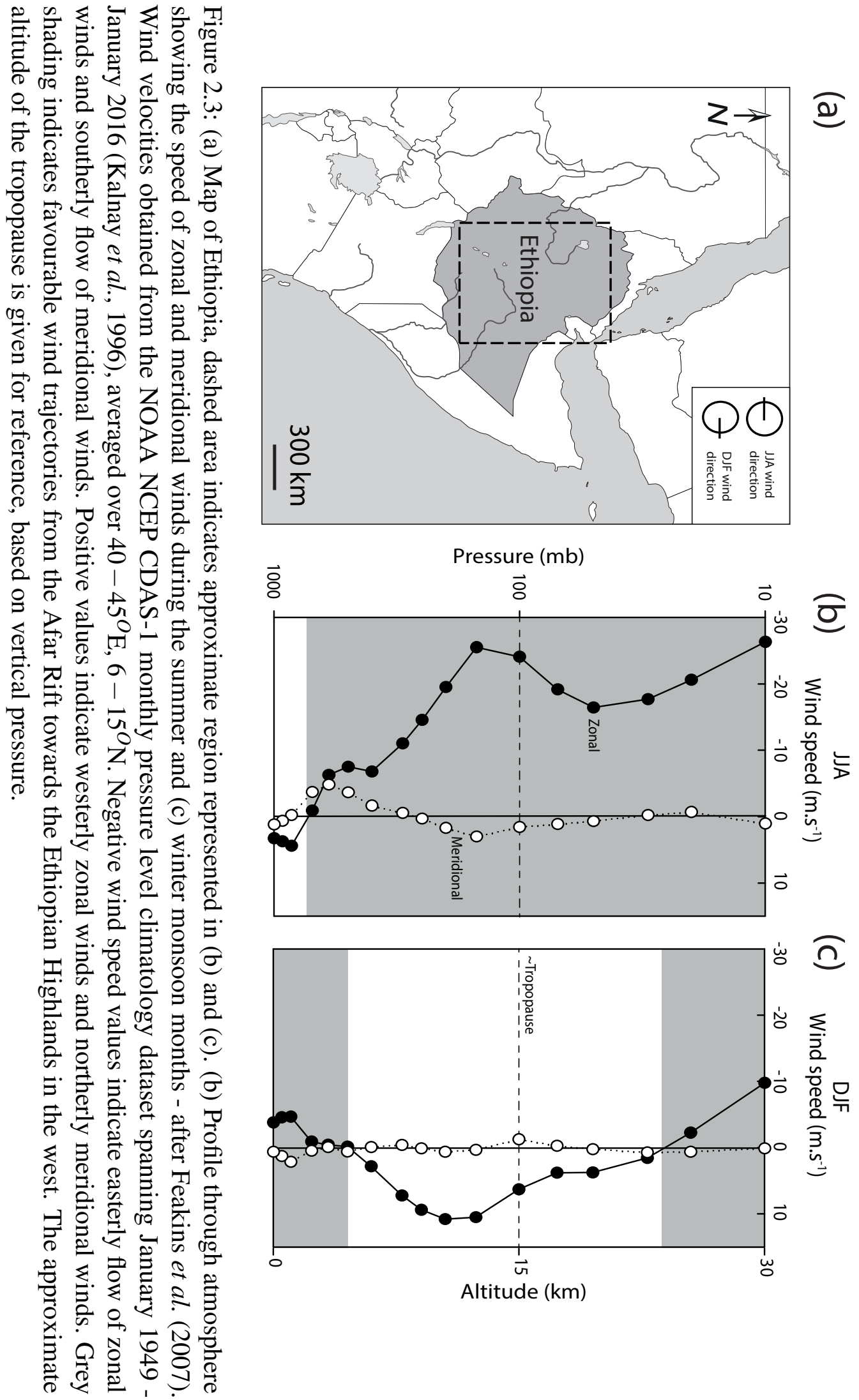




\subsubsection{Identifying cryptotephras in lake sediments}

Whilst distal records often preserve a more complete record of past volcanism, they typically receive lower volumes of finer grained tephra than proximal locations, making tephra identification more difficult.

This study investigates both visible tephras and cryptotephras in Ethiopian lake sediments. Studying cryptotephras promises to build a higher resolution tephra framework for Ethiopia, facilitating correlation over wider spatial areas and providing insight into the dispersal of ultra-distal deposits.

Various methods have been used in the literature to identify 'non-visible' cryptotephras in lake sediments; these are briefly outlined below to provide a rationale for the methods used in this work.

Cryptotephras hosted in terrestrial and marine sediments are typically identified using the standard density separation technique reviewed by Blockley et al. (2005), Lane et al. (2014) and Davies (2015). The technique involves first sampling the sediments at contiguous $\sim 10 \mathrm{~cm}$ depths and extracting tephra glass shards using the high density liquid, sodium polytungstate $(1.95-2.55$ $\mathrm{g} / \mathrm{cm}^{3}$ ). The glass shards from each sample can then be counted under an optical microscope and regions containing high concentrations of shards resampled at $1 \mathrm{~cm}$ intervals in order to define the position of the isochrons. Shard counts are typically expressed as shards per gram (s/g) of dried sediment and can be plotted against the site's stratigraphy in order to review the position of a cryptotephra (e.g. see Fig. 2.2b). The profile of the cryptotephra is influenced by the eruption duration and characteristics along with secondary processes such as bioturbation and soil erosion, which may distribute the cryptotephra throughout the stratigraphy. If glass shards show a sudden appearance in the host sediment 
and tail off gradually, the basal rise is typically interpreted as the primary airfall event (Lane et al., 2014).

Counting procedures are time consuming; numerous studies have utilised other methods to successfully identify cryptotephras in terrestrial and marine sediments. These techniques are reviewed by Gehrels et al. (2008) and include ground-penetrating radar (Lowe, 1985), remnant magnetisation and magnetic susceptibility (Hodgson et al., 1998; Takemura et al., 2000; de Fontaine et al., 2007; Carter et al., 2002; Rasmussen et al., 2003; Gomez et al., 2007; Venuti and Verosub, 2010; McCanta et al., 2015), spectrophotometry (sediment reflectance and luminescence) (Caseldine et al., 1999; Gehrels et al., 2008; McCanta et al., 2015) X-radiography (Turner et al., 2008; Lowe, 2011), X-ray fluorescence (XRF) (Hogg and McCraw, 1983; Gehrels et al., 2008) and XRF core scanning (Gehrels et al., 2008; Marshall et al., 2009; Langdon et al., 2011; Vogel et al., 2010; Kylander et al., 2011; McCanta et al., 2015). To date, none of these techniques have proved as effective in detecting the finest cryptotephras as density separation techniques.

This study uses XRF core scanning, in combination with density separation techniques, to identify cryptotephras in lake sediments. Comparatively few studies have combined these techniques to identify cryptotephras, particularly in lake sediments. The first systematic study to apply this technique to cryptotephra detection in lakes sediments was undertaken by Kylander et al. (2011) on archives from the Faroe Islands. Kylander et al. (2011) successfully identified basaltic visible and crypto-tephras (containing $>1,000$ shards $/ \mathrm{cm}^{3}$ ) on the basis of elevated K, Mn, Fe, Ca and Ti counts. Damaschke et al. (2013) identified alkaline visible tephras in sediments from Lake Prespa (Balkans) based on increased K and $\mathrm{Rb}$ and/or $\mathrm{Sr}$ counts. However, cryptotephras were not associated with 
this geochemical signature. Wulf et al. (2013) identified the phonolitic Laacher See cryptotephra using XRF mapping of resin-impregnated sediments from Trzechowskie palaeolake (Poland) on the basis of increased K, Al and Fe counts (Fig. 2.4).

Silicic cryptotephras are generally more difficult to identify using XRF core scanning. For example, Wastegård et al. (2013) found that even visible rhyolitic tephras in the Laguna Potrok Aike (Argentina) core were associated with only slight variations in K and Ti counts. Furthermore, Kylander et al. (2011) found that rhyolitic cryptotephras of low shard concentrations $\left(<850\right.$ shards $\left./ \mathrm{cm}^{3}\right)$ in Faroe Island lake sediments were not detected by XRF core scanning. Balascio et al. (2015) created synthetic core sediments spiked with basaltic and rhyolitic cryptotephras. Basaltic cryptotephras were identifiable using XRF core scanning, but more silicic cryptotephras were not associated with a distinct elemental response.

Few studies have used XRF core scanning to identify cryptotephras in Ethiopian lake sediments. Marshall (2006) identified elevated K, Zr and Rb counts associated with visible silicic tephras in sediments from Lake Ashenge (northern Ethiopia). Marshall (2006) also suggested that increased K, Zr and $\mathrm{Rb}$ counts at other depths throughout the sediments may be associated with cryptotephras. This is verified in this study through higher resolution XRF scanning and glass shard counting. 

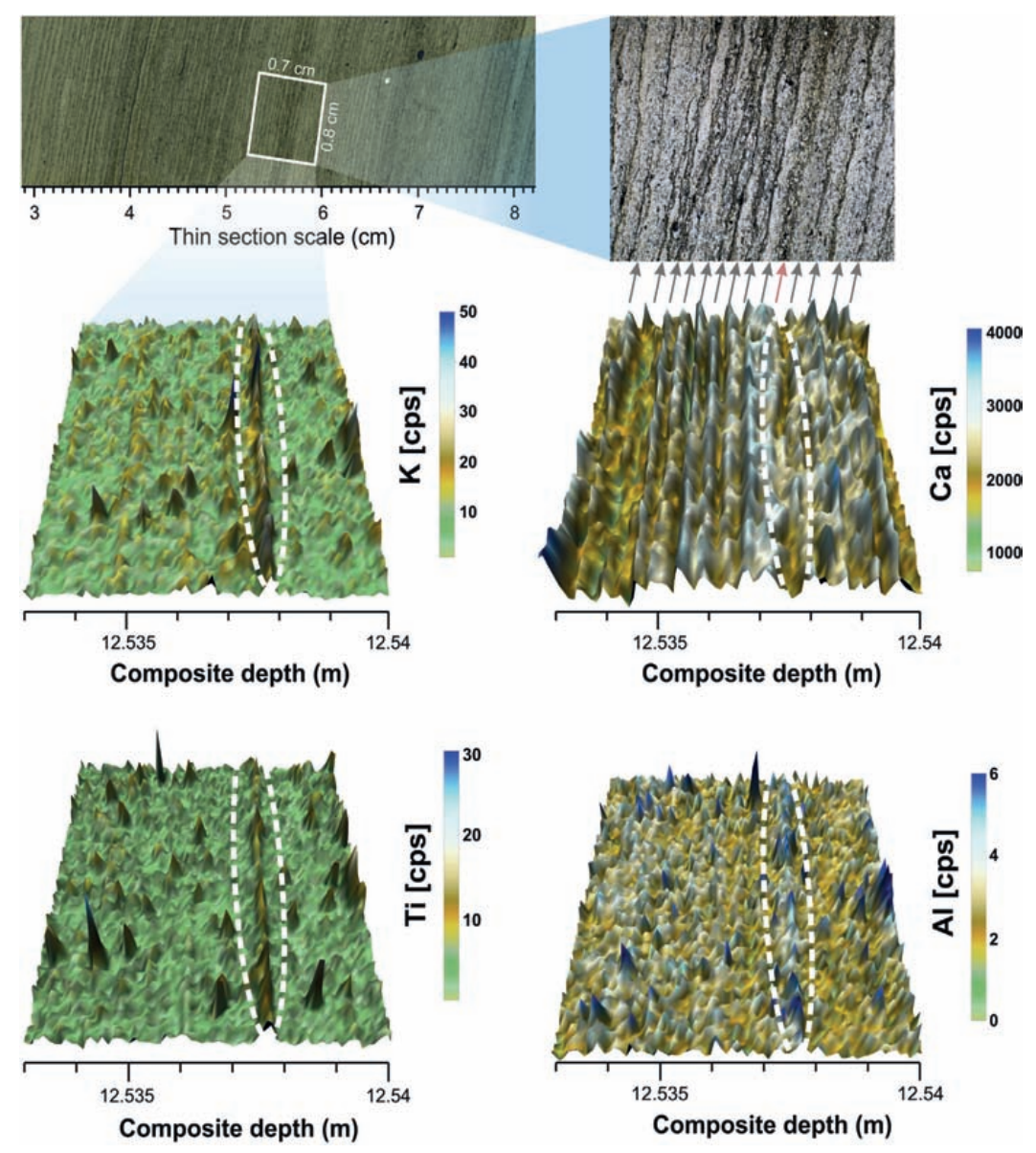

Figure 2.4: Thin section images and 3D images showing the $\mathrm{K}, \mathrm{Ti}, \mathrm{Ca}$ and $\mathrm{Al}$ distribution (obtained through XRF scanning) in sediments from the Trzechowskie palaeolake containing the Laacher See Tephra. The continuous line of increased K, Ti and Al counts represents the Laacher See cryptotephra. Figure from Wulf et al. (2013). 


\subsection{Tephra fingerprinting}

The unique physical and geochemical properties of a tephra from the same eruption allow it to be identified across the fallout zone and distinguished from other tephras of similar ages (Alloway et al., 2007).

Tephra fingerprinting may be undertaken using a variety of analytical instruments on various components of the tephra deposits, including, the individual glass shards, free crystals and phenocrysts or microcrysts (Table 2.1).

Where tephras of different ages have similar geochemical fingerprints; age data and good stratigraphic information are essential for narrowing down the potential correlatives (e.g. Lane et al., 2012).

Commonly multiple criteria are necessary in order to distinguish between tephra deposits; Tryon et al. (2008) suggest that tephra correlations are best considered as testable hypotheses, subject to continual revision and expanded data sets.

\subsubsection{Glass shard morphology}

The morphology of tephra glass shards varies between deposits depending on the magma composition, eruption style and other factors (Heiken, 1972). Shard morphology may be studied under optical microscopy or scanning electron microscopy (SEM) and, in favourable circumstances, may provide a means for discriminating between tephra deposits.

Three main morphological types have been described (Fig. 2.5): bubble wall or cuspate shards, platy shards and pumiceous shards, although other morphologies are common (Heiken, 1972, 1974; Fisher and Schminke, 1984; Rose and Chesner, 1987; Heiken and Wohletz, 1991). Katoh et al. (2000) used 
Table 2.1: Summary of analytical methods used for characterising tephras, adapted from Lowe (2011). INAA: instrumental neutron activation analysis, XRF: X-ray fluorescence, LA- or SN-ICP-MS: laser ablation or solution nebulisation inductively coupled plasma mass spectrometry, SEM: scanning electron microscopy, EDS or WDS: energy or wavelength dispersive spectrometry, SSMS: spark source mass spectrometry, SIMS: secondary ionization mass spectrometry.

\begin{tabular}{ll} 
Tephra component & Method of analysis \\
\hline $\begin{array}{l}\text { Bulk tephra samples } \\
\text { Bulk samples }\end{array}$ & INAA, XRF, SN-ICP-MS \\
$\begin{array}{l}\text { Glass shards } \\
\text { Shard morphology } \\
\text { Major and minor elements }\end{array}$ & $\begin{array}{l}\text { Optical microscope/SEM } \\
\text { EDS or WDS Electron probe } \\
\text { micro-analyser }\end{array}$ \\
Rare earth and trace elements & $\begin{array}{l}\text { LA- or SN-ICP-MS, INAA, } \\
\text { SSMS, SIMS }\end{array}$ \\
$\begin{array}{l}\text { Pb isotopes } \\
\text { Fe-Ti oxides }\end{array}$ & LA-ICP-MS \\
$\begin{array}{l}\text { Major and minor elements } \\
\text { Eruption temperatures \& oxygen fugacities }\end{array}$ & $\begin{array}{l}\text { EDS or WDS Electron probe } \\
\text { micro-analyser }\end{array}$ \\
& $\begin{array}{l}\text { EDS or WDS Electron probe } \\
\text { micro-analyser }\end{array}$ \\
$\begin{array}{l}\text { Ferromagnesian mineals } \\
\text { Assemblages }\end{array}$ & \\
Pyroxene, amphibole, olivine, biotite crystals & Electron microscope \\
Feldspars & \\
Anorthite content of plagioclase crystals & EDS or WDS Electron probe \\
& micro-analyser \\
\hline
\end{tabular}

the morphological properties of glass shards combined with tephra chemistry to create a tephra framework for the Konso Formation, southern Ethiopia.

However, tephras produced by eruptions with similar characteristics and similar melt compositions may have indistinguishable shard morphologies. Therefore correlation based on shard morphology may be inconclusive and this technique is more effective when used alongside other techniques. 

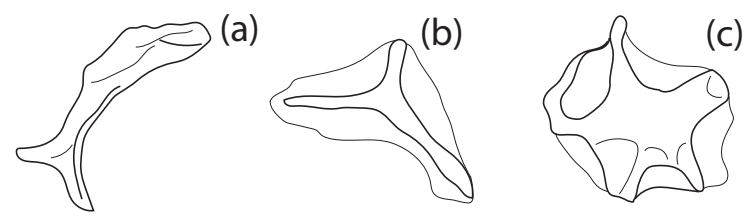

Bubble wall/ cuspate
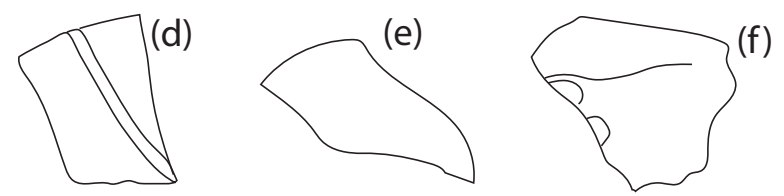

Platy
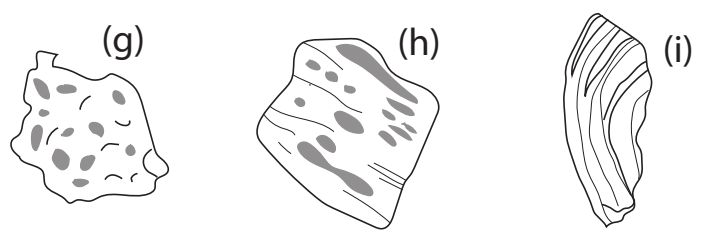

Pumiceous

Figure 2.5: The three main glass shard morphologies (author's image). (a-c) Bubble wall / cuspate glass shard morphologies, (d-f) platy shards possessing a blocky shape and (g-i) pumiceous shards containing vesicles. Note the differing types of pumiceous shards - the vesicles have been stretched to produce (h) and (i), the latter has a more fluted shape.

\subsubsection{Mineral assemblages}

Tephra deposits proximal to the volcanic source $(\sim<100 \mathrm{~km})$ may contain unique assemblages of minerals which may be used to discriminate between tephra deposits. Orthopyroxenes, clinopyroxenes, amphiboles and biotite are common minerals associated with tephras derived from calc-alkaline volcanic centres, whilst peralkaline tephras may contain sodic phases such as aegirine, riebeckite, ferrohedenbergite and aenigmatite (Alloway et al., 2007). Mineral assemblages were used by Brown (1969) and Walter et al. (1987) to identify and trace tephras locally in the Omo Basin (southern Ethiopia) and to identify the Cindery Tuff in the Awash Basin (northern Ethiopia).

The relative abundance of ferromagnesian and accessory minerals in tephras may also provide a valuable correlative tool (e.g. Lowe et al., 2008). However, 
these denser minerals may be preferentially deposited close to the source (Sparks et al., 1997) causing variations in their abundance in deposits. Biotite and Fe-Ti oxides may also be dissolved in acidic peat bogs and olivine may be altered by weathering (Hodder et al., 1991). Furthermore, tephras derived from the same source, or with similar compositions, may have comparable mineral assemblages.

Therefore mineral assemblages may not be a diagnostic tool for correlation beyond proximal areas and this technique is better used in combination with other characterisation methods.

\subsubsection{Glass chemistry}

Glass shards in a tephra have a unique geochemical fingerprint which approximates the composition of the magma at the time of eruption (Lowe, 2011).

Grain specific geochemical analysis of glass shards in tephra deposits is now considered the most diagnostic tool for correlation where stratigraphic, mineralogical and physical properties are inconclusive. Shard-specific analyses are preferable to whole rock analyses because bulk tephra samples may contain variable quantities of accessory and accidental material with distance and direction from the source including phenocrysts, xenocrysts, xenoliths and detrital grains (Shane and Smith, 2000).

Although glass chemistry is extensively used for correlation in Quaternary science, different tephras may have identical compositions (e.g. Lane et al., 2012) and therefore a combination of characterisation methods and stratigraphic and age data provide the most robust correlations.

Two analytical techniques are used in this study to characterise Holocene tephras from Ethiopia in terms of their major (electron probe micro-analyser) and trace element (laser ablation inductively coupled plasma-mass spectrometry) 
concentrations and therefore these methods are discussed below. Advances in these analytical techniques, extending the spatial area of tephra correlation, are also described.

\subsubsection{Electron probe micro-analysis of glass}

Since its development in the late 1960s (Smith and Westgate, 1968), single shard electron probe micro analysis (EPMA) now forms the foundation of tephra studies. Notably, the technique has been extensively used to correlate Pliocene to late Pleistocene tephra in eastern Africa and the Gulf of Aden (e.g. Brown, 1982; Sarna-Wojcicki et al., 1985; WoldeGabriel et al., 1990; Pickford et al., 1991; Brown et al., 1992; Hart et al., 1992; Katoh et al., 2000; WoldeGabriel et al., 2005; Brown et al., 2006; Feakins et al., 2007; Campisano and Feibel, 2008; DiMaggio et al., 2008; Deino et al., 2010; Lane et al., 2013b).

Typically, 10 - 13 major elements ( $\mathrm{Si}, \mathrm{Al}, \mathrm{Ti}, \mathrm{Fe}, \mathrm{Mn}, \mathrm{Mg}, \mathrm{Ca}, \mathrm{Na}, \mathrm{K}$ and P), dependant on glass composition, can be routinely determined using EPMA (Lowe, 2011). Over the past years several analytical limitations have been overcome, allowing accurate and precise analysis of fine glass shards at a high resolution (Hayward, 2011).

Subtle geochemical differences between some tephras require high levels of analytical precision and accuracy (Hayward, 2011). Different laboratories employ variable analytical methods which create inter-laboratory variations when analysing the same materials (Pearce et al., 2014). Therefore, numerous interlaboratory comparisons have been undertaken to ensure robust correlations can be made using different instruments (e.g. Kuehn et al., 2011).

EPMA analysis is associated with 'alkali element migration', the chemical modification of glass during analysis, causing an underestimation of $\mathrm{Na}$ and 
overestimation of Si and Al (Morgan and London, 1996, 2005; Humphreys et al., 2006). This element migration is overcome by the use of a defocussed, $\sim 10$ $\mu$ m diameter beam, at a low $(<10 \mathrm{nA})$ current and the determination of $\mathrm{Na}$ at the start of the analysis (Hunt and Hill, 2001). Hayward (2011) successfully conducted glass analysis with no detected alkali element loss, using a narrower 3

$\mu$ m diameter focused beam, operating at a low beam current of $<0.1 \mathrm{nA} / \mu \mathrm{m}^{2}$. $\mathrm{X}$-rays signals can be measured using two different analysis types: energy dispersive spectrometry (EDS) and wavelength dispersive spectrometry (WDS). EDS analysis measures X-ray energies simultaneously and is therefore favoured for its speed. WDS analysis is capable of measuring individual wavelengths at a higher beam current and monitoring sodium loss (Coulter et al., 2009).

These analytical improvements enable fully quantitative analysis at a high resolution, extending the scope for finer grained and more distal tephras to be correlated.

\subsubsection{Laser ablation ICP-MS analysis of glass}

Many tephras can be distinguished between on the basis of their major element composition. However, different melts may share similar crystallisation trends and mixing patterns prior to their eruption, so tephras of different ages may have similar major element compositions (e.g. Westgate et al., 2013).

In these instances, trace element analysis of tephra glass shards may allow compositional discrimination. This technique was used by Westgate et al. (2013) to discriminate between the Older, Middle and Younger Toba Tuff, which possess a similar major element composition (Fig. 2.6) (Chesner, 1998; Lee et al., 2004). Westgate et al. (2013) identified four primary glass populations with differing $\mathrm{Sr}, \mathrm{Ba}$ and Y concentration within the Younger Toba Tuff (YTT) which easily 
distinguish it from the homogeneous glass populations of the Older and Middle Toba Tuffs.

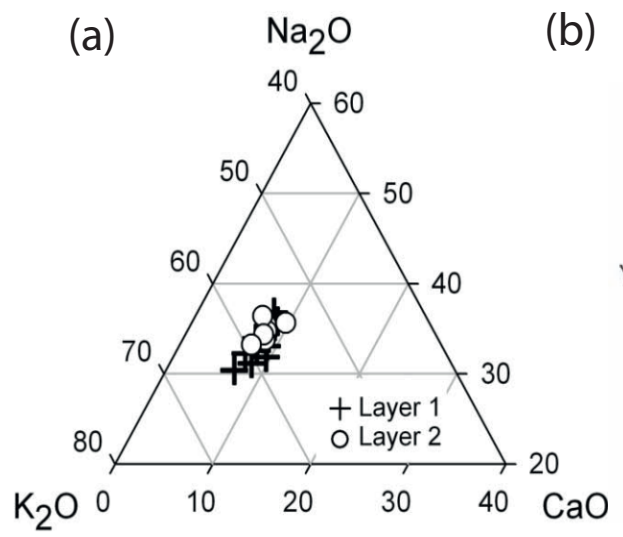

(b)

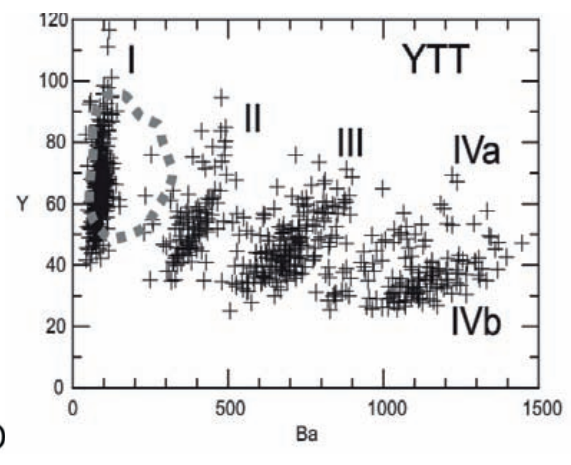

Figure 2.6: Trace element composition of the Youngest Toba Tuff distinguishes it from the Oldest and Middle Toba Tuff. (a) $\mathrm{CaO}-\mathrm{Na}_{2} \mathrm{O}-\mathrm{K}_{2} \mathrm{O}$ ternary diagram showing the compositional similarity between the Oldest Toba Tuff (open circles) and Youngest Toba Tuff (crosses), figure from Lee et al. (2004). (b) Bi-plots of $\mathrm{Ba}-\mathrm{Y}(\mathrm{ppm})$ concentrations divide the YTT tephra into four major glass compositions and a smaller, fifth compositional group (IVa). In contrast the OTT and MTT have homogeneous trace element compositions (dotted grey outline shows the homogeneous composition of OTT glass shards). Figure from Pearce et al. (2014).

The potential of laser ablation inductively coupled plasma-mass spectrometry (LA-ICP-MS) for analysing trace elements in tephra glass shards was first realised by Westgate et al. (1994). Since then, LA-ICP-MS has been used frequently in Quaternary science to characterise tephras (Bryant et al., 1999; Pearce et al., 2008; Harangi et al., 2005; Narcisi et al., 2006; Jordan et al., 2007; Brendryen et al., 2010; Tomlinson et al., 2010; Abbott et al., 2011, 2012; Smith et al., 2011b,a; Bramham-Law et al., 2013). Contrastingly, LA-ICP-MS is rarely used to discriminate east African tephras; this is due, in part, to the comparatively later development of LA-ICP-MS over the past 10-15 years (Pearce et al., 2011). However, Ukstins Peate et al. (2003, 2008) used LA-ICP-MS to correlate 
Indian Ocean deep sea tephras to Oligocene silicic pyroclastic units in the AfroArabian Flood Volcanic Province of Ethiopia. Numerous studies have used instrumental neutron activation analysis (INAA) to characterise trace elements in early-Pliocene to late Pleistocene tephras from eastern Africa (Walter et al., 1987; Hart et al., 1992; Walter and Aronson, 1993; WoldeGabriel et al., 1999; Clark et al., 2003).

The desire to analyse finer, more distal, glass shards has driven analytical improvements to LA-ICP-MS (Bryant et al., 1999; Pearce et al., 1999, 2014). However, analytical precision and accuracy is affected by element fractionation. This process is caused by calibration of glass analyses against National Institute of Technology (NIST) reference materials, which possess a different matrix to any geological sample. The calibration standard and sample therefore respond differently to ablation, causing an analytical bias known as element fractionation (Günther and Hattendorf, 2005). During sample ablation a surface condensate forms on inner walls of the ablation crater (Fig. 2.7) and this is widely cited as the cause of element fractionation (Eggins et al., 1998; Hergenröder, 2006; Sylvester, 2008; Pearce et al., 2011). This melt film occupies a greater proportion of narrower $<20 \mu \mathrm{m}$ diameter ablation craters and therefore the analytical bias increases with decreasing crater diameter. Element fractionation compromises the accurate and precise analysis of fine grained shards, but can be corrected for by applying a 'fractionation correction factor' (Pearce et al., 2011). This enables 25 petrogenically significant trace elements to be determined when analysing using $10 \mu \mathrm{m}$ crater diameters. 

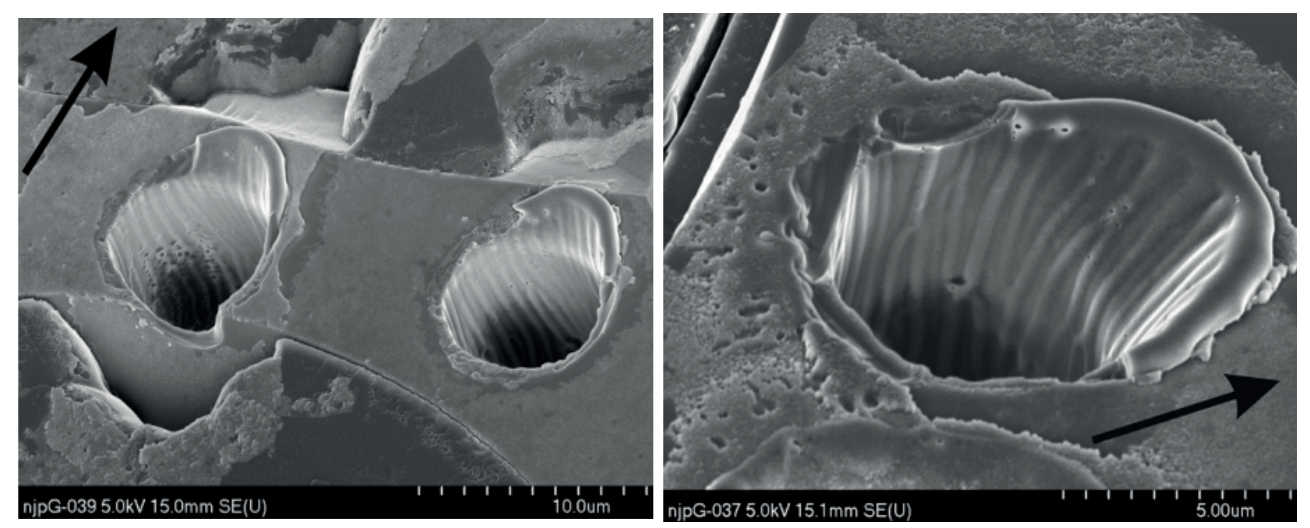

Figure 2.7: SEM images of $6 \mu \mathrm{m}$ and $4 \mu \mathrm{m}$ ablation craters in Minoan glass from Santorini. Note the melt film lining the interior of the craters, the gas flow through the sample chamber is indicated with an arrow. Element fractionation is widely attributed to this melt film, figure from Pearce et al. (2011).

\subsubsection{Fe-Ti oxide and silicate mineral chemistry}

The composition of minerals within a tephra, including feldspars, pyroxene, amphibole, biotite and olivine can be used to discriminate between tephras (Lowe, 2011).

Analyses of the Fe-Ti oxides, titanomagnetite and illmenite by EPMA have been extensively used to distinguish between tephra deposits (Hogg and McCraw, 1983; Cronin et al., 1997; Smith et al., 2002; McHenry, 2005; Turner et al., 2009). For instance, Smith et al. (2011b) noted lower FeO/MgO in biotite from the proximal and distal deposits (in India) of the Younger Toba Tuff as opposed to biotite in the Middle Toba Tuff and Oldest Toba Tuff, and used this to identify and correlate the YTT (Fig. 2.8).

At the Hadar hominin fossil site (northern Ethiopia), Campisano and Feibel (2008) used magnetite, feldspar and glass major element chemistry to characterise Pliocene-Pleistocene tephras from the Hadar and Busidima formations. 


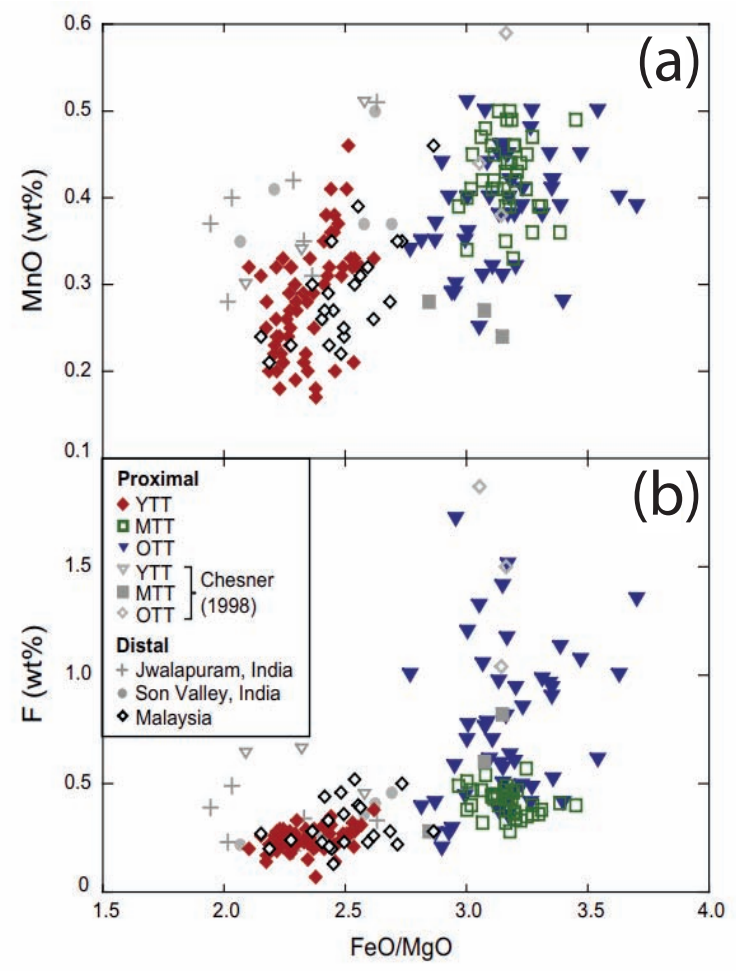

Figure 2.8: Biotite chemistry of proximal and distal Toba deposits; $\mathrm{FeO} / \mathrm{MgO}$ versus (a) $\mathrm{MnO}$ (wt.\%) and (b) $\mathrm{F}$ (wt.\%). Biotite within the YTT is of a different composition to those within the MTT and OTT. Figures from Smith et al. (2011b) 
However, due to the high specific gravity of Fe-Ti oxide minerals, they are generally not found at distal locations and are therefore less frequently used in distal tephra studies (Lowe, 2011). 


\subsection{Using geochemical data for tephra studies}

This study uses major and trace element glass data to investigate tephra correlations, volcanic sources and magmatic processes. This section provides a brief overview of the presentation and interpretation of geochemical data for tephra studies.

\subsubsection{Rock classification}

Igneous rocks are commonly classified using bi-variate oxide-oxide major element plots. The total alkalis-silica (TAS) diagram (Le Bas et al., 1986) is the most commonly used classification scheme for volcanic rocks and an example is shown in Figure 2.9. Concentrations of $\mathrm{SiO}_{2}$ and $\left(\mathrm{Na}_{2} \mathrm{O}+\mathrm{K}_{2} \mathrm{O}\right)$ in a volcanic rock are plotted onto the TAS classification diagram, which divides igneous rocks into ultrabasic, basic, intermediate and acidic types according to their silica content (Fig. 2.9).

Thereafter, igneous rocks can be classified into subalkali and alkali groups. Figure 2.9 shows subalkali and alkali rocks divided according to the dashed line, defined by Irvine and Barager (1971). Alkaline rocks are those that possess an excess of $\left(\mathrm{Na}_{2} \mathrm{O}+\mathrm{K}_{2} \mathrm{O}\right)$ over silica, whilst rocks undersaturated with alkali metals with respect to silica are subalkaline. Alkali rocks constitute $<1 \%$ of all igneous rocks exposed on the Earth surface. They attain their largest volume in continental rift settings (Gill, 2010), notably the East African Rift System (EARS), and are therefore the focus of this study.

Alkali and subalkaline basalts are the parent liquid for many intermediate and acidic magmas. They evolve through extraction of phenocryst phases, typically starting with olivine, followed by plagioclase, clinopyroxene and an oxide, 


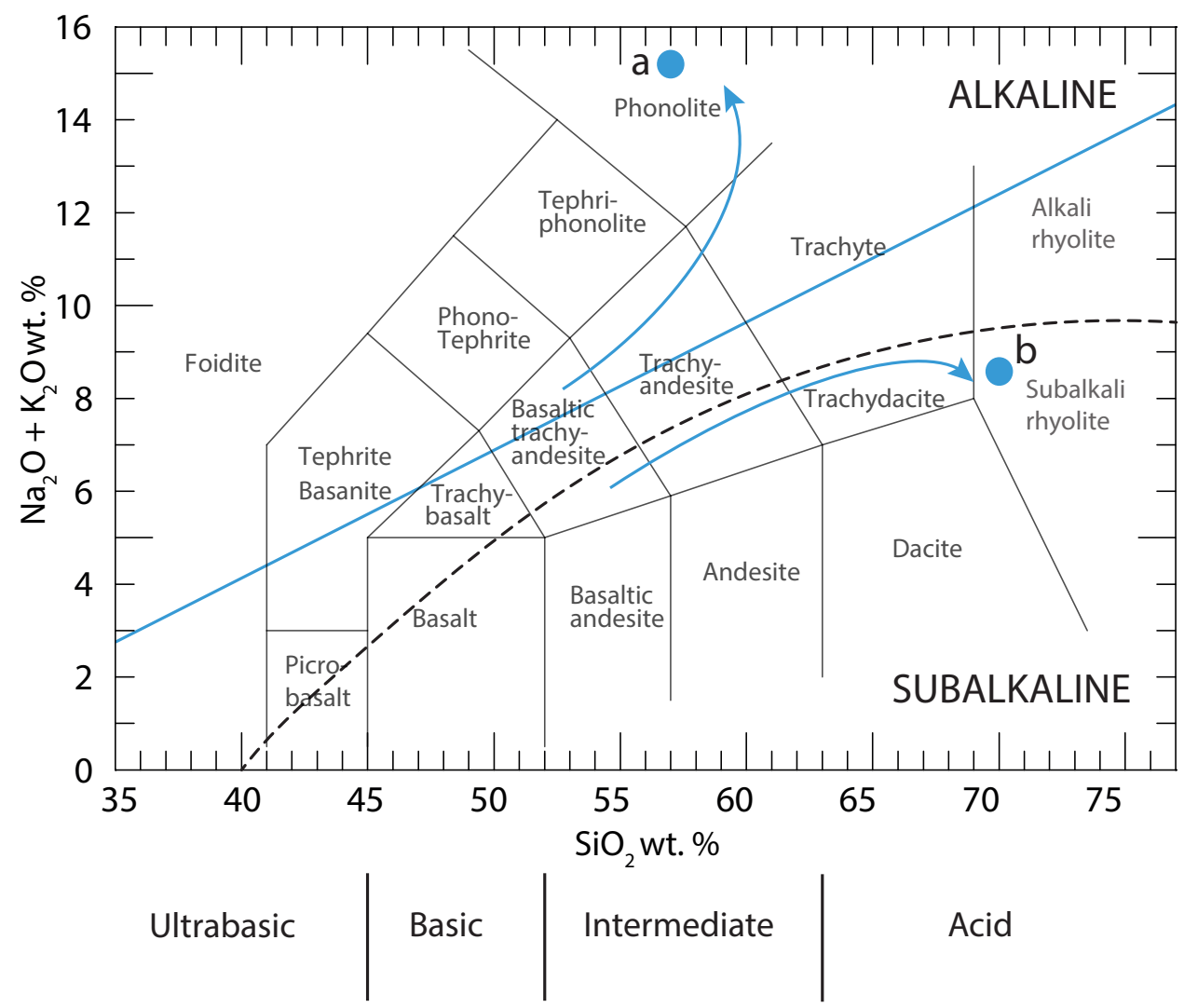

Figure 2.9: Chemical classification of volcanic rocks using the total alkalis versus silica diagram (TAS) of Le Bas et al. (1986). The dashed line subdivides alkalic from subalkalic rocks, co-ordinates from Irvine and Barager (1971). The blue solid line represents the albite-orthoclase thermal barrier, temperature contours decrease away from this plane (Sørensen, 1974). Blue arrows indicate the evolution of silica undersaturated compositions to (a) the feldspar-nepheline minimum and silica oversaturated compositions to (b) the feldspar-quartz minimum. 
according to their stability at different temperatures. However, the sequence of crystallising minerals varies between these two magma types, producing differently evolved magmas. Therefore, alkali basalt magmas cannot evolve into subalkaline basalts, and vice versa (Rogers, 2015). This is related to reactions between the crystallising minerals and melt that consume silica (Rogers, 2015). In alkali melts, the $\mathrm{SiO}_{2}$ deficiency may result in the crystallisation of feldspathoid minerals (silica deficient variants of feldspar) e.g. nepheline, leucite and rare kalsilite.

The reaction between nepheline and quartz, produces albite:

$$
\mathrm{NaAlSi}_{2} \mathrm{O}_{6}+\mathrm{SiO}_{2}=\mathrm{NaAlSi} \mathrm{O}_{8}
$$

In magmas containing an excess of quartz, olivine and quartz further react to produce orthopyroxene:

$$
\mathrm{Mg}_{2} \mathrm{SiO}_{4}+\mathrm{SiO}_{2}=2 \mathrm{MgSiO}_{3}
$$

Therefore, nepheline and orthopyroxene can never co-exist in a magma and be in equilibrium (Rogers, 2015). This is explained further using the quartznepheline-kalsilite or Petrogeny's residua system (Fig.2.10). This system demonstrates the effect of the crystallisation of these end members on the evolution of a melt. Temperature contours decrease away from the albite-orthoclase feldspar thermal barrier, dividing silica oversaturated compositions (containing quartz) from silica undersaturated compositions (containing nepheline) and preventing magma evolution across the barrier (Gill, 2010; Rogers, 2015). Melts that have compositions either side of this thermal divide will follow different fractionation paths towards low temperature compositions that are either silica oversaturated 
(feldspar-quartz minima) or silica undersaturated (feldspar-nepheline minima). For reference, the albite-orthoclase join and feldspar-nepheline and feldsparquartz cotectics are illustrated on a TAS diagram in Fig. 2.9. This thermal barrier causes subalkali basalts to evolve towards the feldspar-quartz cotectic into low alkali dacitic and rhyolitic magmas. In contrast alkali basalts evolve towards the felsdpar-nepheline cotectic to more alkali rich melts, such as trachytes or phonolites (Gill, 2010; Rogers, 2015). Whilst phonolites are highly differentiated, they are classified as intermediate according to their silica content (Fig.2.9), therefore they can be more accurately described as felsic.

Alkali rocks can be further subdivided by comparing the total alkali content of a volcanic rock with its $\mathrm{Al}_{2} \mathrm{O}_{3}$ content, in molar proportions (Eqs. 2.3- 2.5) following Le Bas et al. (1986). Silicic volcanism in Ethiopia has a predominantly peralkaline composition (Peccerillo et al., 2007). Peralkaline rhyolites can be further classified as either pantellerites or comendites (Eqs. 2.6 and 2.7), after Le Maitre (2002).

Peralkaline

$$
\left[\mathrm{Na}_{2} \mathrm{O}+\mathrm{K}_{2} \mathrm{O}\right]_{m o l}>\left[\mathrm{Al}_{2} \mathrm{O}_{3}\right]_{m o l}
$$

Peraluminous

$$
\left[\mathrm{Al}_{2} \mathrm{O}_{3}\right]_{\mathrm{mol}}>\left[\mathrm{Na}_{2} \mathrm{O}+\mathrm{K}_{2} \mathrm{O}+\mathrm{CaO}\right]_{\mathrm{mol}}
$$

Metaluminous

$$
\left[\mathrm{Na}_{2} \mathrm{O}+\mathrm{K}_{2} \mathrm{O}\right]_{\mathrm{mol}}<\left[\mathrm{Al}_{2} \mathrm{O}_{3}\right]_{\mathrm{mol}}<\left[\mathrm{Na}_{2} \mathrm{O}+\mathrm{K}_{2} \mathrm{O}+\mathrm{CaO}\right]_{\mathrm{mol}}
$$


Pantellerites

$$
\mathrm{Al}_{2} \mathrm{O}_{3}<\left[\mathrm{FeO}^{T}+4\right]
$$

Comendites

$$
\mathrm{Al}_{2} \mathrm{O}_{3}>\left[\mathrm{FeO} \mathrm{O}^{T}+4\right]
$$

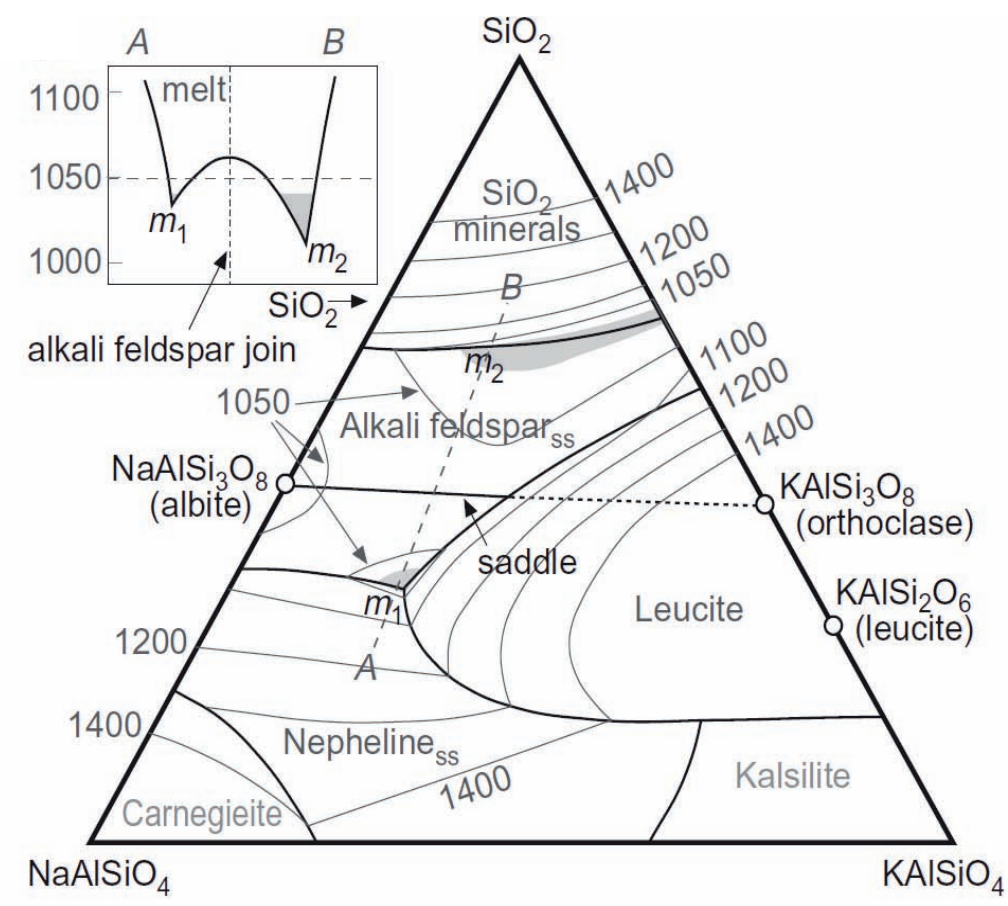

Figure 2.10: Phase relations in the residua system, quartz, nepheline and kalsilite (mass proportions), from Gill (2010). Open circles indicate the composition of the end-member albite, orthoclase and leucite and $m 1$ and $m 2$ show the feldspar-nepheline and feldspar-quartz cotectic, respectively. Temperature contours decrease away from the albite-orthoclase thermal barrier, dividing silica oversaturated compositions from silica undersaturated compostions (shown in inset, along line $\mathrm{AB}$ ). This prohibits the evolution of melts across this thermal barrier.

The silica saturation of a rock can be calculated using the CIPW norm, developed by the petrologists Cross, Iddings, Pirsson and the geochemist Washington, 
during the early 1900s. The major element analysis of a rock is translated into weight proportions of hypothetical minerals. Calculation of the CIPW norm determines the ideal mineralogy of an igneous rock. Rocks that have the potential to crystallise out nepheline are silica undersaturated, whilst those containing orthopyroxene are silica oversaturated.

Furthermore, once the CIPW norm has been calculated, the composition of natural silicate glasses can be projected onto the 'haplogranite' quartz-albiteorthoclase system (Fig. 2.11 - the silica oversaturated portion of Fig. 2.10), following Blundy and Cashman (2001). Prior to translation onto the haplogranite system, the CIPW norms must be recalculated, to account for the effect of anorthite on the feldspar compositions in the projection.

This enables variations in glass compositions to be related to changes in temperature and pressure in the magma chamber. Additionally, this gives an insight into whether crystallisation of the magma was driven by cooling or ascent (decompression). The haplogranite system is used in this study to investigate how variations in tephra composition recorded at different lakes may be related to differing magmatic conditions.

\subsubsection{Magmatic differentiation}

The array of rock compositions seen in see Fig. 2.9 is related to four principal factors. Firstly, the chemistry of magmatic rocks is ultimately determined by and mineralogy of the source region, i.e. crust or mantle. Secondly, magma composition is influenced by the depth and extent of melting. Thirdly, numerous magma chamber processes influence the primary melt composition en route to the surface. These include; fractional crystallisation, magma mixing and contamination or a combination of these processes. Following eruption, the composition 

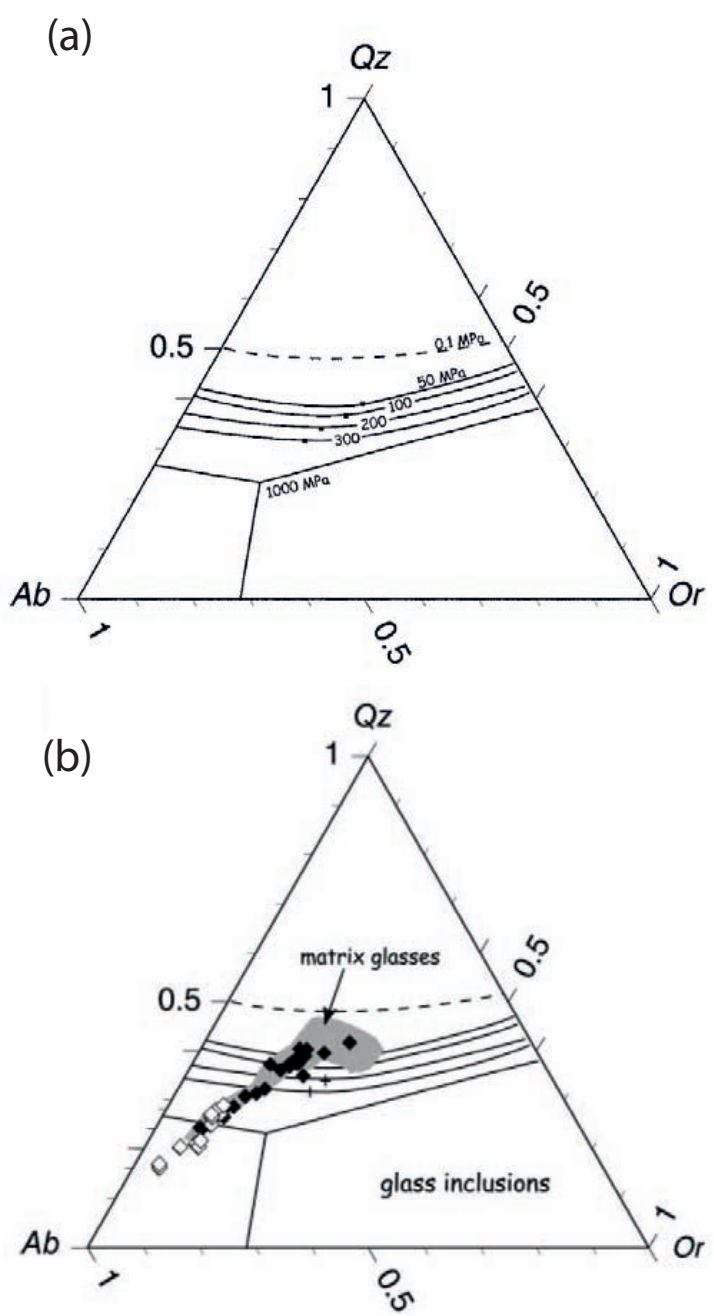

Figure 2.11: The haplogranite, Q-Ab-Or system, figures from Blundy and Cashman (2001). (a) Cotectic lines and compositions of $\mathrm{H}_{2} \mathrm{O}$ saturated minima and eutectics as a function of pressure, units are in weight fraction. (b) Projection of the composition of glass from the 1980 Mount St Helens eruption onto the Q-Ab-Or ternary. 
of igneous rocks may be further modified by outgassing or interaction with a fluid. Therefore, fresh and unaltered samples for geochemical analysis are thus required in order to determine geological processes effectively (Rollinson, 1993; Gill, 2010).

Major elements dominate the bulk composition of igneous rocks, and their abundance and variation give an insight into the depths at which melting took place and the magmatic evolution that followed. Trace elements are more sensitive to melting and crystallisation and give further insight into these processes (Rollinson, 1993). The natural variation in trace element concentrations relates to the differing geochemical behaviour of trace elements in magmatic systems. When the Earth's mantle is melted, trace elements display a preference for either the solid (mineral) phase or the melt phase (Rollinson, 1993). Trace elements which have a preference for the melt are termed incompatible elements. Those which have a preference for mineral phases are termed compatible (Rollinson, 1993). This compatibility and incompatibility will varying in different melt compositions (Rollinson, 1993). The behaviour and distribution of trace elements can be defined using the partition coefficient:

$$
K d=c_{1} / c_{2}
$$

where $c_{1}$ and $c_{2}$ are the concentrations of a trace element in the mineral and the melt, respectively.

If a trace element is equally distributed throughout the melt and mineral phase, it will have a distribution coefficient of 1.0. If a trace element is incompatible and has a preference for the melt, it will have a distribution (or partition) coefficient $<1.0$. Whereas, a compatible trace element, with a preference for the mineral 
phase will have a distribution coefficient $>1.0$ (Rollinson, 1993). Peralkaline rocks typically contain high concentrations of incompatible elements, leading to the formation of unusual accessory minerals. This is associated with higher concentrations of alkalis in the melt, which increase the solubility of these elements. For instance, Watson (1979) demonstrated that $\mathrm{Zr}$ forms a $\mathrm{NaZr}$ complex in peralkaline melt, preventing the mineral zircon from forming. This enables $\mathrm{Zr}$ concentrations to reach higher concentrations than peraluminous melts and melts lying in the quartz-orthoclase-albite composition plane.

\subsubsection{Fractional crystallisation}

The behaviour of trace elements is also determined by various geological processes, including fractional crystallisation, crustal assimilation and magma mixing.

A key process causing variation in natural silicate melts is fractional crystallisation. It has been shown that fractional crystallisation of alkaline basalts is the most likely process responsible for generating peralkaline rhyolites in the Ethiopian Rift (Walter et al., 1987; Peccerillo et al., 2007; Ukstins Peate et al., 2008; Rooney et al., 2012). Magma chambers consist of molten areas (above the liquidus temperature) and areas of crystal mush, which behave rheologically as solids. The temperature difference between the liquidus and solidus is $\sim 200^{\circ} \mathrm{C}$ in subalkaline basalts. Minerals with the highest melting temperatures will form first, leaving an increasingly acidic magma, following Bowen's Reaction Series (Fig. 2.13). Fractional crystallisation is the removal and segregation of the residual melt from the minerals it precipitates, changing the composition of the magma (Marsh, 2015). 
The equation for Rayleigh fractionation is:

$$
C_{L} / C_{0}=F^{(D-1)}
$$

where $\mathrm{C}_{L}$ and $\mathrm{C}_{0}$ are concentrations of a trace element in the melt and the initial system, respectively. $F$ is the weight fraction of the remaining melt and $D$ is the bulk partition coefficient of the fractionating assemblage.

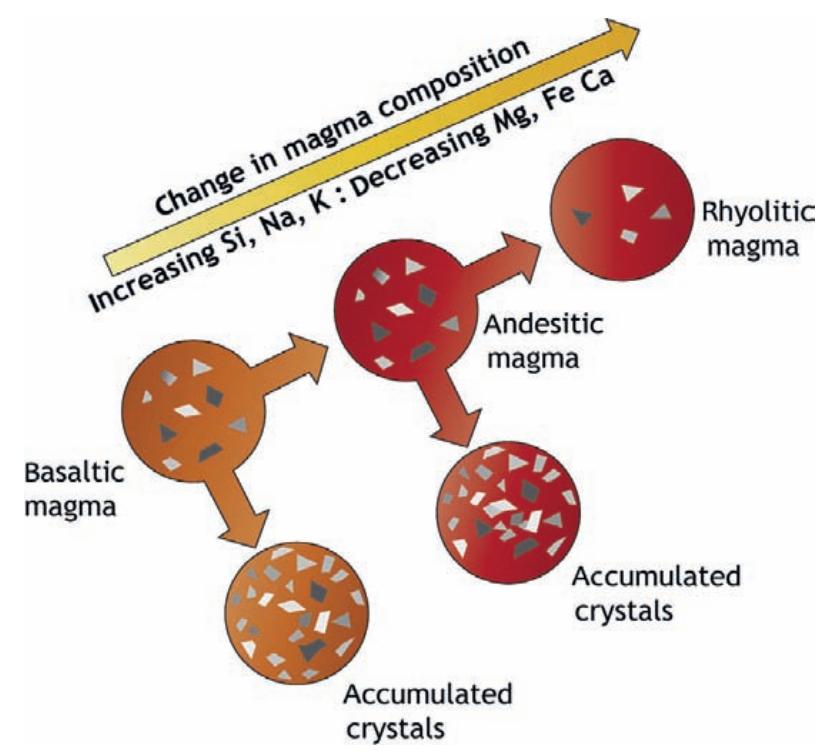

Figure 2.12: Illustration of the evolution of a subalkaline magma by fractional crystallisation as a result of cooling and removal of crystals from the melt, from Rogers (2015).

With increasing fractional crystallisation the residual magma will become increasingly fractionated or 'evolved'. Fractional crystallisation of plagioclase and olivine from basalts simultaneously increases concentrations of $\mathrm{Si}, \mathrm{Na}$ and $\mathrm{K}$ and decreases $\mathrm{Mg}, \mathrm{Fe}$ and $\mathrm{Ca}$ concentrations in the residual melt (see Fig. 2.12). With increasing fractional crystallisation, incompatible elements will also become enriched in the melt. In contrast, concentrations of compatible elements will typically decrease with increasing fractional crystallisation (Rollinson, 1993). 


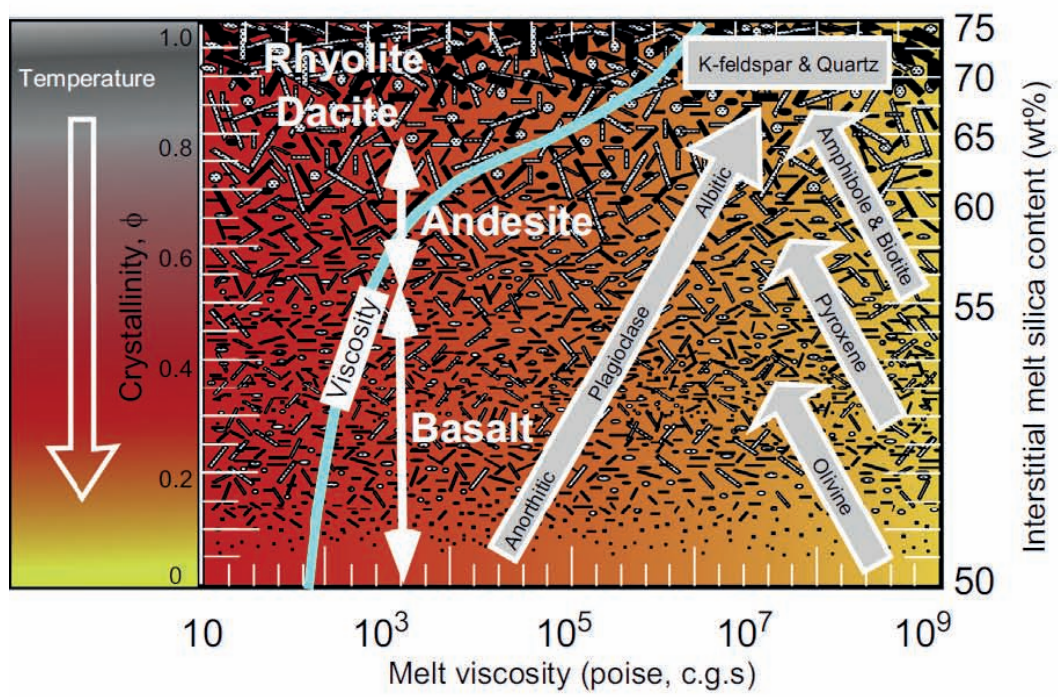

Figure 2.13: Bowen's Reaction Series operating within a zoned magma chamber from Marsh (2015). With the progression of crystallisation, the residual melt becomes increasingly enriched in silica.

The rare earth elements (REE) are amongst the most useful of trace elements for investigating petrogenic processes. The REE comprise $\mathrm{La}$ to $\mathrm{Lu}$ (atomic numbers 57 to 71) and display slight differences in size and behaviour. Therefore, petrogenic processes cause them to be differently fractionated (Rollinson, 1993). In order to study petrogenic processes, REE concentrations can be normalised to chrondritic meteorite compositions. Figure 2.14 shows chondrite normalised compositions of $\sim 3.1$ Ma rhyolitic and trachytic tephras from Ethiopia (Rooney et al., 2012). The tephras show distinct negative Eu anomalies. Europium, unlike other REE, can have a +2 valency and substitute for $\mathrm{Ca}$ in feldspars, thus this anomaly indicates that these compositions have evolved through extraction of a feldspar dominated assemblage (Rollinson, 1993). Furthermore, higher concentrations of incompatible elements in the rhyolitic tephras than the trachytic tephras reflect their more evolved composition (Rooney et al., 2012). 
Pyroclastic deposits frequently show compositional zoning, from highly evolved compositions at the base to less evolved compositions at the top. The earlier, more evolved subunits are typically more widespread due to their generally greater crystallinity and viscosity. This compositional change is a result of the eruption tapping a zoned magma chamber, containing more evolved compositions and the top and denser, less evolved compositions at the base. For example, proximal tephra from the Laacher See $\sim 12.9$ ka eruption (Reide et al., 2011) exhibits dramatic colour changes upwards, associated with the tapping of a compositionally zoned magma chamber.

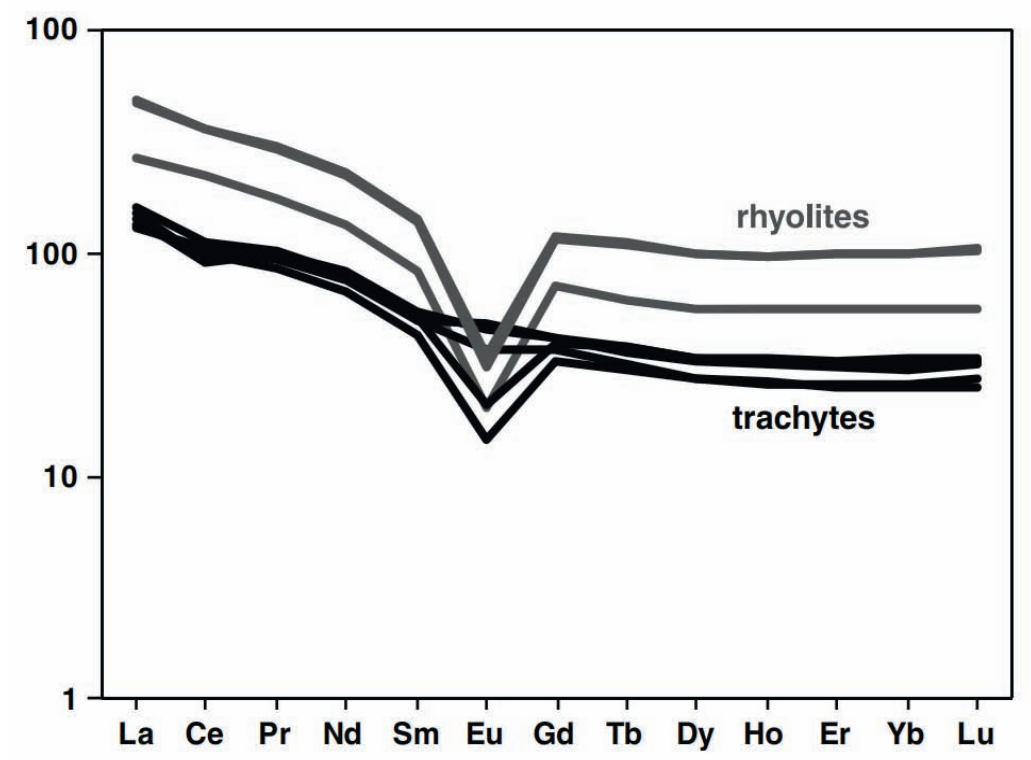

Figure 2.14: Spiderdiagram showing chondrite normalised compositions of tephras from Chefe Donsa, Ethiopia, from Rooney et al. (2012).

\subsubsection{Assimilation fractional crystallisation}

Crustal assimilation is believed to contribute significantly to the diversity of natural magma compositons in continental regions (Gill, 2010). During fractional 
crystallisation, latent heat is realised and passes through and promotes the melting of the wall-rocks (Marsh, 2015). Peccerillo et al. (2007) studied the role of assimilation of Precambrian crust in generating peralkaline rhyolitic magmatism from the Gedemsa Volcano, Ethiopia. Ratios of incompatible elements, particularly large ion lithophile and high field strength elements (LILE/HFSE, e.g. Rb/Nb, Th/Ta, La/Ta, Rb/Zr) are higher in the Precambrian rocks than the Gedemsa volcanic products. Large ion lithophile elements are more incompatible than HFSE during crustal assimilation and therefore melting preserves or increases LILE/HFSE ratios (Watt and Harley, 1993; Beard et al., 1994; Ayres and Harris, 1997). Concentrations of Rb are higher in the crust than the mantle, and therefore $\mathrm{Rb}$ and $\mathrm{Sr}$ radiogenic isotopes are frequently used to identify assimilation (Rollinson, 1993).

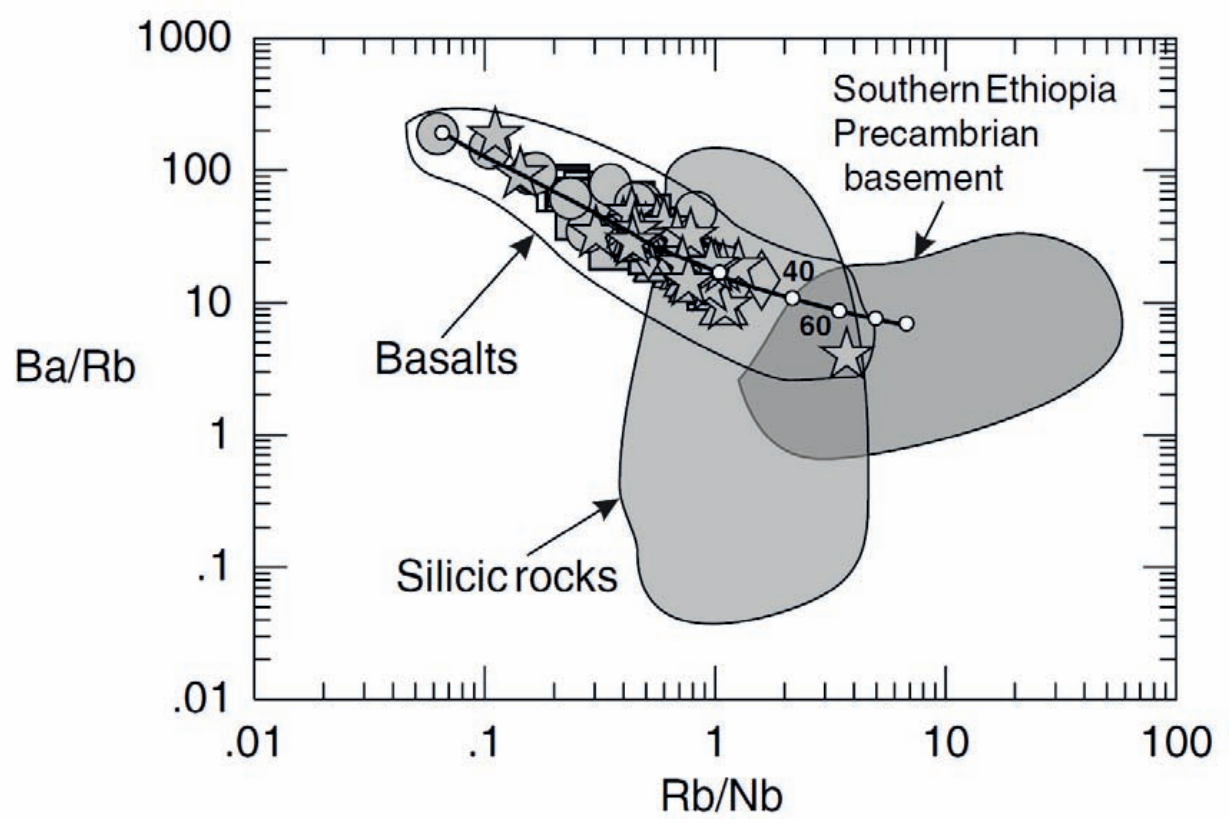

Figure 2.15: $\mathrm{Ba} / \mathrm{Rb}$ vs. $\mathrm{Rb} / \mathrm{Nb}$ diagram for basaltic rocks from the Ethiopian Rift, from Peccerillo et al. (2007), compared to compositional fields occupied by Precambrian basement and silicic rocks. The thick black line represents an assimilation trend of Precambrian basement by basaltic magma, dots indicate the proportion of melting. 


\subsubsection{Magma mixing}

If two magmas with differing compositions come into contact prior to their eruption, they may co-mingle, producing a new intermediate composition between the end members. Mixing of two melts will therefore produce element concentrations along a simple mixing line (Rollinson, 1993). However, melts of very different compositions may not mix effectively, due to differences in their viscosity and density. For example, Walter et al. (1987) investigated the petrogenesis of the Cindery Tuff (3.9 Ma) derived from the Afar region of northern Ethiopia. This is a valuable tephrostratigraphic marker, and preserves evidence of magma mixing; containing rhyolitic, basaltic are rare intermediate glass compositions. Walter et al. (1987) suggested that, due to the non-linear array of selected major element ratios, the range of compositions was not related to simple mixing alone.

\subsubsection{The use of bi-variate plots}

Major and trace element bi-plots are of immense value for tephra studies, and can be used to:

1. Investigate the range of compositions within a tephra deposit and ascertain whether there are any magmatic trends.

2. Compare the range of glass compositions in one tephra deposit with another, specifically to identify differences and similarities.

3. Identify glass shards which are compositional outliers, e.g. accidental mineral analyses.

4. Recognise contaminant glass shards of older tephras as a result of reworking. 
Electron microprobe analyses of glass typically determine 10 major element oxides ( $\mathrm{Si}, \mathrm{Ti}, \mathrm{Al}, \mathrm{Mg}, \mathrm{Fe}, \mathrm{Mn}, \mathrm{Ca}, \mathrm{Na}, \mathrm{K}$ and $\mathrm{P}$ ) and using these elements it is possible to generate 45 different bi-variate plots (Pearce et al., 2008). However, some major elements are of more use for distinguishing between tephras. The choice of elements included in a major element plot is a function of the composition and petrogenesis of the glass. A selection of major element bi-plots showing the composition of Oligocene tephras derived from Yemen and Ethiopia (Ukstins Peate et al., 2008) are shown in Fig. 2.16. These bi-plots distinguish between some of the glass compositions and show linear compositional arrays (Fig. 2.16 b, c, d). These trends indicate that the tephras evolved through fractionational crystallisation of feldspar, clinopyroxene and Fe-Ti oxides, causing the glass to become enriched in $\mathrm{SiO}_{2}$ and depleted in $\mathrm{TiO}_{2}$, $\mathrm{MgO}$ and $\mathrm{FeO}^{T}$.

The previous discussion demonstrated that trace elements are more sensitive to magmatic differentiation. Trace elements are therefore indicative of the processes involved in their petrogeneis, and this determines which trace elements are included in bi-plots. Amongst the 25-28 trace elements typically determined by LA-ICP-MS glass analyses, the most useful are those which exhibit extreme behaviour, including the highly incompatible or highly compatible elements. Selected trace element concentrations in Oligocene tephras derived from Yemen and Ethiopia are plotted as bi-plots in Fig. 2.17 (from (Ukstins Peate et al., 2008)). Bi-plots of two incompatible elements, e.g. Nb vs. U (Fig. 5.10a), show that the tephra glass shards exhibit positive linear trends which are related to enrichment of these elements in the melt during fractional crystallisation. Ukstins Peate et al. (2008) noted that one tephra (4W) exhibited two different incompatible element arrays, suggesting that this tephra may have been reworked 


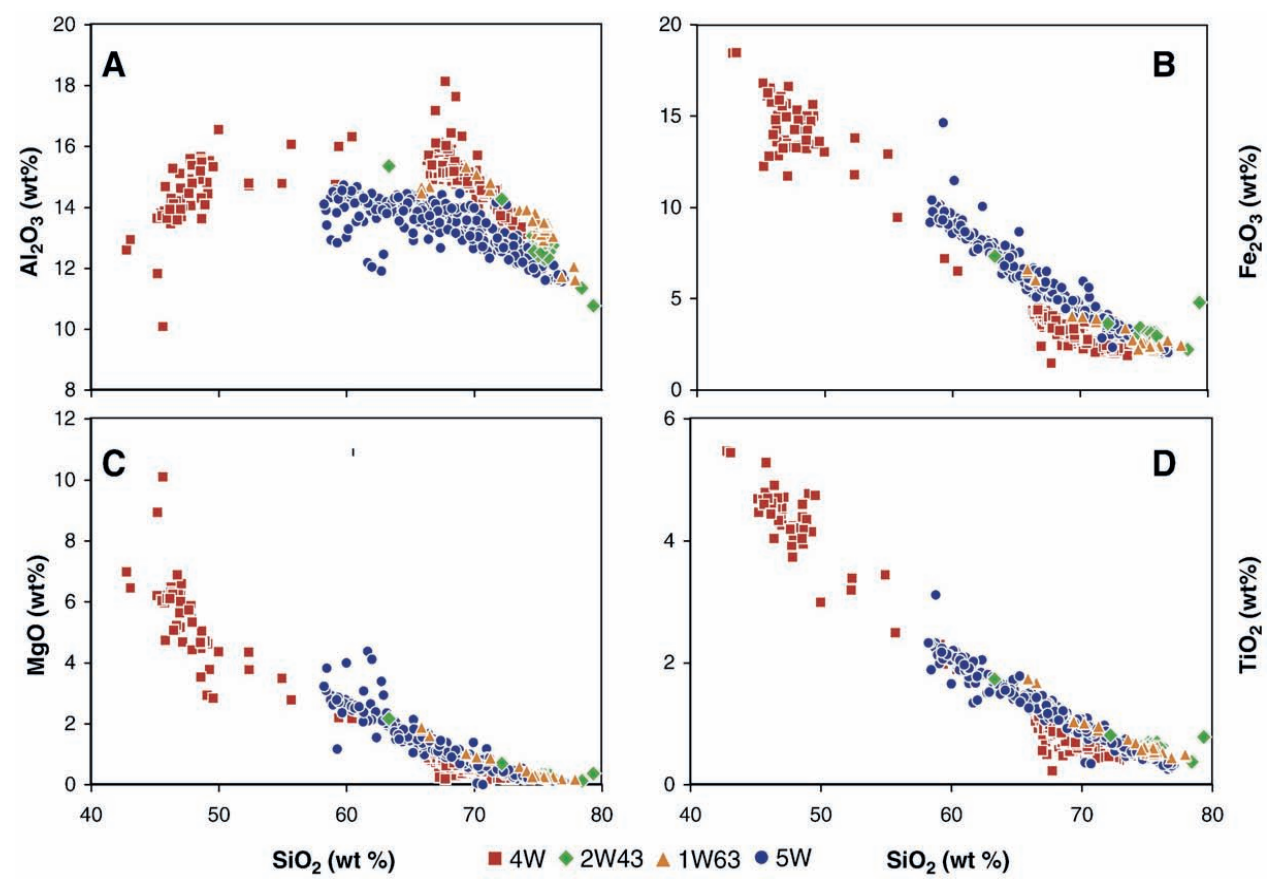

Figure 2.16: Using major element data to distinguish between tephras, an example from Ukstins Peate et al. (2008). Anydrous concentrations of selected major elements are used to distinguish between Indian Ocean tephra layers, correlated to Oligocene pyroclastic units from Yemen and Ethiopia. Data points indicate a major element analysis of a tephra glass shard, showing the full range of compositional variations in a tephra layer. 
and includes older glass compositions. Differences in these incompatible element trends may indicate that these tephras are derived from different sources, which exhibit different geochemical signatures.

Incompatible elements with similar bulk partition coefficients behave similarly during fractional crystallisation, and their relative concentrations will vary little during partial melting. Thus, the slope of the correlation line between two incompatible elements gives the ratio of the concentration of trace elements at the source volcano. This is exemplified in Fig. 2.18, which shows different incompatible element ratios for Red Sea basalts, indicating they have three different mantle sources.
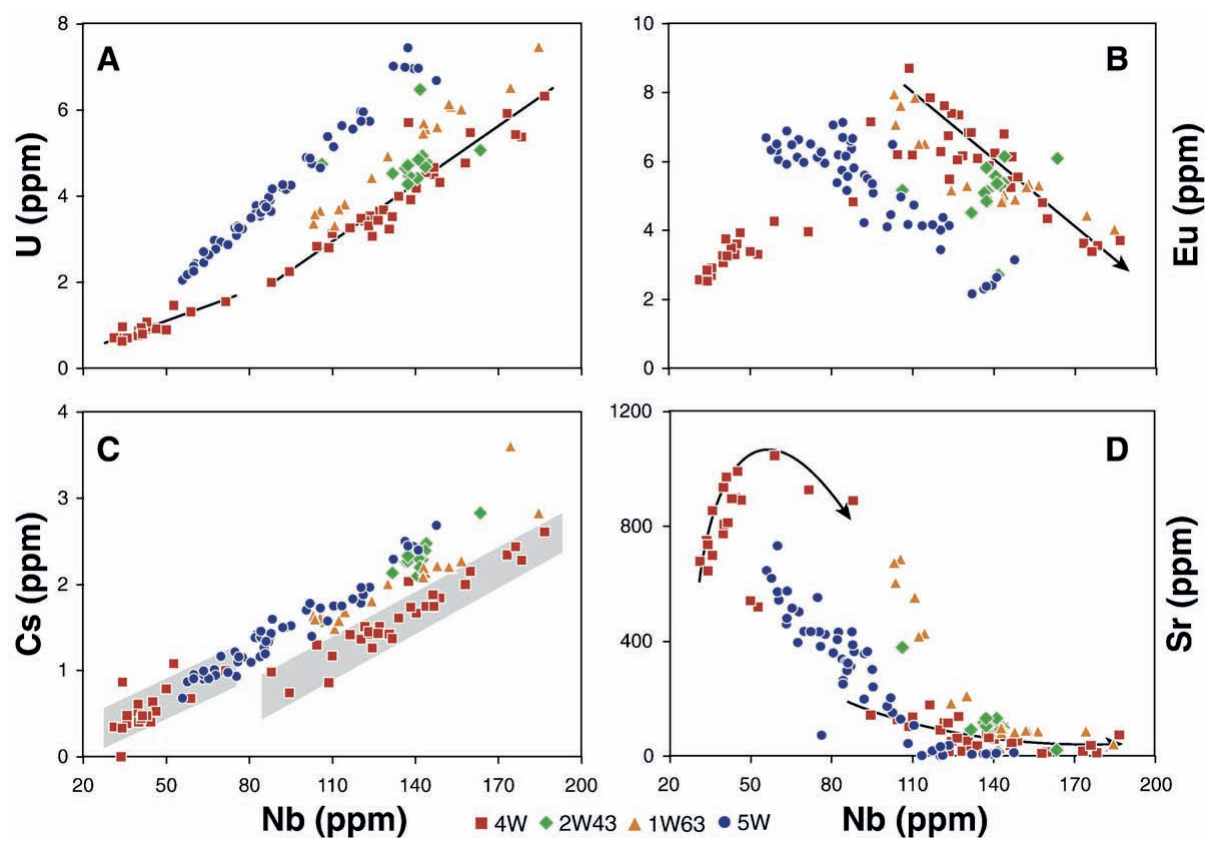

Figure 2.17: Distinguishing between tephras using trace element concentrations. Fig. from Ukstins Peate et al. (2008). Selected trace element concentrations in glass shards from NW Indian Ocean tephras, derived from Ethiopia and Yemen. Individual points indicate an analysis of a single tephra glass shard using LAICP-MS. Incompatible elements (e.g. Nb, Y) plotted against one another form strong positive linear trends. Arrows indicate changes in slope with increasing $\mathrm{Nb}$ concentrations. Tephra $4 \mathrm{~W}$ contains two compositional groups, based on $\mathrm{Nb}$ vs. Cs concentrations in the glass shards. 


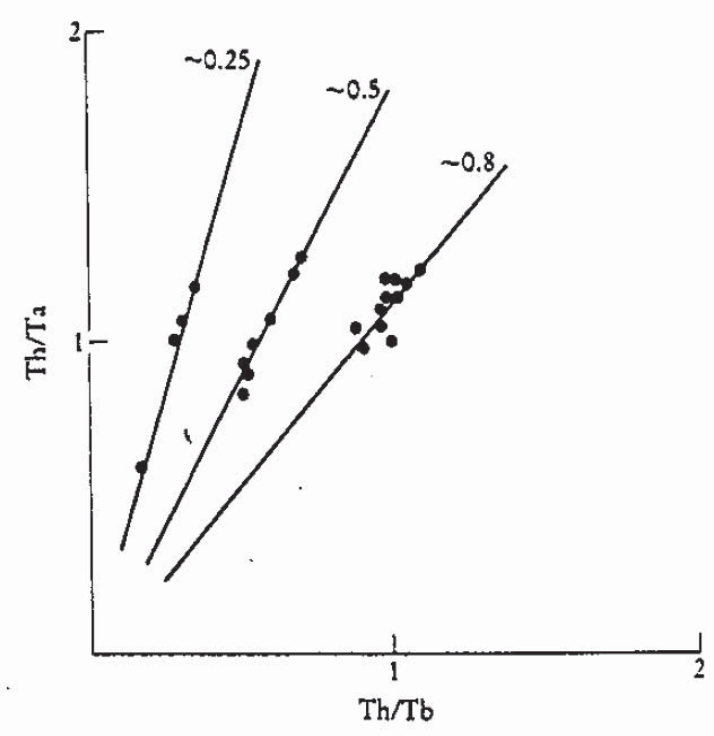

Figure 2.18: Bi-variate plot of Th/Ta vs. Th/Tb for Red Sea basalts from Eissen et al. (1989). The trends of $0.25,0.5$ and 0.8 may represent three different mantle sources.

\subsubsection{Principal component analysis}

Principal component analysis is a statistical approach which converts a large number of variables (e.g. major and trace element concentrations) into a smaller set of variables (principal components) which feature the variance of the original data set (Rollinson, 1993). The first principal component (PC 1) includes most of the variance from the original dataset and following principal components include decreasing amounts of residual variation (Rollinson, 1993; Pearce et al., 2008).

The principal components generated can then be used to produce variation diagrams, which include a large number of variables, as opposed to the typical two or three. A large data set, including multiple samples and variables is produced as part of this study, therefore PCA provides an effective means of 
testing compositional similarities between tephras noted using major and trace element bi-plots. The choice of variables (element concentrations) included in the PCA determines how effective this analysis may be for discrimination. If element concentrations which show a large amount of variance are included in the dataset, smaller scale variance may be masked. Therefore, PCA is most useful when only those tephras which cannot be clearly distinguished using major and trace element bi-plots are included in the analysis.

Pearce et al. (2008) advocate the importance of using major and trace element bi-plots in combination with PCA. The previous section has highlighted that bi-plots provide a valuable means of identifying geochemical trends, outliers and tephra reworking in a dataset. As an example, two potential correlative tephra deposits may share similar compositions and incompatible element ratios, suggesting they may derived from a shared source. However, one tephra may be slightly more evolved and PCA of their compositions may indicate they are not correlatives. However, these tephras may have been produced from a zoned magma chamber, which tapped successively less evolved compositions during the eruption. If the wind direction changed mid-eruption, more evolved compositions would be deposited in some locations and not others. Therefore, these deposits may be correlatives and this exemplifies why PCA should only be used in combination with major and trace element bi-plots.

\subsection{Dating tephras}

In addition to providing isochrons, tephra layers may also be dated using both direct or indirect methods. Primary minerals (including zircon, hornblende, orthoclase, biotite and quartz) and glass contained within the tephra may be 
directly dated, whilst materials enclosed or encapsulating a tephra may be used to indirectly date a horizon (Lowe, 2011).

Tephra may be dated using radiometric, incremental and age-equivalent methods and age-modelling of sediment sequences. These dating techniques and their application to dating tephras in East Africa are summarized in Table 2.2.

In eastern Africa, early Pliocene to late Pleistocene tephras have been directly dated to provide chronologies for hominin fossil sites (e.g. Aronson et al., 1977; Walter, 1989; Deino and Potts, 1990; Walter, 1994; Wiart and Oppenheimer, 2000; Deino and McBrearty, 2002; Deino et al., 2002, 2010). Walter (1994) dated two tephras within the Hadar Formation, Ethiopia, using ${ }^{40} \mathrm{Ar} /{ }^{39} \mathrm{Ar}$ and provided the first reliable dates for the Australopithecus afarensis fossils 'Lucy' and the 'First Family' (3.18 Ma and 3.20 Ma, respectively).

Few historical eruptions have been directly observed and documented in eastern Africa. In Ethiopia the only recorded historical eruptions are believed to have occurred from Fantale and Kone (northern Main Ethiopian Rift) during the 1800s (Harris, 1844; Gibson, 1969). In Eritrea, the Dubbi 1861 eruption, Africa's largest documented historical eruption, was observed by Captain R. L. Playfair who reported the eruption in the Times newspaper (Wiart and Oppenheimer, 2000).

Tephras throughout East Africa have also been indirectly dated using a range of techniques, from magnetostratigraphy (Shuey et al., 1974; Aronson et al., 1977; Harris, 1977; Brown et al., 1978; WoldeGabriel et al., 2001), nanofossil stratigraphy (Sarna-Wojcicki et al., 1985) to $<17$ ka Ethiopian tephras dated by radiocarbon age-modelling (Telford, 1998; Marshall, 2006).

Tephras erupted over the past $50 \mathrm{ka}$ years are typically dated using the radiocarbon technique (Lowe, 2011). In this study, the Holocene lake sediments 
investigated have been previously used for palaeoclimatic reconstruction as part of numerous studies. Therefore, the core sediments have pre-existing radiocarbon age models, which will be used to calculate modelled ages for each of the tephras. 


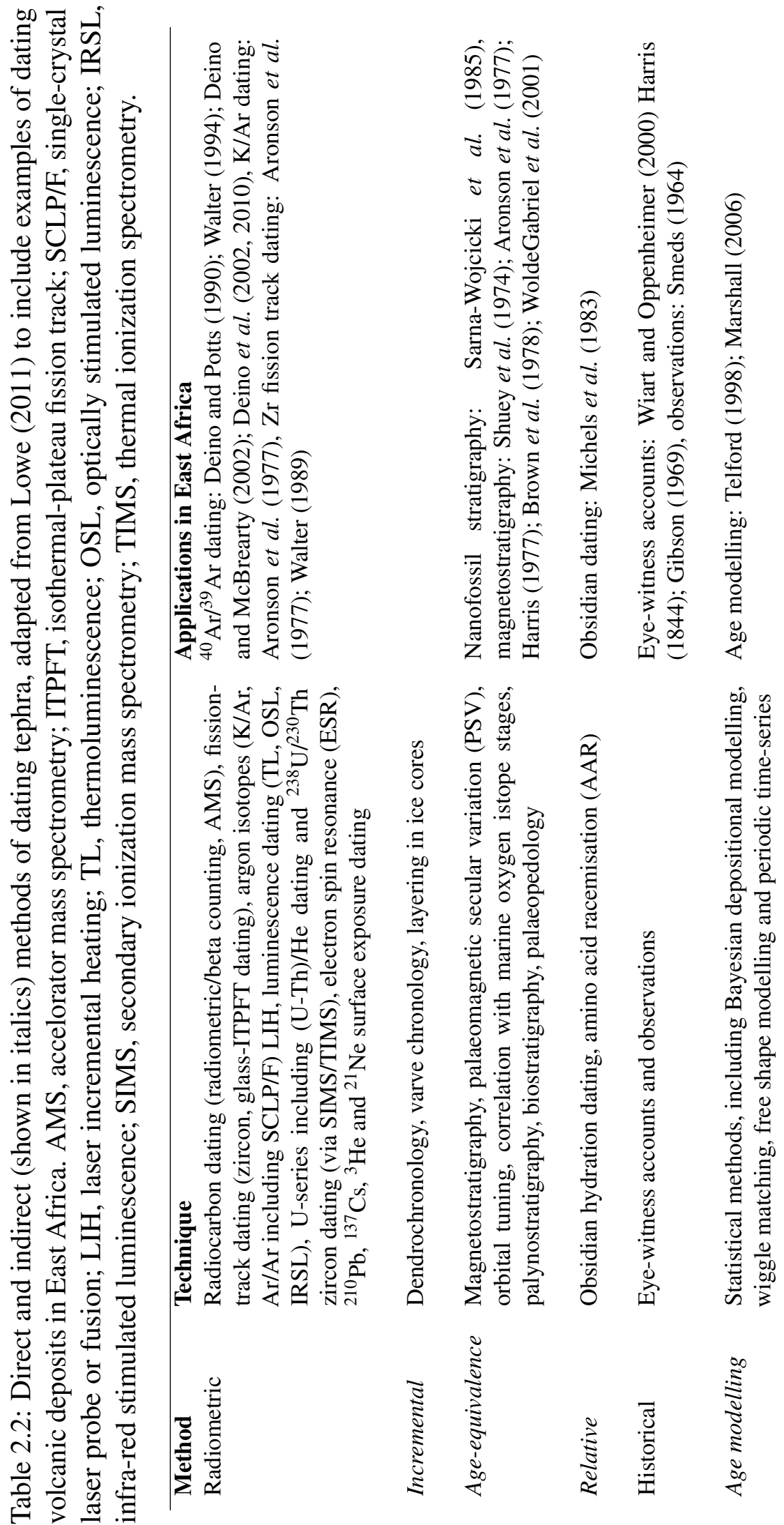




\subsection{Summary}

This section has provided a background to the tephrochronological method used in this study. Tephrochronology is a uniquely high resolution correlation tool where widespread sedimentary archives are linked and dated through tracing tephra layers. The technique has immense practical value and has been applied to an extensive range of subjects; including palaeoenvironmental reconstruction, geochronology, volcanology, archaeology, human evolution and palaeoanthropology. This section has also discussed the advances in tephrochronology, allowing identification of far-travelled cryptotephras and their accurate and precise analysis at high resolutions, enabling correlation of tephras over greater geographical areas.

This chapter has emphasized that tephra deposits in sedimentary records can also provide powerful dossiers of past volcanic eruptions, which has important implications for predicting the occurence and magnitude of future eruptions and therefore hazard mitigation. Furthermore, the potential of lake sediments for providing comprehensive tephra repositories where proximal tephra deposits may be inaccessible has been highlighted.

A brief overview of the use of geochemical data for tephra studies has been provided. Importantly, this overview demonstrated how geochemical data, coupled with principal component analysis, can be used to discriminate and correlate between tephra deposits. Additionally, this outlined how major and trace element data can be used to provide an insight into magma petrogenesis and volcanic sources.

In the forthcoming section, the significant value of tephrochronology for dating early Pliocene to late Pleistocene hominin fossil sites throughout Ethiopia and Kenya is discussed. The contrasting lack of studies on Holocene tephras in 
Ethiopia and absence of a regional volcanic history will be underlined. Through studying Holocene tephras in Ethiopian lake sediment cores, this study aims to construct a $<17$ ka tephrostratigraphy that can be used to give insight into past volcanism and to enable correlation of regional palaeoclimate archives. 



\section{Chapter 3}

\section{East African tephra studies}

This chapter discuses volcanic activity in Ethiopia and potential Quaternaryrecent tephra sources. The second section of this chapter demonstrates how Quaternary tephras have been crucial in providing age control on archaeological sites in Ethiopia and Kenya. Finally, the lack of studies on Holocene tephra deposits in Ethiopia is reviewed.

\subsection{Geological setting}

Volcanic deposits in the East African Rift System (EARS) provide a valuable record of magmatic and related tectonics processes operating in one of the best exposed continental rift systems on Earth. The EARS extends through Ethiopia and Kenya, diverging around the Tanzanian Craton to form western and eastern branches before reuniting and terminating in Mozambique (Macgregor, 2015). Offshore, a third south-eastern branch occurs along the Mozambique channel. Generally, the eastern branch of the EARS is characterized by greater volcanic activity, whereas the western branch is associated with much deeper basins infilled with larger accumulations of sediment. 


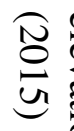

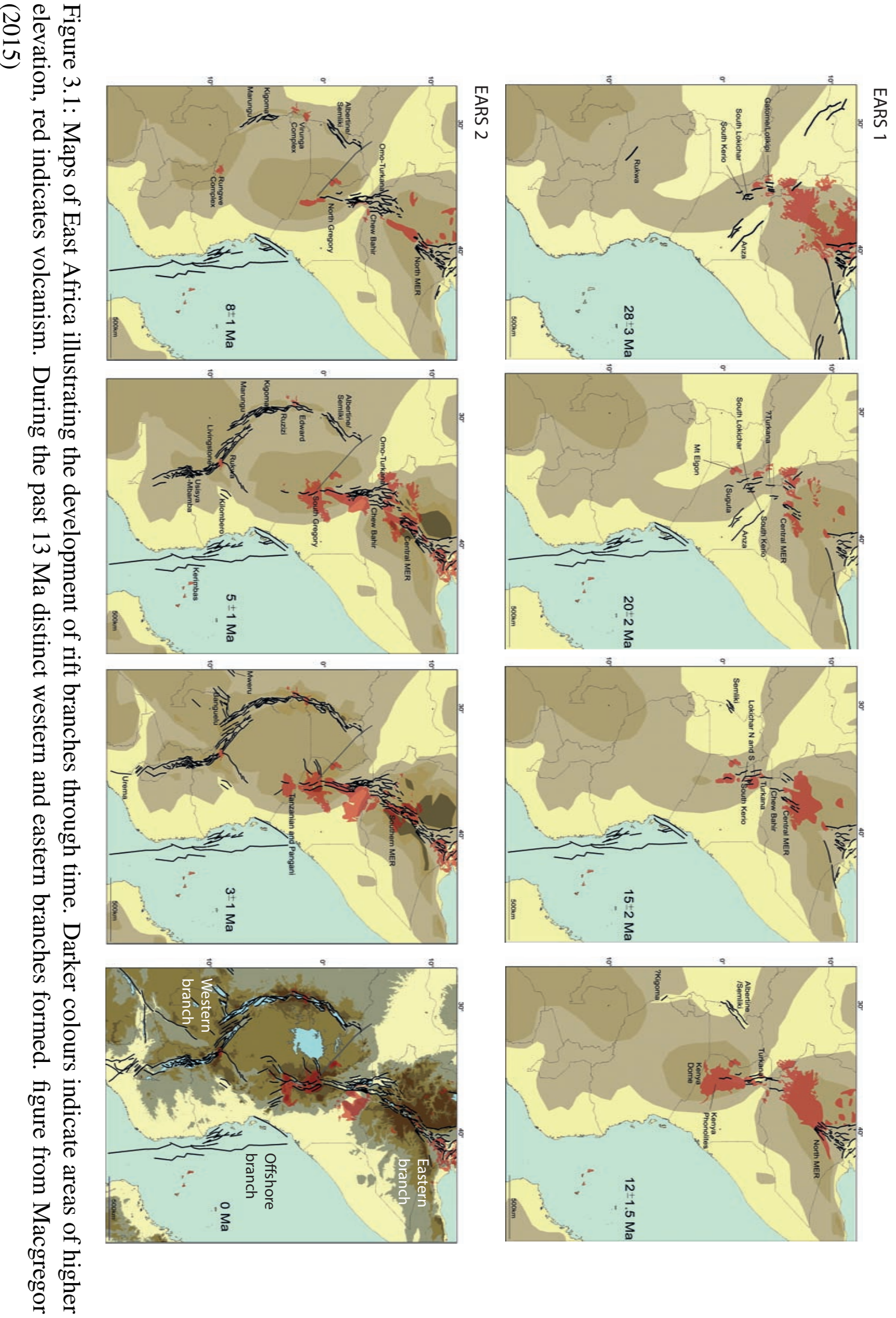


The development of the EARS and associated volcanism is summarised below. The EARS rift propagation can be divided into two phases: EARS 1; rifting confined to the Afar, S. Ethiopia and N. Kenya and EARS 2; widespread rifting forming the western and eastern branches. Rifting processes in the Kenyan and Tanzanian portion of the eastern branch are better understood than those in Ethiopia, where there are conflicting interpretations over dated volcanic outcrops.

\subsubsection{EARS 1: Oligocene - mid Miocene}

Afar Dome and trap volcanism. Rifting confined to Afar, S. Ethiopia and N. Kenya. Development of Kenya Dome.

At $35 \mathrm{Ma}$ a series of N-S trending Rifts were initiated in the South Lokichar Basin of northern Kenya (Fig. 3.1), contrasting the orientation of pre-existing faults and signifying a significant change in stress direction (Macgregor, 2015). Plume related basalt trap volcanism began in Ethiopia at $\sim 31$ Ma with rhyolitic volcanism following at $\sim 30 \mathrm{Ma}$, peak activity occurred between $\sim 31-28 \mathrm{Ma}$ (Bosworth et al., 2005).

Marine sediments were first deposited on the continental crust of the Gulf of Aden between $\sim 30-29$ Ma. The development of a small basin followed at $\sim 28-24 \mathrm{Ma}$, forming the Eritrean Red Sea. At $\sim 25 \mathrm{Ma}$ rifting in the Afar was initiated and the main phase of rifting and shoulder uplift followed at 20 Ma (Bosworth et al., 2005). During the late Oligocene early Miocene rifting commenced in the offshore branch of the EARS (Macgregor, 2015).

Rifting then shifted to the Broadly Rifted Zone of southern Ethiopia at 25-21 Ma (Bonini et al., 2005) and moved northwards to the central Main Ethiopian Rift (MER), where it was well established by $\sim 17-15 \mathrm{Ma}$ (WoldeGabriel et al., 1990). To the south; volcanism occurred in northern Kenya at $15 \mathrm{Ma}$, infilling 
the existing rift topography. Between 13.5 - 11 Ma the 1400 m high Kenya Dome developed (Macgregor, 2015).

\subsubsection{EARS 2: Mid Miocene - Recent}

Widespread rifting and development of distinct western and eastern EARS branches.

During the last $13 \mathrm{Ma}$, rifting developed two distinct eastern and western branches. The onset of this second rifting phase is marked by the migration of rifting northwards in Kenya to Turkana and the initiation of rifts in the northern part of the western EARS branch. Rifting spread south from the Afar to the central MER at $\sim 8 \mathrm{Ma}$ and activated in the Turkana, Omo and Chew Bahir basins. Major topographic development and uplift occurred in Ethiopia at $\sim 5$ Ma. Over the past $\sim 3$ Ma rifting has propagated into the southern MER and also spread southwards to Lake Malawi and Tanganyika (Macgregor, 2015).

\subsection{Volcanism and tephra deposits in Ethiopia}

Ethiopia remains one of the most active regions in the EARS and a present phase of rifting in the Manda-Hararo segment (Afar) began in September 2005; accompanied by the formation of a $60 \mathrm{~km}$ long dyke and rhyolitic eruption (Field et al., 2013).

The Ethiopian Rift System can be divided into sections; the Afar, the Main Ethiopian Rift, the Broadly Rifted Zone and the off-axis Yerer-Tullu Wellel Volcano Tectonic Lineament (WoldeGabriel et al., 2013), each characterized with unique tectonic, volcanic and geomorphic features. Volcanism within each 


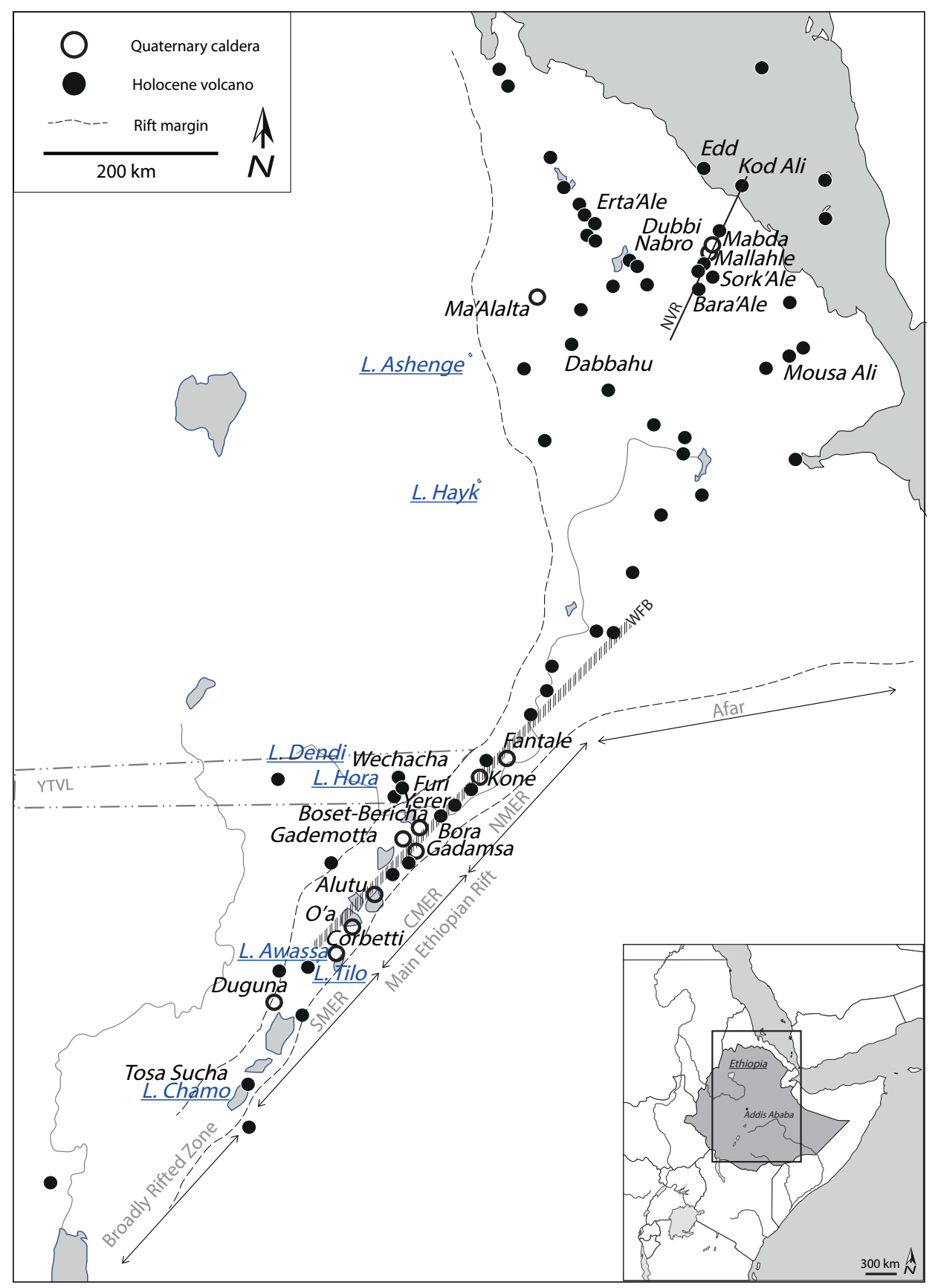

Figure 3.2: Map of Ethiopia showing Quaternary calderas and other volcanoes known or suspected to have been active during the Holocene (Siebert et al., 2011). Lake core sites used in this study are also labelled in blue. It is likely that volcanoes which have not yet been recognised, or those with unknown ages, are not plotted. The Afar Rift, Main Ethiopian Rift and Broadly Rifted Zone are shown (NMER, CMER and SMER = northern, central and southern Main Ethiopian Rifts). NVR = Nabro Volcanic Range (N. Afar), WFB = Wonji Fault Belt (Main Ethiopian Rift), YTVL = Yerer-Tullu Wellel Volcano Tectonic Lineament (E-W trending lineament on the Ethiopian Plateau). 
of these sections of the Ethiopian Rift System is discussed below; with particular reference to Quaternary-recent tephra producing eruptions.

\subsubsection{The Afar Rift}

The Afar Rift possesses a funnel shape spanning $\sim 300 \mathrm{~km}$ in width and $\sim 600$ $\mathrm{km}$ from north to south. The rift is bounded by the Ethiopian and Somalian Plateaus and the Red Sea, marking the junction between the Arabian, Somalian and African plates (Mohr, 1978). Geological expeditions between 1968 - 1973 (CNR-CNRS Afar Team 1973) lead to a four-fold classification of volcanic features in the Afar (Barberi and Varet, 1977); namely the centres associated with the Afar Stratoid Series and transverse, axial and marginal centres.

Flood basalts and ignimbrites were emplaced in the Afar at $\sim 31 \mathrm{Ma}$, reaching thicknesses of $\sim 2 \mathrm{~km}$ (Ebinger et al., 1993; Hofmann et al., 1997; Wolfenden et al., 2004). Miocene igneous rocks were then emplaced; including peralkaline granites $(26-22 \mathrm{Ma})$, trap basalts $(25-12 \mathrm{Ma})$, the Mabla rhyolite series $(14-10 \mathrm{Ma})$ and the Dahla series of basalt flows $(8-6 \mathrm{Ma})$ (Barberi and Varet, 1977).

During the Pliocene-Pleistocene the Afar Stratoid Series was extruded; consisting of basalt flows attaining $1500 \mathrm{~m}$ in thickness and silicic centres. At $\sim 4$ Ma E-NE trending volcanic centres were produced; comprising basaltic transverse centres towards the Red Sea (e.g. Dubbi) and silicic marginal centres and calderas on the borders of the Afar (e.g. Nabro, Ma'Alalta) (Barberi and Varet, 1977). Quaternary axial centres occur along NW-SE trending rift zones, associated fissure eruptions and shield volcanoes produced basalt flows and alkaline silicic rocks. These axial zones are typically interpreted as the equivalent of oceanic spreading centres (Barberi et al., 1974). 
The $100 \mathrm{~km}$ long Erta'Ale range, in the northern apex of the Afar triangle is a renowned and well-studied axial volcano in the region (Wiart and Oppenheimer, 2004; Mohr, 1978). The Quaternary axial volcano, Dabbahu, differs from typical axial volcanoes, showing a full fractional crystallisation suite from alkaline basalts to peralkaline rhyolites and has an estimated eruption volume of $\sim 115$ $\mathrm{km}^{3}$. Dabbahu is one of the closest $(<70 \mathrm{~km})$ volcanoes to the Ashenge lake core site, studied here. Field et al. (2013) describe extensive deposits of pumice of $\sim 10 \mathrm{~m}$ thickness on the flanks of Dabbahu. This variation is due to its location at a higher elevation, at a shallower axial orientation and its closer proximity to the crystalline scarp border (Wiart and Oppenheimer, 2004). Fission track dates on obsidians from the upper flanks give ages of $\sim 44 \mathrm{ka}$ and $\sim 1.5 \mathrm{ka}$. An eruption $(\mathrm{VEI}=3)$ in 2005 deposited tephra over $100 \mathrm{~km}^{2}$, resulting in the formation of a small pumice cone (Ayele et al., 2007a; Ferguson et al., 2010). In September 2005 the eruption of rhyolitic ash from a small pumice cone on the northern flanks of Dabbahu and the largest dike-opening event ever witnessed reawakened interest in the volcano (Field et al., 2013).

Whilst the basaltic axial ranges of the Afar rift are well studied (Barberi et al., 1970; Barberi and Varet, 1977; Oppenheimer and Francis, 1997; Amelung et al., 2000), few marginal and transverse centres have been studied and only smaller silicic centres, including Ma'Alalta (Barberi et al., 1970) and Mousa Alli (de Fino et al., 1973) have been described in any detail. Wiart and Oppenheimer (2004) demonstrate that large magnitude caldera forming eruptions are associated with marginal and transverse centres. The poorly studied Nabro Volcanic Range (NVR) runs for $\sim 100 \mathrm{~km}$ from the margin of the Danakil Depression to the Red Sea and has a subaerial volume of $550 \mathrm{~km}^{3}$. Wiart and Oppenheimer (2004) suggest that this volcanic range was the source of many large magnitude 
silicic eruptions during the Quaternary. Several volcanoes comprise the NVR, including Sork'Ale, Bara'Ale, Mallahle, Nabro, Mabda, Dubbi, the Edd lava field and Kod Ali island located in the Red Sea (Wiart and Oppenheimer, 2004). There is a general trend of younging volcanism westwards along with NVR, associated with the change from mafic to ultramafic products of Kod Ali in the Red Sea, to trachytic tephra and basaltic lava erupted from Dubbi in the east to the youngest rhyolitic products of Nabro and Mallahle in the west (Wiart and Oppenheimer, 2000). Nabro volcano itself, standing at 2,248 $\mathrm{m}$ high, marks the highest point of the NVR, and is formed of a double crater concomitant with the eruption of $20-100 \mathrm{~km}^{3}$ of ignimbrite, which may have formed a regional tephra stratigraphic marker (Wiart and Oppenheimer, 2004). In 2011, the first recorded eruption from Nabro occurred, satellite images show the eruption plume drifting over Sudan, $\sim 1000 \mathrm{~km}$ to the NW, and the ash clouds disrupted international flights over Eritrea and Ethiopia (Siebert et al., 2011; Goitom et al., 2015). Dubbi volcano, on the Red Sea coast, is responsible for the largest known historical eruption in Africa (Mohr, 1978; Wiart and Oppenheimer, 2004). The 1861 eruption was recorded by maritime traffic in the Red Sea; it is reported to have deposited volcanic ash $400 \mathrm{~km}$ to the west on the Ethiopian Plateau and a subsequent effusive phase produced lava flows with a volume of $3.5 \mathrm{~km}^{3}$ (Wiart and Oppenheimer, 2004).

Archives from Lakes Ashenge and Hayk (Ethiopian Highlands) are used in this study; these are located $<70 \mathrm{~km}$ from the volcanoes in the Afar, it is therefore possible that tephras from these volcanoes may be found in these records. 


\subsubsection{The Main Ethiopian Rift}

The MER is a symmetrical graben, bounded by normal step faults and antithetic faults, lying between $5^{\circ}-9^{\circ} \mathrm{N}$ and $37^{\circ} 30-40^{\circ} \mathrm{E}$. Volcanism in the Main Ethiopian Rift (MER) can be broadly split into two phases, reflecting rifting stages. During the Mio-Pliocene volcanism occurred throughout the whole MER, associated with the activity of large boundary fault systems. Deformation and magmatism within the MER is controlled along the Wonji Fault Belt; a 5-12 km wide, NNE-SSW orientated system of en echelon faults associated with Quaternary calderas (Gibson, 1967; WoldeGabriel et al., 1990; Boccaletti et al., 1999). Pyle (1999) states that the MER was most likely the source of explosive volcanic eruptions during the Quaternary. The MER, can be further subdivided into northern, central and southern sections; volcanism within these sections is described below.

\subsubsection{Northern MER}

In the northern MER, the first volcanic deposits were flood basalts related to the Afar plume, erupted at $30 \mathrm{Ma}$ and shield volcanoes subsequently developed on the rift shoulders (Corti, 2009). During the Mio-Pliocene, syn-rift widespread ignimbrites were deposited across the northern MER with intercalated minor silicic and mafic lavas (Chernet et al., 1998). Upper Pliocene basalts (3.5 - 1.6 Ma) and contemporaneous rhyolitic pyroclastic deposits (2.5 - 1.7 Ma) outcrop above (Corti, 2009). Subsequent, syn-rift bimodal volcanic activity is spatially associated with the oblique faults of the Wonji Fault Belt (WoldeGabriel et al., 1990).

The large caldera forming eruptions are typically characterised by trachytic to peralkaline rhyolitic compositions, with a lack of intermediate compositions 
(Corti, 2009). This volcanism is typically $<1.8 \mathrm{Ma}$ (WoldeGabriel et al., 1990; Chernet et al., 1998; Wolfenden et al., 2004), forming large scale calderas at Gademotta, Gadamsa, Kone , Fantale, Bora and Corbetti. Volcanism continued until Holocene-historic times (Corti, 2009). Di Paola (1972) states that Holocene volcanic deposits occur inside the caldera of Gadamsa and Boset-Boricha, which are presently at fumarolic stage. Fantale (Fentale) and Kone (Garibaldi), erupted during the 1800's. Fantale is one of the most active volcanoes in the Ethiopian Rift, it reaches $\sim 600 \mathrm{~m}$ a.s.l. and is topped by a central elliptical caldera of $\sim 3.5 \mathrm{~km}$ diameter and $\sim 300 \mathrm{~m}$ depth (Acocella et al., 2002). The volcano is constructed predominantly from trachytic and alkali rhyolitic tuffs and lava flows erupted from a zoned magma chamber (Webster et al., 1993; Giordano et al., 2014). An eruption from the volcano during the 13th century destroyed a town to the south (Siebert et al., 2011) and two recent episodes of basaltic volcanism produced a lava flow covering $\sim 3 \mathrm{~km}^{2}$. The latest of these was produced by an eruption dated by historical reports and oral tradition to AD 1820 (Gibson, 1967). The Kone volcanic complex is located $\sim 30 \mathrm{~km} \mathrm{SW}$ of Fantale (Fig. 3.2). It is composed of two calderas, measuring $\sim 8 \mathrm{~km}$ and $\sim 11 \mathrm{~km}$ each, which may be associated with the formation of a regional tephra marker (Rampey et al., 2010).

\subsubsection{Cental MER}

Early flood basalt extrusion ( $30 \mathrm{Ma}$ ) also occurs throughout the central MER. Preceding the main rifting, late Miocene ( $11-8 \mathrm{Ma}$ ) basalts and trachybasalts were erupted (Corti, 2009). The onset of major rifting was marked by bimodal volcanism; characterised by voluminous silicic pyroclastics and associated minor basalts which occur extensively across the rift floor and attain thicknesses of $<700 \mathrm{~m}$. These ignimbrites are associated with large calderas; including the 
3.5 Ma 'Munesa Crystal Tuff caldera, presently buried beneath the Ziway-Shala lakes. This caldera produced the 3.446 Ma Sidi Hakoma Tuff ; one of the only regional tephras in Ethiopia to be traced to its source (WoldeGabriel et al., 2013). Subsequent volcanism during the Quaternary $(<1.6 \mathrm{Ma})$ was related to the oblique faults of the Wonji Fault Belt. The bimodal volcanism is associated with major ignimbritic eruptions from large scale calderas; including Duguna, Corbetti and Aluto, O'a (Shalla) (Pyle, 1999; Corti, 2009). The collapse volume of these calderas ranges from $\sim 3$ to $\sim 45 \mathrm{~km}^{3}$, however, O'a, active between $280-180$ $\mathrm{ka} \mathrm{BP}$, is estimated to have had a collapse volume of $120 \mathrm{~km}^{3}$ (WoldeGabriel et al., 1990).

Holocene pyroclastic deposits and obsidians occur at Alutu and Corbetti (Di Paola, 1971, 1972). The $15 \mathrm{~km}$ wide Quaternary Corbetti caldera, located in the central MER, is superimposed on the Pliocene, $30 \mathrm{~km}$ wide, Awassa caldera. Corbetti is the closest volcano to two sites studied here, $<40 \mathrm{~km}$ from Lake Tilo and Lake Awassa is situated in the Awassa caldera.

The recent volcanic history of the Corbetti caldera is poorly documented (Hutchison et al., 2015). The Corbetti caldera is formed exclusively of pyroclastic deposits, including ignimbrite deposits intercalated with pumice and ash layers (Di Paola, 1971). Following the collapse of Corbetti; a large pyroclastic volcano, Wendo Koshe and a composite volcano, Chabbi, emerged in the centre of the caldera during the late Pleistocene (Rapprich et al., 2016). The Chabbi volcano occurs on the eastern margin of the Corbetti caldera, and is constructed from obsidian lava flows, interbedded with pumice fall deposits (Di Paola, 1971; Rapprich et al., 2013, 2016). The Wendo Koshe volcano is located to the west of Chabbi, it is formed of interbedded pumice deposits with a 'monotonous' appearance, thus the eruptive history of this centre is difficult to constrain 
(Rapprich et al., 2016). The most recent eruption from Wendo Koshe at 400 BC formed a widespread pumice deposit, described by Žáček et al. (2014) and Rapprich et al. (2016). This retains a thickness of $10 \mathrm{~cm}$ over $1000 \mathrm{~km}^{2}$ and has been reworked in the Corbetti caldera, and redeposited on the shores of Lake Awassa.

Sediment cores from Lakes Awassa and Chamo are used in this study to construct a tephra framework. These lakes are located proximal to volcanoes in the CMER which may have been active during the Holocene; notably Lake Awassa is formed within the Corbetti caldera. The approach taken in this study, where the distribution of Holocene tephras is mapped, is key to further understanding the scale and hazards posed by these volcanoes, including those which are showing recent signs of unrest.

\subsubsection{Southern MER}

In the southern MER a basaltic phase of volcanism occurred at $11 \mathrm{Ma}$, resulting in the eruption of stratoid basalts. During the upper Miocene-lower Pliocene, volcanism was markedly reduced, to be resumed in the late Pliocene-early Pleistocene with bimodal volcanism and the eruption of widespread ignimbrites (1.6-0.5 Ma) (Bonini et al., 2005; Corti, 2009). At $0.66 \mathrm{Ma}$, trachybasalts, pumice deposits and obsidian flows were emplaced in the Tosa Sucha (northern shores of Lake Chamo). Fissure eruptions and scoria cones have also been emplaced in the Tosa Sucha area during historic times (Corti, 2009).

This study investigates the tephra record preserved in sediments from lake Chamo. There is a lack of recent explosive volcanic activity in the southern MER. Therefore, the Chamo archive may provide a valuable record of distal volcanism from the central and northern MER, and potentially the Afar. 


\subsubsection{The Broadly Rifted Zone, SW Ethiopia}

The $300 \mathrm{~km}$ wide, broadly rifted zone of SW Ethiopia represents the most southerly set of N-S trending basins comprising the EARV. The zone forms the northern extension of the Kenya rift and is made up of three half grabens and a fully developed rift basin. The oldest 45 Ma flood basalts outcrop in the broadly rifted zone (Davidson and Rex, 1980; Ebinger et al., 1993; George et al., 1998). In contrast with the MER, no post-rift volcanic eruptions have been noted in the broadly rifted zone, except for early Pliocene basaltic flows to the north of the failed Chew Bahir rift (WoldeGabriel et al., 2013). The broadly rifted zone represents the waning stages of tectonic and volcanic activity to the north of the Kenyan Rift and displays the characteristics of rift basin terminations (WoldeGabriel et al., 2013).

\subsubsection{Off-axis volcanism: The YTVL}

The Yerer-Tullu Wellel Volcano Tectonic Lineament (YTVL) is an E-W trending fault system or failed rift which extends for $>500 \mathrm{~km}$ from Addis Ababa (Mount Yerer) to the border with Sudan (Tullu Wellel). Two volcanic successions outcrop along the YTVL. The Oligocene - lower Miocene lower succession consists of strongly weathered and faulted flood basalts and associated phonolitic domes (Abebe et al., 1998). The upper volcanic succession is of late Miocene - recent age and is comprised of central volcanoes and small domes aligned in an E-W direction (Abebe et al., 1998). The central volcanoes young from $12-7 \mathrm{Ma}$ in the west (Tullu Wellel) to $<1 \mathrm{Ma}$ in the east (Wenchi, Dendi and Bishoftu) (Adhana, 2014). Volcanism along this volcanic lineament generally becomes more alkaline and less silica saturated towards the west (Adhana, 2014). Lake sediment cores from Lakes Dendi and Lake Hora (Bishoftu) are used in this 
study; both of the lakes are located on the YTVL and therefore may record tephras erupted from this region. A volcanic eruption at $\sim 1400$ BP may have occurred from Mount Wenchi, $13 \mathrm{~km}$ to the southwest of Lake Dendi (Smeds, 1964).

\subsubsection{Quaternary tephras from further afield}

This study focuses on tephras in Ethiopian lake sediments; there is potential for some of these tephras to be derived from further afield. Potential sources of recent tephras throughout Africa, the Mediterranean, Middle East and Atlantic are outlined briefly below.

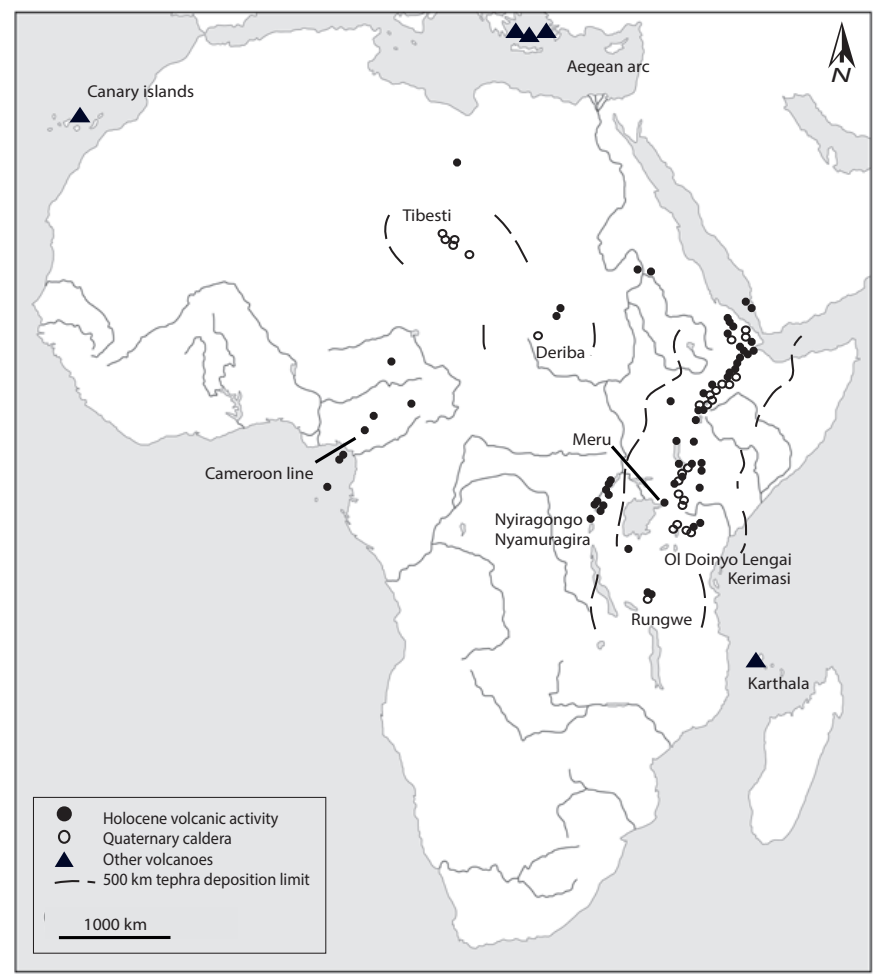

Figure 3.3: Tephra sources from further afield: in Africa, the Mediterranean, Middle East and Atlantic 


\subsubsection{Potential tephra sources in other areas of the EARS}

In the eastern branch of the EARS; trachytic volcanoes in central and southern Kenya have undergone cycles of Krakatoan style collapse, producing voluminous ignimbrite and fall deposits, however few have been correlated. In the Tanzanian sector of the rift, Kerimasi and Ol Doinyo Lengai volcanoes have produced carbonatitic tephra which are regarded as the sources of surface limestones $\sim 100$ $\mathrm{km}$ to the west on the Crater Highlands and Serengeti Plains (Pyle, 1999). One of the largest volcanoes in Africa, Meru, located to the south of Kilimanjaro, exhibited major volcanic activity over the past 300 ka years and experienced large-scale collapse at 7.8 ka years BP producing widespread tephra which is likely to form a prominent distal tephra marker (Wilkinson et al., 1986; Pyle, 1999). Tephra layers from Meru, recorded in sediments from Lake Challa (S. Kenya), indicate that Meru erupted explosively at least five times throughout the Holocene (C. Lane 2015, pers. comm. 15th Jan 2015). The western sector of EARS produced large volumes of basalt from the Nyamuragira and Nyiragongo centres, however, the only explosive volcanism during the Quaternary occurred in the Rungwe mountains to the north of Lake Malawi (Pyle, 1999).

\subsubsection{Potential tephra sources in central and northern Africa}

Quaternary volcanism in central and northern Africa is, in contrast to that in eastern Africa, typically of a smaller scale. Numerous volcanic calderas are visible in the Tibesti mountains and are believed to be of Quaternary age. The Deriba caldera to the east, in Sudan, is regarded as Holocene in age (Pyle, 1999). 


\subsubsection{Potential tephra sources in western Africa}

The volcanoes comprising the Cameroon line in western Africa are thought to have been active during the Quaternary. However, they tend to produce more localised alkaline and basaltic lavas as opposed to widespread pyroclastic deposits. In western Senegal and the Tefidet rift Quaternary volcanism is also recorded, however, no significant tephra production has been attributed to these centres (Pyle, 1999). The distance of these volcanoes from Ethiopia and their localised eruptions means that is unlikely that tephras will be recorded in lake sediments studied here.

\subsubsection{Potential tephra sources in the Mediterranean, Middle East and Atlantic}

Pyle (1999) suggests that major explosive eruptions from caldera volcanoes in the Mediterranean, Middle East and the Atlantic have the potential to disperse distal tephra layers across Africa. Glass shards from the $\sim 3.5 \mathrm{ka}$ Minoan eruption of Santorini have been recorded the sediments of Lake Manzala, in the north-eastern section of the Nile Delta (Eastwood et al., 1999). Distal tephras from the Canary Islands have been recorded in DSDP cores from the west African continental margin and Pyle (1999) suggests these tephras may also have been deposited on the western coast of Africa. Holocene volcanism occurred on the Indian ocean islands of Comoros, Madagascar and Reunion, however, the deposits are primarily basaltic and therefore the likelihood of voluminous tephra production is low (Pyle, 1999). Microscopic cryptotephra from the $\sim 75$ ka Younger Toba Tuff, the largest eruption of the Quaternary, has recently been discovered in lake sediments from Malawi, extending the known dispersal limits of this eruption 
(Lane et al., 2014). This was however, an exceptional event and as of yet, no other eruptions of this nature have been located in the tropics.

\subsection{Tephra studies in East Africa}

Geological and palaeoanthropological exploration of Ethiopian Rift basins over the past 50 years has led to the discovery of the most comprehensive record of human biological and technological change extending over the last 6 million years (WoldeGabriel et al., 2013). Since the discovery of the first fossil remains from Olduvai Gorge (Tanzania) (Leakey et al., 1961), hominid fossils have been recovered from the Afar Rift, Main Ethiopian Rift and the Omo Basin of the broadly rifted zone of SW Ethiopia (see Fig. 3.4). Determining accurate temporal and contextual constraints for these records is crucial.

Early Pliocene to late Pleistocene distal and proximal tephras identified across Ethiopia, Kenya and in marine sediments from the Gulf of Aden and NW Indian Ocean provide key chronological control on these hominin fossils. The tephras have proved essential in unravelling our understanding of hominid evolution and furthermore have resolved controversial ages of the hominin fossils, including age of the renowned 'Lucy' Australopithecus afarensis fossils from Hadar (Afar) (Brown and Cerling, 1982).

The successful application of tephrochronology in eastern Africa is exemplified by the Turkana Basin (northern Kenya). The site is one of the most well preserved and chronologically controlled Plio-Pleistocene fossil records in eastern Africa, containing a total of 135 tephra layers (Feibel, 1999, 2011). Many of the regional tephras were first described in the Turkana Basin by Howell (1968); Bowen and Vondra (1973); Brown and Feibel (1986) during the late 


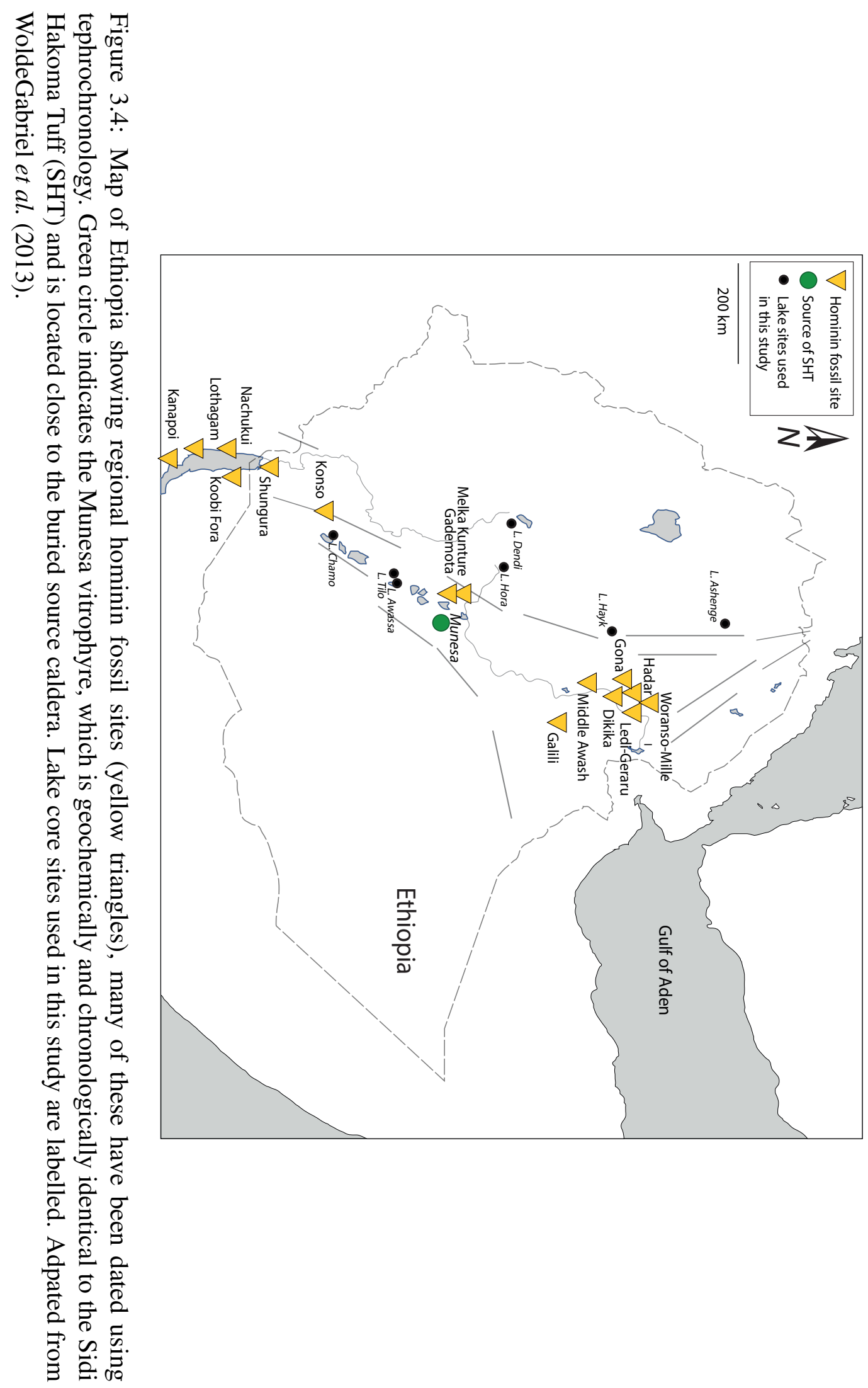


1960s. The first local tephra correlations within the Turkana Basin were based on outcrop tracing and lithological features (Brown, 1969; Brown et al., 1970). This approach proved successful in the Lower Omo Valley section of the Turkana basin, however, correlations were unsuccessful in Koobi Fora Region due to it's complex stratigraphy (Feibel, 1999).

The potential for tephra correlation on a basinal scale in Turkana was realised in the $1970 s$ when three tephras were geochemically correlated between the Koobi Fora and Shungura Formations in the Turkana Basin (Cerling et al., 1979; Cerling and Brown, 1982).

Correlation over regional scales quickly became feasible when the composition of the Tulu Bor Tuff at Turkana was found to geochemically correlate with the Sidi Hakoma Tuff at Hadar in the Afar (northern Ethiopia) (Brown, 1982). Correlative units were then identified at other sites in the MER (Haileab and Brown, 1992; WoldeGabriel et al., 1992; Haileab and Brown, 1994; WoldeGabriel et al., 1999, 2005), Afar Rift (Hart et al., 1992), Uganda (Pickford et al., 1991), the Baringo Basin of N Kenya (Namwamba, 1993) and in marine sediments in the Gulf of Aden (Sarna-Wojcicki et al., 1985) and the Indian Ocean (Brown et al., 1992); linking terrestrial and marine archives.

Tephra from the East African Rift have since been correlated 2700 km away from their source volcanoes to the Gulf of Aden and the NW Indian Ocean (deMenocal and Brown, 1999; Ukstins Peate et al., 2003; Feakins et al., 2007). Feakins et al. (2007) correlated a cryptotephra in the DSDP site 231 Gulf of Aden core to the Lokochot Tuff (first described at Koobi Fora, Turkana) and identified a further 67 cryptotephras in the marine core; all originating from the East African Rift System and revealing three pulses in volcanism at $\sim 4.0-3.2$ Ma, 2.4 Ma and 1.7-1.3 Ma. 
Table 3.1: Regional tephra stratigraphic markers, their age and distribution in the eastern African rift and the NW Indian Ocean, from WoldeGabriel et al. (2013)

\begin{tabular}{lll} 
Tephra & $\begin{array}{l}\text { Age } \\
\text { (Ma) }\end{array}$ & Occurences \\
\hline $\begin{array}{l}\text { Waidedo Vitric } \\
\text { Silbo, Upper White }\end{array}$ & 0.16 & $\begin{array}{l}\text { Konso, Middle Awash, Gona } \\
\text { Omo-Turkana Basin, Konso, Gulf of Aden, NW Indian } \\
\text { Ocean } \\
\text { Omo-Turkana Basin, Konso, Gulf of Aden, NW Indian } \\
\text { Ocean }\end{array}$ \\
KBS Turoha & 1.78 & $\begin{array}{l}\text { Omo-Turkana Basin, Konso, Gulf of Aden, NW Indian } \\
\text { Ocean }\end{array}$ \\
Sidi Hakoma, Tulu Bor, & 3.45 & $\begin{array}{l}\text { Kipcherere Section (Baringo Basin), Omo-Turkana } \\
\text { Basin, central MER, Middle Awash, Hadar, Dikika, } \\
\text { Tuff B. U-10/11 }\end{array}$ \\
Lokochot & 3.57 & $\begin{array}{l}\text { Western Rift (Uganda), Kipcherere Section (Baringo } \\
\text { Basin), Omo-Turkana Basin, central MER, Middle } \\
\text { Awash, Woranso-Mille, Gulf of Aden, NW Indian } \\
\text { Ocean } \\
\text { Western Rift (Uganda), Omo-Turkana Basin, Gulf of } \\
\text { Aden, NW Indian Ocean } \\
\text { Omo-Turkana Basin, Middle Awash, Dikika, Gulf of } \\
\text { Aden, NW Indian Ocean } \\
\text { Omo-Turkana Basin, central MER, Middle Awash, } \\
\text { Gulf of Aden, NW Indian Ocean }\end{array}$ \\
Lomogol & 3.62 \\
Wargolo/VT-3 & 3.80 & 3.97 \\
Moiti/ VT-1 & &
\end{tabular}

Several regional tephras are now recognised (Table 3.1) and range in age from early Pliocene (3.97 Ma) to late Pleistocene (0.16 Ma) and, of these, the $3.446 \pm 0.041 \mathrm{Ma}$ Sidi Hakoma Tuff (SHT) is the most widely recognised and well-characterised. These tephras are believed to have originated from the central sector of the MER, however, the SHT is the only regional tephra which has been reliably correlated to its volcanic source, between the Baringo Basin of central Kenya and the NW Indian Ocean (Hart et al., 1992; Walter and Aronson, 1993).

Of the regional tephra markers, the SHT has gained prominence as a regional stratigraphic marker in Ethiopia due to its distinct properties, versatility and chronostratigraphic and palaeoanthropological importance (WoldeGabriel et al., 2013). The SHT acts as a marker within fossiliferous sediments containing important A. afarensis remains, namely two partial skeletons of 'Lucy' and 'Lucy's Baby-Selam' at Hadar, Dikika and Maka in the SW Afar Rift (Fig. 3.5) 
(WoldeGabriel et al., 2013). The first tuff chemically correlated to the SHT was described in the Omo-Turkana Basin (Howell, 1968; Bowen and Vondra, 1973) but the first regional correlation was not reported until the early 1980s by (Brown, 1982). The importance of the SHT and other regional and local tephra at the Middle Awash site is discussed in detail below.

\subsubsection{The Middle Awash}

The Middle Awash site (southern Afar) has yielded eight hominid species, $\sim 21,000$ vertebrate fossils and thousands of archaeological artefacts (WoldeGabriel et al., 2013).

Tephra deposits from the Ayelu volcano and surrounding Yardi Floodplain (part of Middle Awash) are investigated in this study to see if they are geochemically related to Holocene tephra deposits in Ethiopian lake sediment cores. Therefore tephra studies in the Middle Awash are briefly discussed below.

Unlike other archaeological sites in Ethiopia, Middle Awash palaeoanthropological sites are scattered across a large area and separated by Quaternary lava fields and tephra deposits, modern flood plains, outwash plains, riverine forests and Lake Yardi (Fig. 3.5) (WoldeGabriel et al., 2013). Due to poor exposure, isolated outcrops and dense faulting, the tephrostratigraphy has developed more slowly than in the Turkana Basin (Feibel, 1999; WoldeGabriel et al., 2013).

The palaeoanthropological potential of the Middle Awash site was first realised by Taieb (1974) who collected palaeontological specimens and measured geological sections in the area. The Rift Valley Research Mission in Ethiopia (RVRME) later established several stratigraphic sections using biochronological records, identified hundreds of fossil and archaeological localities and collected many fossils and stone tools (Kalb, 1976). However, data published from 


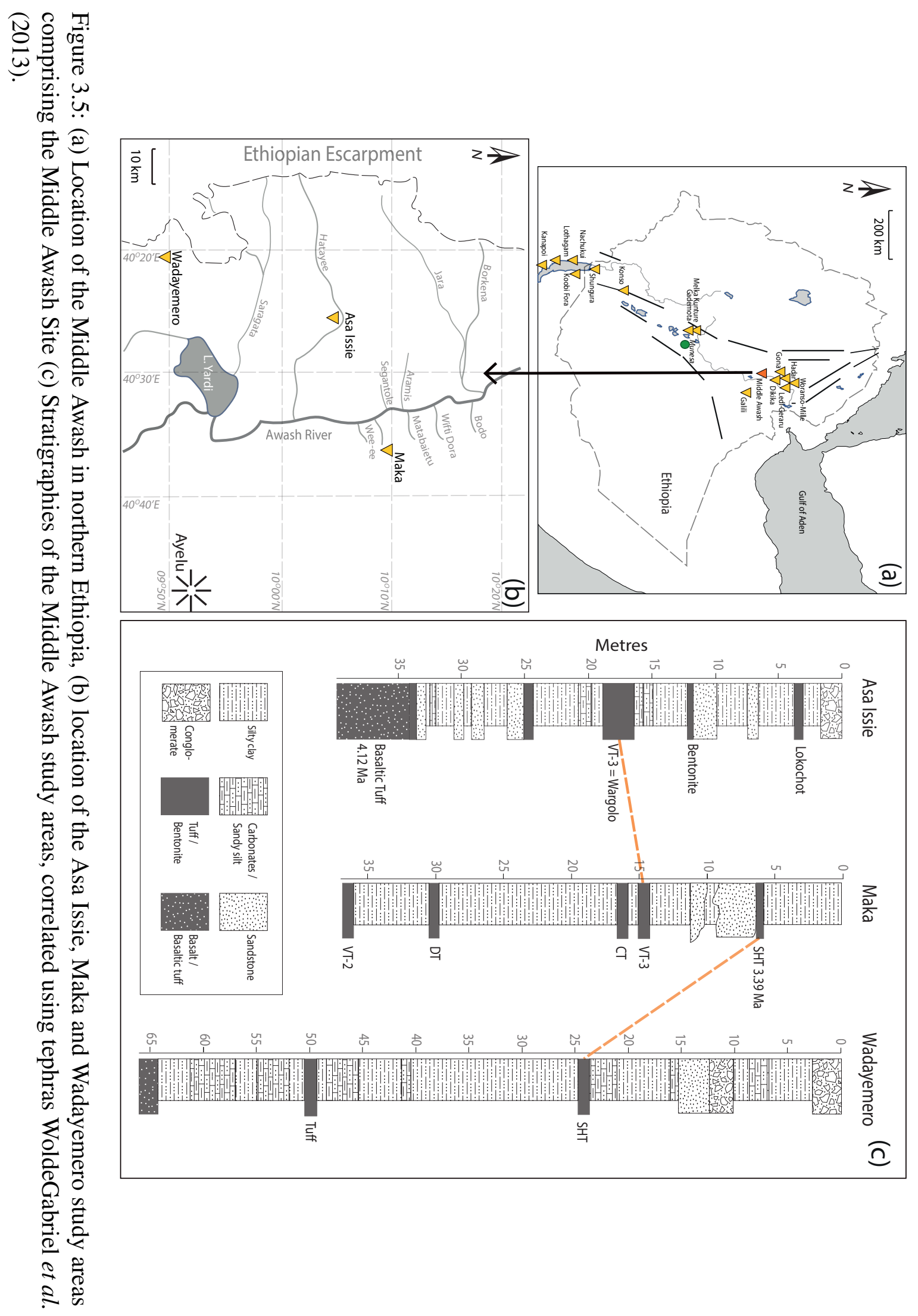


these investigations relied on lithostratigraphic similarities, coarse biochronology and broad structural interferences in order to form a stratigraphic framework, therefore estimated ages proved inaccurate (Kalb, 1993, 1995).

Tephrochonology has successfully synchronized the disparate study areas of the Middle Awash (Fig. 3.5) (de Heinzelin et al., 1999; Asfaw et al., 2002; Clark et al., 2003). This framework allows the accurate and precise dating of fauna and artefacts from archaeological sites and subsequently provides insight into hominin evolution (Clark et al., 2003).

\subsection{A lack of Holocene Ethiopian tephra studies}

The previous section has illustrated that tephrochronology has been successfully applied to early Pliocene - late Pleistocene archaeological sites throughout Ethiopia. However; younger Holocene tephras in Ethiopia remain unstudied and the record of volcanism in this volcanically active region remains brief (Siebert et al., 2011).

In the 15th Century two eruptions from Ethiopia were recorded by Vasco de Gama en route to India via the Cape of Good Hope (Siebert et al., 2011). In the early 1800s, eruptions from Fantale and Kone (northern Main Ethiopian Rift) were recorded (Harris, 1844; Gibson, 1969). However, it was not until the opening of the Suez Canal in 1869 and the subsequent exploration of Africa that regional historic eruptions were recorded in detail; $85 \%$ of the 155 historic eruptions from the African continent were reported after 1870. Volcanoes of suspected Holocene age in Ethiopia, Eritrea and the Ethiopian borders are detailed in Table 3.2. Although 65 volcanoes of this age occur in the region, only 14 of them have recorded historic eruptions (Siebert et al., 2011). 
The largest known eruption from Africa occurred in 1861 from Dubbi in Eritrea (Wiart and Oppenheimer, 2000) (Fig. 3.6 and 3.7). The volcano lies along the Nabro Volcanic Range, which runs from the Eritrean coast in a south-western direction into Ethiopia (Wiart and Oppenheimer, 2000).

Earthquakes during the opening phases of the Dubbi eruption were felt 180 $\mathrm{km}$ away in Yemen and explosions were heard $330 \mathrm{~km}$ away. Pyroclastic density currents destroyed two villages and killed 100 local inhabitants and herds of cattle. Tephra was reported to have fallen across the Ethiopian Plateau, 300 $\mathrm{km}$ to the west and pyroclastic and lava flows travelled $\sim 20 \mathrm{~km}$ from the vent. Volcanism then switched to fire-fountain activity along a $4 \mathrm{~km}$ long fissure; a lava flow associated with this phase travelled $\sim 20 \mathrm{~km}$ from the vent.

Due to aeolian erosion, the tephra deposit from the initial eruption has since been deflated, and no reliable tephra volumes have therefore been calculated (Lenhardt and Oppenheimer, 2014). The $3.5 \mathrm{~km}^{3}$ lava flow volume alone (equivalent to VEI =6), makes this the largest historic eruption recorded in Africa. An anomalously cold Northern Hemisphere 1862 summer recorded in the tree ring record has been tentatively attributed to sulphate aerosols produced by the Dubbi eruption (Wiart and Oppenheimer, 2000).

Lake Ashenge is located $<300 \mathrm{~km}$ to the west of Dubbi; there may be potential for preservation of the Dubbi 1861 tephra in the sediments from this lake, which may give insight into the dispersal of volcanic ash from the eruption. 

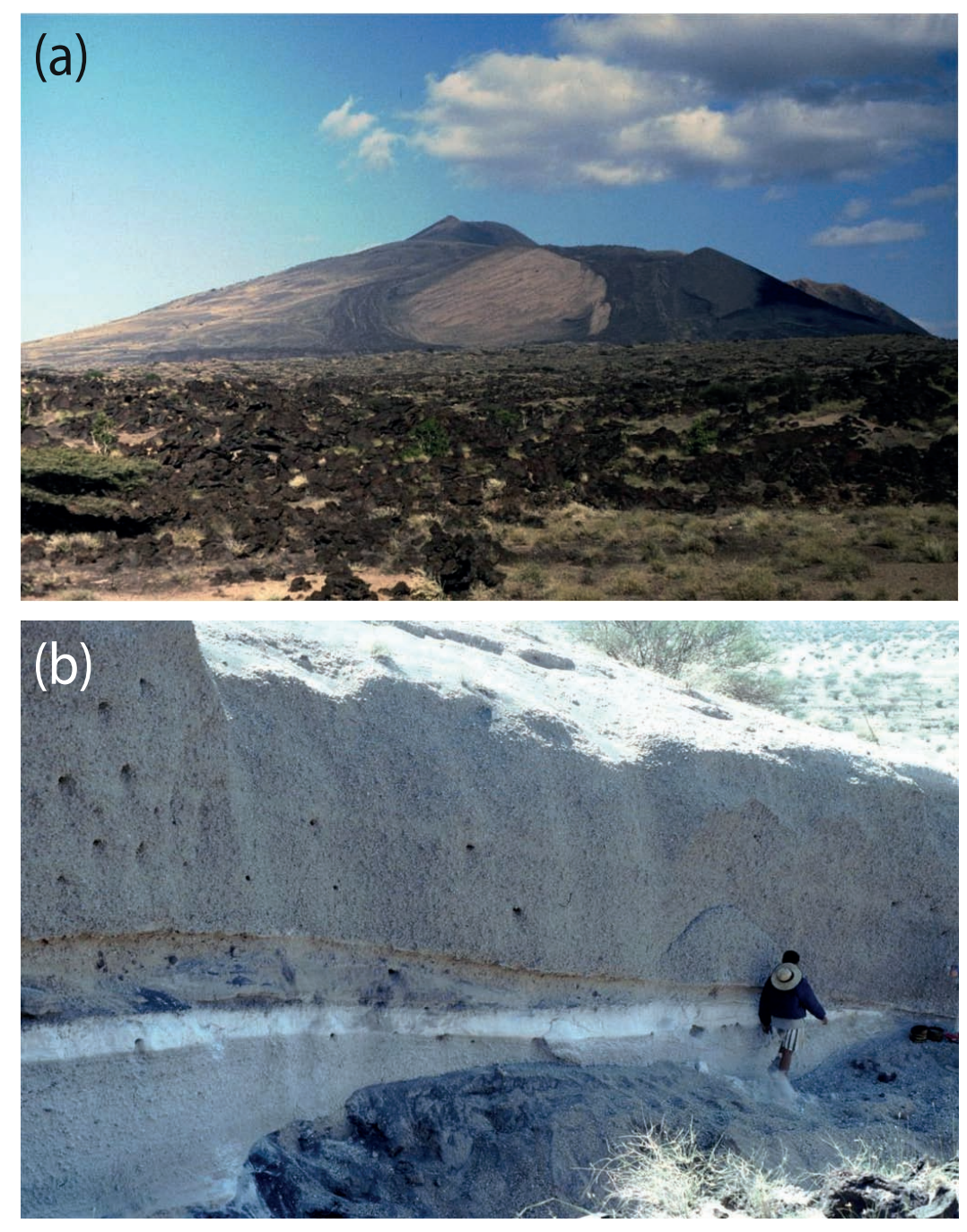

Figure 3.6: (a) The Dubbi volcano (1625 m a.s.l), (b) proximal pumice and ash deposits from the Dubbi 1861, figures from Oppenheimer (2011). 


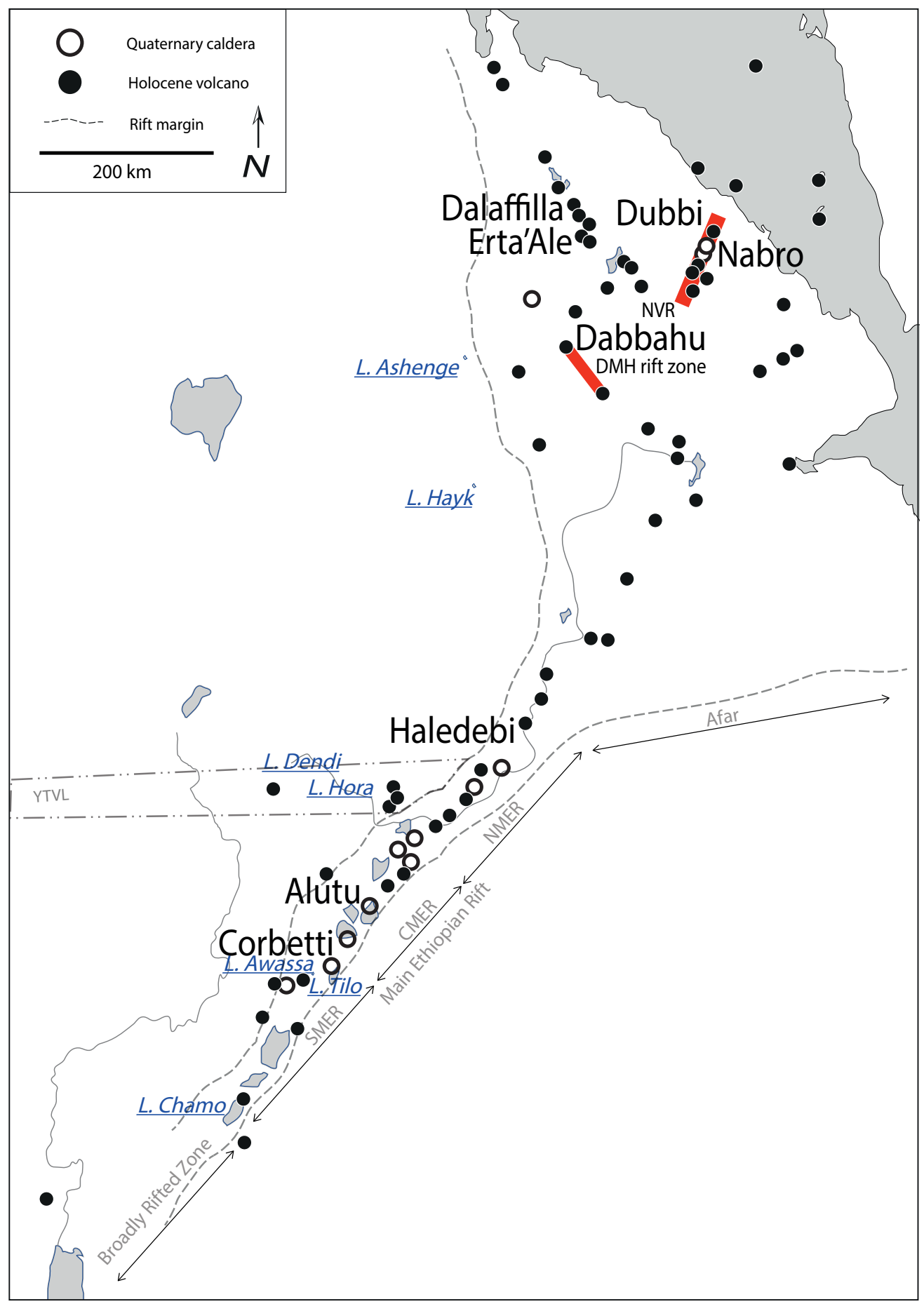

Figure 3.7: Location of volcanoes which have erupted historically or recently in the Afar and those in the Main Ethiopian Rift which are actively deforming. DMH = Dabbahu-Manda Hararo Rift Segment, NVR=Nabro Volcanic Range. 


\subsubsection{Volcanic hazards in Ethiopia}

Numerous eruptions have occurred in the Afar during the last decade, notably at Dabbahu (2005), Dalaffilla (2008), Erta'Ale (2011) and Nabro (2011) (see Fig. 3.7) (Ferguson et al., 2010; Wiart and Oppenheimer, 2000). In the Main Ethiopian Rift, significant pulses of deformation beneath Alutu, Corbetti, Bora, Haledebi (Fig. 3.7) have been observed over the past 20 years (Biggs et al., 2011). This is indicative of magmatic unrest beneath these volcanoes and is often interpreted as a precursor to an eruption. Furthermore, numerous volcanoes throughout Ethiopia are currently at a fumarolic stage (Lenhardt and Oppenheimer, 2014).

Lenhardt and Oppenheimer (2014) cite the potential for a range of volcanic hazards to occur in Ethiopia; including lava flows, pyroclastic density currents, ash falls and volcanic gases.

The hazards posed by volcanoes in this region are exemplified by two recent explosive eruptions. Since September 2005, the Dabbahu-Manda Hararo rift (Fig. 3.7) has been undergoing active rifting, initiated by the opening of a dyke along a $\sim 60 \mathrm{~km}$ rift segment over a time span of $<8 \mathrm{~m}$ (Ferguson et al., 2010) (Fig. 3.8a). The rifting was associated with a small silicic eruption (VEI=3) from Dabbahu, which deposited tephra over $100 \mathrm{~km}^{2}$ and resulted in the evacuation of $>6000$ people from nearby villages (Ayele et al., 2007a; Ferguson et al., 2010).

On June $12^{\text {th }} 2011$, Nabro volcano $(20 \mathrm{~km}$ to the SW of Dubbi and on the same volcanic lineament, Fig. 3.7 3.8b,c) erupted explosively (VEI=4) displacing thousands of people. In Eritrea, 7 people were killed, although it is believed there were more fatalities in Ethiopia. Volcanic ash was dispersed over northern Africa and Eurasia 3 days after the eruption, causing disruption to air traffic (Fig. 3.8) (Lenhardt and Oppenheimer, 2014). Prior to the eruption 
14 earthquakes $(M>4.5)$ occurred in the region, but the eruption remained unexpected due to a lack of monitoring and volcanic history for the volcano (Lenhardt and Oppenheimer, 2014). The Nabro eruption was ranked the largest source of sulphate aerosols to the atmosphere since the 1991 Pinatubo eruption (Sawamura et al., 2012).

Whilst the Afar is sparsely populated, recent and historic eruptions from Dubbi, Dabbahu and Nabro highlight the potential for volcanic events to cause fatalities, displace inhabitants and disrupt international air and maritime traffic (Lenhardt and Oppenheimer, 2014). In the less extreme temperatures of the Main Ethiopian Rift, high population densities inhabit volcanic areas; with 570,000 people living within $5 \mathrm{~km}$ of the actively deforming Corbetti caldera (Siebert et al., 2011) (see Table 3.2).

The lack of volcanic history for this region, coupled with limited volcano monitoring, means that the risks posed by these volcanoes remain uncertain. The World Bank report on volcanic hazards lists the Main Ethiopian Rift volcanoes at a zero level of monitoring and the highest uncertainty level for hazards posed (Biggs et al., 2011). Numerous volcanoes have erupted after centuries of repose, e.g. El Chichón (1982), Mount Pinatubo (1991) and Nabro (2011), and it is therefore possible that Ethiopian volcanoes may erupt suddenly (Lenhardt and Oppenheimer, 2014).

Following the Dabbahu 2005 volcano-seismic crisis, the Afar Rift Consortium (http://www.see.leeds.ac.uk/afar/) was concieved. The project installed a volcano and seismic monitoring network in the Afar and set out to investigate magmatic and tectonic processes and the timing of past eruptions. The later discovery of the active deformation of volcanoes in the Main Ethiopian Rift lead to the formation of the RiftVolc project (http://www.geos.ed.ac.uk/riftvolc) in 2014. 
RiftVolc aims to investigate the controls on active magmatic systems and the potential threats from future volcanic activity. These projects have been crucial in developing our understanding of magmatic processes in Ethiopia and the risk posed by future eruptions, however, their primary focus is on proximal volcanic deposits.

Distal tephras deposited in Holocene lake sediments throughout Ethiopia provide an ideal method to assess how frequently these volcanoes have erupted in the recent past and when future eruptions may occur. Furthermore, data on distal tephras in lake sediments will compliment research by the Afar Rift Consortium and RiftVolc; providing insight into the dispersal of tephras and the interrelationships between volcanic centres. 
Table 3.2: List of volcanoes of known or suspected Holocene age in Ethiopia and bordering areas, modified from and Siebert et al. (2011) and Lenhardt and Oppenheimer (2014). It is likely that there are further volcanoes of Holocene age that have yet to be recognised or dated.

\begin{tabular}{|c|c|c|c|c|c|c|c|}
\hline Name & Country & Type & Latitude & Longitude & $\begin{array}{l}\text { Elevation } \\
\text { asl }(m)\end{array}$ & $\begin{array}{l}\text { Last known } \\
\text { eruption }\end{array}$ & $\begin{array}{l}\text { Population } \\
<5 \mathrm{~km}\end{array}$ \\
\hline Alid & Eritrea & Stratovolcano & $14.88^{\circ} \mathrm{N}$ & $13.92^{\circ} \mathrm{E}$ & 904 & ? & 517 \\
\hline Assab Volc. Field & Eritrea & Volcanic field & $12.95^{\circ} \mathrm{N}$ & $42.43^{\circ} \mathrm{E}$ & 987 & ? & 9 \\
\hline Dubbi & Eritrea & Stratovolcano & $13.58^{\circ} \mathrm{N}$ & $41.80^{\circ} \mathrm{E}$ & 1625 & 1861 & 0 \\
\hline Jalua & Eritrea & Stratovolcano & $15.04^{\circ} \mathrm{N}$ & $39.82^{\circ} \mathrm{E}$ & 713 & ? & 2072 \\
\hline Nabro & Eritrea & Stratovolcano & $13.37^{\circ} \mathrm{N}$ & $41.70^{\circ} \mathrm{E}$ & 2218 & 2011 & 24 \\
\hline Adwa & Ethiopia & Stratovolcano & $10.07^{\circ} \mathrm{N}$ & $40.84^{\circ} \mathrm{E}$ & 1733 & $?$ & 101 \\
\hline Adferá & Ethiopia & Stratovolcano & $13.08^{\circ} \mathrm{N}$ & $40.85^{\circ} \mathrm{E}$ & 1295 & ? & 51 \\
\hline Alayta & Ethiopia & Shield volcano & $12.88^{\circ} \mathrm{N}$ & $40.57^{\circ} \mathrm{E}$ & 1501 & 1915 & 156 \\
\hline Ale Bagu & Ethiopia & Stratovolcano & $13.52^{\circ} \mathrm{N}$ & $40.63^{\circ} \mathrm{E}$ & 1031 & ? & 2 \\
\hline Alu & Ethiopia & Fissure vents & $13.83^{\circ} \mathrm{N}$ & $40.51^{\circ} \mathrm{E}$ & 429 & ? & 0 \\
\hline Alutu & Ethiopia & Stratovolcano & $7.77^{\circ} \mathrm{N}$ & $38.78^{\circ} \mathrm{E}$ & 2335 & $50 \mathrm{BC}(?)$ & 6011 \\
\hline Asavyo & Ethiopia & Shield volcano & $13.07^{\circ} \mathrm{N}$ & $41.60^{\circ} \mathrm{E}$ & 1200 & $?$ & 84 \\
\hline Ayelu & Ethiopia & Stratovolcano & $10.08^{\circ} \mathrm{N}$ & $40.70^{\circ} \mathrm{E}$ & 2145 & ? & 193 \\
\hline Beru & Ethiopia & Volcanic field & $8.95^{\circ} \mathrm{N}$ & $39.75^{\circ} \mathrm{E}$ & 1100 & ? & 3850 \\
\hline Bilate River Field & Ethiopia & Maars & $7.07^{\circ} \mathrm{N}$ & $38.10^{\circ} \mathrm{E}$ & 1700 & ? & 359001 \\
\hline Bishoftu Volcanic Field & Ethiopia & Fissure vents & $8.78^{\circ} \mathrm{N}$ & $38.98^{\circ} \mathrm{E}$ & $>1850$ & ? & 310101 \\
\hline Bora-Bericcio & Ethiopia & Pumice cones & $8.27^{\circ} \mathrm{N}$ & $39.03^{\circ} \mathrm{E}$ & 2285 & ? & 5822 \\
\hline Borale Ale & Ethiopia & Stratovolcano & $13.73^{\circ} \mathrm{N}$ & $40.60^{\circ} \mathrm{E}$ & 668 & ? & 0 \\
\hline Borawli & Ethiopia & Stratovolcano & $13.30^{\circ} \mathrm{N}$ & $40.98^{\circ} \mathrm{E}$ & 812 & ? & 920 \\
\hline Borawli & Ethiopia & Lava domes & $11.63^{\circ} \mathrm{N}$ & $41.45^{\circ} \mathrm{E}$ & 875 & ? & 38 \\
\hline Boset-Bericha & Ethiopia & Stratovolcanoes & $8.56^{\circ} \mathrm{N}$ & $39.48^{\circ} \mathrm{E}$ & 2447 & ? & 3267 \\
\hline Butajiri-Silti Field & Ethiopia & Fissure vents & $8.05^{\circ} \mathrm{N}$ & $38.35^{\circ} \mathrm{E}$ & 2281 & ? & 431631 \\
\hline Chiracha & Ethiopia & Stratovolcano & $6.65^{\circ} \mathrm{N}$ & $38.12^{\circ} \mathrm{E}$ & 1650 & ? & 14959 \\
\hline Corbetti caldera & Ethiopia & Caldera & $7.18^{\circ} \mathrm{N}$ & $38.43^{\circ} \mathrm{E}$ & 2320 & ? & 565206 \\
\hline Dabbahu & Ethiopia & Stratovolcano & $12.60^{\circ} \mathrm{N}$ & $40.48^{\circ} \mathrm{E}$ & 1442 & 2005 & 204 \\
\hline Dabbayra & Ethiopia & Shield volcano & $12.38^{\circ} \mathrm{N}$ & $40.07^{\circ} \mathrm{E}$ & 1302 & $?$ & 804 \\
\hline Dalaffilla & Ethiopia & Stratovolcano & $13.79^{\circ} \mathrm{N}$ & $40.55^{\circ} \mathrm{E}$ & 613 & 2008 & 0 \\
\hline Dallol & Ethiopia & Explosion craters & $14.24^{\circ} \mathrm{N}$ & $40.30^{\circ} \mathrm{E}$ & -48 & 1926 & 461 \\
\hline Dama Ali & Ethiopia & Shield volcano & $11.28^{\circ} \mathrm{N}$ & $41.63^{\circ} \mathrm{E}$ & 1068 & 1631 & 24 \\
\hline Dofen & Ethiopia & Stratovolcano & $9.35^{\circ} \mathrm{N}$ & $40.13^{\circ} \mathrm{E}$ & 1151 & $?$ & 1900 \\
\hline East Ziway & Ethiopia & Fissure vents & $7.95^{\circ} \mathrm{N}$ & $38.93^{\circ} \mathrm{E}$ & 1889 & $?$ & 85845 \\
\hline Erta Ale & Ethiopia & Shield volcano & $13.60^{\circ} \mathrm{N}$ & $40.67^{\circ} \mathrm{E}$ & 613 & 2011 & 2685 \\
\hline Fantale & Ethiopia & Stratovolcano & $8.98^{\circ} \mathrm{N}$ & $39.93^{\circ} \mathrm{E}$ & 2007 & $1820(?)$ & 1919 \\
\hline Gabillema & Ethiopia & Stratovolcano & $11.08^{\circ} \mathrm{N}$ & $41.27^{\circ} \mathrm{E}$ & 1459 & $?$ & 248 \\
\hline Gada Ale & Ethiopia & Stratovolcano & $13.98^{\circ} \mathrm{N}$ & $40.41^{\circ} \mathrm{E}$ & 287 & ? & 101 \\
\hline Gedamsa & Ethiopia & Caldera & $8.35^{\circ} \mathrm{N}$ & $39.18^{\circ} \mathrm{E}$ & 1984 & ? & 216008 \\
\hline Groppo & Ethiopia & Stratovolcano & $11.73^{\circ} \mathrm{N}$ & $40.25^{\circ} \mathrm{E}$ & 930 & ? & 2411 \\
\hline Hayli Gubbi & Ethiopia & Shield volcano & $13.50^{\circ} \mathrm{N}$ & $40.72^{\circ} \mathrm{E}$ & 521 & ? & 0 \\
\hline Hertali & Ethiopia & Fissure vent & $9.78^{\circ} \mathrm{N}$ & $40.33^{\circ} \mathrm{E}$ & $900 ?$ & ? & 474 \\
\hline Hobicha caldera & Ethiopia & Caldera & $6.78^{\circ} \mathrm{N}$ & $37.83^{\circ} \mathrm{E}$ & $1800 ?$ & ? & 466462 \\
\hline Kone & Ethiopia & Calderas & $8.80^{\circ} \mathrm{N}$ & $39.69^{\circ} \mathrm{E}$ & 1619 & $1820 \pm 10$ & 7289 \\
\hline Korath Range & Ethiopia & Tuff cones & $5.10^{\circ} \mathrm{N}$ & $35.88^{\circ} \mathrm{E}$ & 912 & ? & 24549 \\
\hline Kurub & Ethiopia & Shield volcano & $11.88^{\circ} \mathrm{N}$ & $41.21^{\circ} \mathrm{E}$ & 625 & ? & 8 \\
\hline Liado Hayk & Ethiopia & Maars & $9.57^{\circ} \mathrm{N}$ & $40.28^{\circ} \mathrm{E}$ & 878 & ? & 22847 \\
\hline Ma Alalta & Ethiopia & Stratovolcano & $13.02^{\circ} \mathrm{N}$ & $40.20^{\circ} \mathrm{E}$ & 1815 & ? & 3925 \\
\hline Manda Gargori & Ethiopia & Fissure vents & $11.75^{\circ} \mathrm{N}$ & $41.48^{\circ} \mathrm{E}$ & Unknown & ? & 284 \\
\hline Manda Hararo & Ethiopia & Shield volcanoes & $12.17^{\circ} \mathrm{N}$ & $40.82^{\circ} \mathrm{E}$ & $>600$ & 2009 & 191 \\
\hline Mat Ala & Ethiopia & Shield volcano & $13.10^{\circ} \mathrm{N}$ & $41.15^{\circ} \mathrm{E}$ & 523 & $?$ & 45 \\
\hline O'a caldera & Ethiopia & Caldera & $7.47^{\circ} \mathrm{N}$ & $38.58^{\circ} \mathrm{E}$ & 2075 & ? & 148588 \\
\hline Sodore & Ethiopia & Pyroclastic cones & $8.43^{\circ} \mathrm{N}$ & $39.35^{\circ} \mathrm{E}$ & 1765 & ? & 432998 \\
\hline Tat Ali & Ethiopia & Shield volcano & $13.28^{\circ} \mathrm{N}$ & $41.07^{\circ} \mathrm{E}$ & $>700$ & ? & 32 \\
\hline Tepi & Ethiopia & Shield volcano & $7.42^{\circ} \mathrm{N}$ & $35.43^{\circ} \mathrm{E}$ & 2728 & ? & 63395 \\
\hline Tosa Sucha & Ethiopia & Cinder cones & $5.93^{\circ} \mathrm{N}$ & $37.57^{\circ} \mathrm{E}$ & 1650 & ? & 175047 \\
\hline Tullu Moje & Ethiopia & Pumice cones & $8.16^{\circ} \mathrm{N}$ & $39.13^{\circ} \mathrm{E}$ & 2349 & $1900(?)$ & 11514 \\
\hline Unnamed & Ethiopia & Pyroclastic cones & $8.70^{\circ} \mathrm{N}$ & $39.63^{\circ} \mathrm{E}$ & 1300 & $?$ & 134853 \\
\hline Unnamed & Ethiopia & Fissure vents & $8.62^{\circ} \mathrm{N}$ & $38.95^{\circ} \mathrm{E}$ & $1800 ?$ & $?$ & 290221 \\
\hline Unnamed & Ethiopia & Fissure vents & $8.07^{\circ} \mathrm{N}$ & $39.07^{\circ} \mathrm{E}$ & $1800 ?$ & ? & 283786 \\
\hline Unnamed & Ethiopia & Cinder cones & $5.65^{\circ} \mathrm{N}$ & $37.67^{\circ} \mathrm{E}$ & 1200 & ? & 78416 \\
\hline Yangudi & Ethiopia & Complex volcano & $10.58^{\circ} \mathrm{N}$ & $41.04^{\circ} \mathrm{E}$ & 1383 & ? & 33 \\
\hline Gufa & Ethiopia/Djibouti & Volcanic field & $12.55^{\circ} \mathrm{N}$ & $42.53^{\circ} \mathrm{E}$ & $>600$ & ? & 1651 \\
\hline Manda-Inakir & Ethiopia/Djibouti & Fissure vents & $12.38^{\circ} \mathrm{N}$ & $42.20^{\circ} \mathrm{E}$ & $>600$ & 1928 & 116 \\
\hline Mousa Alli & Ethiopia/Djibouti & Stratovolcano & $12.47^{\circ} \mathrm{N}$ & $42.40^{\circ} \mathrm{E}$ & 2028 & ? & 132 \\
\hline Mallahle & Ethiopia/Eritrea & Stratovolcano & $13.27^{\circ} \mathrm{N}$ & $41.65^{\circ} \mathrm{E}$ & 1875 & ? & 912 \\
\hline Sork Ale & Ethiopia/Eritrea & Stratovolcano & $13.18^{\circ} \mathrm{N}$ & $41.73^{\circ} \mathrm{E}$ & 1611 & ? & 174 \\
\hline Mega Basalt Field & Ethiopia/Kenya & Pyroclastic cones & $4.08^{\circ} \mathrm{N}$ & $37.42^{\circ} \mathrm{E}$ & 1067 & ? & 2815 \\
\hline
\end{tabular}




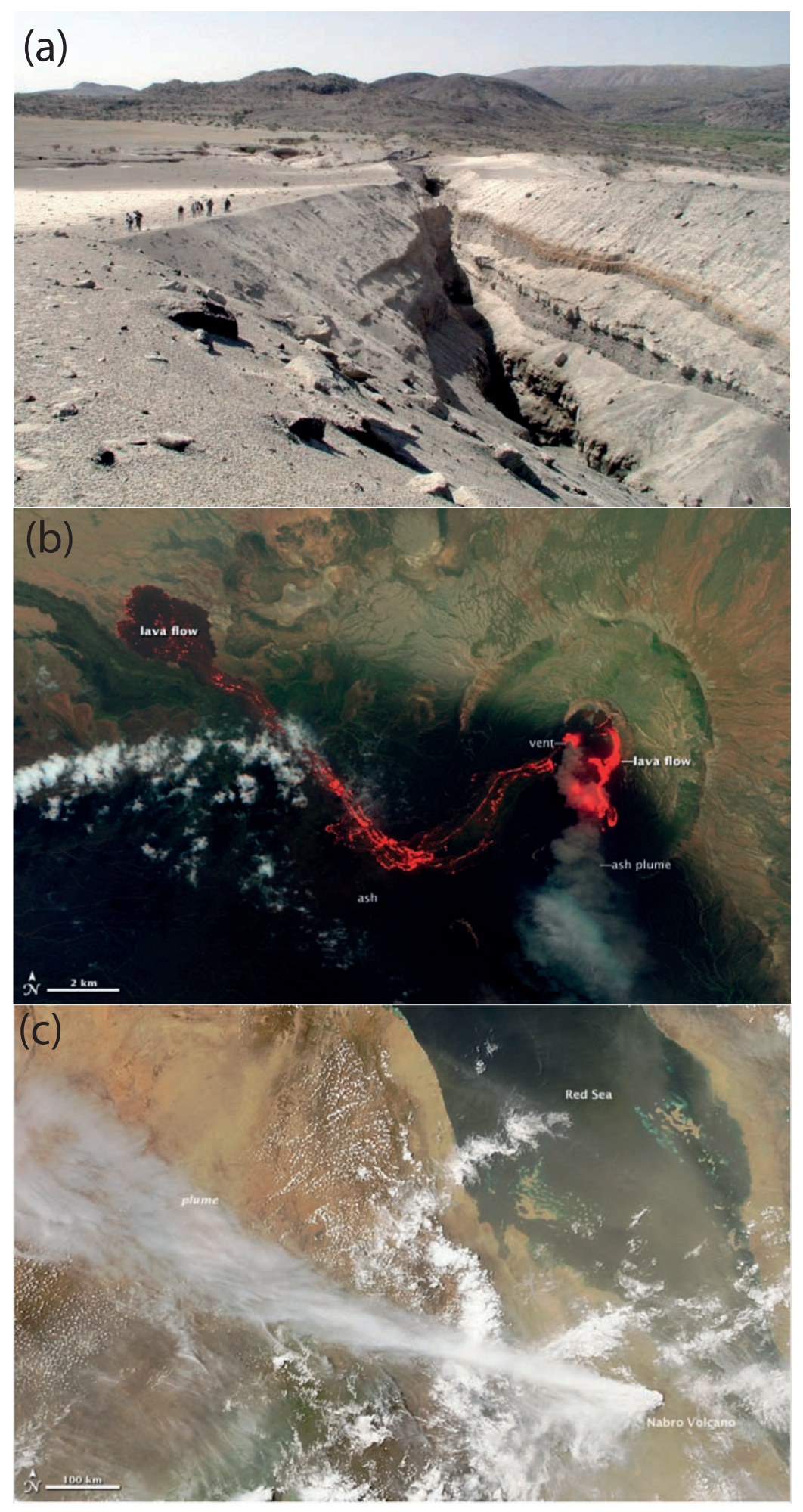

Figure 3.8: (a) Dabbahu 2005 volcano-seismic crisis; view of Dabbahu's newly formed pumice cone and fissure vent, from Siebert et al. (2011) (b) and (c) Satellite images showing lava flows and the ash plume associated with the Nabro 2011 eruption, from NASA (2011). 


\subsection{Summary}

This chapter has demonstrated that numerous volcanic centres in the East African Rift Valley erupted explosively during the Quaternary - Holocene, producing widespread tephra layers. Early Pliocene (3.97 Ma) to late Pleistocene (0.16 Ma) tephra layers provide chronological control on important palaeoanthropological sites throughout eastern Africa and have also been correlated to the palaeoclimate archives within sediment cores from the Gulf of Aden and the NW Indian Ocean.

Numerous volcanoes believed to have been active during the Holocene occur throughout the Ethiopian Rift. Despite many of these being situated close to highly populous areas, their volcanic history and tephra deposits remain poorly understood and unstudied. This is related to the early stage of geological research in this region and the logistical difficulties of undertaking field work in regions such as the Afar. Tephra deposits in Ethiopia can give insight into the tempo and characteristics of past volcanism and therefore have useful implications for hazard monitoring. Furthermore, these tephra deposits can be used to date and correlate archives across this climatically sensitive region.

This study uses Holocene $(<17$ cal. ka) sediment cores collected from Lakes Ashenge, Hayk and Dendi in the Ethiopian Highlands and Lakes Hora Awassa, Tilo and Chamo in the Ethiopian Rift. Correlations between different lake sites and to source volcanoes will enable a Holocene tephra framework to be constructed and will provide a dossier of past volcanism. 


\section{Chapter 4}

\section{Research design and methods}

In the following chapter, field sampling methods are first discussed, including lake sediment coring and proximal tephra sampling. Laboratory methods are then described, including cryptotephra identification methods and the geochemical fingerprinting of tephras.

\subsection{Research design}

This study uses Holocene lacustrine sediment cores collected from Ethiopian lakes as part of a long term collaborative project between Aberystwyth University, Addis Ababa University and latterly the University of Cologne which aims to investigate regional palaeoclimate.

This study uses $<17$ cal. ka sediment cores collected from Lakes Ashenge, Hayk and Dendi in the Ethiopian Highlands and Lakes Hora Awassa, Tilo and Chamo in the Ethiopian Rift. Core site locations and core details are given in Fig. 4.1 and Table 4.1.

Lakes Ashenge, Hayk and Chamo are formed in tectonic basins, whilst Lakes Dendi, Hora, Awassa and Tilo are crater lakes. The core sites can be 
divided geographically and tectonically into three groups (see Fig. 4.1). Lakes Ashenge and Hayk are the most northerly lakes studied here and are located on the Ethiopian Plateau. Lakes Awassa, Tilo and Chamo are located to the south in the Main Ethiopian Rift. Lakes Dendi and Hora are also located in the Ethiopian Plateau but are situated on the E-W orientated Yerer-Tullu Wellel Volcano Tectonic Lineament.

Primarily, these sites were chosen on the basis of their good preservation of tephra deposits. Sites distributed throughout the Ethiopian Rift and surrounding plateau were selected in order to provide a spatially comprehensive record of volcanism and ensure more opportunities for correlation. Core sites were also selected in order that both proximal and distal tephra layers could be studied, therefore providing insight into potential tephra sources and recording interfingering tephra deposits from multiple sources, respectively. Cores from Lakes Ashenge, Hayk and Chamo were used because these lakes are located $>50 \mathrm{~km}$ away from volcanoes active during the Holocene and are therefore likely to receive only distal tephras from multiple volcanic sources. In contrast, Lakes Dendi, Hora, Awassa and Tilo are located close to Holocene volcanoes and contain proximal tephra deposits. Lake Dendi was chosen due to its proximity to volcanoes aligned along the E-W aligned Yerer-Tullu Wellel Volcano Tectonic Lineament. This volcanic lineament is offset from the NE-SW trending Ethiopian Rift and therefore the proximal tephra deposits may vary geochemically.

Lake sediment cores utilised in this study were cored by H. Lamb (Aberystwyth University) and F. Schäbitz (University of Cologne). Sediments were cored using a Livingstone piston corer (Lakes Ashenge, Hora, Awassa and Tilo) or a UWITEC corer (Lakes Hayk, Dendi and Chamo). Details of coring methods, the 
length and temporal coverage of each core and previous studies on each record are given in Table 4.1 .

In order to locate potential volcanic sources for tephras in lake sediment cores, proximal tephra samples from the Afar Rift and central Main Ethiopian Rift were geochemically fingerprinted. Ayelu and Dubbi (Afar) were selected due to their proximity to Lakes Ashenge and Hayk. The Dubbi 1861 eruption produced a widespread tephra layer and proximal tephras from Dubbi were analysed to check if they correlated with a historic tephra in the Ashenge core. Holocene activity has been recorded at the Chabbi volcano (in the Corbetti caldera, CMER) (Siebert et al., 2011) and may be responsible for thick tephras in nearby Lakes Awassa and Tilo. Therefore samples from Chabbi were fingerprinted to check whether it is the source for the Awassa and Tilo tephras. Tephras from Mochena Borago (SW Ethiopia), were analysed to check whether they correlated with tephras occurring in lake sediments, therefore potentially tying down the chronology for this archaeological site and resolving dating problems. 


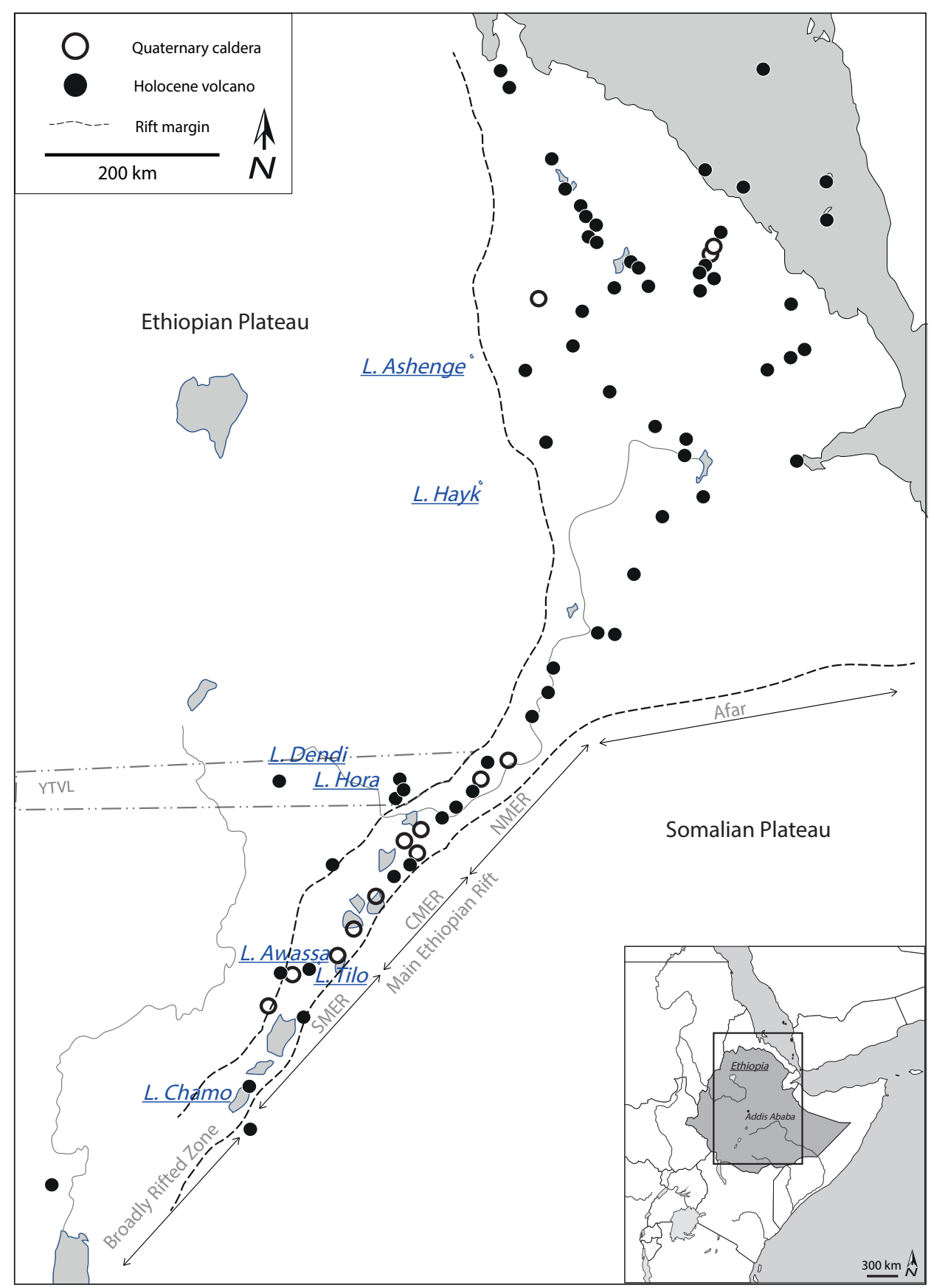

Figure 4.1: Locations of Holocene lake sediment cores collected from throughout Ethiopia, volcanoes suspected to have been active during the Holocene (Siebert et al., 2011) are shown for reference. The lakes studied here can be grouped geographically; Lakes Ashenge and Hayk are located on the Ethiopian Plateau whilst Lakes Awassa, Tilo and Chamo are located to the south in the southern Main Ethiopian Rift. Lakes Dendi and Hora are located off the main rift axis on the E-W orientated Yerer-Tullu Wellel Volcano Tectonic Lineament (YTVL). NMER, CMER and SMER = northern, central and southern Main Ethiopian Rifts. 


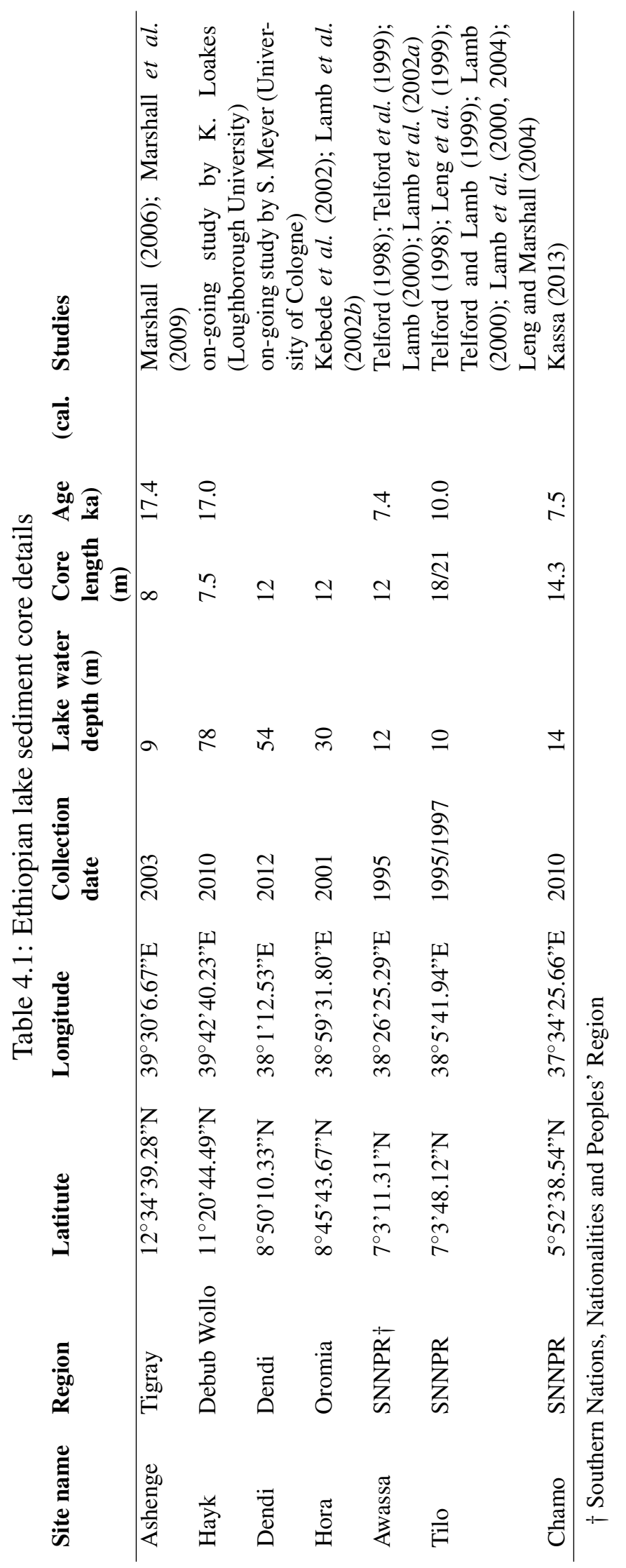




\subsection{Lake core sites}

\subsubsection{Lake core sites in the Ethiopian Highlands: Ashenge and Hayk}

\section{Lake Ashenge}

Ashenge, a closed-basin lake, is the most northerly of the lakes studied here (Fig. 4.2). The lake lies at an altitude of $2400 \mathrm{~m}$ a.s.l. and has an area of $\sim 20$ $\mathrm{km}^{2}$ with a maximum depth of $\sim 20 \mathrm{~m}$. The Lake Ashenge catchment covers $\sim 82 \mathrm{~km}^{2}$; ephemeral streams (Chegwar, Haynet, Shanfa Adewt, Ada Ala) drain into the north of the lake and there is currently no surface outflow (Marshall, 2006). Lake Ashenge is formed within a graben consisting of mid-Tertiary flood basalt. Quaternary alluvial, colluvial and lacustrine deposits outcrop on the basin floor (Marshall, 2006).

\section{Lake Hayk}

Lake Hayk is located $\sim 140 \mathrm{~km}$ to the south of Lake Ashenge, lying at an elevation of $2000 \mathrm{~m}$ a.s.1. (Fig. 4.3). Lake Hayk has a maximum depth of 88 $\mathrm{m}$ and an area of $\sim 23 \mathrm{~km}^{2}$. The principal inflow for this closed lake basin is via the Anchercah River which flows into the southeastern corner of Lake Hayk; there is currently no surface outflow (Lamb et al., 2007; Ghinassi et al., 2012). Lake Hayk is located within an extensional basin which developed in $\sim 1000$ $\mathrm{m}$ of Miocene-Early Pliocene basalts, tuffs and rhyolitic lava flows. These are overlain by Quaternary colluvial, alluvial and lacustrine deposits (Ghinassi et al., 2012). 


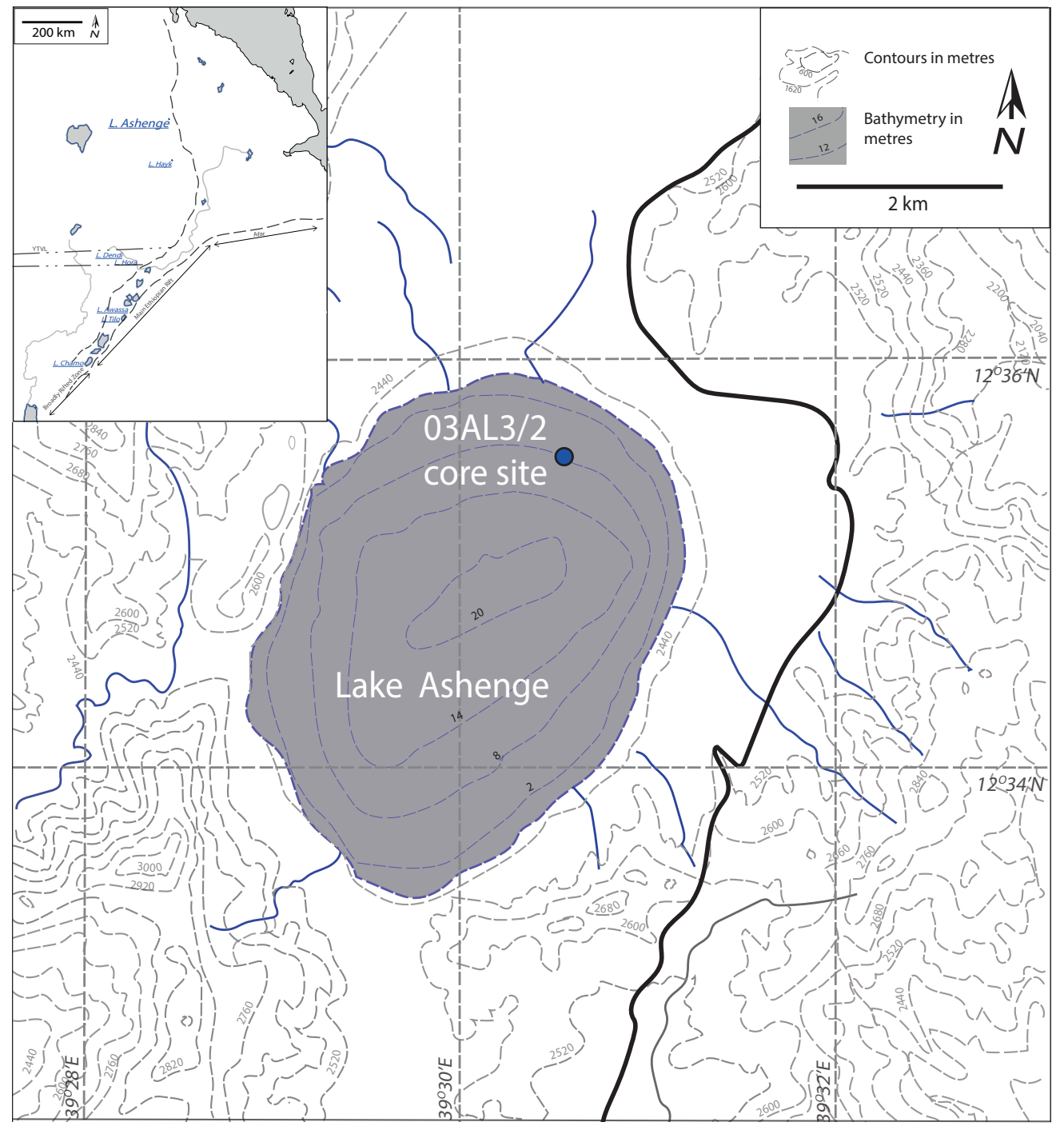

Figure 4.2: Lake Ashenge core 03AL3/2 location, indicated with blue circle. See inset for location of Lake Ashenge on the Ethiopian Plateau, northern Ethiopia. 


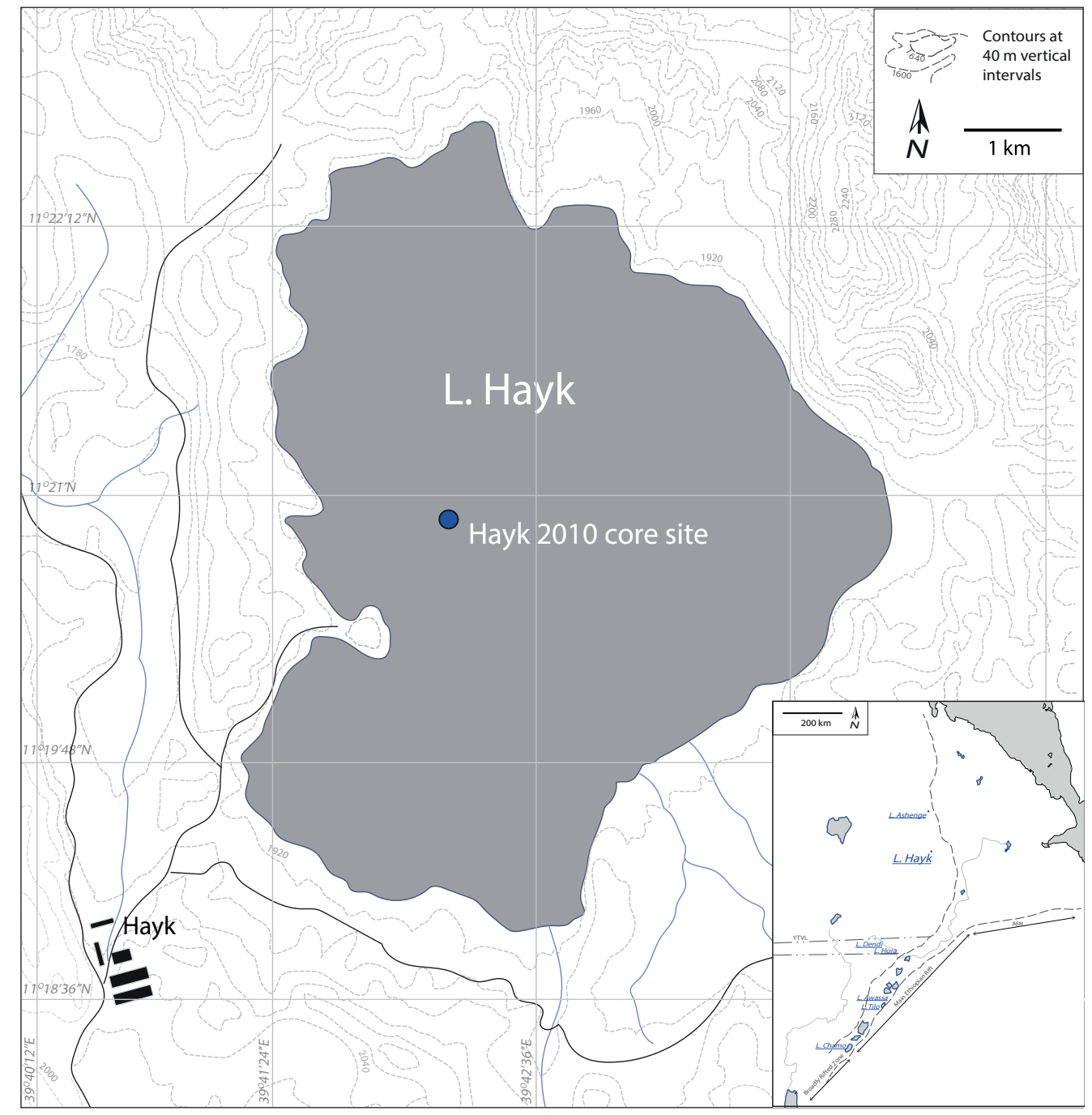

Figure 4.3: Lake Hayk 2010 core site (indicated with blue circle), see inset for location of Lake Hayk in the Ethiopian Plateau, northern Ethiopia. 

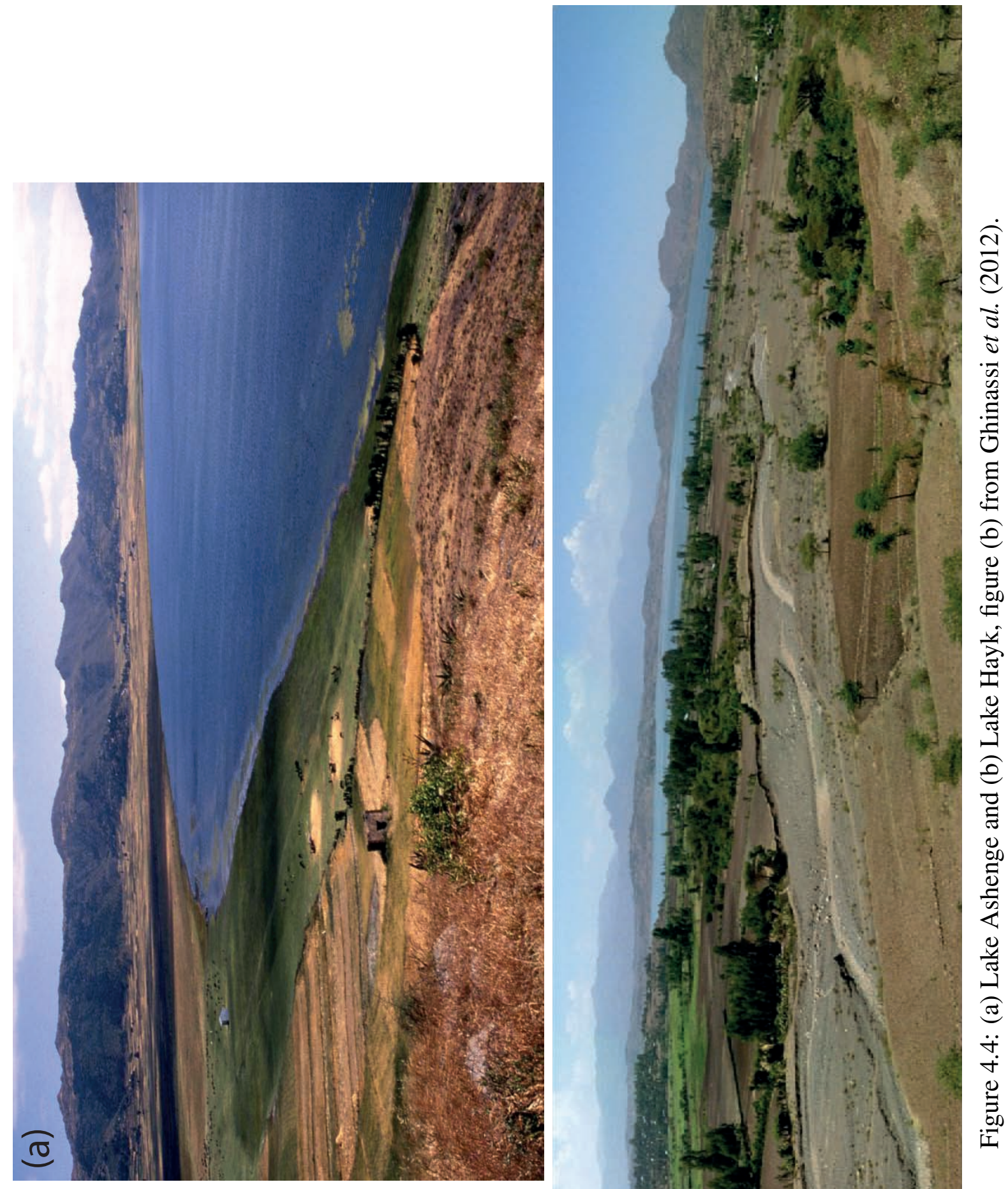

อิ 


\subsubsection{Lake core sites on the Yerer-Tullu Wellel Volcano Tec- tonic Lineament: Dendi and Hora}

\section{Lake Dendi}

Lake Dendi is a double crater lake located $130 \mathrm{~km}$ west of Addis Ababa and at $2800 \mathrm{~m}$ a.s.l. (Fig. 4.5). The lake covers an area of $7.2 \mathrm{~km}^{2}$ and has a maximum depth of $60 \mathrm{~m}$. The lake has no permanent inlets and outlets, but is fed by seasonal springs and rivers during the rainy season.

The lake represents one of the central volcanoes aligned along the E-W trending Yerer-Tullu Wellel Volcano Tectonic Lineament (YTVL).

\section{Lake Hora}

Lake Hora is located at the town of Debre Zeit (Bishoftu) and $\sim 45 \mathrm{~km}$ to the south east of Addis Ababa at an elevation of 2000 m a.s.l. (Fig. 4.6). Lake Hora and the surrounding lakes Babogaya, Bishoftu, Kilole and Arenguade are maar lakes and collectively known as the Bishoftu Lakes. Lake Hora has a maximum depth of $\sim 38 \mathrm{~m}$ and an area of $\sim 1 \mathrm{~km}^{2}$. The lake has no surface inlets or outlets and is fed by direct precipitation, run-off from the crater walls and by groundwater (Kebede et al., 2002).

Lake Hora is located at the eastern limit of the Yerer-Tullu Wellel Volcano Tectonic Lineament, $\sim 100 \mathrm{~km}$ to the east of Lake Dendi. The bedrock in the Bishoftu area is comprised of 9 Ma-old basalts, overlain by $1-4$ Ma basaltic lavas and pyroclastics. Early Holocene volcanic activity in this area produced scoria cones, rhyolitic lava domes and the Bishoftu maars (Gasparon et al., 1993). 


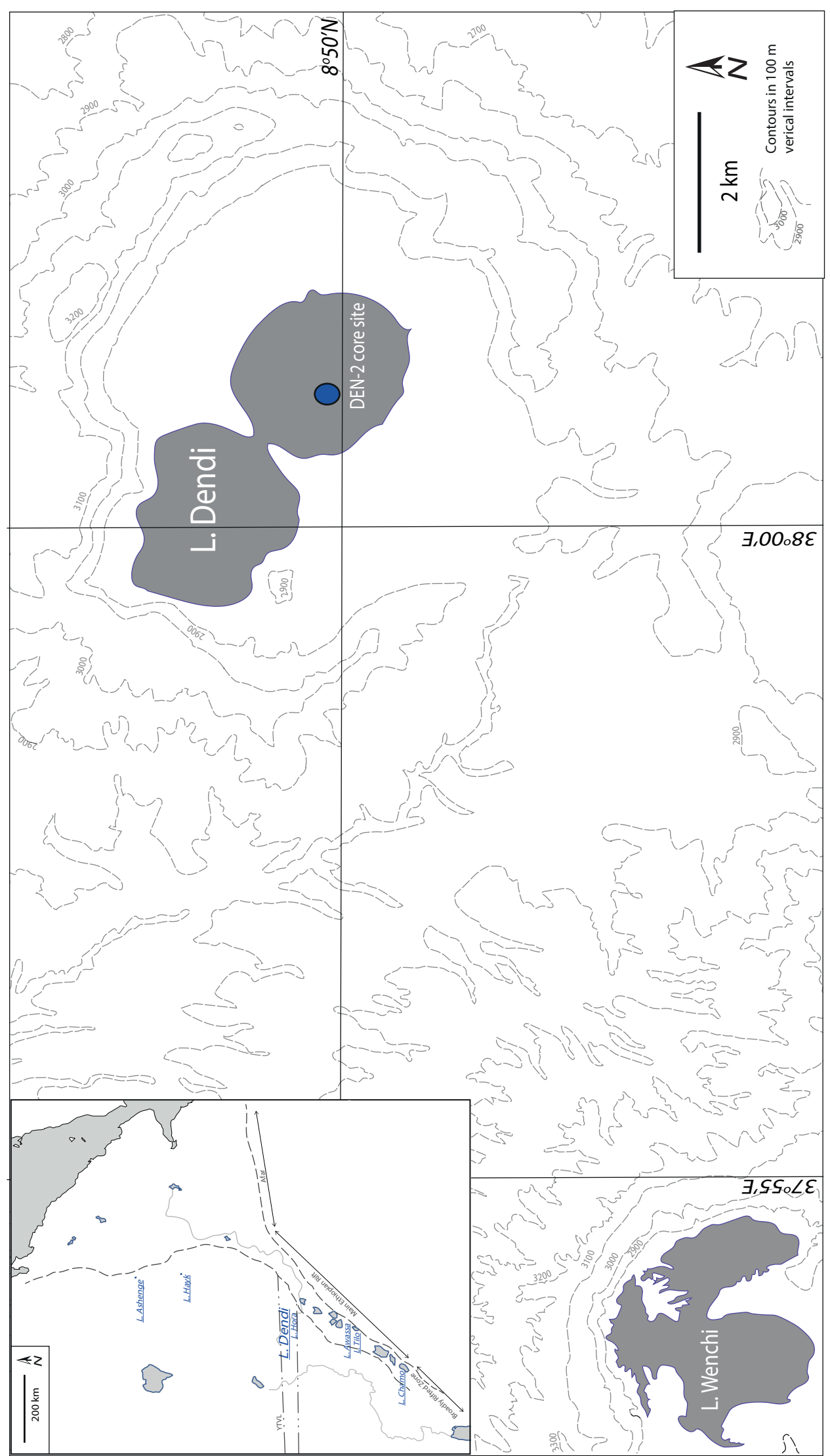

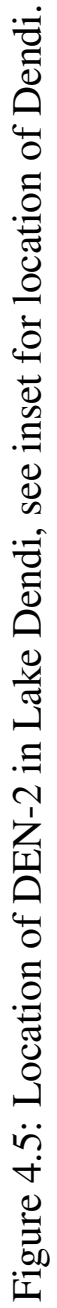




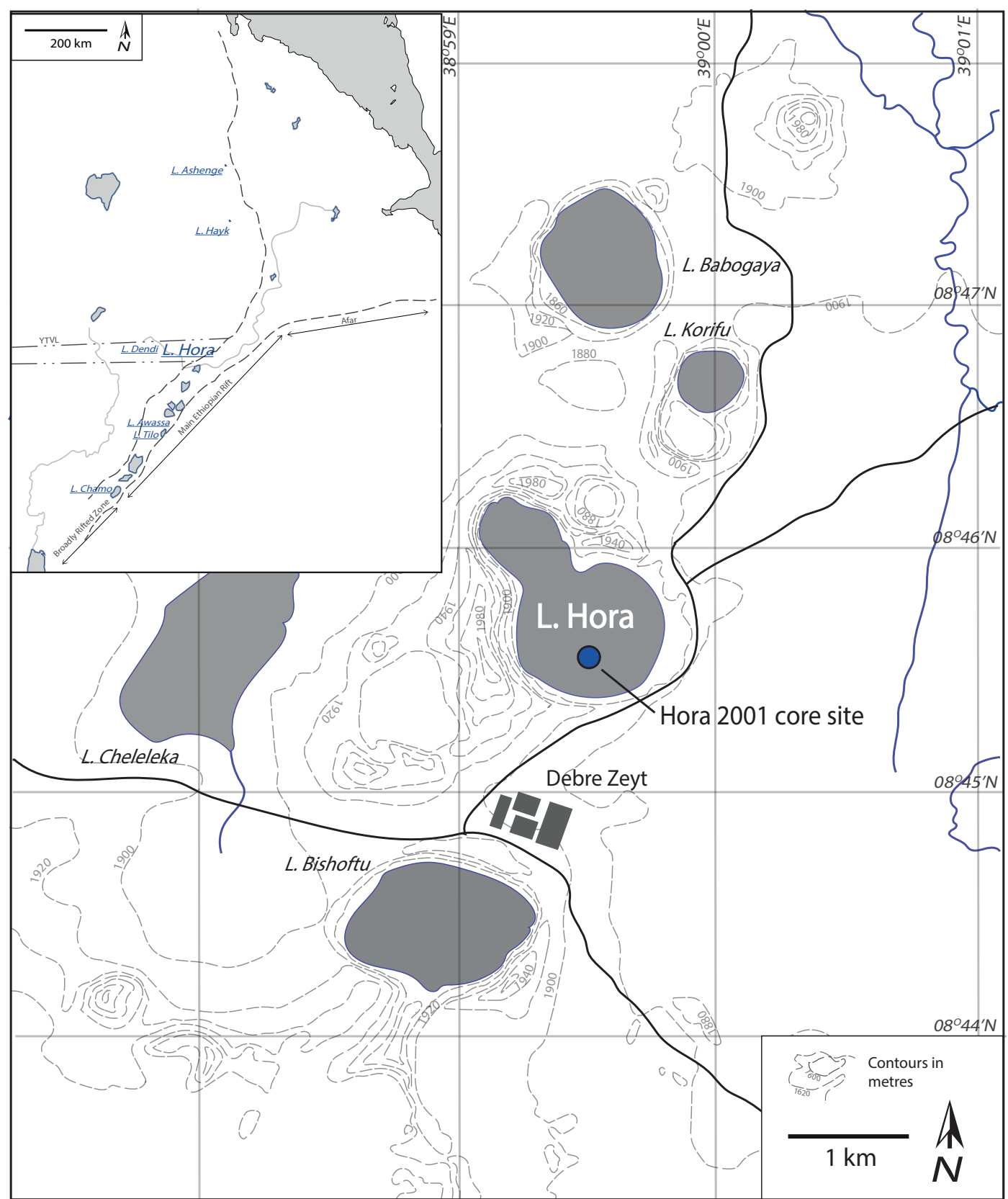

Figure 4.6: Lake Hora 2001 core site location, see inset for location of Lake Hora in Ethiopia. 


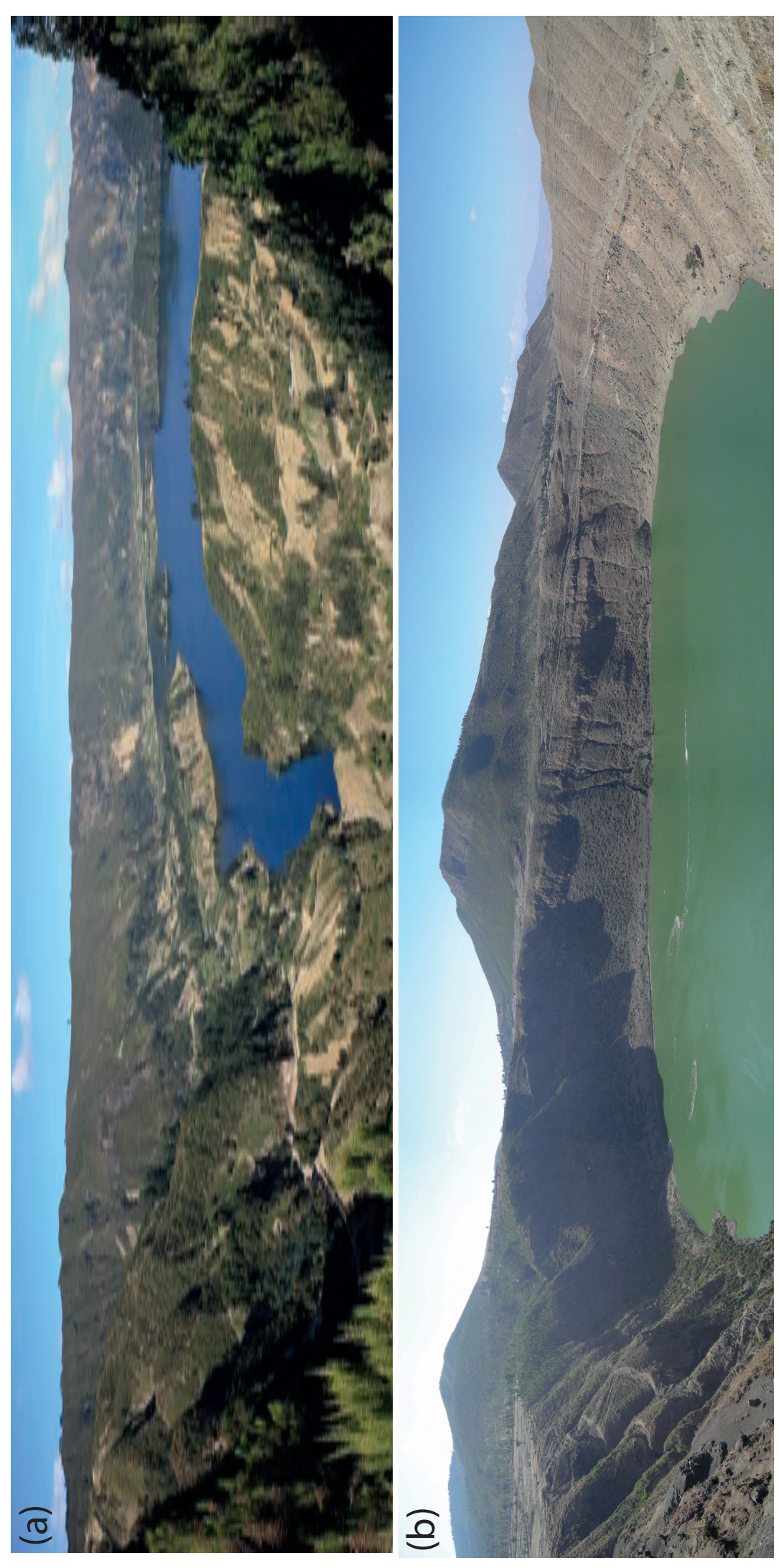

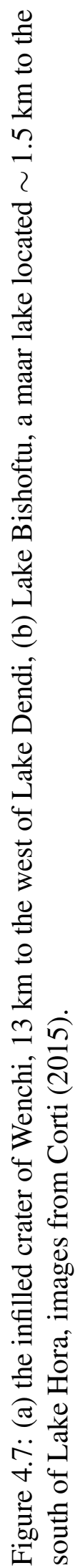




\subsubsection{Lake core sites in the Main Ethiopian Rift: Awassa, Tilo \& Chamo}

\section{Lake Awassa}

Lake Awassa is located in the central Main Ethiopian Rift and lies at an elevation of $1680 \mathrm{~m}$ a.s.l. (Fig. 4.8). The lake currently has a surface area of $\sim 92 \mathrm{~km}^{2}$ with a maximum depth of $23 \mathrm{~m}$. The lake is located within the nested Corbetti caldera complex which forms a $\sim 1300 \mathrm{~km}^{2}$ closed drainage basin. Lake Awassa is fed by streams on the northern and western slopes of the catchment and the Tikur Wuha River which enters via the Dabashi swamp to the north-east (Lamb, 2000).

The oldest deposits within the Corbetti caldera were erupted from the Chilalo Volcano $(\sim 120 \mathrm{~km}$ to the NE) consisting of $4.5-1.5 \mathrm{Ma}$ trachytic lavas and unwelded ignimbrites (WoldeGabriel et al., 1990). Elsewhere in the catchment, highly faulted ignimbrites associated with the Wonji fault belt occur; on the eastern shores of Lake Awassa these are overlain by hyaloclastites (Di Paola, 1971, 1972). Wendo Koshe and Chabbi volcanoes within the Corbetti caldera and on the northern shore of Lake Awassa have erupted obsidian flows and peralkaline pumice falls recently (Fig. 4.8b) (Di Paola, 1971, 1972; Rapprich et al., 2016). The most recent eruption from Wendo Koshe, at 400 BC (Rapprich et al., 2016), produced a widespread pumice deposit that has been reworked and redeposited around the shores of Lake Awassa. 


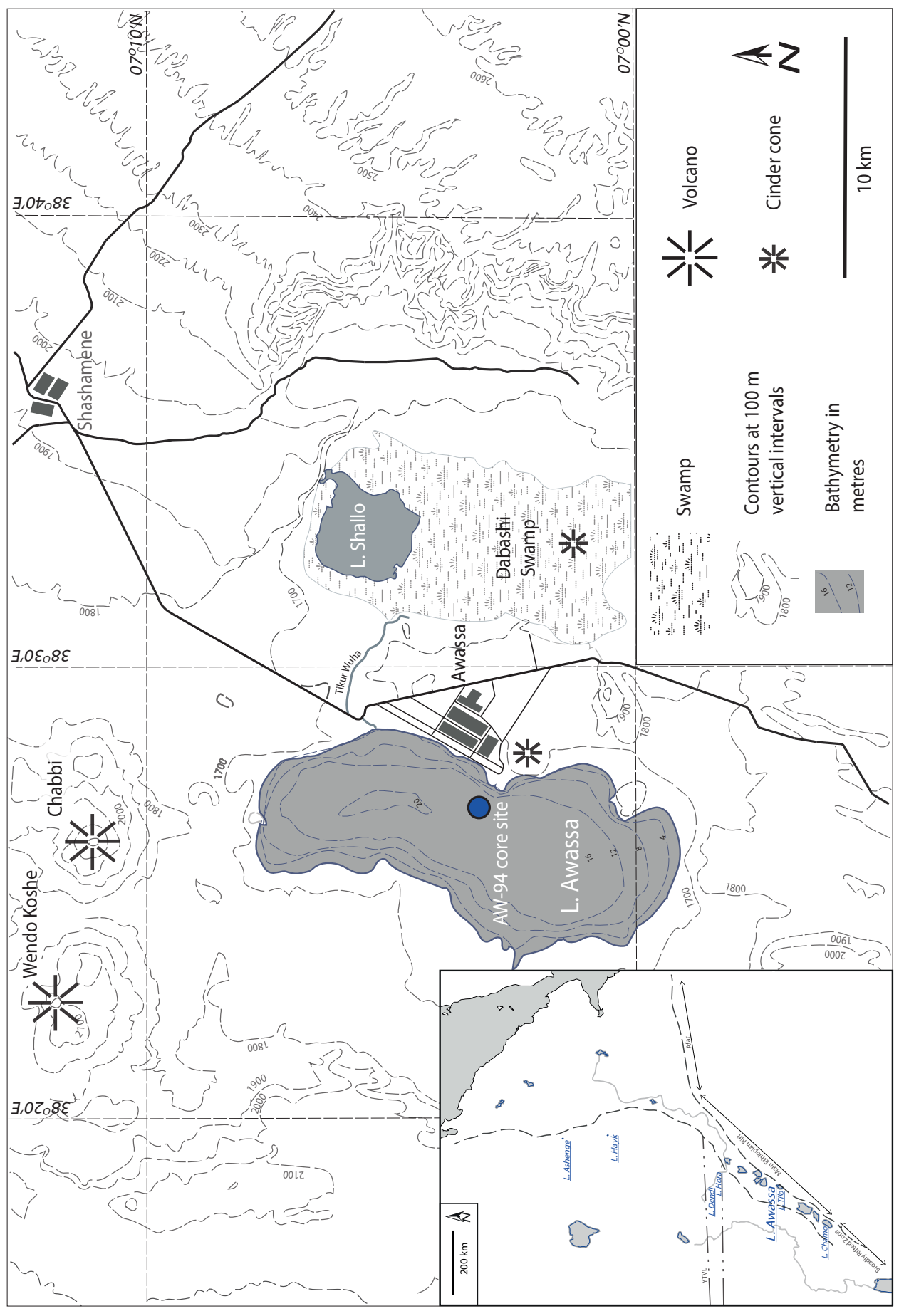




\section{Lake Tilo}

Lake Tilo is one of three crater lakes located $40 \mathrm{~km}$ to the west of Lake Awassa, at an elevation of $1550 \mathrm{~m}$ a.s.l. (Fig. 4.9). The crater lakes Budemeda, Tilo and Mechefera are orientated roughly north-south. Budemeda is the deepest of these lakes $(\sim 30 \mathrm{~m})$ contained within a $\sim 70 \mathrm{~m}$ crater. Mechefera is the shallowest $(\sim 5 \mathrm{~m})$ within $\mathrm{a} \sim 30 \mathrm{~m}$ deep crater with a basaltic cinder cone in the centre. Tilo is intermediate in depth $(\sim 7-11 \mathrm{~m})$, with steep crater rims of $40-80 \mathrm{~m}$ in height (Fig. 4.10b).

Ignimbrite deposits generally form the bedrock in the area surrounding Lake Tilo (Di Paola, 1972) and these are exposed at the base of the Tilo crater walls. Overlying this, $40-80 \mathrm{~m}$ of pyroclastic deposits are exposed in the Tilo crater walls and a porphyritic basalt lava flow outcrops in the southern edge of the crater rim (Lamb et al., 2002a). Lakes Budemeda, Tilo and Mechefera are probably maars occurring above an igneous dyke (Telford, 1998; Lamb, 2000).

\section{Lake Chamo}

Lake Chamo, the most southerly lake investigated in this study, is located $\sim 140$ $\mathrm{km}$ to the south-west of Lake Awassa and $6 \mathrm{~km}$ south of the town of Arba Minch. The lake lies at an elevation of $1100 \mathrm{~m}$ a.s.l. and has a surface area of $\sim 551$ $\mathrm{km}^{2}$ with a maximum depth of $13 \mathrm{~m}$ (Kebede et al., 1994; Kassa, 2013). The Kulfo River drains water from Lake Abaya into Lake Chamo and overflow from Lake Chamo ultimately drains into the Chew Bahir Basin. Lakes Chamo and Abaya were formerly part of a much larger drainage basin which includes Lakes Chew Bahir and Turkana, on the Ethiopia-Kenya border (Awulachew, 2006). 


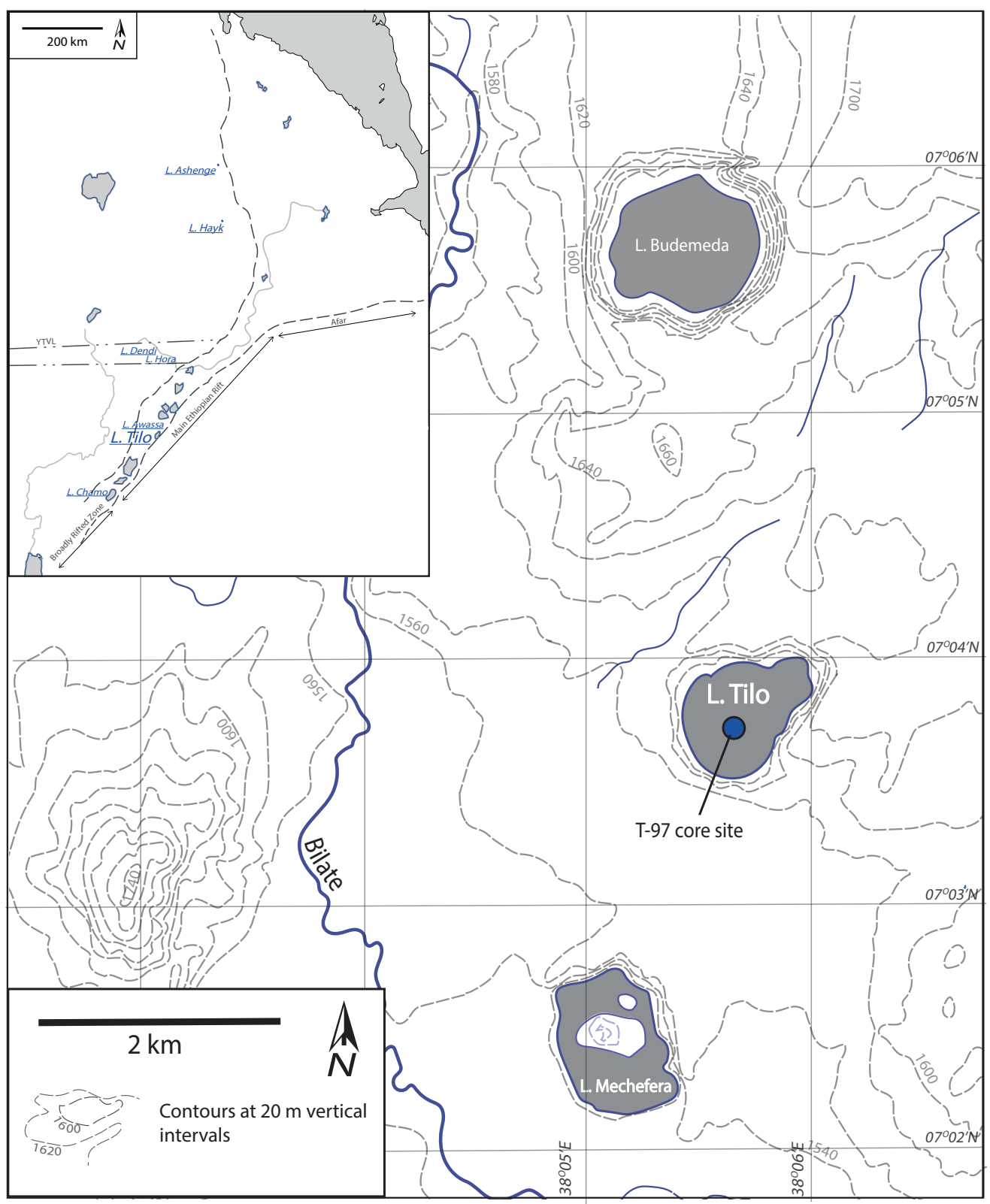

Figure 4.9: Lake Tilo T-97 core site, see inset for location of Lake Tilo in the CMER. 


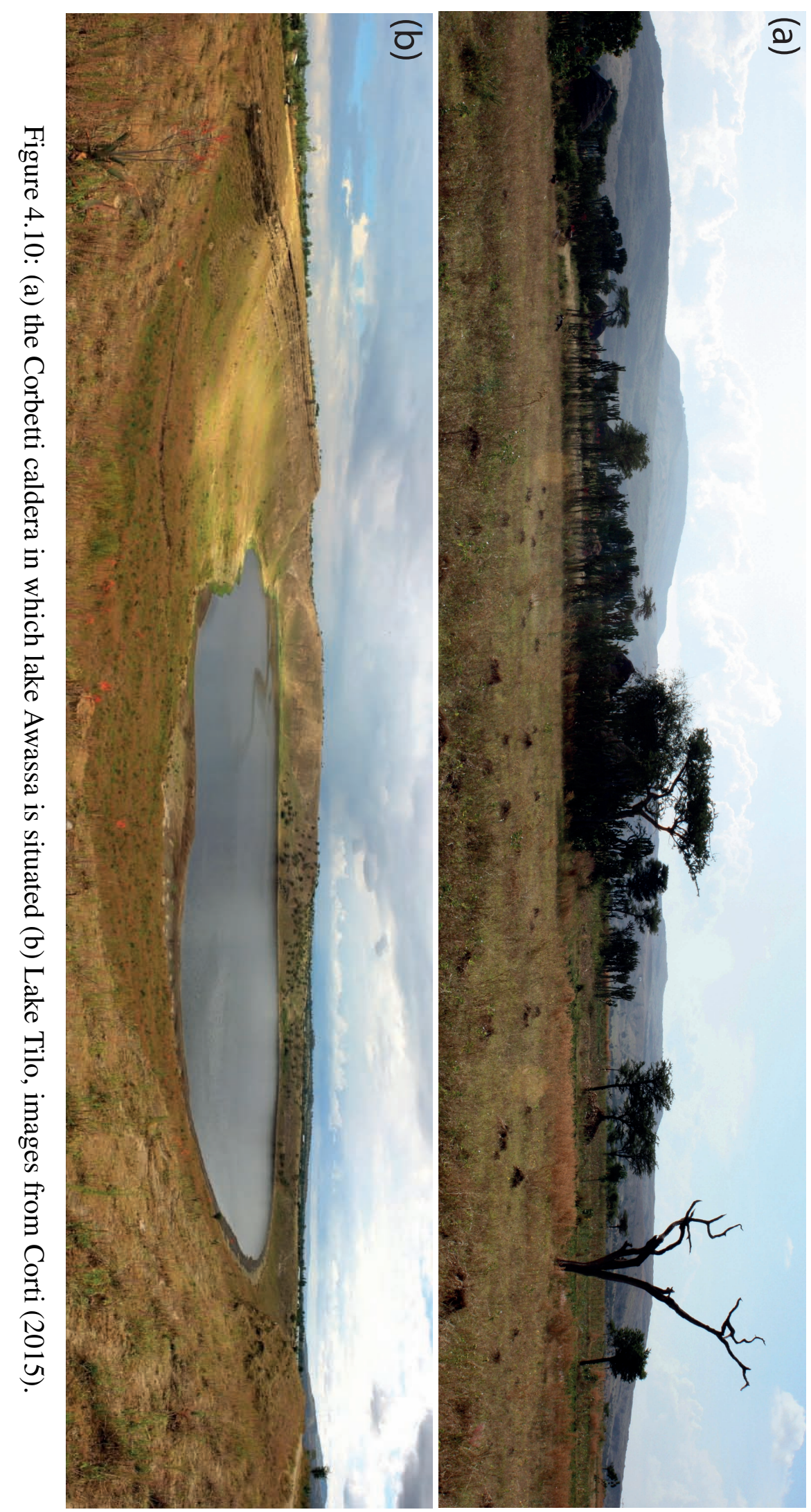




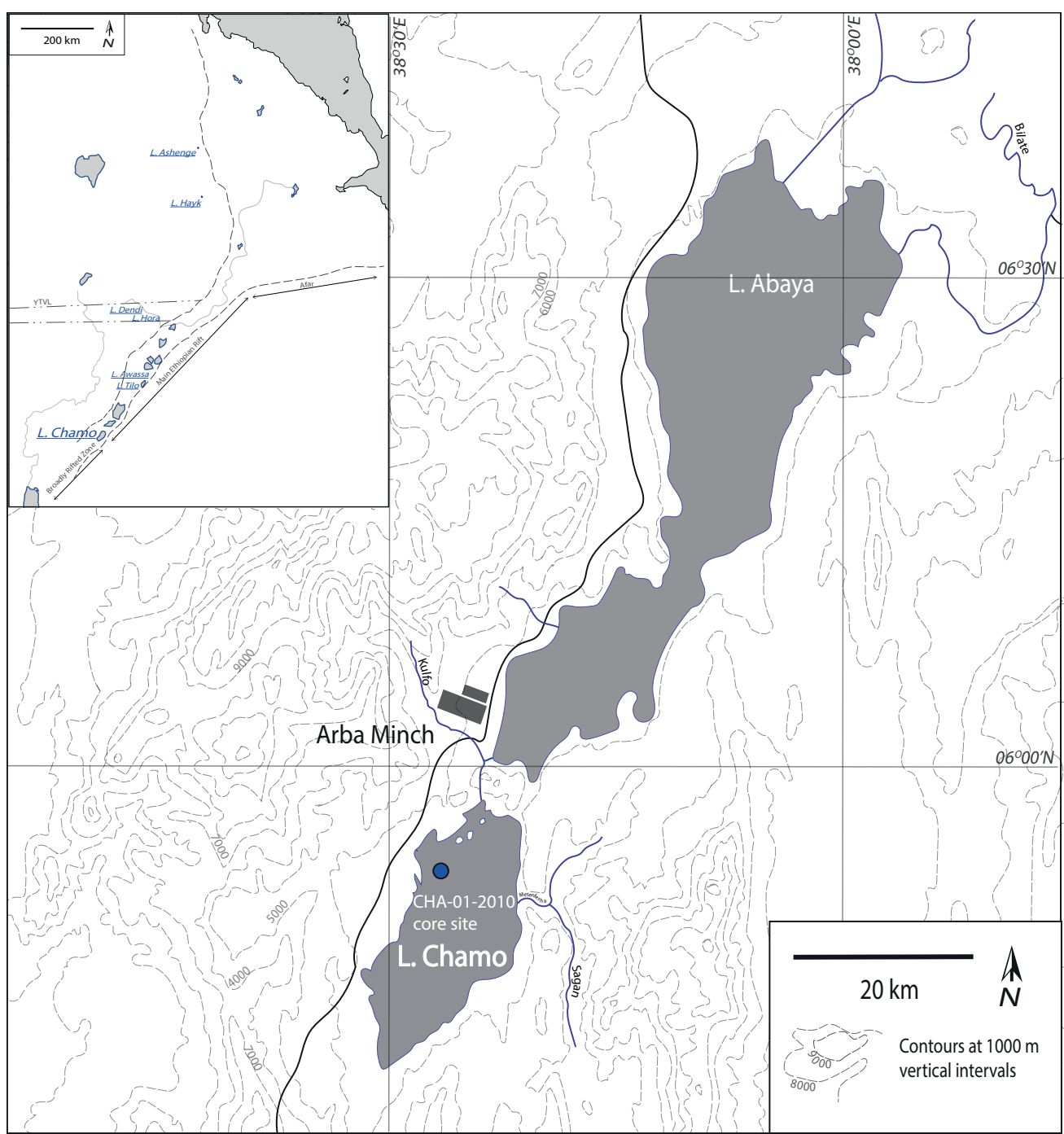

Figure 4.11: Location of core CHA-01-2010 collection in Lake Chamo, see inset for location of Lake Chamo in the CMER. 
Lake Chamo occurs within the Ganjuli Graben, which extends from Lake Abaya to Konso, $\sim 80 \mathrm{~km}$ to the south. Lake Chamo is underlain by Precambrian crystalline basement and Eocene-Miocene mafic lava flows with Quaternary alluvial deposits outcropping above (Ebinger et al., 1993; Nagaoka et al., 2005). Lake Chamo is seperated from Lake Abaya by the Tosa Sucha (Bridge of God) chain of scoria cones; these may have been active historically and have produced olivine basalt flows (Ebinger et al., 1993).

\subsubsection{Proximal tephra samples}

\subsubsection{Proximal tephras from the Afar Rift}

Details of a selection of samples collected from the Afar Rift are given below and are summarised in Table 4.2.

\section{Dubbi}

Two tephra samples were collected by C. Oppenheimer (University of Cambridge) from Dubbi volcano (Eritrea) in January 1998 (Fig. 4.13). Proximal deposits from the Dubbi 1861 eruption were studied by Wiart and Oppenheimer (2000) and are illustrated in the stratigraphic sections in Fig. 4.13. Glass samples from a pyroclastic density current deposit associated with the 1861 eruption have been analysed as part of this study.

\section{Ayelu}

Tephra samples were collected by G. WoldeGabriel (Los Alamos National Laboratory) from the Quaternary rhyolitic volcanic centre, Mount Ayelu, $(\sim 240$ $\mathrm{km}$ to the north-east of Addis Ababa) and the surrounding areas during field work in 2000 (Fig. 4.14). Four late Pleistocene tephra samples were collected from 


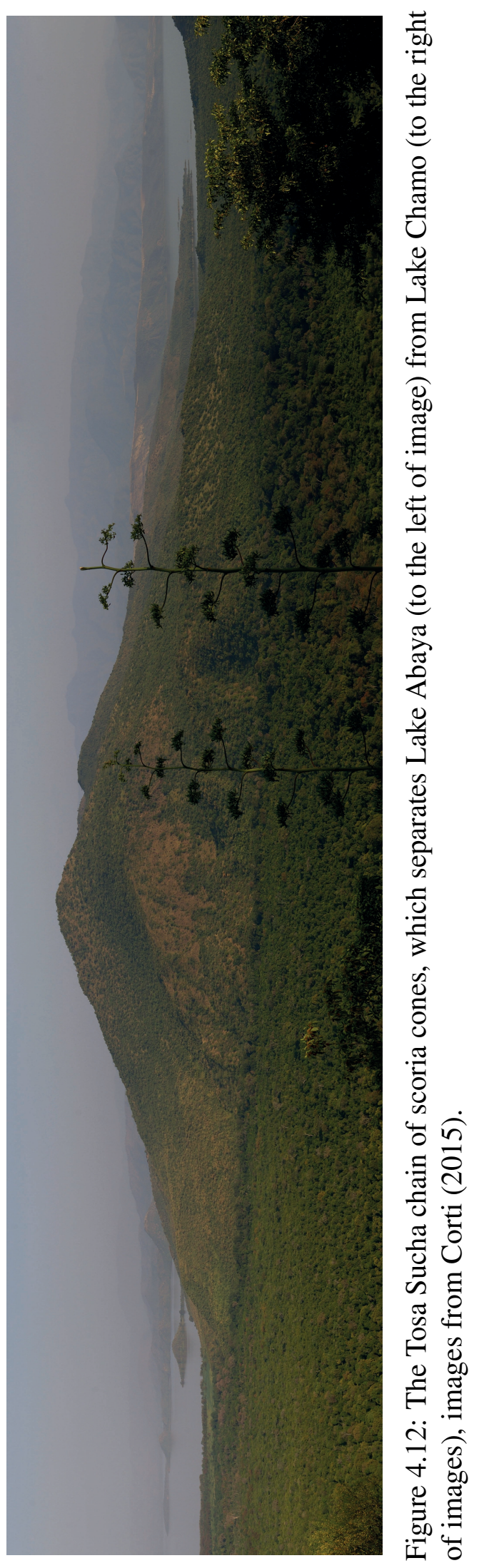




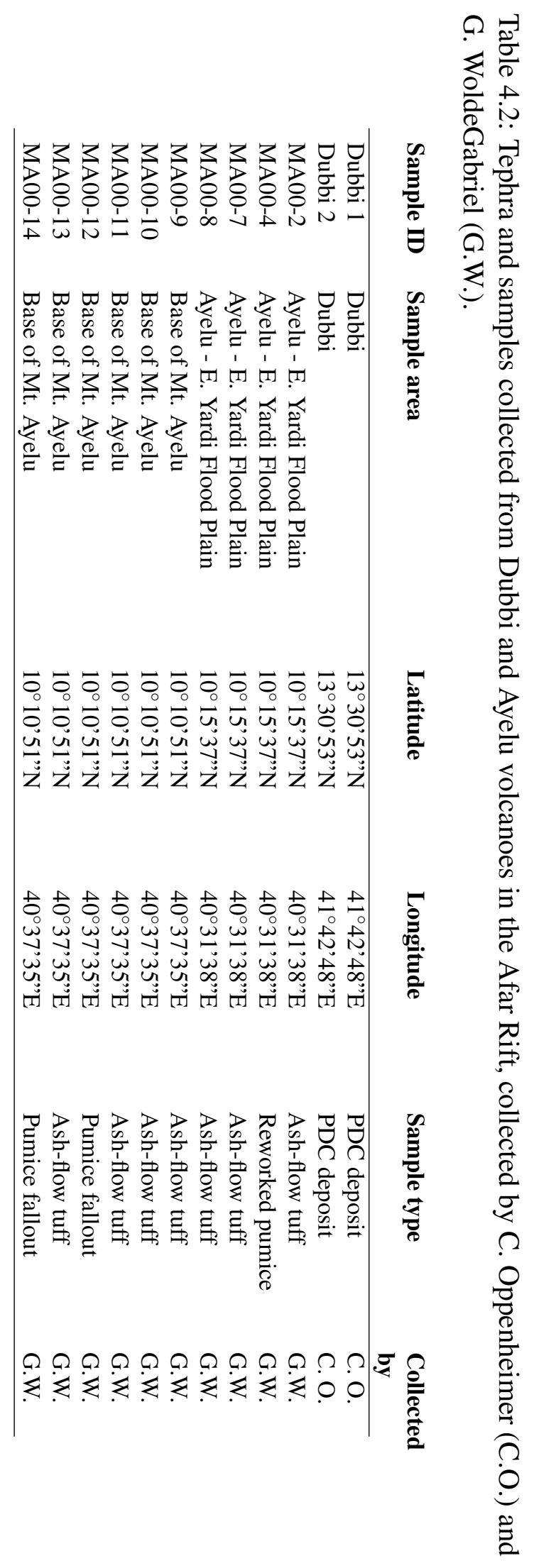



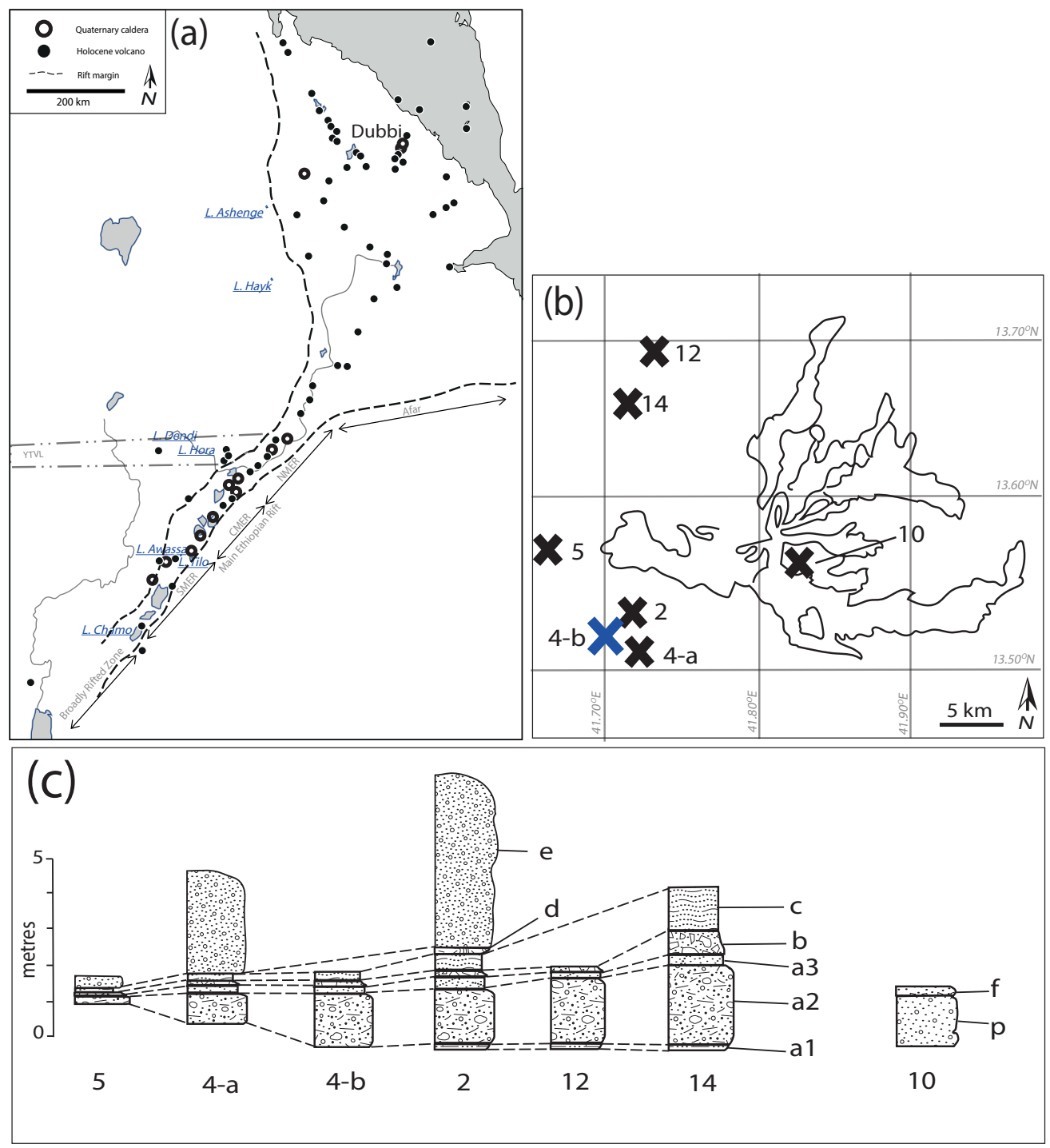

Figure 4.13: (a) Location of Dubbi in the Afar Rift, (b) Schematic of Dubbi volcano with stratigraphic sections logged by Wiart and Oppenheimer (2000) indicated with crosses, tephra from site 4-b (blue cross) has been analysed in this study, (c) Stratigraphic sections logged by Wiart and Oppenheimer (2000) from the areas around Dubbi volcano. a: Pyroclastic flow deposit $(\mathrm{a} 1=$ basal unit, $\mathrm{a} 2=$ pumice flow deposit, a3 = coignimbrite ash), b: scoria fall deposit, c: pyroclastic flow deposit, d: reworked deposit, e and p: pumice fall deposits, f: scoria fall deposits. Figures (b) and (c) are adapted from Wiart and Oppenheimer (2000). 
the Bouri Formation on the East Yardi Flood Plain (Fig. 4.14). In order to check whether the Bouri Formation tephras were locally derived, six tephra samples were also collected from the north western slopes of the Ayelu volcano $(\sim 30 \mathrm{~km}$ to the SE of the East Yardi Flood Plain).

Figure $4.14 \mathrm{~b}$ shows the location of samples collected from the eastern side of the Awash River Flood Plain and the base of Mount Ayelu; Fig. 4.14c shows stratigraphic sections at the two sampling localities.

\subsubsection{Proximal tephras from the central Main Ethiopian Rift}

Details of a selection of samples collected from the central Main Ethiopian Rift are given below and are summarised in Table 4.3 - a broad overview map of samples from this area is shown in Fig. 4.15.

\section{Awassa and Tilo}

During field campaigns in 1995 and 1997, N. Pearce (Aberystwyth University) collected a selection of tephra and obsidian samples from the shores of Lakes Tora, Awassa and Tilo and these have been analysed in this study.

Sample localities around Lake Awassa and inside the Corbetti caldera are seen in Fig. 4.16. Obsidian samples were collected from the northern shores of Lake Awassa (E95010, E95011 and E95019) and a small quarry on the Wondo-Genet Shashamene road to the east of the Lake (E95003). Tephras were also sampled to the east of Lake Awassa, from a gully section on the Awassa - Shashamene road (E95006 and E95007) and from the Shallo swamp (ST1-NW).

Two samples were also collected from the northern shores of Lake Tilo (Fig. 4.17b) ; an obsidian clast (E95025) within an ignimbrite and, $\sim 600 \mathrm{~m}$ to the west, a pumice sample (E97003). 


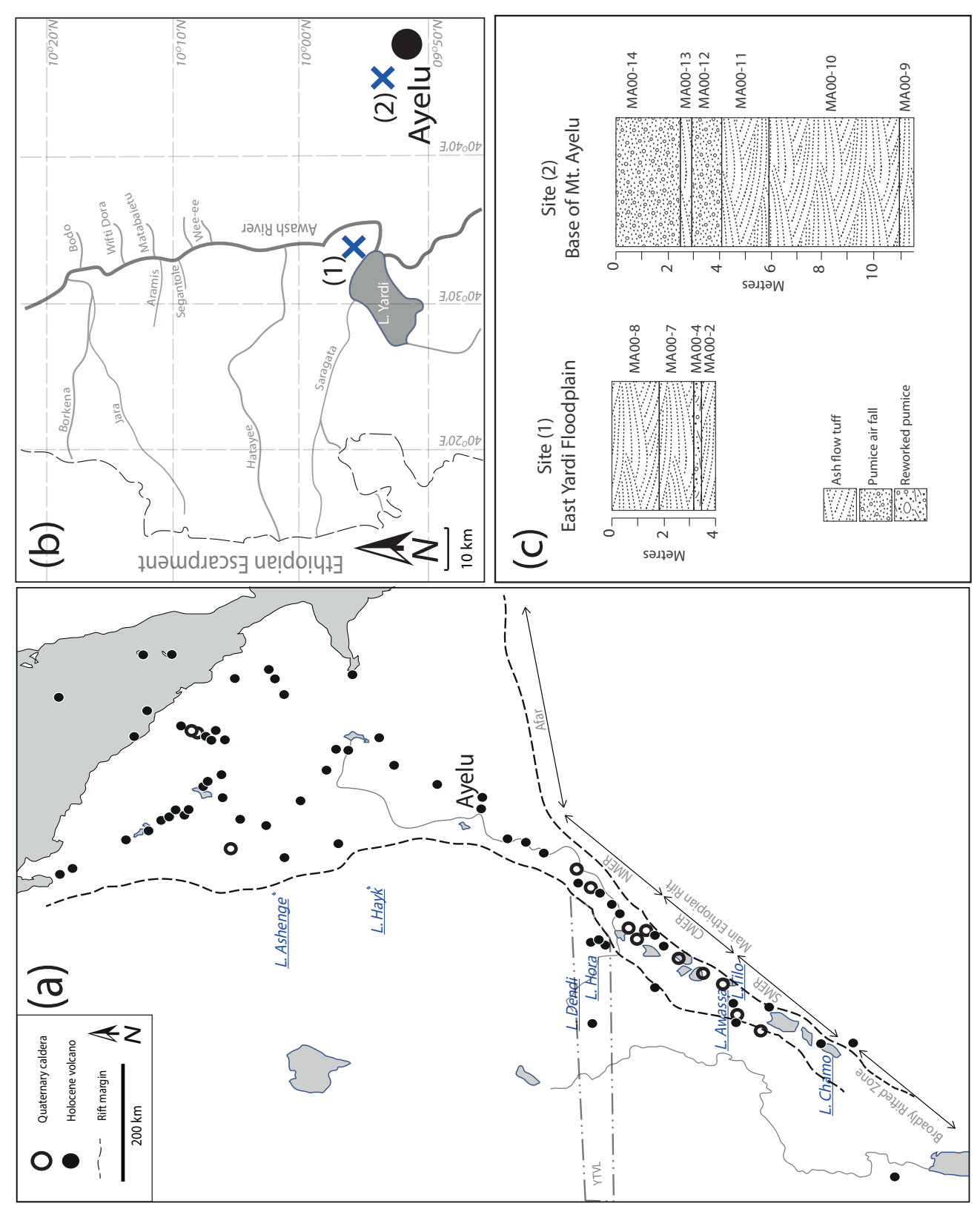

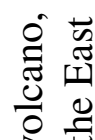

추

定. 仓ै

ฮ त्त्र

롴

$\because 0$

름

空

定

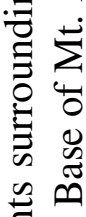

정

이융

클

클 흘

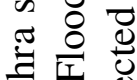

를 : 흥

อ

- $\frac{0}{2}$

느등 증

究

(2) की

$\Xi$ :

三完

完号

世艺

응 ฮ

它

లู 드

ชิ ส․ำ

$\because \stackrel{0}{\cong} \frac{\pi}{0}$

ป

$\forall$ 更

늘

क् 


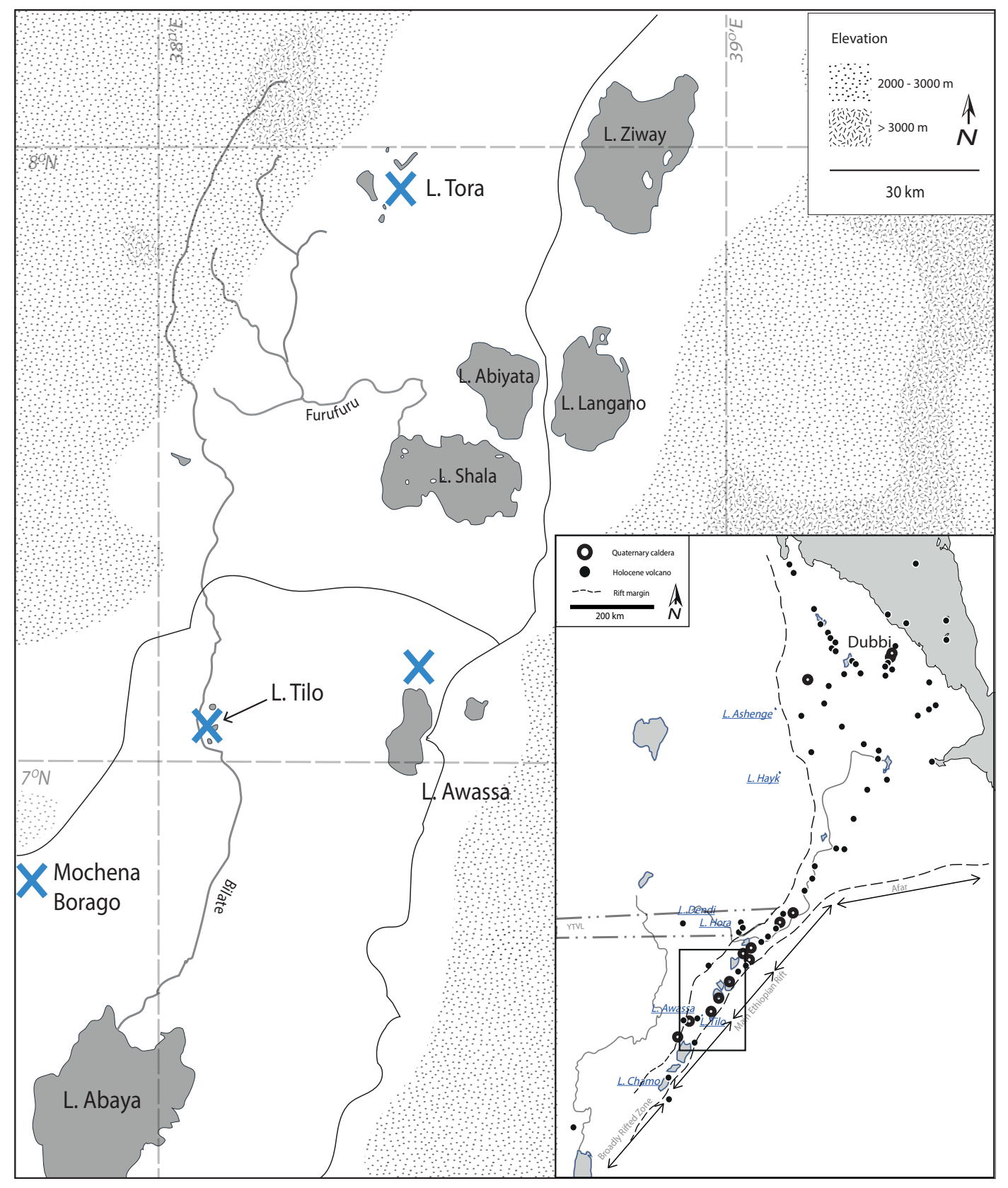

Figure 4.15: Locations of samples collected in Central Main Ethiopian Rift; for location in Ethiopia see inset. Tephra sample locations shown with blue crosses; samples from areas surrounding Lake Tora, Awassa and Tilo were collected by N. Pearce. Tephra samples collected from the Mochena Borago Rockshelter were collected by S. Meyer. 


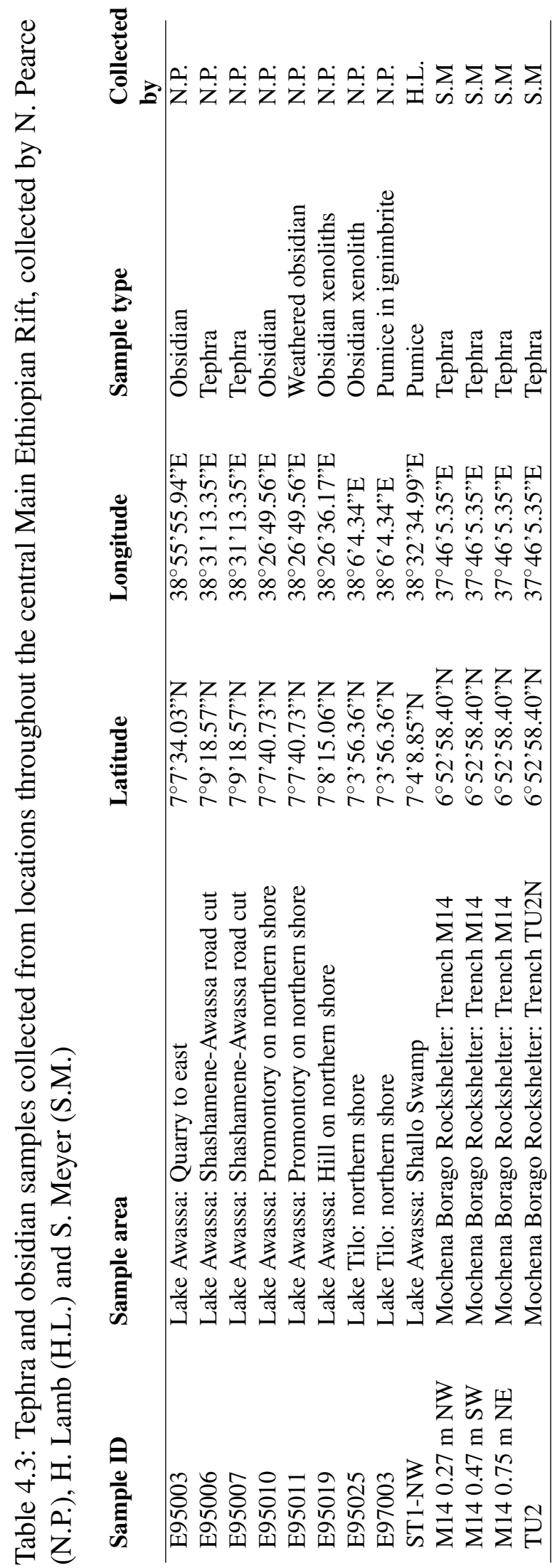




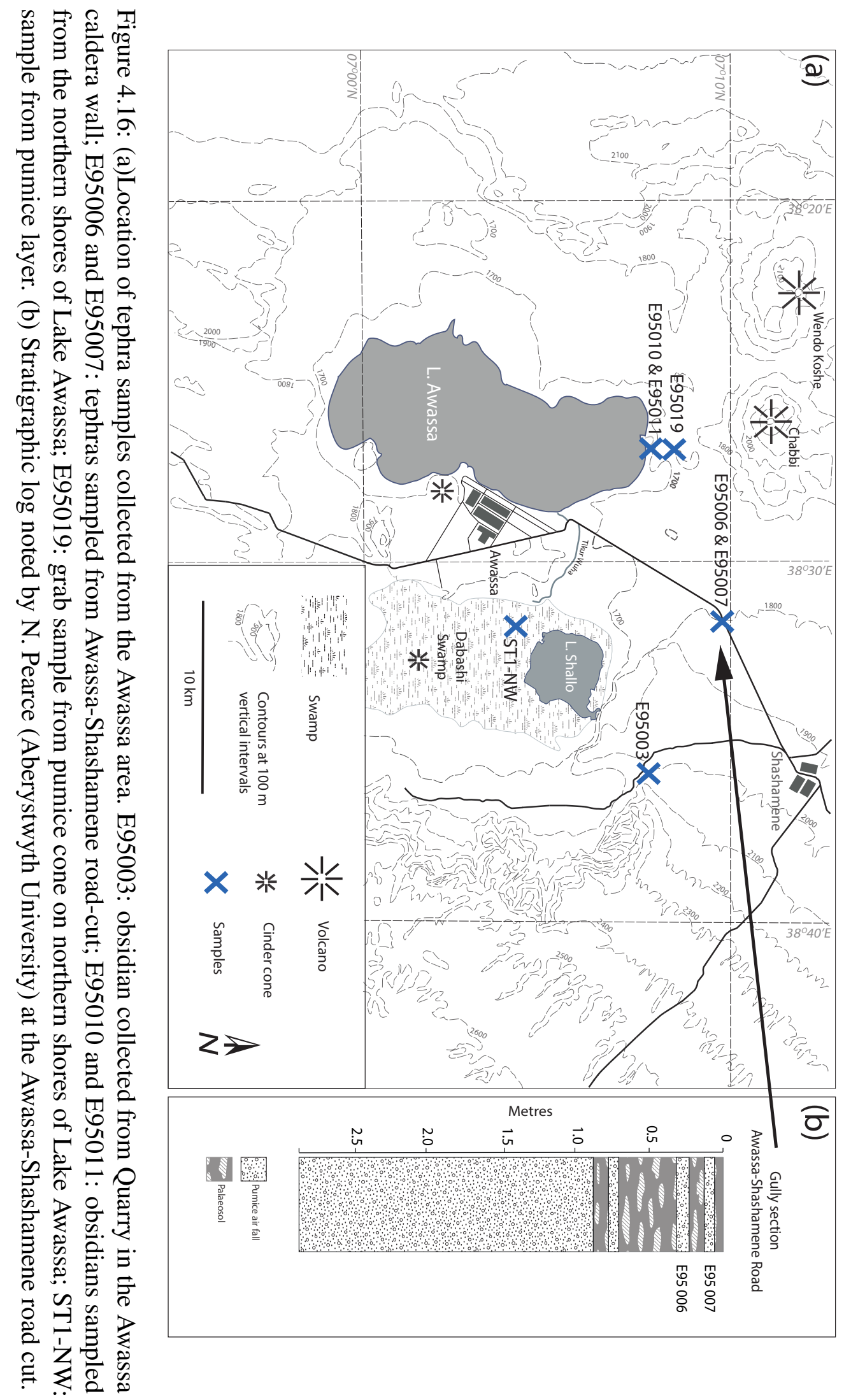



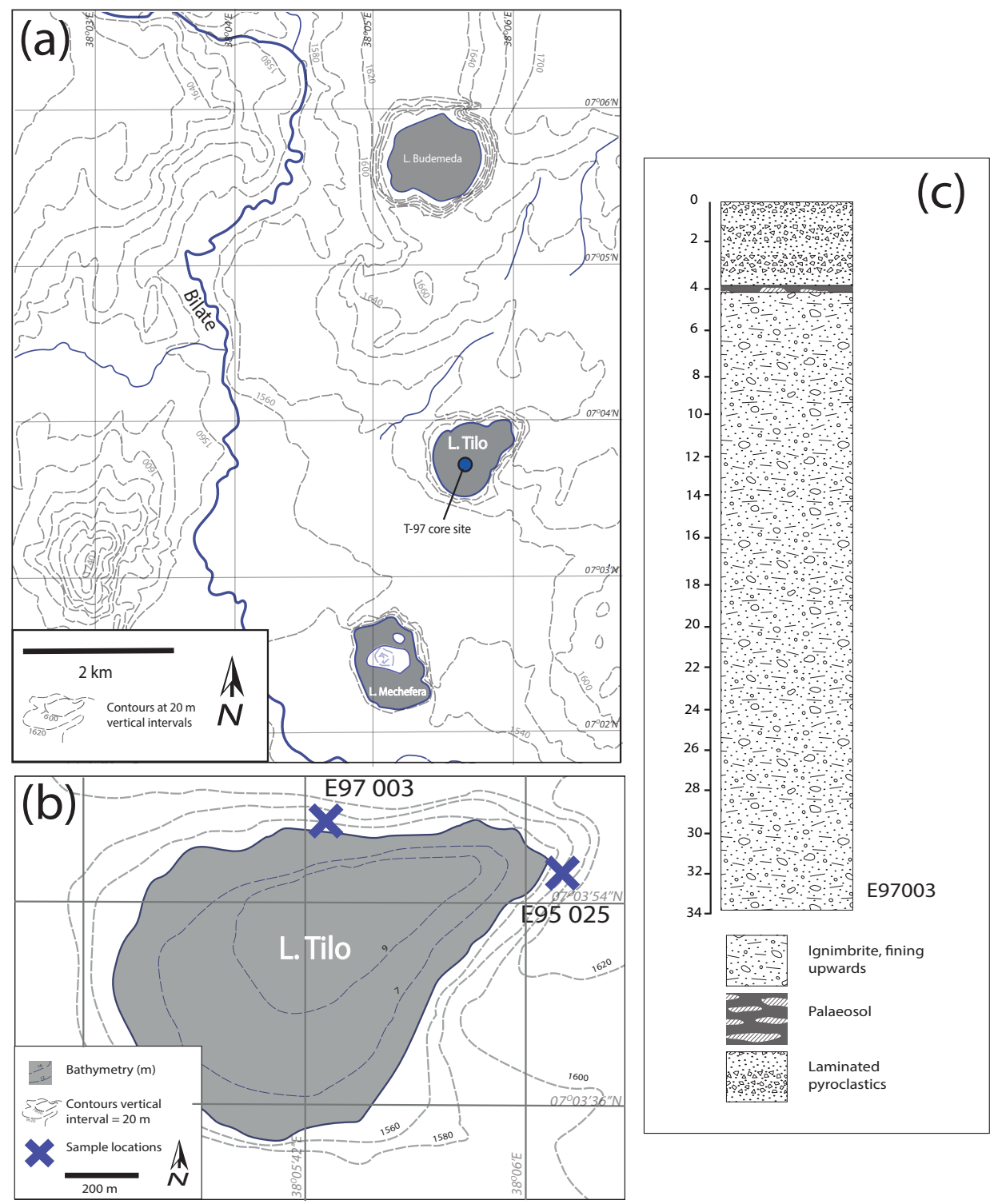

Figure 4.17: (a) and (b) Location of tephra samples collected from the shores of Lake Tilo, crosses indicate the locations from which and E95025 and E97003 were collected (c) Section showing lithology of the northern shore of Lake Tilo, noted by N. Pearce (Aberystwyth University). Sample E97003 was collected from the 'Valley Floor Ignimbrites' comprising the base of the sequence. 


\section{Mochena Borago Rockshelter}

The Mochena Borago Rockshelter is located on the south-western flanks of Mount Damota (Fig. 4.18), a trachytic volcano $\sim 40 \mathrm{~km}$ to the southwest of Lake Tilo. The Mochena Borago Rockshelter deposits and archaeological finds are described in detail by Brandt et al. (2012). The rockshelter is formed within a non-welded ignimbrite which is under and overlain by mafic lava flows. Deposits on the cave-floor range in age from $\sim 53 \mathrm{ka}$ to Holocene.

Three tephra deposits occur in sediments on the cave-floor. The oldest 'YBT' tephra is $20 \mathrm{~cm}$ thick, yellow-brown coloured and radiocarbon dates on charcoal give an age of 45.4 cal. ka BP. Deposits of clay rich silt separate the YBT tephra from a younger, $\sim 12 \mathrm{~cm}$ thick'YBS' ash and gravel rich volcaniclastic mud flow containing charcoal fragments with a radiocarbon age of $43.1 \mathrm{cal}$ ka BP. This deposit is overlain by silty clay deposits. The youngest 'BWT' tephra caps a major unconformity in the Late Pleistocene sediments. The deposit is white in colour, $\sim 20 \mathrm{~cm}$ thick and radiocarbon dates on charcoal fragments in the BWT tephra give an age of $7.6 \mathrm{cal}$. ka BP. However, feldspars in the BWT tephra have an ${ }^{40} \mathrm{Ar} /{ }^{39} \mathrm{Ar}$ age of $3.16 \pm 0.07 \mathrm{Ma}$. Brandt et al. (2012) suggest that the older feldspars within this Holocene tephra may be derived from the older ignimbrite in which the Mochena Borago Rockshelter has formed.

Samples from the youngest Holocene BWT tephra were collected by S. Meyer (University of Cologne) from the Mochena Borago Rockshelter and analysed as part of this study. The proximity of the Mochena Borago rockshelter to Lake Tilo may mean that there is potential for correlations between these sites, improving the Mochena Borago chronology. 


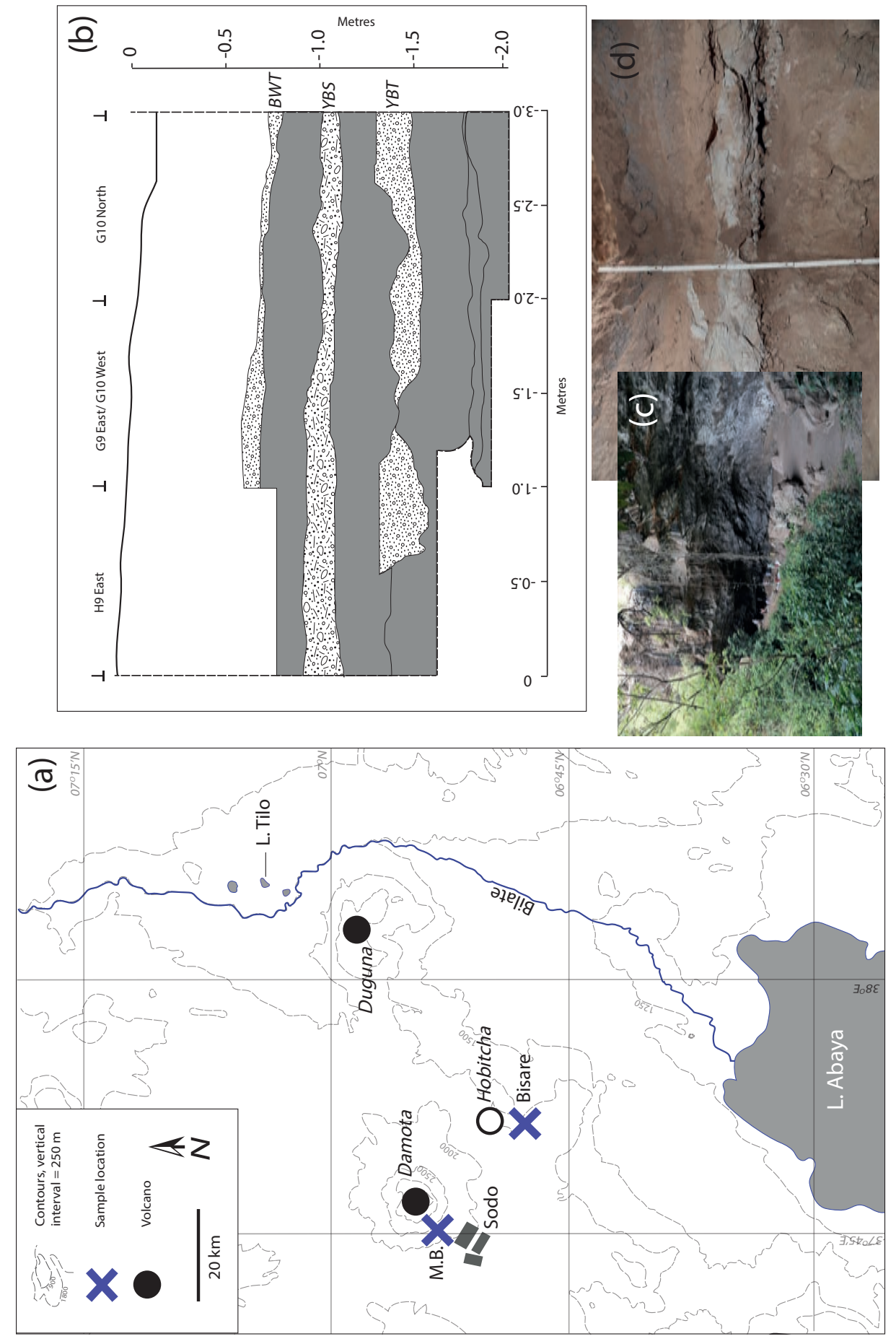

อิ

कิ ง

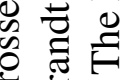

记

응 을

氜焉

这部

ปี

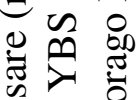

ติ

छี

ষ্

के है

范

등

엉

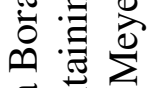

卷 $\dot{0}$

过

$\sum \bar{\Phi}$

Ð

छ

홍 ڤ

ब $\frac{0}{2}$

兽 总

\&

苛

สี

प

응 졿

苂

$\stackrel{1}{3} 3$

తิ

$\ddot{\infty} \stackrel{\imath}{0}$

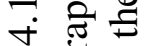

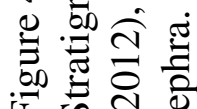




\subsection{Chronology}

\subsubsection{Lake cores}

In this study, tephras in lake cores are dated indirectly on the basis of their modelled radiocarbon age. Most of the sediment cores used here have been previously studied (see Table 4.1), and their radiocarbon dates calibrated against the varying models available at that time.

A combination of new and previously published radiocarbon dates provide the chronologies for the seven lake archives studied here. Tilo sediments were dated using airfall sedimentary charcoal and the Chamo archive was dated using a combination of shell and plant material analyses. All other core sediments were dated using bulk sediment samples. The AMS ${ }^{14} \mathrm{C}$ measurements for the lake sediments are shown in Tables 4.4 and 4.5.

Samples for radiocarbon dating were digested in $2 \mathrm{M} \mathrm{HCl}$ for $8 \mathrm{~h}$ at $80^{\circ} \mathrm{C}$, washed with distilled water and homogenised. Pre-treated samples were heated with $\mathrm{CuO}$ in sealed plastic tubes to recover the $\mathrm{CO}_{2}$, which was then converted to graphite by $\mathrm{Fe} / \mathrm{Zn}$ reduction. The radiocarbon was then measured using accelerator mass spectrometry at: Scottish Universities Environmental Research Centre (Ashenge), Oxford Radiocarbon Accelerator Unit, University of Oxford (Hayk) 14 CHRONO Centre, Queen's University Belfast (Hayk), Beta-Analytic (Hora, Awassa and Tilo) and the Cologne AMS Center (Dendi and Chamo).

Radiocarbon ages were recalibrated using IntCal13 (Reimer et al., 2013), ensuring the ages of tephras in different archives could be compared. Unfortunately, due to uncertainities over coring depths for the Hora sediments, coupled with age reversal throughout the core, a new age model was not generated for this archive. Bayesian P_Sequence depositional models were run for Ashenge, Hayk, Awassa, 
Tilo and Chamo sequences, using OxCal version 4.2 (Bronk Ramsey, 2009a) with outlier analysis (Bronk Ramsey, 2009b). Bernd Wagner (University of Cologne) supplied the Bayesian age model for the Dendi sediments, generated using Bacon software (Blaauw and Christen, 2011). Bayesian models do not assume uniform sedimentation rate or attempt to wiggle match to a calibration curve, whilst P_Sequence models allow for less rigid modelling of the data. Outlier analysis includes ages identified as statistical outliers in the model, but they are given a lower weight. Prior to analysis, sediment depths were converted to event free depths that do not include tephras of $>0.5 \mathrm{~cm}$ thickness, which are presumed to have been deposited instantaneously. Due to the presence of a significant hiatus at around $650 \mathrm{~cm}$ depth in the Lake Ashenge 03AL3/2 stratigraphy, separate P_Sequence age models were run to model deposition above and below this point. Interpolated tephra ages were retrieved using the Date function and are quoted herein as $95.4 \%$ confidence intervals. These new age models are seen in Chapter 5 and were used to calculate tephra ages which include uncertainties in the modelled interpolation.

\subsubsection{Proximal tephras}

Samples collected from a recent tephra deposit at Dubbi volcano are associated with an eruption of the volcano dated at 1861 by historical accounts. Tephras sampled from the Lake Yardi area at the base of Ayelu have not been directly dated. However, they occur within the Bouri Formation, which has been divided into three chronostratigraphic sequences: Hatayae (2.5 - 1.0 Ma), Dakanihylo $(1.0-0.26 \mathrm{Ma})$ and Herto $(0.25-0.16 \mathrm{Ma})$ based on ${ }^{40} \mathrm{Ar} /{ }^{39} \mathrm{Ar}$ dating of tephras and biostratigraphy (de Heinzelin et al., 1999; Asfaw et al., 2002; Clark et al., 2003). Whilst these tephras are older than Holocene tephras investigated in 
Table 4.4: AMS ${ }^{14} \mathrm{C}$ measurements for the Ashenge and Hayk lake sediment cores. All analyses were undertaken on bulk sediment samples. Dates on Ashenge sediments from Marshall et al. (2009) are indicated in bold. Ages were calibrated using IntCal13 (Reimer et al., 2013) run in OxCal version 4.2 (Bronk Ramsey, 2009a). * Sample SUERC-7178 from $645.5 \mathrm{~cm}$ depth was reanalysed (SUERC-7439) using archived $\mathrm{CO}_{2}$ from original sample, both dates have been combined using the $R_{-}$Combine function.

\begin{tabular}{lllll}
$\begin{array}{l}\text { Laboratory } \\
\text { number }\end{array}$ & $\begin{array}{l}{ }^{14} \mathbf{C} \text { ages } \mathbf{y r} \mathbf{B P} \\
( \pm \mathbf{1} \boldsymbol{\sigma})\end{array}$ & $\begin{array}{l}\text { Depth } \\
(\mathbf{c m})\end{array}$ & $\begin{array}{l}\boldsymbol{\delta}^{13} \mathbf{C} \\
\mathbf{( \% )} \mathbf{P D B})\end{array}$ & $\begin{array}{l}\text { Calibrated } \\
\text { ages yr BP }\end{array}$ \\
\hline Ashenge & & & & \\
SUERC-29473 & $378 \pm 37$ & 3.5 & -22.6 & $507-316$ \\
SUERC-6263 & $618 \pm 31$ & 51.5 & -20.9 & $658-550$ \\
SUERC-29476 & $923 \pm 35$ & 104.5 & -21.7 & $927-776$ \\
SUERC-6264 & $1609 \pm 22$ & 175.5 & -24.0 & $1553-1415$ \\
SUERC-29477 & $2082 \pm 37$ & 246.5 & -24.4 & $2150-1951$ \\
SUERC-6265 & $2865 \pm 28$ & 300.5 & -23.0 & $3069-2883$ \\
SUERC-29478 & $3298 \pm 35$ & 341.5 & -22.0 & $3611-3450$ \\
SUERC-29479 & $4143 \pm 38$ & 386.5 & -22.2 & $4808-4527$ \\
SUERC-6266 & $4714 \pm 30$ & 440.5 & & $5581-5324$ \\
SUERC-29480 & $4361 \pm 38$ & 485.5 & -23.6 & $5039-4852$ \\
SUERC-6268 & $5063 \pm 34$ & 551.5 & -22.1 & $5907-5741$ \\
SUERC-29481 & $5671 \pm 39$ & 600.5 & -22.5 & $6564-6324$ \\
SUERC-7178 & $6696 \pm 40$ & 645.5 & -20.8 & $7581-7476$ \\
SUERC-7439* & $6622 \pm 40$ & 645.5 & & $7581-7476$ \\
SUERC-6269 & $10127 \pm 66$ & 657 & -23.4 & $12015-11398$ \\
Beta-187297 & $11920 \pm 40$ & 739.5 & -25.1 & $13961-13574$ \\
SUERC-6270 & $12810 \pm 99$ & 771.5 & -21.3 & $15675-15005$ \\
\hline Hayk & & & & \\
UBA-27072 & $1583 \pm 32$ & 12.5 & & $1546-1395$ \\
OxA-30960 & $2485 \pm 32$ & 100 & -23.4 & $2729-2434$ \\
OxA-30883 & $2795 \pm 31$ & 140 & -23 & $2974-2796$ \\
UBA-25092 & $3563 \pm 36$ & 172 & & $3973-3724$ \\
OxA-30885 & $4068 \pm 33$ & 183 & -23.1 & $4802-4436$ \\
OxA-30886 & $4914 \pm 35$ & 196 & -23.6 & $5717-5591$ \\
OxA-30887 & $7650 \pm 45$ & 240 & -24.2 & $8541-8383$ \\
UBA-27073 & $9643 \pm 79$ & 314.5 & & $11193-10722$ \\
UBA-27074 & $10102 \pm 44$ & 396.5 & & $11987-11415$ \\
UBA-25093 & $10393 \pm 45$ & 429 & & $12237-11838$ \\
UBA-25094 & $10287 \pm 46$ & 442 & & $12368-12020$ \\
UBA-27075 & $10254 \pm 62$ & 447.5 & & $12383-12029$ \\
UBA-27076 & $12846 \pm 67$ & 657.5 & & $15465-15069$ \\
UBA-25095 & $12873 \pm 60$ & 717.5 & & $15726-15261$ \\
\hline
\end{tabular}


Table 4.5: Conventional AMS ${ }^{14} \mathrm{C}$ measurements for the Awassa, Tilo and Chamo lake sediment cores. Dates for Awassa are from Telford (1998), Tilo dates are from Telford and Lamb (1999) and Chamo dates are from (Kassa, 2013).

\begin{tabular}{llllll}
$\begin{array}{l}\text { Laboratory } \\
\text { number }\end{array}$ & $\begin{array}{l}{ }^{14} \mathbf{C} \text { ages } \\
\mathbf{y r} \mathbf{B P}( \pm \\
\mathbf{1} \sigma)\end{array}$ & $\begin{array}{l}\text { depth } \\
(\mathbf{c m})\end{array}$ & $\begin{array}{l}\delta^{13} \mathbf{C} \\
(\%) \mathbf{P D B})\end{array}$ & $\begin{array}{l}\text { Calibrated } \\
\text { ages yr BP }\end{array}$ & Dated material \\
\hline Awassa & & & & \\
Beta-100436 & $1450 \pm 80$ & 259 & -20.9 & $403-761$ & Bulk sediment \\
Beta-100437 & $3180 \pm 90$ & 522 & -19.9 & $1264-1684$ & Bulk sediment \\
Beta-81512 & $4500 \pm 110$ & 687.5 & -19.5 & $2532-3486$ & Bulk sediment \\
Beta-81513 & $6270 \pm 130$ & 1132.5 & -24.4 & $4935-5557$ & Bulk sediment \\
\hline Tilo & & & & & \\
Beta-106145 & $1390 \pm 50$ & 180 & -15.9 & $556-764$ & Charcoal \\
Beta-106146 & $2400 \pm 50$ & 347 & -15.9 & $391-753$ & Charcoal \\
Beta-106147 & $4140 \pm 60$ & 594.5 & -19.1 & $2504-2888$ & Charcoal \\
Beta-90886 & $5520 \pm 80$ & 804 & -18.1 & $4070-4532$ & Charcoal \\
Beta-106148 & $6880 \pm 50$ & 1289.5 & -17.3 & $5664-5878$ & Charcoal \\
Beta-90887 & $7930 \pm 90$ & 1764 & -21.1 & $6613-7062$ & Charcoal \\
Beta-106149 & $8840 \pm 50$ & 2316.5 & -15.6 & $7763-8226$ & Charcoal \\
\hline Chamo & & & & & \\
COL1244.1.1 & $1240 \pm 30$ & 639 & -12.7 & $670-861$ & Plant material \\
COL1246.1.1 & $1490 \pm 80$ & 664 & -56 & $410-711$ & Plant material \\
COL2455 & $3304 \pm 40$ & 865.5 & -18.7 & $234-19$ & Plant material \\
COL1240.1 & $4080 \pm 20$ & 986 & -2.4 & $2161-2839$ & Shell \\
COL1241.1 & $3980 \pm 50$ & 987 & 4.4 & $2353-2943$ & Shell \\
COL1247.1.1 & $6580 \pm 30$ & 1289 & -34.8 & $3719-5618$ & Plant material \\
\hline
\end{tabular}


this study their geochemistry can still be used for broad comparison to identify potential volcanic sources.

Radiocarbon dates on charcoal within the BWT from Mochena Borago give an age of 7,589 $\pm 689 \mathrm{cal}$ yr. BP. However, ${ }^{40} \mathrm{Ar} /{ }^{39} \mathrm{Ar}$ dates on (possibly older contaminant) feldspar within the tephra gives an age of $3.16 \pm 0.07 \mathrm{Ma}$ (Brandt et al., 2012). Tephra and obsidian samples from Awassa, Tilo and Tora (in the CMER) do not have age control, but it is possible that they are contemporaneous with the Holocene tephras recorded in the lake sediments.

\subsection{Tephra identification and analysis}

\subsubsection{Tephra sampling and laboratory processing}

\subsubsection{Visible tephra sampling}

Tephras within lake sediment cores were described, recorded and imaged by the present author at LacCore (University of Minnesota). Tephras were sampled from the cores into sterile, labelled centrifuge tubes, taking care to avoid cross contamination. Tephra samples were wet sieved to $90-250 \mu \mathrm{m}$ and dried at $60^{\circ} \mathrm{C}$. Where tephra in cores exceeded $5 \mathrm{~cm}$ thickness, subsamples were collected from the horizon, either at intervals of $5 \mathrm{~cm}$ or where a lithological change was noted. Coarser sand and gravel grade tephra were first disaggregated using an agate pestle and mortar and all samples were sieved to $>25 \mu \mathrm{m}$.

\subsubsection{Cryptotephra identification}

\section{Glass shard counting}

Non-visible tephra horizons were primarily identified in lake cores through 
extracting and counting the tephra glass shards within the host sediments. The procedure involves two stages: firstly the collection of continuous and contiguous sediment samples at a low resolution ( $\sim 10 \mathrm{~cm}$ depth samples); followed by high resolution $\sim 1 \mathrm{~cm}$ sampling across a $10 \mathrm{~cm}$ region to pinpoint the tephra isochron (Lane et al., 2014; Davies, 2015) (Fig. 4.19).

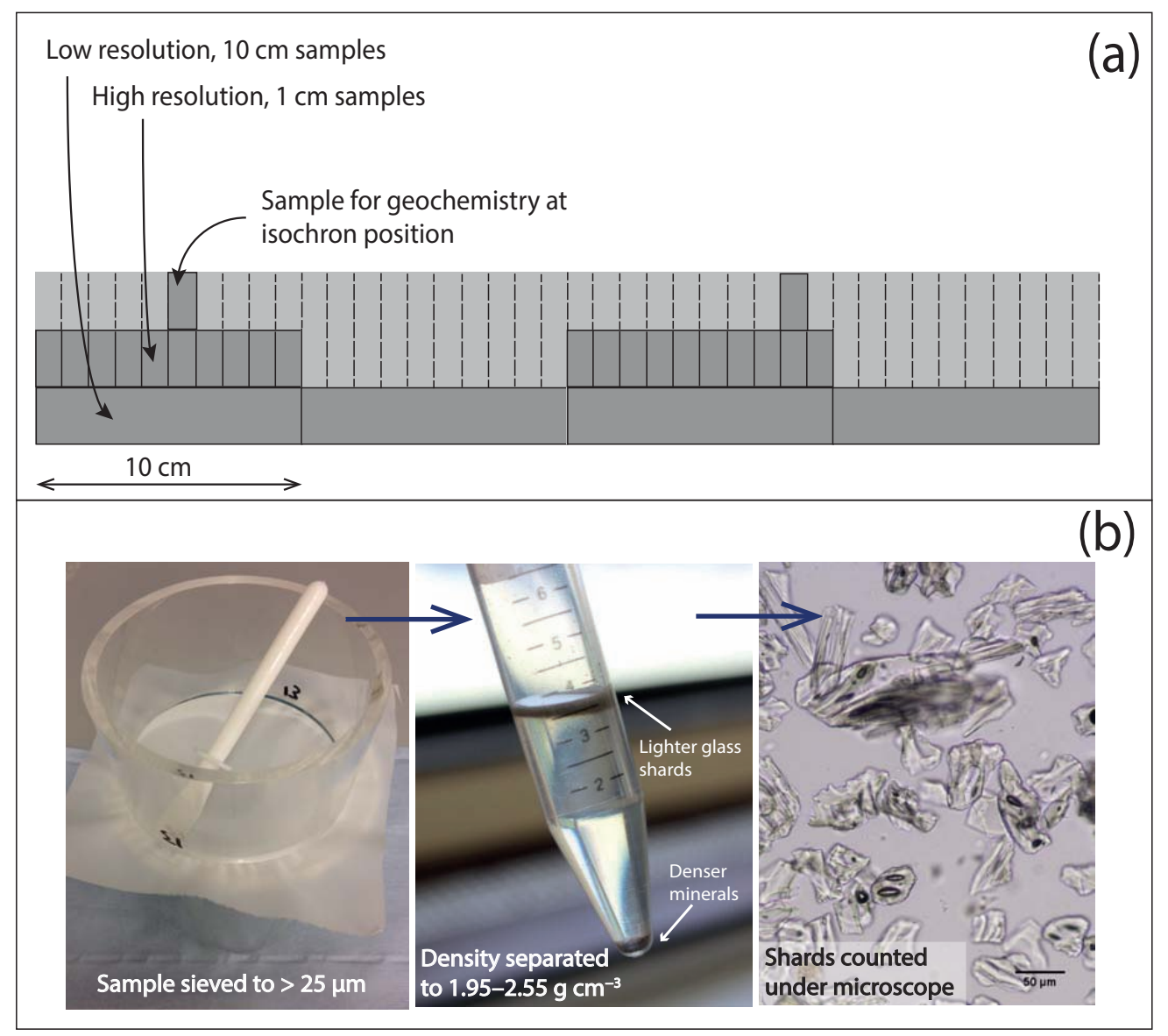

Figure 4.19: Cryptotephra sampling and processing. (a) Sampling core sediments first at a low $(10 \mathrm{~cm})$ resolution and resampling of sediments at a high $(1 \mathrm{~cm})$ resolution to identify the stratigraphic depth of the cryptotephra. (b) Sieving and density separation of sediment samples to isolate glass shards which can then be counted under a microscope.

Low resolution samples were dried and weighed and then treated with $1 \mathrm{M}$ HCL to remove carbonates. Samples were then sieved to $>25 \mu \mathrm{m}$, using dilute detergent to disaggregate samples with a clay content. Glass shards were then 
extracted from the samples using sodium polytungstate at a density of $1.95-2.55$ $\mathrm{g} / \mathrm{cm}^{3}$, following the standard separation procedures described by Blockley et al. (2005).

The extracted residue from each $10 \mathrm{~cm}$ sample was then mounted on thin sections using glycerin jelly and counted under reflected light microscopy. Shard counts were recalculated to give shard concentrations per gram dry weight (gdw) of host sediment and these were plotted against the core stratigraphy. Regions containing tephra were then resampled at a $1 \mathrm{~cm}$ resolution and the samples reprocessed (see Fig. 4.19). The position of the cryptotephra isochron was evaluated through plotting the $1 \mathrm{~cm}$ resolution counts against core depth; where tephra glass shards show a sudden appearance in the stratigraphy and a gradual decrease upwards, the basal rise was typically identified at the isochron (Lane et al., 2014). The core sediments were then resampled at the cryptotephra isochron position in order to obtain glass shards for geochemical analysis. In some instances insufficient core material necessitated the use of glass shards from the $1 \mathrm{~cm}$ interval thin sections for geochemical analysis. The entirety of the Ashenge core was sampled for cryptotephra. However, the Hayk and Chamo lake sediments were sampled at specific stratigraphic depths with the aim of finding dated tephra layers in the Ashenge, Dendi, Tilo and Awassa lake cores. To locate regions for sampling, minimum and maximum sediment depths (to 2 $\sigma)$ corresponding to tephra age ranges were calculated using recalibrated age depth models for Hayk and Chamo.

\section{XRF Core Scanning}

Lake cores were also scanned to determine their geochemistry, magnetic susceptibility and reflectance in order to aid cryptotephra identification. Magnetic 
susceptibility and reflectance measurements were undertaken at $2 \mathrm{~mm}$ intervals at LacCore (University of Minnesota) using a Geotek Multi-Sensor Core Logger. Core geochemistry was measured using an using the Itrax ${ }^{\circledR}$ X-ray fluorescence core scanner (Aberystwyth University) fitted with a $3 \mathrm{~kW}$ molybdenum tube.

The standard methods described by Croudace et al. (2006) were employed when analysing the geochemistry of lake cores. Core sections were loaded onto the horizontal sample cradle of the scanner, with the top of the core facing towards the right. Parameters for the analysis were set using the Core Scanner Navigator Programme on a representative area of the core. The excitation voltage and current of the X-ray tube were then set to $30 \mathrm{kV}$ and $30 \mathrm{~mA}$, respectively. The core dimension limits were set, the surface topography of the core was determined and the core imaged. The radiographic parameters, including the scan increment $(120 \mu \mathrm{m})$ and dwell time (10 secs) were then set for the radiographic scan. Using the Q-spec programme, the elements for analysis and the spectral fitting parameters were refined. The Core Scanner Navigator was then used to move the core from under the X-ray beam and the X-ray line camera diode array was calibrated (Croudace et al., 2006; Marshall, 2006).

The geochemical, magnetic susceptibility and reflectance data were then plotted against the stratigraphy and compared with the glass shard counts in order to test whether these sediment properties can be used to identify cryptotephra.

\subsubsection{Preparation of samples for geochemical analysis}

After core scanning, visible and crypto-tephras were prepared for geochemical analysis. Glass shards were separated from tephra samples for geochemical analysis using the standard separation procedures of Blockley et al. (2005). Tephra samples were mounted in $25 \mathrm{~mm}$ diameter resin blocks with predrilled 
holes for geochemical analysis using procedures employed by J. Westgate (University of Toronto) and V. Smith (University of Oxford). The holes within the resin blocks were labelled and Sellotape ${ }^{\circledR}$ was affixed to the polishing face of the block (see Fig. 4.20). Stuers ${ }^{\circledR}$ Specifix-40 epoxy resin was added to the first sample hole and mixed with a tephra sample using a paper clip to remove air bubbles. The sample hole was then filled with tephra sample and more resin and mixed with a paper clip. This was then repeated until all the holes in each sample mount were filled with different samples, taking care not to cross contaminate samples. The mounts were then placed under weights for a minimum of 48 hours to allow the resin to cure.

In order to expose the interior of the shards for analysis, the mounts were lightly ground by hand on wet 600, 1000, 2000 and 3000 grit emery paper for a total of $\sim 15$ minutes. After checking that the shards had been exposed for analysis, the mounts were polished. Firstly, the stubs were then polished using a $0.3 \mu \mathrm{m}$ grade alumina powder solution for $\sim 15$ minutes, followed by a 0.2 $\mu \mathrm{m}$ grade colloidal silica solution for $\sim 5$ minutes, taking care not to develop topography on the samples. The polished surface of the mounts was then marked with a razor blade to allow location of the samples during geochemical analysis (see Fig. 4.20).

\subsubsection{Electron microprobe analysis of glass shards}

Tephra samples were analysed for major elements using a JEOL 8600 electron probe micro-analyzer (EPMA), equipped with four wavelength dispersive spectrometers and one energy dispersive spectrometer, at the Research Laboratory for Archaeology and the History of Art (RLAHA), Oxford University. Prior to major element analysis each sample mount was carbon coated. WDS-EPMA 


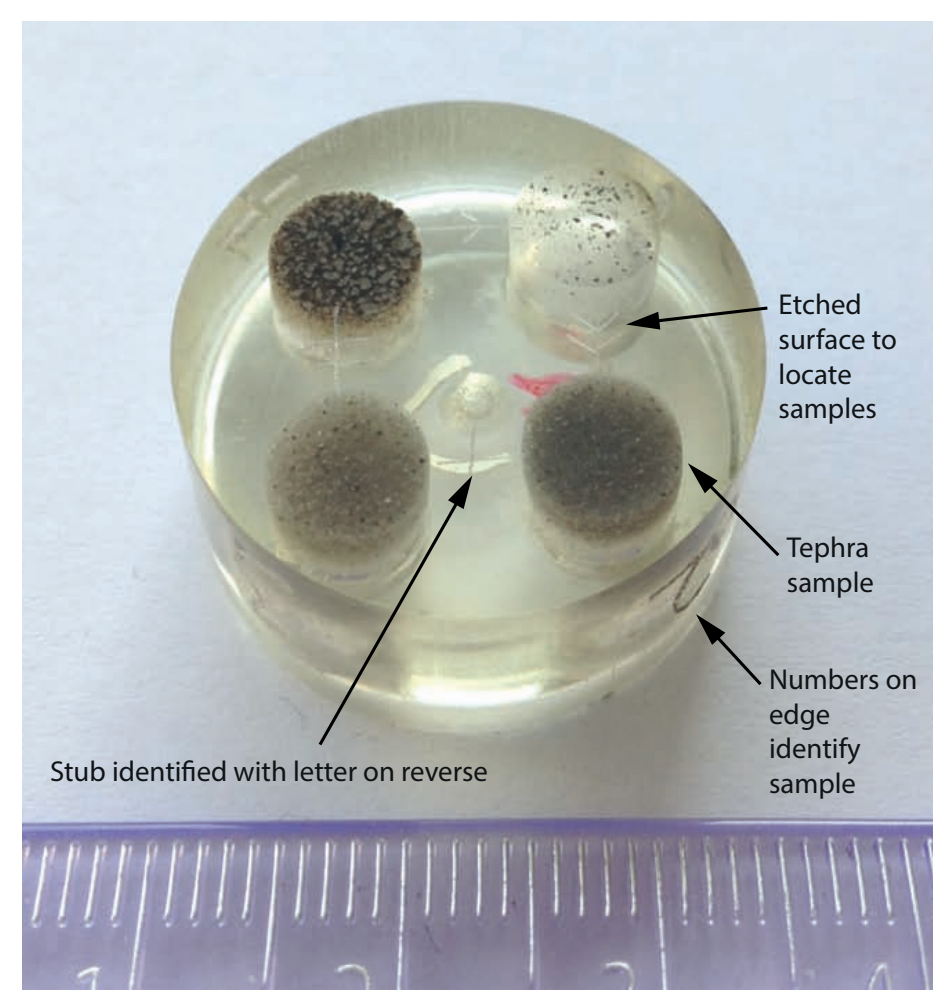

Figure 4.20: Epoxy resin stub containing tephra samples for geochemical analysis. Numbers on the edge of the resin mount identify the tephra sample, marks etched onto the surface aid location of samples during analysis. Scale at base in centimetres.

analytical conditions are given in Table 4.6. A minimum of 20 glass shards in each sample were analysed in order to determine compositional heterogeneity. To reduce alkali element migration glass analyses were undertaken using a 10 $\mu \mathrm{m}$ defocussed electron beam with a $6 \mathrm{nA}$ current and $15 \mathrm{keV}$ accelerating voltage. Sodium was collected for the first 10 secs of analysis, the majority of other elements were collected over 30 secs, however $\mathrm{Cl}$ and $\mathrm{P}$ were collected over 50 - 60 secs. Background counts for each analyte were collected for the same amount of time either side of the peak. Glass analyses were calibrated against a suite of mineral standards and analyte concentrations were calculated using the PAP absorption correction method. The calibration was verified by analysis of the MPI-DING geological reference materials; ATHO-G (rhyolite), StHs6/80-G 
(dacite) and GOR128-G (basalt) (Jochum et al., 2006) between every ten analyses of the tephra samples (Table 4.7). Typically, major element concentrations of the reference materials were determined to within $2 \sigma$ of the reported concentrations from GeoReM (Jochum et al., 2005). The lower limit of detection (LLD) is defined as the concentration at which an element can be detected above the instrument background noise (Perkins and Pearce, 1995). Limits of detection for EPMA analysis, based on repeat analyses of ATHO-G, are given in Table 4.7. In Ethiopian tephras, most analytes were present at concentrations above these LLD. However, $\mathrm{MnO}, \mathrm{MgO}$ and $\mathrm{P}_{2} \mathrm{O}_{5}$, are frequently present at concentrations below the detection limits in the tephras studied here. Analytical errors for the EPMA are typically $\sim<5 \%$ for the majority of elements; $\sim<0.9 \%$ for $\mathrm{SiO}_{2}$, $\sim<3.5 \%$ for $\mathrm{FeO}$ and $\sim<1.2 \%$ for $\mathrm{Al}_{2} \mathrm{O}_{3}$. Less abundant elements typically were determined to a higher error; $\sim<90 \%$ for $\mathrm{P}_{2} \mathrm{O}_{5}, \sim<13 \%$ for $\mathrm{TiO}_{2}$, and $\sim<50 \%$ for $\mathrm{MnO}$. Three reference points were marked onto each sample mount using the beam and the $x-y$ coordinates recorded to allow later relocation of the glass shards when analysing for trace elements.

\subsubsection{Major element data reduction}

Primary magmatic water can account for $<10 \%$ in rhyolites, therefore tephra analyses with low analytical totals of $<90 \%$ were rejected (Pearce et al., 2008; WoldeGabriel and Hart, 2005). All analyses were normalised to an anhydrous basis (to $100 \%$ ) to account for secondary hydration of glasses and magmatic water content (Pearce et al., 2011, 2014). Analyses containing mineral contamination were filtered on the basis of anomalous major element concentrations, e.g. high $\mathrm{SiO}_{2}$ indicates accidental quartz analysis, high $\mathrm{MgO}, \mathrm{CaO}$ and $\mathrm{FeO}$ indicates clinopyroxene and high $\mathrm{Na}_{2} \mathrm{O}, \mathrm{CaO}$ and $\mathrm{Al}_{2} \mathrm{O}_{3}$ indicates feldspars. 
Table 4.6: EPMA analytical operating conditions. Including beam conditions, analyte primary standards and analyte peak and background counting times. Counting times (secs.) are reported as: peak / background + / background -

\begin{tabular}{|c|c|c|}
\hline \multicolumn{3}{|l|}{ Jeol 8600 WDS EPMA } \\
\hline Beam diameter & $10 \mu \mathrm{m}$ defocussed & \\
\hline Accelerating voltage & $15 \mathrm{keV}$ & \\
\hline Current & $6 \mathrm{nA}$ & \\
\hline Analyte & Mineral standard & $\begin{array}{l}\text { Counting times } \\
\text { (secs) }\end{array}$ \\
\hline $\mathrm{Si}$ & Wollastonite & $30 / 15 / 15$ \\
\hline $\mathrm{Ti}$ & Rutile & $30 / 15 / 15$ \\
\hline $\mathrm{Al}$ & Jadeite & $30 / 15 / 15$ \\
\hline $\mathrm{Fe}$ & Haematite & $30 / 15 / 15$ \\
\hline $\mathrm{Mn}$ & Fowlerite & $40 / 20 / 20$ \\
\hline $\mathrm{Mg}$ & Periclase & $30 / 15 / 15$ \\
\hline $\mathrm{Ca}$ & Wollastonite & $30 / 15 / 15$ \\
\hline $\mathrm{Na}$ & Jadeite & $10 / 5 / 5$ \\
\hline $\mathrm{K}$ & Orthoclase & $30 / 15 / 15$ \\
\hline $\mathrm{P}$ & $\mathrm{NdPO}_{4}$ & $60 / 30 / 30$ \\
\hline $\mathrm{Cl}$ & $\mathrm{BaFClPO}_{4}$ & $50 / 25 / 25$ \\
\hline
\end{tabular}

\subsubsection{Laser ablation inductively coupled plasma-mass spec- trometry geochemical analysis}

After major element analysis, the sample mounts were re-polished using alumina powder to remove the carbon coating. Tephra samples were then analysed for trace element concentrations using the Coherent GeoLas ArF 193 nm Excimer laser ablation system coupled to a Thermo Finnigan Element 2 magnetic sector ICP-MS based at Aberystwyth University. The laser and ICP-MS operating conditions are detailed in Table 4.8. The ICP-MS was tuned prior to each analytical session to optimise signal.

Glass shards previously analysed by EPMA were relocated for LA-ICP-MS analysis by inputting the $x-y$ coordinates of the three reference points on each sample mount into the coordinate transformation spreadsheet provided in the supplementary material from Kuehn and Froese (2010). Each shard was analysed at a laser fluence of $10 \mathrm{Jcm}^{-2}$ and a repetition rate of $5 \mathrm{~Hz}$. Where possible, 
Table 4.7: Anydrous average major element concentrations in the MPI-DING reference materials, ATHO-G (rhyolite), St-Hs6/80-G (andesite), GOR128-G (komatiite) and ML3B-G (basalt), analysed over 8 EPMA analytical sessions. Concentrations are in wt. \%, published concentrations, from the GeoReM reference material database (Jochum et al., 2006), are given for comparison. Median lower limits of detection (wt.\%), based on repeat analyses of ATHO-G during each EPMA session, are given in the the table heading.

\begin{tabular}{|c|c|c|c|c|c|c|c|c|c|c|c|}
\hline ATHO-G & $\mathrm{SiO}_{2}$ & $\mathrm{TiO}_{2}$ & $\mathbf{A l}_{2} \mathbf{O}_{3}$ & MgO & $\mathrm{FeO}^{T}$ & MnO & $\mathrm{CaO}$ & $\mathbf{N a}_{2} \mathbf{O}$ & $\mathbf{K}_{2} \mathbf{O}$ & $\mathbf{P}_{2} \mathbf{O}_{5}$ & Cl \\
\hline LLD & 0.08 & 0.05 & 0.05 & 0.04 & 0.08 & 0.07 & 0.04 & 0.08 & 0.03 & 0.10 & 0.02 \\
\hline Average & 75.09 & 0.25 & 12.29 & 0.10 & 3.25 & 0.11 & 1.69 & 4.07 & 2.73 & 0.02 & 0.05 \\
\hline $2 \sigma$ & 1.01 & 0.06 & 0.25 & 0.04 & 0.21 & 0.08 & 0.11 & 0.86 & 0.10 & 0.04 & 0.03 \\
\hline GeoReM & 75.60 & 0.26 & 12.20 & 0.10 & 3.27 & 0.11 & 1.70 & 3.75 & 2.64 & 0.04 & 0.03 \\
\hline \multicolumn{12}{|c|}{ StHs6/80-G } \\
\hline Average & 63.57 & 0.70 & 17.67 & 1.94 & 4.39 & 0.07 & 5.25 & 4.54 & 1.31 & 0.14 & 0.01 \\
\hline $2 \sigma$ & 0.61 & 0.07 & 0.39 & 0.10 & 0.22 & 0.08 & 0.13 & 0.46 & 0.07 & 0.08 & 0.02 \\
\hline GeoReM & 63.70 & 0.70 & 17.80 & 1.97 & 4.37 & 0.08 & 5.28 & 4.44 & 1.29 & 0.16 & 0.01 \\
\hline \multicolumn{12}{|c|}{ GOR128-G } \\
\hline Average & 45.81 & 0.29 & 10.40 & 24.16 & 9.99 & 0.17 & 7.18 & 0.66 & 0.03 & 0.03 & 0.01 \\
\hline $2 \sigma$ & 1.00 & 0.07 & 0.85 & 3.36 & 0.70 & 0.10 & 2.25 & 0.26 & 0.03 & 0.04 & 0.03 \\
\hline GeoReM & 45.39 & 0.30 & 10.87 & 22.27 & 10.30 & 0.15 & 8.45 & 0.79 & 0.03 & 0.04 & 0.01 \\
\hline \multicolumn{12}{|l|}{ ML3B-G } \\
\hline Average & 51.87 & 2.11 & 13.74 & 6.53 & 11.08 & 0.20 & 10.48 & 2.33 & 0.39 & 0.24 & \\
\hline $2 \sigma$ & 0.44 & 0.09 & 0.27 & 0.17 & 0.51 & 0.05 & 0.23 & 0.24 & 0.05 & 0.04 & \\
\hline GeoReM & 51.87 & 2.11 & 13.74 & 6.53 & 11.08 & 0.20 & 10.48 & 2.33 & 0.39 & 0.24 & \\
\hline
\end{tabular}


Table 4.8: Operating conditions for LA-ICP-MS trace element analysis

Thermo Element 2 ICP-MS

\begin{tabular}{ll}
\hline Cool gas & $15.7 \mathrm{Lmin}^{-1}$ \\
Auxiliary gas & $1.05-1.20 \mathrm{Lmin}^{-1}$ \\
Sample gas & $1.25 \mathrm{Lmin}^{-1}$ \\
$\mathrm{RF}$ power & $1050-1150 \mathrm{~W}$ \\
$\mathrm{UO}^{+} / \mathrm{U}^{+}$ & $<0.2 \%$ \\
$\mathrm{ThO}^{+} / \mathrm{Th}^{+}$ & $<0 \% 8 \%$ \\
Analytes & $29 \mathrm{Si},{ }^{43} \mathrm{Ca},{ }^{44} \mathrm{Ca},{ }^{85} \mathrm{Rb},{ }^{88} \mathrm{Sr},{ }^{89} \mathrm{Y},{ }^{90} \mathrm{Zr},{ }^{93} \mathrm{Nb},{ }^{133} \mathrm{Cs}$, \\
& ${ }^{137} \mathrm{Ba},{ }^{139} \mathrm{La},{ }^{140} \mathrm{Ce},{ }^{141} \mathrm{Pr},{ }^{143} \mathrm{Nd},{ }^{17} \mathrm{Sm},{ }^{151} \mathrm{Eu}$, \\
& ${ }^{158} \mathrm{Gd},{ }^{159} \mathrm{~Tb},{ }^{163} \mathrm{Dy},{ }^{165} \mathrm{Ho},{ }^{166} \mathrm{Er},{ }^{169} \mathrm{Tm},{ }^{174} \mathrm{Yb}$, \\
Runs/passes & $175 \mathrm{Lu},{ }^{178} \mathrm{He},{ }^{181} \mathrm{Ta},{ }^{232} \mathrm{Th},{ }^{238} \mathrm{U}$ \\
Samples per peak & $1 / 10$ \\
Mass window & 100 \\
Segment durations & $5 \%$ \\
Acquisition time & $0.05 \mathrm{~seconds}$ \\
& $20 \mathrm{~seconds}$ \\
GeoLas 193 nm Excimer laser & \\
\hline Excitation voltage & \\
Laser fluence & $\sim 24 \mathrm{kV}$ \\
Repetition rate & $10 \mathrm{Jcm}{ }^{-2}$ \\
Pulse length & $5 \mathrm{~Hz}$ \\
Mask thickness & $13-20 \mathrm{~ns}$ \\
& $0.3 \mathrm{~mm}(>10 \mu \mathrm{m}$ craters $), 0.1 \mathrm{~mm}(6 \mu \mathrm{m}$ and 4 \\
\hline
\end{tabular}

shards were analysed using larger crater diameters of $20 \mu \mathrm{m}$ to minimize the element fractionation associated with acquisition using smaller crater diameters (Pearce et al., 2011) and to give a better instrument signal and therefore improved limits of detection. Typically $>20$ shards were analysed in a tephra sample and, if the shards were of sufficient size, several analyses were undertaken alongside one another to determine compositional homogeneity within each shard. Prior to and after the acquisition of glass analyses, a set of gas blanks (the instrumental contribution to the signal, with no sample in the plasma) and calibration spectra (using NIST 612) were acquired in order to monitor instrument drift during the analytical session (Pearce et al., 2011). Two to three tephra samples were analysed during a run, the acquisition time for each analysis is $\sim 20 \mathrm{~s}$ with gas blanks obtained immediately prior to each unknown spectra. The MPI-DING 
Table 4.9: LA-ICP-MS analytical considerations. Median lower limits of detection (LLD), calculated from all analytical sessions. Average trace element concentrations measured in the ATHO-G reference material throughout all analytical sessions. Two standard deviation on the ATHO-G analyses, and published concentrations from the GeoReM database (Jochum et al., 2006) are shown. All concentrations are in ppm.

\begin{tabular}{|c|c|c|c|c|c|c|c|c|c|c|c|c|c|}
\hline & $\mathbf{R b}$ & $\mathrm{Sr}$ & $\mathbf{Y}$ & $\mathbf{Z r}$ & Nb & Cs & $\mathbf{B a}$ & $\mathbf{L a}$ & $\mathrm{Ce}$ & Pr & Nd & Sm & \\
\hline LLD & 0.62 & 1.05 & 0.17 & 0.37 & 0.07 & 0.19 & 1.88 & 0.09 & 0.07 & 0.06 & 0.25 & 0.14 & \\
\hline ATHO-G & 66.5 & 96.4 & 100 & 512 & 63.2 & 1.08 & 546 & 55.7 & 118 & 14.4 & 61.5 & 14.6 & \\
\hline $2 \sigma$ & 4.18 & 6.58 & 6.34 & 45.89 & 3.47 & 0.15 & 53.98 & 3.77 & 8.17 & 1.26 & 4.54 & 1.28 & \\
\hline \multirow[t]{2}{*}{ GeoReM } & 65.3 & 94.1 & 94.5 & 512 & 62.4 & 1.08 & 547 & 55.6 & 121 & 14.6 & 60.9 & 14.2 & \\
\hline & Eu & $\mathbf{T b}$ & Dy & Ho & $\mathbf{E r}$ & $\mathbf{T m}$ & $\mathbf{Y b}$ & Lu & Hf & Ta & $\mathbf{P b}$ & Th & $\mathbf{U}$ \\
\hline LLD & 0.13 & 0.06 & 0.13 & 0.04 & 0.07 & 0.05 & 0.15 & 0.04 & 0.08 & 0.06 & 0.12 & 0.01 & 0.00 \\
\hline ATHO-G & 2.83 & 2.64 & 16.9 & 3.65 & 11.2 & 1.61 & 10.8 & 1.62 & 14.5 & 4.07 & 6.09 & 7.62 & 2.49 \\
\hline $2 \sigma$ & 0.35 & 0.27 & 1.59 & 0.35 & 1.07 & 0.21 & 1.05 & 0.20 & 1.29 & 0.33 & 2.00 & 0.67 & 0.58 \\
\hline GeoReM & 2.76 & 2.51 & 16.2 & 3.43 & 10.3 & 1.52 & 10.5 & 1.54 & 13.7 & 3.90 & 5.67 & 7.40 & 2.37 \\
\hline
\end{tabular}

reference material ATHO-G was analysed five times at a $20 \mu \mathrm{m}$ crater diameters during an analytical session to determine the analytical accuracy. All tephra samples (apart from four trachytic Dendi tephras) analysed as part of this study are rhyolitic, therefore a reference material with a similar compositional matrix was selected. Average analyses of ATHO-G during the analytical sessions are given in Table 4.9, and trace elements were typically determined to within 2 standard deviations of reported concentrations from Jochum et al. (2006).

The majority of glass analyses were performed using $20 \mu \mathrm{m}$ crater diameters, and at this resolution limits of detection were $<0.4 \mathrm{ppm}$ for most elements (Table 4.9). The highly evolved glass compositions analysed here are enriched in incompatible elements, at concentrations well above these LLD's. Limits of detection increase using $10 \mu \mathrm{m}$ crater diameters to typically $<2 \mathrm{ppm}$, due a decrease in the ${ }^{29} \mathrm{Si}$ signal to background ratio.

Detection limits are sensitive to instrumental variations, associated with tuning and gas blanks (Pearce et al., 2011). The ${ }^{29}$ Si blank decreases throughout an analytical session, associated with the warm-up of the ICP-MS (Pearce et al., 
2011). Background counts for $\mathrm{Sr}, \mathrm{Rb}, \mathrm{Cs}$ and Ba increase over time, their 'sticky' nature causing them to adhere to the glassware and interface cones of the ICP-MS (Pearce et al., 2011). Thus, detection limits for these analytes are comparatively higher than other elements, at $<1.88 \mathrm{ppm}$ and $<11.3 \mathrm{ppm}$ using $20 \mu \mathrm{m}$ and 10 $\mu \mathrm{m}$ crater diameters, respectively.

The conversion of data in the form of counts per second (cps) to concentration (ppm) requires the prior determination of $\mathrm{SiO}_{2}$ concentrations by EPMA. Where available, grain specific $\mathrm{SiO}_{2}$ concentrations were used as internal standards. However, average $\mathrm{SiO}_{2}$ concentrations in the Ayelu tephras and Corbetti obsidians were used as internal standards. These samples had previously been analysed for major element concentrations by N. Pearce and G. WoldeGabriel, using EPMA at the University of Toronto and Los Alamos National Laboratory, respectively. Using an Excel spreadsheet; gas blank cps were first subtracted from sample cps and the resulting analyte cps were then divided by the internal standard cps and multiplied by the internal standard concentration obtained by EPMA. The analytical drift during the run was then calculated by dividing the average NIST 612 (Pearce et al., 1997) Si counts obtained from $20 \mu \mathrm{m}$ crater diameters from the end of the session by those at the start. The analyses are then corrected for this drift and divided by the calibration slopes, this is calculated by taking the average of all the $20 \mu \mathrm{m}$ or $10 \mu \mathrm{m}$ NIST 612 acquisitions and dividing each slope by the preferred NIST 612 concentrations. Finally, data was fractionation corrected by dividing element concentrations by the fractionation factor calculated by Pearce et al. (2011). 


\subsubsection{Trace element data reduction}

Analyses contaminated by mineral inclusions were then filtered from the dataset on the basis of anomalous trace element concentrations, e.g. high $\mathrm{Zr}$ and $\mathrm{Hf}$ concentrations indicate zircon inclusion, high $\mathrm{Ba}$ and $\mathrm{Sr}$ (feldspar), high Si counts and low trace element concentrations (quartz) and high $\mathrm{Rb}$ and $\mathrm{Cs}$ concentrations (mica) (Pearce et al., 2011, 2014).

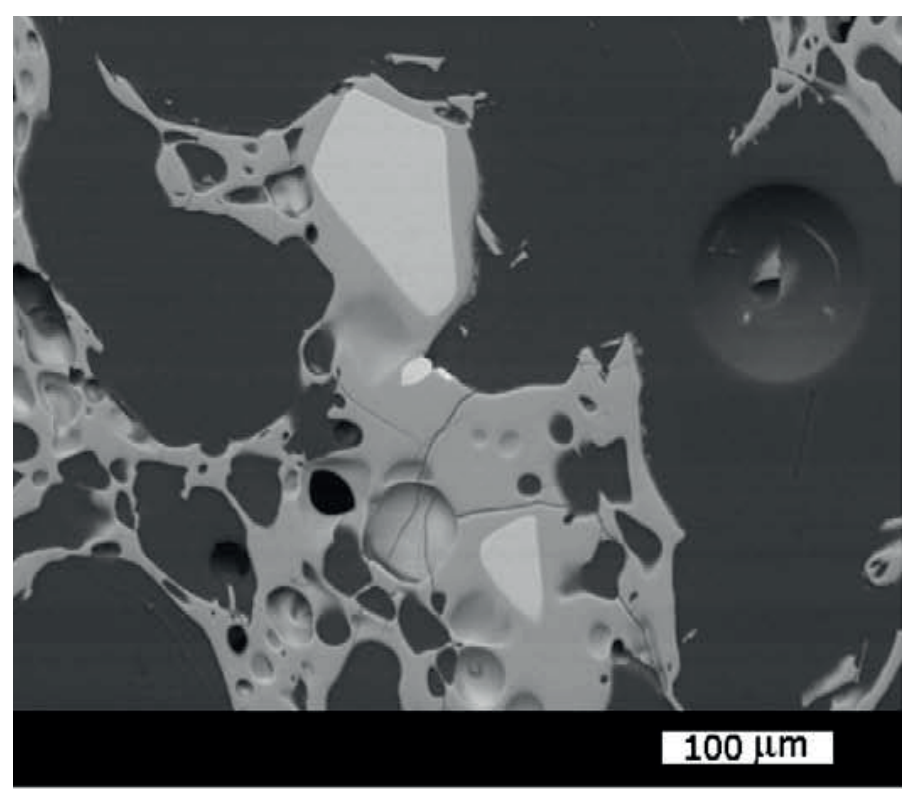

Figure 4.21: Mineral inclusions in glass. Visible or sub surface phenocrysts may contaminate EPMA and LA-ICP-MS analyses. Figure from Tomlinson et al. (2010).

\subsubsection{Major and trace element data interpretation}

The compositions of tephras were compared and differentiated using bi-plots of selected major and trace element concentrations. Generally elements present at lower concentrations in the tephras studied (e.g. $\mathrm{Ti}, \mathrm{Mn}, \mathrm{Mg}, \mathrm{Ca}, \mathrm{Sr}, \mathrm{Cs}$ and $\mathrm{Ba}$ ) were not included in bi-plots, due to greater associated analytical errors. Potential correlations and geochemical differences were tested using principal component 
analysis (PCA) run in Minitab ${ }^{\circledR}$ software. A selection of elements shown to discriminate between the tephras using bi-plots were used to run the PCA. Three principal components were produced by the PCA and these were then plotted on bi-plots to test whether tephras were statistically similar or different. This allowed any compositional similarities and differences between tephras noted from the bi-plots to be statistically tested. 



\section{Chapter 5}

\section{Characteristics and composition of Holocene Ethiopian tephras}

This chapter describes the physical characteristics and Bayesian-modelled age estimates of the tephras identified by this study, from seven lake sediment sequences throughout Ethiopia. The major and trace element compositions of tephra glass shards are also presented in Section 5.4.

The geochemical composition of the tephras studied in each of the lakes is compared and discussed, in order to:

1. Assess glass shard compositional variability throughout the Ethiopian Rift Valley

2. Provide a background and justification for potential tephra correlations explored in Chapters 6 and 7. 


\subsection{The occurrence and characteristics of tephras in lake sediments from the Ethiopian Highlands}

\subsubsection{Lake Ashenge tephras}

The Ashenge lake sediments contain a total of 9 visible tephra and cryptotephra layers. These are labelled AST-1 to AST-9, (see Table 5.1) and range in age from $15.3-0.3$ cal. ka BP, respectively. Four visible tephras (AST-1; $2 ; 5 ; 8$ ) occur in the sediments; these are $1-2.5 \mathrm{~cm}$ thick and comprised of normally graded, grey-white, fine to coarse volcanic ash (Heiken and Wohletz, 1985). Tephras are typically well to moderately well-sorted; however AST-5 is poorlysorted. Zirconium counts, measured using XRF core scanning, for the Ashenge sediments are shown in Fig. 5.2. Zirconium counts increase relative to the background sediment counts at depths where visible tephras occur.

Five cryptotephras were identified in the Ashenge stratigraphy on the basis of shard counting (Fig. 5.2). Four cryptotephras (AST-4; 6; 7;9) are associated with elevated $\mathrm{Zr}$ counts measured in the Ashenge sediments. Shard morphologies (page 25) include bubble wall, platy and stretched and fluted pumiceous shards (Figure 5.1). Age estimates for all tephra layers identified in Lake Ashenge, interpolated from a Bayesian depositional model (see Methods, page 122), are reported in Table 5.1. The precision on the tephra ages varies within the age model, from $\sim 200$ years for AST-1 and AST-2, to nearly $\sim 1500$ years for AST-9 at the $95.4 \%$ confidence level. The youngest tephra (AST-1) dates to the historic age (546 - 321 cal. a BP, 1404 - 1629 AD). This tephra was deposited following a $>4$ ka period where no tephras were identified in the Ashenge sediments. Six tephras (AST-2 to AST-7) are recorded in the Ashenge sediments between $\sim 7.5-\sim 4.8$ cal. ka BP, giving an average frequency of an eruption every 500 
years during this interval. A major sediment hiatus occurs at $\sim 11.8-\sim 7.6$ cal. ka BP, below which two tephras occur in the sediments between $\sim 15.3-\sim 13.5$ cal. ka BP. Tephras deposits are not recorded in the Ashenge sediments between $\sim 15.3$ cal. ka BP and the base of the core at $\sim 17$ cal. ka BP.

Table 5.1: Characteristics of tephras recorded in the Ashenge and Hayk lake sediments. Cryptotephras are indicated with an asterisk. †Radiocarbon age estimates are provided at the $95.4 \%$ confidence interval.

\begin{tabular}{|c|c|c|c|c|}
\hline Tephra ID & $\begin{array}{l}\text { Composite } \\
\text { depth of the } \\
\text { base }(\mathrm{cm})\end{array}$ & $\begin{array}{l}\text { Thickness } \\
\text { (cm) }\end{array}$ & Description & $\begin{array}{l}{ }^{14} \mathbf{C} \text { age } \dagger(\text { cal. a } \\
\text { BP) }\end{array}$ \\
\hline \multicolumn{5}{|l|}{ Ashenge } \\
\hline AST-1 & 12 & 2 & discontinuous layer of grey fine ash & $321-546$ \\
\hline AST-2 & 439 & 1 & grey fine-coarse ash & $4824-5041$ \\
\hline AST-3* & 485 & $<1$ & & $4975-5625$ \\
\hline AST-4* & 527 & $<1$ & & $5334-5871$ \\
\hline AST-5 & 610 & 2.5 & diffuse layer of grey fine-coarse ash & $6348-7155$ \\
\hline AST-6* & 624 & $<1$ & & $6485-7505$ \\
\hline AST-7* & 635 & $<1$ & & $6721-7578$ \\
\hline AST-8 & 745 & 1 & grey fine-coarse ash & $13582-14590$ \\
\hline AST-9* & 758 & $<1$ & & $13847-15332$ \\
\hline \multicolumn{5}{|l|}{ Hayk } \\
\hline HT-1* & 66 & $<1$ & & $1626-2611$ \\
\hline HT-2 & 109 & 0.5 & discontinuous grey fine-coarse ash & $2460-2876$ \\
\hline HT-3* & 119 & $<1$ & & $2513-2929$ \\
\hline HT-4 & 146 & 0.5 & discontinuous grey fine-coarse ash & $2792-3635$ \\
\hline HT-5* & 160 & $<1$ & & $2913-3914$ \\
\hline HT-6* & 169 & $<1$ & & $3197-3981$ \\
\hline HT-7* & 181 & $<1$ & & $3835-4804$ \\
\hline HT-8* & 200 & $<1$ & & $5582-7382$ \\
\hline HT-9* & 268 & $<1$ & & $8432-10514$ \\
\hline HT-10* & 289 & $<1$ & & $8903-11045$ \\
\hline HT-11* & 387 & $<1$ & & $11299-11962$ \\
\hline HT-12* & 462 & $<1$ & & $12027-12952$ \\
\hline
\end{tabular}



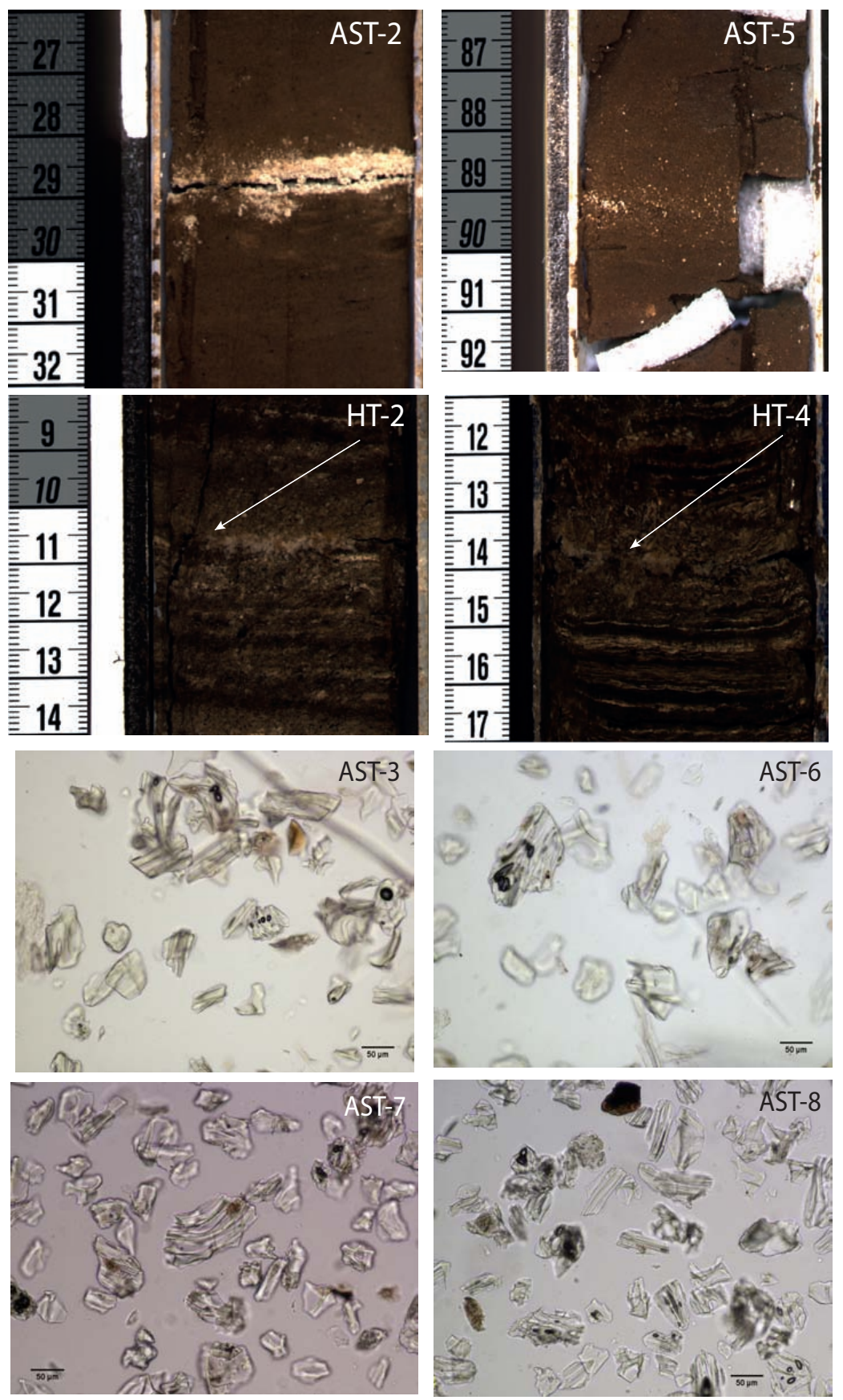

Figure 5.1: Photographs of selected visible tephras in the Lake Ashenge and Hayk sediments, with transmitted light microscope images of glass shards in cryptotephras occuring in the Ashenge core. Microscope image scale $=50 \mu \mathrm{m}$. 


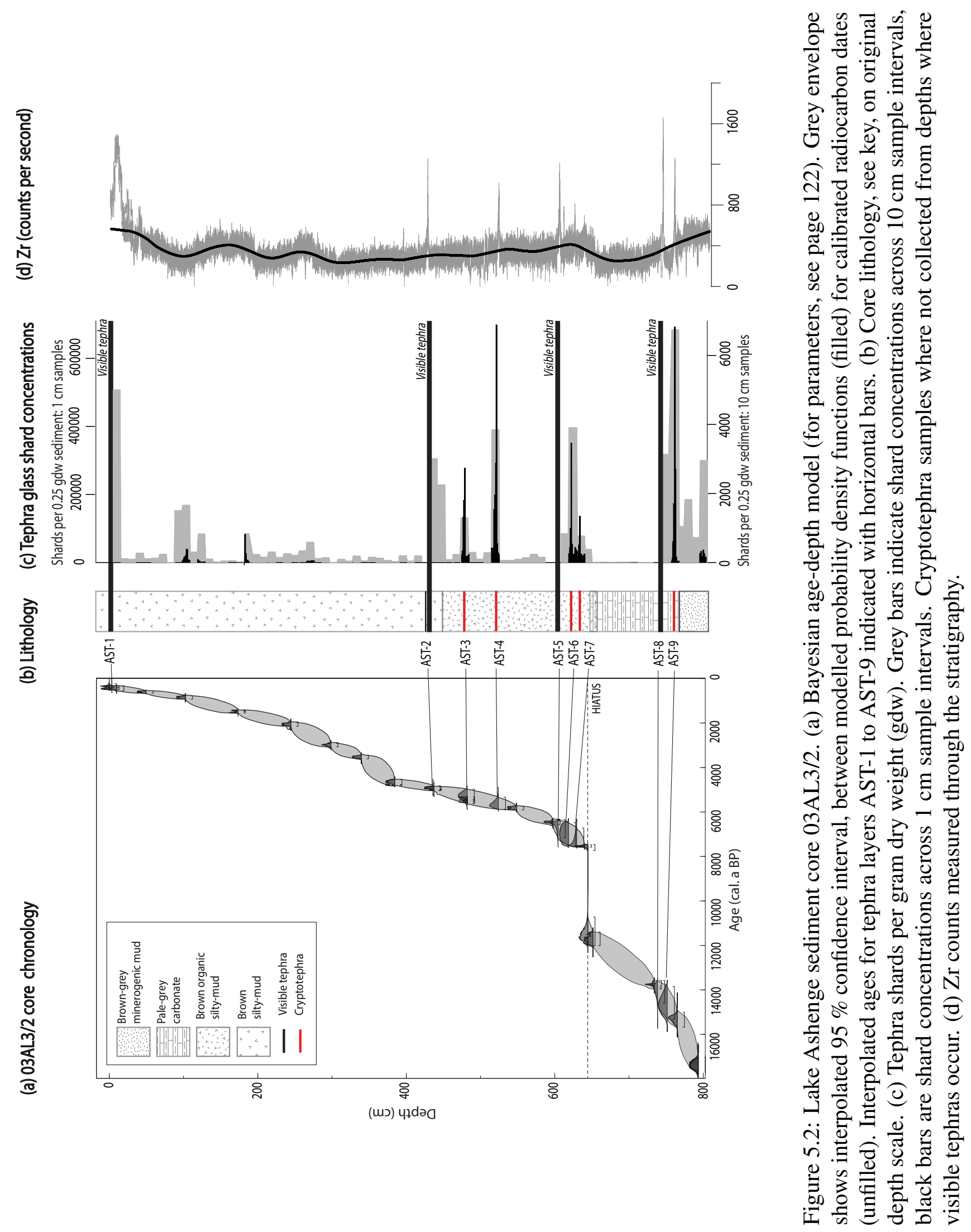




\subsubsection{Lake Hayk tephras}

The Lake Hayk sediments contains two visible tephras and ten cryptotephras, these are labelled HT- 1 to HT-12 and range in age from 1.6-13.0 cal. ka BP, respectively (Table 5.1). The visible tephras (HT-2 and HT-4) occur as discontinuous $0.5-1 \mathrm{~cm}$ thick layers, comprised of grey, well-sorted grey fine to medium ash. Cryptotephras were identified on the basis of shard counts conducted throughout the core sediments (Fig. 5.3). Like the Ashenge cryptotephras, the Hayk cryptotephras contain a range of shard morphologies, including bubble wall, platy and pumiceous shards.

Unfortunately, due to heavy sampling of the core after initial cryptotephra processing, cryptotephras HT-1, HT-3, HT-8 and HT-11 could not be re-sampled for geochemical analysis.

Age ranges for the Hayk tephras, based on Bayesian age modelling of the Hayk sediments (Fig. 5.3), are given in Table 5.1. Precision on the ages of these tephras varies within the age model, ranging from $\sim 400$ years for HT- 2 and HT-3 to $\sim 2000$ years for HT-8; 9 and HT-10, at the $95.4 \%$ confidence level. Between $\sim 13.0-\sim 1.6$ cal. ka BP, tephras are recorded in the Hayk archive at a frequency of 1 every $<950$ years. Tephras are not recorded between the oldest tephra at $\sim 13.0 \mathrm{cal}$. ka BP and the base of the core at $\sim 16.0 \mathrm{cal} . \mathrm{yr} \mathrm{BP}$. 


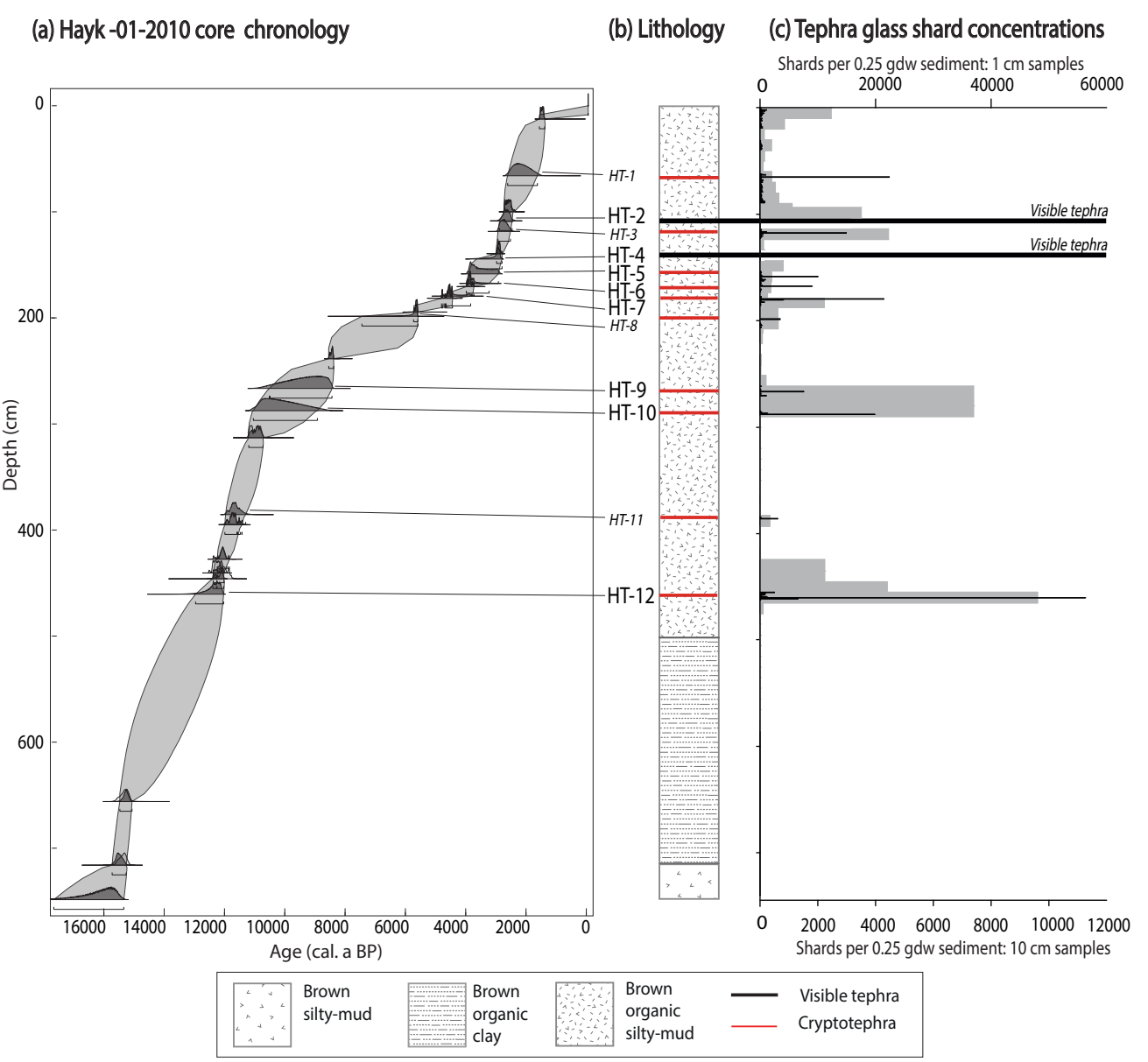

Figure 5.3: Lake Hayk sediment core Hayk-01-2010 (a) Bayesian age model, (b) lithology, (c) tephra shards per gdw sediment. Grey bars are shard concentrations across $10 \mathrm{~cm}$ sample regions; black bars are shard concentrations across $1 \mathrm{~cm}$ sample regions. Horizontal lines indicate the probability density functions for the Hayk tephras within the age model. Cryptotephra samples were not collected from depths where visible tephras occur. Cryptotephras which could not be analysed are labelled in italics. 


\subsection{The occurrence and characteristics of tephras}

\section{in lake sediments from the Yerer-Tullu Wellel}

\section{Volcano Tectonic Lineament}

\subsubsection{Lake Dendi tephras}

Five visible tephras have been identified within the Lake Dendi sediments, labelled here DT-1 to DT-5 (youngest to oldest). The tephras range in thickness from $1-200 \mathrm{~cm}$ and consist of well-sorted fine-coarse buff coloured ash. However, DT-2 has a uniquely grey colour (see Table 5.2). Glass shards comprising the tephra layers typically possess a range of shard morphologies; including bubble wall, cuspate and 'aero' like pumiceous shards.

The basal, $200 \mathrm{~cm}$ thick, tephra (DT-5) is discontinuous and shows evidence of reworking. However, the constituent shards appear vitreous, angular and unaltered (pristine) under transmitted light microscopy (Fig. 5.4).

The tephras range in age from $\sim 10.1-0.7$, on the basis of an unpublished Bayesian age model provided by B. Wagner (University of Cologne).

Table 5.2: Characteristics of tephras recorded in sediments from Lake Dendi.

\begin{tabular}{|c|c|c|c|c|}
\hline Tephra ID & $\begin{array}{l}\text { Composite } \\
\text { depth of the } \\
\text { base }(\mathrm{cm})\end{array}$ & $\begin{array}{l}\text { Thickness } \\
\text { (cm) }\end{array}$ & Description & $\begin{array}{l}{ }^{14} \mathrm{C} \text { age (cal. } \\
\text { yrs BP) }\end{array}$ \\
\hline \multicolumn{5}{|l|}{ Dendi } \\
\hline DT-1 & 79.8 & 1 & buff fine-coarse ash & $\sim 650$ \\
\hline DT-2 & 596.2 & 1 & grey fine-coarse ash & $\sim 6990$ \\
\hline DT-3 & 603.6 & 1 & buff fine-coarse ash & $\sim 7060$ \\
\hline DT-4 & 894.5 & 1.5 & buff fine-coarse ash & $\sim 10100$ \\
\hline DT-5 & 1130 & 200 & $\begin{array}{l}\text { buff fine-coarse } \\
\text { ash, fines upwards } \\
\sim 10610\end{array}$ & \\
\hline \multicolumn{5}{|l|}{ Hora } \\
\hline HRT-1 & $L 6,17 \mathrm{~cm}$ & 0.5 & grey fine medium ash & \\
\hline HRT-2 & $L 8,46 \mathrm{~cm}$ & 1 & grey fine medium ash & \\
\hline
\end{tabular}




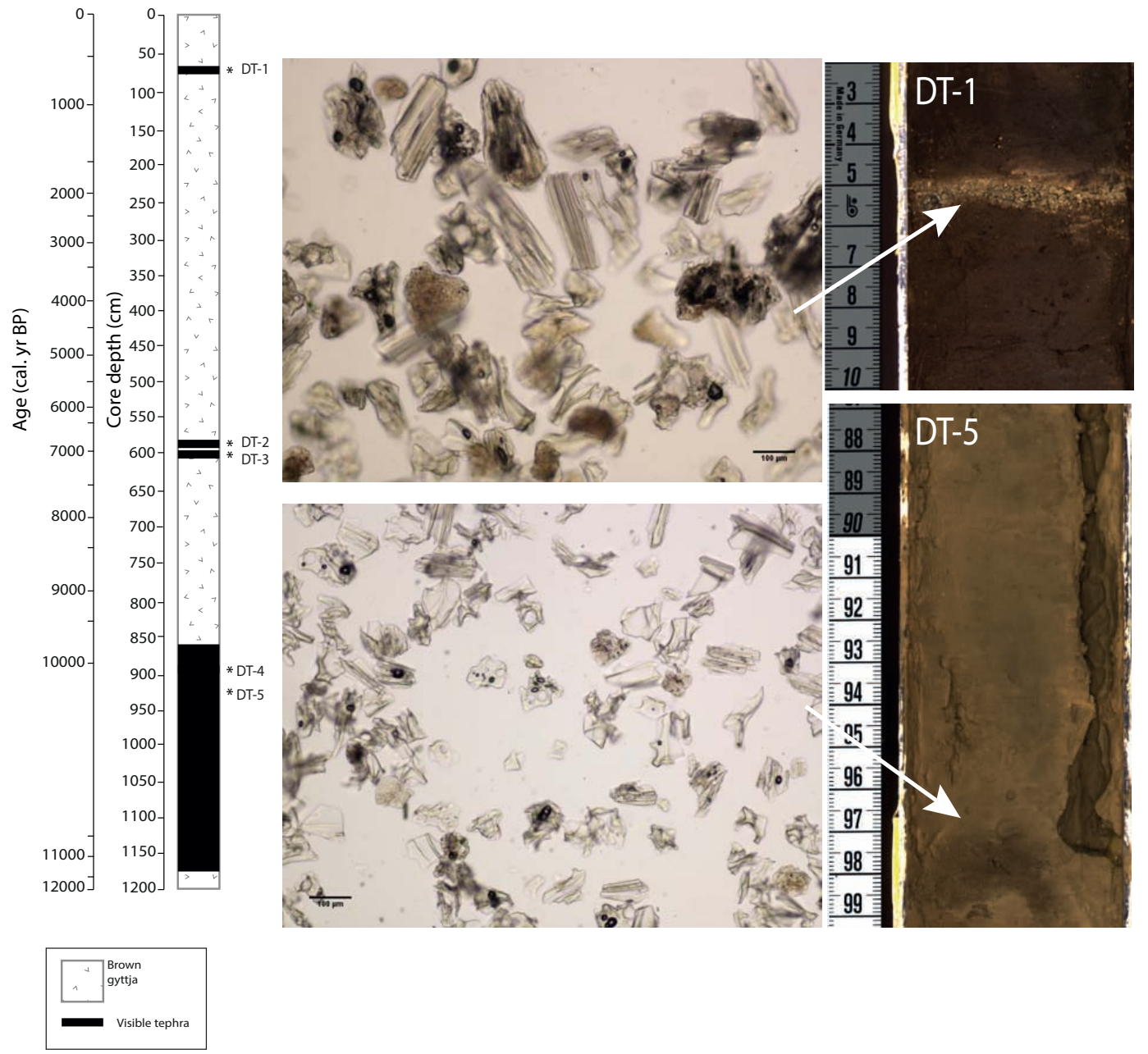

Figure 5.4: Age, occurrence and morphology of visible tephra glass shards in the Dendi sediments. Scale on photographs $=100 \mu \mathrm{m}$. 


\subsubsection{Lake Hora tephras}

Two visible tephras occur within the Lake Hora sediment stratigraphy. These tephra deposits are comprised of grey fine-coarse ash and occur as continuous, well-sorted layers of $0.5-1 \mathrm{~cm}$ thickness. The Hora tephras are Holocene, however, due to uncertainties in coring depths and the age model for the Hora lake sediments, the ages of these tephras are unknown. The tephras are referred to here as HRT-1 (occurring in core section L6) and HRT-2 (core section L8).

\subsection{The occurrence and characteristics of tephras in lake sediments from the central Main Ethiopian Rift}

\subsubsection{Lake Tilo}

Fourteen visible tephra layers occur within the Tilo lake sediments. These are labelled here TT-1 to TT-14 and range in age from $\sim 0.01-\sim 10.0 \mathrm{cal}$. ka BP. The tephras range in thickness from $0.5-48 \mathrm{~cm}$ and are composed of predominantly grey fine to coarse ash; however, TT-8 and TT-12 contain lapilli grain sizes. The tephra layers are typically well-sorted and normally graded, however, TT-1 and TT-5 show reverse grading. Glass shards comprising the tephra layers typically have inflated pumiceous or bubble wall morphologies.

The Bayesian age model for the Tilo sediments is seen in Fig. 5.6 and provides age ranges for the Tilo tephras (see Table 5.3). Precision on the tephra ages varies within the age model; from $\sim 800-900$ years form TT-5, TT-7, TT-8, TT-10 and TT-13 to $\sim 1900$ years for TT-4 and TT-6. Tephras range in age from 
the historic period (TT-1, 1309 - 50 cal. a BP, or $641-1900$ AD) to $10180 \mathrm{cal}$. a BP (TT-14). Tephra layers are recorded frequently throughout the Holocene, averaging a rate of 1 every $\sim 700$ years.

Table 5.3: Characteristics of tephras recorded in sediments from lakes Awassa, Tilo and Chamo. Cryototephras are identified with an asterisk. $\dagger$ Radiocarbon age estimates are provided at the $95.4 \%$ confidence interval.

\begin{tabular}{|c|c|c|c|c|}
\hline Tephra ID & $\begin{array}{l}\text { Composite } \\
\text { depth of the } \\
\text { base }(\mathrm{cm})\end{array}$ & $\begin{array}{l}\text { Thickness } \\
\text { (cm) }\end{array}$ & Description & $\begin{array}{l}{ }^{14} \mathrm{C} \text { age } \dagger(\text { cal. } \\
\text { yrs BP })\end{array}$ \\
\hline \multicolumn{5}{|l|}{ Tilo } \\
\hline TT-1 & 103 & 4.5 & reverse graded, grey coarse ash & $50-1309$ \\
\hline TT-2 & 220 & 20 & $\begin{array}{l}\text { discontinuous, grey fine-coarse } \\
\text { ash }\end{array}$ & $1185-2099$ \\
\hline TT-3 & 238 & 0.5 & grey, fine-coarse ash & $1252-2326$ \\
\hline TT-4 & 272.5 & 2 & grey, fine-coarse ash & $1296-2489$ \\
\hline TT-5 & 292 & 5 & $\begin{array}{l}\text { reverse graded, grey fine-coarse } \\
\text { ash }\end{array}$ & $1345-2601$ \\
\hline TT-6 & 321 & 1 & grey, fine-coarse ash & $1602-2701$ \\
\hline TT-7 & 385 & 1 & grey, fine-coarse ash & $2346-4206$ \\
\hline TT-8 & 427 & 37 & grey coarse ash and lapilli & $2352-4208$ \\
\hline TT-9 & 588 & 38 & grey coarse ash & $3968-4853$ \\
\hline TT-10 & 710 & 30 & grey, fine-coarse ash & $4697-6279$ \\
\hline TT-11 & 763.5 & 6 & grey coarse ash & $5063-6431$ \\
\hline TT-12 & 915 & 35 & grey coarse ash and lapilli & $6144-7048$ \\
\hline TT-13 & 1623 & 5 & grey coarse ash & $8029-8888$ \\
\hline TT-14 & 2272 & 48 & grey-yellow coarse ash & $9344-10180$ \\
\hline \multicolumn{5}{|l|}{ Awassa } \\
\hline AWT-1 & 253 & 14 & grey coarse ash & $1120-1540$ \\
\hline AWT-2 & 550 & 4 & grey coarse ash and lapilli & $3258-4093$ \\
\hline AWT-3 & 818 & 10 & grey coarse ash & $5219-6318$ \\
\hline AWT-4 & 928 & 73 & grey, fine-coarse ash & $5420-6571$ \\
\hline AWT-5 & 1087 & 6 & grey, fine-coarse ash & $6436-7368$ \\
\hline AWT-6 & 1160.5 & 0.5 & grey, fine-coarse ash & $>7499$ \\
\hline AWT-7 & 1189 & 24 & grey, fine-coarse ash & $>7499$ \\
\hline \multicolumn{5}{|l|}{ Chamo } \\
\hline CHT-1* & 702 & $<1 \mathrm{~cm}$ & & $1244-2800$ \\
\hline CHT-2 & 1361 & 1 & grey, fine-coarse ash & $6299-9443$ \\
\hline
\end{tabular}

\subsubsection{Lake Awassa}

Seven visible tephras occur in the Awassa lake sediments, identified in this study as AWT-1 to AWT-7 (youngest to oldest). The tephras range in age from 


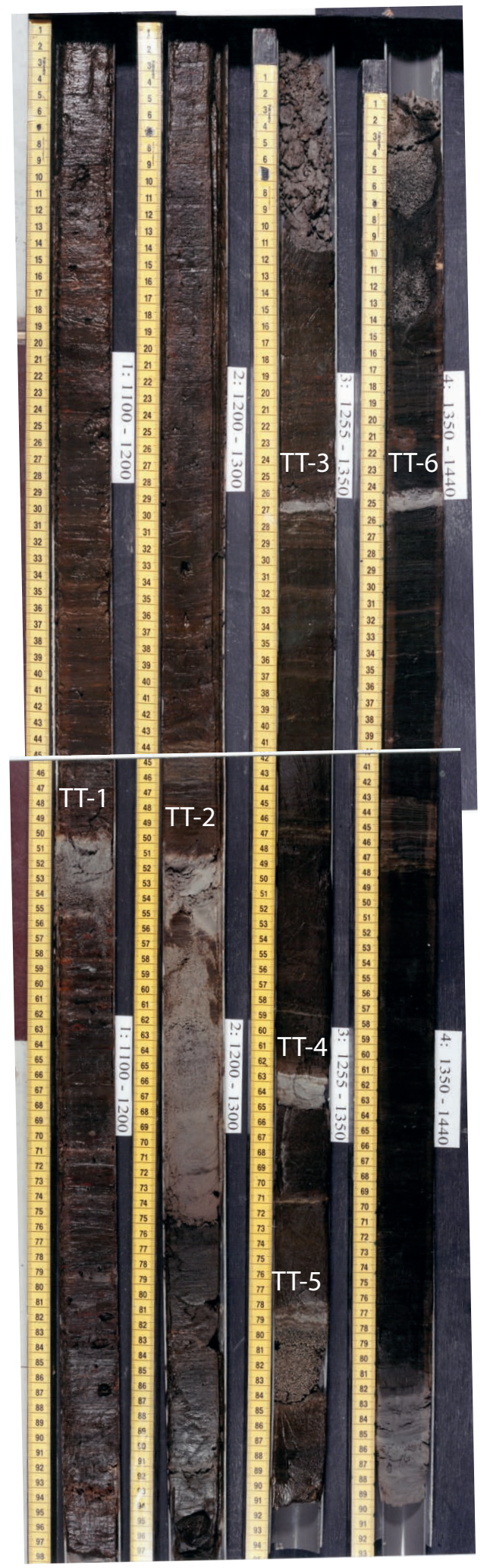

Figure 5.5: Photos of the Tilo tephras TT-1 to TT-6. 
$\begin{array}{ll}\text { (a) Tilo97-1 core chronology } & \text { (b) Lithology }\end{array}$

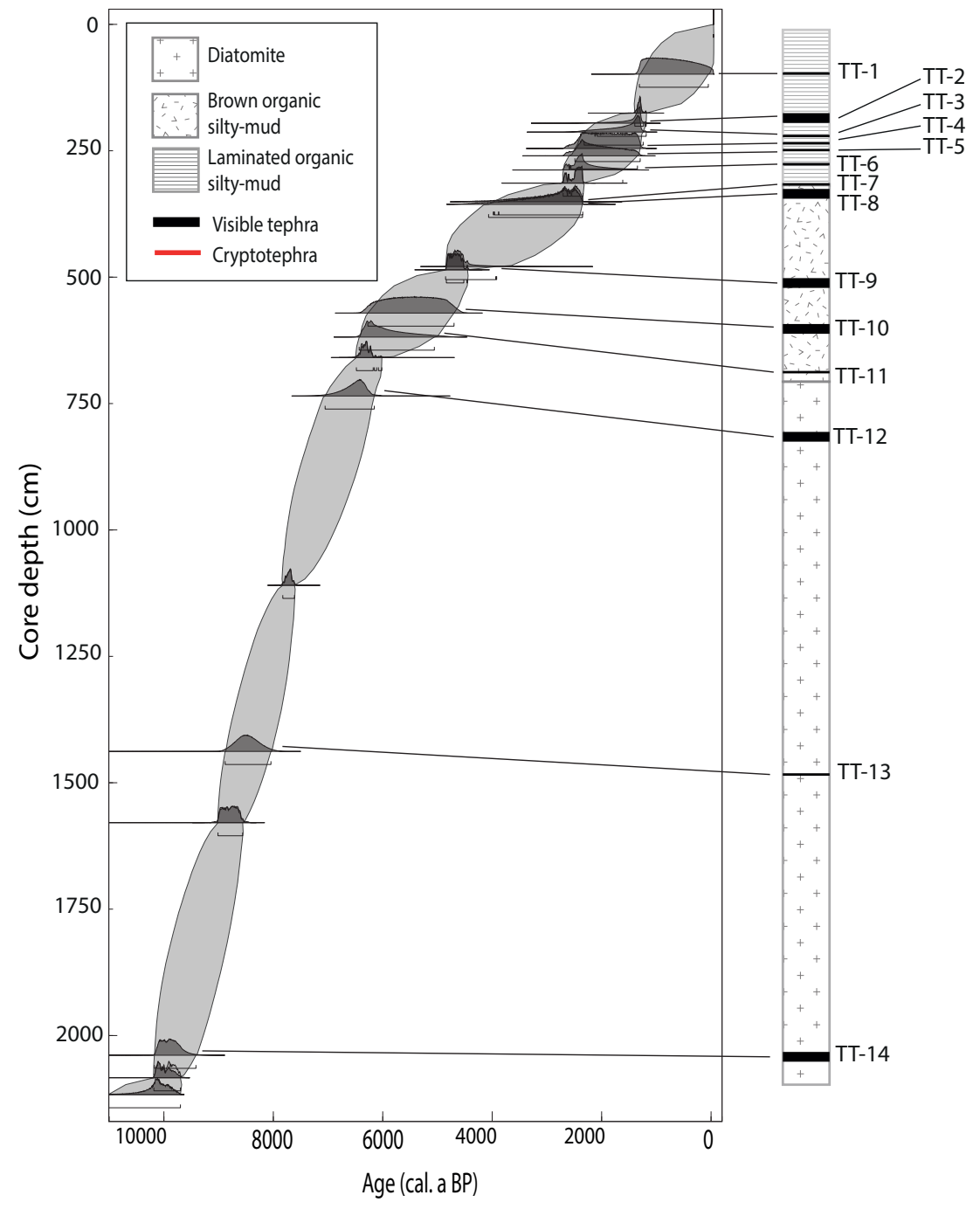

Figure 5.6: Tilo97-1 core, (a) Bayesian age model, using core depths adjusted for the presence of $>0.5 \mathrm{~cm}$ thick tephras, (b) core lithology. Core depths include tephras $>0.5 \mathrm{~cm}$ thick, horizontal lines indicate the position of these tephras in the age model. 
$\sim 7.5-\sim 1.1 \mathrm{cal} . \mathrm{ka} \mathrm{BP}$ and from $0.5-73 \mathrm{~cm}$ thick. The Awassa tephras are typically comprised of well-sorted grey fine to coarse ash, except AWT-2 which is comprised of coarse ash to lapilli. The tephras are normally graded, in contrast AWT-5 and AWT-7 show reverse grading. Glass shards in the Awassa tephras show morphologies ranging from pumiceous to bubble wall.

The Bayesian age model (Fig. 5.7) for the Awassa sediments provides age ranges for the Awassa tephras (see Table 5.3), from $>7.5-1.1 \mathrm{cal}$. ka BP. The precision of tephra ages varies throughout the Awassa age model, from $\sim 400$ years for AWT-1 to $\sim 1100$ years for AWT-3 and AWT-4. It was only possible to calculate the younger age limit for AWT-6 and AWT-7 because sediments below these tephras were not sampled for radiocarbon dating. Tephras AWT-5 and AWT-4 were deposited in rapid succession with $\sim 130$ years separating their eruption. Longer time intervals separate the eruption of AWT-1; 2 and 3, ranging from $\sim 890-1700$ years. Due to degradation of the Awassa core sediments since its initial study, it was only possible to sample AWT-1, AWT-2 and AWT-4 for compositional analysis as part of this study. 
(a) Aw-94 core chronology

(b) Lithology

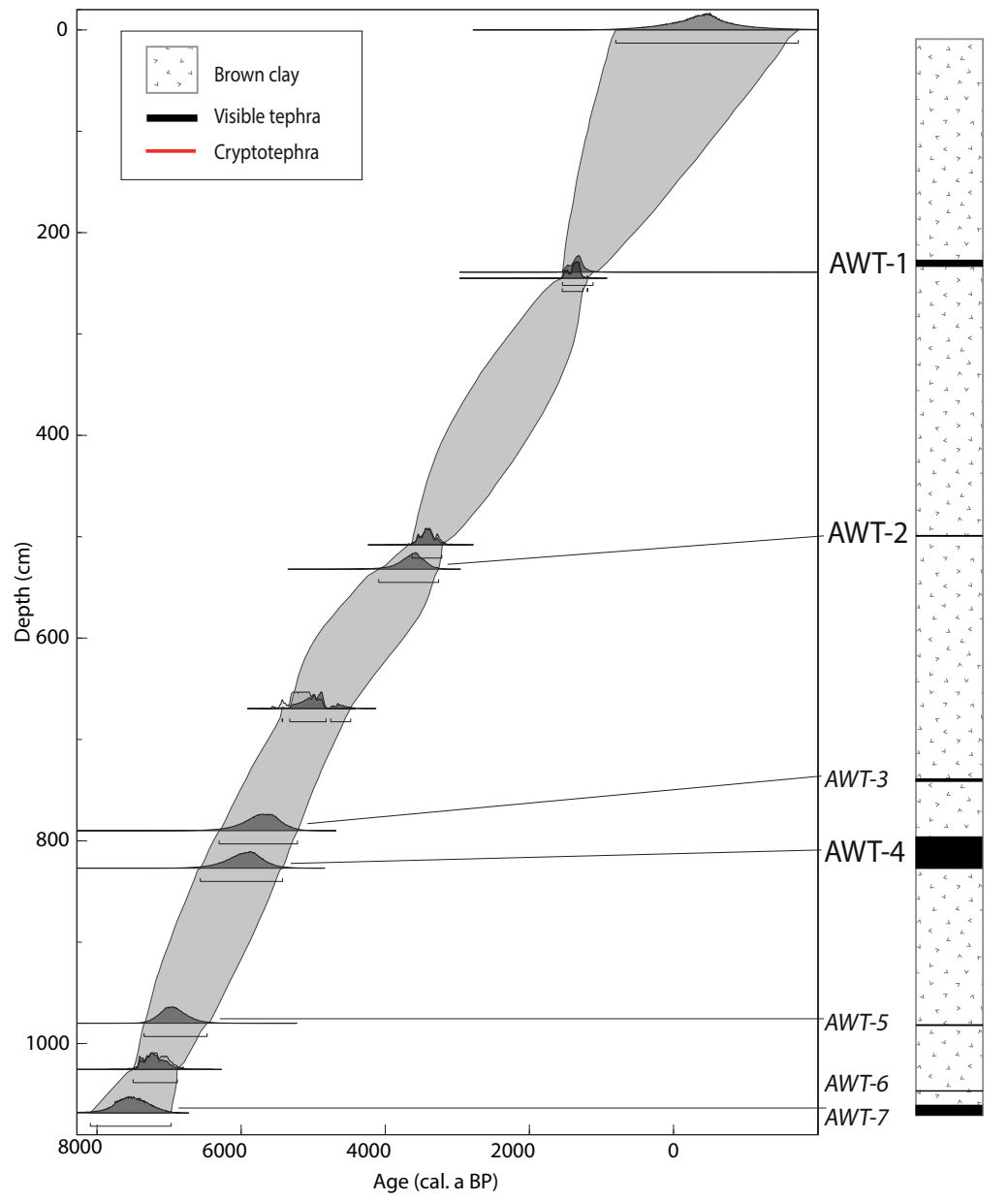

Figure 5.7: Aw-94 core, (a) Bayesian age model, using core depths adjusted for the presence of $>0.5 \mathrm{~cm}$ thick tephras, (b) core lithology. Core depths include tephras $>0.5 \mathrm{~cm}$ thick. Tephras labelled in italics could not be analysed. Horizontal lines indicate depths of the tephras in the age model. 


\subsubsection{Lake Chamo}

Two tephra layers occur in the Lake Chamo sediments, identified here as CHT-1 and CHT-2, and dated to $\sim 9.4-\sim 1.2$ cal. ka BP, respectively (see Table 5.3). Glass shards in the two Chamo tephras display bubble wall to pumiceous shards. CHT-1 is a cryptotephra that was identified using glass shard counting and CHT-2 is a $1 \mathrm{~cm}$ thick layer composed of well-sorted, fine-coarse grey ash. Due to time constraints and sample availability, cryptotephra counting in core CHA-01-2010 was restricted to the depth interval between $502-920 \mathrm{~cm}$ depth $(0.5-4.5 \mathrm{cal}$. ka BP).

Figure 5.8 shows the Bayesian age model for the Chamo core, alongside the core lithology and glass shard concentrations. The precision on the tephra age estimates varies within the Chamo age model, from $\sim 300$ years for CHT-1 to $\sim 4100$ years for CHT-2. No tephras were detected between $5.3-1.5$ cal. ka BP in the Chamo sediments. 


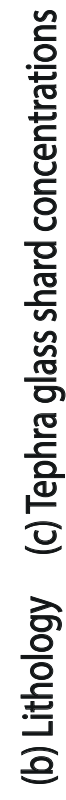

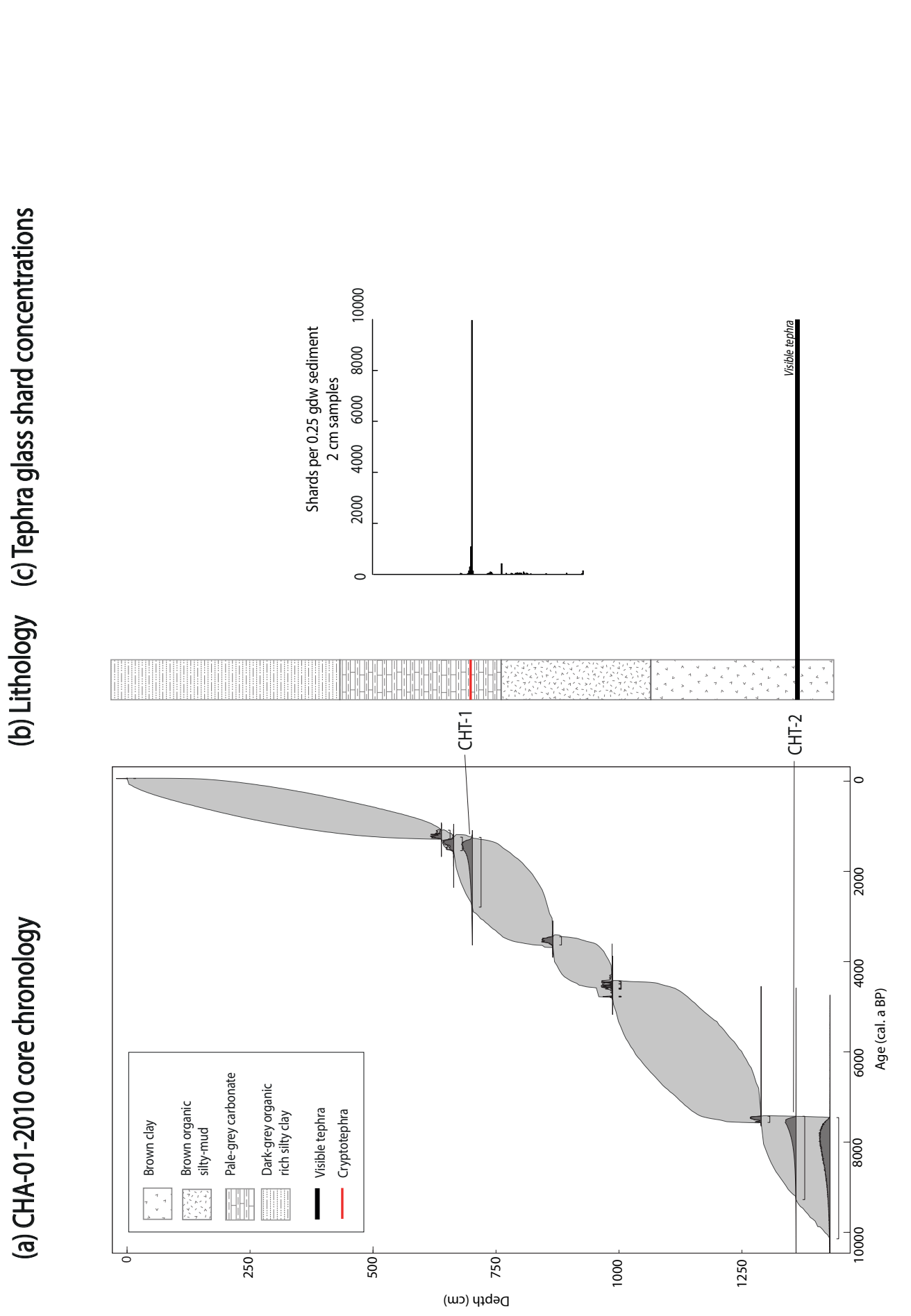

행 응

ठ $-\overline{0}$

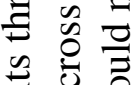

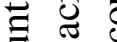

రับิ

$\mathrm{N} \cdot \frac{\mathrm{U}}{\mathrm{B}}$

일

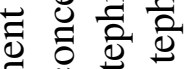

$\Xi 0 \%$

记 胥

3 क U

品 节吉

可

of 0

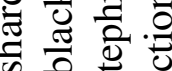

형

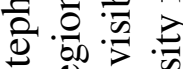

(2) 0 ป

学

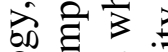

응 㤩

류웡

อิํㅡㅇ ำ

虽

ठ웡

घ

\&. 융.

预

ब

ญ

๑ึ

తิ

० के ह ग

ठํ

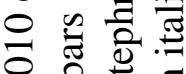

국요

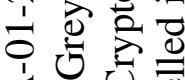

岂的怘

ப등

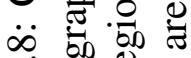

i.

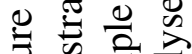

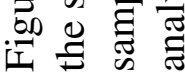




\subsection{The composition of Holocene tephras recorded in Ethiopian lake sediment cores}

This section presents the major and trace element composition of glass shards in tephras detected in seven Ethiopian lake sediment cores. Firstly, this section investigates whether the geochemistry of these tephras varies systematically throughout the Ethiopian Rift. Secondly, the composition of the tephras is compared to provide a justification for potential tephra correlations explored in forthcoming chapters. The analytical precision and accuracy on the glass compositions presented in the following section are given on pages 134 and 136 .

\subsubsection{Petrogenesis and spatial variations in the composition of Holocene tephras from Ethiopia}

Defining the control of regional tectonic processes on volcanism is crucial in understanding the evolution of rift zones (Abebe et al., 2007). The composition of volcanic deposits as a function of geographic distribution has been used in numerous studies to shed light on the relationship between magma composition and rifting (e.g. Barberi et al., 1970; Baker et al., 1972; Barberi et al., 1975; Betton and Civetta, 1984; Hart et al., 1989; WoldeGabriel et al., 1990; Abebe et al., 2007). However, studies focussing on the spatial variation of Holocene volcanism remain limited (e.g. Abebe et al., 1998; Adhana, 2014).

Selected glass shard major and trace element concentrations from all tephras, grouped by lake, are shown in Fig. 5.9 and 5.10. Glass shards recorded in sediments from lakes on the rift floor and margins of the surrounding plateaus have a rhyolitic composition, except 3 trachytic shards which occur in the Awassa and Tilo tephras. In contrast, glass shards recorded in sediments from Lake Dendi 


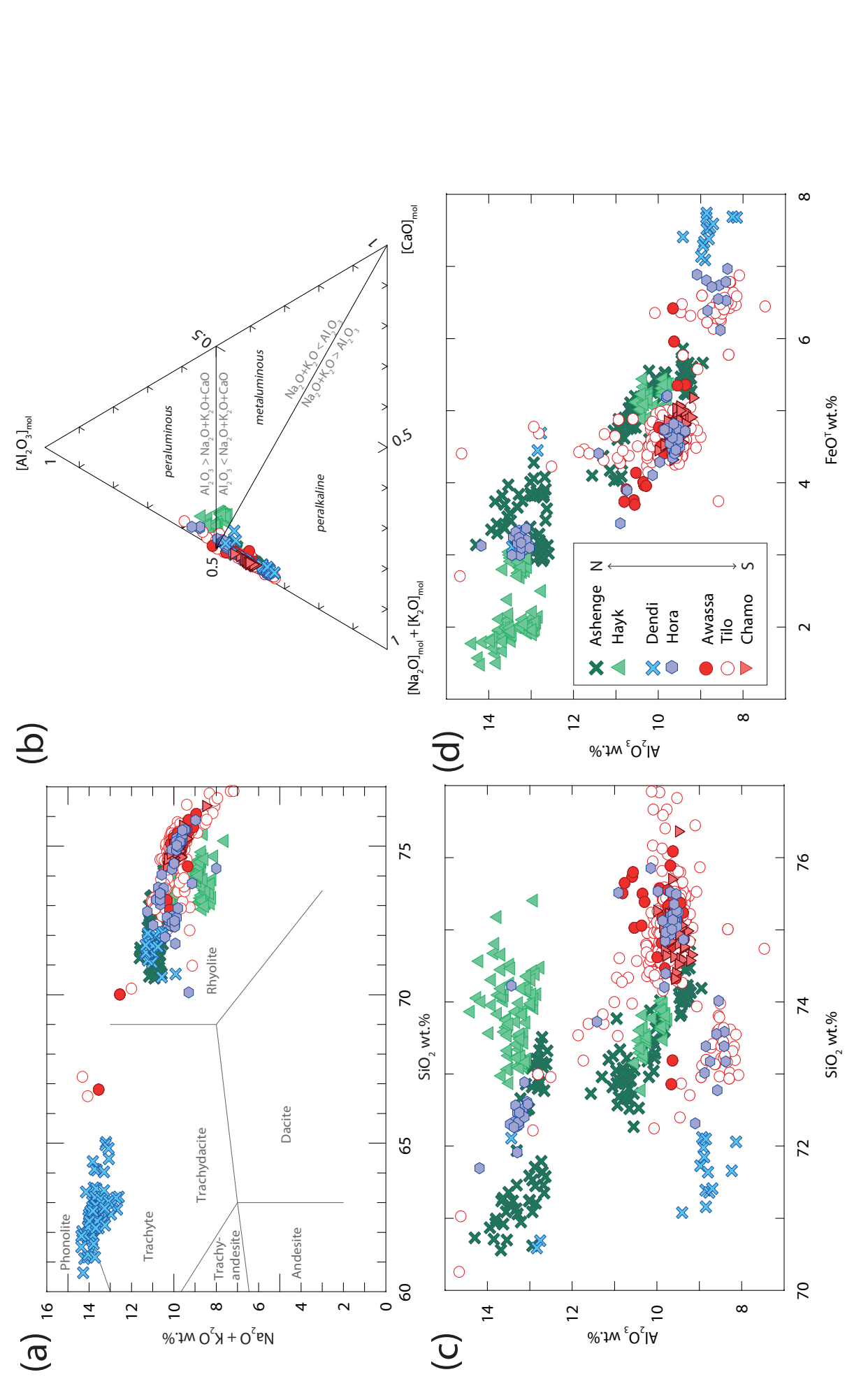

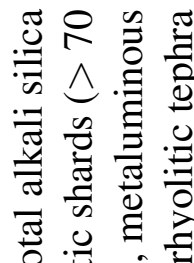

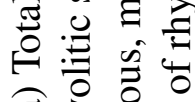
త 象齐夏 永

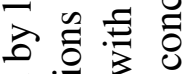
ठ:

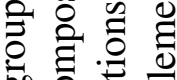
का

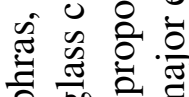

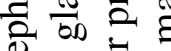
을 흥 สิ 흥 ज䠌

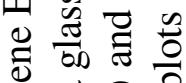

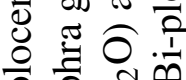
응 중 घ ปี ? ฮี 己 ज行

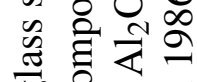
का 840 원 on 20 $\because \approx$

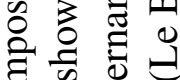
0 ช 6 䒕 बิ

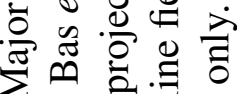

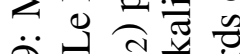
ดे 的券 क

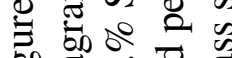

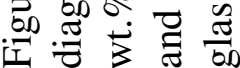




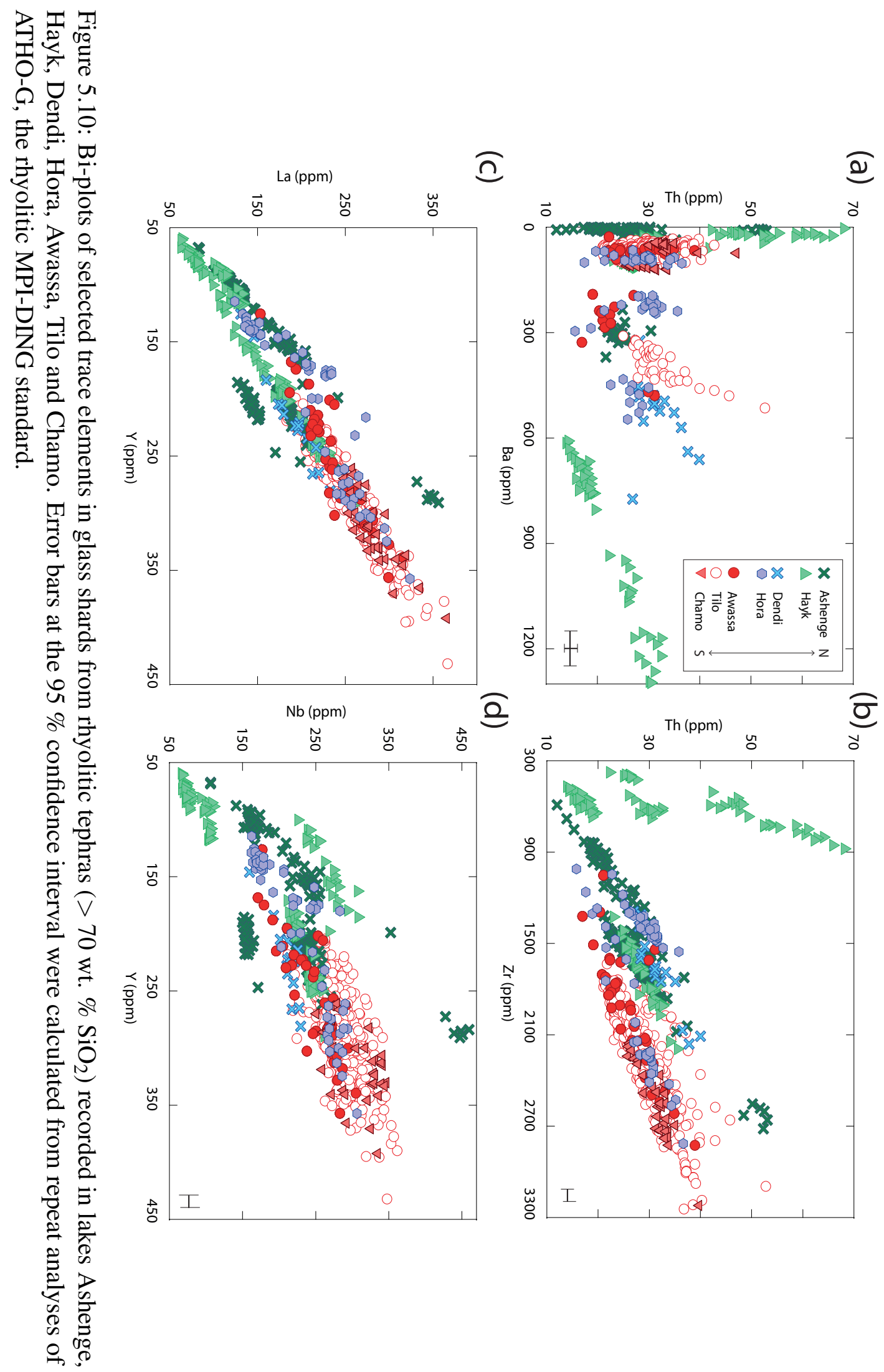


are predominantly phonolitic - trachytic (Fig. 5.9a). The spatial distribution of the tephras is discussed below, in relation to these contrasting compositions.

\section{Rhyolitic tephras}

The majority of rhyolitic ( $>70$ wt. $\% \mathrm{SiO}_{2}$ ) tephra glass shards can also be classified as peralkaline (Fig. 5.9b). However, some shards from Lakes Hayk, Tilo and Hora have marginally peraluminous and metaluminous compositions.

Bi-variate plots (Fig. 5.10) of incompatible element Y, Zr, La and Th for all rhyolitic tephras show positive linear trends (Fig. 5.10b, c). These elements are excluded from the crystallising mineral assemblages, thus becoming concentrated in the melt as fractional crystallisation proceeds. However, glass shards in the majority of tephras show curvilinear positive Y/Nb trends (Fig. 5.10d), indicating that $\mathrm{Nb}$ is becoming progressively less compatible with increasing concentrations of Y. This may be related to the onset of a new phase crystallising during magmatic evolution, in which $\mathrm{Nb}$ may be mildy compatible.

Figure 5.11 shows a chondrite-normalised spider diagram (after Thompson, 1982). It is apparent that all rhyolitic tephras have similar trace element patterns, suggesting that they are derived from magmatic sources which are fractionating similar assemblages of minerals. All tephras display negative $\mathrm{Ba}, \mathrm{K}, \mathrm{Sr}$ and Ti anomalies, indicating that their magmatic evolution was dominated by the fractionation of feldspars and Fe-Ti oxides.

Average glass compositions of rhyolitic tephra glass shards from all lakes are projected onto the haplogranite or quartz-albite-orthoclase ternary diagram in Fig. 5.12, following the methods of Blundy and Cashman (2001). All compositions trend away from orthoclase feldspar towards the $50 \mathrm{MPa}$ cotectic, reiterating 
that the evolution of these tephras was dominated by fractional crystallisation of orthoclase.

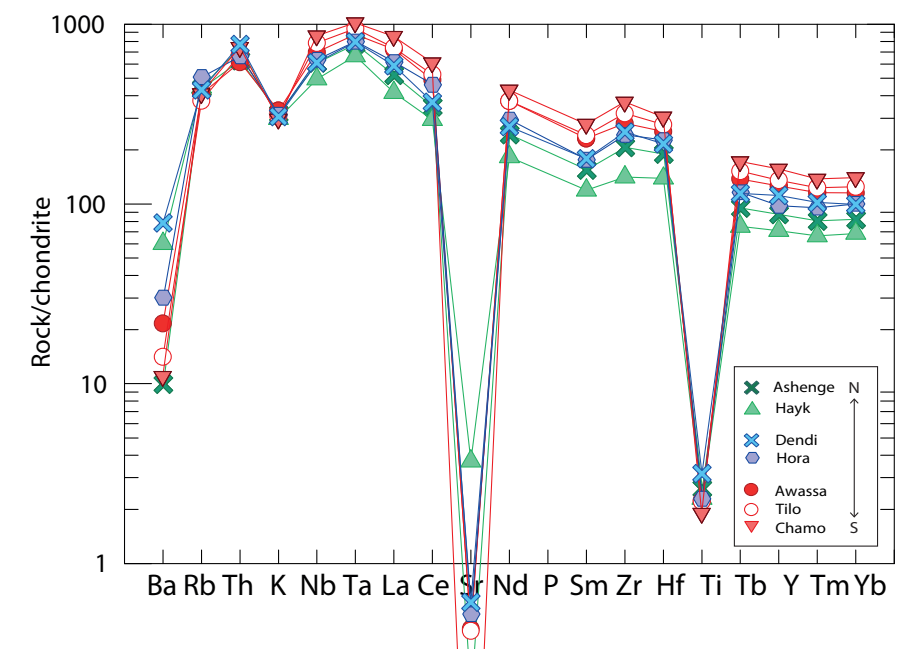

Figure 5.11: Average trace element concentrations of rhyolitic tephra glass shards from all lake sediments studied, normalised to chondrites after Thompson (1982).

Figures 5.10 to 5.12 demonstrate that tephras from lakes Awassa, Tilo and Chamo are more evolved than Ashenge, Hayk, Dendi and Hora tephras. Tephras from the central MER are more depleted in $\mathrm{Zr}$, Hf and HREE and have reached minimum compositions, having evolved through continued fractional crystallisation of orthoclase (Figs. 5.11 and 5.12). However, the Ashenge, Hayk, Hora and Dendi tephras are less evolved and have not reached minimum compositions.

Figure 5.13 shows major and trace element ratios plotted against the latitudes of the lake in which they are recorded. Ratios of $\mathrm{Zr} / \mathrm{Th}$ in the glass shards show the most systematic and apparent changes, ranging from 49.6-92.1 in lake sediments in the south to $11.5-65.7$ in lake sediments to the north (Fig. 5.13f). This indicates that these tephras are derived from different sources, and that the geochemistry of these sources is varying systematically with latitude. 


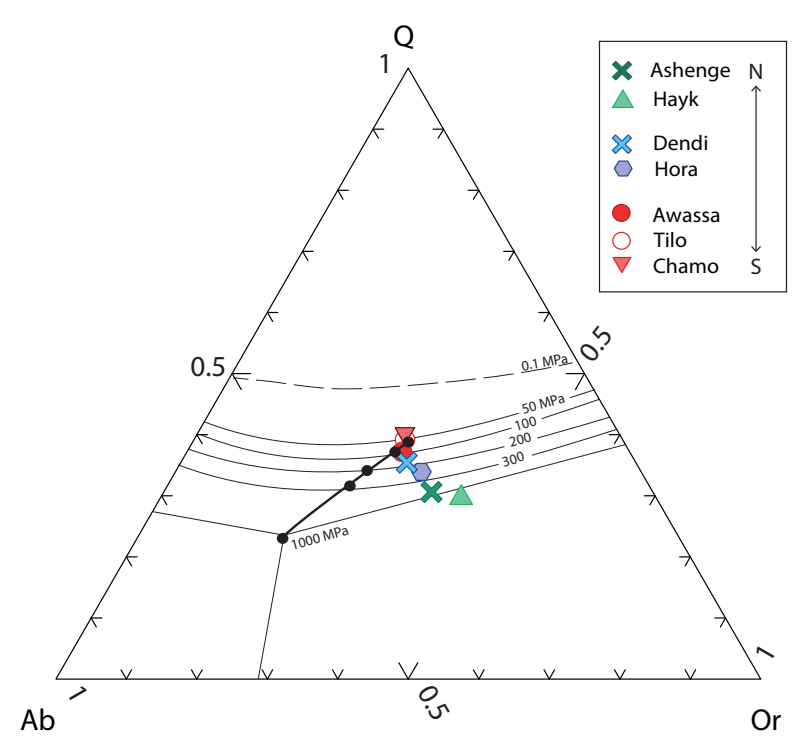

Figure 5.12: Projection of glass composition from rhyolitic tephras recorded in Ethiopian lake sediments onto a Qz-Ab-Or ternary, following methods of Blundy and Cashman (2001). Cotectic lines are from Blundy and Cashman (2001) and minima compositions are from Rollinson (1993).

It is apparent that tephras are broadly more evolved in southern Ethiopian lake archives. There are notable contrasts between the north and south tectonic settings of the lakes. The closest Holocene volcanoes $(<70 \mathrm{~km})$ to lake core sites in northern Ethiopia are located within the Afar Rift, where the highly extended crust is $\sim 20 \mathrm{~km}$ thick. However, the volcanoes in the Main Ethiopian Rift are located closest $(<40 \mathrm{~km})$ to lake core sites from southern Ethiopia, and here the crust reaches $\sim 30 \mathrm{~km}$ thick (Dugda et al., 2005). Therefore, volcanoes supplying tephras to southern Ethiopian lakes may have evolved through greater interaction with the underlying crust.

The potential role of crustal assimilation in these tephras is explored further in Figure 5.14. This shows ratios of $\mathrm{Rb} / \mathrm{Nb}$ versus $\mathrm{Ba} / \mathrm{Nb}$ in rhyolitic tephra glass shards, with the composition of Precambrian Ethiopian basement rocks plotted for comparison (Peccerillo et al., 1998). Melting of crustal rocks preserves or increases $\mathrm{Rb} / \mathrm{Nb}$ and $\mathrm{Ba} / \mathrm{Nb}$ ratios (Watt and Harley, 1993; Beard et al., 
(a)

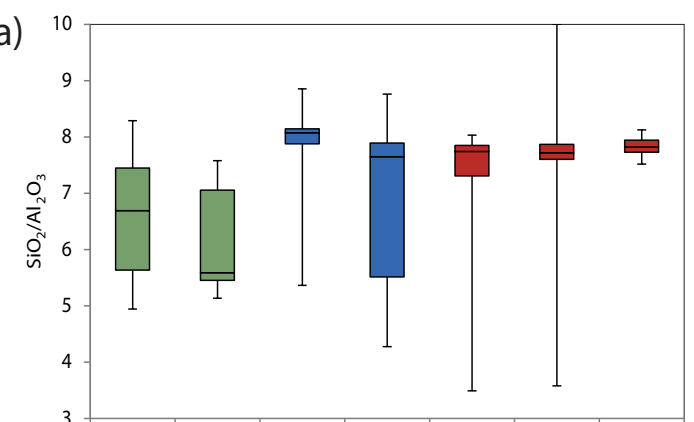

(c)

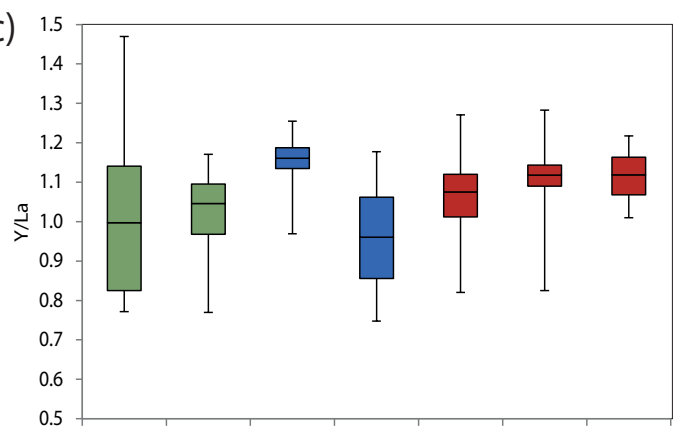

(e)

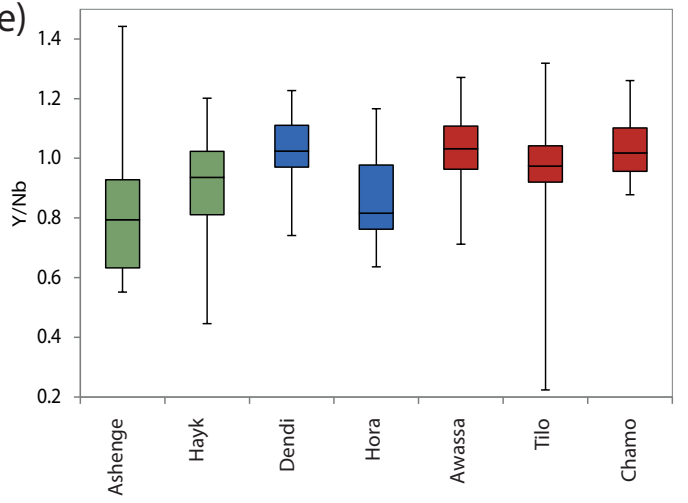

(b)

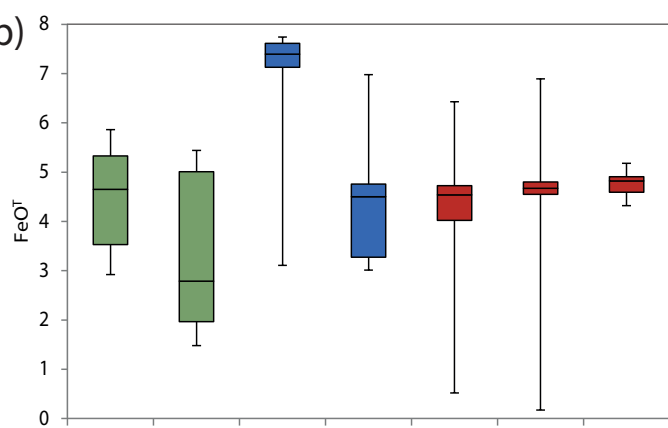

(d) 50

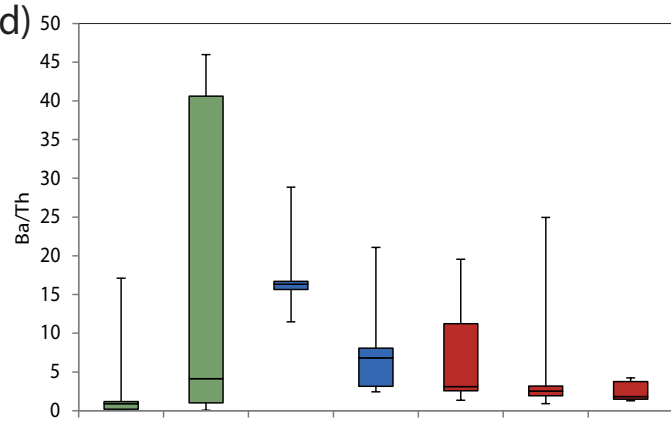

(f)

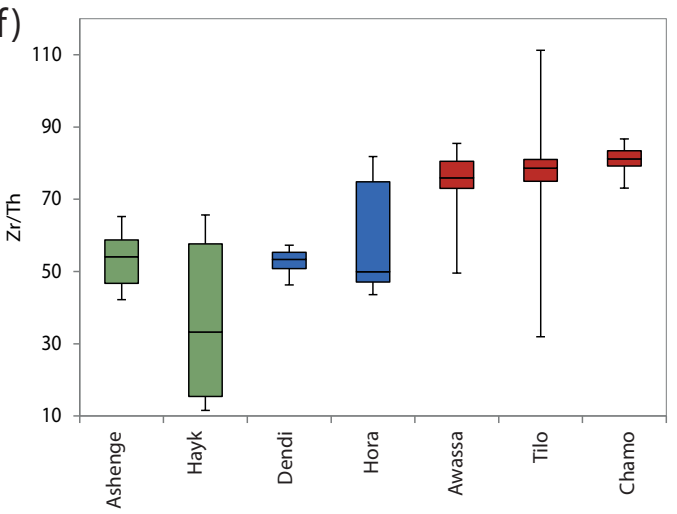

(b)

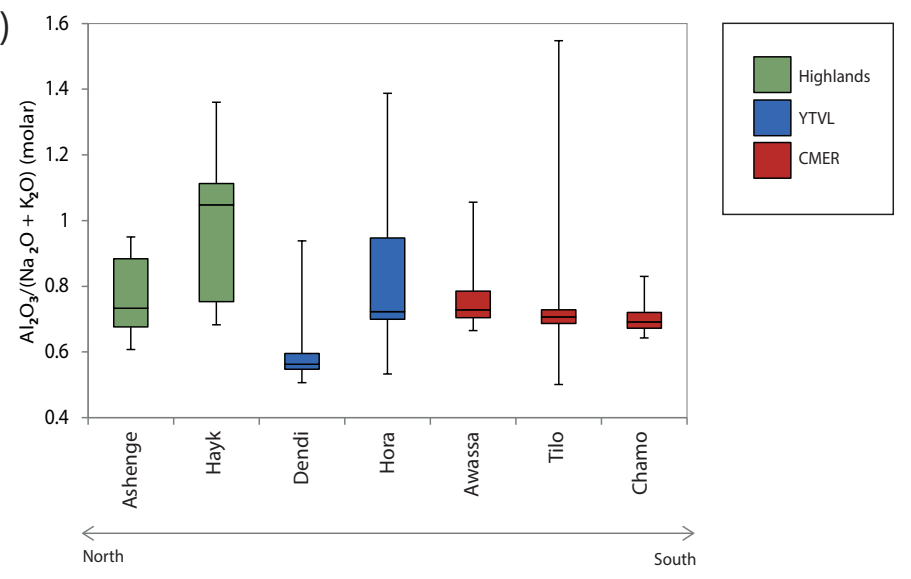

Figure 5.13: Selected major and trace element ratios for all rhyolitic tephra glass shards - ordered from north (left) to south (right). 


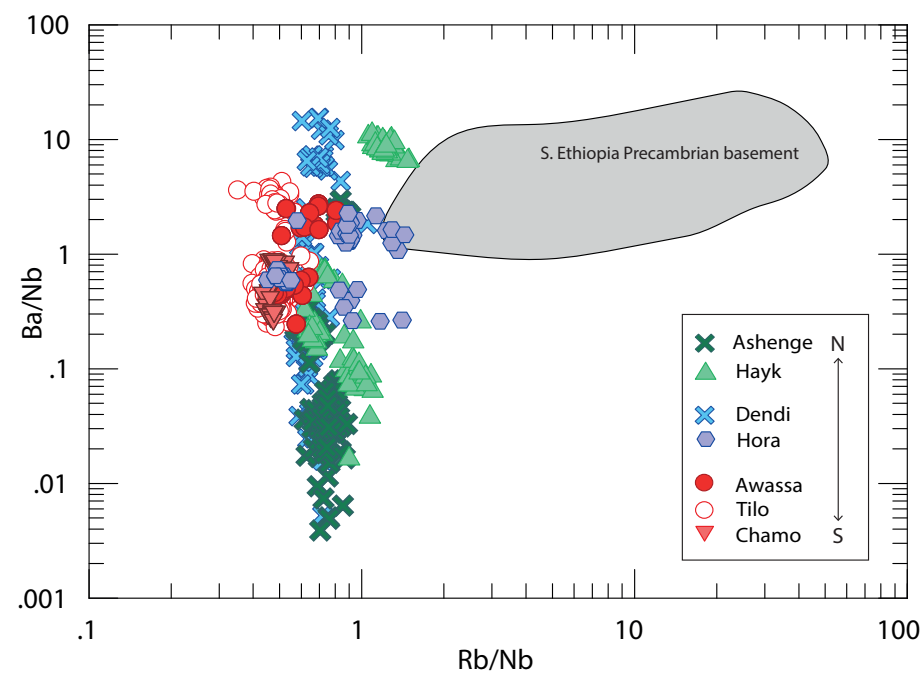

Figure 5.14: $\mathrm{Rb} / \mathrm{Nb}$ versus $\mathrm{Ba} / \mathrm{Nb}$ in glass shards from tephras recorded in all lake sediments. Compositions of Precambrian rocks from southern Ethiopia are from Peccerillo et al. (1998).

1994; Ayres and Harris, 1997), and they act as indicators of crustal assimilation. However, the composition of glass shards is not systematically influenced by interaction with the crust. One population of Hayk glass shards is more compositionally related to the southern Ethiopian basement rocks than other Hayk glass shards. This population may have been erupted from a volcano in the Afar that lay closer to the rift shoulders, where continental crust may have influenced the composition of the melt.

Broad differences in the geochemistry of tephras throughout Ethiopia cannot simply be related to varying amounts of crustal assimilation in the region. However, further interpretation is hindered by numerous limitations. This study assumes that tephras recorded in these archives are locally derived. Nonetheless, there is the possibility that tephras were erupted from distant volcanoes, and may not represent the composition of local sources. Furthermore, the interpretations made here are based only on glass compositions. Sampling of source volcanoes 
and mineral analyses is required to ascertain the full range of compositions erupted.

This study has also generalised regional tectonic processes in the Ethiopian Rift and it is notable that there are smaller scale, basinal, tectonic variations (WoldeGabriel et al., 1990). Macgregor (2015) outlined rifting in Ethiopia did not simply develop from north to south, and indicates that rifting in the central Main Ethiopian Rift commenced before extension in the northern Main Ethiopian Rift. This variation may further determine magma genesis and therefore tephra composition.

\section{Phonolitic-trachytic tephras}

The previous discussion has focussed on the predominant rhyolitic tephras from Ethiopian lake sediments. Numerous studies also document the prevalence of silicic compositions in the rift, with minor basalts and a characteristic lack of intermediate composition (Mohr, 1971; Berhe, 1987; Walter et al., 1987; Mohr and Zanettin, 1988; Hart et al., 1989; Peccerillo et al., 2007).

Contrastingly, the thicker crust at the rift shoulders causes basaltic magmas to evolve at high pressures, and here volcanoes erupt trachytic compositions (Gasparon et al., 1993; Peccerillo et al., 2007). Lakes Dendi and Hora are located along the Yerer-Tullu Wellel Volcano Tectonic Lineament (YTVL), on the rift shoulders (Fig. 5.17). The composition of phonolitic-trachytic Dendi tephras is shown in Fig. 5.15, and it is apparent that they, like the rhyolitic tephras, have evolved through fractional crystallisation of feldspars and Fe-Ti oxides. These phonolitic-trachytic tephras have 5\% nepheline in the calculated CIPW norm, and are therefore marginally silica-undersaturated. The CIPW norm of these tephras is plotted in Fig. 5.16, demonstrating that they have crystallised out 
albite, and as the temperature drops, their melt composition is moving towards the feldspar-nepheline cotectic.

Lake Hora is located $\sim 100 \mathrm{~km}$ east of Lake Dendi and $<40 \mathrm{~km}$ from the Main Ethiopian Rift (Fig. 5.17). The composition of the Hora tephras is, in contrast, silica-oversaturated (see Fig. 5.12). Adhana (2014) documents the change from silica-oversaturated to undersaturated compositions westwards along the YTVL, resulting in a decrease in melting away from the Main Ethiopian Rift. The Yerer-Bishoftu volcanoes and centres in the Main Ethiopian Rift are proximal to Lake Hora, and produce peralkaline rhyolites. Contrastingly, the Wechacha and Wenchi volcanoes, in the vicinity of Lake Dendi, produce silica saturated to marginally undersaturated alkali basalt-trachyte compositions. It is apparent that the Dendi and Hora archives provide effective records of the compositional variation along the YTVL.

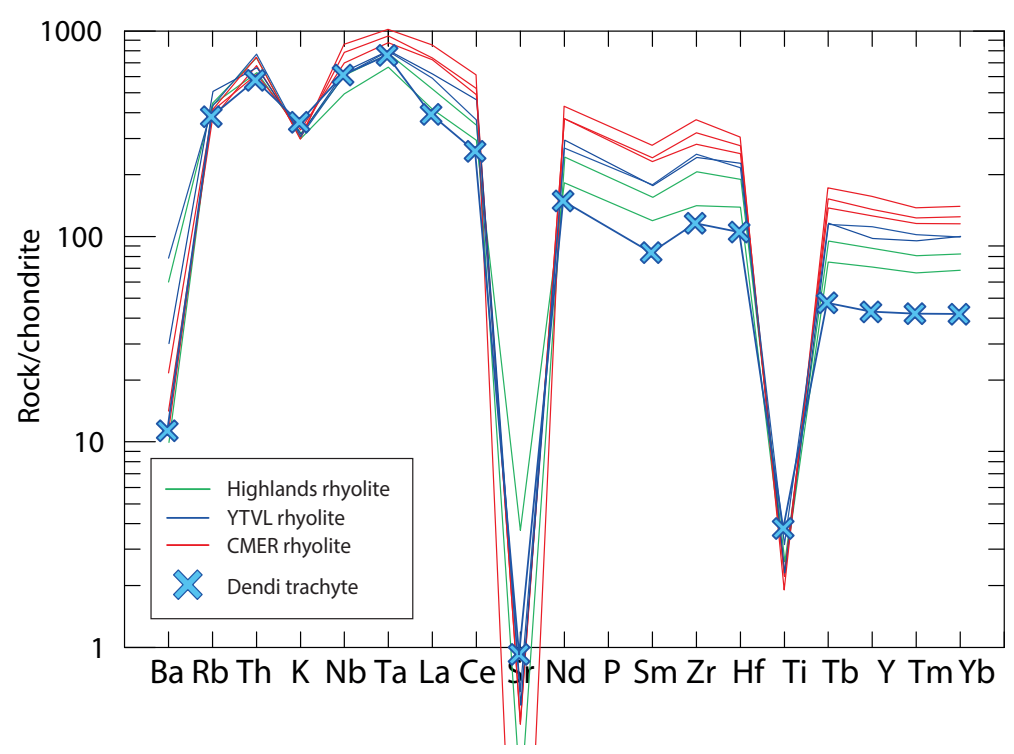

Figure 5.15: Average trace element concentrations in the Dendi phonolitictrachytic tephra glass shards compared with average compositions of rhyolite glass shards from all other lakes, normalised to chondrites after Thompson (1982). 


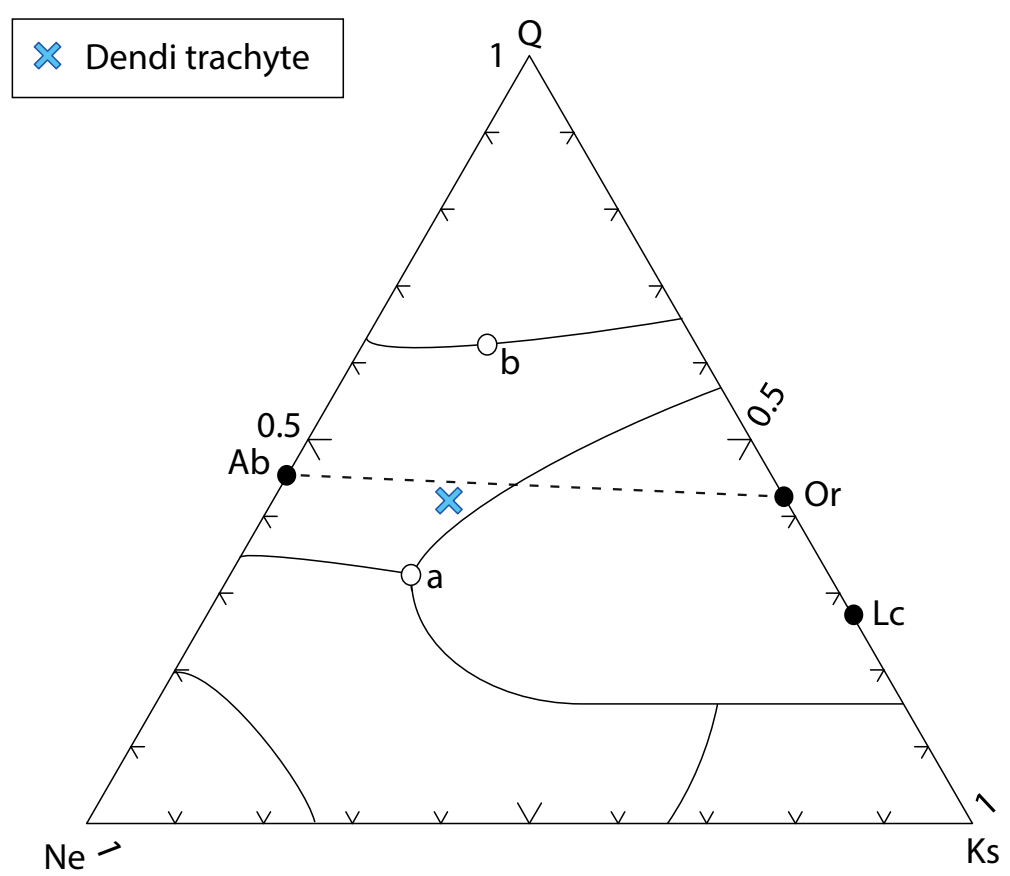

Figure 5.16: Projection of glass composition from phonolitic-trachytic Dendi tephras onto the quartz, nepheline and kalsilite residua system. $1100^{\circ} \mathrm{C}$ contours are indicated, contours decrease either side of the albite-orthoclase thermal barrier (dashed line). The silica undersaturated Dendi tephras are evolving towards the feldspar-nepheline cotectic (a). Silica oversaturated compositions instead evolve towards the feldspar-quartz cotectic (b). 
(a)

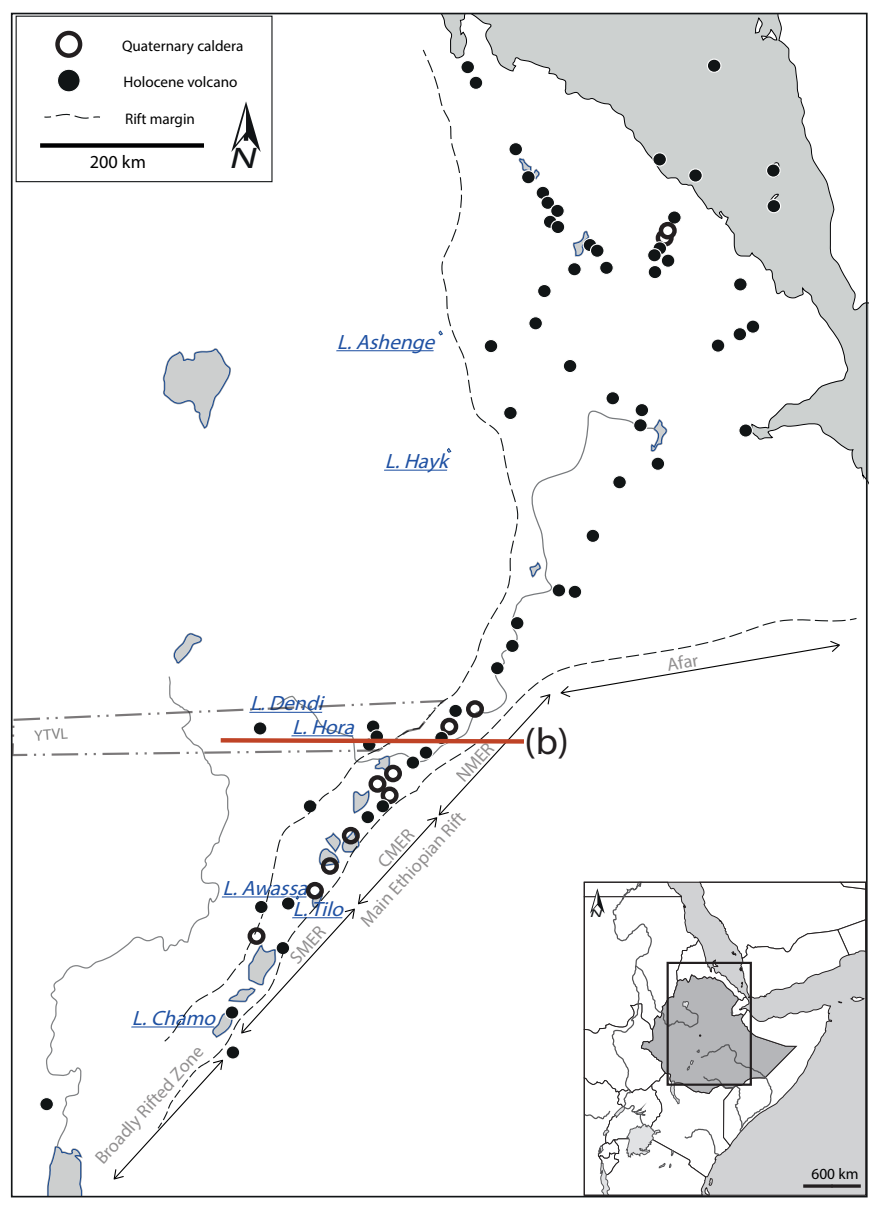

(b) West

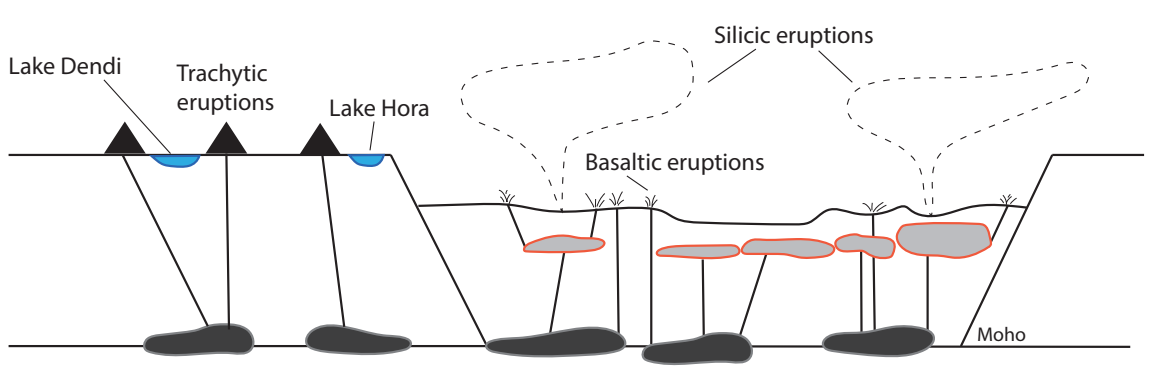

YTVL Main Ethiopian Rift

Figure 5.17: (a) Map of Ethiopia showing lake sites and Holocene volcanoes, (b) cross section schematic through the northern Main Ethiopian Rift and YererTullu Wellel Volcano Tectonic Lineament (YTVL). Red line in (a) shows its approximate location. The distribution of different magmatic types from west to east is shown, basaltic magmas evolve at high pressure to trachytes beneath the rift shoulders, silicic magmas are generated by fractional crystallisations at shallow depths. Figure (b) adapted from Peccerillo et al. (2007). 


\subsubsection{Potential tephra correlations}

The previous discussion has demonstrated that Awassa, Tilo and Chamo tephras are more evolved than tephras occurring in archives from the Highlands. These compositional differences are reiterated in Fig. 5.18. Nonetheless, a population of Ashenge and Hayk tephra glass shards have similar $\mathrm{Zr} / \mathrm{Th}$ ratios $(\approx 53.5-65.7)$ to some Tilo tephra shards $(\mathrm{Zr} / \mathrm{Th} \approx 55.9-65.2)$. However, these Tilo tephra glass shards contain higher $\mathrm{Zr}, \mathrm{Ba}$ and Th concentrations than the Ashenge and Hayk tephras (Fig. 5.18c, e). The compositional differences between these tephras may be a product of their eruption from a zoned magma chamber. Whilst these Tilo tephras are enriched in incompatible elements, they also contain lower $\mathrm{SiO}_{2}$ and $\mathrm{Al}_{2} \mathrm{O}_{3}$ than these Ashenge and Hayk shards. These different fractionation trends indicate these tephras are not co-genetic. Therefore, tephra correlations between these lakes will not be explored in forthcoming chapters.

Section 5.4.1 highlighted that the Dendi trachytic tephras, derived from the western Yerer-Tullu Wellel Volcano Tectonic Lineament (YTVL), are distinct. However, some tephras from the Hora archive (eastern YTVL) have similar $\mathrm{Zr} / \mathrm{Th}$ ratios $(\approx 63.3-81.3)$ to the Awassa, Chamo and most Tilo tephra glass shards $(\approx 56.2-92.1$, Figs. 5.19e). The composition of these tephras is further compared using a PCA, in Figs. 5.19b, d and f, and affirms that these tephras cannot be distinguished.

Furthermore, the sole rhyolitic Dendi tephra, and a population of Hora glass shards, have similar $\mathrm{Zr} / \mathrm{Th}$ ratios $(\approx 43.6-54.3)$ to a population of Ashenge and Hayk tephras $(\mathrm{Zr} / \mathrm{Th} \approx 42.2-65.7)$. However, these Hora and Dendi glass shards contain higher $\mathrm{Ba}$, and principal component analysis of their glass compositions reiterates that they are distinct (Fig 5.20d). It is possible that a change in wind direction during an eruption tapping a zoned magma chamber could cause this 
large variation in tephra composition. For instance, the zoned Laacher See 12.92 cal. ka BP eruption deposited a spatially variable range of tephra compositions (e.g. Reide et al., 2011).

However, assessment of this requires further sampling of regional tephras and source volcanoes to capture the full compositional range of the eruption. The Hora archive may represent a valuable link between tephra records from the Ethiopian Highlands, and those from the central Main Ethiopian Rift. However, the lack of stratigraphic and chronological control for the Hora tephras limits further investigation of these possible tephra correlations.

To establish regional correlations in Ethiopia, further lake core sites are required. The following chapters will investigate localised tephra correlations. Chapter 6 investigates potential correlations between Ashenge and Hayk (Ethiopian Highlands) and Chapter 7 investigates tephra deposits in the Awassa, Tilo and Chamo (CMER) archives. 

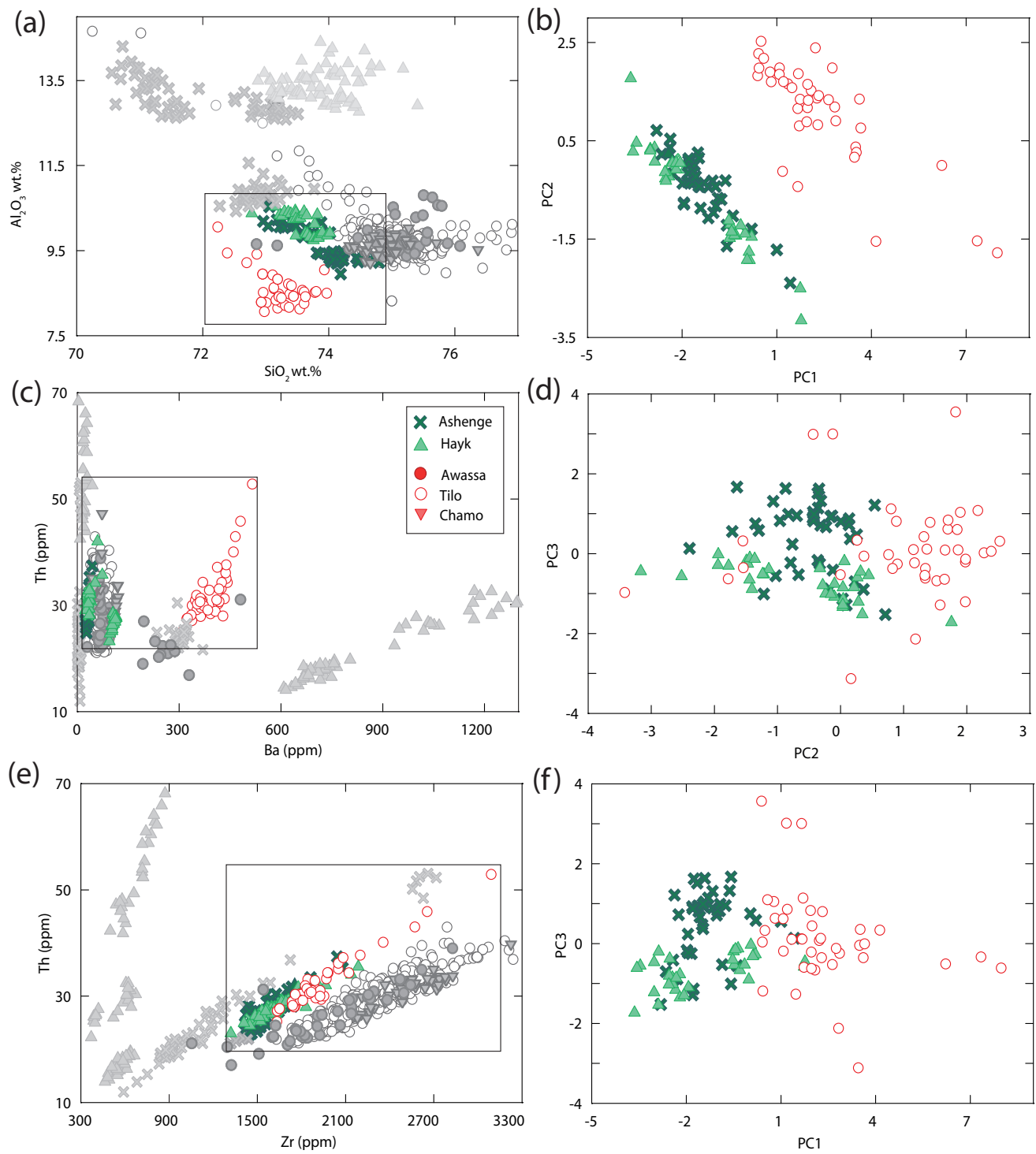

Figure 5.18: (a), (c), (e) Selected major and trace element bi-plots comparing the composition of tephras from lakes Ashenge and Hayk with Awassa, Tilo and Chamo tephras, those shown in grey scale are not included in the principal component analysis. (b), (d), (f) Principal component analysis comparing $\mathrm{SiO}_{2}$, $\mathrm{Al}_{2} \mathrm{O}_{3}, \mathrm{FeO}^{T}, \mathrm{Y}, \mathrm{Zr}, \mathrm{Nb}, \mathrm{Ba}, \mathrm{La}$ and Th concentrations in the compositionally similar Ashenge, Hayk and Tilo tephras. 
(a)
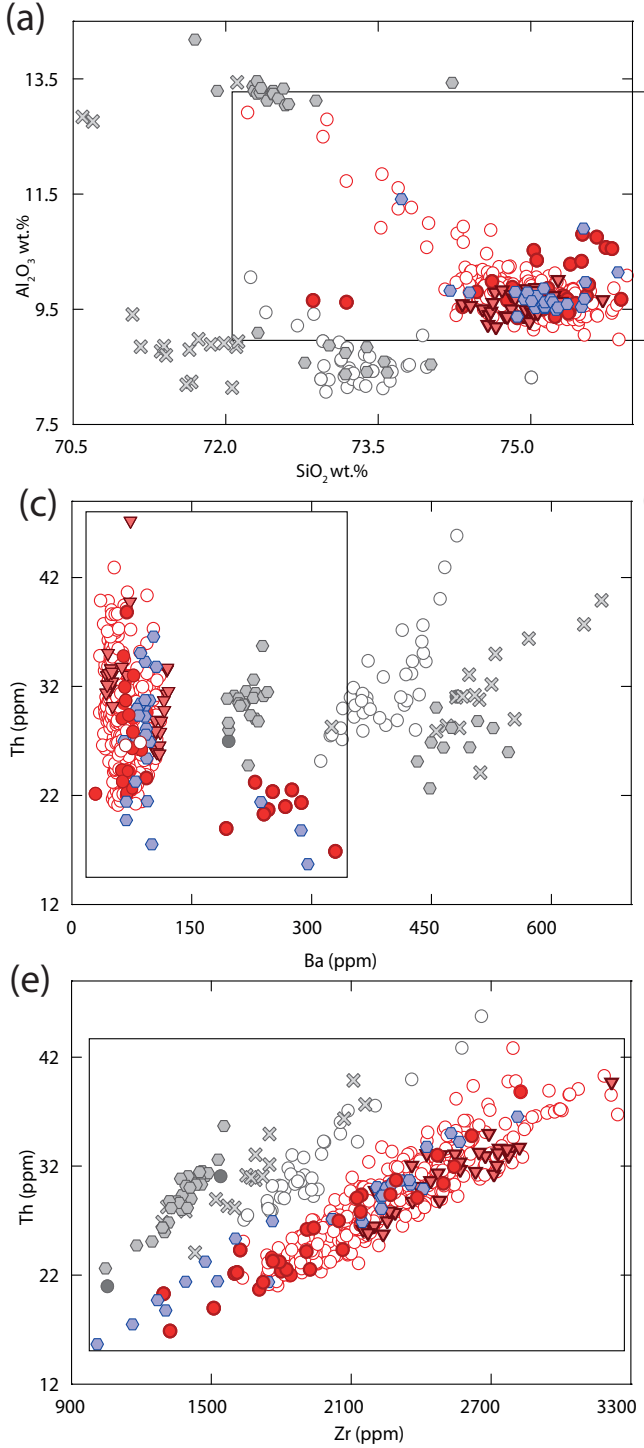

(b)

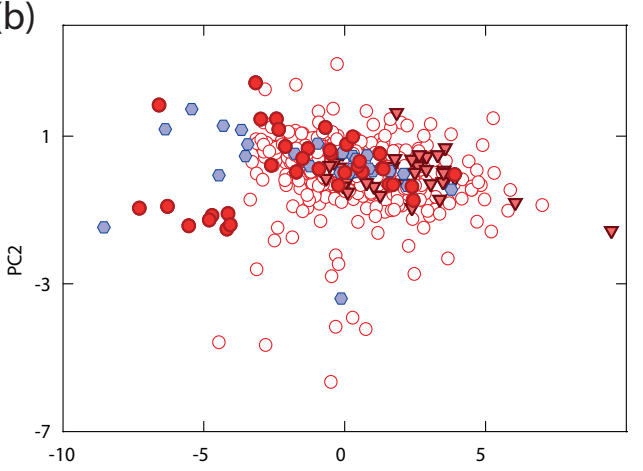

(d)

(f)
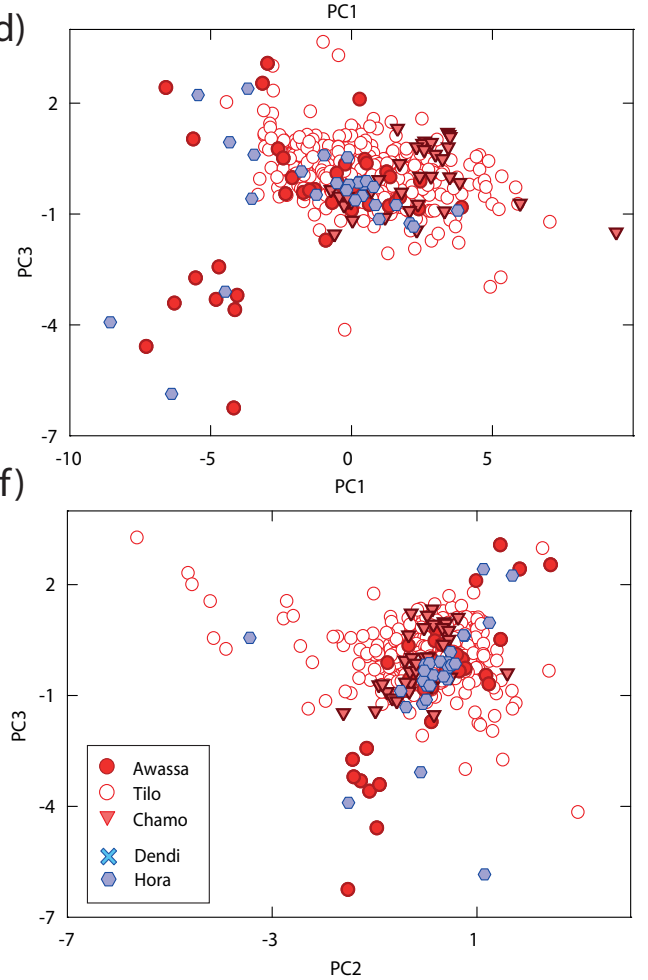

Figure 5.19: (a), (c), (e) Selected major and trace element bi-plots comparing the composition of tephras from lakes Dendi and Hora with Awassa, Tilo and Chamo tephras, those shown in grey scale are not included in the principal component analysis. (b), (d), (f) Principal component analysis comparing $\mathrm{SiO}_{2}, \mathrm{Al}_{2} \mathrm{O}_{3}$, $\mathrm{FeO}^{T}$, Y, $\mathrm{Zr}, \mathrm{Nb}, \mathrm{Ba}$, La and Th concentrations in the compositionally similar Hora, Awassa, Tilo and Chamo glass shards. 

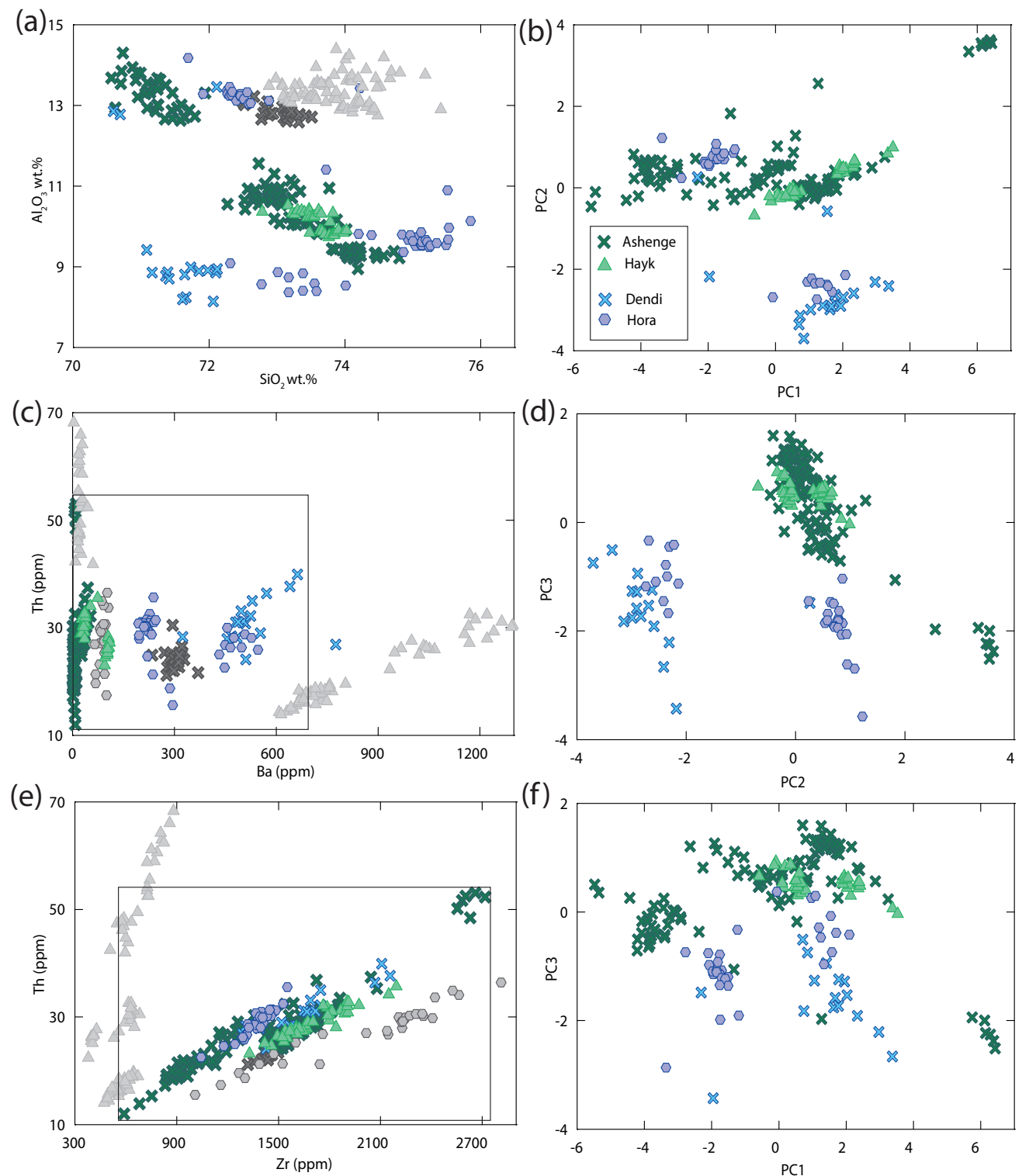

Figure 5.20: (a), (c), (e) Selected major and trace element bi-plots comparing the composition of tephras from lakes Ashenge and Hayk with Dendi and Hora tephras, those shown in grey scale are not included in the principal component analysis. (b), (d), (f) Principal component analysis comparing $\mathrm{SiO}_{2}, \mathrm{Al}_{2} \mathrm{O}_{3}$, $\mathrm{FeO}^{T}, \mathrm{Y}, \mathrm{Zr}, \mathrm{Nb}, \mathrm{Ba}, \mathrm{La}$ and $\mathrm{Th}$ concentrations in the compositionally similar Ashenge, Hayk, Dendi and Hora tephras. 


\subsection{Conclusions}

This chapter has described the occurrence and physical characteristics of visible and crypto-tephras in the Ashenge, Hayk, Dendi, Hora, Awassa, Tilo and Chamo lake sediments. Bayesian age modelling has provided age ranges for the tephras in the archives. Archives from lakes Ashenge and Hayk, in the Ethiopian Highlands, contain a total of 21 visible and crypto-tephras, which range in age from $15.3-$ 0.3 cal. ka BP. A total of 7 visible tephras occur in the Hora and Dendi lake sediments, from the Yerer-Tullu Wellel Volcano Tectonic Lineament. The depths and ages of the Hora tephras remain unknown, whereas, the Dendi tephras range in age from $10.1-0.7$ cal. ka BP. Archives from lakes Awassa, Tilo and Chamo contain 23 visible and crypto-tephras, ranging in age from $10.2-0.01$ cal. ka BP.

The major and trace element composition of tephra glass shards has been presented. Tephra glass shards range in composition from minor phonolites and trachytes to predominant peralkaline rhyolites. However, some rhyolitic shards in lakes Hayk, Tilo and Hora are slightly peraluminous or metaluminous.

This section has investigated whether the geochemistry of the Holocene tephras changes systematically in relation to the location of the lake in which the tephras are recorded. Rhyolitic tephras are typically recorded in archives from lakes on the rift floor and the bordering rift escarpments. In contrast, tephras recorded in Lake Dendi are distinctly phonolitic-trachytic. Lake Dendi is located on the rift shoulders, where the trachytic composition of eruptives has been widely reported (Abebe et al., 1995, 1998; Adhana, 2014). On the rift shoulders, mafic magmas pond in the lower crust and undergo high pressure evolution to form trachytic magmas (see Fig. 5.17). However, in the axial rift zone, magmas ascend more rapidly to form large zoned magma chambers, where 
fractional crystallisation produces a peralkaline silicic upper layer overlying basalts (Peccerillo et al., 2007). Furthermore, it is apparent that tephras recorded in lake sediments from the central Main Ethiopian Rift (CMER) are broadly more evolved than those recorded in lakes to the north. Extension decreases from the Afar Rift towards the Main Ethiopian Rift and this variation may influence melt production. However, it is likely that localised tectonic variations also influence melt composition. Therefore, further sampling of regional volcanoes coupled with chronological control, is required to further investigate this relationship.

Importantly, this chapter has provided the rationale for the tephra correlations explored in the coming chapters. Many of the tephras have distinct compositions; $\mathrm{SiO}_{2}, \mathrm{Al}_{2} \mathrm{O}_{3}, \mathrm{FeO}^{T}, \mathrm{Y}, \mathrm{Zr}, \mathrm{Nb}, \mathrm{Ba}$, La and Th are particularly useful for their discrimmination. Potential regional tephra correlations have been explored both graphically, using major and trace element bi-plots, and statistically, using principal component analysis. It is apparent that regional tephra correlations cannot be established in Ethiopia at this stage. The Hora archive may provide tephra links between central Ethiopia, and those from the Ethiopian Highlands and the central Main Ethiopian Rift. However, stratigraphic and chronological control for the Hora tephras is required before correlations can be assessed. Therefore, local tephra correlations between lakes Ashenge and Hayk will be explored in Chapter 6. This is followed by an investigation of potential correlations between Awassa, Tilo and Chamo archives in Chapter 7. 


\title{
Chapter 6
}

\section{The timing and composition of}

\author{
post-17 ka distal volcanism from
}

\section{the Afar recorded in Lakes}

\section{Ashenge and Hayk}

\subsection{Introduction}

Tephras recorded in lake sediments from Ashenge and Hayk (Ethiopian Highlands) are investigated in this chapter. Potential tephra correlations between these archives are tested and factors influencing these correlations are considered. These archives also provide an important record of past volcanism. The likely sources for these tephras and the information they provide on past eruption frequency is discussed. 


\subsection{The composition of the Ashenge and Hayk tephras}

\subsubsection{The Ashenge tephras}

The major and trace element composition of the Ashenge tephra glass shards is given in Table 6.1 and Fig.6.1. The Ashenge tephra glass shards are compositionally distinct and can be divided into three groups based on their varying $\mathrm{Y} / \mathrm{La}$ and $\mathrm{Zr} / \mathrm{Th}$ ratios. These ratios may be indicative of three different groups of fractionating magma. The composition of the Ashenge tephras is discussed below in terms of glass shards sharing similar incompatible element ratios, and potentially of co-magmatic origin. 


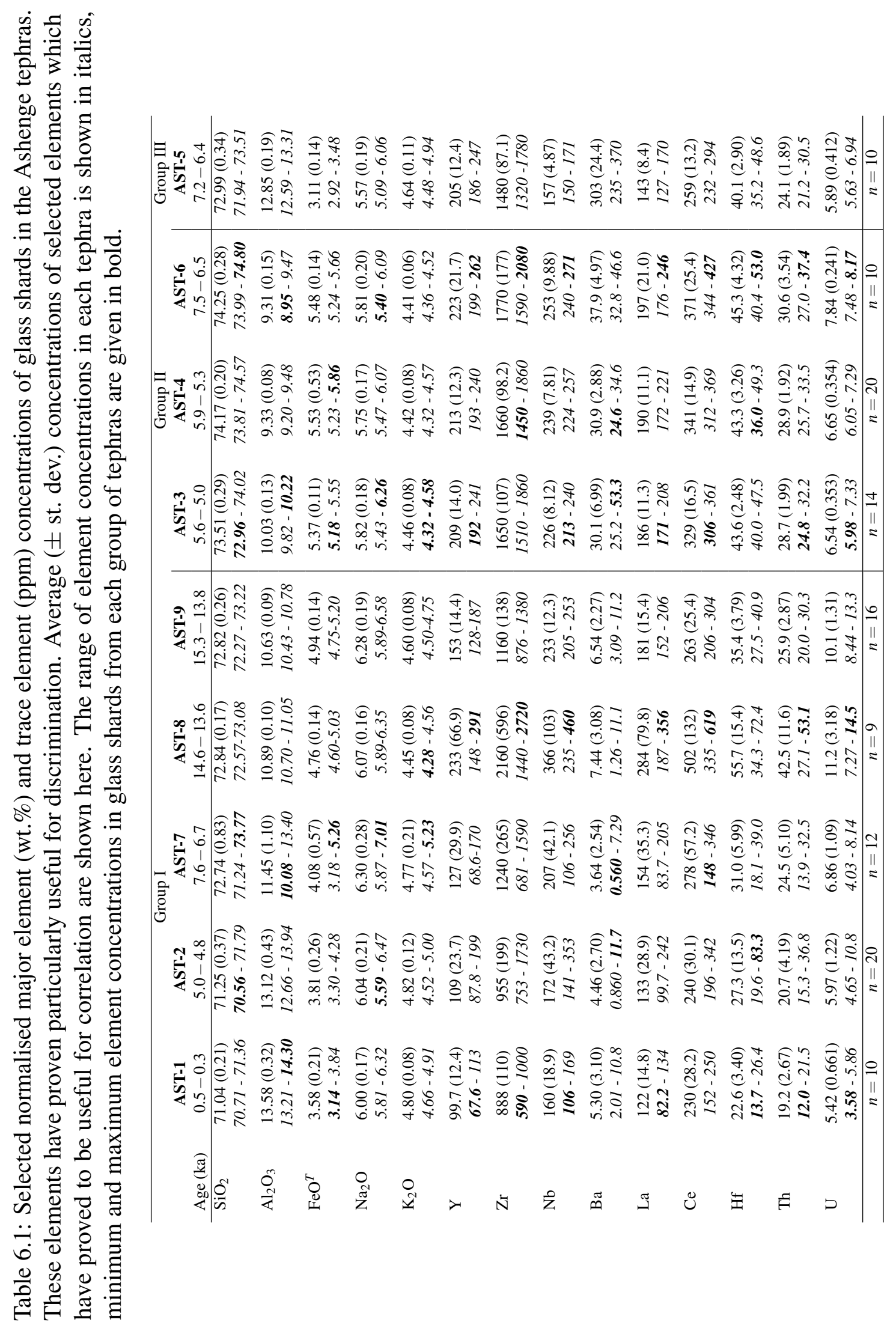



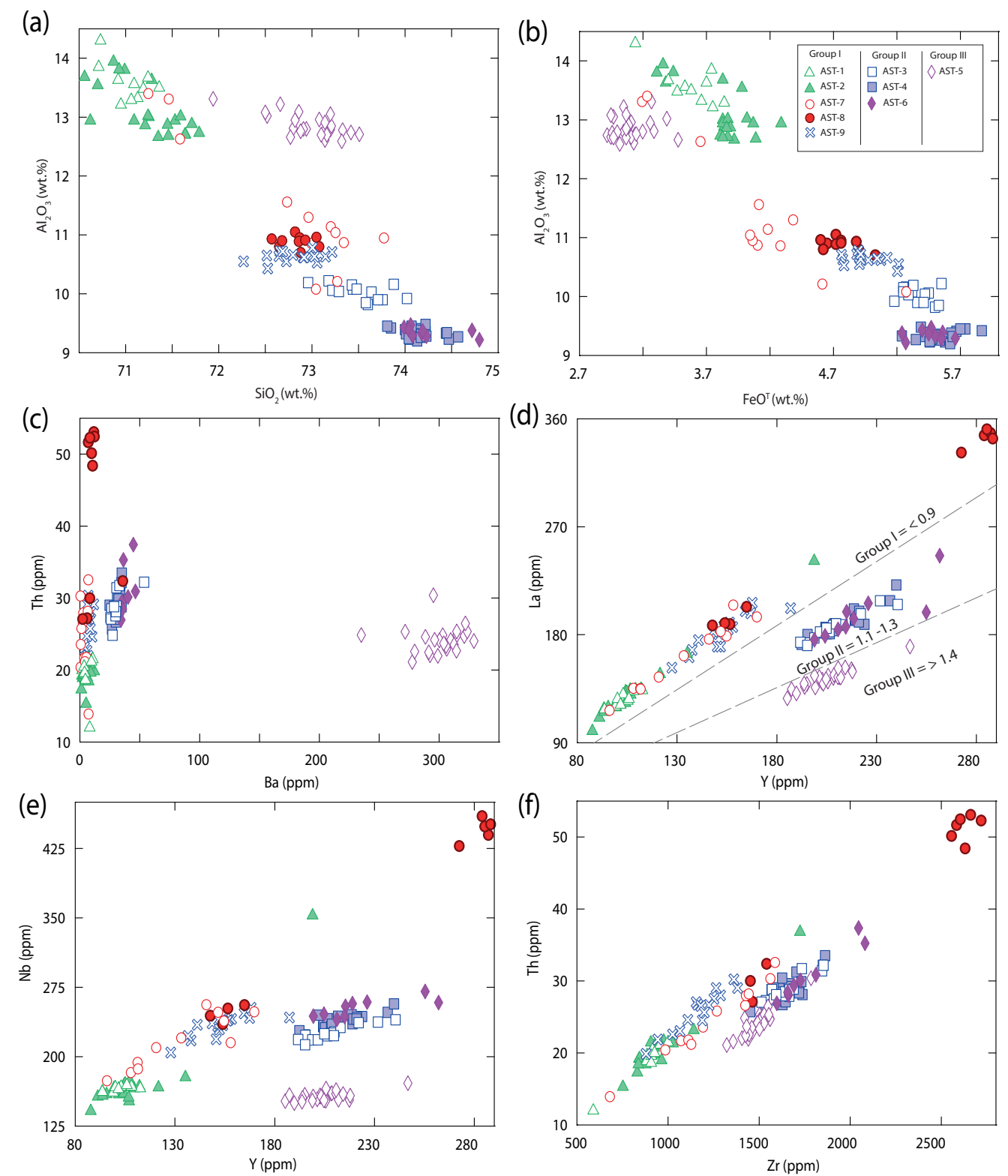

Figure 6.1: Major and trace element composition of single shards from the Ashenge tephras. Incompatible element ratios (d, e, f) divide the Ashenge tephras into three compositional groups. 


\subsubsection{Group I Ashenge tephras: AST-1; 2; 7; 8 \& 9, Y/La $\approx 0.6-0.9$}

The Group I tephras have a wide range of ages $(\sim 15.30-\sim 0.3$ cal. ka BP $)$ and tephras of this composition are not recorded in the Ashenge sediments between $\sim 6.2-\sim 5.0 \mathrm{cal}$. ka BP. The younger and older Group I tephras can be distinguished between: AST-1 and AST-2, contain lower $\mathrm{SiO}_{2}$ and $\mathrm{FeO}^{T}$ concentrations and higher $\mathrm{Al}_{2} \mathrm{O}_{3}$ concentrations than the older AST- 8 and AST-9 (Table 6.1, Fig. 6.1a,b). AST-8 glass shards are compositionally bimodal; one population has a similar composition to other Group I tephras whilst those in the second population are more evolved, containing glass shards with comparatively higher Y, Zr, La and Th concentrations (Fig. 6.1d, e, f). The first tephra recorded after the hiatus in the lake record, AST-7, contains glass shards which cannot be compositionally distinguished from other Group I Ashenge tephra glass shards.

\subsubsection{Group II Ashenge tephras: AST-3; 4 \& 6, Y/La $\approx 1.1$ - 1.3}

Group II Ashenge tephra glass shards (AST-3, 4 and 6) are restricted to the mid-Holocene $(\sim 7.5-\sim 5.0$ cal. ka BP) sediments. Their glass shards have higher Y/La ratios and contain higher Ba concentrations than Group I tephras (Table 6.1, Fig. 6.1c,d). Group II tephra glass shards contain broadly higher $\mathrm{Zr} / \mathrm{Th}$ ratios $(\approx 42.3-61.8)$ when compared to Group I tephra glass shards (Fig. 6.1f). Glass shards in Group II tephras contain the highest $\mathrm{SiO}_{2}$ and $\mathrm{FeO}^{T}$ and the lowest $\mathrm{Al}_{2} \mathrm{O}_{3}$ concentrations when compared with other Ashenge tephras (Table 6.1, Fig. 6.1a, b).

The Group II Ashenge tephras have differing glass shard compositions. Glass shards in AST-3 contain lower $\mathrm{SiO}_{2}$ and higher $\mathrm{Al}_{2} \mathrm{O}_{3}$ concentrations than AST-4 and AST-6 (Table 6.1, Fig. 6.1a, b). 


\subsubsection{Group III Ashenge tephras:, AST-5, Y/La $\approx 1.4-1.5$}

AST-5 ( 7.2- 6.4 cal. ka BP) has a distinct composition when compared with all other Ashenge tephras and is the sole member of Group III. Glass shards in AST-5 have the highest Y/La and Ba concentrations amongst the Ashenge tephras (Table 6.1, Fig. 6.1c,e). Group III tephra shards have the highest $\mathrm{Zr} / \mathrm{Th}$ ratios $(\approx 57.0-65.2)$ of the other Ashenge tephras. Plots of $\mathrm{SiO}_{2}$ against $\mathrm{Al}_{2} \mathrm{O}_{3}$ and $\mathrm{FeO}^{T}$ (Fig. 6.1a, b) concentrations in the Ashenge glass shards show that AST-5 glass shards have distinct major element ratios when compared with other Ashenge glass shards.

\subsubsection{The Hayk tephras}

The rhyolitic Hayk tephra glass shards separate into five different populations on the basis of their varying $\mathrm{Zr} / \mathrm{Th}$ ratios. These differing ratios may suggest that the Hayk tephras are derived from five different centres and the composition of these tephras is explored in detail below in relation to these groupings.

\subsubsection{Group I Hayk tephras: HT-2 \& 4, Zr/Th $\approx 30.4$ - 37.9}

Glass shards in Group I tephras (HT-2 and HT-4) are the youngest tephras $(\sim 3.6-\sim 2.5$ cal. ka BP $)$ in the Hayk core to have been analysed and have the differing $\mathrm{Zr} / \mathrm{Th}$ ratios to older Hayk glass shards.

Group I tephra glass shards contain lower $\mathrm{FeO}^{T}$ concentrations than Hayk Group IV and higher $\mathrm{FeO}^{T}$ concentrations than Hayk Group II, III and V glass shards. Glass shards in the Group I tephras are depleted in $\mathrm{Y}, \mathrm{Nb}, \mathrm{La}$ and $\mathrm{Th}$ relative to glass shards in all other Hayk tephras. Glass shards in Group I tephras contain higher Ba concentrations than Group IV and V glass shards and lower Ba concentrations than Group II and III tephra glass shards. 
HT-2 and HT-4 tephras cannot be distinguished compositionally; although HT-2 glass shards contain broadly higher Y concentrations than HT-4.

\subsubsection{Group II Hayk tephras: HT-5, $\mathrm{Zr} / \mathrm{Th} \approx 18.9$ - 23.2}

The late-Holocene HT-5 $(\sim 3.9-\sim 2.9$ cal. ka BP $)$ is the sole tephra member of Group II, with a distinct $\mathrm{Zr} / \mathrm{Th}$ ratio to glass shards in other Hayk tephras. Glass shards in this tephra are distinguished from other Hayk tephras on the basis of their higher Ba concentrations. HT-5 and HT-6 glass shards have broadly lower Y/La ratios $(\approx 0.8-0.9)$ when compared with other Hayk tephras $(\approx 0.9-1.2)$. However, HT-5 contains higher Y, Zr, La and Ba concentrations than HT-6 glass shards.

\subsubsection{Group III Hayk tephras: HT-6, Zr/Th $\approx 15.1$ - 16.9}

HT-6 (4.0 - 3.2 cal. ka BP) is the only tephra comprising Group III; its glass shards in this tephra contain distinctly lower $\mathrm{Zr}$ concentrations than all other Hayk tephras.

\subsubsection{Group IV Hayk tephras: HT-7 \& 12, Zr/Th $\approx 55.1$ - 65.7}

Group IV Hayk tephras (HT-7 and HT-12) are easily distinguished from other Hayk tephras, containing higher $\mathrm{FeO}^{T}$ and $\mathrm{Zr}$ and lower $\mathrm{Al}_{2} \mathrm{O}_{3}$ than other Hayk tephras (Table 6.2, Fig. 6.2b, f). Group IV tephras have the widest ranges of ages $(\sim 13.0-\sim 3.8$ cal. ka BP) when compared with all other tephra groups recorded in the Hayk sediments.

HT-7 contains higher $\mathrm{Zr}$, La and Th and lower $\mathrm{Al}_{2} \mathrm{O}_{3}$ and $\mathrm{Ba}$ when compared with glass shards in HT-12, the oldest tephra identified in the Hayk sediments (Fig. 6.2a, d, f). 


\subsubsection{Group V Hayk tephras: HT-9 \& 10, Zr/Th $\approx 11.5-14.2$}

Group V tephras (HT-9 and HT-10) are restricted to the early Holocene ( $11.0-\sim 8.4$ cal. yr BP) section of the Hayk sediments. Their glass shards have distinct $\mathrm{Zr} / \mathrm{Th}$ ratios when compared with other Hayk tephra glass shards (Table 6.2, Fig. 6.2f). Glass shards in these tephras are more enriched in Th when compared with other Hayk tephras (Fig. 6.2f).

Glass shards in HT-9 can be compositionally distinguished from those in the older HT-10 tephra. Glass shards in HT-9 contain higher Zr, Nb, La and Th than HT-10 (Fig. 6.2c, d, e, f). 


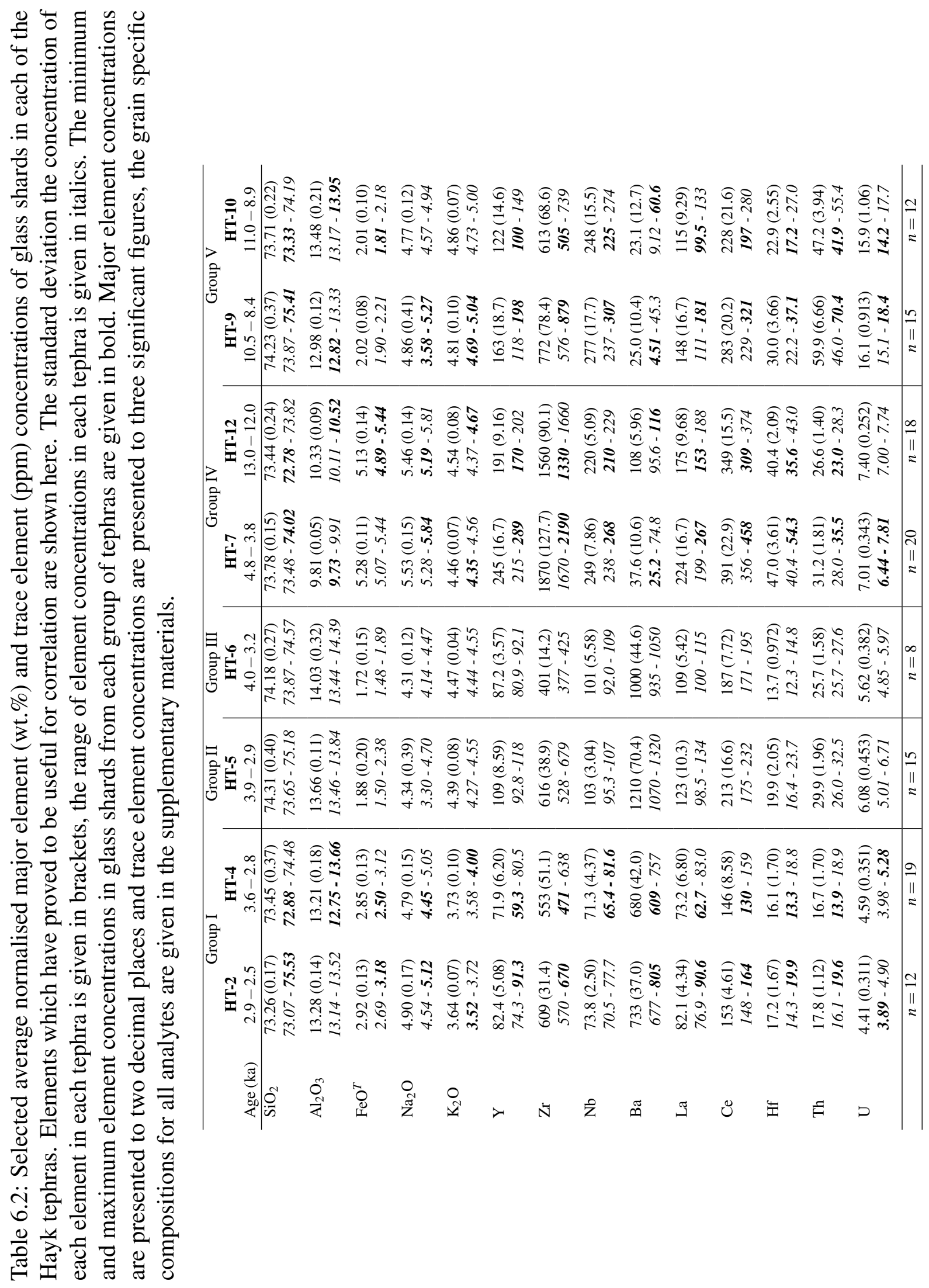


(a) 145

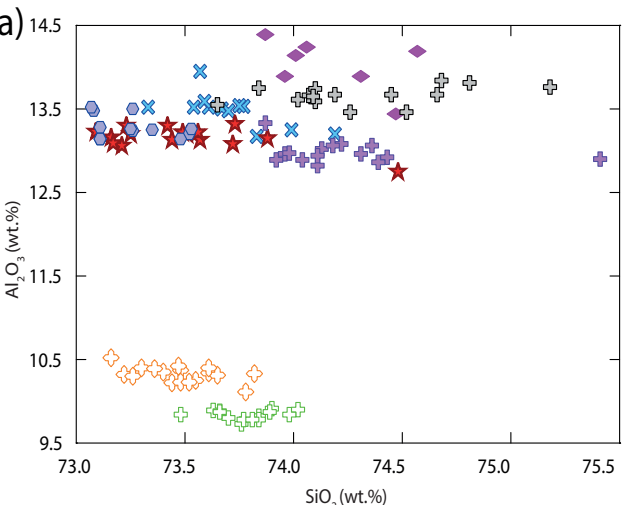

(c)

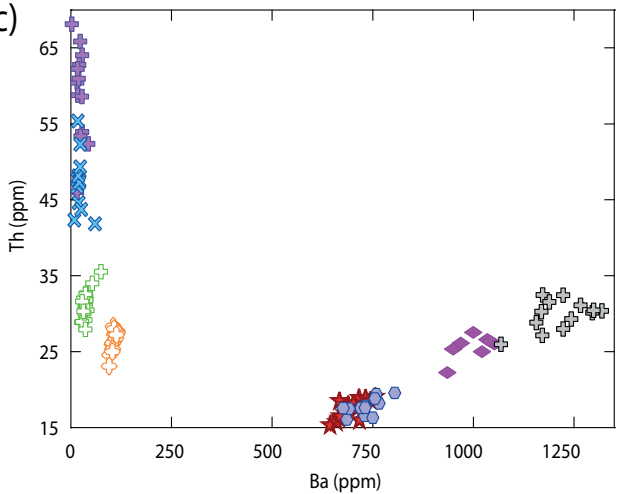

(e)

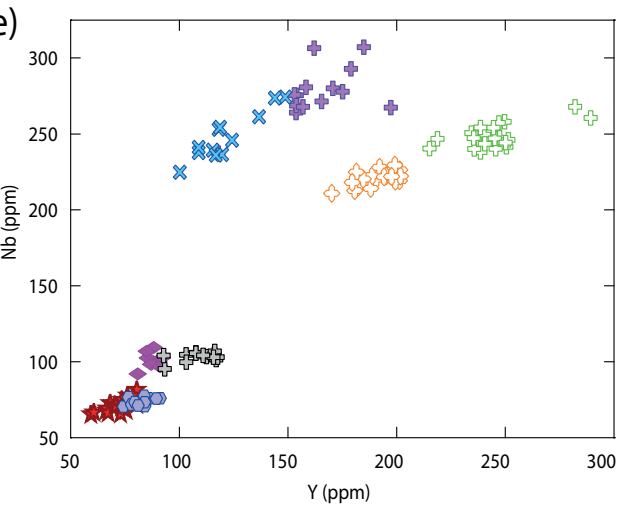

(b)

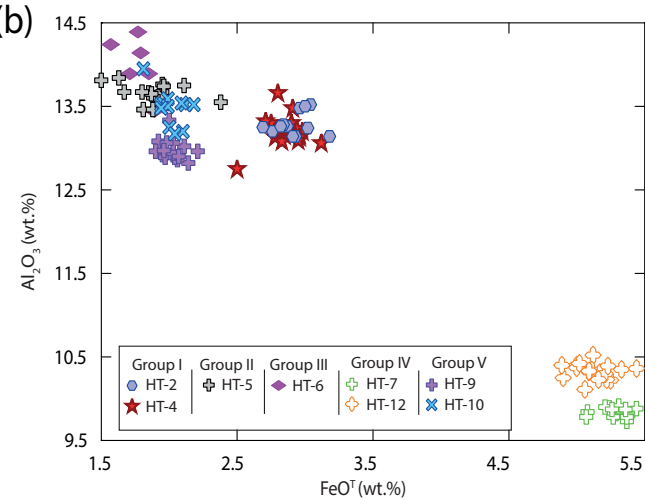

(d)

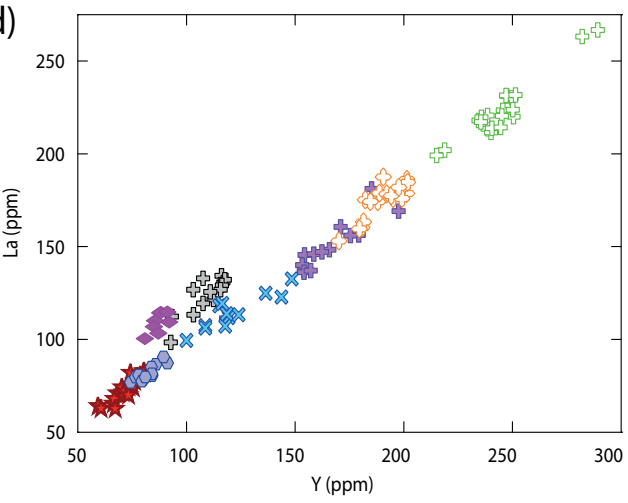

(f)

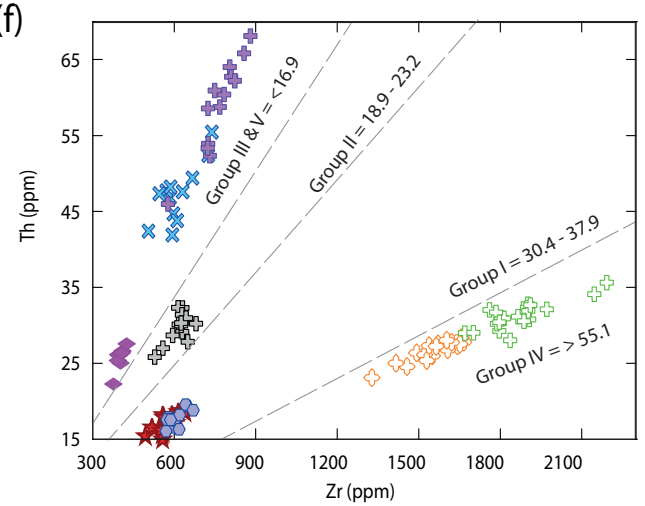

Figure 6.2: Major and trace element composition of single shards from the Hayk tephras. Barium/Th and $\mathrm{Zr} / \mathrm{Th}$ ratios $(\mathrm{c}, \mathrm{f})$ divide the Hayk tephras into five compositional groups. 


\subsection{Discussion}

\subsubsection{Tephra correlations between Lake Ashenge and Hayk}

The major and trace element composition of the Ashenge and Hayk tephra glass shards is compared in Figs. 6.3 and 6.4 to test whether there are potential tephra correlations between the archives. For the majority of tephra deposits in the Ashenge and Hayk cores, the major and trace element compositions of their component glass shards are distinct. Nonetheless, some tephra deposits within both lakes have glass shards which are compositionally similar.

Hayk Group IV tephras (HT-7 and HT-12) have similar Y/La $(\approx 1.0-1.1)$ and $\mathrm{Zr} / \mathrm{Th}(\approx 55.1-65.7)$ ratios to Ashenge Group II $(\mathrm{Y} / \mathrm{La} \approx 1.1-1.3, \mathrm{Zr} / \mathrm{Th}$ $\approx 53.5-61.8$ ) tephras (AST-3, AST-4 and AST-6) (Fig. 6.3). Bi-plots of the first three principal components from principal component analysis of $\mathrm{Y}, \mathrm{Zr}, \mathrm{Nb}, \mathrm{Ba}$, La and Th concentrations in the Ashenge and Hayk tephra glass shards are shown in Fig.6.13. This demonstrates that there are statistical similarities between the compositions of the Ashenge Group II and Hayk Group IV glass shards.

HT-7 glass shards are compositionally similar to AST-3 (Fig. 6.4). However, HT-7 is also more evolved than AST-3, containing higher concentrations of $\mathrm{SiO}_{2}$ and incompatible trace elements and lower concentrations of $\mathrm{Al}_{2} \mathrm{O}_{3}$ than AST-3. Furthermore, HT-7 $(\sim 4.8-\sim 3.8$ cal. ka BP) is too young to correlate with AST-3 ( 5.6- 5.0 cal. ka BP). This is consistent with HT-7 and AST-3 being produced by two separate eruptions from the same source, with a time interval between allowing fractional crystallisation of feldspar and ilmenite from the source magma chamber and the subsequent eruption of the more evolved HT-7. Glass shards in HT-12 (Hayk Group IV) have similar incompatible element ratios to the Ashenge Group II tephras. However glass shards in HT-12 are enriched in 
$\mathrm{Ba}$ (Fig. 6.3c) relative to AST-3, 4 and 6 and HT-12 is too old $(13.0-12.0 \mathrm{cal}$. ka BP) to correlate with the Ashenge Group II tephras.

It is apparent that the lake Ashenge and Hayk sediments record different eruptive events; however, glass shards in Ashenge Group II and Hayk Group IV tephras have similar incompatible element ratios, suggesting that they may be derived from the same source. Furthermore, the new age models presented in this study reveal that, of the 9 tephra layers in Lake Ashenge and 12 in Lake Hayk, there is very little temporal overlap. Tephra HT-8, dated to $\sim 7.8-\sim 5.5 \mathrm{cal}$. ka BP, shows the only possible chronological correlation, overlapping within $95.4 \%$ confidence intervals with tephra layers AST-4, 5, 6, and $7(\sim 7.6-\sim 5.5$ cal. ka BP). Unfortunately, HT-8 could not be analysed, so the potential for correlation here cannot be tested.

Peralkaline rhyolites erupted from the nearby Dabbahu volcano and elsewhere in the Ethiopian Rift are widely reported to have evolved from parental basalts through fractional crystallisation (Barberi et al., 1975; Peccerillo et al., 2007; Field et al., 2013). To test whether AST-3 and HT-7 could have originated from the same magmatic source, fractional crystallisation, using the older AST-3 as the starting composition, was modelled using Petromodeler version 2 (Ersoy, 2013) (Fig. 6.5). A mineral assemblage dominated by orthoclase and plagioclase with minor aenigmatite, aegirine, ilmenite and olivine was used for the model based on CIPW Norm values (Cross et al., 1912) calculated using Igpet06 and mineral assemblages observed in peralkaline rhyolites from the Dabbahu volcano (Field et al., 2013). Fig. 6.5 demonstrates that fractional crystallisation of $30 \%$ $\mathrm{K}$ feldspar, $20 \%$ plagioclase, $5 \%$ aenigmatite, $3 \%$ aegirine, $2 \%$ olivine and 0.5 $\%$ ilmenite could evolve the composition of AST-3 to give a melt with similar Y, $\mathrm{La}, \mathrm{Nb}, \mathrm{Zr}$ and Th concentrations to those in HT-7 glass shards. 
(a)

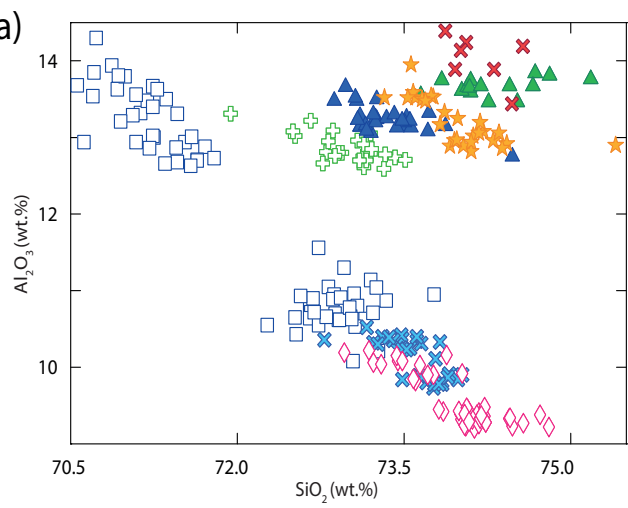

(c)

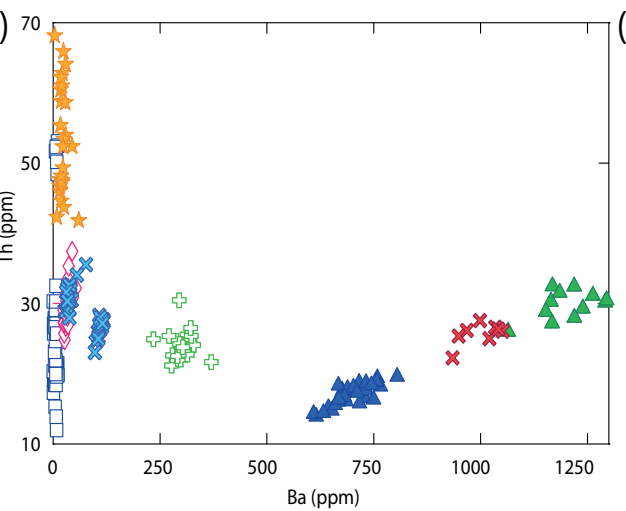

(e)

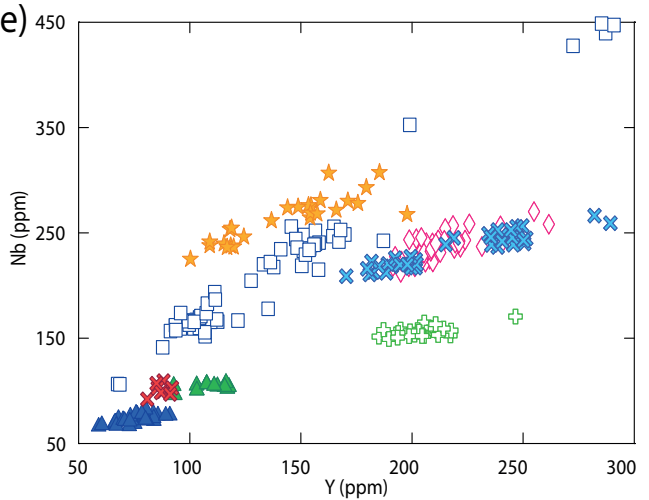

(b)
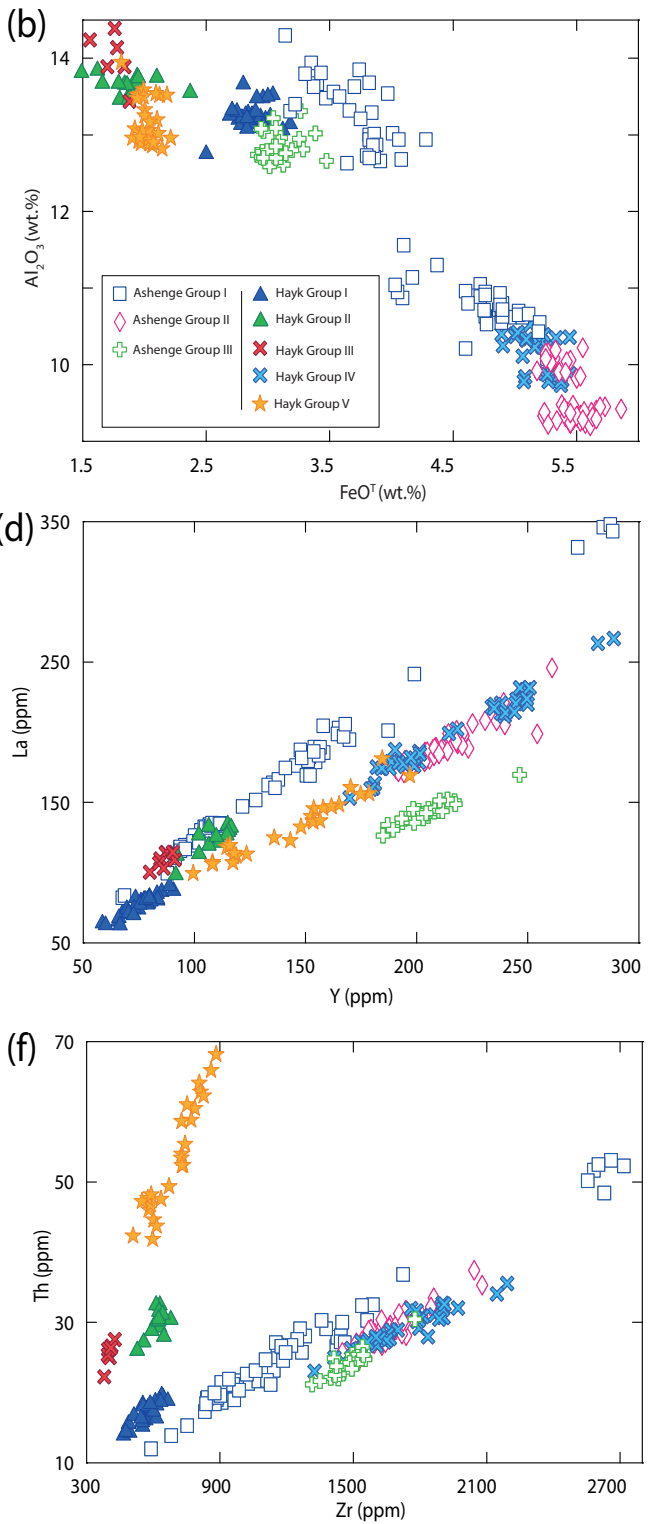

Figure 6.3: Major and trace element bi-plots comparing the composition of the Ashenge and Hayk tephra glass shards 
(a)

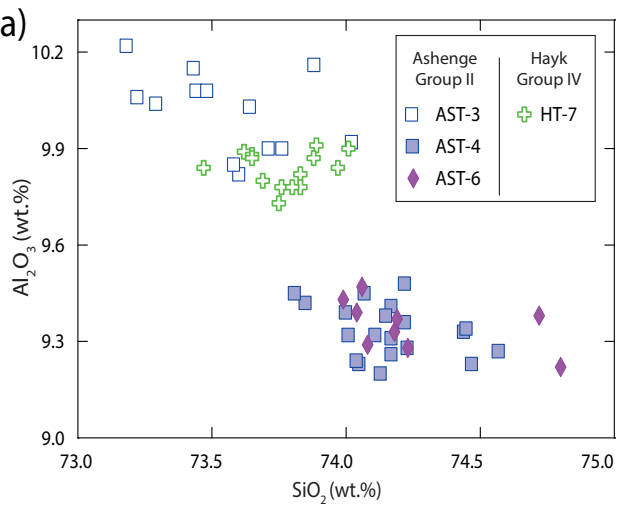

(c)

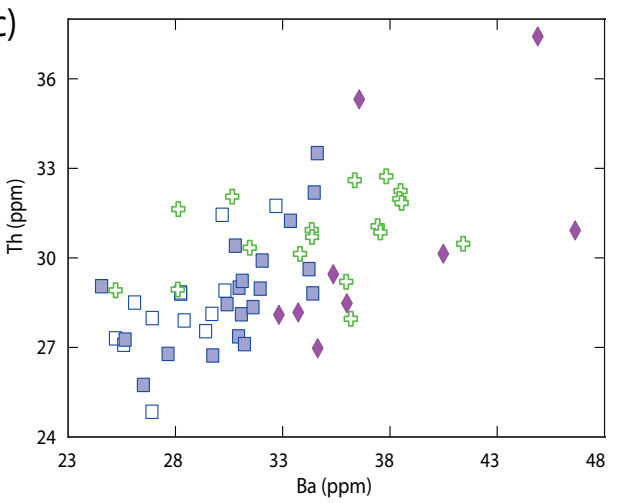

(e)

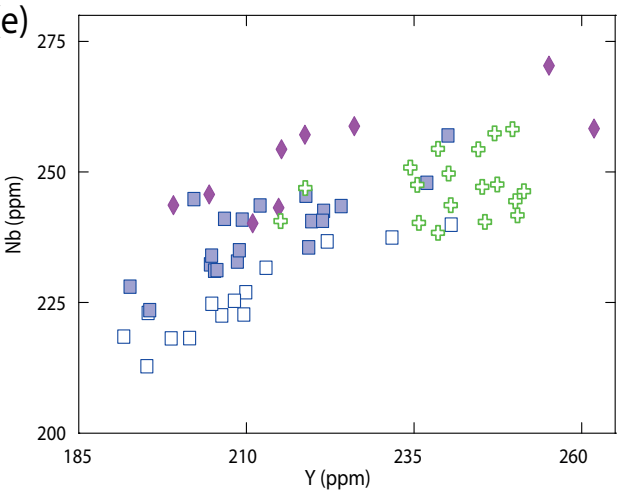

(b)

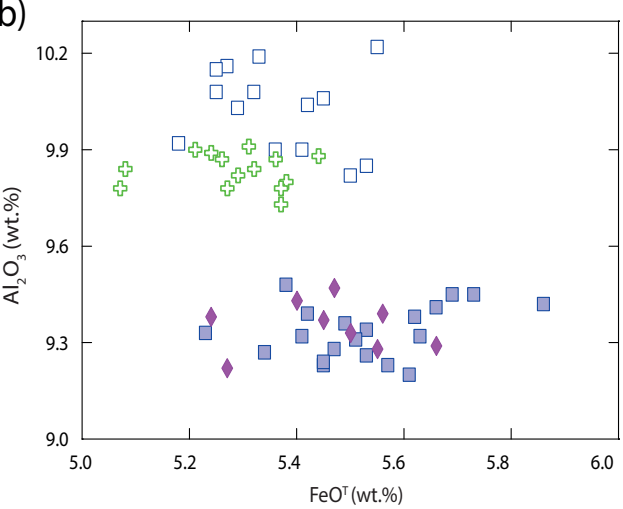

(d)

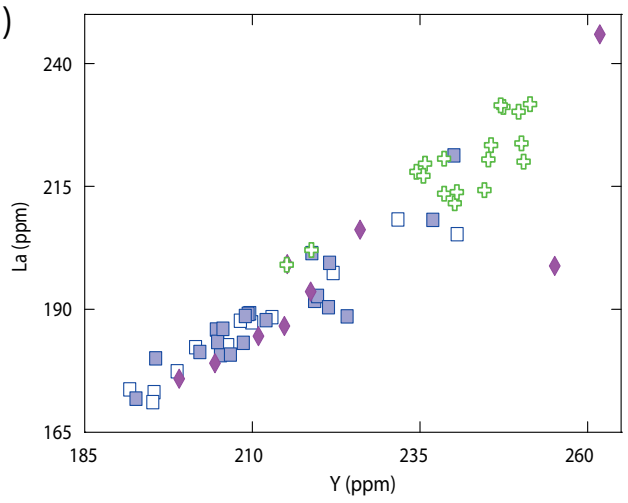

(f)

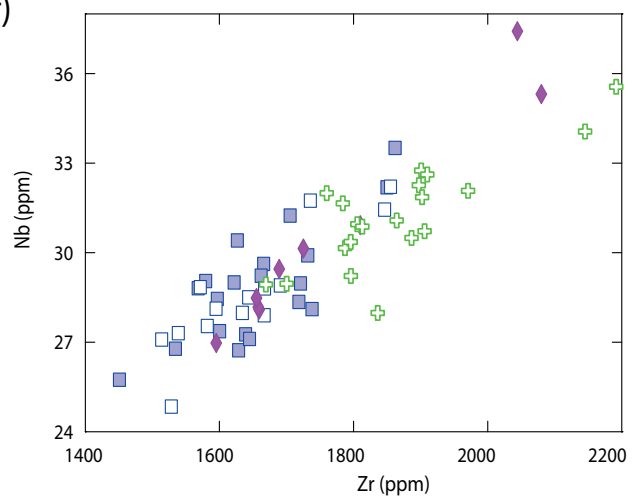

Figure 6.4: Major and trace element bi-plots comparing the composition of HT-7 with Ashenge Group 2 tephras: AST-3; 4; 6. HT-7 has a similar, but more evolved composition than AST-3, containing higher $\mathrm{Y}, \mathrm{Nb}, \mathrm{Zr}, \mathrm{SiO}_{2}, \mathrm{Al}_{2} \mathrm{O}_{3}$ and lower $\mathrm{FeO}^{T}$. 

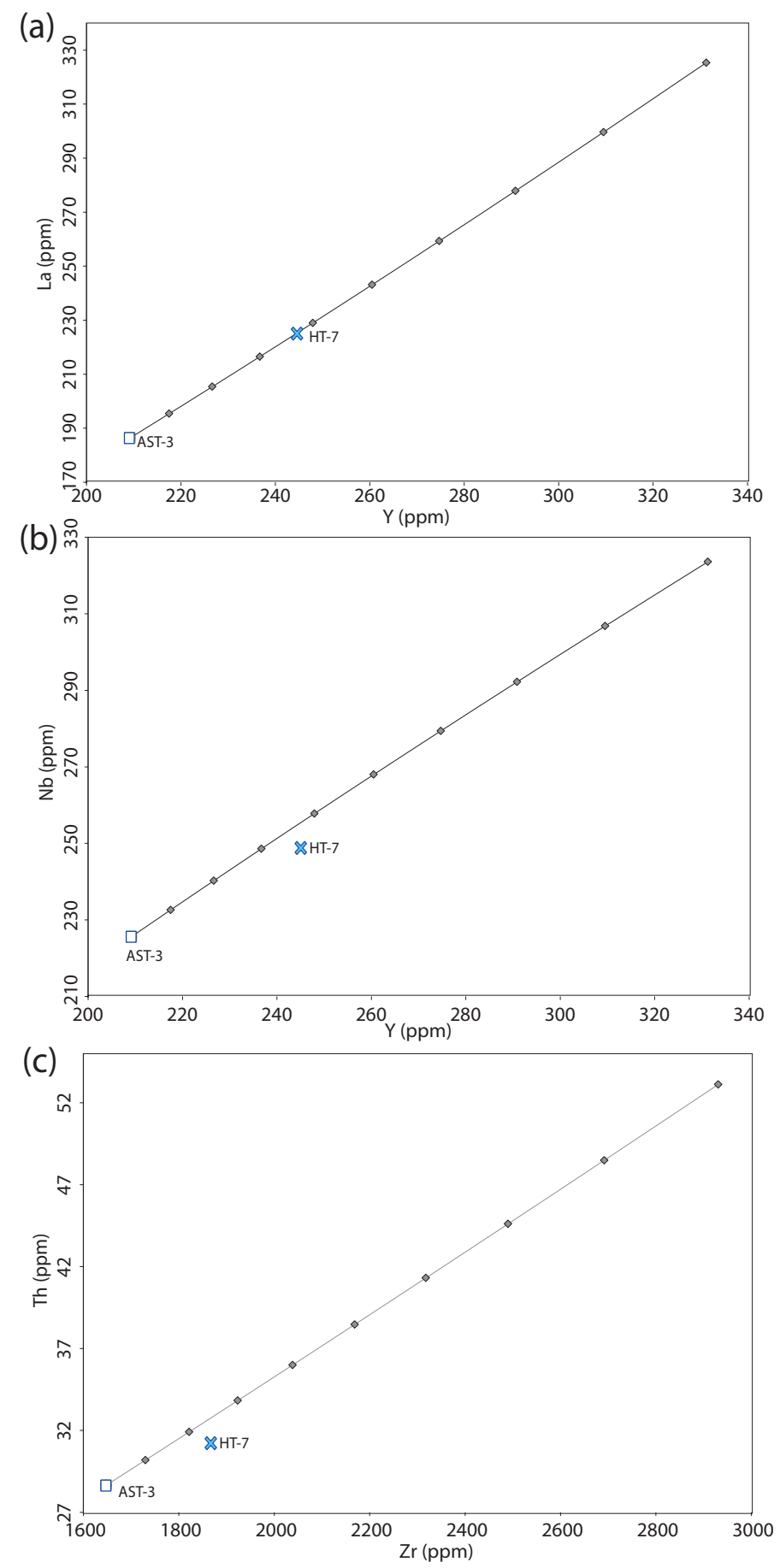

Figure 6.5: Bi-plots showing the average concentrations of selected trace elements in AST-3 and HT-7 tephra glass shards. Lines indicate modelled fractional crystallisation using AST-3 (the older tephra) as a starting composition, with increments indicating $10 \%$ crystallisation. Bulk partition coefficients for trace elements in peralkaline rhyolite melts are from Mahood and Stimac (1990); Pearce (1990) and Ewart and Griffin (1994). 


\subsubsection{The lack of tephra correlations in archives from the Ethiopian Highlands}

The lack of correlations between archives collected from lakes $<140 \mathrm{~km}$ apart in the Ethiopian Highlands may be related to a number of factors, including eruption magnitude, wind speed and direction, and the grain-size of ejecta (Sparks et al., 1997). The wind direction varies seasonally over Ethiopia (Fig. 6.6) and this will affect the dispersal of tephra and consequently the likelihood of it being preserved in a distal record. During the winter, easterly winds may disperse tephra from volcanoes in the Afar towards the Ethiopian Highlands. In the summer the winds reverse, causing tephra produced in the Afar to be predominantly dispersed to the east. However, these are modern wind regimes and may have been different during the late Quaternary.

Lake Ashenge is located to the north of Lake Hayk and this may determine the type and frequency of tephras received; eruptions from the northern Afar may be supplying the tephras in Lake Ashenge, whilst the tephras recorded in Lake Hayk may be derived from the southern Afar. To deposit a tephra from the same event in these different lakes, a change in wind-direction during the eruption may be required (see Fig. 6.6).

The Nabro (Eritrea) 2011 eruption provides a recent analogue for comparison with potential tephra dispersal during the Holocene. The eruption occurred during June, when the predominant wind direction is away from the Afar Rift, towards the west and the Ethiopian Highlands. Tephra deposited by the eruption was observed throughout the Tigray region, including Lake Ashenge, however tephra was not observed in the Lake Hayk area (A. Asrat 2016, pers. comm., 23rd Feb 2016). Lake Hayk $(<300 \mathrm{~km})$ is located farther away from the Nabro volcano than Lake Ashenge $(\sim 250 \mathrm{~km})$ and is therefore less likely to receive 
tephras. Furthermore, Lake Hayk is located on a more southerly axis from Nabro than Ashenge and therefore tephras are unlikely to be transported by the predominantly easterly winds.

Lake Ashenge is located at a high elevation (2500 $\mathrm{m}$ a.s.1.) on the flank of the highlands and close $(<10 \mathrm{~km})$ to the rift margin (see Fig. 6.7). However, Lake Hayk is located within a graben at a comparatively lower elevation (1900 $m$ a.s.1.) and is separated from the Afar Rift to the east by a series of horsts attaining $<2400 \mathrm{~m}$ height. Therefore, Lake Ashenge is more exposed to the Afar Rift to the east and is potentially more likely to receive tephra deposits, this is particularly likely if localised eruptions, that do not attain high eruption columns, produced these tephras. The setting of these lakes may therefore determine the frequency and type of tephra layers deposited in each of the archives.

Lakes Ashenge and Hayk are alkaline lakes $(\mathrm{pH} \sim 8.8-9)$ (Lamb et al., 2007; Marshall et al., 2009). Rhyolitic glass is more soluble in alkali conditions (Mariner and Surdam, 1970) and variations in lake alkalinity through time may therefore determine the preservation of glass shards in the archives. Tephra glass shards observed in the Ashenge and Hayk archives are pristine; however, variable glass preservation during periods of past lake alkalinity may be responsible for the lack of correlations. The glass may have been dissolved or altered by increased alkalinity, and hence the tephras in different archives may no longer compositionally match, limiting the opportunities for correlations. 


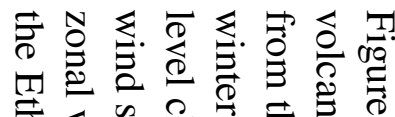

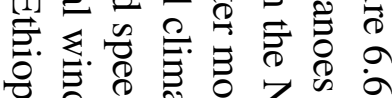
․ㅠㅇㅠ.

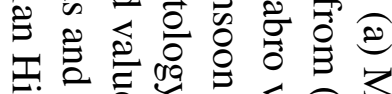

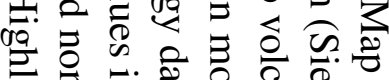

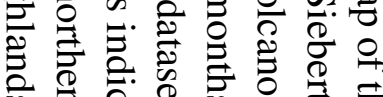

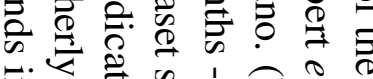

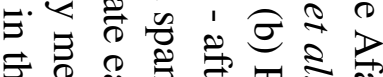
है ब. ¿

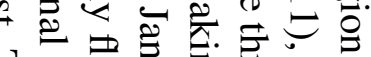

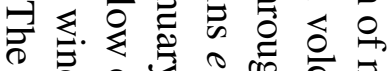

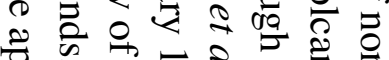

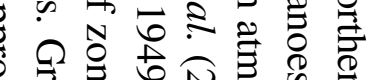
‥

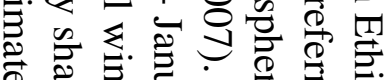

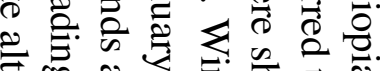

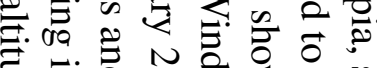
苔志司

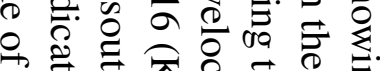

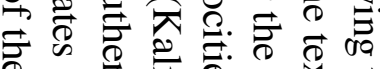

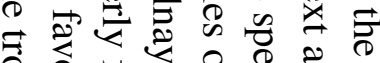

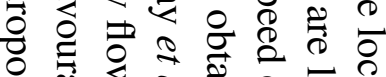

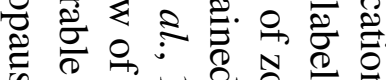
क $3 \leftarrow 20 \cong$

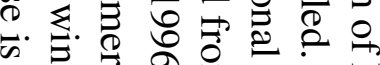

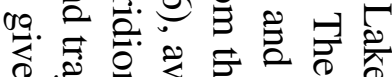
@

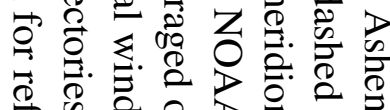

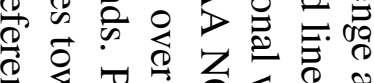

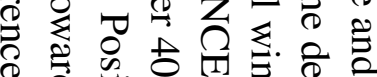

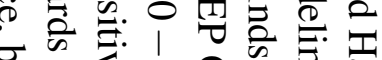
总官它 ¿

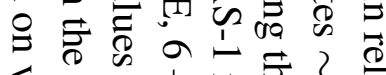

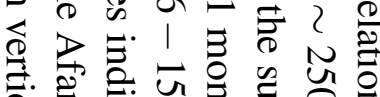

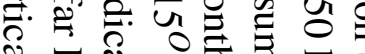

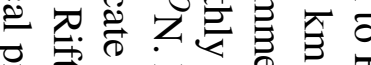

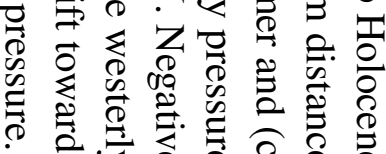
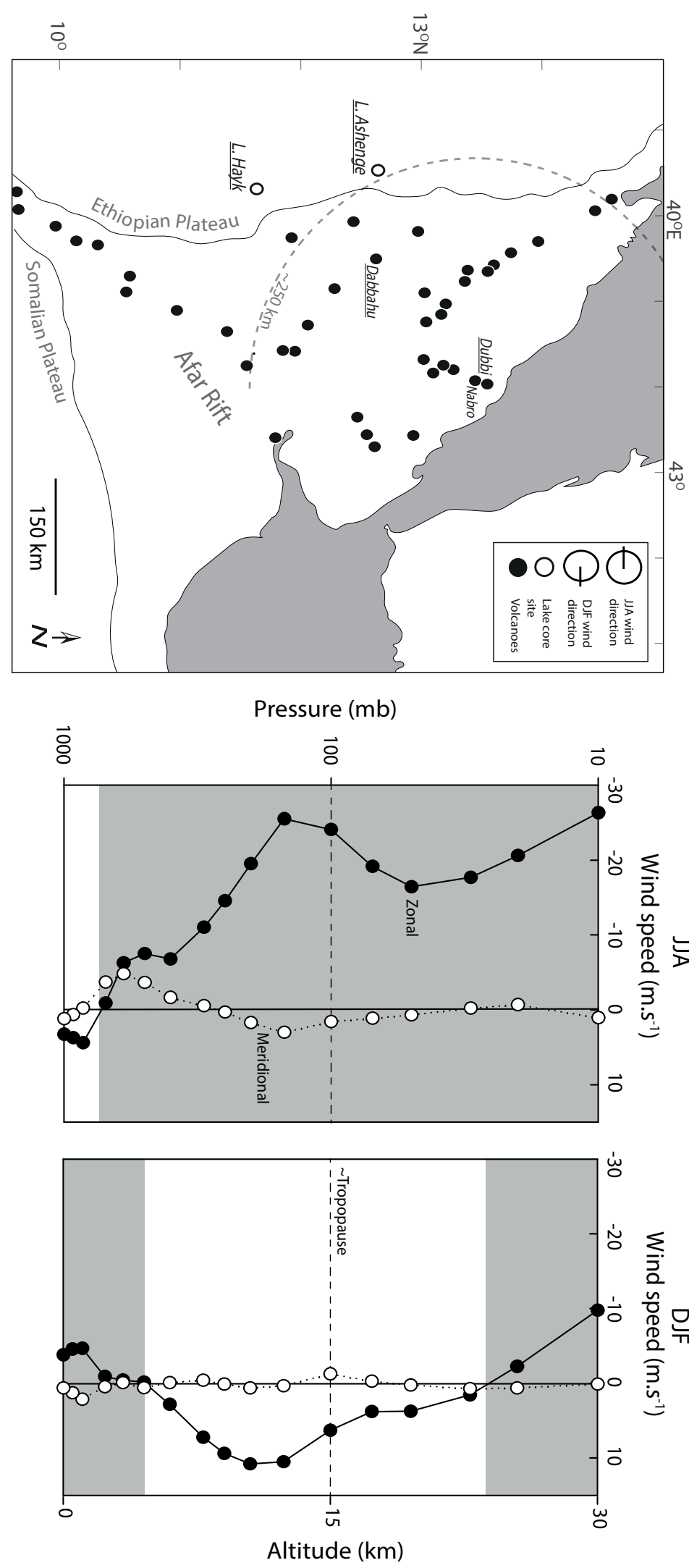


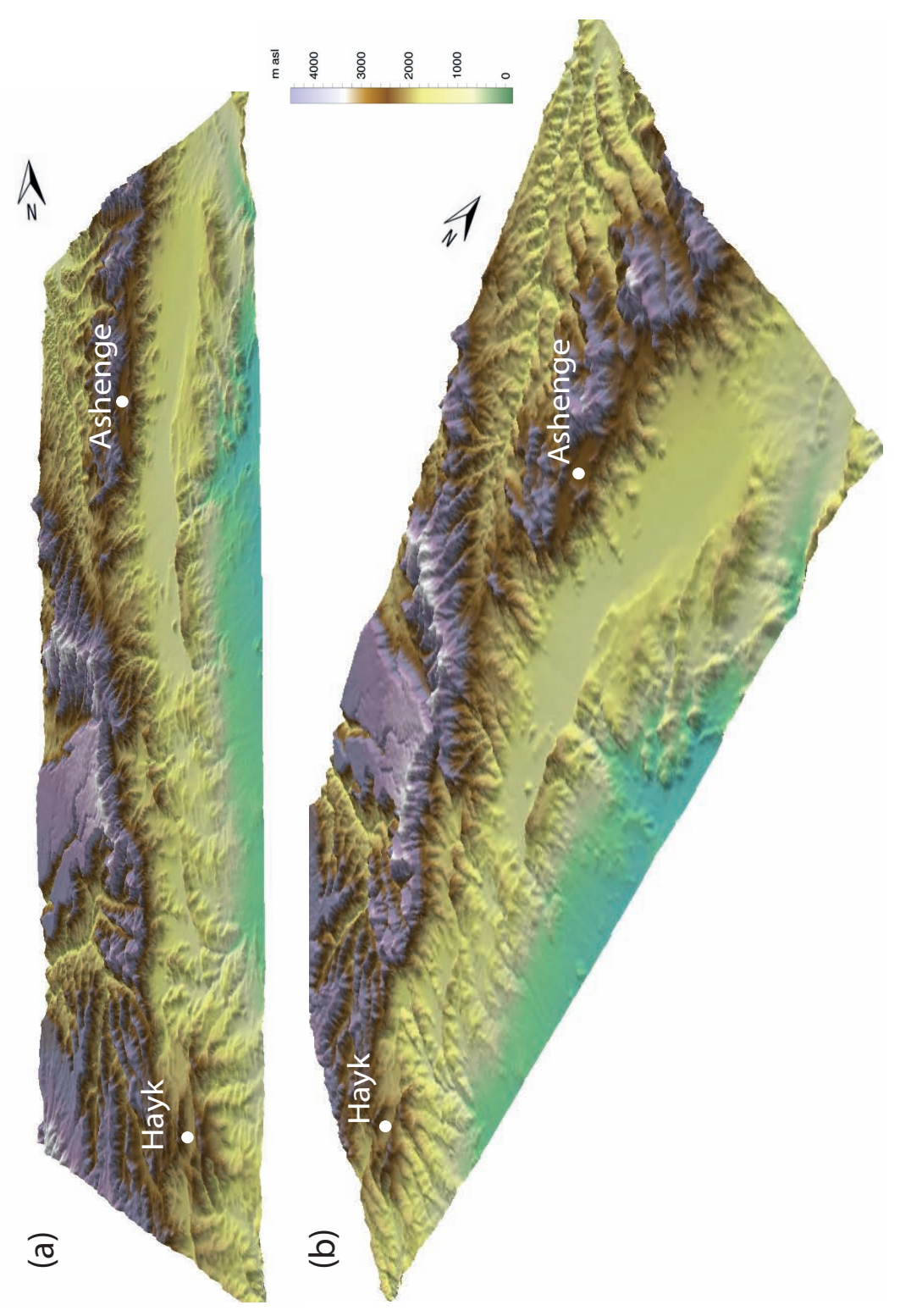

范范

崩焉

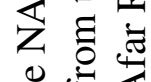

电艺

Ð

을.

ग के d

:

슨 $\frac{2}{3}$

馬

믈 엉

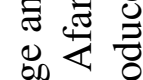

㐫造

क्षे

बे ते

जक को

잌응 즘

正

의

娄

\& $\dot{\therefore}$ के

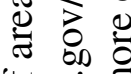

पे $\dot{\circ} \dot{b}$

$\lambda \stackrel{2}{3}$

స्ञ

各 $\frac{0}{2}$

ญ 를

$4 \triangleq$

ঠ

ఏ

.륭

휴워ํ

คิ

$\therefore$ 흥

0 . 0

$\exists$ ?

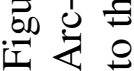




\subsubsection{Eruption tempo and characteristics}

The distribution of visible and crypto-tephras in the Ashenge and Hayk stratigraphies gives an insight into the frequency of past eruptions. Table 5.1 shows Bayesian modelled ages of the tephras recorded in the Ashenge and Hayk archives. Thirteen of the total 21 tephras documented in both archives occur at $\sim 7.5-\sim 1.6$ cal. ka BP; potentially reflecting a peak in explosive volcanism during this period. Tephras are recorded frequently in both archives between $\sim 15.3-\sim 1.6$ cal. ka BP, indicating explosive eruptions in this area occurred at an average of every $\sim 1000$ years during this period. The only recent tephra recorded in the Ashenge and Hayk stratigraphies over the past $1.6 \mathrm{cal}$. ka BP is the $\sim 0.5-\sim 0.3$ cal. ka BP AST-1, in the Ashenge core.

Selected compositional parameters (major and trace element concentrations and incompatible element ratios) from glass shards in separate tephra groups are plotted against their age in Fig. 6.8. Glass shards from each individual tephra in lakes Ashenge and Hayk occupy a wide compositional range. This compositional heterogeneity suggests that these tephras are derived from evolving or compositionally zoned magma chambers. However, multiple contemporaneous eruptions from different sources may also result in compositional differences in glass shards within a tephra layer.

The Ashenge Group I tephras have a wider range of ages $(\sim 15.3-\sim 0.3$ cal. ka BP) than other tephra compositional groups recorded in the archives. The Ashenge Group I tephras may represent intermittent eruptions from a distant caldera active over a long time period. A lack of documented Ashenge Group I tephras at $\sim 16.7-\sim 13.6$ cal. $\mathrm{ka} \mathrm{BP}$ and $\sim 4.8-\sim 0.3$ cal. ka BP are potentially associated with periods of repose. 
Whilst the similar incompatible element ratios of the Ashenge Group I tephras suggests these tephras have a co-magmatic origin, their tephra glass shards become depleted in $\mathrm{SiO}_{2}, \mathrm{FeO}^{T}$ and $\mathrm{Y}$ and enriched in $\mathrm{Al}_{2} \mathrm{O}_{3}$ concentrations through time. This trend is the opposite to that which would be expected for simple crystal fractionation of a feldspar dominated assemblage. To constrain the petrogenesis of these tephras, detailed mapping and sampling of the potential source volcanoes is required. However, it is apparent that other processes (potentially recharge and/or assimilation) are involved in their petrogenesis.

The fractional crystallisation of Group I Ashenge tephras is modelled in Fig. 6.9, using the oldest tephra (AST-9) as the starting melt composition. Figure 6.9 reiterates that the evolution of the Ashenge Group I tephras is complex. Crystallisation of a mineral assemblage comprised of orthoclase (50 $\%)$, plagioclase $(15 \%)$, aenigmatite $(5 \%)$, clinopyroxene $(5 \%)$, olivine $(2 \%)$ and ilmenite $(0.2 \%)$ will evolve the melt composition from AST-9 towards AST-8. However, it is apparent that fractional crystallisation of this assemblage could not reduce incompatible element concentrations in the melt to subsequently produce AST-7; 2 and 1 compositions.

Other compositional groups (e.g. Hayk Group I and V) recorded in the archives are comprised of eruptions covering relatively short times spans $(<\sim 3$ ka). These tephras are more homogeneous than eruptions depositing the Ashenge Group I tephras, this may be an indication of compositional zoning developing in the magma chambers with relatively longer repose periods. However, the Hayk Group I and V tephra glass shards show enrichment in Y through time when compared to older tephras from the same compositional group. This suggests that the evolution of the Hayk tephras was dominated by fractional crystallisation of feldspar, differing to the Ashenge Group I melt evolution. 
Fractional crystallisation of the Hayk Group I and Hayk Group V tephras is modelled in Figs. 6.10 and 6.11, using the oldest tephras from each group as starting compositions. Crystallisation of orthoclase (50\%), plagioclase (15 $\%)$, aenigmatite $(5 \%)$, clinopyroxene (5\%), olivine (2\%) and ilmenite (1\%) from the Hayk Group I and V melts produces similar compositions to younger tephras from each group. This reinforces the fact that the Hayk Group I and V tephras evolved through crystallisation of a different mineral assemblage to those dominating the evolution of the Ashenge Group I tephras. 

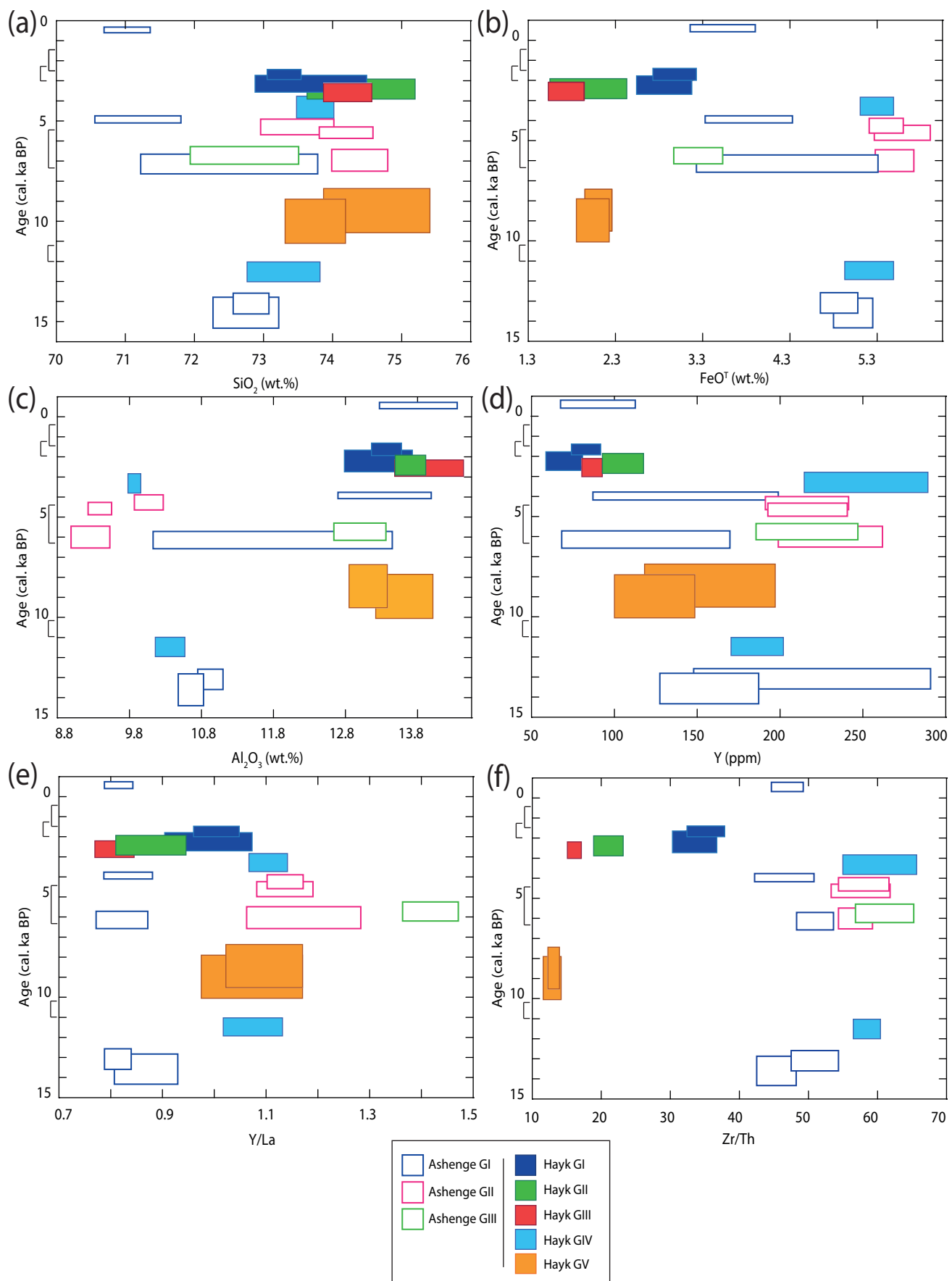

Figure 6.8: Major and trace element concentrations and incompatible element ratios of glass shards in the Ashenge and Hayk tephras plotted against their modelled tephra age. Brackets on the Age axis indicate the age ranges of tephras that were not analysed. 

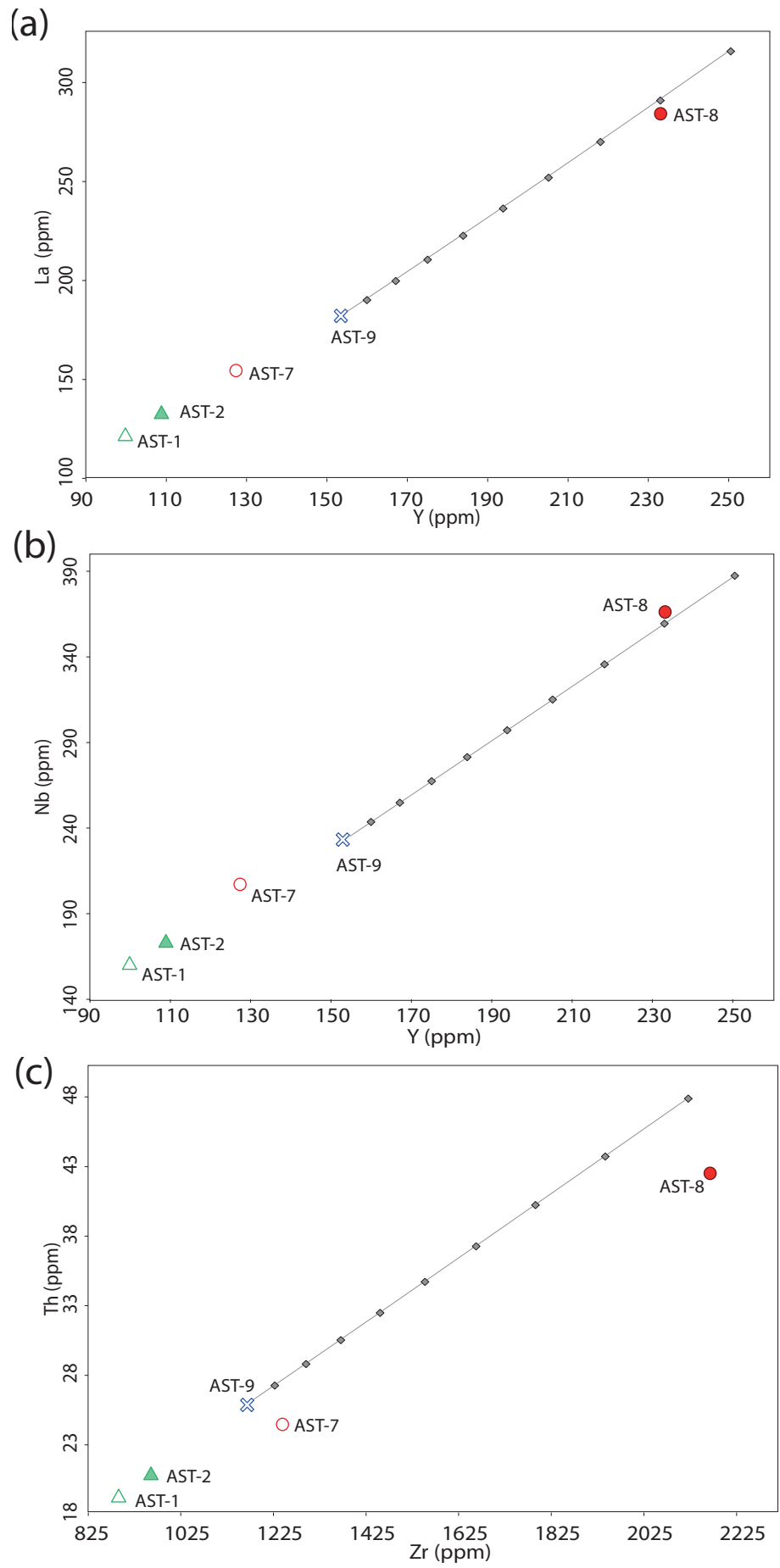

Figure 6.9: Bi-plots showing the average concentrations of selected trace elements in AST-3 and HT-7 tephra glass shards. Lines indicate modelled fractional crystallisation using AST-3 (the older tephra) as a starting composition, with increments indicating $10 \%$ crystallisation. Bulk partition coefficients for trace elements in peralkaline rhyolite melts are from Mahood and Stimac (1990); Pearce (1990) and Ewart and Griffin (1994). 

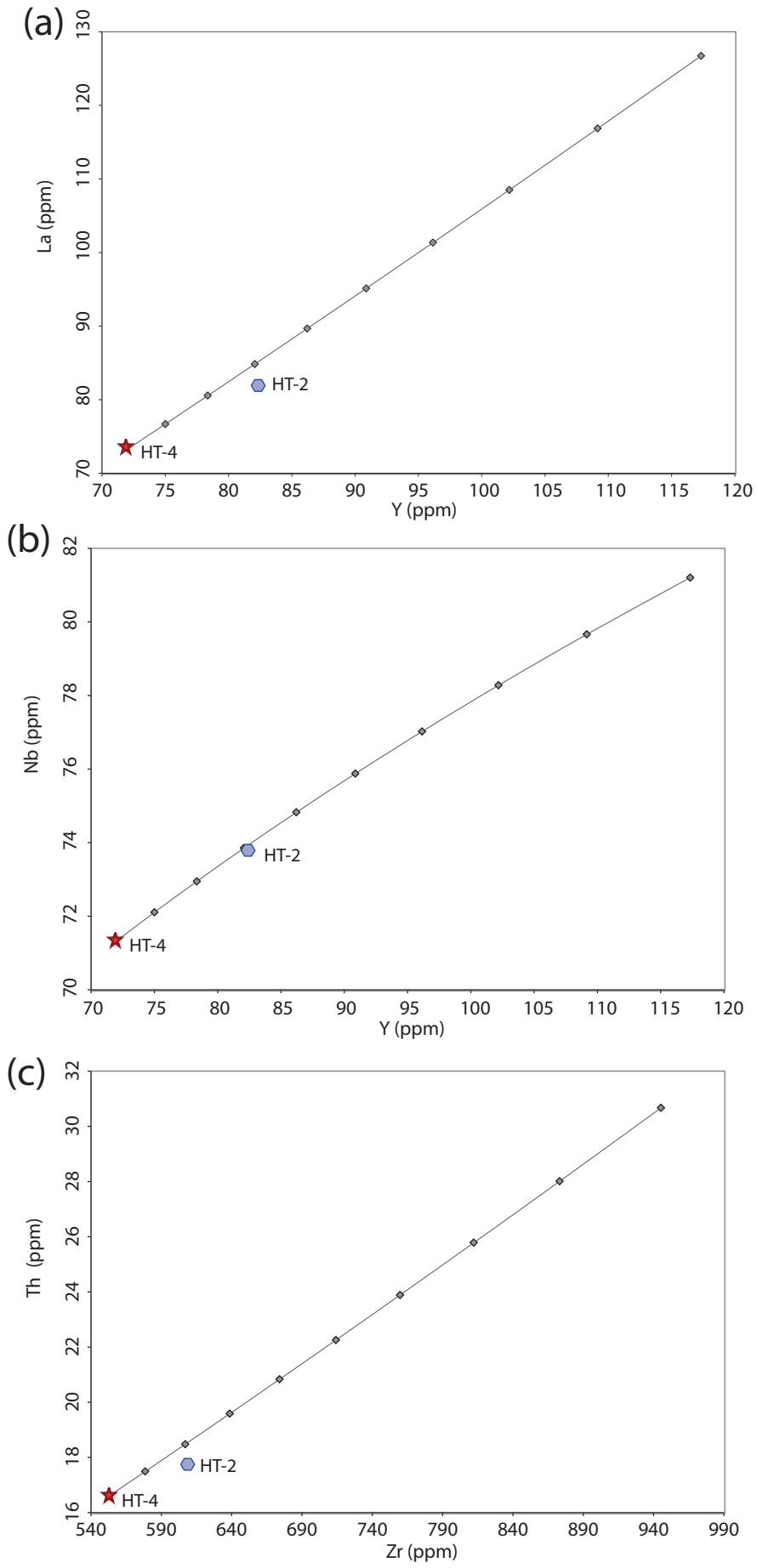

Figure 6.10: Bi-plots showing the average concentrations of selected trace elements in HT-2 and HT-4 tephra glass shards. Lines indicate modelled fractional crystallisation using HT-4 (the older tephra) as a starting composition, with increments indicating $10 \%$ crystallisation. Bulk partition coefficients for trace elements in peralkaline rhyolite melts are from Mahood and Stimac (1990); Pearce (1990) and Ewart and Griffin (1994). 
(a)

(b)
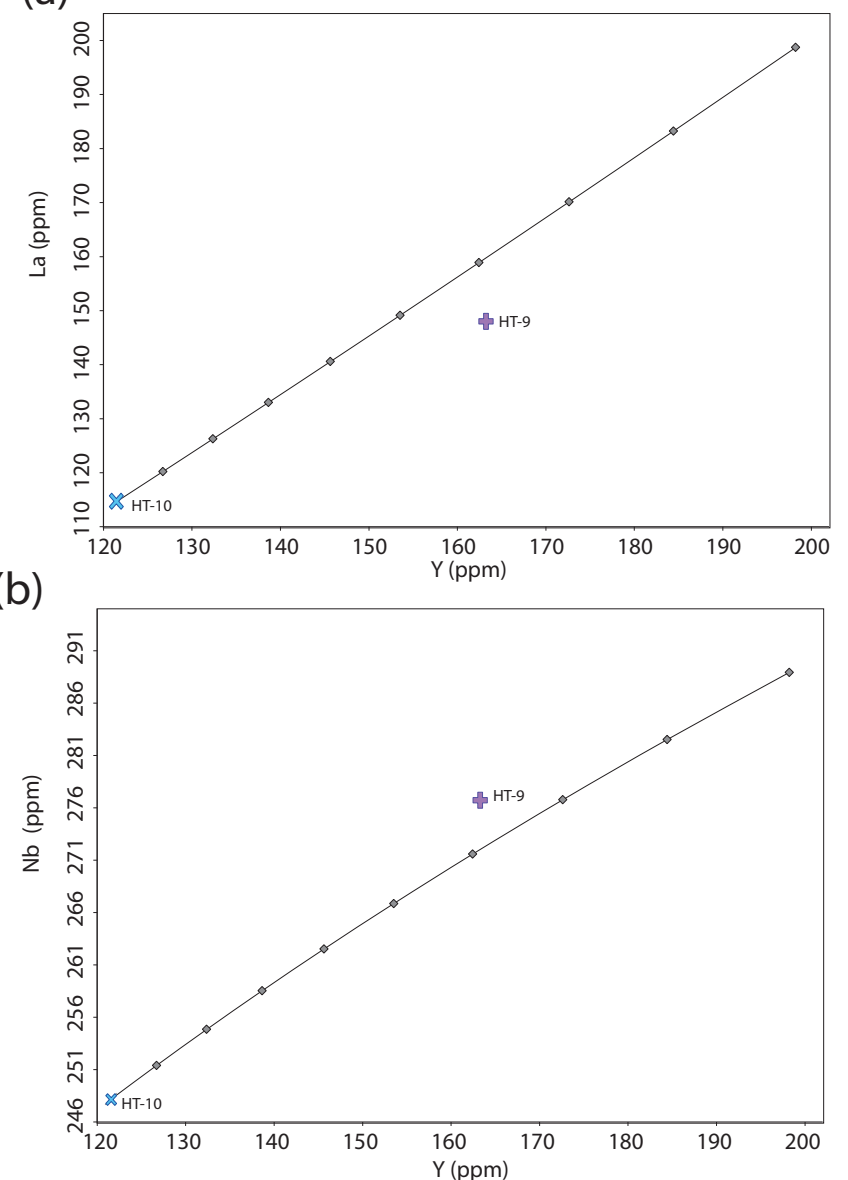

(c)

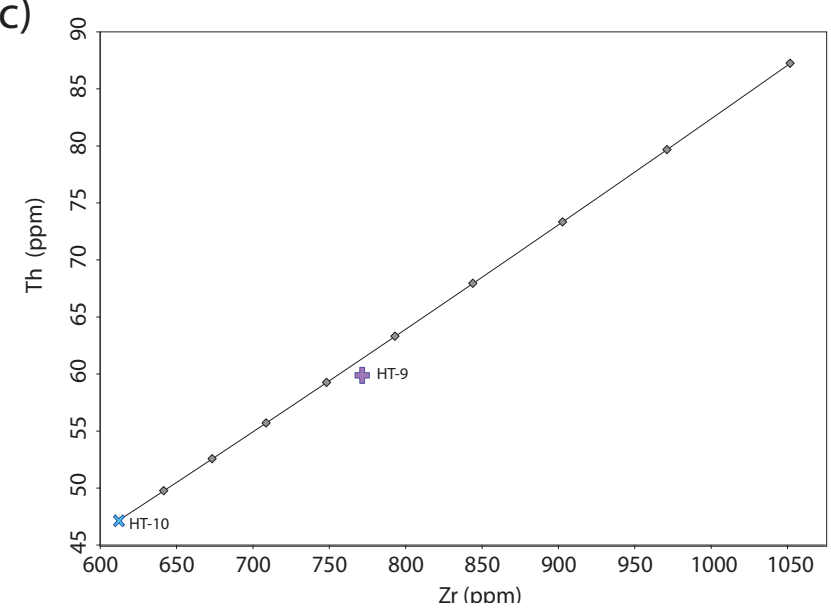

Figure 6.11: Bi-plots showing the average concentrations of selected trace elements in HT-9 and HT-10 tephra glass shards. Lines indicate modelled fractional crystallisation using HT-10 (the older tephra) as a starting composition, with increments indicating $10 \%$ crystallisation. Bulk partition coefficients for trace elements in peralkaline rhyolite melts are from Mahood and Stimac (1990); Pearce (1990) and Ewart and Griffin (1994). 


\subsubsection{Provenance of the Holocene Lake Ashenge and Hayk tephras}

The closest volcanoes to lakes Ashenge and Hayk that are thought to have been active during the Holocene are located to the east in the Afar Rift (Fig. 6.6). Given the lack of correlations between lakes Ashenge and Hayk, it is likely that the tephras recorded in these archives are locally derived.

There is a scarcity of geochemical and chronological data from Holocene volcanic deposits in the Afar Rift. Therefore it is currently not possible to assess correlations with all possible source volcanoes which could have generated tephras deposited in lakes Ashenge and Hayk during the Holocene. The Ashenge and Hayk tephras are compared here with published glass analyses on proximal pumice and obsidians from Dabbahu volcano and new glass analyses on proximal tephra deposits from the Dubbi volcano (Eritrea).

Dabbahu (Boina) (Fig. 6.6) is the closest volcano to Lakes Ashenge and Hayk with published geochemical data. Dabbahu is a Pleistocene - Holocene volcanic massif; its basalt-pantellerite suite having evolved through fractional crystallisation dominated by orthoclase, clinopyroxene and apatite to produce late stage obsidian flows, lava domes and pumice cones at its summit (Barberi et al., 1975; Field et al., 2012). Fission track dates on obsidians from the upper flanks give ages of $\sim 44 \mathrm{ka}$ and $\sim 1.5 \mathrm{ka}$ and a recent eruption (VEI=3) in 2005 deposited tephra over $100 \mathrm{~km}^{2}$ (Barberi et al., 1975; Ayele et al., 2007a; Ferguson et al., 2010).

Glass analyses of proximal pumice and obsidian samples from Dabbahu (Field et al., 2012) are compared with Ashenge and Hayk tephra glass shard analyses in Fig. 6.12. Dabbahu glass contains similar Y/La ratios $(\approx 0.95)$ to some of the Hayk Group I, IV and V tephra glass shards $(\approx 0.9-1.2)$. However, 
Dabbahu glass contains higher $\mathrm{Zr} / \mathrm{Th}$ ratios (> 98.8) than the Ashenge and Hayk tephra glass shards $(<65.7)$. Fig. 6.13 further demonstrates that there is a statistical difference between the composition of the Ashenge and Hayk tephras and the Dabbahu obsidians and pumices. Therefore further sampling and 'sideby-side' analyses of glass from Dabbahu proximal deposits are required to assess the similarity of the incompatible element ratios to those of the Ashenge Group I glass shards.

The uppermost tephra in the Ashenge archive (AST-1, 546 - 321 cal. a BP) is the only historic tephra documented in the Ashenge and Hayk records. The 1861 eruption of Dubbi (Eritrea, $270 \mathrm{~km} \mathrm{NE}$ of Ashenge, Fig. 6.6) is reputed to be Africa's largest historic eruption (VEI=3); dispersing volcanic ash $300 \mathrm{~km}$ to the west on the Ethiopian Plateau (Wiart and Oppenheimer, 2000). A previous eruption (VEI=2) from Dubbi at 1400 AD may also have occurred (Gouin, 1979) and this is comparable to the modelled date of $1404-1629$ AD for AST-1.

Analyses of tephra glass shards from the Dubbi 1861 pyroclastic flow deposits (collected by C. Oppenheimer, University of Cambridge) were analysed as part of this study. The composition of AST-1 glass shards can be broadly compared with those from the 1861 Dubbi tephra, in order to ascertain whether AST-1 was deposited by a possible older eruption from Dubbi ( Fig. 6.12). The AST-1 tephra glass shards have similar $\mathrm{Zr} / \mathrm{Th}$ ratios $(\approx 44.6-49.2)$ to the Dubbi glass shards $(\approx 43.3-52.3)$. However, AST-1 glass shards contain lower $\mathrm{Al}_{2} \mathrm{O}_{3}$ and incompatible element concentrations and higher $\mathrm{FeO}^{T}$ concentrations than the Dubbi 1861 tephra glass shards (Fig. 6.12). Further glass analysis of a wider range of proximal samples from Dubbi is therefore required to investigate the source of AST-1. 
(a)

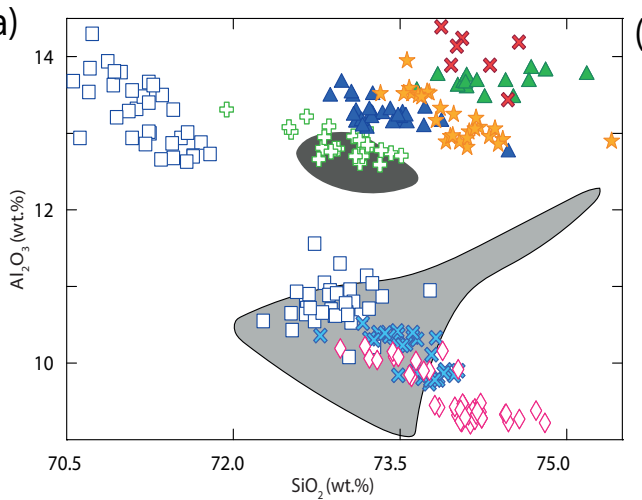

(c)

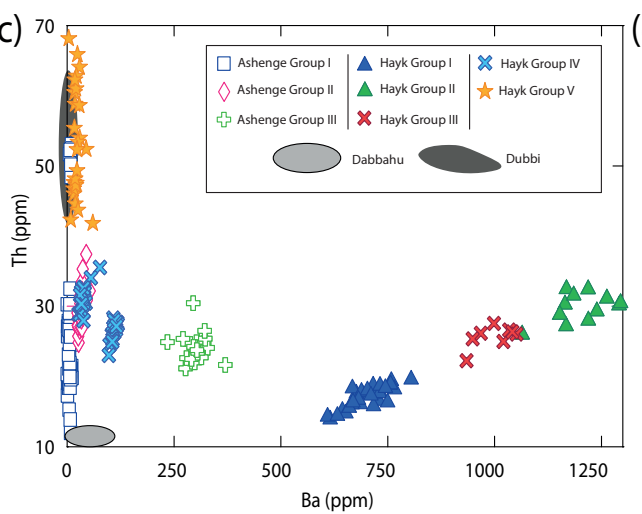

(e)

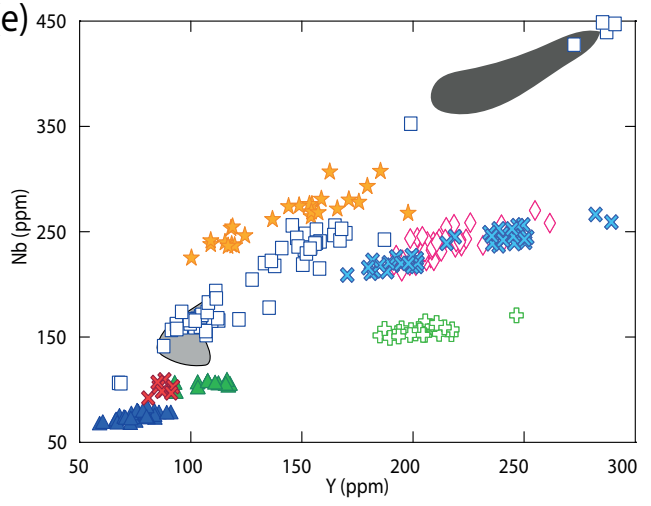

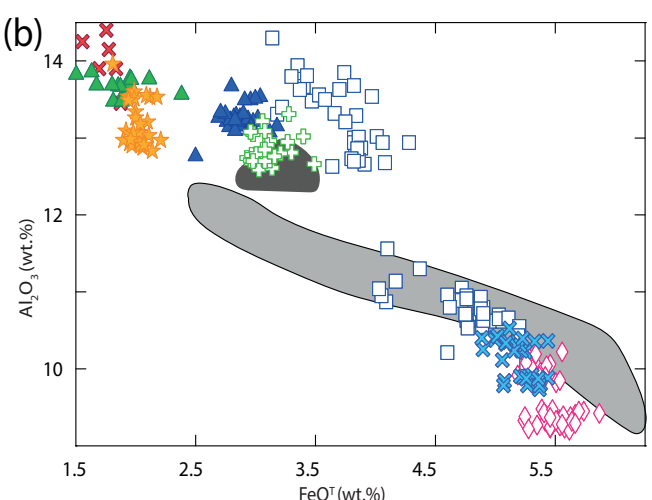
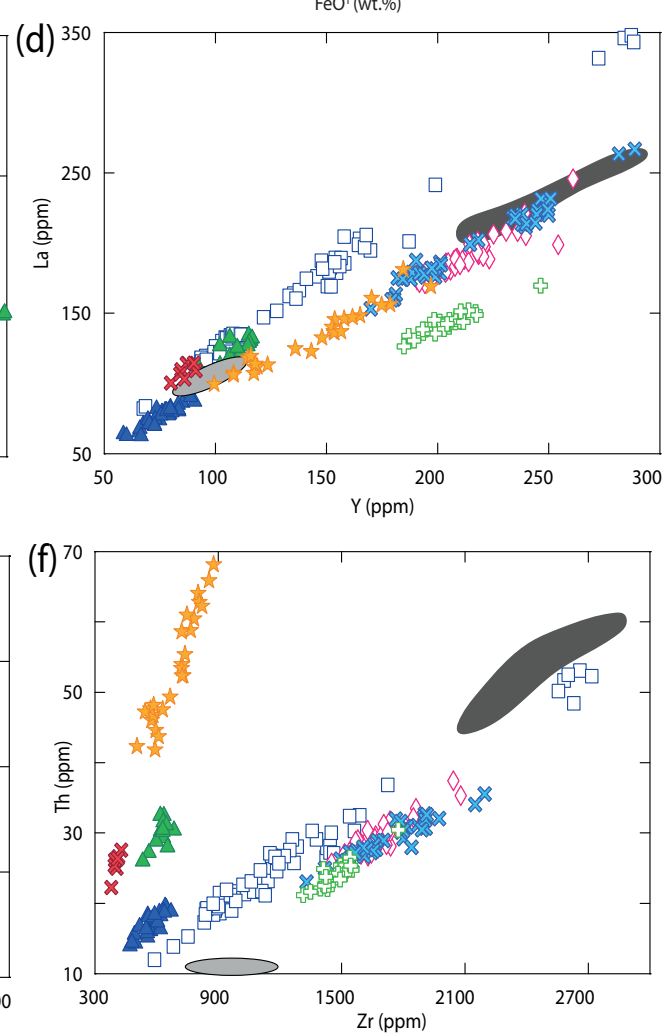

Figure 6.12: Comparison of the composition of Ashenge and Hayk tephras with proximal tephra samples from the Dabbahu and Dubbi volcanoes in the Afar. Glass analyses on pumice and obsidian from Dubbahu are from Field et al. (2012), Dubbi proximal samples were analysed as part of this study. 

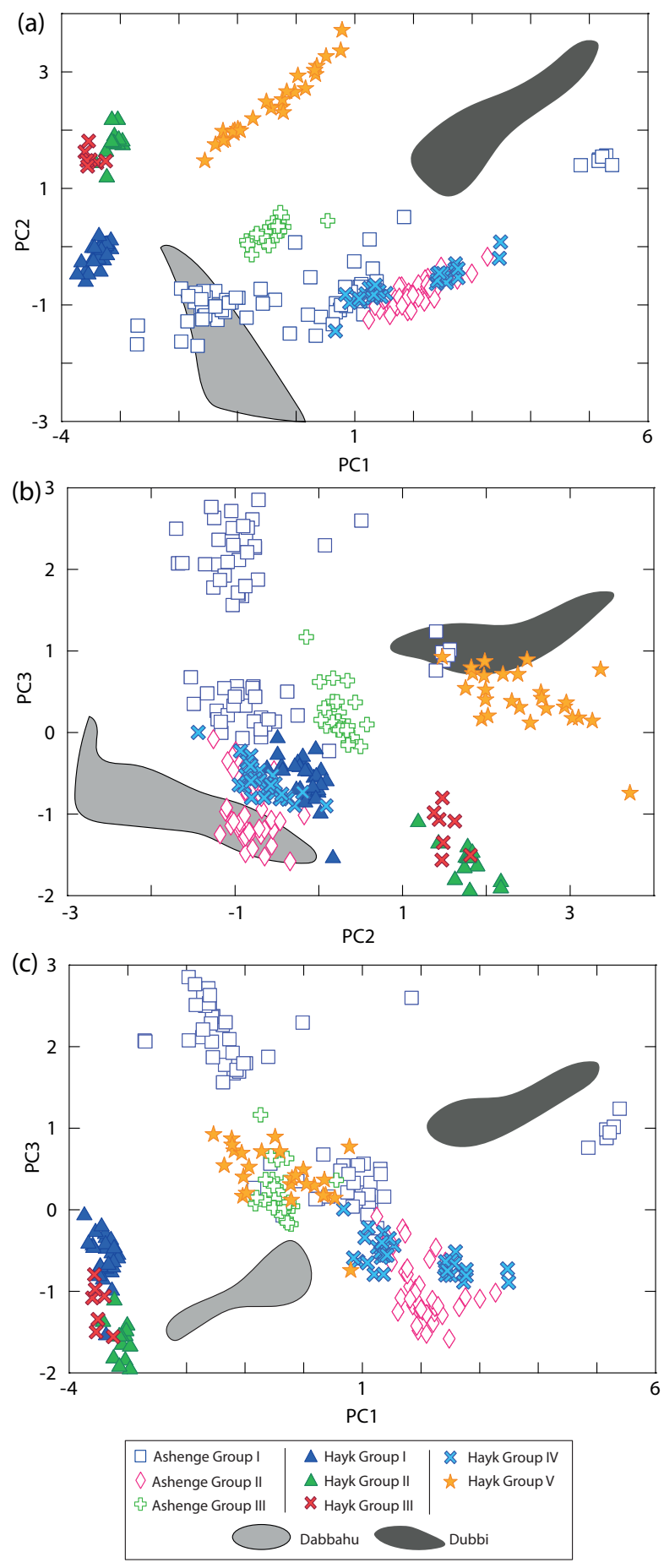

Figure 6.13: Bi plots of the first three principal components from principal component analysis of $\mathrm{SiO}_{2}, \mathrm{Al}_{2} \mathrm{O}_{3}, \mathrm{FeO}^{T}, \mathrm{Y}, \mathrm{Zr}, \mathrm{Nb}, \mathrm{Ba}, \mathrm{La}$ and $\mathrm{Th}$ concentrations of tephras from Ashenge, Hayk, Dabbahu and Dubbi. 


\subsection{Conclusions}

Distal tephras in lake sediment archives from the Ethiopian Highlands provide a $<17$ cal. ka BP record of volcanism from the Afar Rift. This section presents an initial late Pleistocene to Holocene tephra framework for the Afar Rift, the first to cover this temporal and spatial range. This is the first instance where cryptotephras have been identified and dated in terrestrial archives from Ethiopia; of the 21 tephra layers across the two study sites, 15 of these were identified as cryptotephra layers. These results highlight the essential contribution of cryptotephra studies to our understanding of past volcanism.

This chapter provides the first database of major and trace element glass compositions for tephras from Ethiopia to cover this temporal range. Glass compositions include comendites, pantellerites and minor peraluminous and metaluminous rhyolites. Between 15.3 - 1.6 cal. ka BP, explosive eruptions occurred at a frequency of $<1000$ years. The majority of tephras were recorded at $\sim 7.5-\sim 1.6 \mathrm{cal}$. ka BP, possibly reflecting a peak in volcanic activity, and the only historically documented tephra layer recorded in the archives occurs at $\sim 0.5-\sim 0.3 \mathrm{cal}$. ka BP. This new tephra framework provides an insight into the volcanic history of the Afar that has important implications for hazard assessments in a region where the record of recent volcanism has remained largely undocumented.

Distinct major and trace element compositions of the lakes Ashenge and Hayk tephras indicate that they record different eruptive events. The lack of correlations between archives collected from $<140 \mathrm{~km}$ apart may be associated with numerous factors. It is apparent that, due to the location of both lakes, a change in wind direction during the eruption would be required to disperse tephra produced by eruptions in the Afar Rift towards both lake sites. The topographic 
setting of each lake may influence the frequency and type of tephras deposited in each lake. Lake Ashenge is more exposed than Lake Hayk, the latter sheltered from localised eruptions in the Afar Rift by a series of horsts. Both lakes are alkali and, due to the increased solubility of rhyolitic glass in alkaline waters, this may determine the preservation of tephra glass shards and limit opportunities for tephra correlation.

The Ashenge and Hayk tephra glass shards have different incompatible element ratios, indicating they may have been erupted from as many as seven volcanic centres over the past $<15 \mathrm{cal}$. ka BP, most likely located in the nearby Afar Rift. Some tephras recorded in both lakes have similar incompatible element ratios, suggesting they may represent different eruptive events from the same source. It is apparent that the Ashenge and Hayk melts evolved through fractional crystallisation dominated by feldspar and ilmenite, however, it is likely that other processes including recharge and/or assimilation may have contributed to their evolution. Comparison of the Ashenge and Hayk tephra compositions with glass analyses of proximal deposits from the Dabbahu and Dubbi volcanoes is inconclusive. Further glass analyses of a wider range of proximal samples, combined with chronological control is required to investigate whether these volcanoes may have supplied the Ashenge and Hayk tephras.

Lake sediments have been shown to provide an accessible record of past volcanism from the remote Afar Rift. A greater network of sites must now be studied, which would capture not only the eruption frequency, but also the patterns of dispersal. This approach is, however, challenged by the lack of published major and trace element analyses of tephra glass shards from outcrops proximal to volcanoes in the Afar Rift. Further geochemical characterisation of the regional volcanoes is therefore essential to identify the sources of tephras 
recorded in the lakes Ashenge and Hayk sediments as well as those that will be uncovered in future studies. 



\section{Chapter 7}

\section{The composition, timing and}

\section{characteristics of post $\sim 10 \mathrm{ka}$}

\section{eruptions from Corbetti recorded}

\section{in lakes Awassa, Tilo and Chamo}

\subsection{Introduction}

This chapter explores whether tephras can be correlated between the Awassa, Tilo and Chamo archives. No published glass shard data are available for tephras from nearby volcanic centres. However, comparisons are made here between the composition of tephra layers in Tilo, Awassa and Chamo and obsidians and tephra samples from the Corbetti caldera. This is the first attempt to identify the likely source of these tephra layers and the implications of these findings are discussed with regards to regional volcanic hazards. 


\subsection{The composition of the Awassa, Tilo and Chamo}

\section{tephras}

\subsubsection{The Tilo tephras}

The major and trace element composition of the 14 Tilo tephras is given in Table 7.1 and Fig. 7.1. Most of the Tilo tephras are peralkaline rhyolites, and can be further classified as pantellerites (Le Maitre, 2002). These pantelleritic glass shards are comprised of two populations, containing varying $\mathrm{FeO}^{T}, \mathrm{Ba}, \mathrm{Zr}$ and Th concentrations. Notably, these two glass population have different $\mathrm{Zr} / \mathrm{Th}$ ratios and this indicates that they are derived from two different volcanic sources (Fig. 7.1f). The composition of the Tilo tephras is discussed below in terms of these two populations.

Table 7.1: Normalised major element (wt.\%) and trace element (ppm) concentrations of glass shards in the Tilo tephras. Average $( \pm 1 \mathrm{st}$. dev.) concentrations of selected elements which have proved to be useful for correlation are shown here. The range of element concentrations in each tephra is shown in italics.

\begin{tabular}{llllllll}
\hline & TT-1 & TT-2 & TT-3 & TT-4 & TT-5 & TT-6 & TT-7 \\
$\mathrm{Age}(\mathrm{ka})$ & $1.3-0.5$ & $2.1-1.2$ & $2.3-1.3$ & $2.5-1.3$ & $2.6-1.3$ & $2.7-1.6$ & $4.2-2.3$ \\
\hline $\mathrm{SiO}_{2}$ & $74.91(0.55)$ & $74.94(0.56)$ & $73.38(0.38)$ & $74.80(0.24)$ & $74.84(0.46)$ & $73.35(0.69)$ & $74.84(0.23)$ \\
& $72.99-75.41$ & $72.95-75.84$ & $72.39-73.97$ & $74.35-75.31$ & $73.69-76.66$ & $72.24-75.00$ & $74.41-75.22$ \\
$\mathrm{Al}_{2} \mathrm{O}_{3}$ & $10.08(0.75)$ & $9.92(0.66)$ & $8.57(0.33)$ & $9.87(0.14)$ & $9.92(0.27)$ & $8.57(0.52)$ & $9.83(0.12)$ \\
& $9.56-12.81$ & $9.39-12.51$ & $8.16-9.46$ & $9.71-10.24$ & $9.65-11.26$ & $7.47-10.07$ & $9.70-10.16$ \\
$\mathrm{FeO}^{T}$ & $4.57(0.11)$ & $4.56(0.15)$ & $6.39(0.25)$ & $4.60(0.12)$ & $4.64(0.14)$ & $6.45(0.26)$ & $4.66(0.13)$ \\
& $4.38-4.75$ & $4.24-4.87$ & $5.59-6.79$ & $4.39-4.81$ & $4.36-4.97$ & $5.79-6.89$ & $4.43-4.88$ \\
$\mathrm{Na}_{2} \mathrm{O}$ & $5.31(0.17)$ & $5.45(0.19)$ & $6.38(0.30)$ & $5.38(0.17)$ & $5.28(0.39)$ & $6.45(0.19)$ & $5.39(0.13)$ \\
& $4.99-5.58$ & $4.76-5.79$ & $5.79-6.84$ & $5.06-5.76$ & $3.56-5.70$ & $6.12-6.84$ & $5.20-5.59$ \\
$\mathrm{~K}_{2} \mathrm{O}$ & $4.48(0.13)$ & $4.47(0.10)$ & $4.31(0.11)$ & $4.48(0.14)$ & $4.46(0.08)$ & $4.16(0.17)$ & $4.43(0.08)$ \\
& $4.16-4.68$ & $4.27-4.66$ & $4.09-4.47$ & $4.21-4.61$ & $4.28-4.63$ & $3.76-4.42$ & $4.31-4.61$ \\
$\mathrm{Y}$ & $260(18.4)$ & $259(34.2)$ & $265(45.3)$ & $265(14.7)$ & $280(44.2)$ & $231(17.5)$ & $230(16.4)$ \\
& $236-311$ & $199-346$ & $213-377$ & $246-296$ & $212-395$ & $204-274$ & $205-268$ \\
& & & & & & & \\
\end{tabular}


Table 7.1 Continued from previous page

\begin{tabular}{|c|c|c|c|c|c|c|c|}
\hline & TT-1 & TT-2 & TT-3 & TT-4 & TT-5 & TT-6 & TT-7 \\
\hline \multirow[t]{2}{*}{$\mathrm{Zr}$} & $2110(131)$ & $2130(267)$ & $2090(369)$ & $2110(121)$ & $2290(348)$ & $1820(113)$ & $1880(118)$ \\
\hline & $1930-2410$ & $1630-2720$ & $1740-3090$ & $1960-2340$ & $1770-3190$ & $1640-2090$ & $1730-2130$ \\
\hline \multirow[t]{2}{*}{$\mathrm{Nb}$} & $259(8.56)$ & $262(10.7)$ & $286(36.7)$ & $269(8.07)$ & $267(18.4)$ & $274(15.4)$ & $245(6.64)$ \\
\hline & $243-276$ & $222-279$ & $239-356$ & $254-286$ & $233-337$ & 233-301 & $233-260$ \\
\hline \multirow[t]{2}{*}{$\mathrm{Ba}$} & $94.4(5.74)$ & $92.1(10.0)$ & 438 (29.4) & $83.3(6.95)$ & $82.5(9.29)$ & $358(22.8)$ & $57.6(4.74)$ \\
\hline & $81.7-107$ & $71.7-111$ & $394-517$ & $70.5-94.1$ & 56.1-102 & $312-414$ & $51.5-71.9$ \\
\hline \multirow[t]{2}{*}{$\mathrm{La}$} & $234(12.5)$ & $234(24.7)$ & $250(44.5)$ & $232(14.0)$ & $245(33.3)$ & $224(16.6)$ & $201(13.8)$ \\
\hline & $215-259$ & $193-292$ & $204-363$ & $214-259$ & 191-323 & $198-263$ & $181-226$ \\
\hline \multirow[t]{2}{*}{$\mathrm{Hf}$} & $52.5(4.02)$ & $53.5(6.05)$ & $53.1(8.53)$ & $56.4(4.44)$ & $58.0(8.98)$ & $45.4(3.46)$ & 46.7 (3.18) \\
\hline & 47.7-63.0 & $44.2-65.3$ & $44.6-75.1$ & $50.6-65.0$ & $45.4-80.3$ & $38.6-53.7$ & $41.1-52.1$ \\
\hline \multirow[t]{2}{*}{$\mathrm{Th}$} & $26.4(1.71)$ & $26.9(3.39)$ & $35.2(6.60)$ & $28.1(2.21)$ & $28.4(4.08)$ & $30.1(2.52)$ & $23.1(1.63)$ \\
\hline & $24.3-29.7$ & $21.8-33.4$ & $28.0-52.8$ & $25.1-32.0$ & $22.6-40.3$ & $25.1-37.1$ & $21.1-26.4$ \\
\hline \multirow[t]{3}{*}{$\mathrm{U}$} & $6.32(0.37)$ & $6.66(0.857)$ & $7.61(0.924)$ & $7.42(0.445)$ & $7.31(0.583)$ & $7.37(0.583)$ & $6.58(0.239)$ \\
\hline & $5.80-7.29$ & $4.18-8.60$ & $6.15-9.40$ & $6.78-8.26$ & $5.84-8.16$ & $6.44-8.35$ & $5.98-6.92$ \\
\hline & $n=16$ & $n=48$ & $n=18$ & $n=19$ & $n=40$ & $n=23$ & $n=19$ \\
\hline
\end{tabular}

\begin{tabular}{|c|c|c|c|c|c|c|c|}
\hline & TT-8 & TT-9 & TT-10 & TT-11 & TT-12 & TT-13 & TT-14 \\
\hline Age (ka) & $4.2-2.34$ & $4.9-4.0$ & $6.3-4.7$ & $6.4-5.1$ & $7.0-6.1$ & $8.9-8.0$ & $10.2-9.3$ \\
\hline \multirow[t]{2}{*}{$\mathrm{SiO}_{2}$} & $74.97(0.52)$ & $75.18(0.52)$ & $75.14(0.49)$ & $75.12(1.01)$ & $74.82(0.90)$ & $74.73(2.14)$ & $75.07(1.23)$ \\
\hline & $73.82-76.91$ & $74.36-75.65$ & $74.58-78.39$ & $70.25-77.13$ & $71.02-78.00$ & $66.63-78.05$ & $67.28-76.58$ \\
\hline \multirow[t]{2}{*}{$\mathrm{Al}_{2} \mathrm{O}_{3}$} & $9.87(0.26)$ & $9.69(0.26)$ & $9.65(0.22)$ & $9.82(0.83)$ & $9.93(0.73)$ & $9.88(2.04)$ & $9.75(1.24)$ \\
\hline & $9.41-11.28$ & $9.40-10.06$ & $8.57-10.26$ & $9.25-14.67$ & $9.43-14.63$ & $9.16-18.28$ & $8.99-17.76$ \\
\hline \multirow[t]{2}{*}{$\mathrm{FeO}^{T}$} & $4.67(0.21)$ & $4.68(0.21)$ & $4.64(0.20)$ & $4.62(0.36)$ & $4.70(0.16)$ & $4.65(0.91)$ & $4.58(0.57)$ \\
\hline & $4.33-5.78$ & $4.33-5.02$ & $3.76-5.02$ & $2.72-5.04$ & $4.29-5.05$ & $0.94-5.06$ & $0.66-4.84$ \\
\hline \multirow[t]{2}{*}{$\mathrm{Na}_{2} \mathrm{O}$} & $5.22(0.53)$ & $5.36(0.53)$ & $5.43(0.24)$ & $5.15(0.69)$ & $5.23(0.75)$ & $5.51(0.98)$ & $5.49(0.34)$ \\
\hline & $2.73-5.73$ & $4.86-5.80$ & $4.10-5.73$ & $2.80-5.99$ & $1.81-5.91$ & $1.96-6.18$ & $3.56-5.91$ \\
\hline \multirow[t]{2}{*}{$\mathrm{K}_{2} \mathrm{O}$} & $4.47(0.09)$ & $4.45(0.09)$ & $4.48(0.13)$ & $4.53(0.26)$ & $4.45(0.10)$ & $4.65(0.94)$ & $4.50(0.56)$ \\
\hline & $4.20-4.66$ & $4.25-4.62$ & $3.75-4.68$ & $4.35-6.01$ & $4.13-4.69$ & $4.27-8.48$ & $4.10-8.40$ \\
\hline \multirow[t]{2}{*}{$\mathrm{Y}$} & $264(23.7)$ & $256(23.7)$ & $267(32.9)$ & $310(32.9)$ & $305(30.4)$ & $356(27.8)$ & $291(20.8)$ \\
\hline & $218-321$ & $216-298$ & $209-347$ & $223-369$ & $238-394$ & $300-432$ & $239-345$ \\
\hline \multirow[t]{2}{*}{$\mathrm{Zr}$} & $2120(184)$ & $2100(184)$ & $2190(248)$ & $2440(238)$ & $2300(229)$ & $2960(212)$ & $2410(164)$ \\
\hline & $1750-2500$ & $1740-2400$ & $1770-2780$ & $1790-2850$ & $1790-2800$ & $2460-3460$ & $2030-2750$ \\
\hline \multirow[t]{2}{*}{$\mathrm{Nb}$} & $265(17.1)$ & $272(17.1)$ & $276(13.4)$ & $293(28.3)$ & $296(19.1)$ & 335 (13.9) & $303(14.0)$ \\
\hline & $211-311$ & $247-289$ & $227-297$ & $212-330$ & $255-330$ & $313-361$ & 264-335 \\
\hline \multirow[t]{2}{*}{$\mathrm{Ba}$} & $71.4(8.48)$ & $64.2(8.48)$ & $67.3(7.60)$ & $55.9(13.0)$ & $49.2(6.33)$ & $55.0(6.63)$ & $56.4(6.05)$ \\
\hline & $59.0-96.68$ & $51.8-78.8$ & $56.4-88.0$ & $35.2-96.2$ & $35.5-65.8$ & $44.6-70.1$ & 46.4-74.1 \\
\hline \multirow[t]{2}{*}{$\mathrm{La}$} & $234(23.4)$ & $233(23.4)$ & $243(30.1)$ & $268(24.7)$ & $268(24.3)$ & $315(22.9)$ & $259(17.8)$ \\
\hline & & & & \multicolumn{4}{|c|}{ Continued on next page } \\
\hline
\end{tabular}




\begin{tabular}{|c|c|c|c|c|c|c|c|}
\hline & TT-8 & TT-9 & TT-10 & TT-11 & TT-12 & TT-13 & TT-14 \\
\hline & 191-293 & $198-266$ & $190-311$ & $205-310$ & $206-323$ & $264-367$ & $212-302$ \\
\hline \multirow[t]{2}{*}{$\mathrm{Hf}$} & $52.4(5.83)$ & $52.3(5.83)$ & $54.0(6.21)$ & 63.7 (8.09) & $64.0(6.51)$ & $73.3(5.40)$ & $58.2(4.47)$ \\
\hline & $39.8-67.1$ & $41.6-63.5$ & $42.4-67.0$ & $46.9-78.8$ & $46.4-77.8$ & $59.9-79.9$ & $48.2-72.1$ \\
\hline \multirow[t]{2}{*}{ Th } & $26.6(2.89)$ & $26.6(2.89)$ & $27.5(3.19)$ & $31.8(3.71)$ & $31.8(3.46)$ & $36.6(2.66)$ & $30.0(2.02)$ \\
\hline & $21.2-35.2$ & $22.0-31.3$ & $21.4-34.6$ & $23.5-39.8$ & $24.6-42.9$ & $30.4-40.6$ & $25.1-37.2$ \\
\hline \multirow[t]{4}{*}{$\mathrm{U}$} & $6.82(0.597)$ & $6.97(0.597)$ & $7.07(0.41)$ & $7.36(0.75)$ & $7.81(0.775)$ & $8.30(0.461)$ & $8.10(1.35)$ \\
\hline & $5.20-9.12$ & $6.22-8.20$ & $6.21-7.90$ & $5.16-8.70$ & $6.40-9.72$ & $7.36-9.16$ & $6.57-16.3$ \\
\hline & $n=57$ & $n=59$ & $n=61$ & $n=39$ & $n=58$ & $n=19$ & $n=52$ \\
\hline & & & & & & Concluded & \\
\hline
\end{tabular}

\subsubsection{Composition of the Tilo Group I tephras}

Glass shards in TT-3 $(2.3-1.3$ cal. ka BP) and TT-6 $(2.7-1.6$ cal. ka BP $)$ contain higher $\mathrm{FeO}^{T}$ and $\mathrm{Ba}$ than all other glass shards in the Tilo tephras (Table 7.1, Fig. 7.1b, c). Furthermore, TT-3 and TT-6 have lower Zr/Th ratios (55.9 - 65.2) than all other Tilo tephra glass shards (56.2-92.1, Fig. 7.1f). Glass shards in TT-3 and TT-6 can be distinguished, TT-3 contains higher Ba concentrations than TT-6 (Fig. 7.1b).

\subsubsection{Composition of the Tilo Group II tephras}

The remaining 12 Tilo tephras share similar major and trace element compositions and $\mathrm{Y} / \mathrm{Zr}$ and $\mathrm{Zr} / \mathrm{Th}$ ratios (Fig. 7.2), indicating that the may be derived from a shared volcanic source. Barium behaves as a moderately incompatible element in the Tilo tephras, showing positive linear trends when plotted against Th. Figure 7.2f shows that $\mathrm{Ba}$ concentrations increase in the Tilo Group II tephras through time, allowing the majority of these tephras to be distinguished. The Tilo Group II tephras are discussed below, in relation to the varying Ba concentrations of their glass shards. 

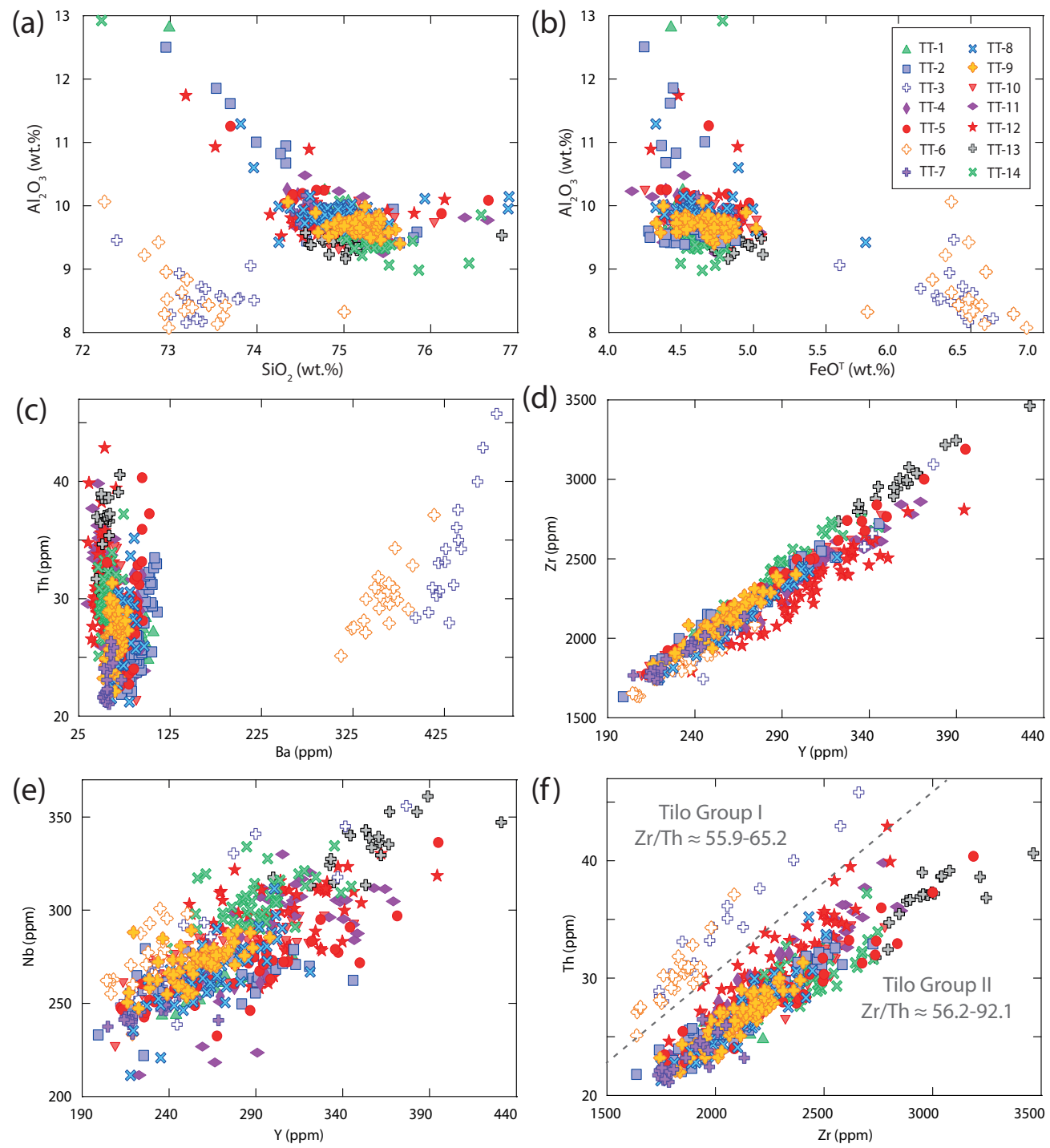

Figure 7.1: Major and trace element compositions of the Tilo tephra glass shards. 
The oldest period of volcanism from this source deposited TT-11; 12; 13 and $14(10.2-5.1 \mathrm{cal} \mathrm{ka}$ BP). Glass shards in these tephras contain the lowest $\mathrm{Ba} /$ Th ratios $(\approx 0.9-2.4)$ amongst the Tilo tephras (Fig. 7.2f). Glass shards in TT-11; 12; 13 and 14 can be broadly distinguished. TT-12 contains lower $\mathrm{Y}$ concentrations and TT-13 contains higher $\mathrm{FeO}^{T}$ and $\mathrm{Zr}$ than other tephras deposited during this oldest volcanic episode (Fig. 7.1b,d).

The most recent episode of volcanism produced TT-1; 2; 4 and 5 between $2.6-0.5$ cal ka BP. Tephra glass shards in these tephras contain higher Ba/Th ratios $(\approx 2.6-4.1)$ than the majority of glass shards in older tephras (Fig. 7.2f). TT-1 and TT-2 glass shards can be distinguished, containing broadly higher concentrations of Ba than TT-4 and TT-5.

Tephras TT-7; 8; 9 and 10 were deposited between the oldest and youngest volcanic episodes, during 6.3-2.3 cal. ka BP. Glass shards in these tephras have similar $\mathrm{Ba} / \mathrm{Th}$ ratios $(\approx 1.9-3.5)$ to tephras produced by younger and older volcanic episodes (Fig. 7.2f). The only tephra which can be distinguished from other tephras deposited during this episode is TT-7, which contains glass shards with comparatively lower Y, Ba and Th concentrations (Fig. 7.2a, e).

\subsubsection{Composition of the Awassa tephras}

The major and trace element composition of 3 of the total 7 Awassa tephra glass shards is presented in Table 7.3 and Fig. 7.3. The Awassa tephra glass shards are pantelleritic and share similar $\mathrm{Y} / \mathrm{Zr}$ and $\mathrm{Zr} / \mathrm{Th}$ ratios (Fig. 7.3d, f), suggesting that they are co-genetic. However, $\mathrm{FeO}^{T}, \mathrm{Y}, \mathrm{Zr}, \mathrm{La}, \mathrm{Nb}$ and $\mathrm{Th}$ concentrations display inter-eruptive variations and divide the Awassa tephras into three glass populations. Glass shards in AWT-1 (1.5 - 1.1 cal. ka BP) contain lower concentrations of $\mathrm{Y}, \mathrm{Zr}$ and $\mathrm{Nb}$ than older Awassa tephras (Fig. 
(a)

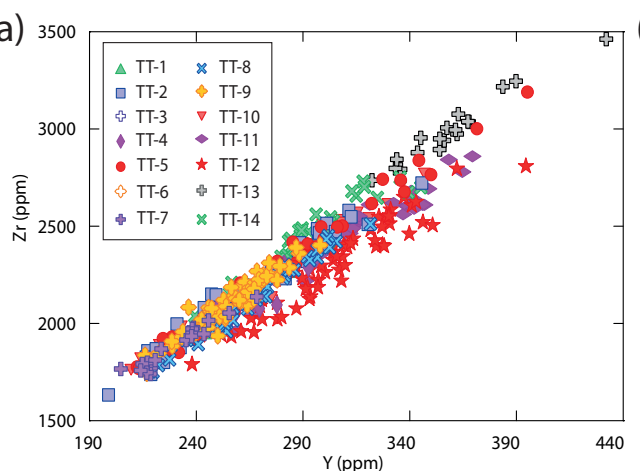

(c)

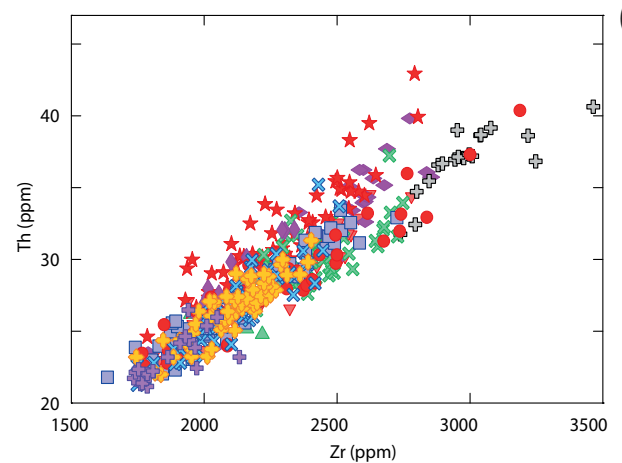

(e)

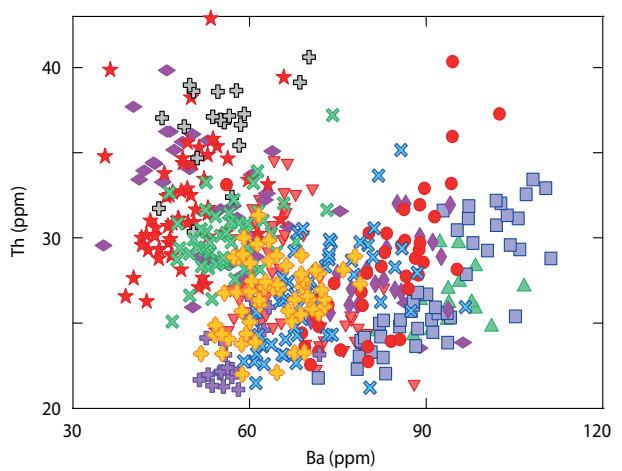

(b) 3500

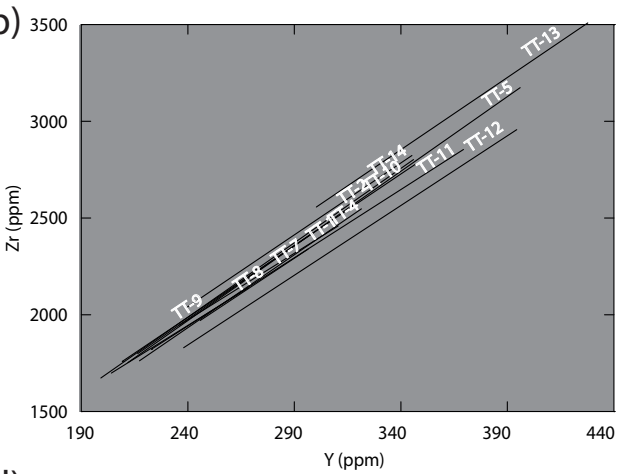

(d)

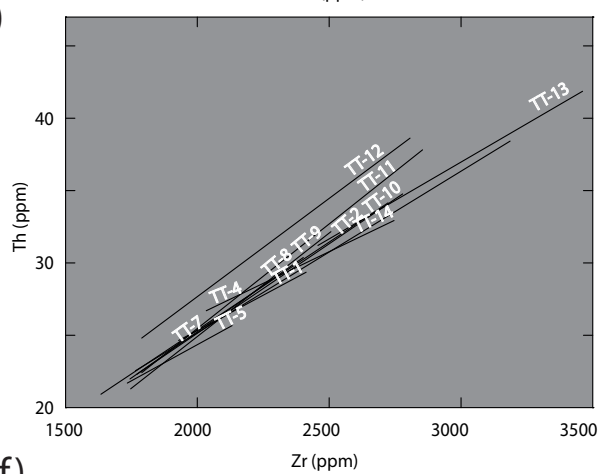

(f)

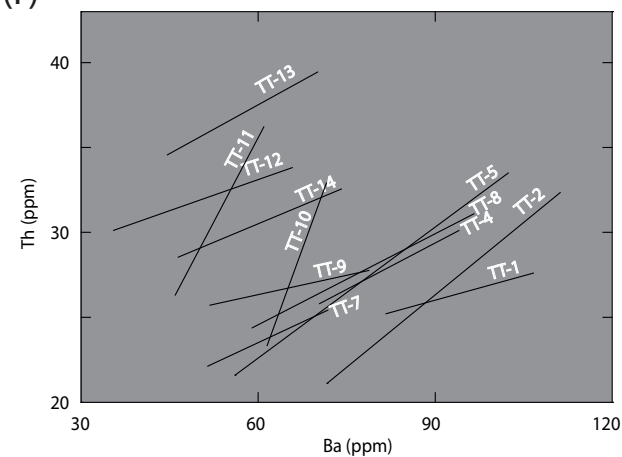

Figure 7.2: Ratios of $\mathrm{Y} / \mathrm{Zr}, \mathrm{Zr} / \mathrm{Th}$ and $\mathrm{Ba} / \mathrm{Th}$ in the Tilo Group II glass shards (see Fig. 7.1f), (b), (d) and (f) linear regression trends through showing the relationship between incompatible element concentrations in the Tilo tephras. The Tilo Group II tephras show similar Y/Zr and Zr/Th element ratios, suggesting they are derived from the same source. 
7.3d, e). Glass shards in AWT-1 are bimodal; one glass population contains higher Ba concentrations than other Awassa tephras, whilst other AWT-1 glass shards contain similar Ba concentrations to other Awassa tephras (Fig. 7.3c). AWT-1 contains glass shards which display the widest range of $\mathrm{Al}_{2} \mathrm{O}_{3}, \mathrm{FeO}^{T}$ and $\mathrm{Ba}$ concentrations amongst the Awassa tephras (Fig. 7.3b, c). Glass shards in AWT-2 $(4.9-3.3$ cal. ka BP) and AWT-4 (6.6 - 5.4 cal. ka BP) are compositionally similar, however, AWT-2 contains higher Y concentrations than all other Awassa tephras and lower concentrations of Zr and Th than AWT-2 (Fig. 7.3d, f). 
Table 7.3: Normalised major element (wt.\%) and trace element (ppm) concentrations of glass shards in the Awassa tephras. Average ( \pm st. dev.) concentrations of selected elements which have proved to be useful for correlation are shown here. The range of element concentrations in each tephra is shown in italics.

\begin{tabular}{|c|c|c|c|}
\hline Age $(\mathrm{kg})$ & $\begin{array}{l}\text { AWT-1 } \\
\text { AW }\end{array}$ & $\begin{array}{l}\text { AWT-2 } \\
49-33\end{array}$ & $\begin{array}{l}\text { AWT-4 } \\
66-54\end{array}$ \\
\hline \multirow[t]{2}{*}{$\mathrm{SiO}_{2}$} & $74.08(2.49)$ & $75.42(0.27)$ & $74.93(0.34)$ \\
\hline & $66.81-75.80$ & 75.09-76.09 & 74.33-75.37 \\
\hline \multirow{2}{*}{$\mathrm{Al}_{2} \mathrm{O}_{3}$} & $11.12(2.54)$ & $9.62(0.14)$ & $9.65(0.13)$ \\
\hline & $9.35-19.13$ & $9.37-9.92$ & $9.43-9.88$ \\
\hline \multirow[t]{2}{*}{$\mathrm{FeO}^{T}$} & $4.06(1.39)$ & $4.60(0.12)$ & $4.78(0.23)$ \\
\hline & $0.52-6.43$ & $4.41-4.89$ & $4.53-5.36$ \\
\hline \multirow[t]{2}{*}{$\mathrm{Na}_{2} \mathrm{O}$} & $5.03(0.68)$ & $5.20(0.27)$ & $5.23(0.15)$ \\
\hline & $3.44-6.17$ & $4.58-5.59$ & $4.97-5.51$ \\
\hline \multirow{2}{*}{$\mathrm{K}_{2} \mathrm{O}$} & $5.08(0.98)$ & $4.47(0.11)$ & $4.43(0.14)$ \\
\hline & $4.26-7.36$ & $4.34-4.71$ & $4.18-4.55$ \\
\hline \multirow[t]{2}{*}{$\mathrm{Y}$} & $203(28.7)$ & $285(34.0)$ & $294(26.5)$ \\
\hline & $126-237$ & $227-357$ & $256-339$ \\
\hline \multirow[t]{2}{*}{$\mathrm{Zr}$} & $1620(236)$ & $2030(254)$ & $2400(228)$ \\
\hline & $1060-1910$ & $1610-2470$ & $2130-2830$ \\
\hline \multirow[t]{2}{*}{$\mathrm{Nb}$} & $213(27.2)$ & $260(19.0)$ & $278(16.0)$ \\
\hline & $171-260$ & $221-287$ & 246-305 \\
\hline \multirow[t]{2}{*}{$\mathrm{Ba}$} & 237 (130) & $81.2(33.0)$ & $69.8(9.74)$ \\
\hline & $29.7-481$ & 62.7-196 & $60.1-94.1$ \\
\hline \multirow[t]{2}{*}{$\mathrm{La}$} & $210(21.3)$ & $251(25.3)$ & $269(27.1)$ \\
\hline & $153-238$ & 211-299 & 235-316 \\
\hline \multirow[t]{2}{*}{ Hf } & $44.1(4.94)$ & $51.8(5.61)$ & $63.6(5.56)$ \\
\hline & $31.5-52.9$ & $43.9-62.61$ & $56.6-72.3$ \\
\hline \multirow[t]{2}{*}{ Th } & $22.8(3.69)$ & $26.5(3.18)$ & $31.4(3.46)$ \\
\hline & $16.9-31.1$ & $22.2-33.0$ & $26.6-38.8$ \\
\hline \multirow[t]{3}{*}{$\mathrm{U}$} & $6.43(1.15)$ & $7.54(1.82)$ & $8.11(0.71)$ \\
\hline & $5.01-8.98$ & $5.23-13.3$ & $7.09-9.11$ \\
\hline & $n$ & $n=28$ & $n=10$ \\
\hline
\end{tabular}


(a)
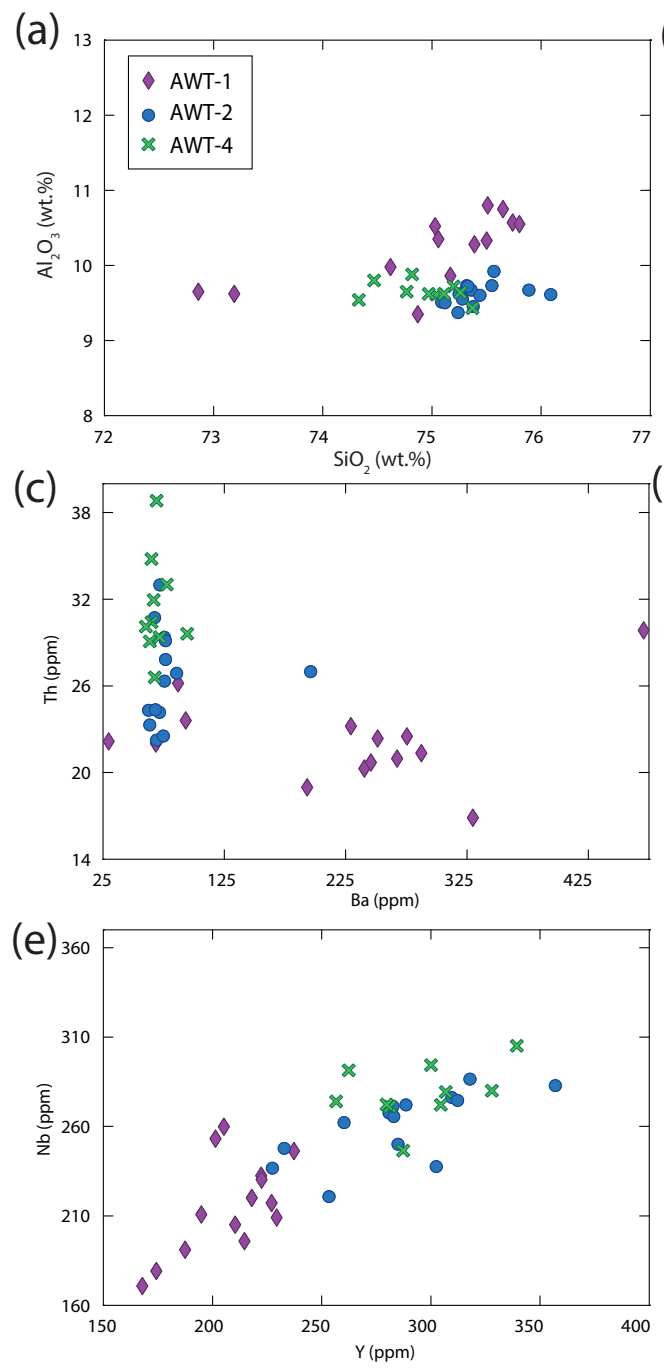

(b)
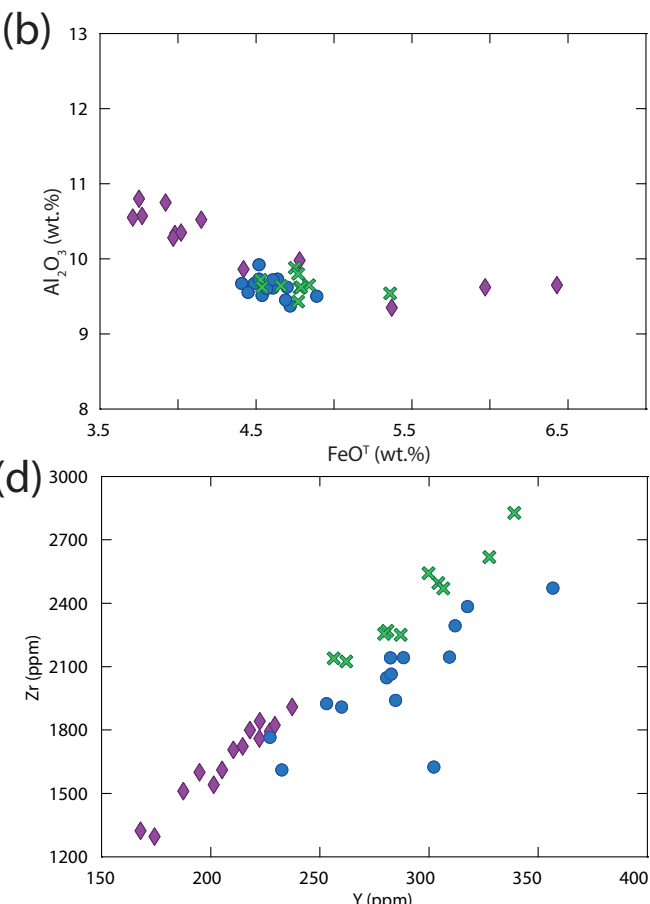

(f)

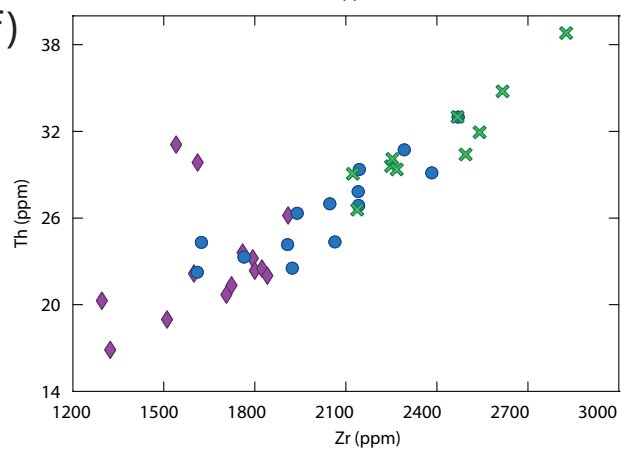

Figure 7.3: Major and trace element compositions of the Awassa tephra glass shards. 


\subsubsection{Composition of the Chamo tephras}

The compositions of glass shards in the 2 Chamo tephras is given in Table 7.4 and Fig. 7.4. The Chamo tephras are pantellerites and have similar $\mathrm{Y} / \mathrm{Zr}$ and $\mathrm{Zr} / \mathrm{Th}$ ratios, indicating that they may be derived from a shared volcanic source (Fig. 7.4d, f). Concentrations of $\mathrm{Al}_{2} \mathrm{O}_{3}, \mathrm{Nb}, \mathrm{Ba}$ and Th show the variation between CHT-1 and CHT-2, enabling them to be distinguished. Glass shards in the younger tephra, CHT-1 $\left(2.8-1.2\right.$ cal. ka BP), contain higher $\mathrm{Al}_{2} \mathrm{O}_{3}$ and $\mathrm{Ba}$ concentrations and lower $\mathrm{Zr}, \mathrm{Nb}$ and Th concentrations than CHT-2 (9.4-6.3 cal. ka BP) glass shards (Fig. 7.4a, c, e, f). 
Table 7.4: Normalised major element (wt.\%) and trace element (ppm) concentrations of glass shards in the Chamo tephras. Average ( \pm st. dev.) concentrations of selected elements which have proved to be useful for correlation are shown here. The range of element concentrations in each tephra is shown in italics.

\begin{tabular}{|c|c|c|}
\hline & CHT-1 & CHT-2 \\
\hline Age (ka) & $2.8-1.2$ & $9.4-6.3$ \\
\hline \multirow[t]{2}{*}{$\mathrm{SiO}_{2}$} & $75.04(0.26)$ & $74.86(0.43)$ \\
\hline & $74.65-75.72$ & $74.33-76.37$ \\
\hline \multirow[t]{2}{*}{$\mathrm{Al}_{2} \mathrm{O}_{3}$} & $9.74(0.12)$ & $9.44(0.12)$ \\
\hline & $9.50-10.01$ & $9.19-9.61$ \\
\hline \multirow[t]{2}{*}{$\mathrm{FeO}^{T}$} & $4.63(0.17)$ & $4.90(0.14)$ \\
\hline & $4.32-4.86$ & $4.56-5.18$ \\
\hline \multirow[t]{2}{*}{$\mathrm{Na}_{2} \mathrm{O}$} & $5.29(0.16)$ & $5.61(0.41)$ \\
\hline & $4.87-5.50$ & $4.06-6.07$ \\
\hline \multirow[t]{2}{*}{$\mathrm{K}_{2} \mathrm{O}$} & $4.42(0.12)$ & $4.33(0.08)$ \\
\hline & $4.10-4.56$ & $4.20-4.47$ \\
\hline \multirow[t]{2}{*}{$\mathrm{Y}$} & $302(34.6)$ & $332(38.2)$ \\
\hline & $262-366$ & $283-452$ \\
\hline \multirow[t]{2}{*}{$\mathrm{Zr}$} & $2420(235)$ & $2700(324)$ \\
\hline & $2150-2790$ & $2360-3760$ \\
\hline \multirow[t]{2}{*}{$\mathrm{Nb}$} & $276(16.3)$ & $333(13.6)$ \\
\hline & $250-320$ & $304-371$ \\
\hline \multirow[t]{2}{*}{$\mathrm{Ba}$} & $108(12.5)$ & $50.6(8.93)$ \\
\hline & $68.4-121$ & $42.7-73.2$ \\
\hline \multirow[t]{2}{*}{$\mathrm{La}$} & $283(26.7)$ & $288(43.3)$ \\
\hline & $246-335$ & $254-436$ \\
\hline \multirow[t]{2}{*}{ Hf } & $57.4(5.55)$ & $65.7(8.10)$ \\
\hline & $47.2-66.4$ & $57.7-94.9$ \\
\hline \multirow[t]{2}{*}{ Th } & $29.3(2.74)$ & 33.9 (3.74) \\
\hline & $25.8-33.7$ & $30.2-47.2$ \\
\hline \multirow[t]{3}{*}{$\mathrm{U}$} & $6.82(0.529)$ & $9.06(0.499)$ \\
\hline & $5.71-7.54$ & $7.68-9.93$ \\
\hline & $n=16$ & $n=19$ \\
\hline
\end{tabular}



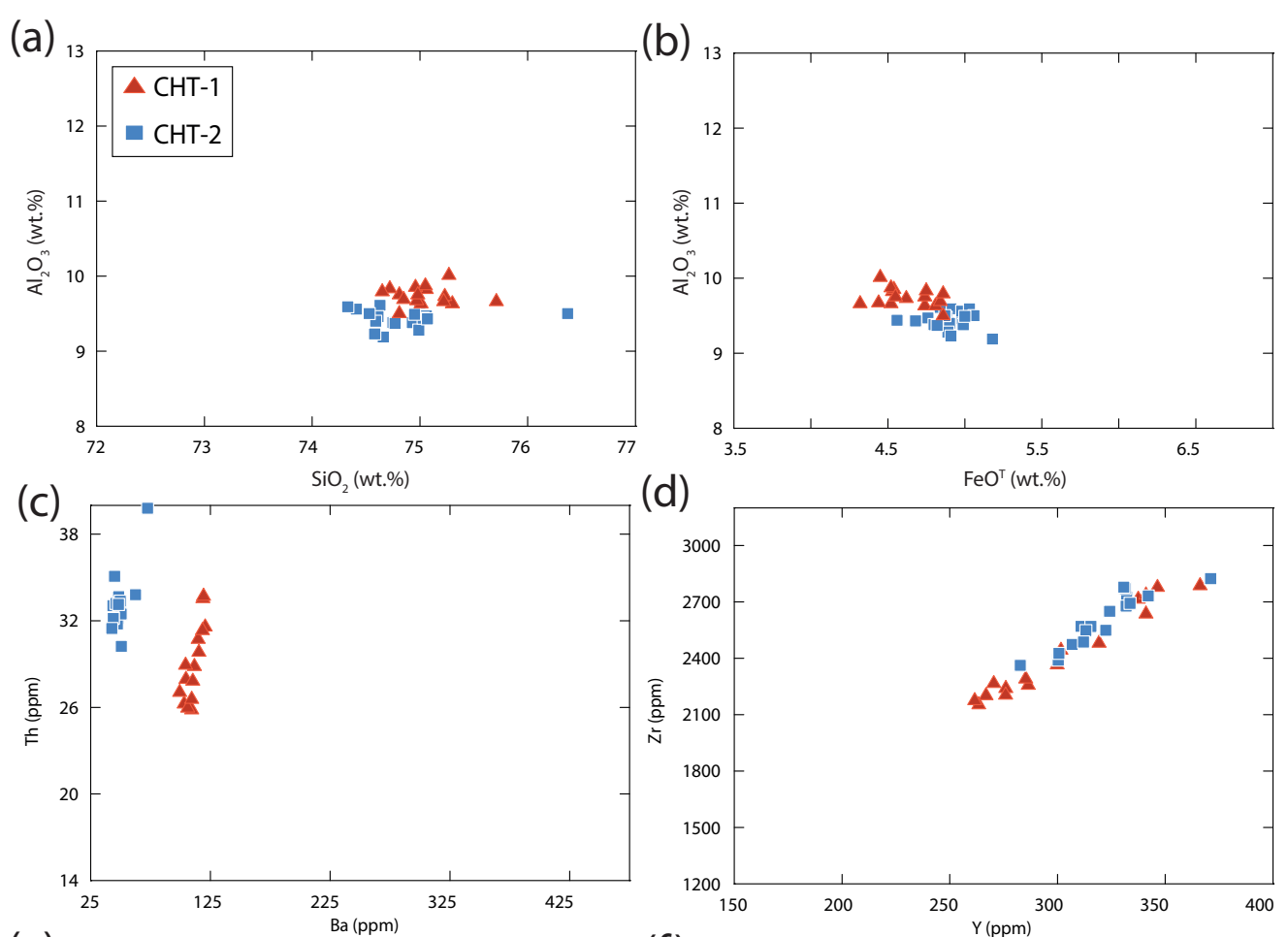

(d)
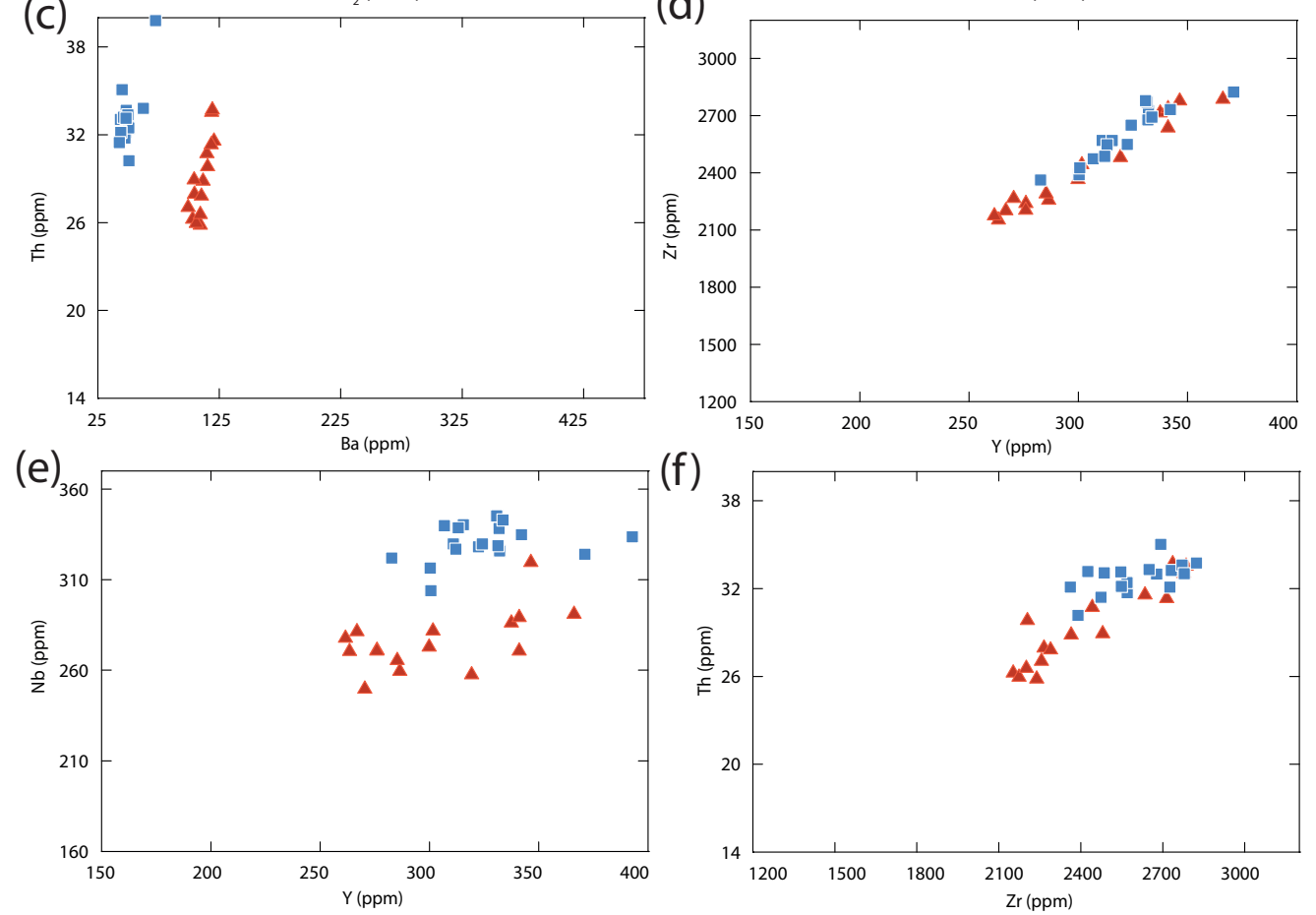

Figure 7.4: Major and trace element compositions of the Chamo tephra glass shards. 


\subsection{Discussion}

\subsubsection{Potential tephra correlations}

The composition of tephra glass shards from lakes Tilo, Chamo and Awassa is compared in Figs. 7.5 to 7.10 , in order to test whether the tephras in these archives can be correlated.

Figure 7.5 indicates that Tilo Group I (TT-3 and TT-6) glass shards are distinct from other tephras recorded in lakes Awassa and Chamo. Notably, TT-3 and TT-6 glass shards contain higher $\mathrm{FeO}^{T}$ and $\mathrm{Ba}$ concentrations, lower $\mathrm{SiO}_{2}$ concentrations and different $\mathrm{Zr} / \mathrm{Th}$ ratios when compared with all other glass shards (Fig. 7.5a, b, c, f). Glass shards in AWT-1 are also distinct from all other tephras. AWT-1 glass shards contain lower Ba concentrations than the Tilo Group I tephras, but higher Ba concentrations than all other tephra glass shards (Fig. 7.5c).

The Chamo tephras are distinct from the other Awassa (AWT-2 and AWT-4) tephras. The youngest Chamo tephra, CHT-1 (2.8 - 1.2 cal. ka BP), contains higher Ba concentrations than AWT-2 and AWT-4. The oldest Chamo tephra, CHT-2 (9.4 - 6.3 cal. ka BP), contains lower Ba concentrations than AWT-2 and AWT-4 (Fig. 7.5c). However, both the Chamo tephras and AWT-2 and AWT-4 Awassa tephras have comparable compositions to the Tilo Group II tephras (Fig. 7.5c). Furthermore, these glass shards contain similar major and trace element concentrations and have similar $\mathrm{Zr} / \mathrm{Th}$ ratios (Fig. 7.5f), suggesting the tephras recorded in these archives may be derived from a shared source.

Nonetheless, there are compositional similarities between the Chamo and Awassa tephras (AWT-2 and AWT-4) and the Group II Tilo tephras. Notably, most of the Chamo and Awassa tephra glass shards have similar $\mathrm{Zr} / \mathrm{Th}$ ratios 

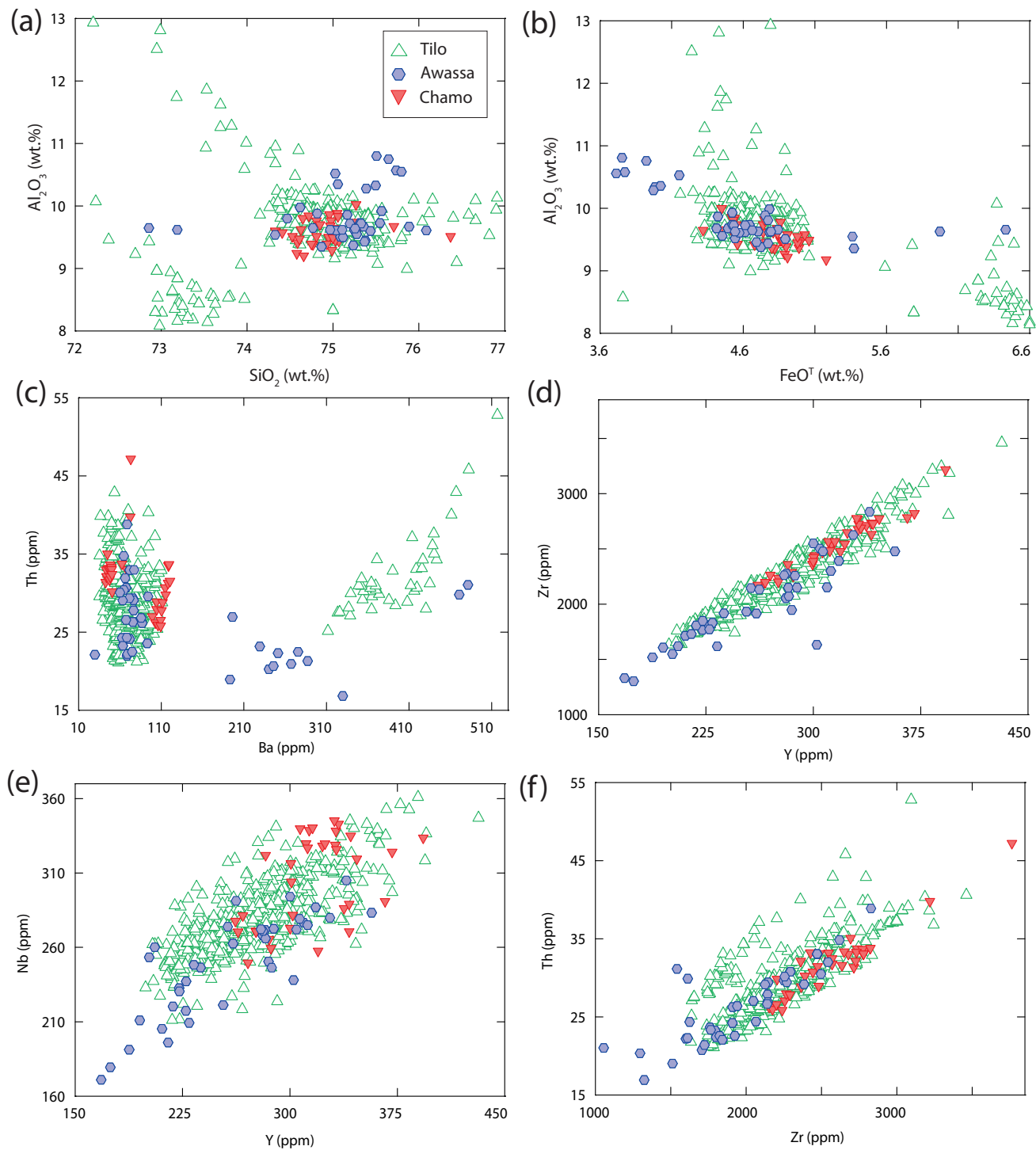

Figure 7.5: Major and trace element compositions of the Awassa, Tilo and Chamo tephra glass shards 
$(\approx 64.0-86.7)$ to the Tilo Group II tephras $(\approx 56.2-92.1)$, suggesting that the tephras from these different archives may originate from a single source.

Glass shards in CHT-1 have a comparable composition to younger Tilo tephras, TT-1, TT-2, TT-4 and TT-5 (2.6 - 0.5 cal. ka BP). However, glass shards in TT-4 contain lower Zr concentrations and TT-4 and TT-5 glass shards have lower Ba concentrations than CHT-1 (Fig. 7.6c, d). It is therefore apparent that CHT-1 has a more comparable composition to TT-1 and TT-2 glass shards. The compositional similarities between these tephras noted using bi-plots are further investigated using principal component analysis in Fig.7.7. This allows the concentrations of $\mathrm{SiO}_{2}, \mathrm{Al}_{2} \mathrm{O}_{3}, \mathrm{FeO}^{T}, \mathrm{Y}, \mathrm{Zr}, \mathrm{Nb}, \mathrm{Ba}, \mathrm{La}$ and $\mathrm{Th}$ in these tephra glass shards to be statistically compared. Figure. $7.7 \mathrm{~b}$ verifies the compositional differences between CHT-1 and TT-4 and TT-5 noted previously, and indicates that TT-1 is compositionally different to CHT-1. On this basis, TT-2 $(2.1-1.2$ cal. ka BP) may have been produced by the same eruptive event as CHT-1 $(2.8-1.2$ cal. ka BP), and this is supported by their comparable age ranges.

The oldest recorded Chamo tephra, CHT-2, contains glass shards which are compositionally similar to older Tilo Group II tephras (TT-11; 12; 13 and TT-14, 10.2 - 5.1 cal. ka BP). Further comparison of these tephras (Fig.7.8) shows that TT-14 contains broadly higher $\mathrm{SiO}_{2}$ and $\mathrm{Ba}$ concentrations and lower $\mathrm{FeO}^{T}$, $\mathrm{Y}$ and Th concentrations than CHT-2. TT-12 is also distinct from CHT-2, its glass shards contain comparably lower $\mathrm{Al}_{2} \mathrm{O}_{3}$ and Th concentrations and higher Y concentrations (Fig.7.8a, c, d). It is not clear whether TT-11 or TT-13 are potential correlatives of CHT-2 based on the major and trace element composition of their glass shards. CHT-2 glass shards are statistically compared with older Tilo Group II tephras in Fig. 7.9, and this suggests that TT-13 (8.9-8.0 cal. ka BP) has a more comparable composition to CHT-2 (9.4 - 6.3 cal. ka BP). These 
(a)
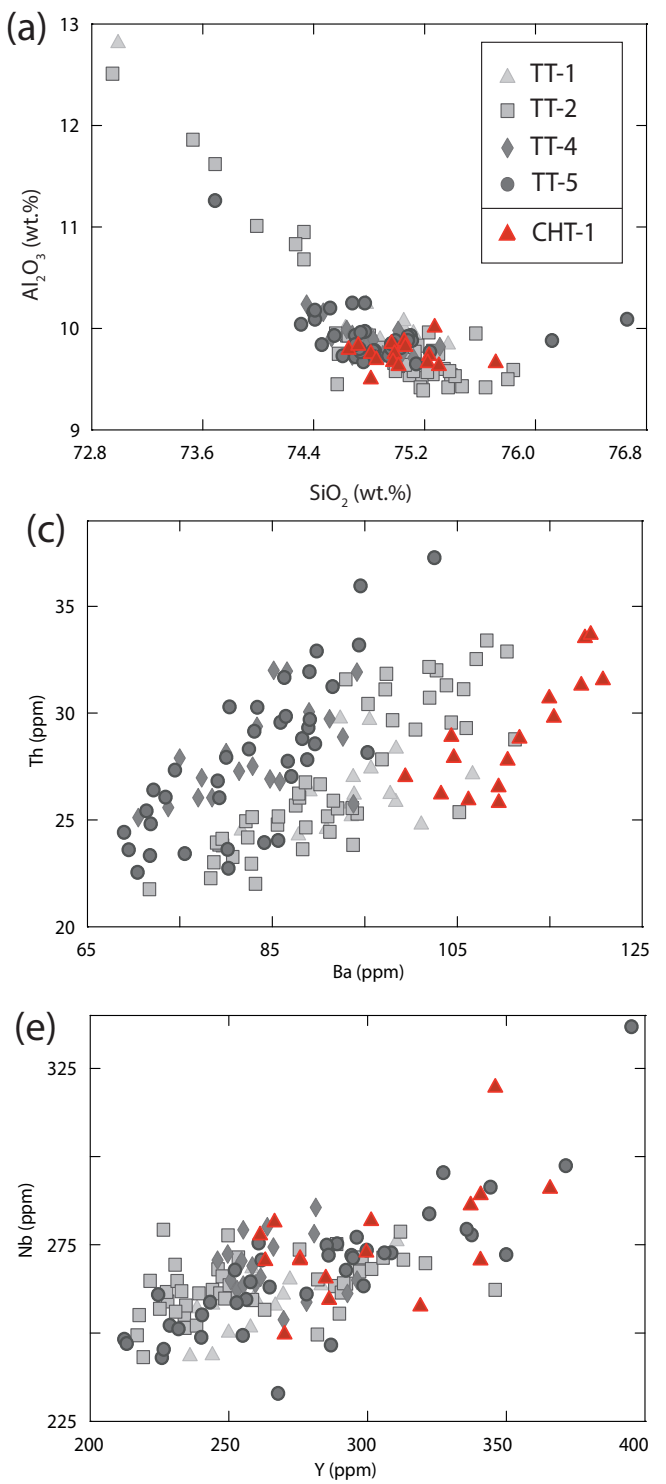

(b)
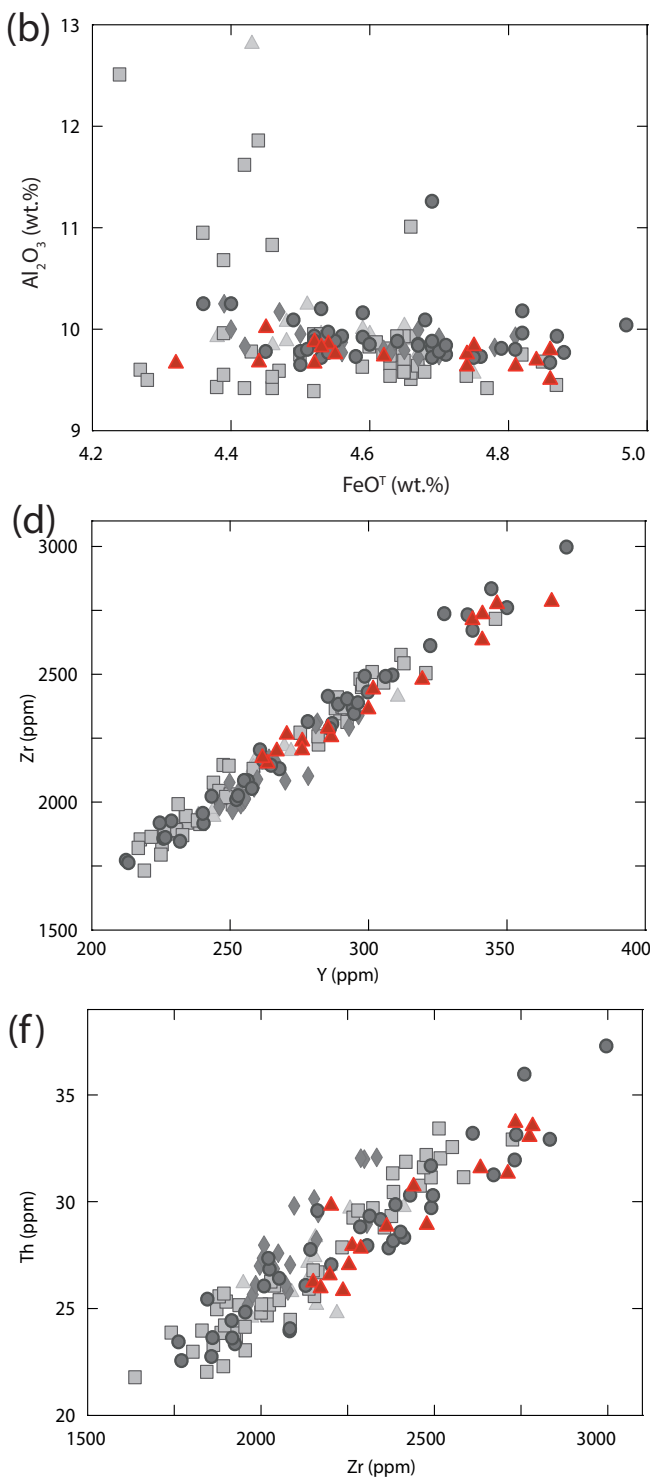

Figure 7.6: Biplots comparing concentrations of selected major and trace elements in the CHT-1 glass shards and TT-1; 2; 4 and TT-5 glass shards. 

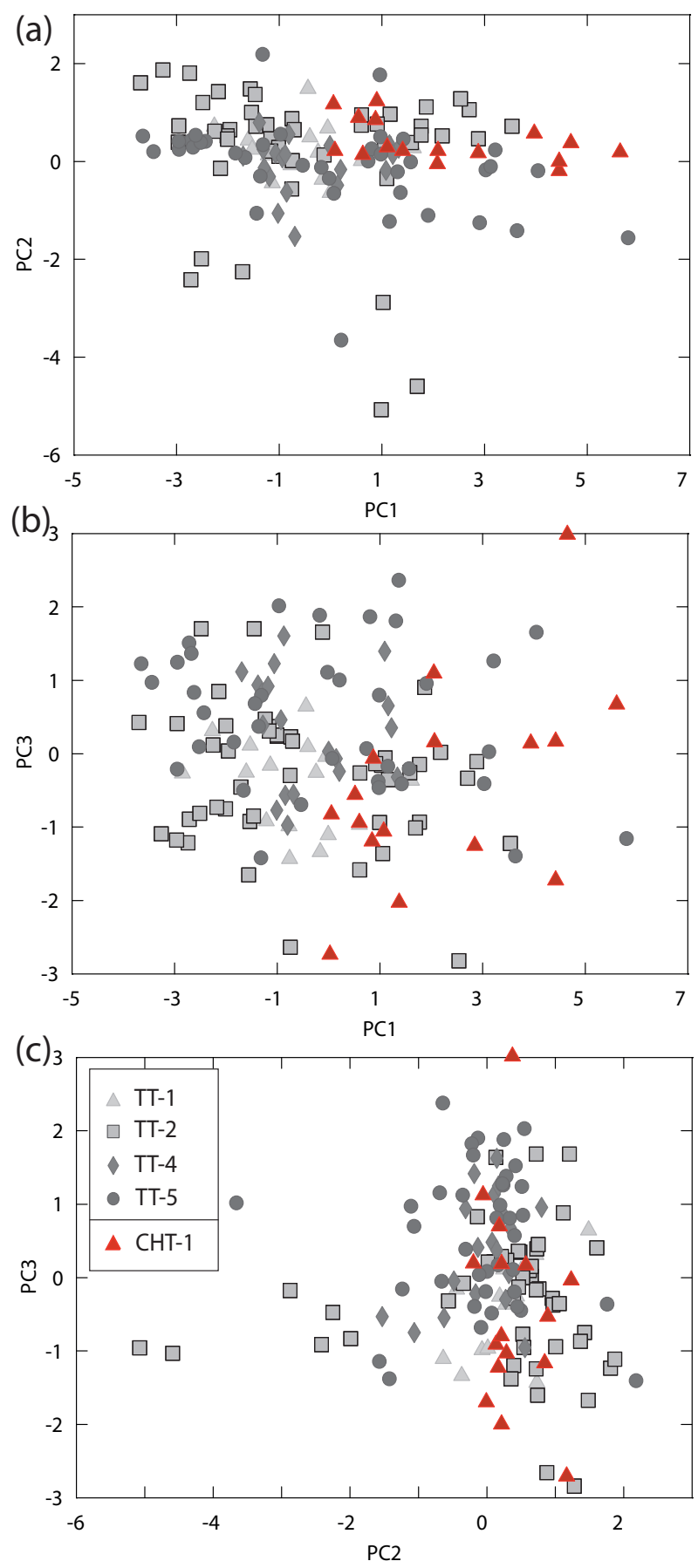

Figure 7.7: Bi-plots of the first three principal components from a principal component analysis of the compositionally similar CHT-1, TT-1; 2; 4 and TT-5 tephra glass shards. $\mathrm{SiO}_{2}, \mathrm{Al}_{2} \mathrm{O}_{3}, \mathrm{FeO}^{T}, \mathrm{Y}, \mathrm{Zr}, \mathrm{Nb}, \mathrm{Ba}$, La and $\mathrm{Th}$ are used as variables. 
tephras have similar ages, and it is highly likely that CHT-2 is derived from the same source as TT-13. However, this link remains tentative and requires testing with further sampling and glass analysis.
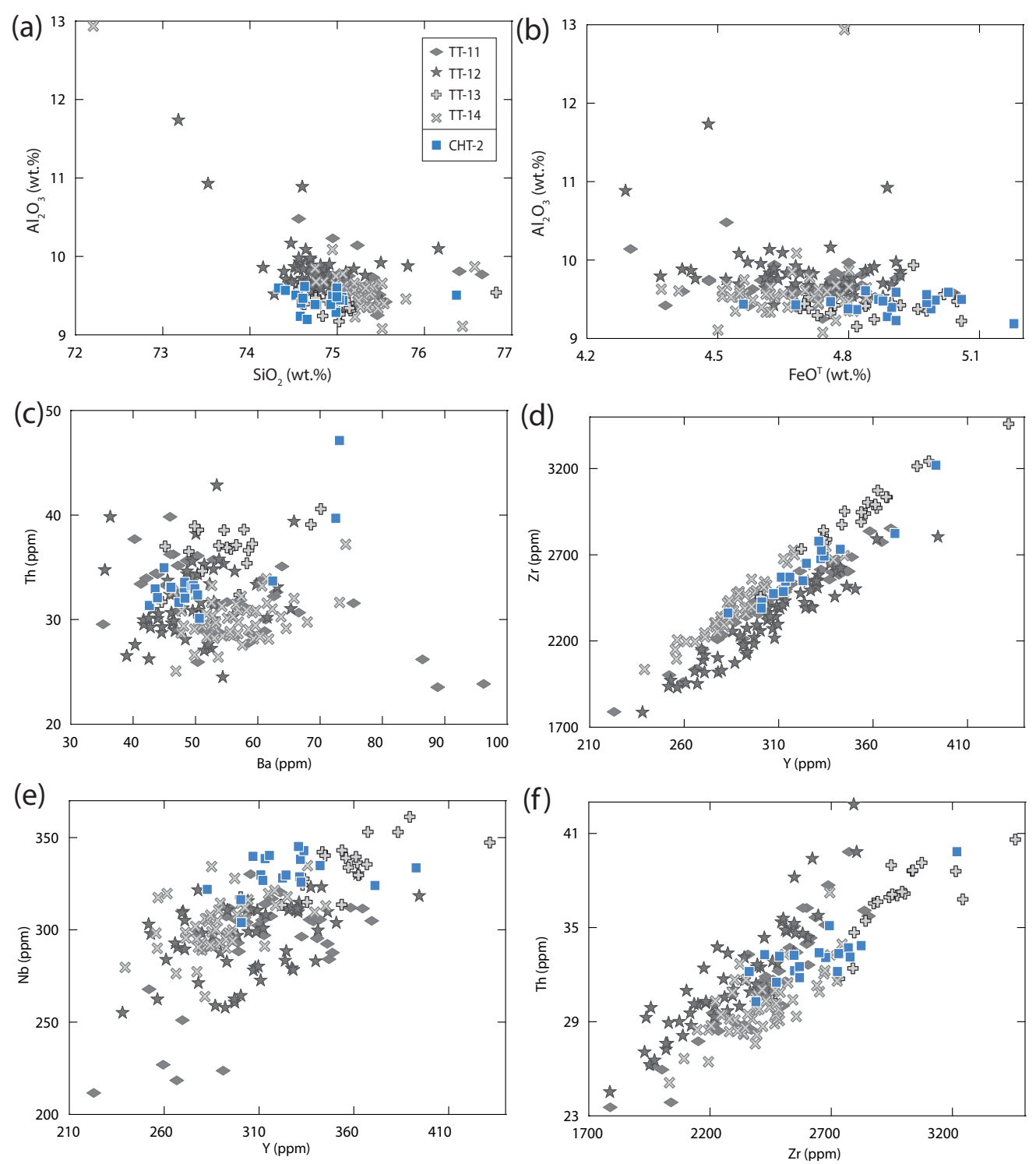

Figure 7.8: Bi-plots showing selected major and trace element compositions of the CHT-2 and TT-11;12;13 and TT-14 glass shards. 

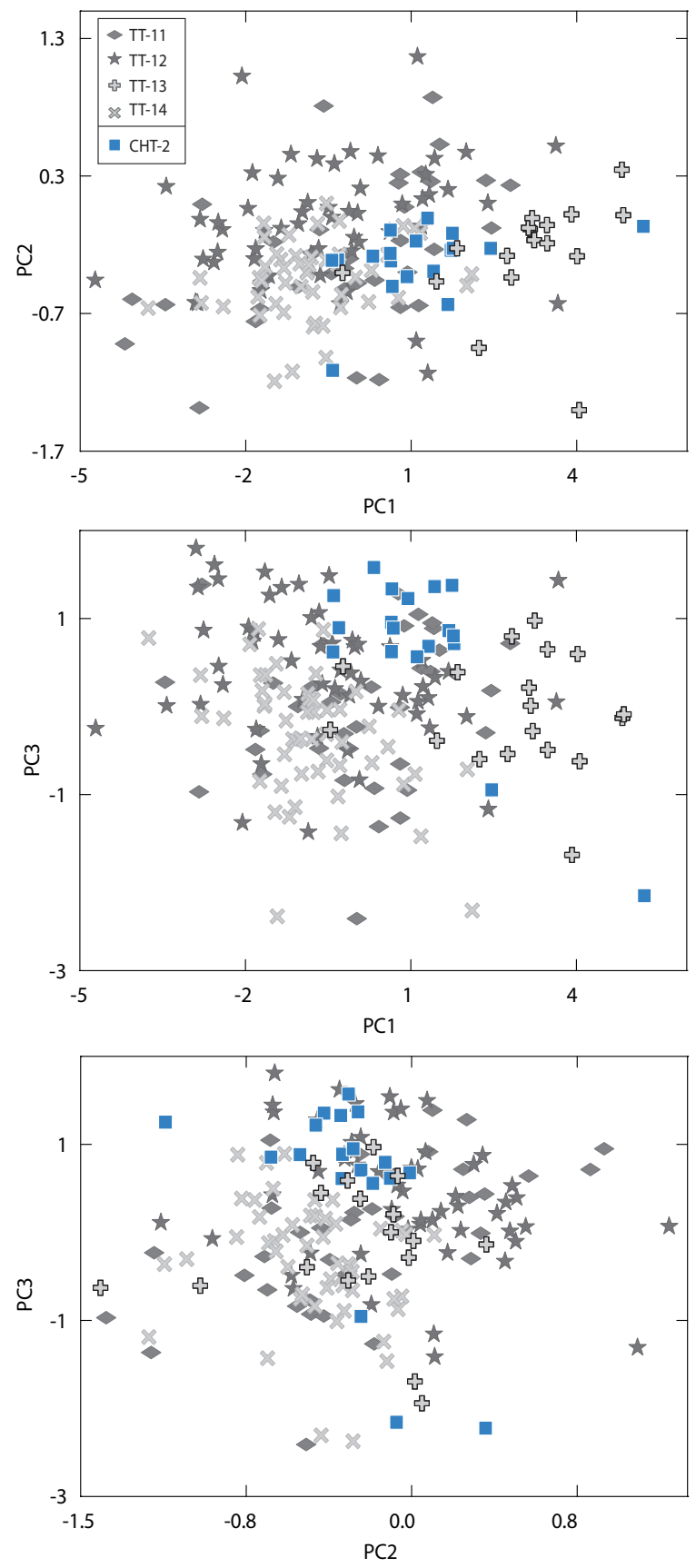

Figure 7.9: Bi-plots of the first three principal components from a principal component analysis of the compositionally similar CHT-2 and TT-11;12;13 tephra glass shards. $\mathrm{SiO}_{2}, \mathrm{Al}_{2} \mathrm{O}_{3}, \mathrm{FeO}^{T}, \mathrm{Y}, \mathrm{Zr}, \mathrm{Nb}, \mathrm{Ba}$, $\mathrm{La}$ and $\mathrm{Th}$ are used as variables. 
The Awassa tephras, AWT-2 and AWT-4 (6.6 - 3.3 cal. ka BP) contain glass shards which have a comparable composition to TT-7; 8; 9 and TT-10 (6.3-2.3 cal. ka BP). Glass shards in TT-7 contain lower Y, Nb, Ba and Th concentrations than AWT-2 and AWT-4 (Fig.7.10c, e). The composition of glass shards in AWT-2, AWT-4 and the $6.3-2.3$ ka Tilo tephras is statistically compared in Fig.7.11. This further demonstrates that TT-7 is compositionally different from AWT-2 and AWT-4, however, no further differences between these tephras are noted. Whilst it is apparent that these tephras are most likely derived from the same source, it is not possible to ascertain which tephras were produced by the same eruptive event and correlate between the Awassa and Tilo archives.

Therefore, it is apparent that the majority of tephras recorded in the Awassa, Tilo and Chamo archives are derived from a shared source. CHT-1 and CHT-2 can be tentatively correlated to TT-2 and TT-13, respectively (see Fig.7.12). The Awassa tephras, AWT-2 and AWT-4 are compositionally similar to TT-8; 9 and TT-10, however, it is not possible to ascertain which of the Tilo tephras are correlatives based on their composition. 

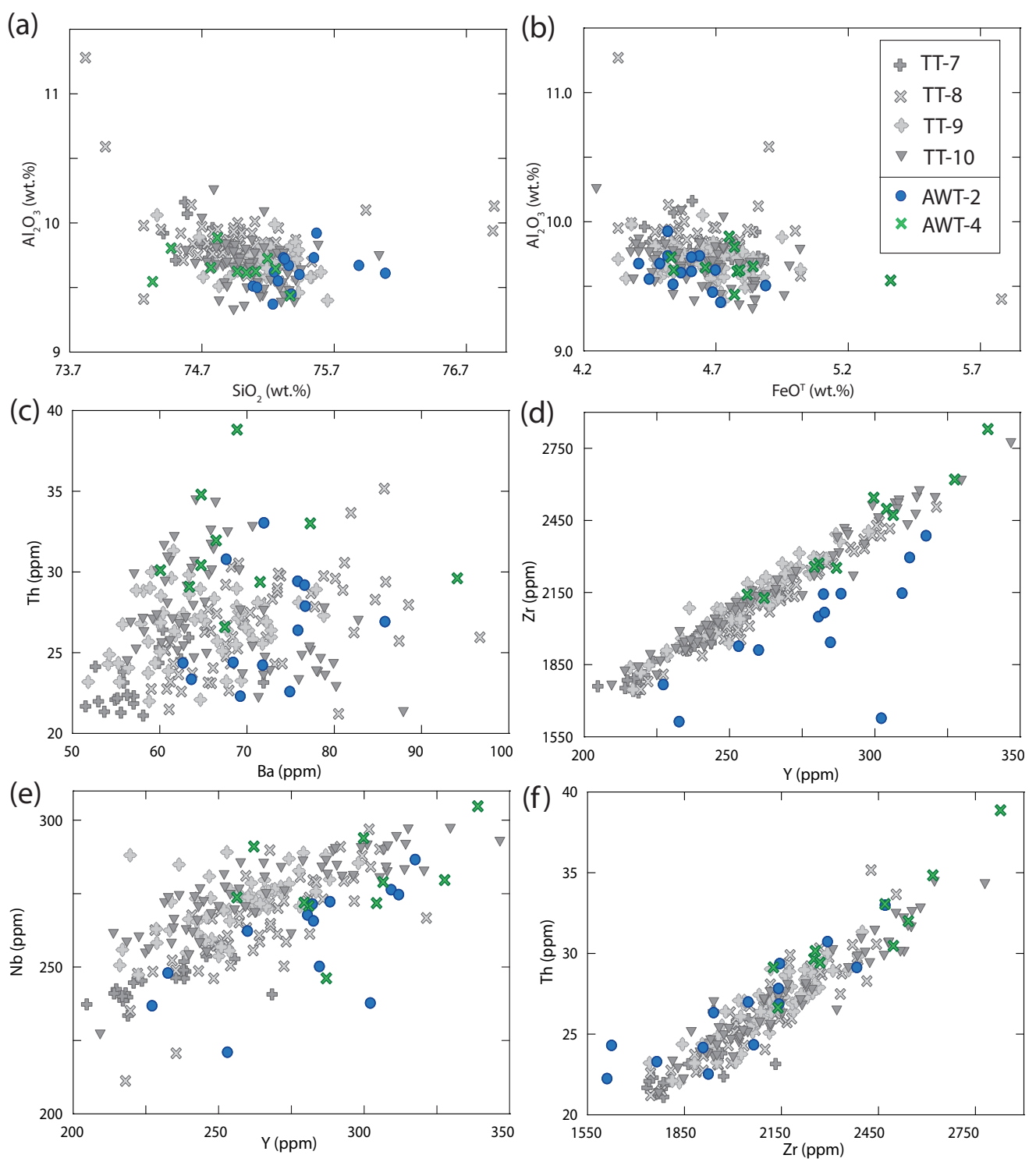

Figure 7.10: Bi-plots showing selected major and trace element concentrations in the AWT-2, AWT-4, and TT-7;8;9 and TT-10 tephra glass shards. 
(a)
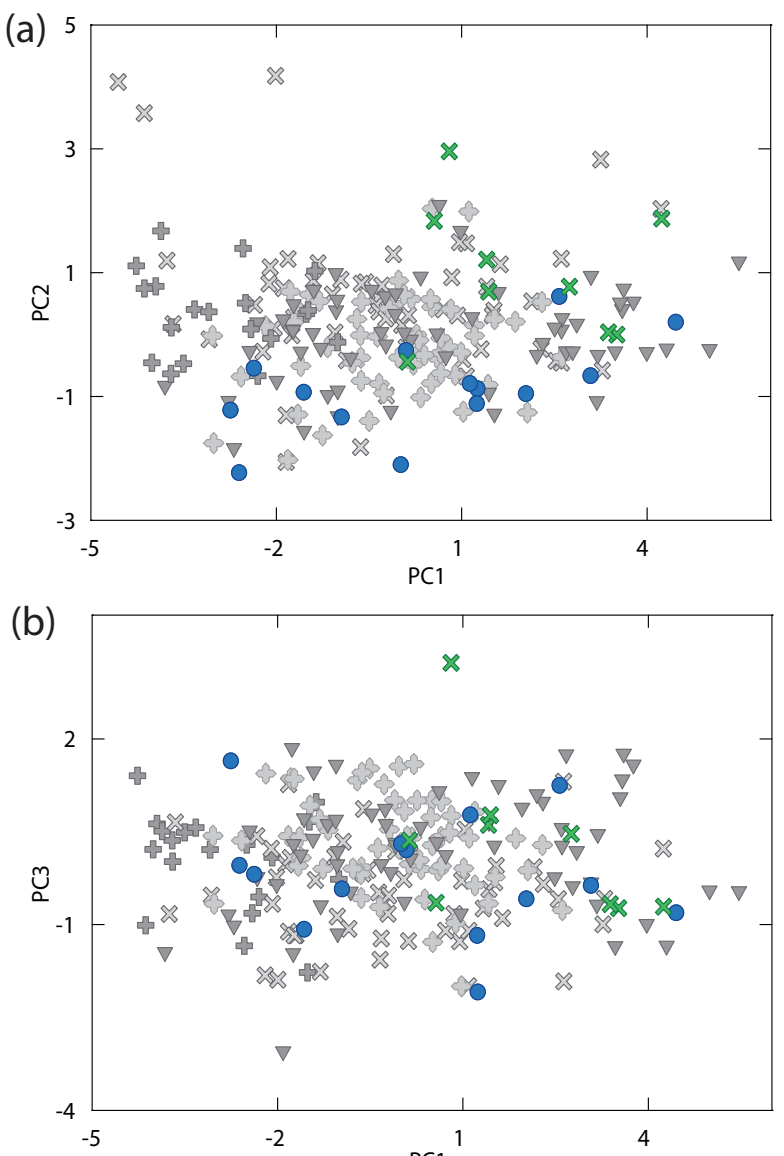

(c)

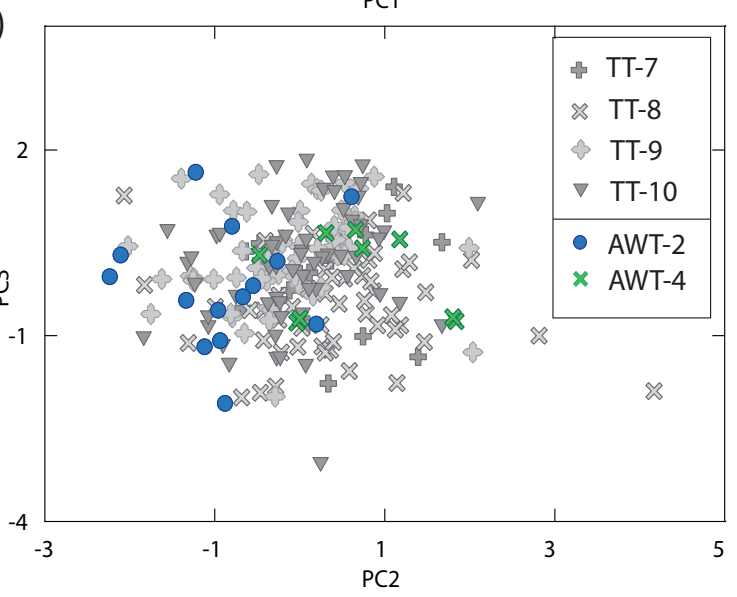

Figure 7.11: Bi-plots of the first three principal components from a principal component analysis of the compositionally similar AWT-2, AWT-4, and TT-7;8;9 and TT-10 tephra glass shards. $\mathrm{SiO}_{2}, \mathrm{Al}_{2} \mathrm{O}_{3}, \mathrm{FeO}^{T}, \mathrm{Y}, \mathrm{Zr}, \mathrm{Nb}, \mathrm{Ba}, \mathrm{La}$ and Th are used as variables. 


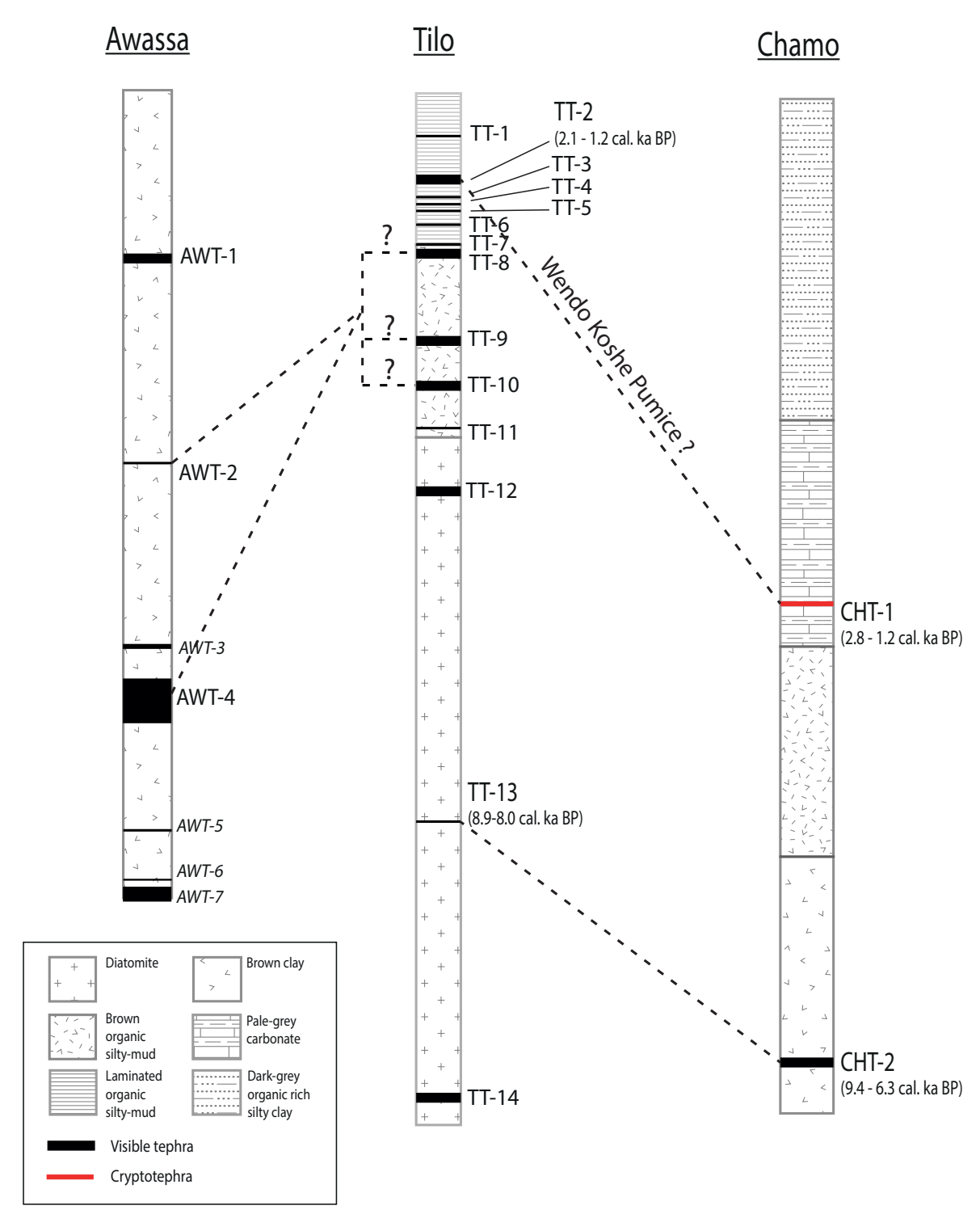

Figure 7.12: Correlations between Awassa, Tilo and Chamo archives. Based on their geochemistry, it is not possible to ascertain whether TT-8; 9 or TT-10 are correlatives of AWT-2 and AWT-4. CHT-1 and TT-2 may represent the latest Wendo Koshe eruption (see page 235). 


\subsubsection{Provenance of tephras deposited in central MER lakes}

Many of the tephras recorded in these archives have similar incompatible element ratios and are therefore potentially derived from one shared source. However, variable incompatible element ratios suggest eruptions from other centres deposited two tephras in Lake Tilo (TT-3 and TT-6) and one tephra in Lake Awassa (AWT-1). Lake Awassa is located within the Corbetti caldera, whilst Lake Tilo is located $<40 \mathrm{~km}$ from this centre (Fig.7.13b). Since the collapse of this caldera during the Quaternary, the recent centres Wendo Koshe and Chabbi (Fig.7.13b) have developed on the northern shores of Lake Awassa and are associated with obsidian flows and rhyolitic monotonous pumice deposits. Žáček et al. (2014) and Rapprich et al. (2016) described the most recent eruption from Wendo Koshe, which dispersed a $10 \mathrm{~cm}$ thick pumice lapilli deposit over an area of $1000 \mathrm{~km}^{2}$. Radiocarbon dates on paleosol underlying the deposit date the eruption to $\sim 400$ BC (Rapprich et al., 2016). This deposit overlies a yellowish phreatomagmatic

tuff. Žáček et al. (2014) suggests this originates from Fike Volcano (Fig.7.13a), between lakes Shalla and Abijata, on the basis of field observations.

In order to test if Corbetti is the source for many Awassa, Tilo and Chamo tephras, selected pumice and obsidian samples from the Chabbi volcano and Tilo crater walls have been analysed as part of this study (Fig.7.14). Published whole rock analyses of Holocene obsidian and pumice deposits from the Wendo Koshe volcano, from Rapprich et al. (2016) are shown for comparison in (Fig.7.14). These published bulk analyses contain contaminant minerals, and only incompatible element ratios can therefore be compared.

Unfortunately, comparison of the composition of tephras from these archives with other centres in the MER is limited. This is due to the scarcity of published glass analyses and chronological control on proximal samples from volcanoes in 
this area. The Pleistocene volcano, Duguna, is located $\sim 10 \mathrm{~km}$ south of Lake Tilo (Fig.7.13b). This has produced tephra deposits of $>30 \mathrm{~m}$ thickness, with reported ages on deposits from the eastern flanks of $430-460 \mathrm{ka}$. However, to the author's knowledge, there are no published geochemical data characterising this centre. Published compositions of melt inclusions within obsidians from the Fantale (Taylor et al., 1997) and Boseti (Macdonald et al., 2012) volcanoes (Fig.7.13a) are shown for comparison in Fig.7.14. Although obsidian flows are effusive and do not occur as widespread deposits, their glass composition gives a broad geochemical signature for a volcano.

Glass shards in TT-3 and TT- 6 have different $\mathrm{Zr} / \mathrm{Th}$ ratios to the proximal obsidian samples from Corbetti and are therefore most likely derived from a different volcanic centre (Fig.7.14f). However, further sampling of proximal tephras and obsidians is required to constrain the potential source of TT-3 and TT-6.

Comparison of these tephras with the composition of melt inclusions in obsidians from Fantale show that they are distinct. The Fantale obsidians have different $\mathrm{Zr} / \mathrm{Th}$ ratios $(\approx 41.9-53.2)$ to tephras from the Awassa, Tilo and Chamo archives $(\approx 56.2-92.1)$. The Boseti melt inclusions have distinct major element compositions to the Awassa, Tilo and Chamo tephras (Fig.7.14a, b). However, further trace element analysis of glass shards is required to test if this centre could be a source of these tephras.

Obsidian and pumices samples from Chabbi and Wendo Koshe (Rapprich et al., 2016) have similar $\mathrm{Zr} / \mathrm{Th}$ ratios (Chabbi $\approx 70.3-87.5$, Wendo Koshe $\approx 83.4-97.4)$ to Group II Tilo tephras and Awassa and Chamo tephras $(\approx$ $56.2-92.1$ ). Therefore, it is possible that the majority of Awassa, Tilo and Chamo tephras are derived from centres within the Corbetti caldera. If Corbetti 


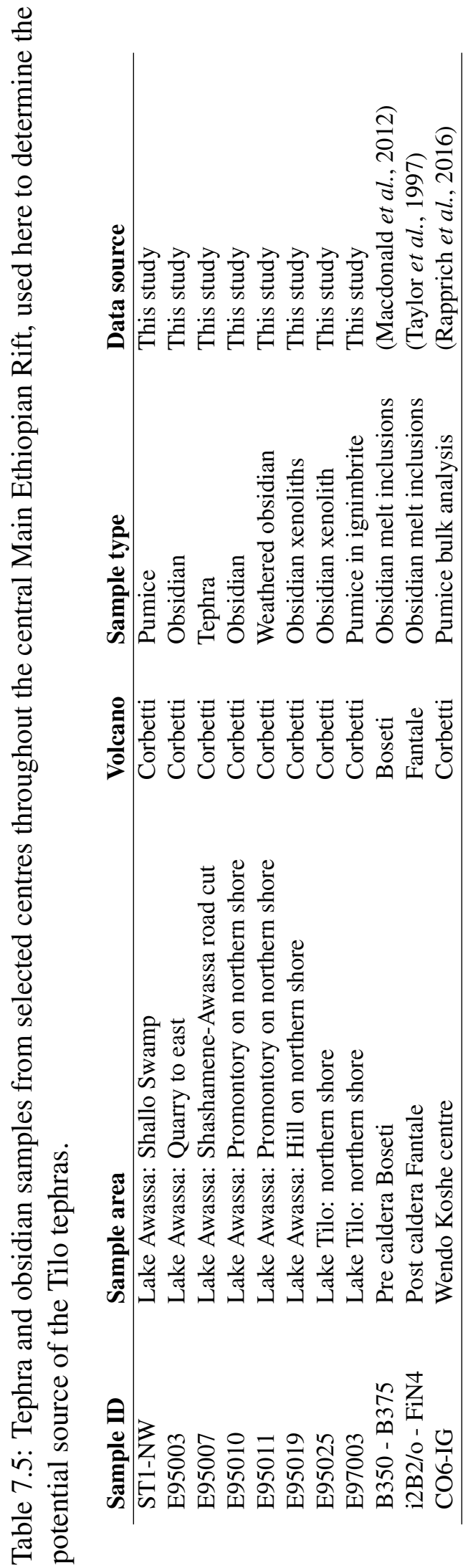




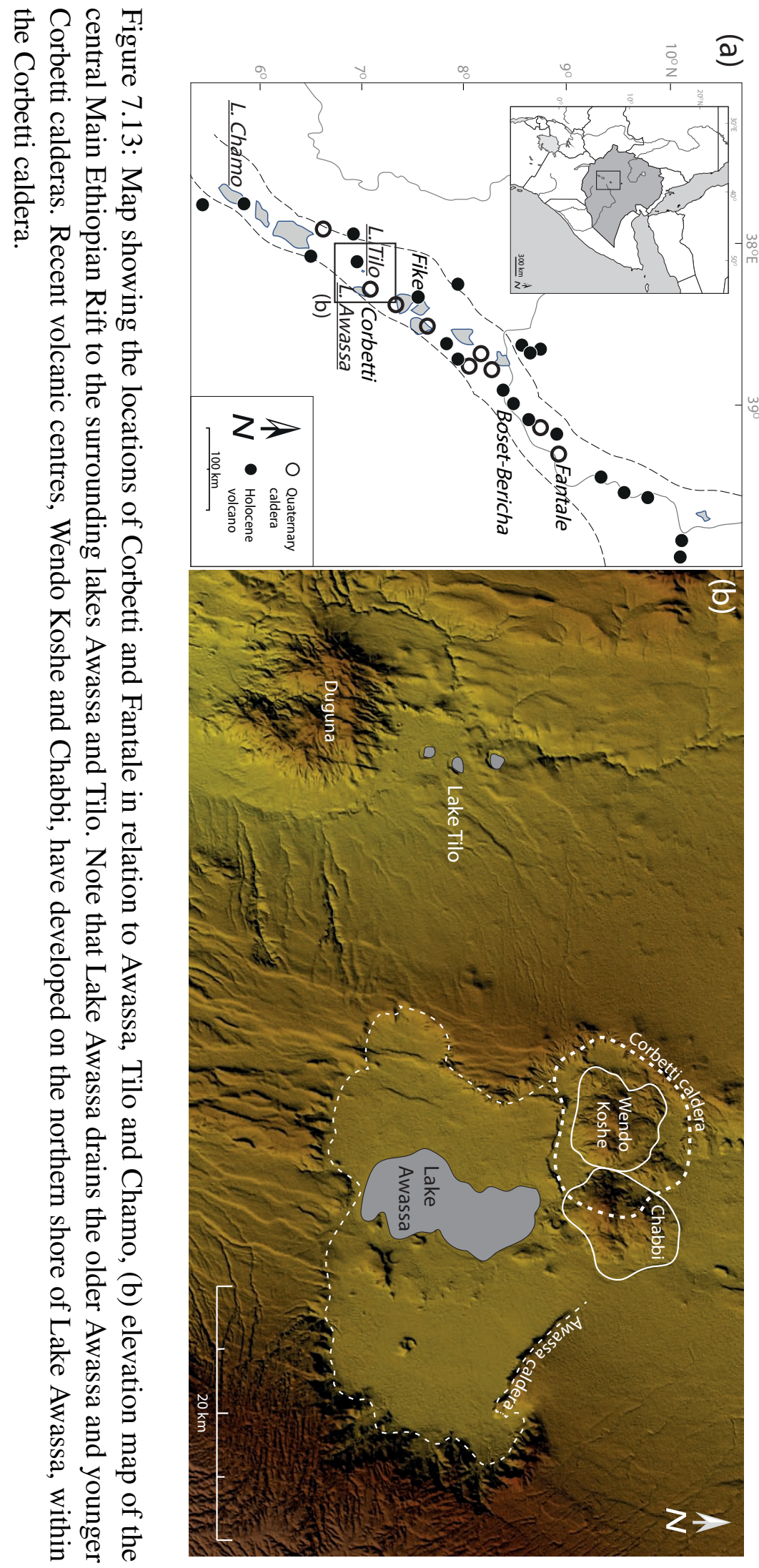



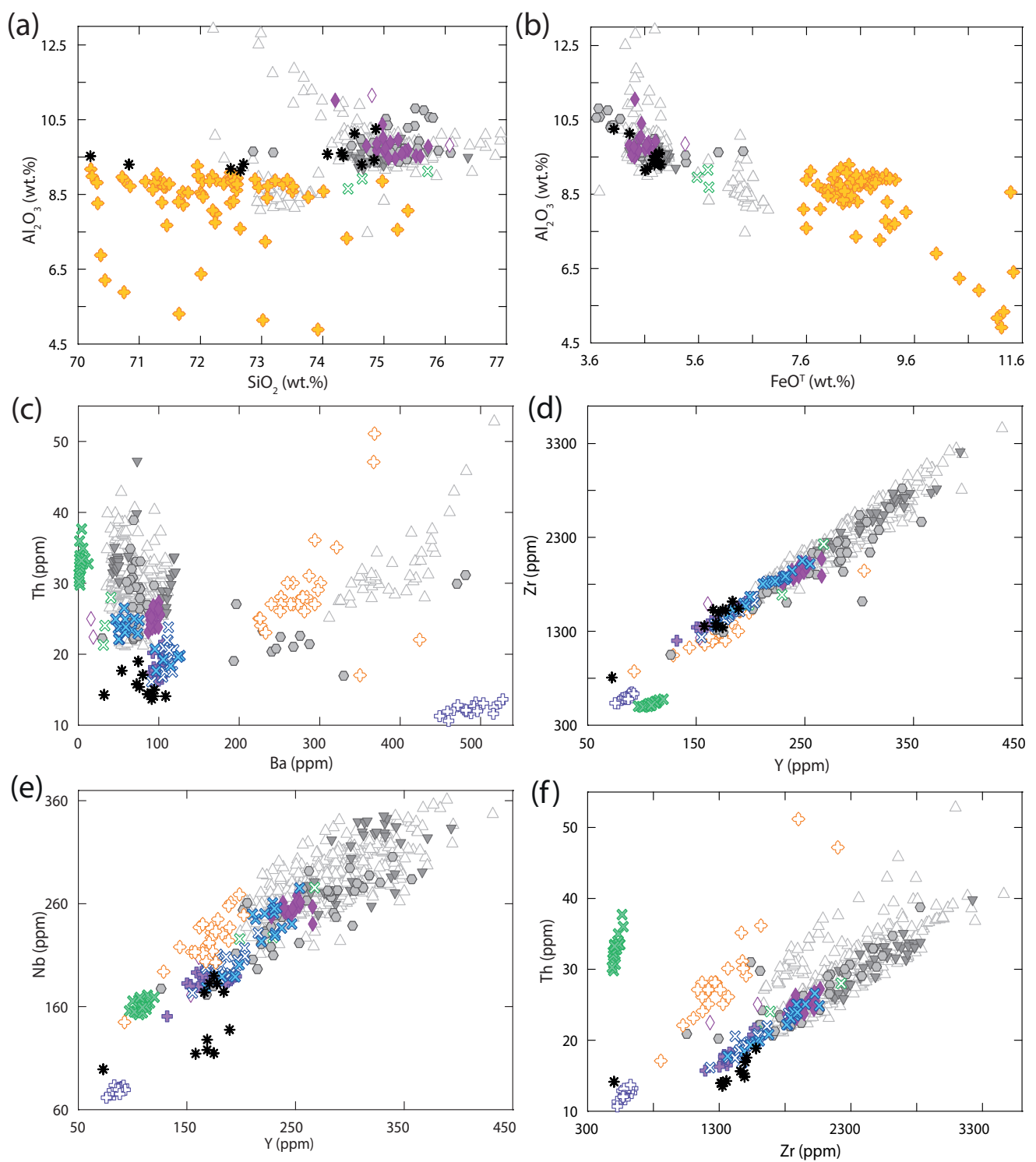

\begin{tabular}{|c|c|c|}
\hline Outcrops & & Published data \\
\hline ST-NW 1 & & \& Boseti (Macdonald et al., 2012) \\
\hline $\begin{array}{l}\diamond E 95007 \\
\text { 引 E95003 } \\
\text { \E95010 }\end{array}$ & 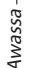 & $\begin{array}{l}\text { F Fantale (Taylor et al., 1997) } \\
\text { * Corbetti (Rapprich et al., 2016) }\end{array}$ \\
\hline $\begin{array}{l}\text { \&3 E95011 } \\
\text { E E95019 }\end{array}$ & $\perp$ & $\begin{array}{l}\text { Lake archives } \\
\triangle \text { Tilo }\end{array}$ \\
\hline $\begin{array}{l}\text { X E95025 } \\
\text { \& E97003 }\end{array}$ & $\stackrel{ }{F}$ & $\begin{array}{l}\square \text { Awassa } \\
\nabla \text { Chamo }\end{array}$ \\
\hline
\end{tabular}

Figure 7.14: Comparison of the composition of tephra glass shards from Awassa, Tilo and Chamo with the composition of outcrop samples from Corbetti, Tilo crater walls and published melt inclusion data on obsidians erupted from Boseti and Fantale volcanoes from Taylor et al. (1997); Macdonald et al. (2012). 
is the source for these tephras, this would explain the thickness $(<48 \mathrm{~cm})$ of the tephras from nearby lake Tilo. Glass analysis of tephras from Corbetti are now required to confirm these correlations. Despite the limitations, these comparisons are the first and best attempt to characterise and correlate these tephras to a source.

An obsidian sample (E95003) from a Quarry to the east of Awassa and obsidian xenolith from the Tilo crater walls (E95025) have distinct compositions $(\mathrm{Zr} / \mathrm{Th} \approx 43.9-50.7$ and $\approx 15.0-16.7$, respectively $)$. It is possible that these samples are older and the xenolith could be derived from a different centre, potentially explaining their distinct composition.

The only tephra outcrop sample to have a similar composition to the lakes Awassa, Tilo and Chamo tephras is ST-NW1, collected from the Shalo Swamp ( $\sim 10 \mathrm{~km}$ east of Lake Awassa). The ST-NW1 glass shards have similar Zr/Th ratios $(\approx 71.1-82.6)$ and compositions to the youngest group of Tilo tephras (TT-1; 2; 4 and TT-5, Zr/Th $\approx 71.6-89.6$ ) and the youngest Chamo tephra (CHT-1; $\mathrm{Zr} / \mathrm{Th} \approx 73.9-86.7)$. Glass shards in ST-NW1 contain higher Ba concentrations than TT- 4 and TT-5 and have a more comparable composition to TT-1, TT-2 and CHT-1 (Fig. 7.15c). However, CHT-1 glass shards are more evolved than the ST-NW1 glass shards (Fig. 7.15d, e, f). The similarities between the ST-NW1, the youngest Tilo tephras and CHT-1 glass shards are explored further using a PCA in Fig. 7.16. This demonstrates that TT-4 and TT-5 have different compositions to ST-NW1 (Fig. 7.16a, c) and supports the similarities between TT-1 and TT-2 noted previously. It is not possible to clearly identify whether TT-1 or TT-2 are correlatives of ST-NW1. Figure 7.16 reiterates that STNW1 and CHT-1 have statistically different compositions, however, the collective compositional fields occupied by ST-NW1 and CHT-1 occupy a broadly similar 
area to the TT-2 glass shards. It is possible that ST-NW1 and CHT-1 were produced by the same eruptive event and a change in wind direction during the eruption caused less evolved compositions to be erupted close to the source, at the Shalo Swamp (eastern shores of Lake Awassa), and more evolved compositions to be deposited only at distal locations, at Lake Chamo. This widespread tephra deposit may be the Wendo Koshe pumice, produced by the most recent explosive eruption from Wendo Koshe (Rapprich et al., 2016). If TT-2 is the Wendo Koshe pumice, the older and compositionally distinct TT-3 (Tilo Group I), may be the pyroclastic deposit from Fike Volcano that underlies the Wendo Koshe pumice in the Awassa area. However, further glass analyses of the Wendo Koshe pumice and the Fike Volcano pyroclastic deposits are required to ascertain this.

Therefore, it is possible that many tephras recorded in the Awassa, Tilo and Chamo archives are derived from centres within the Corbetti caldera. However, the source of two Tilo tephras and one Awassa tephra, which have distinct compositions, remains uncertain. To determine the source of these distinct tephras, further detailed field work and glass analyses on proximal tephra samples is required.

\subsubsection{The tempo, petrogenesis and characteristics of $<10 \mathrm{ka}$ Corbetti eruptions}

The previous section demonstrated that most tephras recorded in lakes Awassa, Tilo and Chamo are potentially derived from the Corbetti caldera. The distribution and frequency of tephra deposits in these archives gives an indication of the frequency of regional eruptions, most likely derived from Corbetti. The Tilo archive preserves the most comprehensive record of regional volcanism. Lake Awassa drains the $1300 \mathrm{~km}^{2}$ Corbetti caldera, whilst Tilo is a $<1 \mathrm{~km}$ diameter, 

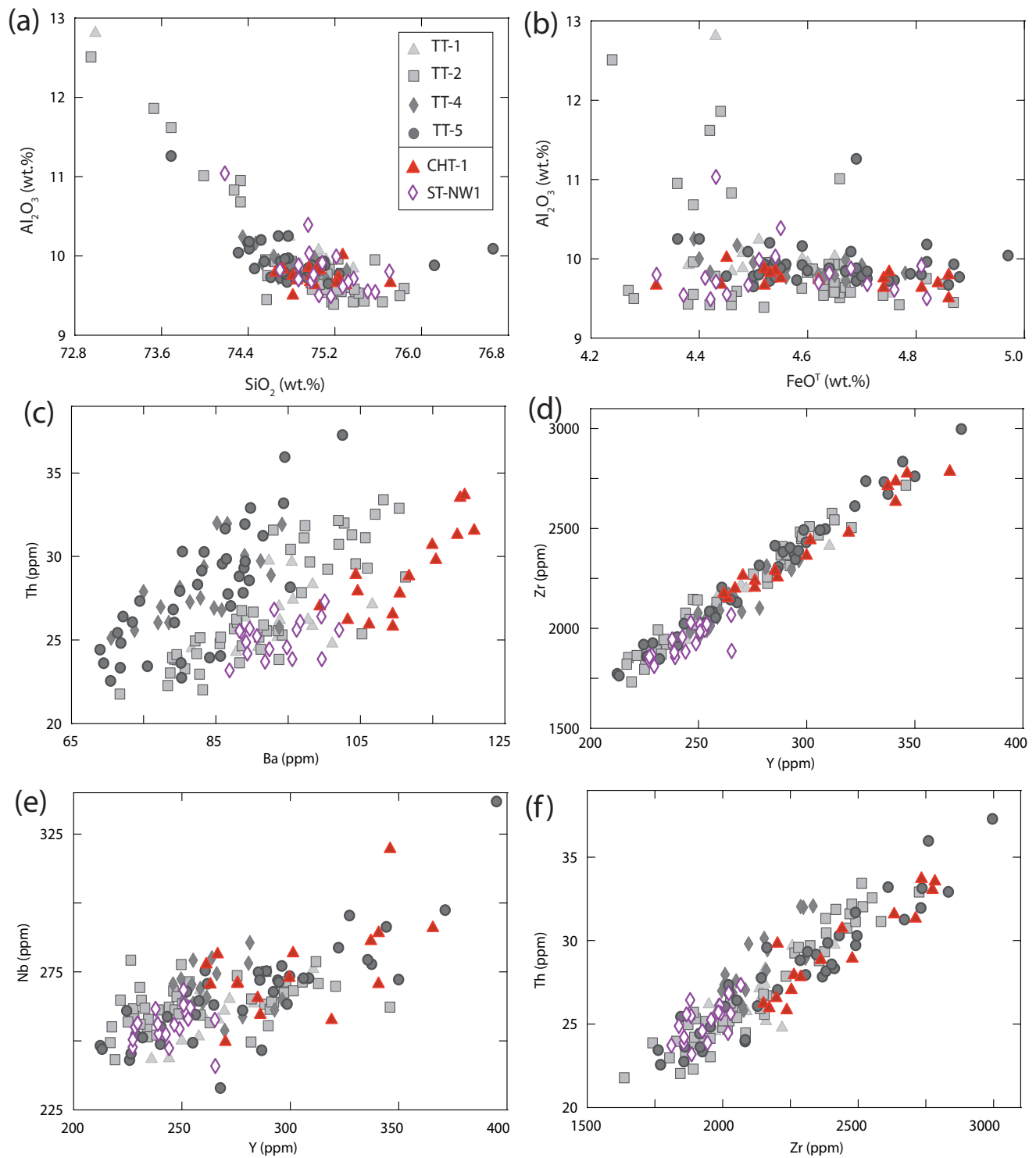

Figure 7.15: Bi-plots comparing concentrations of selected major and trace elements in the ST-NW1, CHT-1, TT-1;2;4 and TT-5 tephra glass shards 

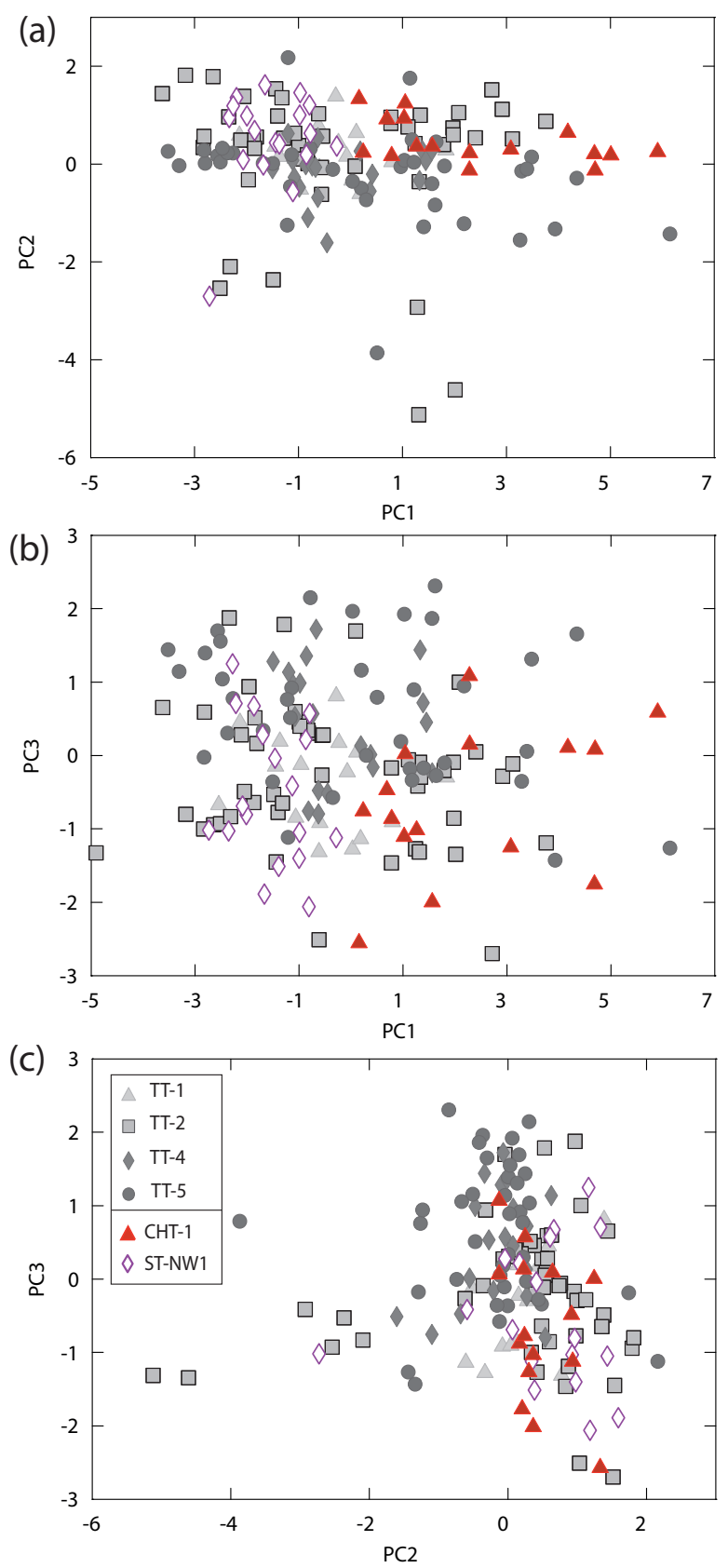

Figure 7.16: Bi-plots of the first three principal components from a principal component analysis of the compositionally similar ST-NW1, CHT-1, TT-1;2;4 and TT- 5 tephra glass shards. $\mathrm{SiO}_{2}, \mathrm{Al}_{2} \mathrm{O}_{3}, \mathrm{FeO}^{T}, \mathrm{Y}, \mathrm{Zr}, \mathrm{Nb}, \mathrm{Ba}, \mathrm{La}$ and Th are used as variables. 
steep sided crater lake with no in or out-lets (Fig. 7.13). It is possible that the Awassa tephras cannot be correlated to Tilo tephras because they contain mixed populations, having been reworked and mixed with older tephras within the Awassa catchment. However, tephras deposited in Tilo are most likely primary deposits, and their occurrence and thickness therefore provide an accurate reflection of past eruption frequency, and an indication of eruption explosivity.

The Tilo archive records 12 eruptions which appear to be derived from Corbetti during the past $10.2 \mathrm{ka}$. Fig. 7.17 shows selected trace element ratios in these 12 tephra deposits against their age ranges, giving an indication of the timing and composition of past eruptions. Many of the Tilo tephras range in thickness from several centimetres to half a metre, at a distance of $\sim 40 \mathrm{~km}$ from Corbetti, suggesting that numerous recent eruptions from this centre have been highly explosive.

The first Corbetti eruption recorded in the Tilo archive occurred at 10.2-9.3 cal. ka BP, depositing the thickest $(48 \mathrm{~cm})$ tephra (TT-14) in the Tilo archive. Following a short period $(\sim 450$ years $)$ during which no tephras were recorded in the Tilo archive, an eruption occurred from Corbetti $(8.9-8.0$ cal. ka BP), depositing TT-13 at Lake Tilo and CHT-2 at Lake Chamo $(\sim 170 \mathrm{~km}$ to the southwest). $\mathrm{A} \sim 980$ year period without tephra deposition at Lake Tilo followed, potentially reflecting the longest interval of quiescence at Corbetti over the past $\sim 10 \mathrm{ka}$. However, this could be related to changes in dominant wind direction during this time, or lower preservation potential at Lake Tilo. An explosive eruption from Corbetti followed at 7.0 - 6.1 cal. ka BP, depositing TT-12 at Lake Tilo. Over the past $\sim 7.0 \mathrm{ka}, 10$ explosive eruptions occurred from the Corbetti caldera and at frequent intervals, averaging one eruption every $\sim 700$ years. All tephras deposited in the Tilo archive during the past $7.0 \mathrm{ka}$ have overlapping age 
(a)

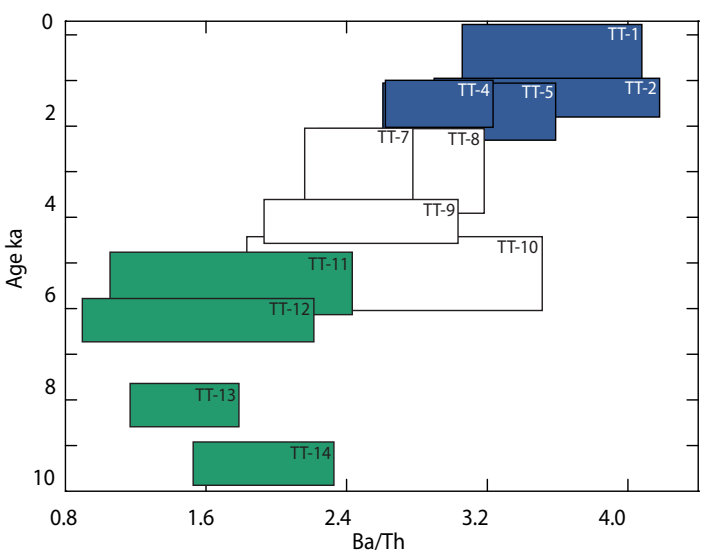

(b)

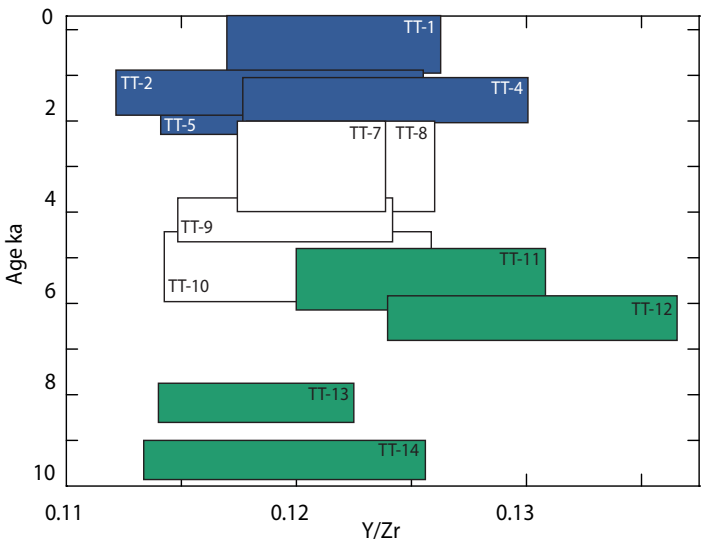

(c)

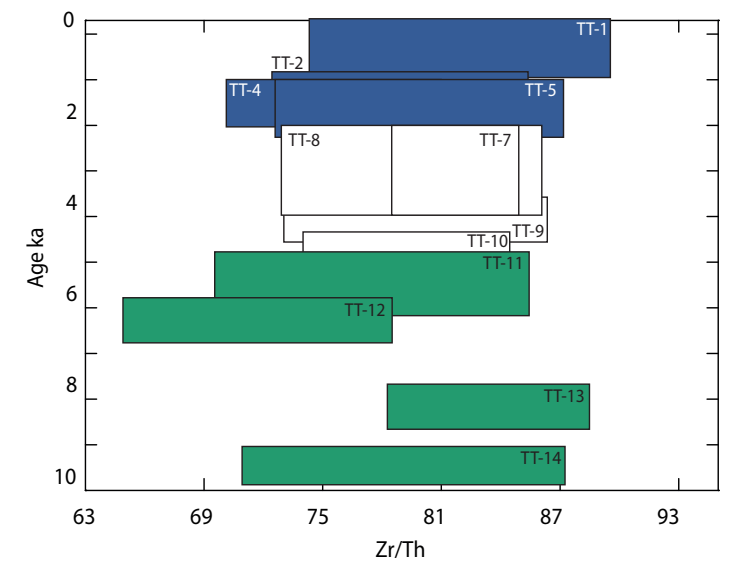

Figure 7.17: Selected trace element ratios in the Tilo Group II tephra glass shards plotted against their age ranges, modelled at the $95.4 \%$ confidence interval. Groups of tephras which have similar compositions and ages are indicated in the same colour. 
ranges at $95.4 \%$ confidence intervals. During $\sim 6.3-2.3 \mathrm{ka}$, three eruptions from Corbetti deposited three, $30-37 \mathrm{~cm}$ thick, tephras at Lake Tilo. These tephras were also recorded as reworked deposits in Lake Awassa. The most explosive of recent eruptions from Corbetti, potentially the Wendo Koshe Pumice eruption, deposited the $20 \mathrm{~cm}$ thick TT-2 tephra in Lake Tilo at $2.1-1.2 \mathrm{cal}$. ka BP. The same eruption most likely deposited tephra at Shalo Swamp (east of Lake Awassa) and at Lake Chamo, to the south-west.

The most recent eruption from Corbetti caldera occurred at $1.3-0.5 \mathrm{cal}$. ka BP (641 - 1900 AD), depositing TT-1 in Lake Tilo. This is younger than the most recent 400 BC Wendo Koshe eruption described by Rapprich et al. (2016).

Figures 7.5 and 7.17 show that the Awassa and Tilo tephra glass shards have wide intra-eruptive compositional ranges, indicating these tephras originated from an evolving or compositionally zoned magma chamber. In contrast, the Chamo tephras are more homogeneous (Fig. 7.5), although it is possible that only part of the compositional range is represented at distal sites as wind direction can change during an eruption. However, it should be noted that fewer glass shards from the Chamo tephras were analysed. Figure 7.17 shows how the composition of tephras originating from Corbetti has changed over the past 10.2 ka. Concentrations of incompatible elements in the Tilo tephra glass shards remain relatively consistent through time. This may reflect the frequency of the eruptions from Corbetti, with little time between eruptions for fractional crystallisation to evolve the composition. Rapprich et al. (2016) also described the uniform geochemistry of the post-caldera eruptives from Corbetti over time. Nonetheless, following the longest period of quiescence recorded in the Tilo archive, erupted glass compositions (TT-12) contain higher concentrations of Y in relation the older TT-13 glass shards. It is apparent that between the eruption 
of TT-13 and TT-12, there was sufficient time for fractional crystallisation to cause enrichment of $\mathrm{Y}$ in the melt.

Barium concentrations vary the most dramatically in the Tilo tephras, showing an increasing trend through time. However, Fig. 7.17a shows that this relationship is more complex. For instance, TT-11; 12; 13 and 14 (10.2-5.1 ka) show a progressive depletion in Ba concentrations through time, contrary to the overall trend. During 6.3 - 2.3 ka, the tephras deposited (TT-7; 8; 9 and 10) have broadly consistent Ba concentrations through time. Recent volcanism, between 2.6-0.1 ka, deposited tephras TT-1; 2; 4 and 5, which are increasingly enriched in Ba through time.

It is apparent that $\mathrm{Ba}$ appears to be behaving as an incompatible element in the Tilo tephra glass shards (Fig. 7.1c). This is contrary to the typical compatibility of Ba in feldspars. However, Mahood and Stimac (1990) described the complex behaviour of $\mathrm{Ba}$ in peralkaline melts and found that $\mathrm{Ba}$ is only weakly compatible in pantellerites. It is therefore possible that Ba may be behaving as a weakly compatible to incompatible element in the pantellerite Tilo tephras.

However, Section 5.4.1 highlighted that the Tilo tephras are highly evolved. Due to the minimum composition of the Tilo tephras, it is possible that they could not undergo further fractional crystallisation.

Assimilation of crustal rocks containing high $\mathrm{Ba}$ concentrations could cause its continued enrichment in the Tilo tephras through time. Figure 7.18 models the change in composition of the Tilo tephras through assimilation fractional crystallisation. The southern Ethiopian Precambrian basement rocks contain variable Ba concentrations (39-1730 ppm), here, the average composition of high-Ba granitoid basement rocks from Peccerillo et al. (1998) are used as the assimilant. The model assumes that $8 \%$ of the crustal rocks were melted. The 
Tilo tephras are highly evolved and their melt most likely relatively cool and incapable of melting large volumes of crustal rock.

Figure 7.18 shows that assimilation of even high-Ba basement rocks cannot increase $\mathrm{Ba}$ concentrations sufficiently to explain the range of compositions exhibited by the Tilo tephras.

The youngest Tilo tephras (TT-1 to TT-5) show the most systematic increase in $\mathrm{Ba}$ concentrations through time. However, using the oldest of these tephras (TT-5) as the starting composition, assimilation of the basement still causes modelled $\mathrm{Ba}$ concentrations to decrease, rather than increase.

Tephras TT-7; 8; 9 and TT-10 show complex magmatic evolution, with fluctations in Ba concentrations between the eruption of each tephra. These steplike changes may be related to replenishment of the Corbetti magma chamber with less fractionated magma. Figure $7.18 \mathrm{~b}$ and $\mathrm{c}$ shows that concentrations of incompatible elements decrease between the eruption of TT-13 and TT-14 and again TT-13 and TT-12. Fractional crystallisation typically increases these elements in the residual melt, and this pattern may therefore suggest magma recharge played a role in the evolution of these tephras. Sampling of proximal deposits from Corbetti, coupled with mineral analyses and isotope data are required in order to identify the magmatic processes involved in the petrogenesis of the Tilo tephras. 

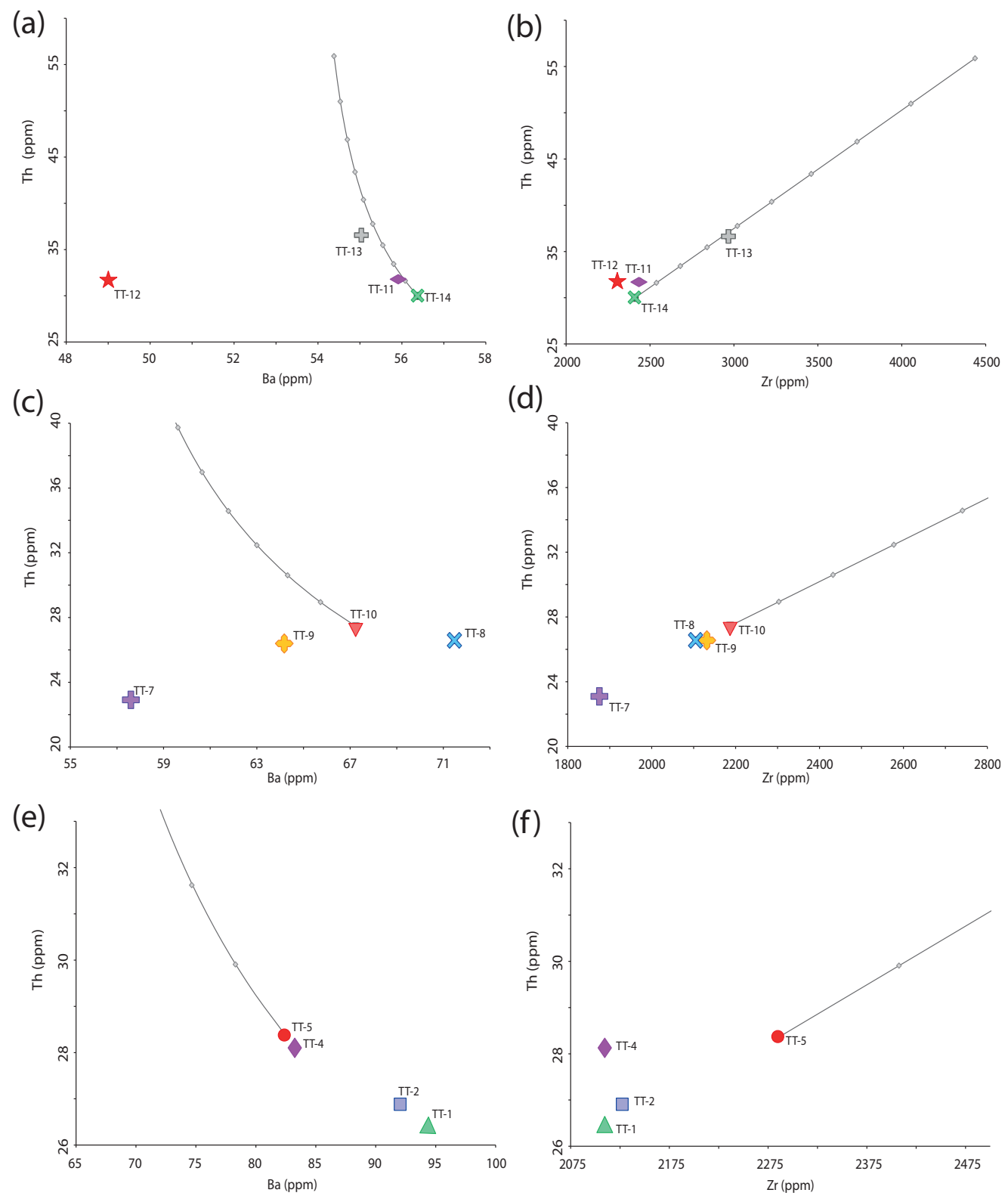

Figure 7.18: Bi-plots showing the average concentrations of selected trace elements in Tilo tephra glass shards. The Tilo tephras are grouped on the basis of their varying Ba concentrations through time (see Fig. 7.17). Lines indicate modelled assimilation fractional crystallisation using the older tephra from each 'episode' as the starting composition, with increments indicating $1 \%$ assimilation of the crust. High-Ba granitoid basement rocks from Peccerillo et al. (1998) were used as the assimilant. A mineral assemblage of $20 \%$ orthoclase, $20 \%$ plagioclase, $5 \%$ aenigmatite, $3 \%$ C-pyroxene, $2 \%$ olivine, $0.2 \%$ apatite and $0.1 \%$ ilmenite was used, based on CIPW norm calculations and petrography of Corbetti pyroclastic deposits noted by Di Paola (1971). Bulk partition coefficients for trace elements in peralkaline rhyolite melts are from Mahood and Stimac (1990); Pearce (1990) and Ewart and Griffin (1994). 


\subsection{Conclusions}

Tephras recorded in lake archives from Awassa, Tilo and Chamo provide the first record of Holocene volcanism from the central Main Ethiopian Rift. Twenty three tephras occur in these archives, varying from proximal tephras attaining half a metre in thickness in the Awassa and Tilo archives, to distal $<1 \mathrm{~cm}$ tephras in the Chamo archive. A total of $\sim 1200$ major and trace element analyses on 19 of these tephras have been presented here. Two tephras preserved in the Chamo archive, CHT-2 (9.4 - 6.3 cal. ka BP) and CHT-1 (2.8 - 1.2 cal. ka BP), are tentatively correlated to two Tilo tephras, respectively TT-13 (8.9-8.0 cal. ka BP) and TT-2 (2.0 - 1.2 cal. ka BP), on the basis of their major and trace element compositions. Furthermore, two Awassa tephras, AWT-4 (6.6 - 5.4 cal. ka BP) and AWT-2 (4.9-3.3 cal ka BP) have similar compositions to TT-8; 9 and TT-10 (6.3 - 2.3 cal. ka BP), however it is not possible to ascertain which are correlatives.

The correlation of CHT-2 to TT-13 ties down the chronology for the lower half of the Chamo core, where the radiocarbon dates have greater uncertainties.

The distinct incompatible element ratios of the Awassa, Tilo and Chamo tephras suggest they may have been derived from potentially three volcanic centres. However, many of the Awassa, Tilo and Chamo tephra glass shards have similar incompatible element ratios and compositions, suggesting that one volcanic source may have erupted most of these tephras. Glass analyses of proximal obsidian and tephra samples from Corbetti caldera (located on the northern shores of lake Awassa, $<40 \mathrm{~km}$ east of lake Tilo and $170 \mathrm{~km}$ north of Lake Chamo) show that this is the most likely source for many Awassa, Tilo and Chamo tephras. It is possible that TT-2 and CHT-1 represent the Wendo Koshe 
Pumice, produced by the 400 BC eruption from the Wendi Koshe volcano, inside the Corbetti caldera (Rapprich et al., 2016).

Biggs et al. (2011) demonstrated that Corbetti has undergone numerous uplift and subsidence events of $10-15 \mathrm{~cm}$ over the past decade, suggesting that this volcano remains very much active. The hazards posed by this volcano are significant; 570,000 people live within $5 \mathrm{~km}$ of Corbetti and this volcano is listed at the highest risk level in the World Bank report on volcanic hazards in the MER (Siebert et al., 2011; Aspinall et al., 2011). Furthermore, Rapprich et al. (2016) suggests that future eruptions from Corbetti could cover nearby Awassa and Shashamene towns in $\sim 0.5 \mathrm{~m}$ of pumice. The local inhabitants remain unaware of the potential hazards posed by Corbetti and no crisis management plan exists (Rapprich et al., 2016).

This is the first study to date that provides a $<10$ ka volcanic history for this volcano, and therefore has important implications for hazards assessments in this area. Twelve of the total 14 tephras deposited in the Tilo archive over the past $<10 \mathrm{ka}$ are potentially derived from Corbetti, averaging an eruption frequency throughout the archive of $\sim 1$ eruption every 800 years. The latest, historic, eruption may have occurred from Corbetti at $1309-50$ cal. ka BP $(641-1900$ $\mathrm{AD})$. This is younger than the most recent, $400 \mathrm{BC}$ eruption from Wendo Koshe reported by Rapprich et al. (2016). The Tilo archive shows that 6 highly explosive eruptions occurred from Corbetti over the past $10 \mathrm{ka}$. Furthermore, two of these eruptions at $8.9-8.0$ cal. ka BP and as recently as $2.1-1.2$ cal. ka BP were sufficiently powerful to deposit tephra $170 \mathrm{~km}$ to the south, at Lake Chamo. It is likely that many of these eruptions from Corbetti during the past $<10 \mathrm{ka}$ deposited additional regional tephra layers, which may be identified in future studies. Identification of these tephras in other locations throughout Ethiopia will 
allow more detailed mapping of the dispersal of these tephras from Corbetti and enable the explosivity of these eruptions to be calculated.

The magmatic evolution of tephras derived from Corbetti during the past $10 \mathrm{ka}$ is complex. Potentially due to the frequency of eruptions from Corbetti, fractional crystallisation may not have had time to significantly influence the composition of the Tilo tephras between each eruption. An apparent increase in $\mathrm{Ba}$ concentrations in the Tilo tephras through time is not related simply to assimilation of high-Ba basement rocks. Clearly, further field work and proximal sampling of the Corbetti eruptives is required to constrain the petrogenesis of these tephras. It is likely that mineral and isotope analyses will also shed light on the magmatic evolution of the Corbetti tephras.

Finally, this chapter has demonstrated that lake sediments from a range of geographic settings, preserving proximal and cryptotephras, can provide valuable records of past volcanism. The value of these archives for reconstructing past volcanism is dependant on the geographic setting of these lakes. Sediments from Lake Tilo, located in a small closed basin, has provided the most complete record of past volcanism from this area. The archives from the central Main Ethiopian Rift provide an insight into the frequency and magnitude of eruptions from centres that have no volcanic history and pose a high risk. Given the frequency and thickness of previous events recorded in the Tilo archive, it is likely that future eruptions from Corbetti will be highly explosive. Further field work at Corbetti is required to understand the risks posed by this centre, and this is the subject of current investigations by the RiftVolc project (http://www.geos.ed.ac.uk/riftvolc) and the Ethiopian and Czech geological surveys (Rapprich et al., 2013; Žáček et al., 2014; Rapprich et al., 2016). 


\section{Chapter 8}

\section{Conclusions}

\subsection{Context}

The Ethiopian Rift Valley represents a fascinating natural laboratory where active continental rifting can be observed and associated magmatic and tectonic processes studied. The rift basins have provided desirable conditions for the proliferation of life, and subsequent preservation of fossil remains. Beginning in the 1960s, the Ethiopian Rift Valley has been intensely explored, leading to the discovery of the most comprehensive record of human evolution spanning the past 6 million years (WoldeGabriel et al., 2013). Quaternary tephra deposits, erupted from volcanoes throughout Ethiopia, and inter-bedded within fossiliferous sedimentary sequences at archaeological sites, have assumed paramount importance in providing crucial chronological control for hominin fossils (e.g. Brown, 1982; Pickford et al., 1991; WoldeGabriel et al., 1999; Katoh et al., 2000; Clark et al., 2003; Brown et al., 2006; Haile-Selassie et al., 2007; Campisano and Feibel, 2008; DiMaggio et al., 2008; Saylor et al., 2016). 
Volcanic activity continued into the Holocene, and there are currently 65 volcanoes of suspected Holocene age throughout Ethiopia (Siebert et al., 2011). Four volcanoes (Corbetti, Alutu, Bora and Haledebi) in the Main Ethiopian Rift are actively deforming and many more are at fumarolic stage (Biggs et al., 2011; Siebert et al., 2011). Despite this, only 14 volcanoes in the region have a recorded historic eruption and the recent volcanic history of Ethiopia remains largely unconstrained (Siebert et al., 2011). The hazards posed by these volcanoes are underestimated, and the World Bank report on volcanic hazards lists the risk posed by the Main Ethiopian Rift volcanoes at the highest level of uncertainty (Aspinall et al., 2011). Furthermore, towns, cities and industries in the Main Ethiopian Rift are rapidly developing, notably $\sim 570,000$ people live $<5 \mathrm{~km}$ from the actively deforming Corbetti volcano (Siebert et al., 2011). The potential for regional volcanoes to erupt without warning is exemplified by the Nabro (2011) eruption from Eritrea. Volcanic ash dispersed by the eruption disrupted international air traffic, and no volcanic monitoring network existed at the time of the eruption, so there was no warning (Lenhardt and Oppenheimer, 2014; Goitom et al., 2015). Projects including the Ethiopia-Afar Geoscientific Lithospheric Experiment (EAGLE), Afar Rift Consortium and RiftVolc have supplied valuable information on past and current volcanism and hazards (e.g. Ayele et al., 2007b; Bastow et al., 2011; Keir et al., 2011; Ferguson et al., 2013). However, to date, studies focussing on the Holocene tephra record in Ethiopia remain scarce.

The early stage of regional geological studies, may in part, be related to the logistical challenges of undertaking field work in remote and inhospitable regions, notably the Afar Rift (Wiart and Oppenheimer, 2004). Proximal deposits close to volcanic centres may be buried, eroded or have no clear stratigraphic context and may therefore not provide a comprehensive record of past volcanism 
(e.g. Rawson et al., 2015). In contrast, lakes throughout the Ethiopian Rift Valley and surrounding rift shoulders preserve tephras in aggrading systems (White and Riggs, 2001). Thus, sediment archives from these lakes provide more complete records of past volcanism, and provide information on the timing of past eruptions and the inter-relationships between different centres (e.g. Feakins et al., 2007). Lake sediments have good potential for radiocarbon dating and these dates can be used in conjunction with stratigraphic information in Bayesian age models, e.g. OxCal (Bronk Ramsey, 2009a), to further constrain the ages of eruptive events (e.g. Rawson et al., 2015).

This study aimed to construct an initial late Pleistocene to Holocene tephra frame work for Ethiopia, using sediment archives collected from lakes throughout the region and a selection of samples from outcrops proximal to volcanoes. This represents the first systematic study of visible and crypto-tephras occurring in Ethiopian lake sediments. This work set out to assess if this lake sediment tephrostratigraphic approach can successfully be applied in this region and whether lake archives provide comprehensive records of volcanism. Specific research questions were asked, including: can tephras in Ethiopian lake archives be correlated? What are the sources for these tephras? What do these deposits tell us about the timing of past eruptions? Answering these questions would give an insight into past eruptions, and therefore provide important information on volcanic hazards associated with future eruptions. Finally, this study set out to investigate the magma genesis of recent volcanism in Ethiopia, and how tectonic setting may influence erupted magma composition, providing valuable information on the evolution of some of the least studied peralkaline volcanoes on Earth (Hutchison et al., 2015). 


\subsection{A late Pleistocene-Holocene tephrostratigraphy for Ethiopia}

This study has successfully presented the first late Pleistocene to Holocene tephrostratigraphy for Ethiopia, constructed using sediment archives from seven lakes: Ashenge and Hayk (Ethiopian Highlands), Dendi and Hora (Yerer-Tullu Welle Volcano Tectonic Lineament) and Awassa, Tilo and Chamo (central Main Ethiopian Rift). This tephra record represents the most detailed account of Holocene volcanism in selected areas of the Ethiopian Rift so far available. This is the first major and trace element single grain glass dataset of Holocene Ethiopian tephras. The dataset will enable the future identification of these tephras in other locations, and provides information on the magmatic evolution of regional peralkaline volcanoes. Bayesian age models have provided an initial indication of eruption recurrence rates in this area, which have important implications for hazard assessments. The implications of this tephra framework, in relation to specific research questions, outlined in Chapter 1, are discussed below and are summarised in Fig. 8.1.

\subsubsection{Ethiopian lake archives provide a valuable record of past volcanism}

Lake sediment archives have proved a powerful resource for constructing a record of Ethiopian volcanism. This work has investigated lake archives from a range of geographic settings, containing complementary records of both proximal tephras and crypto-tephras. This study has shown that this tephrostratigraphic approach has numerous advantages over studying proximal tephras exposed at volcanoes. Notably, archives from lakes Ashenge, Hayk, Dendi, Hora and Tilo preserve 
inter-fingering tephra deposits from multiple volcanoes. This has enabled the timing of past volcanism from a number of centres to be assessed simultaneously. These interpretations would be significantly more challenging based on their proximal counterparts. Furthermore, this regional tephrostratigraphic approach has shown the capacity for developing a regional understanding of the dispersal and explosivity of past eruptions.

This study also demonstrates the considerable potential for future application of this approach elsewhere in Ethiopia. The Hominin Sites and Paleolakes Drilling Project (HSPDP, https://hspdp.asu.edu/) has collected some 2,000 m of lake sediments, extending back $4 \mathrm{Ma}$, from locations throughout Ethiopia and Kenya to investigate the palaeoclimatic context of hominin evolution. It is likely that some of the tephras studied here will be identified in late Pleistocene to Holocene sections of these sediments, and this will enable the dispersal of these tephras to be further refined. Lake sediments show potential for refining the tephrostratigraphy and dispersal of Quaternary tephras which have already proved so invaluable for dating east African archaeological sites.

The completeness of lake sediment tephra records depends upon the dispersal of tephras and their subsequent deposition and dispersal at the lake site. This is demonstrated by lakes Ashenge and Hayk, from the Ethiopian Highlands. These lakes are located $<140 \mathrm{~km}$ apart, along the rift escarpment and close to volcanoes in the Afar Rift. However, archives from these lakes record different eruptive events. It is possible that local eruptions, potentially from the nearby Afar Rift, dispersed these tephras over only small areas. Futhermore, it is probable that the dispersal of these tephras is largely dependant on wind direction. The dominantly easterly winds provide favourable conditions for tephra dispersal towards lakes Ashenge and Hayk, in the west. However, to record an eruptive event in both 


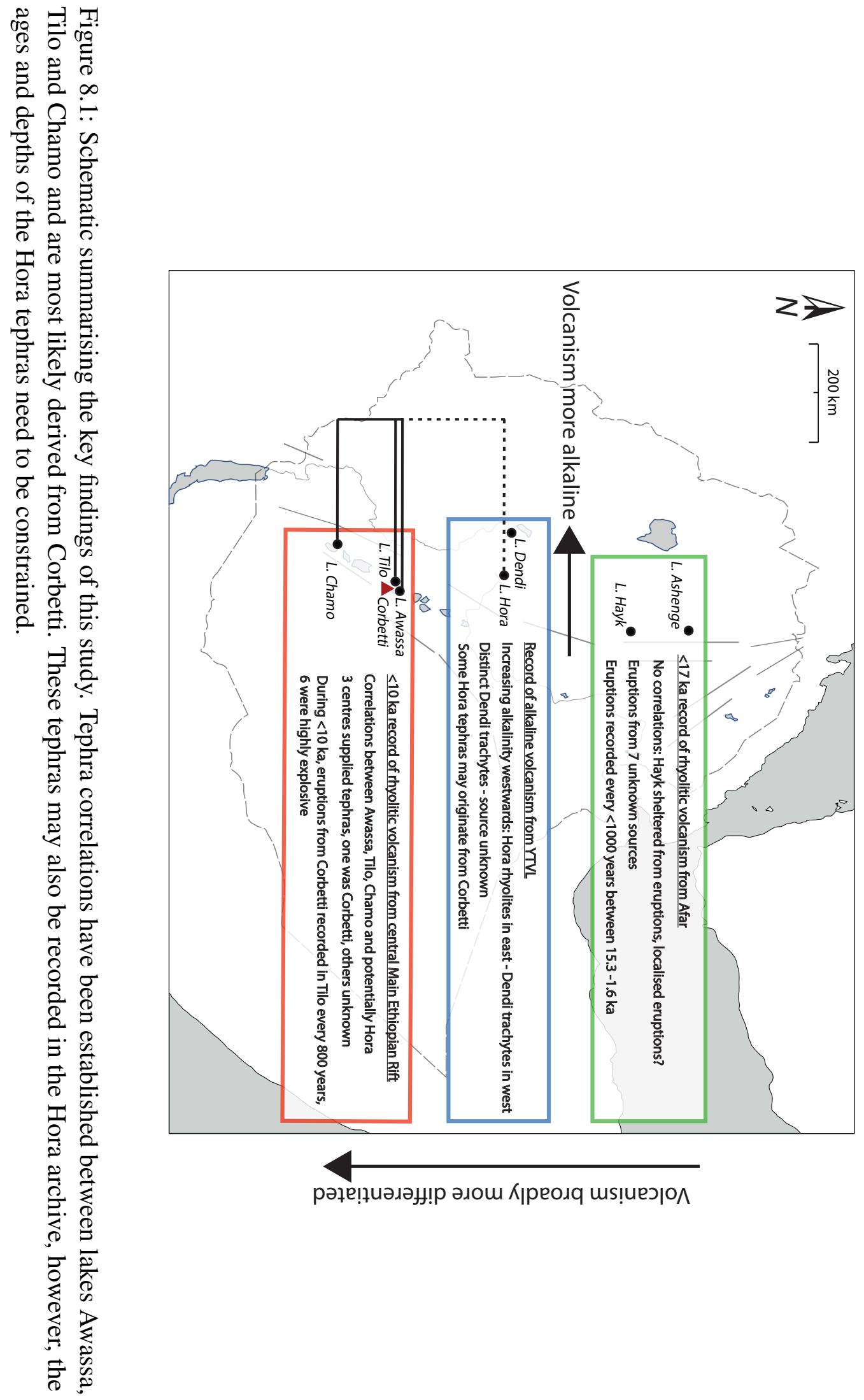


archives, a change in wind direction mid-eruption would be required to disperse tephra towards Hayk, located to the south of Ashenge. Ashenge and Hayk are located on the edge of the rift shoulders; however, Hayk is sheltered from volcanoes in the Afar Rift by a series of horsts. Lake Ashenge is, in contrast, more exposed and its surrounding topography may essentially 'funnel' localised volcanic plumes towards the lake basin. These differences may explain why A. Asrat (Addis Ababa University) noted that tephra from the Nabro 2011 eruption was deposited in the vicinity of Lake Ashenge, but not at Lake Hayk (A. Asrat 2016, pers. comm., 23rd Feb 2016). Thus, it is possible that location and basin morphology of these lakes may have limited the potential for an eruption to be simultaneously recorded in both archives. Depsite these challenges, archives from Ashenge and Hayk provide the most comprehensive record of the timing and composition of Holocene eruptions from volcanoes in the Afar so far available.

Archives from the central Main Ethiopian Rift demonstrate that the setting and the lake catchment morphology influence the type and frequency of tephras recorded in sediments. The Tilo and Awassa archives were collected from lakes $<40 \mathrm{~km}$ apart, and contain proximal tephras of $\sim 50 \mathrm{~cm}$ thickness. The Tilo archive proved the most comprehensive archive from this region. However tephras in the Awassa archive cannot be directly correlated directly to Tilo tephras. The Awassa tephras contain mixed glass populations, possibly associated with reworking, which explains why these tephras cannot be correlated to individual eruptive events in the Tilo archive. The $<1 \mathrm{~km}$ diameter, steep sided, Tilo crater lake has no direct in or outflow. However, Lake Awassa has a contrasting morphology, possessing an area of $\sim 92 \mathrm{~km}^{2}$ and draining the $1300 \mathrm{~km}^{2}$ Corbetti caldera. Tephras deposited within the Awassa catchment may therefore be mixed with older tephras prior to redeposition on the Awassa lake floor. Thus, there 
is more potential for the Awassa tephras to be mixed with pre-existing tephra deposits in the Corbetti caldera, prior to their deposition at the lake bed. The Tilo tephras most likely represent primary air-fall deposits, and their thicknesses are potentially a real reflection on the explosivity of past eruptions from Corbetti. Rapprich et al. (2016) demonstrate that the volcanic history of Corbetti is difficult to constrain based on proximal deposits. This work shows the significant value of lake sediment archives like Tilo, which provides an accessible record of 12 eruptions from Corbetti during the past $10 \mathrm{ka}$.

The lake sediment tephrostratigraphic approach can be successfully applied in Ethiopia. This study paves the way for future studies to refine this tephra record spatially and temporally. Nonetheless, the interpretation of past volcanism using tephra records in lake sediments must be considered within the wider context, including variations in lake basin morphology and wind direction. These factors may influence the potential for tephra correlation and have implications for estimations of past eruption frequency and explosivity. This work shows that lakes with smaller drainage basins, located in an exposed setting and down-wind of volcanoes, are more likely to record comprehensive tephra records.

\subsubsection{The composition of $<17 \mathrm{ka}$ tephras varies spatially}

This study presents a database of the major and trace element glass compositions ( 2100 analyses) of 47 visible and crypto-tephras recorded in Ethiopian lake archives. This database will aid the future identification of the tephras at proximal and distal localities. The geochemistry of these tephras also gives an important insight into the magmatic evolution of peralkaline silcic volcanism.

Tephras deposited throughout the Ethiopian Rift are dominantly peralkaline rhyolites (comendites and pantellerites) with minor peraluminous and metalu- 
minous rhyolites. Previous studies have shown that silicic rift volcanism is most likely derived from fractional crystallisation of basalts at shallow depth (Walter et al., 1987; Peccerillo et al., 2007; Ukstins Peate et al., 2008; Rooney et al., 2012). The geochemistry of late Pleistocene-Holocene tephras indicates that these have also evolved through fractional crystallisation of an assemblage dominated by K-feldspar and Fe-Ti oxides.

The composition of late Pleistocene-Holocene tephras recorded in Ethiopian archives varies spatially. Tephras recorded in Tilo, Awassa and Chamo lake sediments contain broadly higher concentrations of the incompatible elements, Y, $\mathrm{Zr}$ and La than tephras in archives from lakes Ashenge and Hayk. Tephras recorded in central MER lakes are the most highly differentiated rhyolitic tephras investigated in this study, and have reached minimum compositions. It is likely that these variations may be related to the differing tectonic settings of the source volcanoes supplying tephras to different regions of Ethiopia. The closest volcanoes to lakes Hayk and Ashenge are in the Afar Rift $(<70 \mathrm{~km})$. Volcanoes in the central Main Ethiopian Rift are located $<40 \mathrm{~km}$ from the Tilo and Awassa lakes. On the basis that these tephras are derived from local volcanoes, there is significantly thinner crust $(\sim 20 \mathrm{~km})$ in the Afar than the central Main Ethiopian Rift ( $~ 30 \mathrm{~km})$. However, despite these differences, there is no apparent difference in the amount of crustal contamination involved in the petrogenesis of tephras recorded in lake archives throughout Ethiopia. In fact, the role of crustal contamination in the evolution of many of these tephras appears to be negligible. This supports work by Peccerillo et al. (2007), who suggest that fractional crystallisation is instead the main cause of magmatic differentiation in this region. However, this work suggests that processes other than fractional crystallisation, potentially recharge, may have influenced the 
evolution of Ethiopian 17 ka tephras. Further sampling from regional volcanoes, coupled with $\mathrm{Sr}$ isotope analysis of eruptives, is now required to constrain the role of crustal assimilation in the evolution of these tephras more confidently.

Peralkaline silicic volcanism in the axial rift is therefore generated by shallow depth fractional crystallisation of mafic magmas. However, at the rift shoulders, the thicker crust causes magmas to pond at greater depths and evolve through high pressure fractional crystallisation to produce phonolites and trachytes. The off-axis Yerer-Tullu Wellel Volcano Tectonic Lineament (YTVL) is made up of alkaline central volcanoes associated with high pressure evolution. The composition of eruptives along this lineament varies from phonolitic-trachytic on the Sudan border, to peralkaline rhyolites $\sim 40 \mathrm{~km}$ from Addis Ababa. The Dendi archive was collected from a crater lake along the western YTVL. The Dendi tephras are dominantly phonolitic-trachytic tephras and most likely derived from a nearby alkaline volcano. Contrastingly, the Hora archive was collected from eastern limits of the YTVL, and contains peralkaline rhyolites which may originate from the axial rift or the centres in the eastern YTVL.

This work shows that the composition of late Pleistocene - Holocene tephras varies spatially. The most marked differences are seen between the peralkaline rhyolitic tephras erupted from the axial rift, versus the phonolitic-trachytic tephras erupted from the rift shoulders.

\subsubsection{Widespread tephras can be correlated between archives from the central Main Ethiopian Rift}

The potential for correlation between tephra layers recorded in lakes along the Ethiopian Rift is directly influenced by the eruption explosivity, tephra dispersal and subsequent depositional processes. This study has successfully established 
tephra correlations between lakes Awassa, Tilo and Chamo, in the central Main Ethiopian Rift. It is likely that these $<10$ ka eruptions were highly explosive and thus dispersed tephras throughout the central Main Ethiopian Rift. Two tephras in the Awassa archive, AWT-4 (6.6 - 5.4 cal. ka BP) and AWT-2 (4.9-3.3 cal. ka BP) may correlate to tephras from the Lake Tilo $(<40 \mathrm{~km}$ from Lake Awassa). However, the Awassa tephras may be reworked and it is not possible to narrow down whether Tilo tephras TT-8; TT-9 or TT-10 $(6.3-2.3 \mathrm{cal}$. ka BP) are correlatives. Two tephras were dispersed $\sim 170 \mathrm{~km}$ to the south of Tilo and recorded in the Chamo archive. Chamo tephra CHT-2 (9.4-6.3 cal. ka BP) and CHT-4 (2.8 - 1.2 cal. ka BP) can be tentatively correlated to Tilo tephras TT-13 (8.9 - 8.0 cal. ka BP) and TT-2 (2.0 - 1.2 cal. ka BP), respectively. It is apparent that conditions, including eruption explosivity and wind direction, were favourable for the dispersal of two of these tephras to distal locations, at Chamo. Further sampling of other depths in the Chamo sediments will most likely yield further cryptotephra deposits. Depending on variations in tephra taphonomy and preservation, there is potential for finding these tephras in Holocene sections of the Chew Bahir lake core ( $\sim 150 \mathrm{~km} \mathrm{SW}$ of Chamo), drilled as part of the Hominin Sites and Paleolakes Drilling Project. These tephras were not dispersed to the Ethiopian Highlands, in the north. Tilo, Awassa and Chamo tephras are geochemically similar to tephras recorded in the Hora archive, to the north. However, the nature of any correlations cannot be futher investigated due to the lack of stratigraphic context and chronological control for the Hora tephras.

Contrastingly, archives from the Ashenge, Hayk (Ethiopian Highlands) and Dendi (Yerer-Tullu Wellel Volcano Tectonic Lineament) lakes cannot be correlated between. Lake Ashenge and Hayk are located $\sim 140 \mathrm{~km}$ from one another, however, they record different eruptive events. It is probable that this is 
related to the contrasting location and basin morphology of these lakes, coupled with the potentially localised nature of the eruptive events. Lake Hayk is sheltered by a series of horsts from volcanoes in the Afar, and this will influence the type and frequency of tephras recorded in these archives. Investigation of further lake archives in the Ethiopian Highlands may identify these tephras in the future. Nonetheless, the Ashenge and Hayk archives provide an important indication of past eruption frequency, most likely from the nearby Afar Rift.

The Dendi tephras have a distinctly phonolitic-trachytic composition and thus cannot be correlated to other archives. These thick, $<2 \mathrm{~m}$, tephras show evidence of reworking, and were most likely erupted from an alkaline centre in the western Yerer-Tullu Wellel Volcano Tectonic Lineament. It is probable that these eruptions were insufficiently explosive to disperse the Dendi tephras over greater areas, explaining why these tephras cannot be correlated. The Dendi archive contains one peralkaline rhyolitic tephra, which is most likely derived from a centre nearer the axial rift, but this cannot be correlated to other archives.

\subsubsection{Frequent $<17$ ka explosive volcanic eruptions from cen- tres in the Afar and CMER}

The initial late Pleistocene-Holocene tephra record presented here provides an insight into the timing of past eruptions and dispersal of tephras in Ethiopia.

The major and trace element composition of widely dispersed tephras from the central Main Ethiopian Rift indicates that they are derived from three different magmatic sources. However, it is likely that a single volcanic source supplied 16 of the 19 tephras studied recorded in the Tilo, Awassa and Chamo archives. Obsidian and tephra samples from the Corbetti caldera (northern shores of Lake Awassa) have been analysed as part of this study. The composition of the many of 
tephras recorded in the Tilo, Awassa and Chamo archives is distinguishable from the Corbetti obsidians and tephras. It is likely that Corbetti is the source of these tephras, and the Tilo archive provides a comprehensive record of past volcanism from this centre. Eruptions from Corbetti are recorded in the Tilo archive every $\sim 800$ years during the past $10 \mathrm{ka}$, with the most recent explosive eruption recorded at $641-1900 \mathrm{AD}$. The thickness and dispersal of these tephras gives an indication that at least 6 eruptions from Corbetti over the past 10 ka were highly explosive. There is good potential for future identification of these widespread tephras in other archives, and this will enable isopachs for these eruptions to be constructed. This is the first systematic study of recent eruptions and deposits from Corbetti, and has important implications for hazard monitoring. Previous work by Biggs et al. (2011) and Rapprich et al. (2016) shows that Corbetti has experienced Holocene eruptions, and remains active today. However, the volcanic history of Corbetti has remained, until now, poorly constrained and the local inhabitants of Awassa and Shashamene are unaware of the threat Corbetti poses. The record of Corbetti eruptions preserved in archives from the central Main Ethiopian Rift demonstrates that future eruptions may be explosive and cause significant disruption in this area. This tephra record shows that Corbetti poses a significant risk to the 570,000 local inhabitants, and these hazards must be prepared for.

In the sparsely populated and remote Afar Rift, the risks posed by future eruptions are less severe. Nonetheless, the 2011 eruption of Nabro (Eritrea) caused widespread disruption to air-traffic over the region. Archives from lakes Ashenge and Hayk (Ethiopian highlands) contain 21 visible and crypto-tephras. The tephra record shows that 7 centres, probably located in the nearby Afar Rift, erupted during the past $17 \mathrm{ka}$. The Ashenge and Hayk archives record 
different eruptive-events, however, it is possible that some of the tephras in these archives are derived from a shared source. These tephras provide valuable information about the timing of past eruptions, with one explosive eruption recorded every $<1000$ years between $15.3-1.6$ cal. ka BP. An historic tephra, AST-1 (1404 - 1629 AD), is documented in the Ashenge archive. The only documented regional eruption of a similar age is from Dubbi (Eritrea, $270 \mathrm{~km}$ NE of Ashenge) at $1400 \mathrm{AD}$. The 1861 eruption from this volcano is reputed to be Africa's largest historic eruption. However, comparison of the historic Ashenge tephra with the glass composition of proximal 1861 Dubbi tephra is inconclusive, and further field work, sampling and tephra analysis is required to ascertain if this is the source. Comparison of other Ashenge and Hayk tephras with published glass compositions from the nearby Dabbahu does not definitively indicate this is the source of these eruptions. The seven sources of the Ashenge and Hayk tephras thus remain unknown. A lack of correlations between these lake archives may indicate that these eruptions were not highly explosive. Thus, future eruptions from these centres may not cause significant disruption to local inhabitants, or widespread disruption to air-traffic. Nonetheless, the dispersal of these eruptions may not only be a function of their explosivity, but the topography surrounding each lake. This work demonstrates that numerous centres in the Afar have erupted frequently and their associated risks should not be underestimated.

\subsection{Research limitations and further work}

Sediment archives from Ethiopian lakes can be used to construct a regional tephrostratigraphy for the late Pleistocene to Holocene. Furthermore, the tephrostratigraphy presented here has provided valuable information on the timing and 
style of past eruptions, and magmatic processes. The lake sediment tephrostratigraphic approach used here shows great potential for application to other areas in Ethiopia, in order to build upon this tephra framework.

A greater network of archives from lakes throughout Ethiopia must now be studied. Core sites throughout Ethiopia were selected to ensure a spatially comprehensive record of past volcanism was captured. Expanding this network will increase the likelihood for eruptive events, including from localised eruptions, to be represented in the tephra record. Resolving this tephrostratigraphy at a higher spatial resolution will in turn contribute more information about the timing and dispersal of past eruptions. This will enable isopachs to be constructed and past eruption explosivity to be calculated more confidently. These factors will have important implications for assessing the hazards associated with future eruptions. This works shows that site specific processes may result in the uneven distribution and deposition of tephras. Thus, not all eruptive events may be captured in a single sediment core from a lake. Future tephrostratigraphic investigations of Ethiopian lake archives should therefore use multiple sediment cores from a single lake (Davies, 2015).

This study has demonstrated the essential contribution of cryptotephra studies in developing our understanding of past volcanism in Ethiopia. Further regional cryptotephra studies will increase the potential for tephra correlations and expand the spatial area over which they can be established. More detailed investigation of the Ashenge and Hayk sediments, and sampling of other depths in the Chamo sediments may yield further cryptotephras.

The lake sediment tephrostratigraphic approach used in this study is limited by the lack of published geochemical data for regional source volcanoes. This has hindered the potential for correlation of many tephras to source volcanoes. 
This study investigated regional magmatic processes, finding that tephras from southern Ethiopian lakes are typically more evolved. The regional approach adopted in this study has provided a wider context for the petrogenesis of recent volcanism. However, interpretations of magma genesis made using tephra records have significant drawbacks where the source volcanoes cannot be identified. Magma evolution needs to be considered within the context of the tectonic setting of the source volcano. This work assumes that Holocene tephras studied here are locally derived, however, they could be from other locations in the Ethiopian Rift. They may therefore not represent local volcanism and further field work is required. Detailed sampling at these centres, coupled with major and trace element and isotope analysis is the most effective and reliable method for investigating magmatic processes.

Ideally, this work would be improved through using more lake sites, coupled with detailed field work at volcanoes throughout the region. Furthermore, airfall or co-ignimbrite ash deposits at regional volcanic centres need to be thoroughly sampled and geochemically fingerprinted. Detailed field work at source volcanoes has obvious time constraints and, moreover, outcrop samples may be poorly exposed and inaccessible. However, the thickness and dispersal of the tephras presented here gives an initial indication of where potential source regions may be, and where field work could focus. This $<17 \mathrm{ka}$ tephrostratigraphy shows that further field work at Corbetti, and centres in the Afar Rift, is required.

Finally, this study highlights the need for further work to assess hazards associated with future eruptions. Ethiopia is developing rapidly and infrastructure is advancing onto volcanic areas, without consideration of associated hazards. Field work at regional volcanoes and monitoring of these volcanoes will mitigate 
these hazards, and this is part of ongoing work by RiftVolc and the Ethiopian and Czech Geological Surveys (e.g. Ayele et al., 2015; Goitom et al., 2015; Hutchison et al., 2015; Keir et al., 2015; Rapprich et al., 2016). 



\section{References}

Abbott, P. M., Davies, S. M., Austin, W. E. N., Pearce, N. J. G., Hibbert, F. D. 2011. Identification of cryptotephra horizons in a North East Atlantic marine record spanning marine isotope stages 4 and 5a ( 60,000-82,000 a b2k). Quaternary International, 246 (1-2), 177-189.

Abbott, P. M., Davies, S. M., Steffensen, J. P., Pearce, N. J. G., Bigler, M., Johnsen, S. J., Seierstad, I. K., Svensson, A., Wastegård, S. 2012. A detailed framework of Marine Isotope Stages 4 and 5 volcanic events recorded in two Greenland ice-cores. Quaternary Science Reviews, 36, 59-77.

Abebe, b., Acocella, V., Korme, T., Ayalew, D. 2007. Quaternary faulting and volcanism in the Main Ethiopian Rift. Journal of African Earth Sciences, 48 (2-3), 115-124.

Abebe, T., Mazzarini, F., Innocenti, F., Manetti, P. 1995. The Yerer-Tullu Wellel extensional structure (central Ethiopia): evidences from remote sensing, petrologic and geochronologic data. In Quantitative Remote Sensing for Science and Application, volume 1. Firenze, Italy, volume 1, pp. 374 - 376.

Abebe, T., Mazzarini, F., Innocenti, F., Manetti, P. 1998. The Yerer-Tullu Wellel volcanotectonic lineament: a transtensional structure in central Ethiopia and 
the associated magmatic activity. Journal of African Earth Sciences, 26 (1), $135-150$.

Acocella, V., Korme, T., Salvini, F., Funiciello, R. 2002. Elliptic calderas in the Ethiopian Rift: control of pre-existing stuctures. Journal of Volcanology and Geothermal Research, 119 (1-4), 189-203.

Adhana, T. A. 2014. The occurrence of a complete continental rift type of volcanic rocks suite along the Yerer-Tullu Wellel Volcano Tectonic Lineament, Central Ethiopia. Journal of African Earth Sciences, 99 (2), 374-385.

Alloway, B. V., Larsen, G., Lowe, D. J., Shane, P. A. R., Westgate., J. A. 2007. Encyclopedia of Quaternary Science, Elsevier, volume 4, chapter Tephrochronology. pp. 2869-2898.

Ambrose, S. H. 1998. Late Pleistocene human population bottlenecks, volcanic winter, and differentiation of modern humans. Journal of Human Evolution, 34 (6), 623-651.

Amelung, F., Oppenheimer, C., Segall, P., Zebker, H. 2000. Ground deformation near Gada 'Ale Volcano, Afar, observed by Radar Interferometry. Geophysical Research Letters, 27 (19), 3093-3096.

Anderson, R., Nuhfer, E., Dean, W. 1985. Sinking of volcanic ash in uncompacted sediment in Williams Lake, Washington. Science, 225 (4661), 505-508.

Aronson, J. L., Schmitt, T. J., Walter, R. C., Taieb, M., Tiercelin, J. J., Johanson, D. C., Naeser, C. W., Nairn, A. E. M. 1977. New geochronologic and palaeomagnetic data for the hominid-bearing Hadar Formation of Ethiopia. Nature, 267 (5609), 323 - 327. 
Asfaw, B., Gilbert, W. H., Beyene, Y., Hart, W. K., Renne, P. R., WoldeGabriel, G., Vrba, E. S., White, T. D. 2002. Remains of Homo erectus from Bouri, Middle Awash, Ethiopia. Nature, 416, 317-320.

Aspinall, W., Auker, M., Hincks, S., T. Mahony, Nadim, F., Pooley, J., Sparks, R. S. J., Syre, E. 2011. Volcano hazard and exposure in GFDRR priority countries and risk mitigation measures. In Volcano Risk Study 0100806001-R: Washington, D.C., Global Facility for Disaster Reduction and Recovery.

Awulachew, S. B. 2006. Characteristics Investigation of physical and bathymetric characteristics of Lakes Abaya and Chamo, Ethiopia, and their management implications. Lakes \& Reservoirs: Research and Management, 11 (3), 133140.

Ayele, A., Ebinger, C. J., Van Alstyne, C., Keir, D., Nixon, C. W., Belachew, M., Hammond, J. O. S. 2015. Seismicity of the central Afar rift and implications for Tendaho dam hazards. In Wright, T. J., Ayele, A., Ferguson, D. J., Kidane, T., Vye-Brown, C. (eds.) Magmatic Rifting and Active Volcanism, volume 420, Geological Society, London, Special Publications.

Ayele, A., Jacques, E., Kassim, M., Kidane, T., Omar, A., Tait, S., Nercessian, A., de Chabalier, J.-B., King, G. 2007a. The volcano-seismic crisis in Afar, Ethiopia, starting September 2005. Earth and Planetary Science Letters, 255 (1-2), 177-187.

Ayele, A., Stuart, G., Bastow, I. D., Keir, D. 2007b. The August 2002 earthquake sequence in north Afar: insights into the neotectonics of the Danakil microplate. Journal of African Earth Sciences, 48 (2-3), 70-79. 
Ayres, M., Harris, N. 1997. REE fractionation and Nd-isotope disequilibrium during crustal anatexis: constraints from Himalayan leucogranites. Chemical Geology, 139 (1-4), 249-269.

Baker, B. H., Mohr, P. A., Williams, L. A. J. 1972. Geology of the Eastern Rift System of Africa. The Geological Society of America Special Papers, 136, $1-67$.

Balascio, N. L., Francus, P., Bradley, R. S., Schupack, B. B., Miller, G. H., Kvisvik, B. C., Bakke, J., Thordarson, T. 2015. Micro-XRF Studies of Sediment Cores, Springer Netherlands, volume 17, chapter Investigating the Use of Scanning X-Ray Fluorescence to Locate Cryptotephra in Minerogenic Lacustrine Sediment: Experimental Results. pp. 305-324.

Barberi, F., Bonatti, E., Marinelli, G., Varet, J. 1974. Transverse tectonics during the split of a continent: Data from Afar rift. Tectonophysics, 23 (1-2), 17-29.

Barberi, F., Borsi, S., Ferrara, G., Marinelli, G., Varet, J. 1970. Relations between tectonics and magmatology in the northern Danakil Depression (Ethiopia). Philosophical Transactions of the Royal Society of London. Series A, Mathematical and Physical Sciences, 267 (1181), 293-311.

Barberi, F., Ferrara, C., Santacroce, R., Treuil, M., Varet, J. 1975. A Transitional Basalt-Pantellerite Sequence of Fractional Crystallisation, the Boina Centre (Afar Rift, Ethiopia). Journal of Petrology, 16 (1), 22-56.

Barberi, F., Varet, J. 1977. Volcanism of Afar: Small-scale plate tectonics implications. Geological Society of America Bulletin, 88 (9), 1251-1266.

Bastow, I. D., Keir, D., Daly, E. 2011. The Ethiopia Afar Geoscientific Lithospheric Experiment (EAGLE): Probing the transition from continental 
rifting to incipient seafloor spreading. In Beccaluva, L., Bianchini, G., Wilson, M. (eds.) Volcanism and Evolution of the African Lithosphere, Geological Society of America Special Paper 478.

Beard, J. S., Lofgren, G. E., Sinha, K., Tollom, R. P. 1994. Partial melting of apatite-bearing charnockite, granulite, and diorite: melt compositions, restite mineralogy, and petrologic implications. Journal of Geophysical Research, 99 (B11), 21,591-21,603.

Berhe, S. M. 1987. Geology, geochronology and geodynamic implications of the Cenozoic magmatic province in W and SE Ethiopia. Journal of Geological Society, 144 (2), 213-226.

Betton, P. J., Civetta, L. 1984. Strontium and neodymium isotopic evidence for the heterogeneous nature and development of the mantle beneath Afar (Ethiopia). Earth and Planetary Science Letters, 71 (1), 59-70.

Biggs, J., Anthony, E. Y., Ebinger, C. J. 2009. Multiple inflation and deflation events at Kenyan volcanoes, East African Rift. Geological Society of America Bulletin, 37 (11), 979-982.

Biggs, J., Bastow, I. D., Keir, D., Lewi, E. 2011. Pulses of deformation reveal frequently recurring shallow magmatic activity beneath the Main Ethiopian Rift. Geochemistry, Geophysics, Geosystems, 12 (9), 1-11.

Blaauw, M., Christen, J. A. 2011. Flexible paleoclimate age-depth models using an autoregressive gamma process. Bayesian Analysis, 6 (3), 457-474.

Blockley, S. P. E., Pyne-O’Donnell, S. D. F., Lowe, J. J., Matthews, I. P., Stone, A., Pollard, A. M., Turney, C. S. M., Molyneux, E. G. 2005. A new and less destructive laboratory procedure for the physical separation of distal 
glass tephra shards from sediments. Quaternary Science Reviews, 24 (16-17), 1952-1960.

Blundy, J., Cashman, K. 2001. Ascent-driven crystallisation of dacite magmas at Mount St Helens, 1980 - 1986. Contributions to Mineralogy and Petrology, 140 (6), 631-650.

Boccaletti, M., Mazzuoli, R., Bonini, M., Trua, T., Abebe, B. 1999. PlioQuaternary volcanotectonic activity in the northern sector of the Main Ethiopian Rift: relationships with oblique rifting. Journal of African Earth Sciences, 29 (4), 679-698.

Bonini, M., Corti, G., Innocenti, F., Manetti, P., Mazzarini, F., Abebe, T., Pecskay, Z. 2005. Evolution of the Main Ethiopian Rift in the frame of Afar and Kenya rifts propagation. Tectonics, 24 (1), 1-21.

Bosworth, W., Huchon, P., McClay, K. 2005. The Red Sea and Gulf of Aden Basins. Journal of African Earth Sciences, 43 (1-3), 334-378.

Bowen, B. E., Vondra, C. F. 1973. Stratigraphical relationships of the PlioPleistocene deposits, East Rudolf, Kenya. Nature, 242 (5397), 391-393.

Boygle, J. 1999. Variability of tephra in lake and catchment sediments, Svínavatn, Iceland. Global and Planetary Change, 21 (1-3), 129-149.

Bramham-Law, C. W. F., Theurerkauf, M., Lane, C. S., Mangerud, J. 2013. New findings regarding the Saksunarvatn Ash in Germany. Journal of Quaternary Science, 28 (3), 248-257.

Brandt, S. A., Fisher, E. C., Hildebrand, E. A., Vogelsang, R., Ambrose, S. H., Lesur, J., Wang, H. 2012. Early MIS 3 occupation of Mochena Borago 
Rockshelter, Southwest Ethiopian Highland: Implications for Late Pleistocene archaeology, palaeoenvironments and modern human dispersals. Quaternary International, 274, 38-54.

Brendryen, J., Haflidason, H., Sejrup, H. P. 2010. Norwegian Sea tephrostratigraphy of marine isotope stages 4 and 5: Prospects and problems for tephrochronology in the North Atlantic region. Quaternary Science Reviews, 29, 847-864.

Bronk Ramsey, C. 2009a. Bayesian analysis of radiocarbon dates. Radiocarbon, $51(1), 337-360$.

Bronk Ramsey, C. 2009b. Dealing with outliers and offsets in radiocarbon dating. Radiocarbon, 51 (3), 1023-1045.

Brown, F. H. 1969. Observations on the stratigraphy and radiometric age of the “Omo Beds”. Quaternaria, 11, 7-14.

Brown, F. H. 1982. Tulu Bor Tuff at Koobi Fora correlated to the Sidi Hakoma Tuff at Hadar. Nature, 300, 631-635.

Brown, F. H., Cerling, T. E. 1982. Stratigraphic significance of the Tulu Bor tuff of the Koobi Fora formation. Nature, 299 (5880), 212-215.

Brown, F. H., de Heinzelin, J., Howell, F. C. 1970. Pliocene/Pleistocene formations in the lower Omo basin, southern Ethiopia. Quaternaria, 13, 247-268.

Brown, F. H., Feibel, C. S. 1986. Revision of lithostratigraphic nomenclature in the Koobi Fora region, Kenya. Journal of the Geological Society, 143, 297-310. 
Brown, F. H., Haileab, B., McDougall, I. 2006. Sequence of tuffs between the KBS Tuff and the Chari Tuff in the Turkana Basin, Kenya and Ethiopia. Journal of the Geological Society, 163, 185-204.

Brown, F. H., Sarna-Wojcicki, A. M., Meyer, C. E., Haileab, B. 1992. Correlation of Pliocene and Pleistocene tephra layers between the Turkana Basin of East Africa and the Gulf of Aden. Quaternary International, 13-14 (6), 453-468.

Brown, F. H., Shuey, R. T., Croes, M. K. 1978. Magnetostratigraphy of the Shungura and Usno Formations, southwestern Ethiopia: new data and comprehensive reanalysis. Geophysical Journal International, 54 (3), 519538.

Bryant, C., Arculus, R., Eggins, S. 1999. Laser ablation-inductively coupled plasma-mass spectrometry and tephras: A new approach to understanding arc-magma genesis. Geology, 27 (12), 1119-1122.

Campisano, C., Feibel, C. S. 2008. The Geology of Early Humans in the Horn of Africa: Geological Society of America Special Paper 446, The Geological Society of America, chapter Tephrostratigraphy of the Hadar and Busidima Formations at Hadar, Afar Depression, Ethiopia.

Carey, S., Bursik, M. 2015. Chapter 32 - Volcanic Plumes. In Sigurdsson, H. (ed.) The Encyclopedia of Volcanoes (Second Edition), Academic Press, Amsterdam. Second edition edition, pp. $571-585$.

Carter, L., Manighetti, B., Elliot, M., Trustrum, N. 2002. Source, sea level and circulation effects on the sediment flux to the deep ocean over the past $15 \mathrm{ka}$ off eastern New Zealand. Global and Planetary Change, 33 (3-4), 339-355. 
Caseldine, C. J., Baker, A., Barnes, W. L. 1999. A rapid, non-destructive scanning method for detecting distal tephra layers in peats. The Holocene, 9 (5), 635-638.

Cerling, T. E., Brown, F. H. 1982. Tuffaceous marker horizons in the Koobi Fora region and the lower Omo valley. Nature, 299, 216-221.

Cerling, T. E., Brown F. H. amd Cerling, B. W., Curtis, G. H., Drake, R. E. 1979. Preliminary correlations between the Koobi Fora and Shungura Formations, East Africa. Nature, 279, 118-121.

Chernet, T., Hart, W. K., Aronson, J. L., Walter, R. C. 1998. New age constraints on the timing of volcanism and tectonism in the northern Main Ethiopian Rift - southern Afar transition zone (Ethiopia). Journal of Volcanology and Geothermal Research, 80 (3-4), 267-280.

Chesner, C. A. 1998. Petrogenesis of the Toba Tuffs, Sumatra, Indonesia. Journal of Petrology, 39 (3), 397438.

Clark, J. D., Beyene, Y., WoldeGabriel, G., Hart, W. K., Renne, P. R., Gilbert, H., Defleur, A., Suwa, G., Katoh, S., Ludwig, K. R., Boisserie, J.-R., Asfaw, B., White, T. D. 2003. Stratigraphic, chronological and behavioural contexts of Pleistocene Homo sapiens from Middle Awash, Ethiopia. Nature, 423, $747-752$.

Corti, G. 2009. Continental rift evolution: From rift initiation to incipient breakup in the Main Ethiopian Rift, East Africa. Earth-Science Reviews, 96 (1-2), $1-53$.

Corti, G. 2015. The Ethiopian Rift Valley. URL http://ethiopianrift.igg.cnr.it/ETHvolcanoes.html 
Coulter, S., Pilcher, Hall, V. A., Plunkett, G., Davies, S. M. 2009. Testing the reliability of the JEOL FEGSEM 6500F electron microprobe for quantitative major element analysis of glass shards from rhyolitic tephra. Boreas, 39 (1), $163-169$.

Cronin, S. J., Neall, V. E., Palmer, A. S., Stewart, R. B. 1997. Methods of identifying late Quaternary rhyolitic tephras on the ring plains of Ruapehu and Tongariro volcanoes, New Zealand. New Zealand Journal of Geology and Geophysics, 40 (2), 175-184.

Cross, W., Iddings, J. P., Pirsson, L. V., Washington, H. S. 1912. Modifications of the Quantitive System of Classification of Igneous Rocks. The Journal of Geology, 20 (6), 550-561.

Croudace, I. W., Rindby, A., Rothwell, R. G. 2006. ITRAX: Description and evaluation of a new multi-function X-ray core scanner. In Rothwell, R. G. (ed.) New Techniques in Sediment Core Analysis, Geological Society of London. pp. $51-63$.

Damaschke, M., Sulpizio, R., Zanchetta, Wagner, B., Bohm, A., Nowaczyk, N., Rethemeyer, J., Hilgers, A. 2013. Tephrostratigraphic studies on a sediment core from Lake Prespa in the Balkans. Climate of the Past, 9, 267-287.

Dartevelle, S., Ernst, G. G. J., Stix, J., Bernard, A. 2002. Origin of the Mount Pinatubo climactic eruption cloud: Implications for volcanic hazards and atmospheric impacts. Geological Society of America Bulletin, 30 (7), 663666.

Davidson, A., Rex, D. C. 1980. Age of volcanism and rifting in southwestern Ethiopia. Nature, 283, 657-658. 
Davies, S. M. 2015. Cryptotephras: the revolution in correlation and precision dating. Journal of Quaternary Science, 30 (2), 114-130.

Davies, S. M., Larsen, G., Wastegård, S., Turney, C. S. M., Valerie, A. H., Coyle, L., Thordarson, T. 2010. Widespread dispersal of Icelandic tephra: how does the Eyjafjöll eruption of 2010 compare to past Icelandic events? Journal of Quaternary Science, 25 (5), 605-611.

de Fino, M., La Volpe, L., Lirer, L. 1973. Volcanology and petrology of the Assab Range (Ethiopia). Bulletin Volcanologique, 37 (1), 95-110.

de Fontaine, C. S., Kaufman, D. S., Anderson, R. S., Werner, A., Waythomas, C. F., Brown, T. A. 2007. Late Quaternary distal tephra-fall deposits in lacustrine sediments, Kenai Peninsula, Alaska. Quaternary Research, 68 (1), $64-78$.

de Heinzelin, J., Clark, J. D., White, T., Hart, W., Renne, P., WoldeGabriel, G., Beyene, Y., Vrba, E. 1999. Environment and Behavior of 2.5 - Million - Year -Old Bouri Hominids. Science, 284 (5414), 625-629.

Deino, A. L., McBrearty, S. 2002. ${ }^{40} \mathrm{Ar} /{ }^{39}$ Ar dating of the Kapthurin Formation, Baringo, Kenya. Journal of human evolution, 42 (1-2), 185-210.

Deino, A. L., Potts, R. 1990. Single-Crystal ${ }^{40} \mathrm{Ar} /{ }^{39} \mathrm{Ar}$ Dating of the Olorgesailie Formation, Southern Kenya Rift. Journal of Geophysical Research, 95 (B6), 8453-8470.

Deino, A. L., Scott, G. R., Saylor, B., Alene, M., Angelini, J. D., Haile-Selassie, Y. 2010. ${ }^{40} \mathrm{Ar} /{ }^{39} \mathrm{Ar}$ dating, paleomagnetism, and tephrochemistry of Pliocene strata of the hominid-bearing Woranso-Mille area, west-central Afar Rift, Ethiopia. Journal of Human Evolution, 52 (2), 111-126. 
Deino, A. L., Tauxe, L., Monaghan, M., Hill, A. 2002. ${ }^{40} \mathrm{Ar} /{ }^{39} \mathrm{Ar}$ geochronology and paleomagnetic stratigraphy of the Lukeino and lower Chemeron Formations at Tabarin and Kapcheberek, Tugen Hills, Kenya. Journal of Human Evolution, 42 (1-2), 117-140.

deMenocal, P. B., Brown, F. 1999. The Evolution Neogene Terrestrial Ecosystems in Europe, Cambridge University Press, chapter Pliocene tephra correlations between East African hominid locations, the Gulf of Aden, and the Arabian Sea. pp. 23-54.

Di Paola, G. M. 1971. Geology of the Corbetti Caldera area (Main Ethiopian Rift Valley). Bulletin Volcanologique, 35 (2), 497-506.

Di Paola, G. M. 1972. The Ethiopian Rift Valley (between $7^{\circ} 00^{\prime}$ and $8^{\circ} 40^{\prime}$ lat North). Bulletin Volcanologique, 36 (4), 517-560.

DiMaggio, E., Campisano, C., Arrowsmith, J. R., Reed, K., Swisher, C. I., Lockwood, C. 2008. The Geology of Early Humans in the Horn of Africa: Geological Society of America Special Paper 446, The Geological Society of America, chapter Correlation and stratigraphy of the BKT-2 volcanic complex in west-central Afar, Ethiopia. pp. $163-177$.

Dugda, M. T., Nyblade, A. A., Julia, J., Langston, C. A., Ammon, C. J., Simiyu, S. 2005. Crustal structure in Ethiopian and Kenya from receiver function analysis: Implications for rift development in eastern Africa. Journal of Geophysical Research, 110 (B1), 1-15.

Dugmore, A. 1989. Icelandic volcanic ash in Scotland. Scottish Geographical Magazine, 105 (3), 168-172. 
Eastwood, W. J., Pearce, N. J. G., Westgate, J. A., Perkins, W. T., Lamb, H. F., Roberts, N. 1999. Geochemistry of Santorini tephra in lake sediments from Southwest Turkey. Global and Planetary Change, 21 (1-3), 17-29.

Ebinger, C. J., Yemane, T., WoldeGabriel, G., Aronson, J., Walter, R. C. 1993. Late Eocene-Recent volcanism and faulting in the southern main Ethiopian rift. Journal of the Geological Society, 150, 99-108.

Eggins, S. M., Kingsley, L. P. J., Shelley, J. M. G. 1998. Deposition and element fractionation processes during atmospheric pressure laser sampling for analysis by ICP-MS. Applied Surface Science, 127-129, 278-286.

Eissen, J.-P., Juteau, T., Joron, J.-L., Dupre, B., Humler, E., Al'Mukamedov, A. 1989. Petrology and geochemistry of basalts from the Red Sea Axial Rift at $18^{\circ}$ North. Journal of Petrology, 30 (4), 791-839.

Ersoy, E. Y. 2013. PETROMODELER (Petrological Modeler): a Microsoft ${ }^{\circledR}$ Excel $^{\complement}$ spreadsheet program for modelling melting, mixing, crystallization and assimilation processes in magmatic systems. Turkish Journal of Earth Sciences, 22, 115-125.

Ewart, A., Griffin, W. L. 1994. Application of Proton-Microprobe Data to Trace-Element Partitioning in Volcanic-Rocks. Chemical Geology, 117 (1-4), $251-284$.

Feakins, S. J., Brown, F. H., deMenocal, P. B. 2007. Plio-Pleistocene microtephra in DSDP site 231, Gulf of Aden. Journal of African Earth Sciences, 48 (5), $341-352$. 
Feibel, C. S. 1999. Tephrostratigraphy and geological context in paleoanthropology. Evolutionary Anthropology: Issues, News, and Reviews, $8(3), 87-111$.

Feibel, C. S. 2011. A Geological History of the Turkana Basin. Evolutionary Anthropology, 20 (6), 206-216.

Ferguson, D., Barnie, T. D., Pyle, D. M., Oppenheimer, C., Yirgu, G., Lewi, E., Kidane, T., Carn, S., Hamling, I. 2010. Recent rift-related volcanism in Afar, Ethiopia. Earth and Planetary Science Letters, 292 (3-4), 409-418.

Ferguson, D., Maclennan, J., Bastow, I. D., Pyle, D., Jones, S., Keir, D., Blundy, J., Plank, T., Yirgu, G. 2013. Melting during late-stage rifting in Afar is hot and deep. Nature, 499, 70-73.

Field, L., Blundy, J., Brooker, R. A., Wright, T., Yirgu, G. 2012. Magma storage conditions beneath Dabbahu Volcano (Ethiopia) constrained by petrology, seismicity and satellite geodesy. Bulletin of Volcanology, 74, 981-1004.

Field, L., Blundy, J., Calvert, A., Yirgu, G. 2013. Magmatic history of Dabbahu, a composite volcano in the Afar Rift, Ethiopia. Geological Society of America Bulletin, 125 (1-2), 128-147.

Fisher, R., Schminke, H.-U. 1984. Pyroclastic Rocks. Springer Berlin Heidelberg.

Gasparon, M., Innocenti, F., Manetti, P., Peccerillo, A., A., T. 1993. Genesis of the Pliocene to Recent bimodal mafic-felsic volcanism in the Debre Zeyt area, central Ethiopia: volcanological and geochemical constraints. Journal of East African Earth Sciences, 17 (2), 145-165. 
Gehrels, M. J., Newnham, R. M., Lowe, D. J., Wynne, S., Hazell, Z. J., Caseldine, C. J. 2008. Towards rapid assay of cryptotephra in peat cores: Review and evaluation of various methods. Quaternary International, 178 (1), 68-84.

George, R., Rogers, N., Kelley, S. 1998. Earliest magmatism in Ethiopia: Evidence for two mantle plumes in one flood basalt province. Geology, 26 (10), 923-926.

Ghinassi, M., D’Oriano, F., Benvenuti, M., Awramik, S., Bartolini, C., Fedi, M., Ferrari, G., Papini, M., Sagri, M., Talbot, M. 2012. Shoreline fluctuations of Lake Hayk (northern Ethiopia) during the last 3500 years: Geomorphological, sedimentary, and isotope records. Palaeogeography, Palaeoclimatology, Palaeoecology, 365-366, 209-226.

Gibbons, A. 1993. Pleistocene Population Explosions. Science, 262 (5130), $27-28$.

Gibson, I. L. 1967. Preliminary account of the volcanic geology of Fantale, Shoa, Ethiopia. Bulletin of the Geophysical Observatory, Addis Ababa, 10, 59-68.

Gibson, I. L. 1969. The structure and volcanic geology of an axial portion of the Main Ethiopian Rift. Tectonophysics, 8 (4-6), 561-565.

Gill, R. 2010. Igneous Rocks and Processes: A Practical Guide. WileyBlackwell.

Giordano, F., D’Antonio, M., Civetta, L., Tonarini, S., Orsi, G., Ayalew, D., Yirgu, G., Dell'Erba, F., Di Vito, M. A., Isaia, R. 2014. Genesis and evolution of mafic and felsic mmagma at Quaternary volcanoes wiwith the Main Ethiopian Rift: Insights from Gedemsa and Fant'Ale complexes. Lithos, 188, 130-144. 
Goitom, B., Oppenheimer, C., Hammond, J. S., Grandin, R., Barnie, T., Donovan, A., Ogubazghi, G., Yohannes, E., Kibrom, G., Kendall, J.-M., Carn, S., Fee, D., C, S., Keir, D., Ayele, A., Blundy, J., Hamlyn, J., Wright, T., Berhe, S. 2015. First recorded eruption of Nabro volcano, Eritrea, 2011. Bulletin of Volcanology, 77 (85).

Gomez, B., Carter, L., Trustrum, N. A. 2007. A 2400 yr record of natural events and anthropogenic impacts in intercorrelated terrestrial and marine sediment cores: Waipaoa sedimentary system, New Zealand. Geological Society of America Bulletin, 119 (11-12), 1415-1432.

Gouin, P. 1979. Earthquake history of Ethiopia and the Horn of Africa. Ottawa : International Development Research Centre.

Günther, D., Hattendorf, B. 2005. Solid sample analysis using laser ablation inductively coupled plasma mass spectrometry. TrAC Trends in Analytical Chemistry, 24 (3), 255-265.

Haile-Selassie, Y., Deino, A., Saylor, B., Umer, M., Latimer, B. 2007. Preliminary geology and paleontology of new hominid-bearing Pliocene localities in the central Afar region of Ethiopia. Anthropological Science, 115 (3), 215-222.

Haileab, B., Brown, F. H. 1992. Turkana Basin-Middle Awash Valley correlations and the age of the Sagantole and Hadar formations. Journal of Human Evolution, 22 (6), 453-468.

Haileab, B., Brown, F. H. 1994. Turkana Basin - Middle Awash Valley correlations and the age of the Sagantole and Hadar Formations. Journal of Human Evolution, 22 (6), 453-468. 
Harangi, S., Mason, P. R. D., Lukács, R. 2005. Correlation and petrogenesis of silicic pyroclastic rocks in the Northern Pannonian Basin, Eastern-Central Europe: In situ trace element data of glass shards and mineral chemical constraints. Journal of Volcanology and Geothermal Research, 143 (4), 237257.

Harris, J. M. 1977. Palaeomagnetic stratigraphy of the Koobi Fora Formation, east of Lake Turkana (Lake Rudolf), Kenya. Nature, 268 (5621), 669-670.

Harris, W. C. 1844. The Highlands of Aethiopia, volume 1. Longman Brown.

Hart, W. K., Walter, R. C., WoldeGabriel, G. 1992. Tephra sources and correlations in Ethiopia: Application of elemental and neodymium isotope data. Quaternary International, 13-14, 77-86.

Hart, W. K., WoldeGabriel, G., Walter, R. C., Mertzman, S. A. 1989. Basalt Volcanism in Ethiopia: Constraints on Continental Rift and Mantle Interactions. Journal of Geophysical Research, 94 (B6), 7731-7748.

Hayward, C. 2011. High spatial resolution electron probe microanalysis of tephras and melt inclusions without beam-induced chemical modification. The Holocene, 22 (1), 119-125.

Heiken, G. 1972. Morphology and Petrography of Volcanic Ashes. Geological Society of America Bulletin, 83 (7), 1961-1988.

Heiken, G. 1974. An Atlas of Volcanic Ash. Technical report, Smithsonian Inst. Press, Washington, United States.

Heiken, G., Wohletz, K. 1985. Volcanic Ash. Los Alamos series in basic and applied sciences, University of California Press. 
Heiken, G., Wohletz, K. 1991. Sedimentation in Volcanic Settings, Society of Economic Paleontologists and Mineralogists, Special Publication, volume 45, chapter Fragmentation processes in explosive volcanic eruptions. pp. 19-26.

Hergenröder, R. 2006. Hydrodynamic sputtering as a possible source for fractionation in LA-ICP-MS. Journal of Analytical Atomic Spectrometry, 21, 517-524.

Hewlitt, G. 2000. The genetic legacy of the Quaternary ice Ages. Nature, 405.

Hodder, A. P. W., de Lange, P. J., Lowe, D. J. 1991. Dissolution and depletion of ferromagnesian minerals from Holocene tephra layers in an acid bog, New Zealand, and implications for tephra correlation. Journal of Quaternary Science, 6 (3), 195-208.

Hodgson, D. A., Dyson, C. L., Jones, V. J., Smellie, J. L. 1998. Tephra analysis of sediments from Midge Lake (South Shetland Islands) and Sombre Lake (South Orkney Islands), Antarctica. Antarctic Science, 10 (1), 13-20.

Hofmann, C., Courtillot, V., Féraud, G., Rochette, P., Yirgu, G., Ketefo, E., Pik, R. 1997. Timing of the Ethiopian flood basalt event and implications for plume birth and global change. Nature, 389, 838-841.

Hogg, A. G., McCraw, J. D. 1983. Late Quaternary tephras of Coromandel Peninsula, North Island, New Zealand: A mixed peralkaline and calcalkaline tephra sequence. New Zealand Journal of Geology and Geophysics, 26, 163187.

Howell, C. 1968. Omo research expedition. Nature, 219, 567-572. 
Humphreys, M. C. S., Kearns, S. L., Blundy, J. D. 2006. SIMS investigation of electron-beam damage to hydrous, rhyolitic glasses: Implications for melt inclusion analysis. American Mineralogist, 91 (4), 667-679.

Hunt, J. B., Hill, P. G. 2001. Tephrological implications of beam size - samplesize effects in electron microprobe analysis of glass shards. Journal of Quaternary Science, 16 (2), 105-117.

Hurst, T., Smith, W. 2004. A Monte Carlo methodology for modelling ashfall hazards. Journal of Volcanology and Geothermal Research, 138 (3-4), 393403.

Hutchison, W., Mather, T. A., Pyle, D. M., Biggs, J., Yirgu, G. 2015. Structural controls on fluid pathways in an active rift system: A case study of the Aluto volcanic complex. Geosphere, 11 (3), 542-562.

Irvine, T. N., Barager, W. R. A. 1971. A guide to the chemical classification of the common volcanic rocks. Canadian Journal of Earth Sciences, 8 (5), $523-548$.

Jackson, L. J., Stone, J. R., Cohen, A. S., Yost, C. L. 2015. High-resolution paleoecological records from Lake Malawi show no significant cooling associated with the Mount Toba supereruption at ca. 75 ka. Geology, 43 (9), $823-826$.

Jenkins, S. F., Magill, C. R., McAneney, K. J. 2007. Multi-stage volcanic events: A statistical investigation. Journal of Volcanology and Geothermal Research, $161(4), 275-288$.

Jensen, B. J., Pyne-ODonnell, S., Plunkett, G., Froese, D. G., Hughes, P. D., Sigl, M., McConnell, J. R., Amesbury, M. J., Blackwell, P. G., van den Bogaard, C., 
Buck, C. E., Charman, D. J., Clague, J. J., Valerie, Hall, Koch, J., Mackay, H., Mallon, G., McColl, L., Pilcher, J. R. 2014. Transatlantic distribution of the Alaskan White River Ash. Geology, 42 (10), 875-878.

Jochum, K. P., Nohl, U., Herwig, K., Lammel, E., Stoll, B., Hofmann, A. W. 2005. GeoReM: a new geochemical database for reference materials and isotopic standards. Geostandards and Geoanalytical Research, 29 (3), 333-338.

Jochum, K. P., Stoll, B., Herwig, K., Willbold, M., Hofmann, A. W., Amini, M., Aarburg, S., Abouchami, W., Hellebrand, E., Mocek, B., Raczek, I., Stracke, A., Alard, O., Bouman, C., Becker, S., Dücking, M., Brätz, H., Klemd, R., de Bruin, D., Canil, D., Cornell, D., de Hoog, C., Dalpé, C., Danyushevsky, L., Eisenhauer, A., Gao, Y., Snow, J. E., Groschopf, N., Günther, D., Latkoczy, C., Guillong, M., Hauri, E. H., Höfer, H. E., Lahaye, Y., Horz, K., Jacob, D. E., Kasemann, S. A., Kent, A. J. R., Ludwig, T., Zack, T., Mason, P. R. D., Meixner, A., Rosner, M., Misawa, K., Nash, B. P., Pfänder, J., Premo, W. R., Sun, W. D., Tiepolo, M., Vannucci, R., Vennemann, T., Wayne, D., Woodhead, J. D. 2006. MPI-DING reference glasses for in situ microanalysis: New reference values for element concentrations and isotope ratios. Geochemistry, Geophysics, Geosystems, 7 (2), 1-44.

Jordan, B. R., Sigurdsson, H., Carey, S. N., Rogers, R., Ehrenborg, J. 2007. Geochemical variation along and across the Central American Miocene paleoarc in Honduras and Nicaragua. Geochimica et Cosmochimica Acta, 71 (14), 3581-3591.

Julien, P. Y. 1995. Erosion and Sedimentation. Cambridge University Press.

Kalb, J. E. 1976. Rift Valley Research Mission in Ethiopia, Annual report 1976-1977. Technical report, Ethiopian Ministry of Culture (Addis Ababa). 
Kalb, J. E. 1993. Refined Stratigraphy of the Hominid-Bearing Awash Group, Middle Awash Valley, Afar Depression, Ethiopia. Newsletters on Stratigraphy, 29 (1), 21-62.

Kalb, J. E. 1995. Fossil elephantoids, Awash paleolake basins, and the Afar triple junction, Ethiopia. Palaeogeography, Palaeoclimatology, Palaeoecology, $114(2-4), 357-368$.

Kalnay, E., Kanamitsu, M., Kistler, R., Collins, W., Deaven, D., Gandin, L., Iredell, M., Saha, S., White, G., Woolen, J., Zhu, Y., Chelliah, M., Ebisuzaki, W., Higgins, W., Janowiak, J., Mo, K., Ropelewski, C., Wang, J., Leetma, A., Reynolds, R., Jenne, R., Joseph, D. 1996. The NCEP/NCAR 40 year reanalysis project. Bulletin of the American Meteorological Society, 77, 437-471.

Kassa, T. G. 2013. Holocene environmental history of Lake Chamo, South Ethiopia. Ph.D. thesis, University of Cologne.

Katoh, S., Nagaoka, S., WoldeGabriel, G., Renne, P., Snow, M. G., Beyene, Y., Suwa, G. 2000. Chronostratigraphy and correlation of the Plio-Pleistocene tephra layers of the Konso Formation, southern Main Ethiopian Rift, Ethiopia. Quaternary Science Reviews, 19 (13), 1305-1317.

Kebede, E., Mariam, Z. G., Ahlgren, I. 1994. The Ethiopian Rift Valley lakes: chemical characteristics of a salinity-alkalinity series. Hydrobiologia, 288 (1), $1-12$.

Kebede, S., Lamb, H. F., Telford, R. J., Leng, M. J., Umer, M. 2002. Lake Groundwater Relationships, Oxygen Isotope Balance and Climate Sensitivity of the Bishoftu Crater Lakes, Ethiopia. In Odada, E. O., Olago, D. O. (eds.) 
Advances in Global Change Research, volume 12, Springer Netherlands. pp. 261-275.

Keir, D., Bastow, I. D., Corti, G., Mazzarini, F., Rooney, T. O. 2015. The origin of along-rift variations in faulting and magmatism in the Ethiopian Rift. Tectonics, 34 (3), 464-477. 2014TC003698.

Keir, D., Belachew, M., Ebinger, C. J., Kendall, J. M., Hammond, J. O. S., Stuart, G. W., Ayele, A., Rowland, J. V. 2011. Mapping the evolving strain field during continental breakup from crustal anisotropy in the Afar Depression. Nature Communications, 285 (2), 1-7.

Köninger, S., Stollhofen, H. 2001. Volcaniclastic sedimentation in lacustrine settings, Blackwell Science, chapter Environmental and tectonic controls on preservation potential of distal fallout ashes in fluvio-lacustrine settings: the Carboniferous-Permian Saar-Nahe Basin, south western Germany. pp. 263285.

Kuehn, S. C., Froese, D. G. 2010. Tephra from ice- A simple method to routinely mount, polish, and quantitatively analyze sparse fine particles. Microscopy and microanalysis : the official journal of Microscopy Society of America, Microbeam Analysis Society, Microscopical Society of Canada, 16 (2), 218225.

Kuehn, S. C., Froese, D. G., Shane, P. A. R. 2011. The INTAV intercomparison of electron-beam microanalysis of glass by tephrochronology laboratories: Results and recommendations. Quaternary International, 246 (1-2), 19-47. 
Kylander, M. E., Lind, E. M., Wastegård, S., Lowemark, L. 2011. Recommendations for using XRF core scanning as a tool in tephrochronology. The Holocene, 22 (3), 371-375.

Lamb, A. L. 2000. Stable Isotope Geochemistry of Lakes Tilo and Awassa, Ethiopia: a Holocene record of volcanic and climatic change. Ph.D. thesis, University of Wales Aberystwyth.

Lamb, A. L., Leng, M. J., Lamb, H. F., Mohammed, M. U. 2000. A 9000-year oxygen and carbon isotope record of hydrological change in a small Ethiopian crater lake. The Holocene, 10 (2), 167-177.

Lamb, A. L., Leng, M. J., Lamb, H. F., Telford, R. J., Mohammed, M. U. $2002 a$. Climatic and non-climatic effects on the $\delta^{18} O$ and $\delta^{13} C$ compositions of Lake Awassa, Ethiopia, during the last 6.5 ka. Quaternary Science Reviews, 21 (1-2), 2199-2211.

Lamb, A. L., Leng, M. J., Mohammed, M. U., Lamb, H. F. 2004. Holocene climate and vegetation change in the Main Ethiopian Rift Valley, inferred from the composition ( $\mathrm{C} / \mathrm{N}$ and $\left.\delta^{13} C\right)$ of lacustrine organic matter. Quaternary Science Reviews, 23 (7-8), 881-891.

Lamb, H. F., Kebede, S., Leng, M. J., Ricketts, D., Telford, R. J., Umer, M. 2002b. Origin and Isotopic Composition of Aragonite Laminae in an Ethiopian Crater Lake. The East African Great Lakes: Limnology, Palaeolimnology and Biodiversity, 12, 487-508.

Lamb, H. F., Leng, M. J., Telford, R. J., Ayenew, T., Umer, M. 2007. Oxygen and carbon isotope composition of authigenic carbonate from an Ethiopian lake: a climate record of the last 2000 years. The Holocene, 17 (4), 517-526. 
Lane, C. S., Blockley, S. P. E., Magerud, J., Smith, V. C., Lohne, Ø. S., Tomlinson, E. L., Matthews, I. P., Lotter, A. F. 2012. Was the 12.1 ka Icelandic Vedde Ash one of a kind? Quaternary Science Reviews, 33, 87-99.

Lane, C. S., Brauer, A., Blockley, S. P. E., Dulski, P. 2013a. Volcanic ash reveals time-transgressive abrupt climate change during the Younger Dryas. Geology, 41 (12), 1251-1254.

Lane, C. S., Chorn, B. T., Johnson, T. C. 2013b. Ash from the Toba supereruption in Lake Malawi shows no volcanic winter in East Africa at 75 ka. Proceedings of the National Academy of Sciences of the United States of America, 110 (20), 8025-8029.

Lane, C. S., Cullen, V. L., White, D., Bramham-Law, C. W. F., Smith, V. C. 2014. Cryptotephra as a dating and correlation tool in archaeology. Journal of Archaeological Science, 42, 42-50.

Langdon, P. G., Caseldine, C. J., Croudace, I. W., Jarvis, S., Wastegård, S., Crowford, T. C. 2011. A chironomid-based reconstruction of summer temperatures in NW Iceland since AD 1650. Quaternary Research, 75 (3), $451-460$.

Lawson, I. T., Swindles, G. T., Plunkett, G., Greenberg, D. 2012. The spatial distribution of Holocene cryptotephras in north-west Europe since $7 \mathrm{ka}$ : implications for understanding ash fall events from Icelandic eruptions. Quaternary Science Reviews, 41, 57-66.

Le Bas, M. J., Le Maitre, R. W., Streisen, A., Zanettin, B. 1986. A chemical classification of volcanic rocks based on the total alkali-silica diagram. Journal of Petrology, 27 (3), 745-750. 
Le Maitre, R. W. 2002. Igneous Rocks: A Classification and Glossary of Terms: Recommendations of the International Union of Geological Sciences Subcommission on the Systematics of Igneous Rocks. Cambridge University Press.

Leakey, L., Evernden, J., Curtis, G. 1961. Age of Bed I, Olduvai Gorge, Tanganyika. Nature, 191, 478-479.

Lee, M.-Y., C.-H., C., K.-Y., W., Lizuka, Y., Carey, S. 2004. First Toba supereruption revival. Geology, 32 (1), 61-64.

Leng, M. J., Lamb, A. L., Lamb, H. F., Telford, R. J. 1999. Palaeoclimatic implications of isotopic data from modern and early Holocene shells of the freshwater snail Melanoides tuberculata, from lakes in the Ethiopian Rift Valley. Journal of Paleolimnology, 21, 97-106.

Leng, M. J., Marshall, J. D. 2004. Palaeoclimate interpretation of stable isotope data from lake sediment archives. Quaternary Science Reviews, 23 (7-8), $811-831$.

Lenhardt, N., Oppenheimer, C. 2014. Extreme Natural Hazards, Disaster Risks and Societal Implications, Cambridge University Press, chapter Volcanism in Africa: geological perspectives, hazards and societal implications. pp. 169-199.

Lowe, D. J. 1985. Application of impulse radar to continuous profiling of tephrabearing lake sediments and peats: An initial evaluation. New Zealand Journal of Geology and Geophysics, 28 (4), 667-674.

Lowe, D. J. 2011. Tephrochronology and its application: A review. Quaternary Geochronology, 6 (2), 107-153. 
Lowe, D. J., Shane, P. A. R., Alloway, B. V., Newnham, R. M. 2008. Fingerprints and age models for widespread New Zealand tephra marker beds erupted since 30,000 years ago: a framework for NZ-INTIMATE. Quaternary Science Reviews, 27 (1-2), 95-126.

Lowe, J., Barton, N., Blockley, S., Ramsey, C. B., Cullen, V. L., Davies, W., Gamble, C., Hardiman, K. G. M., Housley, R., Lane, C. S., Lee, S., Lewis, M., MacLeod, A., Menzies, M., Müller, W., Pollard, M., Price, C., Roberts, A. P., Rohlinge, E. J., Satowa, C., Smith, V. C., Stringer, C. B., Tomlinson, E. L., White, D., Albert, P., Arienzoi, I., Barker, G., Borić, D., Carandente, A., Civetta, L., Ferrier, C., Guadelli, J.-L., Karkanas, P., Koumouzelis, M., Mller, U. C., Orsi, G., Pross, J., Rosi, M., Shalamanov-Korobarq, L., Sirakovr, N., Tzedakiss, P. C. 2012. Volcanic ash layers illuminate the resilience of Neanderthals and early modern humans to natural hazards. Proceedings of the National Academy of Sciences of the United States of America, 109 (34), 532537.

Macdonald, R., Bagiński, Ronga, F., Dzierżanowski, M., P. amd Lustrino, Marzoli, A., Melluso, L. 2012. Evidence for extreme fractionation of peralkaline silicic magmas, the Boseti volcanic complex, Main Ethiopian Rift. Mineralogy and Petrology, 104 (3), 163-175.

Macgregor, D. 2015. History of the development of the East African Rift System: A series of interpreted maps through time. Journal of African Earth Sciences, 101, 232-252.

Mahood, G. A., Stimac, J. A. 1990. Trace-element partitioning in pantellerites and trachytes. Geochimica et Cosmochimica Acta, 54 (8), 2257-2276. 
Manville, V., Segschneider, B., White, J. D. L. 2002. Hydrodynamic behaviour of Taupo 1800a pumice: implications for the sedimentology of remobilized pyroclasts. Sedimentology, 49 (5), 955-976.

Mariner, R. H., Surdam, R. C. 1970. Alkalinity and formation of zeolites in saline alkaline lakes. Science, 170 (3961), 977-980.

Marsh, B. D. 2015. Chapter 8 - Magma Chambers. In Sigurdsson, H. (ed.) The Encyclopedia of Volcanoes (Second Edition), Academic Press, Amsterdam. Second edition edition, pp. $185-201$.

Marshall, M. H. 2006. Late Pleistocene and Holocene palaeolimnology of Lakes Tana and Ashenge, northern Ethiopia. Ph.D. thesis, University of Wales Aberystwyth.

Marshall, M. H., Lamb, H. F., Davies, S. J., Leng, M. J., Kubsa, Z., Umer, M., Bryant, C. 2009. Climatic change in northern Ethiopia during the past 17,000 years: A diatom and stable isotope record from Lake Ashenge. Palaeogeography, Palaeoclimatology, Palaeoecology, 279 (1-2), 114-127.

McCanta, M. C., Hatfield, R. G., Thomson, B. J., Hook, S. J., Fisher, E. 2015. Identifying cryptotephra units using correlated rapid, nondestructive methods: VSWIR spectroscopy, X-ray fluorescence and magnetic susceptibility. Geochemistry, Geophysics, Geosystems, 16 (12), 4029-4056.

McDougall, I. 1985. ${ }^{40} \mathrm{Ar} /{ }^{39} \mathrm{Ar}$ dating of the hominid-bearing PliocenePleistocene sequence at Koobi Fora, Lake Turkana, northern Kenya. Geological Society of America Bulletin, 96 (2), 159-175.

McHenry, L. 2005. Phenocryst composition as a tool for correlating fresh and altered tephra, Bed I, Olduvai Gorge, Tanzania. Stratigraphy, 2 (2), 101-115. 
Michels, J. W., Tsong, I. S. T., Nelson, C. M. 1983. Obsidian Dating and East African Archeology. Science, 219 (4583), 361-366.

Mohr, P., Zanettin, B. 1988. Continental Flood Basalts, Kluwer, chapter The Ethiopian Flood Basalt Province. pp. 63-110.

Mohr, P. A. 1971. Ethiopian Rift and Plateaus: Some Volcanic Petrochemical Differences. Journal of Geophysical Research, 76 (8), 1967-1983.

Mohr, P. A. 1978. Afar. Annual Review of Earth and Planetary Sciences, 6, $145-172$.

Morgan, G. B., London, D. 1996. Optimizing the electron microprobe analysis of hydrous alkali aluminosilicate glasses. American Mineralogist, 81 (9-10), $1176-1185$.

Morgan, G. B., London, D. 2005. Effect of current density on the electron microprobe analysis of alkali aluminosilicate glasses. American Mineralogist, 90, 1131-1138.

Nagaoka, S., Katoh, S., WoldeGabriel, G., Sato, H., Nakaya, H., Beyene, Y., Suwa, G. 2005. Lithostratigraphy and sedimentary environments of the hominid-bearing Pliocene-Pleistocene Konso Formation in the southern Main Ethiopian Rift, Ethiopia. Palaeogeography, Palaeoclimatology, Palaeoecology, $216(3-4), 333-357$.

Namwamba, F. L. 1993. Tephrostratigraphy of the Chemeron Formation Baringo Basin, Kenya. Master's thesis, The University of Utah.

Narcisi, B., Petit, J. R., Tiepolo, M. 2006. A volcanic marker (92ka) for dating deep east Antarctic ice cores. Quaternary Science Reviews, 25 (21-22), 26822687. 
NASA. 2011. Earth Observatory - Eruption at Nabro Volcano, Eritrea.

URL http://earthobservatory .nasa.gov/NaturalHazards/view.php?id=50988

Newhall, C. G., Self, S. 1982. The Volcanic Explosivity Index (VEI): An Estimate of Explosive Magnitude for Historical Volcanism. Journal of Geophysical Research, 87 (C2), 1231-1238.

Oppenheimer, C. 2011. Eruptions that Shook the World. Cambridge University Press.

Oppenheimer, C., Francis, P. 1997. Remote sensing of heat, lava and fumarole emissions from Erta' Ale volcano, Ethiopia. International Journal of Remote Sensing, 18 (8), 1661-1692.

Payne, R. J., Kilfeather, A. A., van der Meer, J. J. M., Blackford, J. J. 2005. Experiments on the taphonomy of tephra in peat. Suoseura - Finnish Peatland Society, 56 (4), 147-156.

Pearce, N. J. G. 1990. Zirconium and niobium-bearing ilmenites from the Igaliko dyke swarm, South Greenland. Mineralogical Magazine, 54, 585-588.

Pearce, N. J. G., Abbott, P. M., Martin-Jones, C. M. 2014. Microbeam methods for the analysis of glass in fine-grained tephra deposits: a SMART perspective on current and future trends. In Austin, W. E. N., Abbott, P. M., Davies, S. M., Pearce, N. J. G., Wastegård, S. (eds.) Marine Tephrochronology, Geological Society of London, Special Publications.

Pearce, N. J. G., Alloway, B. V., Westgate, J. A. 2008. Mid-Pleistocene silicic tephra beds in the Auckland region, New Zealand: Their correlation and origins based on the trace element analyses of single glass shards. Quaternary International, 178 (1), 16-43. 
Pearce, N. J. G., Bendall, C. A., Westgate, J. A. 2008. Comment on "Some numerical considerations in the geochemical analysis of distal microtephra' by A.M. Pollard, S.P.E. Blockley and C.S. Lane. Applied Geochemistry, 23 (10), $1353-1364$.

Pearce, N. J. G., Perkins, W. T., Westgate, J. A., Gorton, M. P., Jackson, S. E., Neal, C. R., Chenery, S. P. 1997. A Compilation of New and Published Major and Trace Element Data for NIST SRM 610 and NIST SRM 612 Glass Reference Materials. Geostandards Newsletter, 21, 115-144.

Pearce, N. J. G., Perkins, W. T., Westgate, J. A., Wade, S. C. 2011. Traceelement microanalysis by LA-ICP-MS: The quest for comprehensive chemical characterisation of single, sub- $\sim 10 \mu \mathrm{m}$ volcanic glass shards. Quaternary International, 246 (1-2), 57-81.

Pearce, N. J. G., Westgate, J. A., Gatti, E., Pattan, J. N., Parthiban, G., Achyuthan, H. 2014. Individual glass shard trace element analyses confirm that all known Toba tephra reported from India is from the c. 75-ka Youngest Toba eruption. Journal of Quaternary Science, 29 (8), 729-734.

Pearce, N. J. G., Westgate, J. A., Perkins, W. T., Eastwood, W. J., Shane, P. 1999. The application of laser ablation ICP-MS to the analysis of volcanic glass shards from tephra deposits: bulk glass and single shard analysis. Global and Planetary Change, 21 (1-3), 151-171.

Peccerillo, A., Donati, C., Santo, A. P., Orlando, A., Yirgu, G., Ayalew, D. 2007. Petrogenesis of silicic peralkaline rocks in the Ethiopian Rift: Geochemical evidence and volcanological Implications. Journal of African Earth Sciences, $48(2-3), 161-173$. 
Peccerillo, A., Mandefro, B., Solomon, G., Hambisa, G., Beru, H., Tesfaye, K. 1998. The Precambrian rocks from Southern Ethiopia: petrology, geochemistry and their interaction with the recent volcanism from the Ethiopian Rift Valley. Neues Jahrbuch für Minereralogie, Abhandlungen, 173, 237-262.

Perkins, W. T., Pearce, N. J. G. 1995. Mineral microanalysis by laserprobe inductively coupled plasma mass spectrometry. In Potts, P. J., Bowles, J. F. W., Reed, S. J. B., Cave, M. R. (eds.) Microprobe Techniques in the Earth Sciences, The Mineralogical Society, London.

Persson, C. 1966. Försök till tefrokronologisk datering av några svenska torvmossar. Geologisku Förenitzgens i Stockholm Förhandlingar, 88 (3), $361-395$.

Pickford, M., Senut, B., Poupeau, G., Brown, F. H., Haileab, B. 1991. Correlation of tephra layers from the Western Rift Valley (Uganda) to the Turkana Basin (Ethiopia/Kenya) and the Gulf of Aden. Comptes Rendus de L'Academie des Sciences Serie II, 313, 223-229.

Pyle, D. M. 1989. The thickness, volume and grainsize of tephra fall deposits. Bulletin of Volcanology, 51 (1), 1-15.

Pyle, D. M. 1999. Widely dispersed Quaternary tephra in Africa. Global and Planetary Change, 21 (1-3), 95-112.

Rampey, M., Oppenheimer, C., Pyle, D. M., Yirgu, G. 2010. Caldera-forming eruptions of the Quaternary Kone Volcanic Complex, Ethiopia. Journal of African Earth Sciences, 58 (1), 51-66.

Rampino, M. R., Ambrose, S. H. 2000. Volcanic winter in the Garden of Eden: the Toba super-eruption and the Late Pleistocene human population crash. In 
McCoy, F. W., Heiken, G. (eds.) Volcanic Hazards and Disasters in Human Antiquity, Special Paper 345, Geological Society of America, chapter 6. pp. 71-82.

Rapprich, V., Č́žzek, D., Daniel, K., Firdawok, L., Habtamu, B., Hroch, T., Kopačková, V., Málek, J., Malík, J., Mišurec, J., Orgoň, A., Šebesta, J., Šíma, J., Tsigehana, T., Verner, K., Yewubinesh, B. 2013. Explanation Booklet to the Set of Geoscience maps of Ethiopia at scale 1:50,000, subsheet 0738C4 Awassa. Technical report, Czech Geological Survey/Aquatest/Geological Survey of Ethiopia, Praha/Addis Ababa, Czech Republic/Ethiopia.

Rapprich, V., Žáček, V., Verner, K., Erban, V., Goslar, T., Bekele, Y., Legesa, F., Hroch, T., Hejtmánková, P. 2016. Wendo Koshe Pumice: The latest Holocene silicic explosive eruption product of the Corbetti Volcanic System (Southern Ethiopia). Journal of Volcanology and Geothermal Research, 310, 159 - 171.

Rasmussen, T. L., Wastegård, S., Kuijpers, A., van Weering, T. C. E., Heinemeier, J., Thomsen, E. 2003. Stratigraphy and distribution of tephra layers in marine sediment cores from the Faeroe Islands, North Atlantic. Marine Geology, 199 (3-4), 263-277.

Rawson, H., Naranjo, J. A., Smith, V. C., Fontijn, K., Pyle, D. M., Mather, T. A., Moreno, H. 2015. The frequency and magnitude of post-glacial explosive eruptions at Volcán Mocho-Choshuenco, southern Chile. Journal of Volcanology and Geothermal Research, 299, 103-129.

Reide, F., Bazely, O., Newton, A. J., Lane, C. S. 2011. A Laacher See-eruption supplement to Tephrabase: Investigating distal tephra fallout dynamics. Quaternary International, 246 (1-2), 134-144. 
Reimer, P. J., Bard, E., Bayliss, A., Warren Beck, J., Blackwell, P. G., Bronk Ramsey, C., Buck, C. E., Cheng, H., Lawrence Edwards, R., Friedrich, M., Grootes, P. M., Guilderson, T. P., Haflidason, H., Hajdas, I., Hatté, C., Heaton, T. J., Hoffmann, D. L., Hogg, A. G., Hughen, K. A., Kaiser, K. F., Kromer, B., Manning, S. W., Niu, M., Reimer, R. W., Richards, D. A., Marian Scott, E., Southon, J. R., Staff, R. A., Turney, C. S. M., van der Plicht, J. 2013. IntCal13 and Marine13 radiocarbon age calibration curves 0-50,000 years cal BP. Radiocarbon, 55 (4), 1869-1887.

Renne, P. R., WoldeGabriel, G., Hart, W. K., Heiken, G., White, T. D. 1999. Chronostratigraphy of the Miocene-Pliocene Sagantole Formation, Middle Awash Valley, Afar rift, Ethiopia. Geological Society of America Bulletin, $111(6), 869-885$.

Rogers, N. 2015. Chapter 4 - The Composition and Origin of Magmas. In Sigurdsson, H. (ed.) The Encyclopedia of Volcanoes (Second Edition), Academic Press, Amsterdam. Second edition edition, pp. 93 - 112.

Rollinson, H. 1993. Using Geochemical Data: Evaluation, Presentation, Interpretation. Geochemistry series, Longman Scientific \& Technical.

Rooney, T. O., Hart, W. K., Hall, C. M., Ayalew, D., Ghiorso, M. S., Hidalgo, P., Yirgu, G. 2012. Peralkaline magma evolution and the tephra record in the Ethiopian Rift. Contributions to Mineralogy and Petrology, 164 (3), 407-426.

Rose, W. I., Chesner, C. A. 1987. Dispersal of ash in the great Toba eruption, 75 ka. Geology, 15 (10), 913-917.

Rose, W. I., Durant, A. J. 2009. Fine ash content of explosive eruptions. Journal of Volcanology and Geothermal Research, 186 (1-2), 32-39. 
Sarna-Wojcicki, A. M., Meyer, C. E., Roth, P. H., Brown, F. H. 1985. Ages of tuff beds at East African early hominid sites and sediments in the Gulf of Aden. Nature, 313, 306-308.

Sawamura, P., Vernier, J. P., Barnes, J. E., Berkoff, T. A., Welton, E., AladosArboledas, L., Navas-Guzmán, F., Pappalardo, G., Mona, L., Madonna, F., Lange, D., Sicard, M., Godin-Beekmann, S., Payen, G., Wang, Z., Hu, S., Tripathi, S. N., Cordoba-Jabonero, C., Hoff, R. M. 2012. Stratospheric AOD after the 2011 eruption of Nabro volcano measured by lidars over the Northern Hemisphere. Environmental Research Letters, 7 (3), 1-9.

Saylor, B. Z., Angelini, J., Deino, A., Alene, M., Fournelle, J. H., Haile-Selassie, Y. 2016. Tephrostratigraphy of the Waki-Mille area of the Woranso-Mille paleoanthropological research project, Afar, Ethiopia. Journal of Human Evolution, 93, 25-45.

Shane, P. A., Smith, I. 2000. Geochemical fingerprinting of basaltic tephra deposits in the Auckland Volcanic Field. New Zealand Journal of Geology \& Geophysics, 43 (4), 569-577.

Shane, P. A. R., Hoverd, J. 2002. Distal record of multi-sourced tephra in Onepoto Basin, Auckland, New Zealand: implications for volcanic chronology, frequency and hazards. Bulletin of Volcanology, 64 (7), 441-454.

Shuey, R. T., Brown, F. H., Croes, M. K. 1974. Magnetostratigraphy of the Shungura Formation, southwestern Ethiopia: Fine structure of the lower Matuyama polarity epoch. Earth and Planetary Science Letters, 23 (2), 249260. 
Siebert, L., Simkin, T., Kimberly, P. 2011. Volcanoes of the World: Third Edition. University of California Press.

Smeds, H. 1964. A Note on Recent Volcanic Activity on the Ethiopian Plateau, as Witnessed by a Rise of the Level of Lake Wonchi $1400 \pm 140$ B.P. Acta Geographica, 18 (1), 32.

Smith, D. G. W., Westgate, J. A. 1968. Electron probe technique for characterising pyroclastic deposits. Earth and Planetary Science Letters, 5, 313-319.

Smith, V. C., Isaia, R., Pearce, N. J. G. 2011a. Tephrostratigraphy and glass compositions of post-15 kyr Campi Flegrei eruptions: implications for eruption history and chronostratigraphic markers. Quaternary Science Reviews, 30 (2526), 3638-3660.

Smith, V. C., Pearce, N. J. G., Matthews, N. E., Westgate, J. A., Petraglia, M. D., Haslam, M., Lane, C. S., Korisettar, R., Pal, J. N. 2011b. Geochemical fingerprinting of the widespread Toba tephra using biotite compositions. Quaternary International, 246 (1-2), 97-104.

Smith, V. C., Shane, P. A. R., Smith, I. E. M. 2002. Tephrostratigraphy and geochemical fingerprinting of the Mangaone Subgroup tephra beds, Okataina Volcanic Centre, New Zealand. New Zealand Journal of Geology and Geophysics, 45 (2), 207-219.

Smith, V. C., Staff, R. A., Blockley, S. P. E., Bronk Ramsey, C., Nakagawa, T., Mark, D. F., Takemura, K., Danhara, T., Suigetsu 2006 Project Members. 2013. Identification and correlation of visible tephras in the Lake Suigetsu SG06 sedimentary archive, Japan: chronostratigraphic markers for synchronising 
of east Asian/west Pacific palaeoclimatic records across the last $150 \mathrm{ka}$. Quaternary Science Reviews, 67, 121-137.

Sørensen, H. 1974. The Alkaline Rocks. Wiley-Interscience publication, J. Wiley. Sparks, R. S. J., Bursik, M. I., Ablay, G. J., Thomas, R. M. E., Carey, S. N. 1992. Sedimentation of tephra by volcanic plumes. Part 2: controls on thickness and grain-size variations of tephra fall deposits. Bulletin of Volcanology, 54 (8), $685-695$.

Sparks, R. S. J., Bursik, M. I., Carey, S., Gilbert, J. G., Glaze, L. S., Sigurdson, H., Woods, A. 1997. Volcanic Plumes. John Wiley \& Sons.

Sparks, R. S. J., Walker, G. P. L. 1977. The significance of vitric-enriched air-fall ashes associated with crystal-enriched ignimbrites. Journal of Volcanology and Geothermal Research, 2 (4), 329-341.

Swindles, G. T., Lawson, I. T., Savov, I. P., Connor, C. B., Plunkett, G. 2011. A 7000 yr perspective on volcanic ash clouds affecting northern Europe. Geology, 39 (9), 887-890.

Sylvester, P. 2008. Matrix effects in Laser Ablation-ICP-MS. In Mineralogical Association of Canada Short Course 40. pp. 67-78.

Taieb, M. 1974. Evolution Quaternaire du Basin de l'Awash, Ethiopia. Ph.D. thesis, University of Paris.

Takemura, K., Hayashida, A., Okamura, M., Matsouka, H., Ali, M., Kuniko, Y., Torii, M. 2000. Stratigraphy of multiple piston-core sediments for the last 30,000 years from Lake Biwa, Japan. Journal of Paleolimnology, 23 (2), 185-199. 
Taylor, R. P., Jackson, S. E., Longerich, H. P., Webster, J. D. 1997. In situ trace-element analysis of individual silicate melt inclusions by laser ablation microprobe-inductively coupled plasma-mass spectrometry (LAM-ICP-MS). Geochimica et Cosmochimica Acta, 61 (13), 2559-2567.

Telford, R. J. 1998. Diatom stratigraphies of Lake Awassa and Tilo, Ethiopia: Holocene records of groundwater variability and climate change. Ph.D. thesis, University of Wales Aberystwyth.

Telford, R. J., Lamb, A. L. 1999. Groundwater-Mediated Response to Holocene Climatic Change Recorded by the Diatom Stratigraphy of an Ethiopian Crater Lake. Quaternary Research, 52 (1), 63-75.

Telford, R. J., Lamb, H., Umer, M. 1999. Diatom-derived palaeoconductivity estimates for Lake Awassa, Ethiopia: evidence for pulsed inflows of saline groundwater? Journal of Paleolimnology, 21 (4), 409-421.

Thompson, R. N. 1982. Magmatism of the British Tertiary volcanic province. Scottish Journal of Geology, 18 (1), 49.

Tomlinson, E. L., Thordarson, T., Müller, W., Thirlwall, M., Menzies, M. A. 2010. Microanalysis of tephra by LA-ICP-MS - Strategies, advantages and limitations assessed using the Thorsmörk ignimbrite (Southern Iceland). Chemical Geology, 279 (3-4), 73-89.

Tryon, C., Roach, N., Logan, M. 2008. The Middle Stone Age of the northern Kenyan Rift: age and context of new archaeological sites from the Kapedo Tuffs. Journal of Human Evolution, 55 (4), 652-664. 
Turner, M. B., Bebbington, M. S., Cronin, S. J., Stewart, R. B. 2009. Merging eruption datasets: building an integrated Holocene eruptive record for Mt Taranaki, New Zealand. Bulletin of Volcanology, 71 (8), 903-918.

Turner, M. B., Cronin, S. J., Stewart, R. B., Bebbington, M., Smith, I. E. M. 2008. Using titanomagnetite textures to elucidate volcanic eruption histories. Geology, 36 (1), 31-34.

Turney, C. S. M. 1998. Extraction of rhyolitic component of Vedde microtephra from minerogenic lake sediments. Journal of Paleolimnology, 19 (2), 199-206.

Ukstins Peate, I., Baker, J. A., Kent, A. J. R., Al-Kadasi, M., Al-Subbary, A., Ayalew, D., Menzies, M. 2003. Correlation of Indian Ocean tephra to individual Oligocene silicic eruptions from Afro-Arabian flood volcanism. Earth and Planetary Science Letters, 211 (3-4), 311-327.

Ukstins Peate, I., Kent, A. J. R., Baker, J. A., Menzies, M. A. 2008. Extreme geochemical heterogeneity in Afro-Arabian Oligocene tephras: Preserving fractional crystallization and mafic recharge processes in silicic magma chambers. Lithos, 102 (1-2), 260-278.

Venuti, A., Verosub, K. L. 2010. Paleomagnetic record of basaltic volcanism from Pukaki and Onepoto maar lake cores, Auckland Volcanic Field, New Zealand. New Zealand Journal of Geology and Geophysics, 53 (1), 71-79.

Vogel, H., Zanchetta, G., Sulpizio, R., Wagner, B., Nowaczyk, N. 2010. A tephrostratigraphic record for the last glacial-interglacial cycle from Lake Ohrid, Albania and Macedonia. Journal of Quaternary Science, 25 (3), 320338. 
Žáček, V., Rapprich, V., Aman, Y., Berhanu, B., Č́̌̌̌ek, D., Dereje, K., Erban, V., Ezra, T., Firdawok, L., Habtamu, M., Hroch, T., Kopačková, V., P. Kycl, J. M., Mišurec, J., Orgoň, A., Pécskay, Z., Šíma, J., Tarekegu, D., Verner, K. 2014. Explanation booklet to the Set of Geoscience maps of Ethiopia at a scale 1 : 50,000: sub-sheet 0738-D3 Shashemene. Technical report, Czech Geological Survey/Aquatest/Geological Survey of Ethiopia, Praha/Addis Ababa, Czech Republic/Ethiopia.

Walker, G. P. L. 1971. Grain-Size Characteristics of Pyroclastic Deposits. The Journal of Geology, 79 (6), 696-714.

Walker, G. P. L. 1973. Explosive volcanic eruptions - a new classification scheme. International Journal of Earth Sciences, 62 (2), 431-446.

Walter, R. C. 1989. Application and limitation of fission-track geochronology to Quarternary tephras. Quaternary International, 1, 35-46.

Walter, R. C. 1994. Age of Lucy and the First Family: Single-crystal 40Ar/39Ar dating of the Denen Dora and lower Kada Hadar members of the Hadar Formation, Ethiopia. Geology, 22 (1), 6-10.

Walter, R. C., Aronson, J. 1993. Age and source of the Sidi Hakoma Tuff, Hadar Formation, Ethiopia. Journal of Human Evolution, 25, 229-240.

Walter, R. C., Hart, W. K., Westgate, J. A. 1987. Petrogenesis of a basalt-rhyolite tephra from the west-central Afar, Ethiopia. Contributions to Mineralogy and Petrology, 95 (4), 462-480.

Wastegård, S. 2005. Late Quaternary tephrochronology of Sweden: a review. Quaternary International, 130 (1), 49-62. 
Wastegård, S., Veres, D., Kliem, P., Hahn, A., Ohlendorf, C., Zolitschka, The PASADO Science Team. 2013. Towards a late Quaternary tephrochronological framework for the southernmost part of South America e the Laguna Potrok Aike tephra record. Quaternary Science Reviews, 71, 81-90.

Watson, E. B. 1979. Zircon saturation in felsic liquids - Experimental results and applications to trace-element geochemistry. Contributions to Mineralogy and Petrology, 70 (4), 407-419.

Watt, G. R., Harley, S. L. 1993. Accessory phase controls on the geochemistry of crustal melts and restites produced during water undersaturated partial melting. Contributions to Mineralogy and Petrology, 101 (4), 220-231.

Webster, J. D., Taylor, R. P., Bean, C. 1993. Pre-eruptive melt composition and constraints on degassing of a water-rich pantellerite magma, Fantale volcano, Ethiopia. Contributions to Mineralogy and Petrology, 114 (1), 53-62.

Westgate, J. A., Pearce, N. J. G., Perkins, W. T., Preece, S. J., Chesner, C. A., Muhammad, R. F. 2013. Tephrochronology of the Toba tuffs: four primary glass populations define the 75-ka Youngest Toba Tuff, northern Sumatra, Indonesia. Journal of Quaternary Science, 28 (8), 772-776.

Westgate, J. A., Perkins, W. T., Fuge, R., Pearce, N. J. G., Wintle, A. G. 1994. Trace element analysis of volcanic glass shards by laser ablation inductively coupled plasma mass spectrometry: application to Quaternary tephrochronological studies. Applied Geochemistry, 9 (3), 323-355.

White, J. D. L., Riggs, R. 2001. Volcaniclastic Sedimentation in Lacustrine Settings, Blackwell Science, chapter Introduction: styles and significance of lacustrine volcaniclastic sedimentation. pp. 1-6. 
Wiart, P., Oppenheimer, C. 2000. Largest known historical eruption in Africa: Dubbi volcano, Eritrea, 1861. Geology, 28 (4), 291-294.

Wiart, P., Oppenheimer, C. 2004. Large magnitude silicic volcanism in north Afar: the Nabro Volcanic Range and Ma'alalta volcano. Bulletin of Volcanology, 67 (2), 99-115.

Wilkinson, P., Mitchell, J. G., Cattermole, P. J., Downie, C. 1986. Volcanic chronology of the Men-Kilimanjaro region, Northern Tanzania. Journal of the Geological Society, 143, 601-605.

WoldeGabriel, G. 1994. Ecological and temporal placement of early Pliocene hominids at Aramis. Nature, 371, 330-333.

WoldeGabriel, G., Aronson, J. L., Walter, R. C. 1990. Geology, geochronology, and rift basin development in the central sector of the Main Ethiopia Rift. Geological Society of America Bulletin, 102 (4), 439-458.

WoldeGabriel, G., Endale, T., White, T. D., Thouveny, N., Hart, W. K., Renne, P. R., Asfaw, B. 2013. The role of tephra studies in African paleoanthropology as exemplified by the Sidi Hakoma Tuff. Journal of African Earth Sciences, 77, 41-58.

WoldeGabriel, G., Haile-Selassie, Y., Renne, P. R., Hart, W. K., Ambrose, S. H., Asfaw, B., Heiken, G., White, T. 2001. Geology and palaeontology of the Late Miocene Middle Awash valley, Afar rift, Ethiopia. Nature, 412, 175-178.

WoldeGabriel, G., Hart, W., Katoh, S., Beyene, Y., Suwa, G. 2005. Correlation of Plio-Pleistocene Tephra in Ethiopia and Kenyan rift basins: Temporal calibration of geological features and hominid fossil records. Journal of Volcanology and Geothermal Research, 147 (1-2), 81-108. 
WoldeGabriel, G., Hart, W. K. 2005. Innovative tephra studies in the East African rift system. Eos, 86 (27), 255.

WoldeGabriel, G., Walker, R., Aronson, J. L., Hart, W. 1992. Geochronology and distribution of silicic volcanic rocks of Plio-Pleistocene age from the central sector of the Main Ethiopian Rift. Quaternary International, 13-14 (69-76).

WoldeGabriel, G., Walter, R. C., Hart, W. K., Mertzman, J. L., S. A. amd Aronson. 1999. Temporal relations in the geochemical features of felsic volcanism in the central sector of the Main Ethiopian Rift. Acta Vulcanologica, 11 (1), 53-67.

Wolfenden, E., Ebinger, C., Yirgub, G., Deino, A., Ayalew, D. 2004. Evolution of the northern Main Ethiopian rift: birth of a triple junction. Earth and Planetary Science Letters, 224 (1-2), 213-228.

Woods, A. W., Wohletz, K. 1991. Dimensions and dynamics of co-ignimbrite eruption columns. Nature, 350, 225-227.

Wulf, S., Ott, F., Słowinski, M., Noryókiewicz, A. M., Dröger, N., Martin-Puertas, C., Czymzik, M., Neugebauer, I., Dulski, P., Bourne, A. J., Błaszkiewicz, M., Brauer, A. 2013. Tracing the Laacher See Tephra in the varved sediment record of the Trzechowskie palaeolake in central Northern Poland. Quaternary Science Reviews, 76, 129-139. 


\section{Appendices}

\section{.1 Sample details}

The inventory seen below can be used by future workers to locate samples for further study - contact information is given at the start of this section. Most lake sediment archives used in this study are stored at Aberyswtyth University, however the Dendi records are based at the University of Cologne. Processed Ashenge, Hayk and Chamo sediments, of different densities, are stored at Aberystwyth University and may yield additional cryptotephras through further study. Tephra and obsidian samples from Corbetti and Tilo are housed at Aberystwyth University, whilst Dubbi proximal samples are located at the University of Cambridge. For information regarding the epoxy resin stubs containing tephras for analysis, contact Catherine Martin-Jones (presently at Aberystwyth University).

\section{Contact information}

\begin{tabular}{|c|c|c|}
\hline Catherine Martin-Jones & $\begin{array}{l}\text { Department of Geography and Earth Sciences, } \\
\text { Aberystwyth University }\end{array}$ & martinjonescatherine@gmail.com \\
\hline Henry Lamb & $\begin{array}{l}\text { Department of Geography and Earth Sciences, } \\
\text { Aberystwyth University }\end{array}$ & hfl@aber.ac.uk \\
\hline Nick Pearce & $\begin{array}{l}\text { Department of Geography and Earth Sciences, } \\
\text { Aberystwyth University }\end{array}$ & njp@aber.ac.uk \\
\hline Christine Lane & $\begin{array}{l}\text { School of Environment, Education and Development, } \\
\text { University of Manchester }\end{array}$ & christine.lane@manchester.ac.uk \\
\hline Frank Schaebitz & Seminar for Geography, University of Cologne & ape15@uni-koeln.de \\
\hline Clive Oppenheimer & Department of Geography, University of Cambridge & co200@cam.ac.uk \\
\hline
\end{tabular}




\section{Lake sediment core details}

\begin{tabular}{|c|c|c|c|c|}
\hline Site & Core name & c/o & Stored at & Notes \\
\hline Ashenge & $03 \mathrm{AL} 3 / 2$ & Henry Lamb & Aberystwyth cold store & $\begin{array}{l}5 \mathrm{~cm} \text { diameter, } 1 \text { long split } \\
\text { cores in sealed plastic }\end{array}$ \\
\hline Hayk & Hayk 2010 & Henry Lamb & Aberystwyth cold store & $\begin{array}{l}5.8 \mathrm{~cm} \text { diameter, } 1 \text { long } \\
\text { split cores in sealed plastic }\end{array}$ \\
\hline Dendi & DEN-1 and DEN-2 & Frank Schaebitz & $\begin{array}{l}\text { Seminar for Geography, } \\
\text { Cologne }\end{array}$ & $\begin{array}{l}5.8 \mathrm{~cm} \text { diameter, } 1 \text { long } \\
\text { split cores in sealed plastic }\end{array}$ \\
\hline Hora & Hora 2001 & Henry Lamb & Aberystwyth boat house & $\begin{array}{l}5 \mathrm{~cm} \text { diameter, } 1 \text { long split } \\
\text { cores in sealed plastic }\end{array}$ \\
\hline Awassa & AW-94 & Henry Lamb & Aberystwyth boat house & $\begin{array}{l}5 \mathrm{~cm} \text { diameter, } 1 \text { long split } \\
\text { cores in sealed plastic }\end{array}$ \\
\hline Tilo & $\mathrm{T}-97$ & Henry Lamb & Aberystwyth boat house & $\begin{array}{l}5 \mathrm{~cm} \text { diameter, } 1 \text { long split } \\
\text { cores in sealed plastic }\end{array}$ \\
\hline Chamo & CHA-01-2010 & $\begin{array}{l}\text { Frank } \\
\text { Schaebitz/Henry } \\
\text { Lamb }\end{array}$ & Aberystwyth cold store & $\begin{array}{l}\text { Sediment in } 2 \times 2 \mathrm{~cm} \\
\text { oriented cubes }\end{array}$ \\
\hline
\end{tabular}




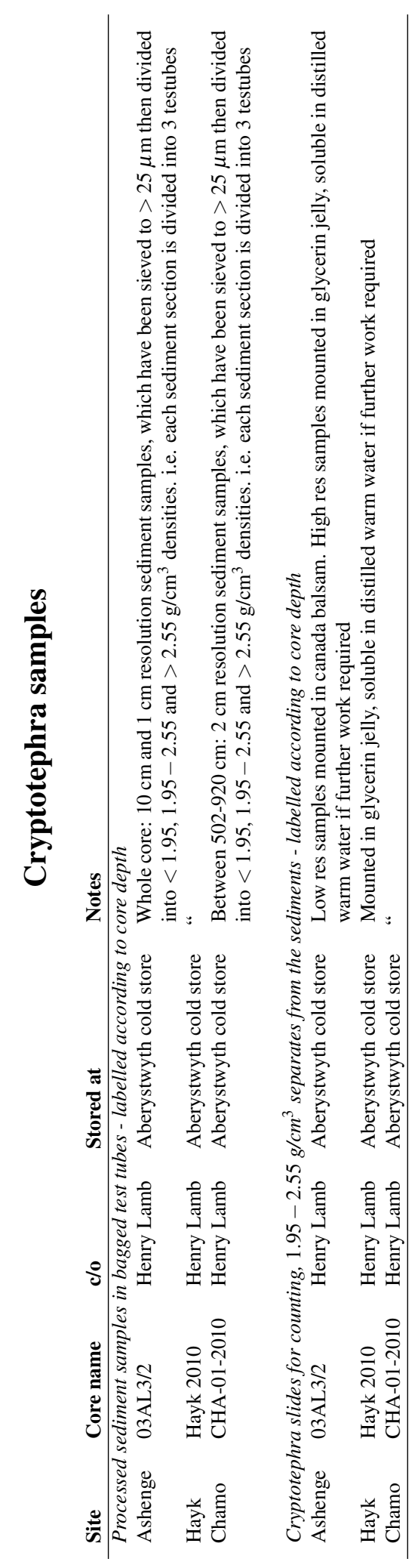




\section{Proximal tephra samples}

\begin{tabular}{lllll} 
Site & Sample type & Sample label & c/o & Stored at \\
\hline Corbetti & Obsidian thin section & E95010 & Nick Pearce & \\
& Obsidian thin section & E95011 & Nick Pearce & \\
& Obsidian thin section & E95019 & Nick Pearce & \\
& Obsidian thin section & E95003 & Nick Pearce & \\
& Bagged pumice & E95006 & Nick Pearce & Llandinam A5 rock drawers \\
& Bagged pumice & E95007 & Nick Pearce & Llandinam A5 rock drawers \\
& Auger sample & ST1-NW & Henry Lamb & Aberystwyth boat house \\
Tilo crater walls & Obsidian xenolith & E95025 & Nick Pearce & Llandinam A5 rock drawers \\
& Bagged pumice & E97003 & Nick Pearce & Llandinam A5 rock drawers \\
Dubbi & Bagged PDC & Dubbi 1861 & Clive Oppenheimer & \\
\hline
\end{tabular}

\section{EPMA/ LA-ICP-MS epoxy resin blocks}

\begin{tabular}{|c|c|c|c|c|}
\hline EPMA session & Stub label & Sample sites & Tephra IDs & c/o \\
\hline \multirow[t]{6}{*}{ Feb-14 } & 4 hole no label & Ashenge/ Dendi & $\begin{array}{l}\text { AST-5, DT-1, DT-2, } \\
\text { DT-3, }\end{array}$ & Catherine Martin-Jones \\
\hline & 6 hole no label & Ashenge & AST-1, AST-2, AST-8 & “ \\
\hline & $\mathrm{B}$ & Tilo & TT-3, TT-4, TT-5 & “ \\
\hline & $\mathrm{C}$ & Tilo & TT-6, ТT-7, ТT-8 & “ \\
\hline & $\mathrm{F}$ & Tilo & TT-11, TT-12 & “ \\
\hline & $\mathrm{H}$ & Tilo & $\begin{array}{l}\text { TT-14, AT-1, AT-2, } \\
\text { AT-4 }\end{array}$ & “ \\
\hline \multirow[t]{9}{*}{ Aug-14 } & A & Tilo & TT-1, TT-2 & Catherine Martin-Jones \\
\hline & $\mathrm{D}$ & Tilo & TT-8, TT-9 & “ \\
\hline & $\mathrm{E}$ & Tilo & TT-10, TT-11 & “ \\
\hline & G & Tilo & TT-13, TT-14 & “ \\
\hline & B2 & Corbetti & $\begin{array}{l}\text { ST1-SW, ST1-NW, } \\
\text { E97003, E97006 }\end{array}$ & “ \\
\hline & $\mathrm{C} 2$ & Ashenge/Hayk/Corbetti & $\begin{array}{l}\text { AST-5, HT-1, HT-2, } \\
\text { E95007 }\end{array}$ & “ \\
\hline & D2 & Corbetti/Dendi & $\begin{array}{l}\text { E95002, DT1-1, DT1- } \\
2, \text { DT1-3 }\end{array}$ & “ \\
\hline & A3 & Ashenge & $\begin{array}{l}\text { AST-3, AST-4, AST-6, } \\
\text { AST-7 }\end{array}$ & “ \\
\hline & D3 & Ashenge/Awassa/Hora & $\begin{array}{l}\text { AST-9, AT-1, AT-2, } \\
\text { HRT-1 }\end{array}$ & “ \\
\hline \multirow[t]{6}{*}{ Jun-15 } & A2 & Awassa/Hora & $\begin{array}{l}\text { AWT-4, AWT-7, HRT- } \\
2\end{array}$ & Catherine Martin-Jones \\
\hline & A & Hayk & $\begin{array}{l}\text { HT-1, HT-3, HT-6, } \\
\text { HT-10 }\end{array}$ & “ \\
\hline & $\mathrm{B}$ & Hayk & $\begin{array}{l}\text { HT-5, HT-9, HT-11, } \\
\text { HT-12 }\end{array}$ & “ \\
\hline & $\mathrm{C}$ & Hayk/Chamo & $\begin{array}{l}\text { HT-7, HT-8, CHT-1, } \\
\text { CHT-2 }\end{array}$ & “ \\
\hline & $\mathrm{D}$ & Mochena Borago & $\begin{array}{lll}\text { BIS-1, } & \text { BIS-2, } & \text { M14 } \\
0.27 \mathrm{~m} \quad \mathrm{NW}, & \text { M14 } \\
0.75 \mathrm{~m} \mathrm{NE} & \end{array}$ & “ \\
\hline & $\mathrm{E}$ & Dubbi/Mochena Borago & $\begin{array}{l}\text { Dubbi 1, Dubbi 2, } \\
\text { M14 0.47m SW, TU2 }\end{array}$ & “ \\
\hline
\end{tabular}




\section{.2 Crypotephra glass shard counts}

The following table gives glass shard concentrations in Ashenge, Hayk and Chamo lake sediments. Shard counting was first undertaken across continuous $10 \mathrm{~cm}$ regions in the sediments. At depths where high glass shard counts were identified, the relevant sections were resampled at a $1 \mathrm{~cm}$ resolutions, to identify the exact position of the cryptotephra. The Chamo sediments were only sampled at a $1 \mathrm{~cm}$ resolution. Shard counts are recorded per gram dry weight (gdw) sediment. Elevated glass shard counts at the $1 \mathrm{~cm}$ resolution, indicating cryptotephra horizons, are indicated in bold.

Tephra glass shard counts in the Ashenge, Hayk and Chamo lake sediments

\begin{tabular}{|c|c|c|c|c|c|c|c|}
\hline \multicolumn{3}{|c|}{ Ashenge } & \multicolumn{3}{|c|}{ Hayk } & \multicolumn{2}{|c|}{ Chamo } \\
\hline $\begin{array}{l}\text { Core depth } \\
\text { (cm) }\end{array}$ & $\begin{array}{l}\text { Shards per } \\
\text { gdw } 10 \mathrm{~cm} \\
\text { sample }\end{array}$ & $\begin{array}{l}\text { Shards per } \\
\text { gdw } 1 \mathrm{~cm} \\
\text { sample }\end{array}$ & $\begin{array}{l}\text { Core depth } \\
\text { (cm) }\end{array}$ & $\begin{array}{l}\text { Shards per } \\
\text { gdw } 10 \mathrm{~cm} \\
\text { sample }\end{array}$ & $\begin{array}{l}\text { Shards per } \\
\text { gdw } 1 \mathrm{~cm} \\
\text { sample }\end{array}$ & $\begin{array}{l}\text { Core depth } \\
\text { (cm) }\end{array}$ & $\begin{array}{l}\text { Shards per } \\
\text { gdw } 1 \mathrm{~cm} \\
\text { sample }\end{array}$ \\
\hline 10 & 5000 & & 0 & 2457 & 844 & 680 & 135 \\
\hline 11 & 5000 & & 1 & 2457 & 162 & 682 & 70 \\
\hline 12 & 5000 & & 2 & 2457 & 1103 & 684 & 25 \\
\hline 13 & 5000 & & 3 & 2457 & 798 & 686 & 28 \\
\hline 14 & 5000 & & 4 & 2457 & 247 & 688 & 31 \\
\hline 15 & 5000 & & 5 & 2457 & 549 & 690 & 16 \\
\hline 16 & 5000 & & 6 & 2457 & 313 & 692 & 63 \\
\hline 17 & 5000 & & 7 & 2457 & 333 & 694 & 111 \\
\hline 18 & 5000 & & 8 & 2457 & 172 & 696 & 515 \\
\hline 19 & 5000 & & 9 & 2457 & 44 & 698 & 1141 \\
\hline 20 & 6250 & & 10 & 841 & 314 & 700 & 4282 \\
\hline 21 & 6250 & & 11 & 841 & 220 & 702 & 39826 \\
\hline 22 & 6250 & & 12 & 841 & 312 & 704 & 501 \\
\hline 23 & 6250 & & 13 & 841 & 103 & 706 & 10 \\
\hline 24 & 6250 & & 14 & 841 & 60 & 708 & 25 \\
\hline 25 & 6250 & & 15 & 841 & 164 & 710 & 5 \\
\hline 26 & 6250 & & 16 & 841 & 161 & 712 & 32 \\
\hline 27 & 6250 & & 17 & 841 & 226 & 714 & 14 \\
\hline 28 & 6250 & & 18 & 841 & 281 & 716 & 20 \\
\hline 29 & 6250 & & 19 & 841 & 303 & 718 & 7 \\
\hline 30 & 5000 & & 20 & 140 & & 720 & 22 \\
\hline 31 & 5000 & & 21 & 140 & & 724 & 52 \\
\hline 32 & 5000 & & 22 & 140 & & 726 & 47 \\
\hline 33 & 5000 & & 23 & 140 & & 728 & 62 \\
\hline 34 & 5000 & & 24 & 140 & & 732 & 68 \\
\hline 35 & 5000 & & 25 & 140 & & 734 & 123 \\
\hline 36 & 5000 & & 26 & 140 & & 736 & 183 \\
\hline 37 & 5000 & & 27 & 140 & & 738 & 339 \\
\hline 38 & 5000 & & 28 & 140 & & 740 & 315 \\
\hline 39 & 5000 & & 29 & 140 & & 742 & 71 \\
\hline 40 & 109 & & 30 & 393 & 49 & 744 & 46 \\
\hline 41 & 109 & & 31 & 393 & 66 & 746 & 47 \\
\hline 42 & 109 & & 32 & 393 & 70 & 748 & 4 \\
\hline 43 & 109 & & 33 & 393 & 90 & 750 & 3 \\
\hline 44 & 109 & & 34 & 393 & 131 & 752 & 34 \\
\hline 45 & 109 & & 35 & 393 & 288 & 754 & 8 \\
\hline 46 & 109 & & 36 & 393 & 296 & 756 & 7 \\
\hline 47 & 109 & & 37 & 393 & 102 & 758 & 50 \\
\hline 48 & 109 & & 38 & 393 & 207 & 760 & 1641 \\
\hline 49 & 109 & & 39 & 393 & 144 & 761 & 26 \\
\hline 50 & 89 & & 40 & 150 & & 763 & 9 \\
\hline 51 & 89 & & 41 & 150 & & 765 & 24 \\
\hline 52 & 89 & & 42 & 150 & & 767 & 57 \\
\hline 53 & 89 & & 43 & 150 & & 769 & 131 \\
\hline 54 & 89 & & 44 & 150 & & 771 & 16 \\
\hline 55 & 89 & & 45 & 150 & & 773 & 28 \\
\hline 56 & 89 & & 46 & 150 & & 775 & 38 \\
\hline 57 & 89 & & 47 & 150 & & 777 & 13 \\
\hline \multirow[t]{2}{*}{58} & 89 & & 48 & 150 & & 779 & 132 \\
\hline & & & & & & \multicolumn{2}{|c|}{ Continued on next page } \\
\hline
\end{tabular}


Tephra glass shard counts in the Ashenge, Hayk and Chamo lake sediments

\begin{tabular}{|c|c|c|c|c|c|c|c|}
\hline & Ashenge & & & Hayk & & & \\
\hline $\begin{array}{l}\text { Core depth } \\
\text { (cm) }\end{array}$ & $\begin{array}{l}\text { Shards per } \\
\text { gdw } 10 \mathrm{~cm} \\
\text { sample }\end{array}$ & $\begin{array}{l}\text { Shards per } \\
\text { gdw } 1 \mathrm{~cm} \\
\text { sample }\end{array}$ & $\begin{array}{l}\text { Core depth } \\
\text { (cm) }\end{array}$ & $\begin{array}{l}\text { Shards per } \\
\text { gdw } 10 \mathrm{~cm} \\
\text { sample }\end{array}$ & $\begin{array}{l}\text { Shards per } \\
\text { gdw } 1 \mathrm{~cm} \\
\text { sample }\end{array}$ & $\begin{array}{l}\text { Core depth } \\
\text { (cm) }\end{array}$ & $\begin{array}{l}\text { Shards per } \\
\text { gdw } 1 \mathrm{~cm} \\
\text { sample }\end{array}$ \\
\hline 59 & 89 & & 49 & 150 & & 781 & 99 \\
\hline 60 & 274 & & 50 & 150 & & 783 & 46 \\
\hline 61 & 274 & & 51 & 104 & & 785 & 60 \\
\hline 62 & 274 & & 52 & 104 & & 787 & 124 \\
\hline 63 & 274 & & 53 & 104 & & 789 & 161 \\
\hline 64 & 274 & & 54 & 104 & & 791 & 224 \\
\hline 65 & 274 & & 55 & 104 & & 793 & 84 \\
\hline 66 & 274 & & 56 & 104 & & 795 & 202 \\
\hline 67 & 274 & & 57 & 104 & & 797 & 182 \\
\hline 68 & 274 & & 58 & 104 & & 799 & 136 \\
\hline 69 & 274 & & 59 & 104 & & 803 & 344 \\
\hline 70 & 112 & & 60 & 399 & 43 & 805 & 161 \\
\hline 71 & 112 & & 61 & 399 & 26 & 807 & 43 \\
\hline 72 & 112 & & 62 & 399 & 148 & 809 & 188 \\
\hline 73 & 112 & & 63 & 399 & 955 & 811 & 101 \\
\hline 74 & 112 & & 64 & 399 & 148 & 813 & 9 \\
\hline 75 & 112 & & 65 & 399 & 22358 & 815 & 5 \\
\hline 76 & 112 & & 66 & 399 & 213 & 817 & 84 \\
\hline 77 & 112 & & 67 & 399 & 104 & 819 & 8 \\
\hline 78 & 112 & & 68 & 399 & 490 & 821 & 1 \\
\hline 79 & 112 & & 69 & 399 & 250 & 823 & 0 \\
\hline 80 & 125 & & 70 & 399 & 391 & 825 & 0 \\
\hline 81 & 125 & & 71 & 529 & 97 & 827 & 0 \\
\hline 82 & 125 & & 72 & 529 & 202 & 829 & 0 \\
\hline 83 & 125 & & 73 & 529 & 269 & 831 & 0 \\
\hline 84 & 125 & & 74 & 529 & 353 & 833 & 0 \\
\hline 85 & 125 & & 75 & 529 & 292 & 835 & 0 \\
\hline 86 & 125 & & 76 & 529 & 148 & 837 & 0 \\
\hline 87 & 125 & & 77 & 529 & 286 & 839 & 0 \\
\hline 88 & 125 & & 78 & 529 & 322 & 841 & 0 \\
\hline 89 & 125 & & 79 & 529 & 420 & 843 & 0 \\
\hline 90 & 234 & & 80 & 644 & 87 & 845 & 1 \\
\hline 91 & 234 & & 81 & 644 & 208 & 847 & 97 \\
\hline 92 & 234 & & 82 & 644 & 245 & 849 & 6 \\
\hline 93 & 234 & & 83 & 644 & 240 & 851 & 36 \\
\hline 94 & 234 & & 84 & 644 & 94 & 853 & 0 \\
\hline 95 & 234 & & 85 & 644 & 205 & 855 & 0 \\
\hline 96 & 234 & & 86 & 644 & 287 & 857 & 0 \\
\hline 97 & 234 & & 87 & 644 & 461 & 859 & 26 \\
\hline 98 & 234 & & 88 & 644 & 816 & 861 & 23 \\
\hline 99 & 234 & & 89 & 644 & 772 & 863 & 0 \\
\hline 100 & 0 & & 90 & 1109 & & 865 & 2 \\
\hline 101 & 0 & & 91 & 1109 & & 867 & 22 \\
\hline 102 & 0 & & 92 & 1109 & & 869 & 0 \\
\hline 103 & 0 & & 93.5 & 1109 & & 871 & 0 \\
\hline 104 & 0 & & 94.5 & 3506 & & 873 & 0 \\
\hline 105 & 0 & & 95.5 & 3506 & & 875 & 0 \\
\hline 106 & 0 & & 96.5 & 3506 & & 877 & 0 \\
\hline 107 & 0 & & 97.5 & 3506 & & 879 & 0 \\
\hline 108 & 0 & & 98.5 & 3506 & & 881 & 0 \\
\hline 109 & 0 & & 99.5 & 3506 & & 883 & 0 \\
\hline 110 & 1505 & & 100.5 & 3506 & & 885 & 0 \\
\hline 111 & 1505 & 4765 & 101.5 & 3506 & & 887 & 148 \\
\hline 112 & 1505 & 8667 & 102.5 & 3506 & & 889 & 0 \\
\hline 113 & 1505 & 15867 & 103.5 & 3506 & & 891 & 2 \\
\hline 114 & 1505 & 10462 & 104.5 & 3172 & & 893 & 1 \\
\hline 115 & 1505 & 20615 & 105.5 & 3172 & & 895 & 0 \\
\hline 116 & 1505 & 38692 & 106.5 & 3172 & & 897 & 2 \\
\hline 117 & 1505 & 38000 & 107.5 & 3172 & & 899 & 0 \\
\hline 118 & 1505 & 4667 & 108.5 & 3172 & & 901 & 4 \\
\hline 119 & 1505 & 7286 & 109.5 & 3172 & & 903 & 0 \\
\hline 120 & 1659 & 5571 & 110.5 & 3172 & & 905 & 1 \\
\hline 121 & 1659 & & 111.5 & 3172 & & 907 & 0 \\
\hline 122 & 1659 & & 112.5 & 3172 & & 911 & 0 \\
\hline 123 & 1659 & & 113.5 & 4551 & 10367 & 913 & 0 \\
\hline 124 & 1659 & & 114.5 & 4551 & 228 & 915 & 3 \\
\hline 125 & 1659 & & 115.5 & 4551 & 158 & 917 & 100 \\
\hline 126 & 1659 & & 116.5 & 4551 & 1100 & 919 & 544 \\
\hline 127 & 1659 & & 117.5 & 4551 & 14909 & 921 & 2 \\
\hline 128 & 1659 & & 118.5 & 4551 & 484 & 923 & 3 \\
\hline 129 & 1659 & & 119.5 & 4551 & 112 & & \\
\hline 130 & 301 & & 120.5 & 4551 & 344 & & \\
\hline 131 & 301 & 8429 & 121.5 & 4551 & 101 & & \\
\hline 132 & 301 & 4158 & 122.5 & 4551 & 83 & & \\
\hline 133 & 301 & 3476 & 123.5 & 4551 & & & \\
\hline 134 & 301 & 706 & 124.5 & 2618 & & & \\
\hline 135 & 301 & 308 & 125.5 & 2618 & & & \\
\hline 136 & 301 & 765 & 126.5 & 2618 & & & \\
\hline 137 & 301 & 1200 & 127.5 & 2618 & & & \\
\hline 138 & 301 & 692 & 128.5 & 2618 & & & \\
\hline 139 & 301 & 2125 & 129.5 & 2618 & & & \\
\hline 140 & 825 & 900 & 130.5 & 2618 & & & \\
\hline \multirow[t]{2}{*}{141} & 825 & & 131.5 & 2618 & & & \\
\hline & & & & & & \multicolumn{2}{|c|}{ Continued on next page } \\
\hline
\end{tabular}


Tephra glass shard counts in the Ashenge, Hayk and Chamo lake sediments

\begin{tabular}{|c|c|c|c|c|c|c|c|}
\hline \multicolumn{3}{|c|}{ Ashenge } & \multicolumn{3}{|c|}{ Hayk } & & \\
\hline $\begin{array}{l}\text { Core depth } \\
(\mathrm{cm})\end{array}$ & $\begin{array}{l}\text { Shards per } \\
\text { gdw } 10 \mathrm{~cm} \\
\text { sample }\end{array}$ & $\begin{array}{l}\text { Shards per } \\
\text { gdw } 1 \mathrm{~cm} \\
\text { sample }\end{array}$ & $\begin{array}{l}\text { Core depth } \\
\text { (cm) }\end{array}$ & $\begin{array}{l}\text { Shards per } \\
\text { gdw } 10 \mathrm{~cm} \\
\text { sample }\end{array}$ & $\begin{array}{l}\text { Shards per } \\
\text { gdw } 1 \mathrm{~cm} \\
\text { sample }\end{array}$ & $\begin{array}{l}\text { Core depth } \\
\text { (cm) }\end{array}$ & $\begin{array}{l}\text { Shards per } \\
\text { gdw } 1 \mathrm{~cm} \\
\text { sample }\end{array}$ \\
\hline 142 & 825 & & 132.5 & 2618 & & & \\
\hline 143 & 825 & & 133.5 & 2618 & & & \\
\hline 144 & 825 & & 134.5 & 2618 & & & \\
\hline 145 & 825 & & 135.5 & 2618 & & & \\
\hline 146 & 825 & & 136.5 & 2618 & & & \\
\hline 147 & 825 & & 137.5 & 2618 & & & \\
\hline 148 & 825 & & 138.5 & 2618 & & & \\
\hline 149 & 825 & & 139.5 & 2618 & & & \\
\hline 150 & 102 & & 140.5 & 2618 & & & \\
\hline 151 & 102 & & 141.5 & 2618 & & & \\
\hline 152 & 102 & & 142.5 & 2618 & & & \\
\hline 153 & 102 & & 143.5 & 2618 & & & \\
\hline 154 & 102 & & 144.5 & 1549 & & & \\
\hline 155 & 102 & & 145.5 & 1549 & & & \\
\hline 156 & 102 & & 146.5 & 1549 & & & \\
\hline 157 & 102 & & 147.5 & 1549 & & & \\
\hline 158 & 102 & & 148.5 & 1549 & & & \\
\hline 159 & 102 & & 149.5 & 1549 & & & \\
\hline 160 & 10 & & 150.5 & 1549 & & & \\
\hline 161 & 10 & & 151.5 & 1549 & & & \\
\hline 162 & 10 & & 152.5 & 1549 & & & \\
\hline 163 & 10 & & 153.5 & 1549 & 80 & & \\
\hline 164 & 10 & & 154.5 & 1549 & 216 & & \\
\hline 165 & 10 & & 155.5 & 422 & 88 & & \\
\hline 166 & 10 & & 156.5 & 422 & 120 & & \\
\hline 167 & 10 & & 157.5 & 422 & 199 & & \\
\hline 168 & 10 & & 158.5 & 422 & 9925 & & \\
\hline 169 & 10 & & 159.5 & 422 & 108 & & \\
\hline 170 & 47 & & 160.5 & 422 & 281 & & \\
\hline 171 & 47 & & 161.5 & 422 & 884 & & \\
\hline 172 & 47 & & 162.5 & 422 & 629 & & \\
\hline 173 & 47 & & 163.5 & 422 & 87 & & \\
\hline 174 & 47 & & 164.5 & 356 & 179 & & \\
\hline 175 & 47 & & 165.5 & 356 & 78 & & \\
\hline 176 & 47 & & 166.5 & 356 & 190 & & \\
\hline 177 & 47 & & 167.5 & 356 & 8898 & & \\
\hline 178 & 47 & & 168.5 & 356 & 56 & & \\
\hline 179 & 47 & & 169.5 & 356 & 40 & & \\
\hline 180 & 51 & & 170.5 & 356 & 198 & & \\
\hline 181 & 51 & & 171.5 & 356 & 89 & & \\
\hline 182 & 51 & & 172.5 & 356 & 73 & & \\
\hline 183 & 51 & & & & & & \\
\hline 184 & 51 & & 177.5 & 2161 & 173 & & \\
\hline 185 & 51 & & 178.5 & 2161 & 205 & & \\
\hline 186 & 51 & & 179.5 & 2161 & 21409 & & \\
\hline 187 & 51 & & 180.5 & 2161 & 3920 & & \\
\hline 188 & 51 & & 181.5 & 2161 & 69 & & \\
\hline 189 & 51 & & 182.5 & 2161 & 638 & & \\
\hline 190 & 19 & & 183.5 & 2161 & 63 & & \\
\hline 191 & 19 & & 184.5 & 2161 & 98 & & \\
\hline 192 & 19 & & 185.5 & 2161 & 92 & & \\
\hline 193 & 19 & & 186.5 & 2161 & 26 & & \\
\hline 194 & 19 & & 187.5 & 611 & & & \\
\hline 195 & 19 & & 188.5 & 611 & & & \\
\hline 196 & 19 & & 189.5 & 611 & & & \\
\hline 197 & 19 & & 190.5 & 611 & & & \\
\hline 198 & 19 & & 191.5 & 611 & & & \\
\hline 199 & 19 & & 192.5 & 611 & & & \\
\hline 200 & 20 & & 193.5 & 611 & & & \\
\hline 201 & 833 & 82467 & 194.5 & 611 & & & \\
\hline 202 & 833 & 25786 & 195.5 & 611 & & & \\
\hline 203 & 833 & 4500 & 196.5 & 611 & & & \\
\hline 204 & 833 & 7077 & 197.5 & 622 & 19 & & \\
\hline 205 & 833 & 3714 & 198.5 & 622 & 3446 & & \\
\hline 206 & 833 & 2056 & 199.5 & 622 & 50 & & \\
\hline 211 & 233 & & 200.5 & 622 & 47 & & \\
\hline 212 & 233 & & 201.5 & 622 & 9 & & \\
\hline 213 & 233 & & 202.5 & 622 & 83 & & \\
\hline 214 & 233 & & 203.5 & 622 & 182 & & \\
\hline 215 & 233 & & 204.5 & 622 & 226 & & \\
\hline 216 & 233 & & 205.5 & 622 & 46 & & \\
\hline 217 & 233 & & 206.5 & 622 & 182 & & \\
\hline 218 & 233 & & 207.5 & 93 & & & \\
\hline 219 & 233 & & 208.5 & 93 & & & \\
\hline 220 & 233 & & 209.5 & 93 & & & \\
\hline 221 & 153 & & 210.5 & 93 & & & \\
\hline 222 & 153 & & 211.5 & 93 & & & \\
\hline 223 & 153 & & 212.5 & 77 & & & \\
\hline 224 & 153 & & 213.5 & 77 & & & \\
\hline 225 & 153 & & 214.5 & 77 & & & \\
\hline 226 & 153 & & 215.5 & 77 & & & \\
\hline 227 & 153 & & 216.5 & 77 & & & \\
\hline 228 & 153 & & 217.5 & 77 & & & \\
\hline & & & & & & Continu & on next page \\
\hline
\end{tabular}


Tephra glass shard counts in the Ashenge, Hayk and Chamo lake sediments

\begin{tabular}{|c|c|c|c|c|c|c|c|}
\hline \multicolumn{3}{|c|}{$\begin{array}{l}\text { Ashenge } \\
\end{array}$} & \multicolumn{3}{|c|}{ Hayk } & \multicolumn{2}{|c|}{ Chamo } \\
\hline $\begin{array}{l}\text { Core depth } \\
\text { (cm) }\end{array}$ & $\begin{array}{l}\text { Shards per } \\
\text { gdw } 10 \mathrm{~cm} \\
\text { sample }\end{array}$ & $\begin{array}{l}\text { Shards per } \\
\text { gdw } 1 \mathrm{~cm} \\
\text { sample }\end{array}$ & $\begin{array}{l}\text { Core depth } \\
\text { (cm) }\end{array}$ & $\begin{array}{l}\text { Shards per } \\
\text { gdw } 10 \mathrm{~cm} \\
\text { sample }\end{array}$ & $\begin{array}{l}\text { Shards per } \\
\text { gdw } 1 \mathrm{~cm} \\
\text { sample }\end{array}$ & $\begin{array}{l}\text { Core depth } \\
\text { (cm) }\end{array}$ & $\begin{array}{l}\text { Shards per } \\
\text { gdw } 1 \mathrm{~cm} \\
\text { sample }\end{array}$ \\
\hline 229 & 153 & & 218.5 & 77 & & & \\
\hline 230 & 153 & & 219.5 & 77 & & & \\
\hline 231 & 304 & & 220.5 & 77 & & & \\
\hline 232 & 304 & & 221.5 & 77 & & & \\
\hline 233 & 304 & & 222.5 & 9 & & & \\
\hline 234 & 304 & & 223.5 & 9 & & & \\
\hline 235 & 304 & & 224.5 & 9 & & & \\
\hline 236 & 304 & & 225.5 & 9 & & & \\
\hline 237 & 304 & & 226.5 & 9 & & & \\
\hline 238 & 304 & & 227.5 & 9 & & & \\
\hline 239 & 304 & & 228.5 & 9 & & & \\
\hline 240 & 304 & & 229.5 & 9 & & & \\
\hline 241 & 146 & & 230.5 & 9 & & & \\
\hline 242 & 146 & & 231.5 & 9 & & & \\
\hline 243 & 146 & & 232.5 & 36 & & & \\
\hline 244 & 146 & & 233.5 & 36 & & & \\
\hline 245 & 146 & & 234.5 & 36 & & & \\
\hline 246 & 146 & & 235.5 & 36 & & & \\
\hline 247 & 146 & & 236.5 & 36 & & & \\
\hline 248 & 146 & & 237.5 & 36 & & & \\
\hline 249 & 146 & & 238.5 & 36 & & & \\
\hline 250 & 146 & & 239.5 & 36 & & & \\
\hline 251 & 254 & & 240.5 & 36 & & & \\
\hline 252 & 254 & & 241.5 & 36 & & & \\
\hline 253 & 254 & & 242.5 & 23 & & & \\
\hline 254 & 254 & & 243.5 & 23 & & & \\
\hline 255 & 254 & & 244.5 & 23 & & & \\
\hline 256 & 254 & & 245.5 & 23 & & & \\
\hline 257 & 254 & & 246.5 & 23 & & & \\
\hline 258 & 254 & & 247.5 & 23 & & & \\
\hline 259 & 254 & & 248.5 & 23 & & & \\
\hline 260 & 254 & & 249.5 & 23 & & & \\
\hline 261 & 210 & & 250.5 & 23 & & & \\
\hline 262 & 210 & & 251.5 & 23 & & & \\
\hline 263 & 210 & & 252.5 & 283 & & & \\
\hline 264 & 210 & & 253.5 & 283 & & & \\
\hline 265 & 210 & & 254.5 & 283 & & & \\
\hline 266 & 210 & & 255.5 & 283 & & & \\
\hline 267 & 210 & & 256.5 & 283 & & & \\
\hline 268 & 210 & & 257.5 & 283 & & & \\
\hline 269 & 210 & & 258.5 & 283 & & & \\
\hline 270 & 210 & & 259.5 & 283 & & & \\
\hline 271 & 339 & & 260.5 & 283 & & & \\
\hline 272 & 339 & & 261.5 & 7390 & 104 & & \\
\hline 273 & 339 & & 264.5 & 7390 & 88 & & \\
\hline 274 & 339 & & 265.5 & 7390 & 102 & & \\
\hline 275 & 339 & & 266.5 & 7390 & 7539 & & \\
\hline 276 & 339 & & 267.5 & 7390 & 20 & & \\
\hline 277 & 339 & & 268.5 & 7390 & 123 & & \\
\hline 278 & 339 & & 269.5 & 7390 & 15 & & \\
\hline 279 & 339 & & 270.5 & 7390 & 1040 & & \\
\hline 280 & 339 & & 280 & 7390 & 27 & & \\
\hline 281 & 587 & 2923 & 281 & 7390 & 14 & & \\
\hline 282 & 587 & 3667 & 282 & 7390 & 17 & & \\
\hline 283 & 587 & 4364 & 283 & 7390 & 27 & & \\
\hline 284 & 587 & 4000 & 284 & 7390 & 59 & & \\
\hline 285 & 587 & 2615 & 285 & 7390 & 84 & & \\
\hline 286 & 587 & 3071 & 286 & 7390 & 245 & & \\
\hline 287 & 587 & 5316 & 287 & 7390 & 1182 & & \\
\hline 288 & 587 & 5294 & 288 & 7390 & 19741 & & \\
\hline 289 & 587 & 4762 & 289 & 7390 & 11 & & \\
\hline 290 & 587 & 5000 & 290 & 2 & & & \\
\hline 291 & 116 & & 291 & 2 & & & \\
\hline 292 & 116 & & 292 & 2 & & & \\
\hline 293 & 116 & & 293 & 2 & & & \\
\hline 294 & 116 & & 294 & 2 & & & \\
\hline 295 & 116 & & 295 & 2 & & & \\
\hline 296 & 116 & & 296 & 2 & & & \\
\hline 297 & 116 & & 297 & 2 & & & \\
\hline 298 & 116 & & 298 & 2 & & & \\
\hline 299 & 116 & & 299 & 2 & & & \\
\hline 300 & 116 & & 300 & 2 & & & \\
\hline 301 & 137 & & 301 & 2 & & & \\
\hline 302 & 137 & & 302 & 5 & & & \\
\hline 303 & 137 & & 303 & 5 & & & \\
\hline 304 & 137 & & 304 & 5 & & & \\
\hline 305 & 137 & & 305 & 5 & & & \\
\hline 306 & 137 & & 306 & 5 & & & \\
\hline 307 & 137 & & 307 & 5 & & & \\
\hline 308 & 137 & & 308 & 5 & & & \\
\hline 309 & 137 & & 309 & 5 & & & \\
\hline 310 & 137 & & 310 & 5 & & & \\
\hline 311 & 0 & & 311 & 5 & & & \\
\hline
\end{tabular}


Tephra glass shard counts in the Ashenge, Hayk and Chamo lake sediments

\begin{tabular}{|c|c|c|c|c|c|c|c|}
\hline \multicolumn{3}{|c|}{ Ashenge } & \multicolumn{3}{|c|}{ Hayk } & $\mathrm{Ch}$ & \\
\hline $\begin{array}{l}\text { Core depth } \\
\text { (cm) }\end{array}$ & $\begin{array}{l}\text { Shards per } \\
\text { gdw } 10 \mathrm{~cm} \\
\text { sample }\end{array}$ & $\begin{array}{l}\text { Shards per } \\
\text { gdw } 1 \mathrm{~cm} \\
\text { sample }\end{array}$ & $\begin{array}{l}\text { Core depth } \\
\text { (cm) }\end{array}$ & $\begin{array}{l}\text { Shards per } \\
\text { gdw } 10 \mathrm{~cm} \\
\text { sample }\end{array}$ & $\begin{array}{l}\text { Shards per } \\
\text { gdw } 1 \mathrm{~cm} \\
\text { sample }\end{array}$ & $\begin{array}{l}\text { Core depth } \\
\text { (cm) }\end{array}$ & $\begin{array}{l}\text { Shards per } \\
\text { gdw } 1 \mathrm{~cm} \\
\text { sample }\end{array}$ \\
\hline 312 & 0 & & 312 & 5 & & & \\
\hline 313 & 0 & & 313 & 6 & & & \\
\hline 314 & 0 & & 314 & 6 & & & \\
\hline 315 & 0 & & 315 & 6 & & & \\
\hline 316 & 0 & & 316 & 6 & & & \\
\hline 317 & 0 & & 317 & 6 & & & \\
\hline 318 & 0 & & 318 & 6 & & & \\
\hline 319 & 0 & & 319 & 6 & & & \\
\hline 320 & 0 & & 320 & 6 & & & \\
\hline 321 & 89 & & 321 & 6 & & & \\
\hline 322 & 89 & & 322 & 6 & & & \\
\hline 323 & 89 & & 323 & 6 & & & \\
\hline 324 & 89 & & 324 & 6 & & & \\
\hline 325 & 89 & & 325 & 6 & & & \\
\hline 326 & 89 & & 326 & 6 & & & \\
\hline 327 & 89 & & 327 & 6 & & & \\
\hline 328 & 89 & & 328 & 6 & & & \\
\hline 329 & 89 & & 329 & 6 & & & \\
\hline 330 & 89 & & 330 & 6 & & & \\
\hline 331 & 41 & & 331 & 9 & & & \\
\hline 332 & 41 & & 332 & 9 & & & \\
\hline 333 & 41 & & 333 & 9 & & & \\
\hline 334 & 41 & & 334 & 9 & & & \\
\hline 335 & 41 & & 335 & 9 & & & \\
\hline 336 & 41 & & 336 & 9 & & & \\
\hline 337 & 41 & & 337 & 9 & & & \\
\hline 338 & 41 & & 338 & 9 & & & \\
\hline 339 & 41 & & 339 & 9 & & & \\
\hline 340 & 41 & & 340 & 9 & & & \\
\hline 341 & 187 & & 341 & 6 & & & \\
\hline 342 & 187 & & 342 & 6 & & & \\
\hline 343 & 187 & & 343 & 6 & & & \\
\hline 344 & 187 & & 344 & 6 & & & \\
\hline 345 & 187 & & 345 & 6 & & & \\
\hline 346 & 187 & & 346 & 6 & & & \\
\hline 347 & 187 & & 347 & 6 & & & \\
\hline 348 & 187 & & 348 & 6 & & & \\
\hline 349 & 187 & & 349 & 6 & & & \\
\hline 350 & 187 & & 350 & 6 & & & \\
\hline 351 & 49 & & 351 & 6 & & & \\
\hline 352 & 49 & & 352 & 6 & & & \\
\hline 353 & 49 & & 353 & 2 & & & \\
\hline 354 & 49 & & 354 & 2 & & & \\
\hline 355 & 49 & & 355 & 2 & & & \\
\hline 356 & 49 & & 356 & 2 & & & \\
\hline 357 & 49 & & 357 & 2 & & & \\
\hline 358 & 49 & & 358 & 2 & & & \\
\hline 359 & 49 & & 359 & 2 & & & \\
\hline 360 & 49 & & 360 & 2 & & & \\
\hline 361 & 151 & & 361 & 2 & & & \\
\hline 362 & 151 & & 362 & 2 & & & \\
\hline 363 & 151 & & 363 & 2 & & & \\
\hline 364 & 151 & & 364 & 11 & & & \\
\hline 365 & 151 & & 365 & 11 & & & \\
\hline 366 & 151 & & 366 & 11 & & & \\
\hline 367 & 151 & & 367 & 11 & & & \\
\hline 368 & 151 & & 368 & 11 & & & \\
\hline 369 & 151 & & 369 & 11 & & & \\
\hline 370 & 151 & & 370 & 11 & & & \\
\hline 371 & 127 & & 371 & 11 & & & \\
\hline 372 & 127 & & 372 & 11 & & & \\
\hline 373 & 127 & & 373 & 11 & & & \\
\hline 374 & 127 & & 374 & 7 & & & \\
\hline 375 & 127 & & 375 & 7 & & & \\
\hline 376 & 127 & & 376 & 7 & & & \\
\hline 377 & 127 & & 377 & 7 & & & \\
\hline 378 & 127 & & 378 & 7 & & & \\
\hline 379 & 127 & & 379 & 7 & & & \\
\hline 380 & 127 & & 380 & 7 & & & \\
\hline 381 & 64 & & 381 & 7 & & & \\
\hline 382 & 64 & & 382 & 336 & & & \\
\hline 383 & 64 & & 383 & 336 & & & \\
\hline 384 & 64 & & 384 & 336 & 7 & & \\
\hline 385 & 64 & & 385 & 336 & 141 & & \\
\hline 386 & 64 & & 386 & 336 & 3015 & & \\
\hline 387 & 64 & & 387 & 336 & 2 & & \\
\hline 388 & 64 & & 388 & 336 & 6 & & \\
\hline 389 & 64 & & 389 & 336 & 8 & & \\
\hline 390 & 64 & & 390 & 336 & 5 & & \\
\hline 391 & 29 & & 392.5 & 336 & 10 & & \\
\hline 392 & 29 & & 393 & 336 & 1 & & \\
\hline 393 & 29 & & 394 & 7 & & & \\
\hline 394 & 29 & & 395 & 7 & & & \\
\hline & & & & & & Continue & on next page \\
\hline
\end{tabular}


Tephra glass shard counts in the Ashenge, Hayk and Chamo lake sediments

\begin{tabular}{|c|c|c|c|c|c|c|c|}
\hline \multicolumn{3}{|c|}{ Ashenge } & \multicolumn{3}{|c|}{ Hayk } & \multicolumn{2}{|c|}{ Chamo } \\
\hline $\begin{array}{l}\text { Core depth } \\
\text { (cm) }\end{array}$ & $\begin{array}{l}\text { Shards per } \\
\text { gdw } 10 \mathrm{~cm} \\
\text { sample }\end{array}$ & $\begin{array}{l}\text { Shards per } \\
\text { gdw } 1 \mathrm{~cm} \\
\text { sample }\end{array}$ & $\begin{array}{l}\text { Core depth } \\
\text { (cm) }\end{array}$ & $\begin{array}{l}\text { Shards per } \\
\text { gdw } 10 \mathrm{~cm} \\
\text { sample }\end{array}$ & $\begin{array}{l}\text { Shards per } \\
\text { gdw } 1 \mathrm{~cm} \\
\text { sample }\end{array}$ & $\begin{array}{l}\text { Core depth } \\
\text { (cm) }\end{array}$ & $\begin{array}{l}\text { Shards per } \\
\text { gdw } 1 \mathrm{~cm} \\
\text { sample }\end{array}$ \\
\hline 395 & 29 & & 396 & 7 & & & \\
\hline 396 & 29 & & 397 & 7 & & & \\
\hline 397 & 29 & & 398 & 7 & & & \\
\hline 398 & 29 & & 399 & 7 & & & \\
\hline 399 & 29 & & 400 & 7 & & & \\
\hline 400 & 29 & & 401 & 7 & & & \\
\hline 401 & 195 & & 402 & 7 & & & \\
\hline 402 & 195 & & 403 & 7 & & & \\
\hline 403 & 195 & & 404 & 5 & & & \\
\hline 404 & 195 & & 405 & 5 & & & \\
\hline 405 & 195 & & 406 & 5 & & & \\
\hline 406 & 195 & & 407 & 5 & & & \\
\hline 407 & 195 & & 408 & 5 & & & \\
\hline 408 & 195 & & 409 & 5 & & & \\
\hline 409 & 195 & & 410 & 5 & & & \\
\hline 410 & 195 & & 411 & 5 & & & \\
\hline 411 & 39 & & 412 & 5 & & & \\
\hline 412 & 39 & & 413 & 5 & & & \\
\hline 413 & 39 & & 414 & 5 & & & \\
\hline 414 & 39 & & 415 & 10 & & & \\
\hline 415 & 39 & & 416 & 10 & & & \\
\hline 416 & 39 & & 417 & 10 & & & \\
\hline 417 & 39 & & 418 & 10 & & & \\
\hline 418 & 39 & & 419 & 10 & & & \\
\hline 419 & 39 & & 420 & 10 & & & \\
\hline 420 & 39 & & 421 & 10 & & & \\
\hline 421 & 192 & & 422 & 10 & & & \\
\hline 422 & 192 & & 423 & 10 & & & \\
\hline 423 & 192 & & 424 & 2235 & & & \\
\hline 424 & 192 & & 425 & 2235 & & & \\
\hline 425 & 192 & & 426 & 2235 & & & \\
\hline 426 & 192 & & 427 & 2235 & & & \\
\hline 427 & 192 & & 428 & 2235 & & & \\
\hline 428 & 192 & & 429 & 2235 & & & \\
\hline 429 & 192 & & 430 & 2235 & & & \\
\hline 430 & 192 & & 431 & 2235 & & & \\
\hline 431 & 2089 & & 432 & 2235 & & & \\
\hline 432 & 2089 & & 433 & 2235 & & & \\
\hline 433 & 2089 & & 434 & 2235 & & & \\
\hline 434 & 2089 & & 435 & 2235 & & & \\
\hline 435 & 2089 & & 436 & 2235 & & & \\
\hline 436 & 2089 & & 437 & 2235 & & & \\
\hline 437 & 2089 & & 438 & 2235 & & & \\
\hline 438 & 2089 & & 439 & 2235 & & & \\
\hline 439 & 2089 & & 440 & 2235 & & & \\
\hline 440 & 2089 & & 441 & 2235 & & & \\
\hline 441 & 6250 & & 442 & 2235 & & & \\
\hline 442 & 6250 & & 443 & 2235 & & & \\
\hline 443 & 6250 & & 444 & 2235 & & & \\
\hline 444 & 6250 & & 445 & 4399 & & & \\
\hline 445 & 6250 & & 446 & 4399 & & & \\
\hline 446 & 6250 & & 447 & 4399 & & & \\
\hline 447 & 6250 & & 448 & 4399 & & & \\
\hline 448 & 6250 & & 449 & 4399 & & & \\
\hline 449 & 6250 & & 450 & 4399 & & & \\
\hline 450 & 6250 & & 451 & 4399 & & & \\
\hline 451 & 2250 & & 452 & 4399 & & & \\
\hline 452 & 2250 & & 453 & 4399 & & & \\
\hline 453 & 2250 & & 454 & 4399 & & & \\
\hline 454 & 2250 & & 455 & 4399 & & & \\
\hline 455 & 2250 & & 455.5 & 9606 & 2467 & & \\
\hline 456 & 2250 & & 456.5 & 9606 & 910 & & \\
\hline 457 & 2250 & & 457.5 & 9606 & 775 & & \\
\hline 458 & 2250 & & 458.5 & 9606 & 133 & & \\
\hline 459 & 2250 & & 459.5 & 9606 & 1078 & & \\
\hline 460 & 2250 & & 460.5 & 9606 & 56220 & & \\
\hline 461 & 84 & & 461.5 & 9606 & 6540 & & \\
\hline 462 & 84 & & 462.5 & 9606 & 69 & & \\
\hline 463 & 84 & & 463.5 & 9606 & 37 & & \\
\hline 464 & 84 & & 464.5 & 9606 & 12 & & \\
\hline 465 & 84 & & 465.5 & 9606 & 56 & & \\
\hline 466 & 84 & & 466.5 & 106 & & & \\
\hline 467 & 84 & & 467.5 & 106 & & & \\
\hline 468 & 84 & & 468.5 & 106 & & & \\
\hline 469 & 84 & & 469.5 & 106 & & & \\
\hline 470 & 84 & & 470.5 & 106 & & & \\
\hline 471 & 231 & & 471.5 & 106 & & & \\
\hline 472 & 231 & & 472.5 & 106 & & & \\
\hline 473 & 231 & & 473.5 & 106 & & & \\
\hline 474 & 231 & & 474.5 & 106 & & & \\
\hline 475 & 231 & & 475.5 & 106 & & & \\
\hline 476 & 231 & & 476.5 & 6 & & & \\
\hline 477 & 231 & & 477.5 & 6 & & & \\
\hline
\end{tabular}


Tephra glass shard counts in the Ashenge, Hayk and Chamo lake sediments

\begin{tabular}{|c|c|c|c|c|c|c|c|}
\hline \multicolumn{3}{|c|}{ Ashenge } & \multicolumn{3}{|c|}{ Hayk } & & \\
\hline $\begin{array}{l}\text { Core depth } \\
\text { (cm) }\end{array}$ & $\begin{array}{l}\text { Shards per } \\
\text { gdw } 10 \mathrm{~cm} \\
\text { sample }\end{array}$ & $\begin{array}{l}\text { Shards per } \\
\text { gdw } 1 \mathrm{~cm} \\
\text { sample }\end{array}$ & $\begin{array}{l}\text { Core depth } \\
\text { (cm) }\end{array}$ & $\begin{array}{l}\text { Shards per } \\
\text { gdw } 10 \mathrm{~cm} \\
\text { sample }\end{array}$ & $\begin{array}{l}\text { Shards per } \\
\text { gdw } 1 \mathrm{~cm} \\
\text { sample }\end{array}$ & $\begin{array}{l}\text { Core depth } \\
\text { (cm) }\end{array}$ & $\begin{array}{l}\text { Shards per } \\
\text { gdw } 1 \mathrm{~cm} \\
\text { sample }\end{array}$ \\
\hline 478 & 231 & & 478.5 & 6 & & & \\
\hline 479 & 231 & & 479.5 & 6 & & & \\
\hline 480 & 231 & & 480.5 & 6 & & & \\
\hline 481 & 1294 & 22083 & 481.5 & 6 & & & \\
\hline 482 & 1294 & 33833 & 482.5 & 6 & & & \\
\hline 483 & 1294 & 132714 & 483.5 & 6 & & & \\
\hline 484 & 1294 & 182625 & 484.5 & 6 & & & \\
\hline 485 & 1294 & 277250 & 485.5 & 6 & & & \\
\hline 486 & 1294 & 8600 & 486.5 & 3 & & & \\
\hline 487 & 1294 & 18429 & 487.5 & 3 & & & \\
\hline 488 & 1294 & 16125 & 488.5 & 3 & & & \\
\hline 489 & 1294 & 19333 & 489.5 & 3 & & & \\
\hline 490 & 1294 & 23667 & 490.5 & 3 & & & \\
\hline 491 & 293 & & 491.5 & 3 & & & \\
\hline 492 & 293 & & 492.5 & 3 & & & \\
\hline 493 & 293 & & 493.5 & 3 & & & \\
\hline 494 & 293 & & 494.5 & 3 & & & \\
\hline 495 & 293 & & 495.5 & 3 & & & \\
\hline 496 & 293 & & 496.5 & 3 & & & \\
\hline 497 & 293 & & 497.5 & 2 & & & \\
\hline 498 & 293 & & 498.5 & 2 & & & \\
\hline 499 & 293 & & 499.5 & 2 & & & \\
\hline 500 & 293 & & 500.5 & 2 & & & \\
\hline 501 & 96 & & 501.5 & 2 & & & \\
\hline 502 & 96 & & 502.5 & 2 & & & \\
\hline 503 & 96 & & 503.5 & 2 & & & \\
\hline 504 & 96 & & 504.5 & 2 & & & \\
\hline 505 & 96 & & 505.5 & 2 & & & \\
\hline 506 & 96 & & 506.5 & 2 & & & \\
\hline 507 & 96 & & 507.5 & 2 & & & \\
\hline 508 & 96 & & 508.5 & 2 & & & \\
\hline 509 & 96 & & 509.5 & 2 & & & \\
\hline 510 & 96 & & 510.5 & 2 & & & \\
\hline 511 & 282 & & 511.5 & 2 & & & \\
\hline 512 & 282 & & 512.5 & 2 & & & \\
\hline 513 & 282 & & 513.5 & 2 & & & \\
\hline 514 & 282 & & 514.5 & 2 & & & \\
\hline 515 & 282 & & 515.5 & 2 & & & \\
\hline 516 & 282 & & 516.5 & 1 & & & \\
\hline 517 & 282 & & 517.5 & 1 & & & \\
\hline 518 & 282 & & 518.5 & 1 & & & \\
\hline 519 & 282 & & 519.5 & 1 & & & \\
\hline 520 & 282 & & 520.5 & 1 & & & \\
\hline 521 & 3846 & 42400 & 521.5 & 1 & & & \\
\hline 522 & 3846 & 22500 & 522.5 & 1 & & & \\
\hline 523 & 3846 & 42700 & 523.5 & 1 & & & \\
\hline 524 & 3846 & 155500 & 524.5 & 1 & & & \\
\hline 525 & 3846 & 198571 & 525.5 & 1 & & & \\
\hline 526 & 3846 & 291563 & 526.5 & 1 & & & \\
\hline 527 & 3846 & 697643 & 527.5 & 1 & & & \\
\hline 528 & 3846 & 55583 & 528.5 & 1 & & & \\
\hline 529 & 3846 & 28833 & 529.5 & 1 & & & \\
\hline 530 & 3846 & 22923 & 530.5 & 1 & & & \\
\hline 531 & 63 & & 531.5 & 1 & & & \\
\hline 532 & 63 & & 532.5 & 1 & & & \\
\hline 533 & 63 & & 533.5 & 1 & & & \\
\hline 534 & 63 & & 534.5 & 1 & & & \\
\hline 535 & 63 & & 535.5 & 1 & & & \\
\hline 536 & 63 & & 536.5 & 2 & & & \\
\hline 537 & 63 & & 537.5 & 2 & & & \\
\hline 538 & 63 & & 538.5 & 2 & & & \\
\hline 539 & 63 & & 539.5 & 2 & & & \\
\hline 540 & 63 & & 540.5 & 2 & & & \\
\hline 541 & 64 & & 541.5 & 2 & & & \\
\hline 542 & 64 & & 542.5 & 2 & & & \\
\hline 543 & 64 & & 543.5 & 2 & & & \\
\hline 544 & 64 & & 544.5 & 2 & & & \\
\hline 545 & 64 & & 545.5 & 2 & & & \\
\hline 546 & 64 & & 546.5 & 2 & & & \\
\hline 547 & 64 & & 547.5 & 1 & & & \\
\hline 548 & 64 & & 548.5 & 1 & & & \\
\hline 549 & 64 & & 549.5 & 1 & & & \\
\hline 550 & 64 & & 550.5 & 1 & & & \\
\hline 551 & 90 & & 551.5 & 1 & & & \\
\hline 552 & 90 & & 552.5 & 1 & & & \\
\hline 553 & 90 & & 553.5 & 1 & & & \\
\hline 554 & 90 & & 554.5 & 1 & & & \\
\hline 555 & 90 & & 555.5 & 1 & & & \\
\hline 556 & 90 & & 556.5 & 2 & & & \\
\hline 557 & 90 & & 557.5 & 2 & & & \\
\hline 558 & 90 & & 558.5 & 2 & & & \\
\hline 559 & 90 & & 559.5 & 2 & & & \\
\hline 560 & 90 & & 560.5 & 2 & & & \\
\hline & & & & & & Continu & on next page \\
\hline
\end{tabular}


Tephra glass shard counts in the Ashenge, Hayk and Chamo lake sediments

\begin{tabular}{|c|c|c|c|c|c|c|c|}
\hline \multicolumn{3}{|c|}{$\begin{array}{l}\text { Ashenge } \\
\end{array}$} & \multicolumn{3}{|c|}{ Hayk } & \multicolumn{2}{|c|}{ Chamo } \\
\hline $\begin{array}{l}\text { Core depth } \\
\text { (cm) }\end{array}$ & $\begin{array}{l}\text { Shards per } \\
\text { gdw } 10 \mathrm{~cm} \\
\text { sample }\end{array}$ & $\begin{array}{l}\text { Shards per } \\
\text { gdw } 1 \mathrm{~cm} \\
\text { sample }\end{array}$ & $\begin{array}{l}\text { Core depth } \\
\text { (cm) }\end{array}$ & $\begin{array}{l}\text { Shards per } \\
\text { gdw } 10 \mathrm{~cm} \\
\text { sample }\end{array}$ & $\begin{array}{l}\text { Shards per } \\
\text { gdw } 1 \mathrm{~cm} \\
\text { sample }\end{array}$ & $\begin{array}{l}\text { Core depth } \\
\text { (cm) }\end{array}$ & $\begin{array}{l}\text { Shards per } \\
\text { gdw } 1 \mathrm{~cm} \\
\text { sample }\end{array}$ \\
\hline 561 & 135 & & 561.5 & 2 & & & \\
\hline 562 & 135 & & 562.5 & 2 & & & \\
\hline 563 & 135 & & 563.5 & 2 & & & \\
\hline 564 & 135 & & 564.5 & 2 & & & \\
\hline 565 & 135 & & 565.5 & 2 & & & \\
\hline 566 & 135 & & 566.5 & 2 & & & \\
\hline 567 & 135 & & 567.5 & 2 & & & \\
\hline 568 & 135 & & 568.5 & 2 & & & \\
\hline 569 & 135 & & 569.5 & 2 & & & \\
\hline 570 & 135 & & 570.5 & 2 & & & \\
\hline 571 & 239 & & 571.5 & 2 & & & \\
\hline 572 & 239 & & 572.5 & 2 & & & \\
\hline 573 & 239 & & 573.5 & 2 & & & \\
\hline 574 & 239 & & 574.5 & 2 & & & \\
\hline 575 & 239 & & 575.5 & 2 & & & \\
\hline 576 & 239 & & 576.5 & 11 & & & \\
\hline 577 & 239 & & 577.5 & 11 & & & \\
\hline 578 & 239 & & 578.5 & 11 & & & \\
\hline 579 & 239 & & 579.5 & 11 & & & \\
\hline 580 & 239 & & 580.5 & 11 & & & \\
\hline 581 & 151 & & 581.5 & 11 & & & \\
\hline 582 & 151 & & 582.5 & 11 & & & \\
\hline 583 & 151 & & 583.5 & 11 & & & \\
\hline 584 & 151 & & 584.5 & 11 & & & \\
\hline 585 & 151 & & 585.5 & 11 & & & \\
\hline 586 & 151 & & & & & & \\
\hline 587 & 151 & & & & & & \\
\hline 588 & 151 & & & & & & \\
\hline 589 & 151 & & & & & & \\
\hline 590 & 151 & & & & & & \\
\hline 591 & 5000 & & & & & & \\
\hline 592 & 5000 & & & & & & \\
\hline 593 & 5000 & & & & & & \\
\hline 594 & 5000 & & & & & & \\
\hline 595 & 5000 & & & & & & \\
\hline 596 & 5000 & & & & & & \\
\hline 597 & 5000 & & & & & & \\
\hline 598 & 5000 & & & & & & \\
\hline 599 & 5000 & & & & & & \\
\hline 600 & 5000 & & & & & & \\
\hline 601 & 5000 & & & & & & \\
\hline 602 & 5000 & & & & & & \\
\hline 603 & 5000 & & & & & & \\
\hline 604 & 5000 & & & & & & \\
\hline 605 & 5000 & & & & & & \\
\hline 606 & 5000 & & & & & & \\
\hline 607 & 5000 & & & & & & \\
\hline 608 & 5000 & & & & & & \\
\hline 609 & 5000 & & & & & & \\
\hline 610 & 5000 & & & & & & \\
\hline 611 & 837 & & & & & & \\
\hline 612 & 837 & & & & & & \\
\hline 613 & 837 & & & & & & \\
\hline 614 & 837 & & & & & & \\
\hline 615 & 837 & & & & & & \\
\hline 616 & 837 & & & & & & \\
\hline 617 & 837 & & & & & & \\
\hline 618 & 837 & & & & & & \\
\hline 619 & 837 & & & & & & \\
\hline 620 & 837 & & & & & & \\
\hline 621 & 3905 & 26200 & & & & & \\
\hline 622 & 3905 & 43588 & & & & & \\
\hline 623 & 3905 & 100222 & & & & & \\
\hline 624 & 3905 & 350345 & & & & & \\
\hline 625 & 3905 & 53708 & & & & & \\
\hline 626 & 3905 & 17625 & & & & & \\
\hline 627 & 3905 & 24105 & & & & & \\
\hline 628 & 3905 & 18462 & & & & & \\
\hline 629 & 3905 & 43850 & & & & & \\
\hline 630 & 3905 & 37063 & & & & & \\
\hline 631 & 3905 & 33533 & & & & & \\
\hline 632 & 766 & 6619 & & & & & \\
\hline 633 & 766 & 31065 & & & & & \\
\hline 634 & 766 & 51217 & & & & & \\
\hline 635 & 766 & 135794 & & & & & \\
\hline 636 & 766 & 9297 & & & & & \\
\hline 637 & 766 & 24621 & & & & & \\
\hline 638 & 766 & 19733 & & & & & \\
\hline 639 & 766 & 9063 & & & & & \\
\hline 640 & 766 & 20917 & & & & & \\
\hline 641 & 766 & 24130 & & & & & \\
\hline 642 & 380 & & & & & & \\
\hline 643 & 380 & & & & & & \\
\hline
\end{tabular}


Tephra glass shard counts in the Ashenge, Hayk and Chamo lake sediments

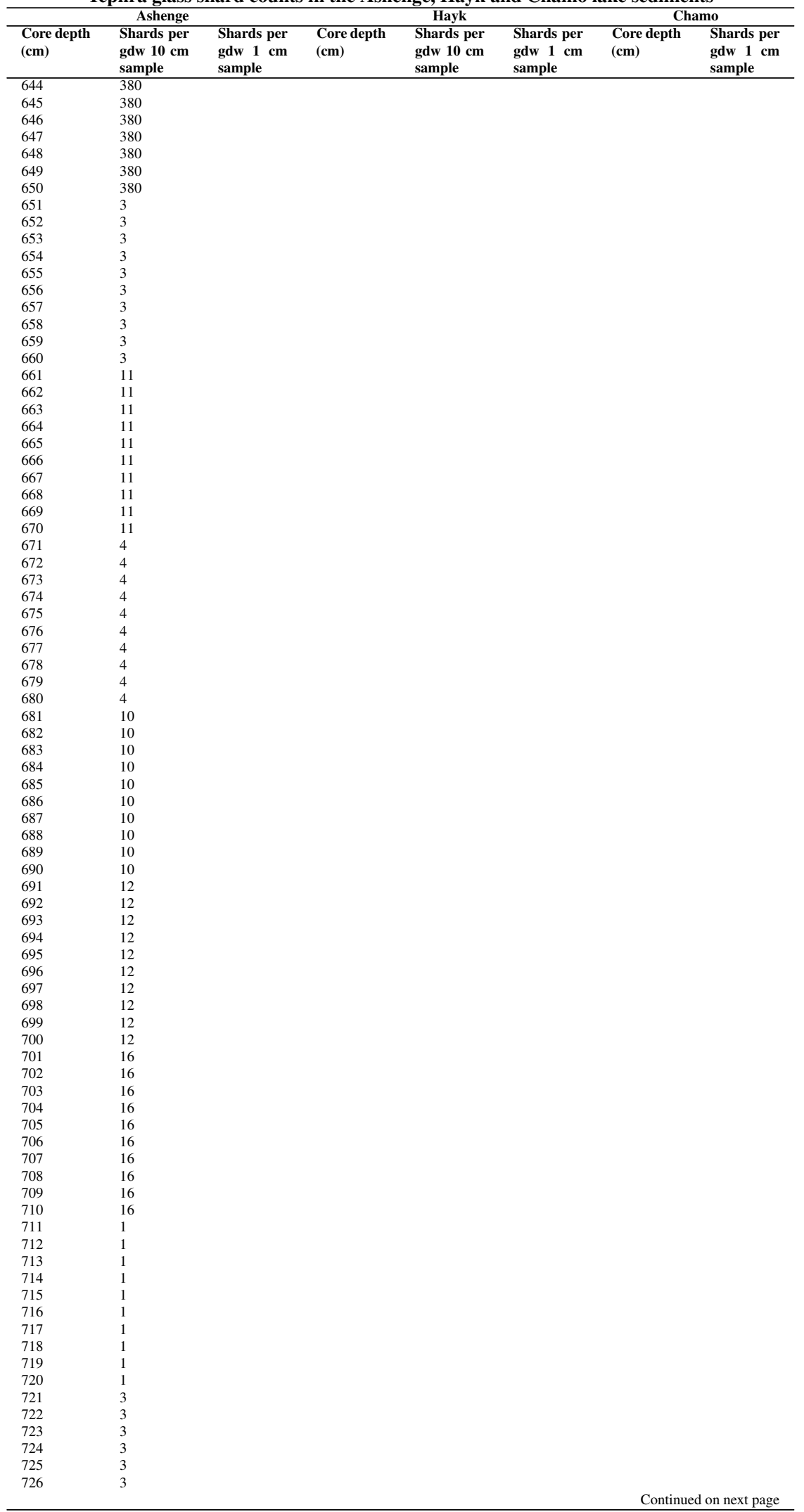


Tephra glass shard counts in the Ashenge, Hayk and Chamo lake sediments

\begin{tabular}{|c|c|c|c|c|c|c|c|}
\hline \multicolumn{3}{|c|}{ Ashenge } & \multicolumn{3}{|c|}{ Hayk } & \multicolumn{2}{|c|}{ Chamo } \\
\hline $\begin{array}{l}\text { Core depth } \\
\text { (cm) }\end{array}$ & $\begin{array}{l}\text { Shards per } \\
\text { gdw } 10 \mathrm{~cm} \\
\text { sample }\end{array}$ & $\begin{array}{l}\text { Shards per } \\
\text { gdw } 1 \mathrm{~cm} \\
\text { sample }\end{array}$ & $\begin{array}{l}\text { Core depth } \\
\text { (cm) }\end{array}$ & $\begin{array}{l}\text { Shards per } \\
\text { gdw } 10 \mathrm{~cm} \\
\text { sample }\end{array}$ & $\begin{array}{l}\text { Shards per } \\
\text { gdw } 1 \mathrm{~cm} \\
\text { sample }\end{array}$ & $\begin{array}{l}\text { Core depth } \\
\text { (cm) }\end{array}$ & $\begin{array}{l}\text { Shards per } \\
\text { gdw } 1 \mathrm{~cm} \\
\text { sample }\end{array}$ \\
\hline 727 & 3 & & & & & & \\
\hline 728 & 3 & & & & & & \\
\hline 729 & 3 & & & & & & \\
\hline 730 & 3 & & & & & & \\
\hline 731 & 5005 & & & & & & \\
\hline 732 & 5005 & & & & & & \\
\hline 733 & 5005 & & & & & & \\
\hline 734 & 5005 & & & & & & \\
\hline 735 & 5005 & & & & & & \\
\hline 736 & 5005 & & & & & & \\
\hline 737 & 5005 & & & & & & \\
\hline 738 & 5005 & & & & & & \\
\hline 739 & 5005 & & & & & & \\
\hline 740 & 5005 & & & & & & \\
\hline 741 & 3130 & & & & & & \\
\hline 742 & 3130 & & & & & & \\
\hline 743 & 3130 & & & & & & \\
\hline 744 & 3130 & & & & & & \\
\hline 745 & 3130 & & & & & & \\
\hline 746 & 3130 & & & & & & \\
\hline 747 & 3130 & & & & & & \\
\hline 748 & 3130 & & & & & & \\
\hline 749 & 3130 & & & & & & \\
\hline 750 & 3130 & & & & & & \\
\hline 754 & 6741 & 4648 & & & & & \\
\hline 755 & 6741 & 12214 & & & & & \\
\hline 756 & 6741 & 60925 & & & & & \\
\hline 757 & 6741 & 173216 & & & & & \\
\hline 758 & 6741 & 691803 & & & & & \\
\hline 759 & 6741 & 273865 & & & & & \\
\hline 760 & 6741 & 15235 & & & & & \\
\hline 761 & 6741 & 1294 & & & & & \\
\hline 762 & 6741 & 3125 & & & & & \\
\hline 763 & 6741 & 3962 & & & & & \\
\hline 764 & 1042 & & & & & & \\
\hline 765 & 1042 & & & & & & \\
\hline 766 & 1042 & & & & & & \\
\hline 767 & 1042 & & & & & & \\
\hline 768 & 1042 & & & & & & \\
\hline 769 & 1042 & & & & & & \\
\hline 770 & 1042 & & & & & & \\
\hline 771 & 1823 & & & & & & \\
\hline 772 & 1823 & & & & & & \\
\hline 773 & 1823 & & & & & & \\
\hline 774 & 1823 & & & & & & \\
\hline 775 & 1823 & & & & & & \\
\hline 776 & 1823 & & & & & & \\
\hline 777 & 1823 & & & & & & \\
\hline 778 & 1823 & & & & & & \\
\hline 779 & 1823 & & & & & & \\
\hline 780 & 1823 & & & & & & \\
\hline 781 & 720 & & & & & & \\
\hline 782 & 720 & & & & & & \\
\hline 783 & 720 & & & & & & \\
\hline 784 & 720 & & & & & & \\
\hline 785 & 720 & & & & & & \\
\hline 786 & 720 & & & & & & \\
\hline 787 & 720 & & & & & & \\
\hline 788 & 720 & & & & & & \\
\hline 789 & 720 & & & & & & \\
\hline 790 & 720 & & & & & & \\
\hline 791 & 2951 & 25438 & & & & & \\
\hline 792 & 2951 & 32109 & & & & & \\
\hline 793 & 2951 & 10838 & & & & & \\
\hline 794 & 2951 & 17964 & & & & & \\
\hline 795 & 2951 & 36397 & & & & & \\
\hline 796 & 2951 & 25962 & & & & & \\
\hline 797 & 2951 & 16817 & & & & & \\
\hline 798 & 2951 & 15319 & & & & & \\
\hline 799 & 2951 & 12837 & & & & & \\
\hline 800 & 2951 & 14774 & & & & & \\
\hline
\end{tabular}




\section{.3 Tephras from the Ethiopian Highlands}

This Appendix firstly provides the glass compositions of tephras from the Ethiopian Highlands. In the latter part of this section, the Oxcal code used to make Bayesian age models for the Ashenge and Hayk archives is provided.

\subsection{Major and trace element glass compositions}

The following tables give shard-specific major and trace element concentrations in the Ashenge and Hayk tephras. Major and trace element analysis of Dubbi 1861 (collected by C. Oppenheimer, University of Cambridge) proximal deposits are given on page 338. Major elements are presented to 2 decimal places and trace elements to 3 significant figures, for the raw data the reader is referred to the electronic version.

Some major elements (e.g. Cl) were not analysed on all analytical sessions, and these are left blank. All $\mathrm{Fe}$ is calculated as $\mathrm{FeO}^{T}$. Lower limits of detection (LLD) for EPMA analyses are given on page 401. The median LLD for the rhyolitic ATHO-G reference material over all EPMA analytical sessions is given in the following table headings. Most major elements occur at concentrations above the LLD in the Ashenge, Hayk and Dubbi glass shards, except $\mathrm{MgO}, \mathrm{MnO}$ and $\mathrm{P}_{2} \mathrm{O}_{5}$ which are present in some shards at very low concentrations.

Trace element analyses were typically undertaken using $20 \mu \mathrm{m}$ crater diameters, however, †indicates glass shards were analysed using $10 \mu \mathrm{m}$ crater diameters. Lower limits of detection for LA-ICP-MS analyses are given on page 407. The median LLD concentrations at $20 \mu \mathrm{m}$ crater diameters of all LA-ICP-MS analytical sessions are given beneath each analyte heading in the following tables. Due to high $\mathrm{Sr}$ and Ba concentrations in the gas blanks, coupled 
with frequent low sample concentrations, some negative concentrations were measured - these are indicated with a dash.

Analyses of MPI-DING reference materials were used to check the EPMA and LA-ICP-MS calibrations. These analyses are given on page 398, and are ordered by analysis date.

Unnormalised major element concentrations (wt.\%) in Ashenge glass shards

\begin{tabular}{|c|c|c|c|c|c|c|c|c|c|c|c|c|c|c|}
\hline Label & Tephra & $\begin{array}{l}\text { Analysis } \\
\text { date }\end{array}$ & $\begin{array}{l}\mathrm{SiO}_{2} \\
\mathbf{0 . 0 8}\end{array}$ & $\begin{array}{l}\mathrm{TiO}_{2} \\
\mathbf{0 . 0 5}\end{array}$ & $\begin{array}{l}\mathrm{Al}_{2} \mathrm{O}_{3} \\
\mathbf{0 . 0 5}\end{array}$ & $\begin{array}{l}\text { MgO } \\
0.04\end{array}$ & $\begin{array}{l}\mathrm{FeO}^{T} \\
0.08\end{array}$ & $\begin{array}{l}\text { MnO } \\
0.07\end{array}$ & $\begin{array}{l}\mathrm{CaO} \\
0.04\end{array}$ & $\begin{array}{l}\mathrm{Na}_{2} \mathrm{O} \\
0.08\end{array}$ & $\begin{array}{l}\mathrm{K}_{2} \mathrm{O} \\
\mathbf{0 . 0 3}\end{array}$ & $\begin{array}{l}\mathbf{P}_{2} \mathbf{O}_{5} \\
\mathbf{0 . 1 0}\end{array}$ & $\begin{array}{l}\mathrm{Cl} \\
0.02\end{array}$ & Total \\
\hline A03AL2/1 & AST-1 & $20 / 02 / 14$ & 69.75 & 0.18 & 13.20 & 0.00 & 3.40 & 0.11 & 0.49 & 5.84 & 4.76 & 0.02 & 0.23 & 97.97 \\
\hline $\mathrm{A} 03 \mathrm{AL} 2 / 2$ & AST-1 & $20 / 02 / 14$ & 68.07 & 0.27 & 12.98 & 0.01 & 3.38 & 0.11 & 0.43 & 5.58 & 4.67 & 0.01 & 0.24 & 95.76 \\
\hline $\mathrm{A} 03 \mathrm{AL} 2 / 3$ & AST-1 & $20 / 02 / 14$ & 70.56 & 0.24 & 13.35 & 0.00 & 3.54 & 0.07 & 0.34 & 5.78 & 4.77 & 0.05 & 0.18 & 98.88 \\
\hline A03AL $2 / 4$ & AST-1 & $20 / 02 / 14$ & 64.24 & 0.24 & 12.02 & 0.03 & 3.47 & 0.09 & 0.44 & 5.35 & 4.28 & 0.01 & 0.23 & 90.40 \\
\hline A03AL2/5 & AST-1 & $20 / 02 / 14$ & 69.89 & 0.24 & 13.43 & 0.00 & 3.65 & 0.15 & 0.46 & 5.91 & 4.64 & 0.00 & 0.17 & 98.55 \\
\hline A03AL2/6 & AST-1 & $20 / 02 / 14$ & 67.69 & 0.23 & 12.60 & 0.00 & 3.58 & 0.07 & 0.44 & 5.97 & 4.63 & 0.00 & 0.19 & 95.40 \\
\hline $\mathrm{A} 03 \mathrm{AL} 2 / 7$ & AST-1 & $20 / 02 / 14$ & 71.12 & 0.23 & 13.65 & 0.00 & 3.39 & 0.06 & 0.37 & 6.03 & 4.78 & 0.00 & 0.20 & 99.83 \\
\hline A03AL $2 / 8$ & AST-1 & $20 / 02 / 14$ & 70.52 & 0.21 & 14.26 & 0.00 & 3.13 & 0.11 & 0.34 & 6.30 & 4.65 & 0.02 & 0.16 & 99.70 \\
\hline A03AL $2 / 9$ & AST-1 & $20 / 02 / 14$ & 69.58 & 0.23 & 13.63 & 0.02 & 3.68 & 0.12 & 0.48 & 5.72 & 4.69 & 0.03 & 0.22 & 98.40 \\
\hline A03AL $2 / 10$ & AST-1 & $20 / 02 / 14$ & 67.74 & 0.22 & 12.69 & 0.00 & 3.49 & 0.06 & 0.44 & 5.73 & 4.68 & 0.02 & 0.19 & 95.24 \\
\hline A03AL2/11 & AST-1 & $20 / 02 / 14$ & 67.46 & 0.19 & 14.93 & 0.00 & 2.54 & 0.03 & 0.32 & 5.37 & 5.55 & 0.02 & 0.14 & 96.54 \\
\hline 03AL2439/1 & AST-2 & $20 / 02 / 14$ & 69.67 & 0.21 & 12.72 & 0.01 & 3.73 & 0.14 & 0.37 & 5.94 & 4.75 & 0.03 & 0.21 & 97.78 \\
\hline 03AL2439/2 & AST-2 & $20 / 02 / 14$ & 69.84 & 0.24 & 12.58 & 0.00 & 3.79 & 0.12 & 0.41 & 5.86 & 4.68 & 0.01 & 0.21 & 97.75 \\
\hline 03AL2439/3 & AST-2 & $20 / 02 / 14$ & 70.70 & 0.25 & 12.54 & 0.00 & 3.81 & 0.15 & 0.36 & 5.84 & 4.83 & 0.00 & 0.21 & 98.69 \\
\hline 03AL2439/4 & AST-2 & $20 / 02 / 14$ & 69.98 & 0.26 & 13.40 & 0.00 & 3.93 & 0.16 & 0.43 & 6.03 & 4.62 & 0.00 & 0.18 & 98.99 \\
\hline 03AL2439/5 & AST-2 & $20 / 02 / 14$ & 68.60 & 0.22 & 12.39 & 0.02 & 3.71 & 0.11 & 0.42 & 5.96 & 4.69 & 0.03 & 0.19 & 96.34 \\
\hline 03AL2439/6 & AST-2 & $20 / 02 / 14$ & 69.26 & 0.26 & 13.43 & 0.00 & 3.75 & 0.15 & 0.43 & 6.04 & 4.68 & 0.04 & 0.12 & 98.16 \\
\hline 03AL2439/7 & AST-2 & $20 / 02 / 14$ & 69.25 & 0.30 & 12.28 & 0.02 & 3.67 & 0.11 & 0.37 & 5.59 & 4.67 & 0.02 & 0.19 & 96.46 \\
\hline 03AL2439/8 & AST-2 & $20 / 02 / 14$ & 68.31 & 0.24 & 12.43 & 0.00 & 3.90 & 0.07 & 0.39 & 5.88 & 4.64 & 0.05 & 0.19 & 96.10 \\
\hline 03AL2439/9 & AST-2 & $20 / 02 / 14$ & 70.81 & 0.25 & 12.56 & 0.00 & 3.77 & 0.13 & 0.37 & 6.28 & 4.46 & 0.03 & 0.19 & 98.84 \\
\hline 03AL2439/10 & AST-2 & $20 / 02 / 14$ & 65.35 & 0.27 & 11.98 & 0.00 & 3.97 & 0.04 & 0.40 & 5.71 & 4.63 & 0.00 & 0.20 & 92.55 \\
\hline 03AL2439/11 & AST-2 & $20 / 02 / 14$ & 67.96 & 0.29 & 12.21 & 0.00 & 3.63 & 0.14 & 0.39 & 5.30 & 4.68 & 0.00 & 0.18 & 94.77 \\
\hline 03AL2439/12 & AST-2 & $20 / 02 / 14$ & 67.27 & 0.26 & 11.93 & 0.00 & 3.84 & 0.05 & 0.22 & 5.74 & 4.56 & 0.03 & 0.23 & 94.13 \\
\hline 03AL2439/14 & AST-2 & $20 / 02 / 14$ & 67.95 & 0.25 & 12.29 & 0.01 & 3.62 & 0.14 & 0.40 & 5.55 & 4.59 & 0.00 & 0.21 & 95.00 \\
\hline 03AL2439/15 & AST-2 & $20 / 02 / 14$ & 70.53 & 0.22 & 13.49 & 0.02 & 3.33 & 0.12 & 0.36 & 5.88 & 4.80 & 0.01 & 0.19 & 98.95 \\
\hline 03AL2439/16 & AST-2 & $20 / 02 / 14$ & 66.22 & 0.24 & 13.02 & 0.00 & 3.13 & 0.06 & 0.30 & 5.72 & 4.57 & 0.02 & 0.15 & 93.43 \\
\hline 03AL2439/17 & AST-2 & $20 / 02 / 14$ & 67.37 & 0.19 & 12.24 & 0.00 & 3.63 & 0.05 & 0.41 & 5.38 & 4.63 & 0.00 & 0.19 & 94.10 \\
\hline 03AL2439/18 & AST-2 & $20 / 02 / 14$ & 69.06 & 0.23 & 13.42 & 0.00 & 3.21 & 0.10 & 0.32 & 6.29 & 4.46 & 0.03 & 0.16 & 97.29 \\
\hline 03AL2439/19 & AST-2 & $20 / 02 / 14$ & 69.32 & 0.28 & 12.30 & 0.02 & 3.80 & 0.20 & 0.52 & 5.95 & 4.57 & 0.00 & 0.20 & 97.16 \\
\hline 03AL2439/20 & AST-2 & $20 / 02 / 14$ & 70.96 & 0.25 & 12.97 & 0.00 & 4.00 & 0.09 & 0.38 & 5.85 & 4.89 & 0.03 & 0.18 & 99.60 \\
\hline 03AL2439/21 & AST-2 & $20 / 02 / 14$ & 68.63 & 0.21 & 13.36 & 0.00 & 3.32 & 0.15 & 0.39 & 5.90 & 4.66 & 0.00 & 0.14 & 96.76 \\
\hline AST-3_1 & AST-3 & $26 / 08 / 14$ & 70.53 & 0.30 & 9.85 & 0.02 & 5.35 & 0.18 & 0.24 & 5.65 & 4.25 & 0.01 & & 96.38 \\
\hline AST-3_3 & AST-3 & $26 / 08 / 14$ & 71.28 & 0.33 & 9.96 & 0.00 & 5.21 & 0.12 & 0.29 & 6.12 & 4.40 & 0.00 & & 97.70 \\
\hline AST-3_4 & AST-3 & $26 / 08 / 14$ & 70.17 & 0.30 & 9.70 & 0.02 & 5.01 & 0.14 & 0.26 & 5.67 & 4.28 & 0.00 & & 95.55 \\
\hline AST-3_6 & AST-3 & $26 / 08 / 14$ & 71.63 & 0.30 & 9.82 & 0.00 & 5.12 & 0.14 & 0.28 & 5.65 & 4.47 & 0.06 & & 97.48 \\
\hline AST-3_7 & AST-3 & $26 / 08 / 14$ & 71.57 & 0.31 & 9.58 & 0.00 & 5.38 & 0.20 & 0.30 & 5.57 & 4.34 & 0.01 & & 97.27 \\
\hline AST-3_9 & AST-3 & $26 / 08 / 14$ & 69.35 & 0.33 & 9.31 & 0.01 & 5.09 & 0.12 & 0.28 & 5.52 & 4.07 & 0.01 & & 94.08 \\
\hline AST-3_10 & AST-3 & $26 / 08 / 14$ & 70.42 & 0.38 & 9.67 & 0.01 & 5.24 & 0.18 & 0.30 & 5.59 & 4.36 & 0.03 & & 96.18 \\
\hline AST-3_12 & STS 2 & $26 / 08 / 14$ & 71.67 & 0.29 & 9.61 & 0.03 & 5.01 & 0.15 & 0.2 & 5.56 & 4.25 & 0.00 & & 96.83 \\
\hline AST-3_14 & ST-3 & $26 / 08 / 14$ & 72.72 & 0.28 & 9.70 & 0.00 & 5.43 & 0.15 & 0.28 & 5.74 & 4.50 & 0.00 & & 98.81 \\
\hline AST-3_15 & 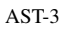 & $26 / 08 / 14$ & 71.47 & 0.31 & 9.59 & 0.01 & 5.19 & 0.16 & 0.31 & 5.48 & 4.36 & 0.00 & & 96.89 \\
\hline AST-3_16 & ST-3 & $26 / 08 / 14$ & 72.19 & 0.37 & 9.89 & 0.00 & 5.34 & 0.21 & 0.31 & 5.81 & 4.38 & 0.01 & & 98.50 \\
\hline AST-3_18 & AST-3 & $26 / 08 / 14$ & 70.51 & 0.30 & 9.68 & 0.00 & 5.11 & 0.19 & 0.27 & 5.69 & 4.25 & 0.00 & & 96.01 \\
\hline AST-3_19 & S & $26 / 08 / 14$ & 72.51 & 0.33 & 9.87 & 0.04 & 5.21 & 0.22 & 0.27 & 5.68 & 4.31 & 0.03 & & 98.47 \\
\hline AST-3_20 & AST-3 & $26 / 08 / 14$ & 71.00 & 0.35 & 9.77 & 0.03 & 5.07 & 0.16 & 0.28 & 5.22 & 4.21 & 0.01 & & 96.10 \\
\hline AST-4_1 & AST-4 & $26 / 08 / 14$ & 72.08 & 0.34 & 8.98 & 0.00 & 5.42 & 0.18 & 0.21 & 5.78 & 4.31 & 0.04 & & 97.34 \\
\hline AST-4_2 & AST-4 & $26 / 08 / 14$ & 71.87 & 0.31 & 8.94 & 0.00 & 5.14 & 0.19 & 0.28 & 5.38 & 4.27 & 0.00 & & 96.38 \\
\hline AST-4_3 & AST-4 & $26 / 08 / 14$ & 70.34 & 0.24 & 8.78 & 0.01 & 5.24 & 0.18 & 0.27 & 5.48 & 4.28 & 0.00 & & 94.82 \\
\hline AST-4_4 & AST-4 & $26 / 08 / 14$ & 71.57 & 0.3 & 8.94 & 0.01 & 5.27 & 0.19 & 0.27 & 5.56 & 4.22 & 0.00 & & 96.41 \\
\hline AST-4_5 & AST-4 & $08 / 14$ & 70.92 & 0.37 & 9.06 & 0.00 & 5.14 & 0.15 & 0.23 & 5.52 & 4.18 & 0.00 & & 95.56 \\
\hline AST-4_6 & ST-4 & $26 / 08 / 14$ & 68.95 & 0.30 & 8.68 & 0.00 & 5.25 & 0.09 & 0.29 & 5.47 & 4.08 & 0.04 & & 93.16 \\
\hline AST-4_7 & AST-4 & $26 / 08 / 14$ & 71.76 & 0.29 & 9.16 & 0.00 & 5.55 & 0.18 & 0.29 & 5.46 & 4.19 & 0.00 & & 96.89 \\
\hline AST-4_8 & A T T & $26 / 08 / 14$ & 71.04 & 0.35 & 8.86 & 0.00 & 5.23 & 0.20 & 026 & 5.82 & 4.18 & 0.01 & & 95.95 \\
\hline AST-4_9 & AST-4 & $26 / 08 / 14$ & 71.11 & 0.29 & 9.10 & 0.00 & 5.48 & 0.11 & 0.26 & 5.77 & 4.22 & 0.00 & & 96.34 \\
\hline AST-4_10 & A T T & $26 / 08 / 14$ & 71.37 & 0.34 & 9.05 & 0.00 & 5.44 & 0.17 & 0.27 & 5.26 & 4.32 & 0.00 & & 96.22 \\
\hline AST-4_11 & AST-4 & $26 / 08 / 14$ & 71.83 & 0.38 & 9.06 & 0.00 & 5.31 & 0.08 & 0.27 & 5.55 & 4.27 & 0.02 & & 96.78 \\
\hline AST-4_12 & AST-4 & $26 / 08 / 14$ & 72.38 & 0.31 & 9.16 & 0.00 & 5.49 & 0.24 & 0.28 & 5.47 & 4.26 & 0.04 & & 97.61 \\
\hline AST-4_13 & AST-4 & $26 / 08 / 14$ & 68.94 & 0.29 & 8.79 & 0.00 & 5.47 & 0.22 & 0.28 & 5.29 & 4.04 & 0.03 & & 93.36 \\
\hline AST-4_14 & AST-4 & $26 / 08 / 14$ & 71.76 & 0.35 & 9.11 & 0.03 & 5.26 & 0.16 & 0.27 & 5.64 & 4.40 & 0.00 & & 96.97 \\
\hline AST-4_15 & AST-4 & $26 / 08 / 14$ & 72.90 & 0.31 & 9.05 & 0.01 & 5.52 & 0.17 & 0.29 & 5.57 & 4.47 & 0.06 & & 98.34 \\
\hline AST-4_16 & AST-4 & $26 / 08 / 14$ & 72.20 & 0.30 & 9.08 & 0.01 & 5.27 & 0.10 & 0.25 & 5.89 & 4.32 & 0.00 & & 97.42 \\
\hline AST & ST-4 & $08 / 14$ & 72.31 & 0.33 & 9.06 & 0.00 & 5.08 & 0.24 & 0.28 & 5.39 & 4.44 & 0.00 & & 97.14 \\
\hline AST-4_18 & AST-4 & $26 / 08 / 14$ & 70.18 & 0.29 & 8.70 & 0.00 & 5.14 & 0.12 & 0.23 & 5.40 & 4.18 & 0.00 & & 94.25 \\
\hline AST & $1-4$ & & 72.27 & 0.34 & 9.06 & 0.01 & 5.37 & 0.14 & 0.22 & 5.46 & 4.20 & 0.00 & & 97.07 \\
\hline AST-4_20 & AST-4 & $26 / 08 / 14$ & 72.75 & 0.41 & 9.13 & 0.01 & 5.41 & 0.15 & 0.23 & 5.57 & 4.42 & 0.01 & & 98.08 \\
\hline 03AL2594/ & AST-5 & $20 / 02 / 14$ & 69.50 & 0.16 & 12.06 & 0.00 & 2.76 & 0.04 & 0.37 & 5.28 & 4.28 & 0.01 & 0.20 & 94.66 \\
\hline \multirow[t]{2}{*}{ 03AL2594/2 } & AST-5 & $20 / 02 / 14$ & 70.91 & 0.22 & 12.23 & 0.00 & 3.04 & 0.05 & 0.37 & 5.48 & 4.45 & 0.01 & 0.20 & 96.95 \\
\hline & & & & & & & & & & & \multicolumn{4}{|c|}{ Continued on next page } \\
\hline
\end{tabular}


Unnormalised major element concentrations (wt.\%) in Ashenge glass shards

\begin{tabular}{|c|c|c|c|c|c|c|c|c|c|c|c|c|c|c|}
\hline Label & Tephra & $\begin{array}{l}\text { Analysis } \\
\text { date }\end{array}$ & $\begin{array}{l}\mathrm{SiO}_{2} \\
0.08\end{array}$ & $\begin{array}{l}\mathrm{TiO}_{2} \\
0.05\end{array}$ & $\begin{array}{l}\mathrm{Al}_{2} \mathbf{O}_{3} \\
\mathbf{0 . 0 5}\end{array}$ & $\begin{array}{l}\text { MgO } \\
0.04\end{array}$ & $\begin{array}{l}\mathrm{FeO}^{T} \\
0.08\end{array}$ & $\begin{array}{l}\text { MnO } \\
0.07\end{array}$ & $\begin{array}{l}\mathrm{CaO} \\
0.04\end{array}$ & $\begin{array}{l}\mathrm{Na}_{2} \mathrm{O} \\
0.08\end{array}$ & $\begin{array}{l}\mathrm{K}_{2} \mathrm{O} \\
0.03\end{array}$ & $\begin{array}{l}\mathbf{P}_{2} \mathbf{O}_{5} \\
0.10\end{array}$ & $\begin{array}{l}\mathrm{Cl} \\
0.02\end{array}$ & Total \\
\hline 03AL2594/3 & AST-5 & $20 / 02 / 14$ & 71.22 & 0.21 & 12.50 & 0.00 & 3.12 & 0.06 & 0.37 & 5.39 & 4.59 & 0.02 & 0.19 & 97.67 \\
\hline 03AL2594/4 & AST-5 & $20 / 02 / 14$ & 67.58 & 0.21 & 11.73 & 0.00 & 2.74 & 0.06 & 0.36 & 5.08 & 4.38 & 0.02 & 0.21 & 92.37 \\
\hline 03AL2594/5 & AST-5 & $20 / 02 / 14$ & 69.23 & 0.25 & 12.03 & 0.01 & 2.91 & 0.06 & 0.29 & 5.29 & 4.45 & 0.02 & 0.17 & 94.71 \\
\hline 03AL2594/7 & AST-5 & $20 / 02 / 14$ & 70.26 & 0.15 & 12.30 & 0.01 & 3.03 & 0.02 & 0.38 & 5.60 & 4.44 & 0.00 & 0.20 & 96.40 \\
\hline 03AL2594/8 & AST-5 & $20 / 02 / 14$ & 70.07 & 0.24 & 12.30 & 0.00 & 2.93 & 0.14 & 0.35 & 5.00 & 4.47 & 0.00 & 0.21 & 95.72 \\
\hline 03AL2594/10 & AST-5 & $20 / 02 / 14$ & 70.61 & 0.19 & 12.27 & 0.01 & 2.85 & 0.06 & 0.36 & 5.53 & 4.45 & 0.00 & 0.20 & 96.53 \\
\hline 03AL2594/11 & AST-5 & $20 / 02 / 14$ & 70.17 & 0.17 & 12.31 & 0.00 & 2.93 & 0.12 & 0.37 & 5.41 & 4.52 & 0.03 & 0.16 & 96.20 \\
\hline 03AL2594/12 & AST-5 & $20 / 02 / 14$ & 72.19 & 0.20 & 12.80 & 0.04 & 3.07 & 0.13 & 0.37 & 5.25 & 4.56 & 0.00 & 0.18 & 98.79 \\
\hline 03AL2594/13 & AST-5 & $20 / 02 / 14$ & 70.21 & 0.21 & 12.36 & 0.00 & 3.17 & 0.11 & 0.37 & 5.42 & 4.37 & 0.03 & 0.19 & 96.45 \\
\hline 03AL2594/14 & AST-5 & $20 / 02 / 14$ & 68.93 & 0.23 & 12.02 & 0.00 & 2.96 & 0.18 & 0.35 & 5.19 & 4.22 & 0.00 & 0.18 & 94.26 \\
\hline 03AL2594/15 & AST-5 & $20 / 02 / 14$ & 70.77 & 0.18 & 12.59 & 0.03 & 3.17 & 0.11 & 0.38 & 5.37 & 4.35 & 0.02 & 0.21 & 97.18 \\
\hline 03AL2594/16 & AST-5 & $20 / 02 / 14$ & 69.79 & 0.17 & 12.16 & 0.01 & 2.82 & 0.08 & 0.36 & 5.31 & 4.26 & 0.00 & 0.20 & 95.18 \\
\hline 03AL2594/17 & AST-5 & $20 / 02 / 14$ & 72.06 & 0.22 & 12.72 & 0.01 & 3.05 & 0.09 & 0.36 & 5.32 & 4.51 & 0.00 & 0.19 & 98.51 \\
\hline 03AL2594/18 & AST-5 & $02 / 14$ & 69.36 & 0.22 & 12.12 & 0.02 & 2.84 & 0.00 & 0.37 & 5.32 & 4.32 & 0.00 & 0.19 & 94.75 \\
\hline 03AL2594/19 & AST-5 & $20 / 02 / 14$ & 68.59 & 0.17 & 11.77 & 0.03 & 2.82 & 0.07 & 0.39 & 5.18 & 4.30 & 0.03 & 0.20 & 93.54 \\
\hline 03AL2594/20 & AST-5 & $20 / 02 / 14$ & 70.31 & 0.25 & 12.15 & 0.00 & 2.97 & 0.08 & 0.40 & 4.87 & 4.42 & 0.01 & 0.19 & 95.64 \\
\hline AST-6_1 & AST-6 & $26 / 08 / 14$ & 71.93 & 0.33 & 8.67 & 0.00 & 5.48 & 0.10 & 0.26 & 5.81 & 4.37 & 0.00 & & 96.96 \\
\hline AST-6_2 & AST-6 & $26 / 08 / 14$ & 72.72 & 0.28 & 8.96 & 0.00 & 5.12 & 0.20 & 0.20 & 5.48 & 4.25 & 0.00 & & 97.23 \\
\hline AST-6_3 & AST-6 & $26 / 08 / 14$ & 73.13 & 0.29 & 9.14 & 0.00 & 5.46 & 0.14 & 0.28 & 5.61 & 4.45 & 0.01 & & 98.52 \\
\hline AST-6_8 & AST-6 & $26 / 08 / 14$ & 73.53 & 0.24 & 9.28 & 0.01 & 5.40 & 0.17 & 0.24 & 5.88 & 4.32 & 0.04 & & 99.12 \\
\hline AST-6_10 & AST-6 & $26 / 08 / 14$ & 72.89 & 0.30 & 9.15 & 0.01 & 5.11 & 0.25 & 0.26 & 5.27 & 4.31 & 0.00 & & 97.55 \\
\hline AST-6_12 & AST-6 & $26 / 08 / 14$ & 71.55 & 0.26 & 9.12 & 0.00 & 5.23 & 0.20 & 0.23 & 5.88 & 4.21 & 0.02 & & 96.70 \\
\hline AST-6_14 & AST-6 & $26 / 08 / 14$ & 67.32 & 0.29 & 8.61 & 0.00 & 4.97 & 0.17 & 0.22 & 5.33 & 3.97 & 0.02 & & 90.90 \\
\hline AST-6_15 & AST-6 & $26 / 08 / 14$ & 72.50 & 0.28 & 9.19 & 0.01 & 5.45 & 0.27 & 0.26 & 5.68 & 4.30 & 0.00 & & 97.93 \\
\hline AST-6_19 & AST-6 & $26 / 08 / 14$ & 70.52 & 0.27 & 8.87 & 0.00 & 5.23 & 0.19 & 0.22 & 5.57 & 4.15 & 0.04 & & 95.06 \\
\hline AST-6_20 & AST-6 & $26 / 08 / 14$ & 73.24 & 0.28 & 9.18 & 0.01 & 5.59 & 0.20 & 0.25 & 5.77 & 4.34 & 0.00 & & 98.86 \\
\hline AST-7_2 & AST-7 & $26 / 08 / 14$ & 68.90 & 0.31 & 9.51 & 0.01 & 4.96 & 0.18 & 0.24 & 5.89 & 4.33 & 0.01 & & 94.34 \\
\hline AST-7_3 & AST-7 & $26 / 08 / 14$ & 66.15 & 0.21 & 12.45 & 0.00 & 2.99 & 0.07 & 0.19 & 5.97 & 4.81 & 0.00 & & 92.86 \\
\hline AST-7_4 & AST-7 & $26 / 08 / 14$ & 67.15 & 0.22 & 9.97 & 0.01 & 3.69 & 0.16 & 0.21 & 5.35 & 4.25 & 0.02 & & 91.03 \\
\hline AST-7_5 & AST-7 & $26 / 08 / 14$ & 68.80 & 0.23 & 10.94 & 0.00 & 3.87 & 0.06 & 0.25 & 5.98 & 4.47 & 0.00 & & 94.59 \\
\hline AST-7_6 & AST-7 & $26 / 08 / 14$ & 66.38 & 0.27 & 9.25 & 0.04 & 4.16 & 0.14 & 0.27 & 5.79 & 4.28 & 0.00 & & 90.60 \\
\hline AST-7_7 & AST-7 & $26 / 08 / 14$ & 69.39 & 0.28 & 10.46 & 0.00 & 3.82 & 0.15 & 0.27 & 5.96 & 4.40 & 0.00 & & 94.73 \\
\hline AST-7_11 & AST-7 & /08/14 & 68.62 & 0.26 & 10.21 & 0.00 & 4.01 & 0.16 & 0.22 & 5.95 & 4.56 & 0.01 & & 94.02 \\
\hline AST-7_13 & AST-7 & /08/14 & 67.92 & 0.14 & 11.98 & 0.02 & 3.46 & 0.10 & 0.26 & 6.65 & 4.34 & 0.01 & & 94.89 \\
\hline AST-7_14 & AST-7 & /08/14 & 68.01 & 0.23 & 10.08 & 0.00 & 3.79 & 0.14 & 0.29 & 5.83 & 4.36 & 0.00 & & 92.74 \\
\hline AST-7_16 & AST-7 & $26 / 08 / 14$ & 69.17 & 0.26 & 10.71 & 0.01 & 4.15 & 0.11 & 0.28 & 5.61 & 4.50 & 0.01 & & 94.81 \\
\hline AST-7_19 & AST-7 & $26 / 08 / 14$ & 67.45 & 0.21 & 10.26 & 0.00 & 3.85 & 0.16 & 0.22 & 5.67 & 4.31 & 0.01 & & 92.14 \\
\hline AST-7_20 & AST-7 & $26 / 08 / 14$ & 67.18 & 0.16 & 12.51 & 0.01 & 2.99 & 0.04 & 0.20 & 5.98 & 4.91 & 0.02 & & 94.02 \\
\hline 03AL2732/3 & AST-8 & $20 / 02 / 14$ & 68.63 & 0.25 & 10.41 & 0.01 & 4.44 & 0.17 & 0.21 & 5.56 & 4.30 & 0.02 & 0.25 & 94.25 \\
\hline 03AL2732/6 & AST-8 & $20 / 02 / 14$ & 70.89 & 0.24 & 10.41 & 0.00 & 4.89 & 0.20 & 0.23 & 5.94 & 4.17 & 0.04 & 0.28 & 97.27 \\
\hline 03AL2732/8 & AST-8 & $20 / 02 / 14$ & 67.95 & 0.27 & 10.19 & 0.01 & 4.35 & 0.22 & 0.22 & 5.87 & 4.18 & 0.00 & 0.23 & 93.49 \\
\hline 03AL $2732 / 10$ & AST-8 & $20 / 02 / 14$ & 69.42 & 0.20 & 10.32 & 0.00 & 4.68 & 0.02 & 0.21 & 6.07 & 4.33 & 0.02 & 0.29 & 95.56 \\
\hline B03AL2732/1 & AST-8 & $20 / 02 / 14$ & 69.98 & 0.25 & 10.50 & 0.00 & 4.41 & 0.15 & 0.25 & 5.77 & 4.24 & 0.00 & 0.25 & 95.80 \\
\hline B03AL2732/2 & AST-8 & $20 / 02 / 14$ & 70.12 & 0.30 & 10.49 & 0.01 & 4.58 & 0.26 & 0.22 & 5.68 & 4.21 & 0.02 & 0.26 & 96.14 \\
\hline B03AL2732/3 & AST-8 & $20 / 02 / 14$ & 68.34 & 0.26 & 10.29 & 0.01 & 4.60 & 0.09 & 0.31 & 5.85 & 4.17 & 0.04 & 0.23 & 94.17 \\
\hline B03AL2732/6 & AST-8 & $20 / 02 / 14$ & 71.10 & 0.34 & 10.50 & 0.00 & 4.50 & 0.13 & 0.21 & 5.84 & 4.37 & 0.03 & 0.28 & 97.28 \\
\hline B03AL2732/10 & AST-8 & $02 / 14$ & 69.22 & 0.27 & 10.40 & 0.01 & 4.52 & 0.24 & 0.26 & 5.62 & 4.19 & 0.03 & 0.22 & 95.00 \\
\hline B03AL2732/11 & AST-8 & $20 / 02 / 14$ & 71.80 & 0.31 & 10.74 & 0.01 & 4.66 & 0.15 & 0.22 & 5.96 & 4.46 & 0.00 & 0.25 & 98.56 \\
\hline AST-9_1 & AST-9 & $26 / 08 / 14$ & 67.01 & 0.23 & 9.76 & 0.00 & 4.56 & 0.19 & 0.28 & 5.66 & 4.19 & 0.03 & & 91.91 \\
\hline AST-9_2 & AST-9 & $26 / 08 / 14$ & 69.90 & 0.24 & 10.32 & 0.00 & 4.67 & 0.15 & 0.27 & 5.84 & 4.33 & 0.02 & & 95.73 \\
\hline AST-9_3 & AST-9 & $26 / 08 / 14$ & 67.39 & 0.28 & 9.86 & 0.00 & 4.37 & 0.17 & 0.26 & 5.42 & 4.28 & 0.02 & & 92.04 \\
\hline AST-9_4 & AST-9 & $26 / 08 / 14$ & 70.16 & 0.28 & 10.21 & 0.00 & 4.71 & 0.14 & 0.25 & 5.92 & 4.40 & 0.01 & & 96.07 \\
\hline AST-9_5 & AST-9 & $26 / 08 / 14$ & 67.94 & 0.27 & 9.94 & 0.00 & 4.76 & 0.12 & 0.26 & 5.74 & 4.23 & 0.04 & & 93.32 \\
\hline AST-9_7 & AST-9 & $26 / 08 / 14$ & 65.83 & 0.24 & 9.61 & 0.00 & 4.73 & 0.19 & 0.23 & 5.93 & 4.31 & 0.01 & & 91.09 \\
\hline AST-9_8 & AST-9 & $26 / 08 / 14$ & 65.61 & 0.25 & 9.43 & 0.00 & 4.70 & 0.24 & 0.22 & 5.71 & 4.30 & 0.00 & & 90.46 \\
\hline AST-9_9 & AST-9 & $26 / 08 / 14$ & 67.04 & 0.29 & 9.89 & 0.01 & 4.52 & 0.12 & 0.24 & 5.79 & 4.34 & 0.00 & & 92.24 \\
\hline AST-9_10 & AST-9 & $26 / 08 / 14$ & 66.45 & 0.22 & 9.66 & 0.00 & 4.32 & 0.17 & 0.21 & 5.62 & 4.19 & 0.00 & & 90.85 \\
\hline AST-9_11 & AST-9 & & 69.28 & 0.2 & 10.2 & 0.0 & 4.64 & 0.15 & 0.22 & 6.18 & 4.34 & 0.03 & & 95.35 \\
\hline AST-9_12 & AST-9 & $26 / 08 / 14$ & 68.48 & 0.26 & 10.00 & 0.00 & 4.58 & 0.19 & 0.26 & 5.77 & 4.22 & 0.02 & & 93.78 \\
\hline AST-9_14 & AST-9 & $26 / 08 / 14$ & 67.89 & 0.28 & 9.78 & 0.00 & 4.43 & 0.21 & 0.22 & 5.87 & 4.24 & 0.00 & & 92.93 \\
\hline AST-9_15 & AST-9 & $26 / 08 / 14$ & 67.27 & 0.27 & 9.85 & 0.00 & 4.53 & 0.09 & 0.25 & 6.02 & 4.31 & 0.00 & & 92.59 \\
\hline AST-9_16 & AST-9 & $26 / 08 / 14$ & 65.84 & 0.25 & 9.59 & 0.00 & 4.57 & 0.10 & 0.26 & 5.55 & 4.10 & 0.02 & & 90.30 \\
\hline AST-9_17 & AST-9 & $26 / 08 / 14$ & 65.93 & 0.21 & 9.68 & 0.00 & 4.58 & 0.15 & 0.22 & 5.94 & 4.21 & 0.00 & & 90.92 \\
\hline AST-9_18 & AST-9 & $26 / 08 / 14$ & 65.69 & 0.24 & 9.53 & 0.00 & 4.42 & 0.08 & 0.26 & 5.94 & 4.10 & 0.05 & & 90.32 \\
\hline
\end{tabular}




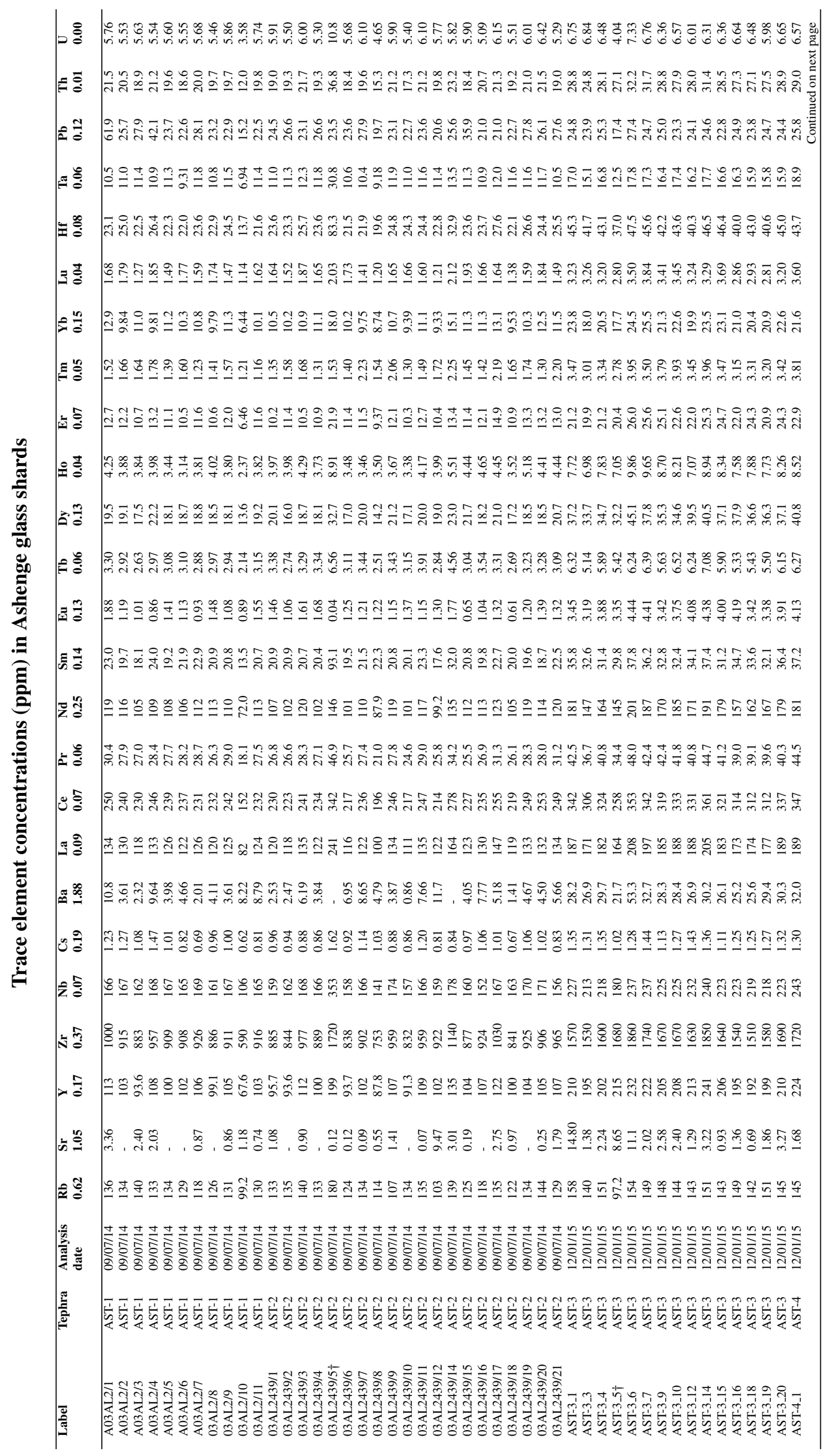




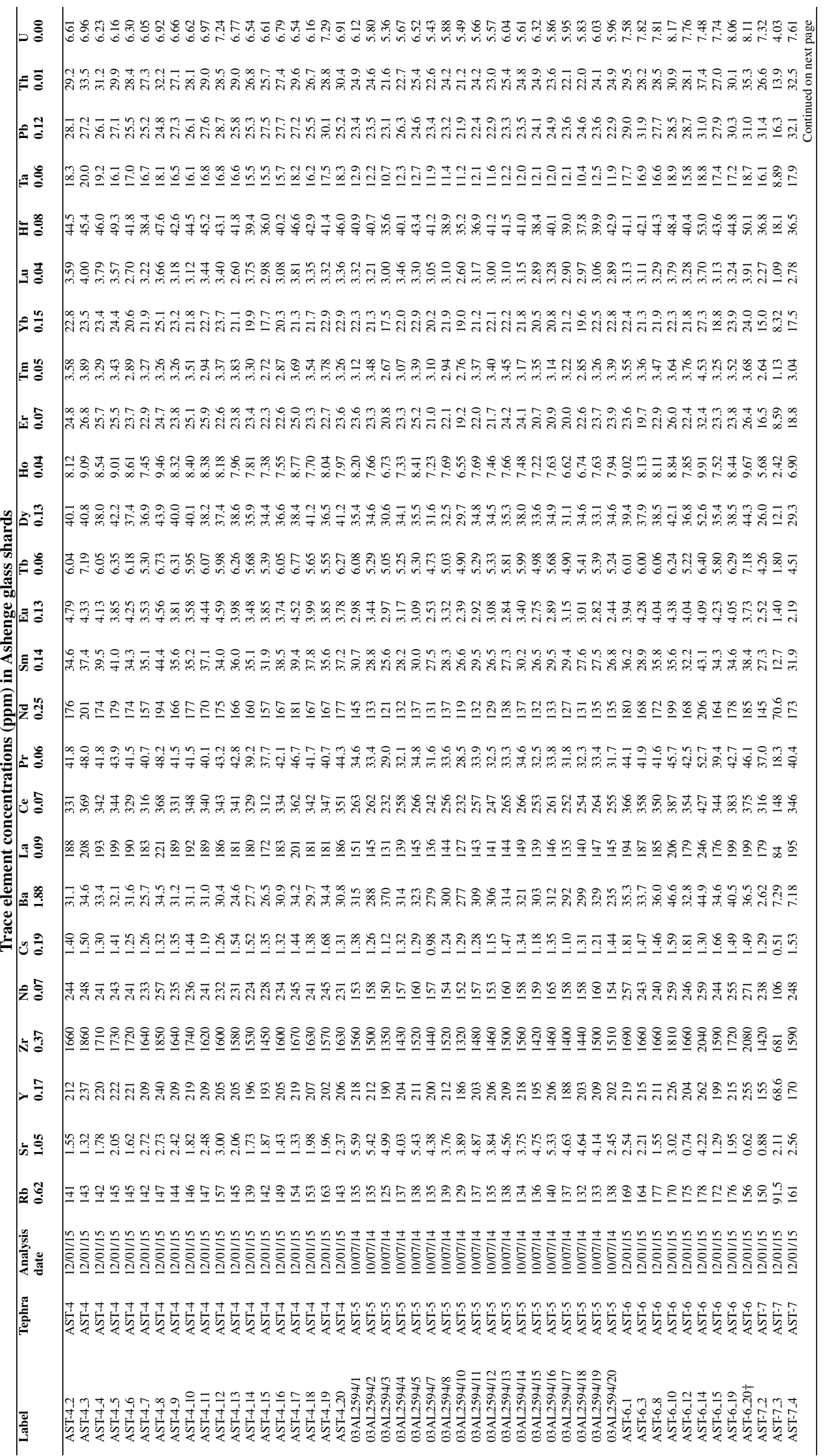




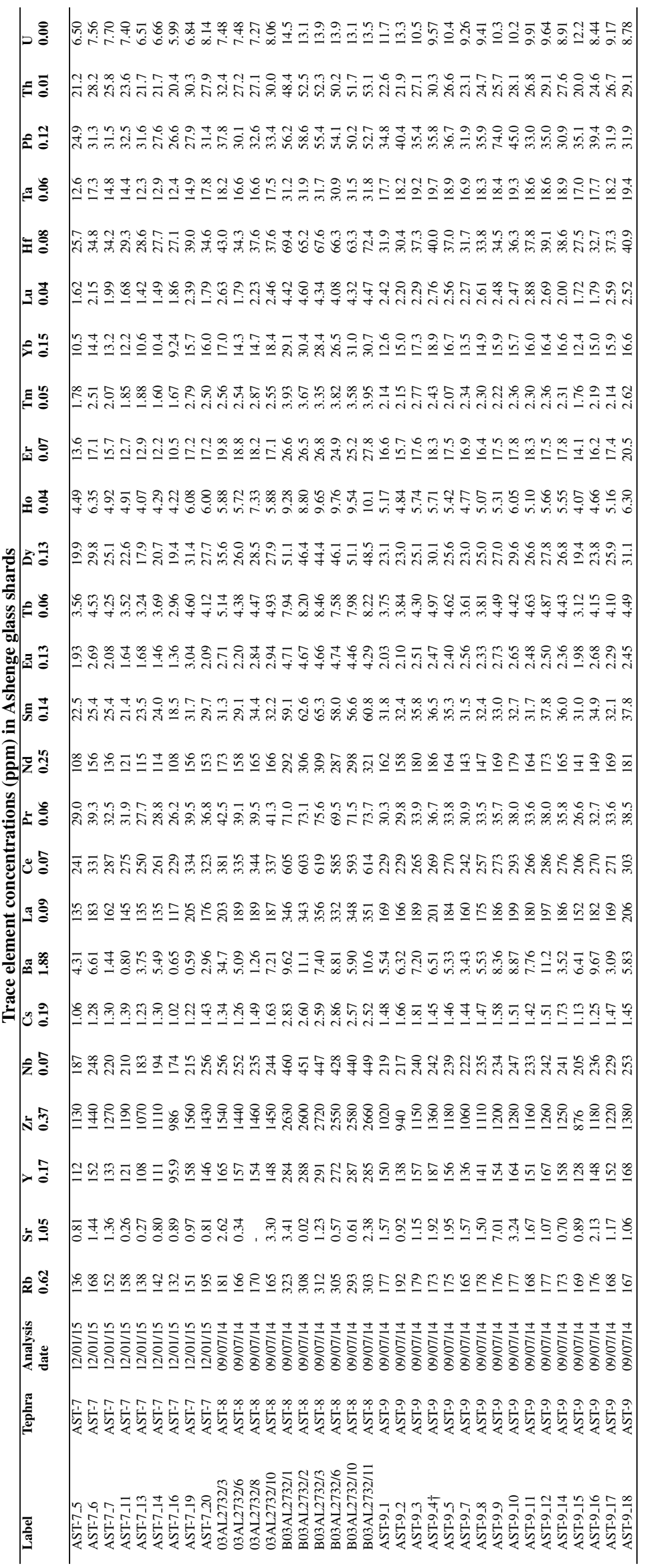


Unnormalised major element concentrations (wt.\%) in Hayk glass shards

\begin{tabular}{|c|c|c|c|c|c|c|c|c|c|c|c|c|c|}
\hline Label & Tephra & $\begin{array}{l}\text { Analysis } \\
\text { date }\end{array}$ & $\begin{array}{l}\mathrm{SiO}_{2} \\
\mathbf{0 . 0 8} \\
\end{array}$ & $\begin{array}{l}\mathrm{TiO}_{2} \\
\mathbf{0 . 0 5}\end{array}$ & $\begin{array}{l}\mathrm{Al}_{2} \mathrm{O}_{3} \\
0.05 \\
\end{array}$ & $\begin{array}{l}\text { MgO } \\
0.04 \\
\end{array}$ & $\begin{array}{l}\mathrm{FeO}^{T} \\
\mathbf{0 . 0 8} \\
\end{array}$ & $\begin{array}{l}\text { MnO } \\
0.07 \\
\end{array}$ & $\begin{array}{l}\mathrm{CaO} \\
0.04\end{array}$ & $\begin{array}{l}\mathrm{Na}_{2} \mathrm{O} \\
0.08 \\
\end{array}$ & $\begin{array}{l}\mathbf{K}_{2} \mathbf{O} \\
\mathbf{0 . 0 3} \\
\end{array}$ & $\begin{array}{l}\mathbf{P}_{2} \mathbf{O}_{5} \\
\mathbf{0 . 1 0}\end{array}$ & $\begin{array}{l}\mathrm{Cl} \\
\mathbf{0 . 0 2}\end{array}$ \\
\hline HT-1_2 & HT-2 & $28 / 08 / 14$ & 71.70 & 0.24 & 13.21 & 0.13 & 2.93 & 0.12 & 1.45 & 4.44 & 3.60 & 0.03 & \\
\hline HT-1_4 & HT-2 & $28 / 08 / 14$ & 70.81 & 0.26 & 12.86 & 0.14 & 2.76 & 0.06 & 1.39 & 4.96 & 3.60 & 0.02 & \\
\hline HT-1_5 & HT-2 & $28 / 08 / 14$ & 71.18 & 0.21 & 12.88 & 0.13 & 2.74 & 0.08 & 1.45 & 4.90 & 3.62 & 0.00 & \\
\hline HT-1_7 & HT-2 & $28 / 08 / 14$ & 71.31 & 0.29 & 12.76 & 0.12 & 2.85 & 0.12 & 1.36 & 4.74 & 3.47 & 0.04 & \\
\hline HT-1_8 & HT-2 & $28 / 08 / 14$ & 70.38 & 0.26 & 12.72 & 0.13 & 2.58 & 0.08 & 1.39 & 4.90 & 3.46 & 0.05 & \\
\hline HT-1_9 & HT-2 & $28 / 08 / 14$ & 69.56 & 0.28 & 12.50 & 0.14 & 2.76 & 0.05 & 1.50 & 4.80 & 3.54 & 0.00 & \\
\hline HT-1_12 & HT-2 & $28 / 08 / 14$ & 69.90 & 0.25 & 12.89 & 0.13 & 2.83 & 0.10 & 1.42 & 4.61 & 3.50 & 0.01 & \\
\hline HT-1_13 & HT-2 & $28 / 08 / 14$ & 71.21 & 0.30 & 12.87 & 0.16 & 2.93 & 0.15 & 1.24 & 4.79 & 3.49 & 0.06 & \\
\hline HT-1_15 & HT-2 & $28 / 08 / 14$ & 70.98 & 0.25 & 12.75 & 0.14 & 2.66 & 0.10 & 1.39 & 4.69 & 3.57 & 0.02 & \\
\hline HT-1_18 & HT-2 & $28 / 08 / 14$ & 69.98 & 0.27 & 12.58 & 0.14 & 3.04 & 0.15 & 1.38 & 4.74 & 3.43 & 0.01 & \\
\hline HT-1_19 & HT-2 & $28 / 08 / 14$ & 71.14 & 0.32 & 13.16 & 0.13 & 2.96 & 0.07 & 1.47 & 4.64 & 3.43 & 0.06 & \\
\hline HT-1_20 & HT-2 & $28 / 08 / 14$ & 72.25 & 0.25 & 13.02 & 0.14 & 2.82 & 0.10 & 1.42 & 4.66 & 3.59 & 0.00 & \\
\hline HT-2_1 & HT-4 & $28 / 08 / 14$ & 69.61 & 0.22 & 12.42 & 0.18 & 2.63 & 0.13 & 1.35 & 4.39 & 3.67 & 0.02 & \\
\hline HT-2_2 & HT-4 & $28 / 08 / 14$ & 70.56 & 0.28 & 12.78 & 0.15 & 2.79 & 0.12 & 1.43 & 4.48 & 3.52 & 0.00 & \\
\hline HT-2_3 & HT-4 & $28 / 08 / 14$ & 70.65 & 0.29 & 12.64 & 0.13 & 2.85 & 0.06 & 1.33 & 4.68 & 3.52 & 0.05 & \\
\hline HT-2_4 & HT-4 & $28 / 08 / 14$ & 71.15 & 0.24 & 12.80 & 0.15 & 2.74 & 0.09 & 1.41 & 4.71 & 3.52 & 0.01 & \\
\hline HT-2_5 & HT-4 & $28 / 08 / 14$ & 70.77 & 0.24 & 12.78 & 0.14 & 2.60 & 0.14 & 1.35 & 4.39 & 3.56 & 0.01 & \\
\hline HT-2_6 & HT-4 & $28 / 08 / 14$ & 70.78 & 0.28 & 12.67 & 0.14 & 2.86 & 0.17 & 1.41 & 4.78 & 3.62 & 0.03 & \\
\hline HT-2_7 & HT-4 & $28 / 08 / 14$ & 71.06 & 0.29 & 13.30 & 0.13 & 2.72 & 0.12 & 1.38 & 4.75 & 3.58 & 0.03 & \\
\hline HT-2_8 & HT-4 & $28 / 08 / 14$ & 71.63 & 0.26 & 12.97 & 0.12 & 2.62 & 0.07 & 1.32 & 4.71 & 3.48 & 0.02 & \\
\hline HT-2_10 & HT-4 & $28 / 08 / 14$ & 69.89 & 0.26 & 12.44 & 0.15 & 2.70 & 0.03 & 1.37 & 4.21 & 3.56 & 0.00 & \\
\hline HT-2_11 & HT-4 & $28 / 08 / 14$ & 69.54 & 0.27 & 12.48 & 0.11 & 2.70 & 0.01 & 1.39 & 4.53 & 3.53 & 0.03 & \\
\hline HT-2_12 & HT-4 & $28 / 08 / 14$ & 70.71 & 0.29 & 12.55 & 0.12 & 2.71 & 0.10 & 1.39 & 4.48 & 3.52 & 0.05 & \\
\hline HT-2_13 & HT-4 & $28 / 08 / 14$ & 69.27 & 0.26 & 12.45 & 0.17 & 2.63 & 0.05 & 1.35 & 4.55 & 3.45 & 0.01 & \\
\hline HT-2_14 & HT-4 & $28 / 08 / 14$ & 69.55 & 0.29 & 12.41 & 0.10 & 2.96 & 0.08 & 1.38 & 4.64 & 3.57 & 0.01 & \\
\hline HT-2_15 & HT-4 & $28 / 08 / 14$ & 69.22 & 0.24 & 12.45 & 0.14 & 2.80 & 0.09 & 1.40 & 4.59 & 3.65 & 0.03 & \\
\hline HT-2_16 & HT-4 & $28 / 08 / 14$ & 68.55 & 0.24 & 12.35 & 0.10 & 2.79 & 0.07 & 1.38 & 4.55 & 3.51 & 0.04 & \\
\hline HT-2_17 & HT-4 & $28 / 08 / 14$ & 68.78 & 0.30 & 12.45 & 0.13 & 2.77 & 0.16 & 1.39 & 4.49 & 3.61 & 0.03 & \\
\hline HT-2_18 & HT-4 & $28 / 08 / 14$ & 69.75 & 0.29 & 12.67 & 0.12 & 2.62 & 0.03 & 1.45 & 4.81 & 3.46 & 0.05 & \\
\hline HT-2_19 & HT-4 & $28 / 08 / 14$ & 67.54 & 0.27 & 12.50 & 0.14 & 2.70 & 0.11 & 1.36 & 4.56 & 3.47 & 0.03 & \\
\hline HT-2_20 & HT-4 & $28 / 08 / 14$ & 69.23 & 0.22 & 11.85 & 0.08 & 2.32 & 0.05 & 1.10 & 4.36 & 3.72 & 0.03 & \\
\hline HT-5_1 & HT-5 & $30 / 06 / 15$ & 70.33 & 0.15 & 13.04 & 0.00 & 1.53 & 0.00 & 0.66 & 3.99 & 4.17 & 0.02 & 0.27 \\
\hline HT-5_2 & HT-5 & $30 / 06 / 15$ & 70.39 & 0.13 & 12.92 & 0.04 & 1.58 & 0.04 & 0.63 & 4.28 & 4.25 & 0.00 & 0.27 \\
\hline HT-5_3 & HT-5 & $30 / 06 / 15$ & 70.61 & 0.11 & 12.95 & 0.03 & 1.82 & 0.02 & 0.90 & 4.34 & 4.28 & 0.00 & 0.23 \\
\hline HT-5_4 & HT-5 & $30 / 06 / 15$ & 71.31 & 0.17 & 12.88 & 0.11 & 1.73 & 0.02 & 0.85 & 4.19 & 4.17 & 0.04 & 0.23 \\
\hline HT-5_7 & HT-5 & $30 / 06 / 15$ & 70.21 & 0.19 & 12.72 & 0.14 & 1.78 & 0.06 & 0.86 & 4.16 & 4.16 & 0.01 & 0.24 \\
\hline HT-5_8 & HT-5 & $30 / 06 / 15$ & 69.92 & 0.14 & 12.86 & 0.14 & 1.84 & 0.07 & 0.82 & 4.35 & 4.09 & 0.00 & 0.24 \\
\hline HT-5_9 & HT-5 & $30 / 06 / 15$ & 70.85 & 0.16 & 13.03 & 0.18 & 2.29 & 0.07 & 0.99 & 4.29 & 4.11 & 0.03 & 0.20 \\
\hline HT-5_10 & HT-5 & $30 / 06 / 15$ & 71.35 & 0.16 & 13.06 & 0.08 & 1.86 & 0.11 & 0.88 & 3.41 & 4.35 & 0.03 & 0.27 \\
\hline HT-5_12 & HT-5 & $30 / 06 / 15$ & 71.16 & 0.15 & 13.03 & 0.11 & 1.85 & 0.13 & 0.77 & 3.12 & 4.10 & 0.00 & 0.24 \\
\hline HT-5_15 & HT-5 & $30 / 06 / 15$ & 70.00 & 0.14 & 13.03 & 0.15 & 2.00 & 0.00 & 0.83 & 4.31 & 4.14 & 0.00 & 0.19 \\
\hline HT-5_16 & HT-5 & $30 / 06 / 15$ & 70.62 & 0.13 & 13.03 & 0.03 & 1.42 & 0.01 & 0.69 & 4.05 & 4.17 & 0.05 & 0.21 \\
\hline HT-5_17 & HT-5 & $30 / 06 / 15$ & 70.49 & 0.18 & 13.00 & 0.12 & 1.76 & 0.00 & 0.74 & 4.47 & 4.18 & 0.00 & 0.22 \\
\hline HT-5_18 & HT-5 & $30 / 06 / 15$ & 69.97 & 0.14 & 12.98 & 0.07 & 1.85 & 0.03 & 0.83 & 4.18 & 4.04 & 0.08 & 0.25 \\
\hline HT-5_19 & HT-5 & $30 / 06 / 15$ & 70.64 & 0.14 & 13.02 & 0.09 & 1.78 & 0.09 & 0.79 & 4.32 & 4.22 & 0.00 & 0.25 \\
\hline HT-5_20 & HT-5 & $30 / 06 / 15$ & 70.55 & 0.17 & 13.00 & 0.16 & 1.71 & 0.11 & 0.81 & 4.28 & 4.08 & 0.00 & 0.23 \\
\hline HT-6_8 & HT-6 & 29/06/15 & 69.02 & 0.11 & 12.96 & 0.03 & 1.72 & 0.05 & 0.77 & 4.08 & 4.25 & 0.05 & 0.27 \\
\hline HT-6_11 & HT-6 & 29/06/15 & 67.78 & 0.13 & 13.04 & 0.01 & 1.44 & 0.06 & 0.63 & 4.09 & 4.07 & 0.05 & 0.23 \\
\hline HT-6_12 & HT-6 & $29 / 06 / 15$ & 69.60 & 0.11 & 13.01 & 0.06 & 1.60 & 0.07 & 0.72 & 4.04 & 4.20 & 0.01 & 0.24 \\
\hline HT-6_13 & HT-6 & $29 / 06 / 15$ & 68.51 & 0.14 & 13.34 & 0.09 & 1.64 & 0.12 & 0.68 & 3.88 & 4.12 & 0.01 & 0.21 \\
\hline HT-6_15 & HT-6 & $29 / 06 / 15$ & 69.55 & 0.12 & 13.29 & 0.03 & 1.68 & 0.00 & 0.74 & 4.15 & 4.17 & 0.00 & 0.25 \\
\hline HT-6_19 & HT-6 & 29/06/15 & 71.00 & 0.15 & 12.81 & 0.08 & 1.80 & 0.07 & 0.79 & 4.10 & 4.28 & 0.01 & 0.25 \\
\hline HT-6_20 & HT-6 & 29/06/15 & 69.16 & 0.12 & 13.16 & 0.06 & 1.37 & 0.00 & 0.60 & 3.84 & 4.11 & 0.00 & 0.31 \\
\hline HT-7_1 & HT-7 & $30 / 06 / 15$ & 71.61 & 0.31 & 9.52 & 0.00 & 5.13 & 0.19 & 0.35 & 5.32 & 4.24 & 0.08 & 0.22 \\
\hline HT-7_2 & HT-7 & $30 / 06 / 15$ & 69.80 & 0.31 & 9.34 & 0.05 & 5.05 & 0.17 & 0.26 & 5.42 & 4.28 & 0.02 & 0.30 \\
\hline HT-7_3 & HT-7 & $30 / 06 / 15$ & 71.49 & 0.33 & 9.51 & 0.02 & 5.22 & 0.17 & 0.28 & 5.36 & 4.39 & 0.00 & 0.25 \\
\hline HT-7_4 & HT-7 & $30 / 06 / 15$ & 72.47 & 0.32 & 9.60 & 0.00 & 5.17 & 0.18 & 0.30 & 5.49 & 4.37 & 0.00 & 0.24 \\
\hline HT-7_5 & HT-7 & $30 / 06 / 15$ & 68.29 & 0.34 & 9.01 & 0.00 & 4.97 & 0.16 & 0.25 & 5.15 & 4.07 & 0.04 & 0.31 \\
\hline HT-7_6 & HT-7 & $30 / 06 / 15$ & 71.39 & 0.35 & 9.59 & 0.00 & 5.08 & 0.20 & 0.30 & 5.39 & 4.38 & 0.00 & 0.27 \\
\hline HT-7_7 & HT-7 & $30 / 06 / 15$ & 71.09 & 0.26 & 9.51 & 0.03 & 5.00 & 0.15 & 0.24 & 5.31 & 4.22 & 0.00 & 0.23 \\
\hline HT-7_8 & HT-7 & $30 / 06 / 15$ & 72.19 & 0.36 & 9.46 & 0.00 & 5.27 & 0.03 & 0.37 & 2.35 & 4.39 & 0.00 & 0.27 \\
\hline HT-7_9 & HT-7 & $30 / 06 / 15$ & 69.67 & 0.26 & 9.27 & 0.00 & 4.78 & 0.27 & 0.32 & 5.10 & 4.21 & 0.02 & 0.27 \\
\hline HT-7_10 & HT-7 & $30 / 06 / 15$ & 71.54 & 0.39 & 9.59 & 0.00 & 5.14 & 0.15 & 0.28 & 5.11 & 4.30 & 0.00 & 0.31 \\
\hline HT-7_11 & HT-7 & $30 / 06 / 15$ & 71.86 & 0.34 & 9.60 & 0.00 & 5.12 & 0.20 & 0.30 & 5.16 & 4.43 & 0.00 & 0.25 \\
\hline HT-7_12 & HT-7 & $30 / 06 / 15$ & 71.99 & 0.33 & 9.65 & 0.01 & 5.32 & 0.18 & 0.27 & 5.31 & 4.42 & 0.00 & 0.25 \\
\hline HT-7_13 & HT-7 & $30 / 06 / 15$ & 68.98 & 0.28 & 9.14 & 0.03 & 5.02 & 0.19 & 0.25 & 5.26 & 4.11 & 0.00 & 0.25 \\
\hline HT-7_14 & HT-7 & $30 / 06 / 15$ & 71.27 & 0.32 & 9.52 & 0.00 & 4.92 & 0.23 & 0.30 & 3.02 & 4.34 & 0.00 & 0.25 \\
\hline HT-7_15 & HT-7 & $30 / 06 / 15$ & 69.24 & 0.34 & 9.31 & 0.03 & 5.10 & 0.15 & 0.28 & 2.09 & 4.15 & 0.02 & 0.35 \\
\hline HT-7_16 & HT-7 & $30 / 06 / 15$ & 71.50 & 0.31 & 9.49 & 0.00 & 5.36 & 0.15 & 0.26 & 3.17 & 4.37 & 0.00 & 0.27 \\
\hline HT-7_17 & HT-7 & $30 / 06 / 15$ & 71.82 & 0.29 & 9.62 & 0.02 & 5.23 & 0.16 & 0.32 & 5.42 & 4.39 & 0.00 & 0.22 \\
\hline HT-7_18 & HT-7 & $30 / 06 / 15$ & 71.41 & 0.30 & 9.32 & 0.01 & 5.00 & 0.30 & 0.25 & 2.10 & 4.26 & 0.00 & 0.31 \\
\hline HT-7_19 & HT-7 & $30 / 06 / 15$ & 72.74 & 0.37 & 9.71 & 0.04 & 5.33 & 0.27 & 0.26 & 2.45 & 4.35 & 0.01 & 0.25 \\
\hline HT-7_20 & HT-7 & $30 / 06 / 15$ & 72.09 & 0.37 & 9.55 & 0.00 & 4.95 & 0.22 & 0.28 & 5.71 & 4.25 & 0.00 & 0.24 \\
\hline HT-9_1 & HT-9 & 29/06/15 & 70.14 & 0.12 & 12.18 & 0.03 & 1.84 & 0.04 & 0.30 & 4.63 & 4.44 & 0.04 & 0.47 \\
\hline HT-9_2 & HT-9 & 29/06/15 & 70.39 & 0.13 & 12.18 & 0.00 & 2.04 & 0.02 & 0.33 & 4.92 & 4.50 & 0.05 & 0.44 \\
\hline HT-9_5 & HT-9 & $29 / 06 / 15$ & 69.78 & 0.15 & 12.17 & 0.07 & 1.86 & 0.10 & 0.31 & 4.97 & 4.49 & 0.00 & 0.49 \\
\hline HT-9_6 & HT-9 & $29 / 06 / 15$ & 70.10 & 0.15 & 12.36 & 0.04 & 1.81 & 0.10 & 0.31 & 4.46 & 4.64 & 0.00 & 0.48 \\
\hline HT-9_7 & HT-9 & $29 / 06 / 15$ & 70.34 & 0.15 & 12.16 & 0.06 & 1.94 & 0.06 & 0.34 & 4.38 & 4.64 & 0.02 & 0.46 \\
\hline HT-9_8 & HT-9 & $29 / 06 / 15$ & 69.45 & 0.16 & 12.09 & 0.02 & 1.91 & 0.07 & 0.34 & 4.85 & 4.48 & 0.00 & 0.42 \\
\hline HT-9_9 & HT-9 & 29/06/15 & 70.06 & 0.12 & 12.31 & 0.01 & 2.00 & 0.08 & 0.32 & 4.74 & 4.43 & 0.00 & 0.45 \\
\hline HT-9_10 & HT-9 & $29 / 06 / 15$ & 68.92 & 0.14 & 12.43 & 0.00 & 1.86 & 0.01 & 0.33 & 4.58 & 4.55 & 0.03 & 0.44 \\
\hline HT-9_11 & HT-9 & $29 / 06 / 15$ & 70.04 & 0.15 & 12.21 & 0.02 & 1.79 & 0.04 & 0.35 & 4.61 & 4.57 & 0.01 & 0.46 \\
\hline HT-9_13 & HT-9 & 29/06/15 & 69.94 & 0.17 & 12.26 & 0.07 & 2.09 & 0.13 & 0.34 & 4.63 & 4.44 & 0.03 & 0.47 \\
\hline & & & & & & & & & & & & tin & 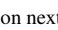 \\
\hline
\end{tabular}


Unnormalised major element concentrations (wt.\%) in Hayk glass shards

\begin{tabular}{|c|c|c|c|c|c|c|c|c|c|c|c|c|c|c|}
\hline Label & Tephra & $\begin{array}{l}\text { Analysis } \\
\text { date }\end{array}$ & $\begin{array}{l}\mathrm{SiO}_{2} \\
\mathbf{0 . 0 8}\end{array}$ & $\begin{array}{l}\mathrm{TiO}_{2} \\
0.05\end{array}$ & $\begin{array}{l}\mathrm{Al}_{2} \mathrm{O}_{3} \\
0.05\end{array}$ & $\begin{array}{l}\text { MgO } \\
0.04\end{array}$ & $\begin{array}{l}\mathrm{FeO}^{T} \\
\mathbf{0 . 0 8}\end{array}$ & $\begin{array}{l}\text { MnO } \\
0.07\end{array}$ & $\begin{array}{l}\mathrm{CaO} \\
0.04\end{array}$ & $\begin{array}{l}\mathrm{Na}_{2} \mathrm{O} \\
0.08\end{array}$ & $\begin{array}{l}\mathrm{K}_{2} \mathrm{O} \\
0.03\end{array}$ & $\begin{array}{l}\mathbf{P}_{2} \mathbf{O}_{5} \\
\mathbf{0 . 1 0}\end{array}$ & $\begin{array}{l}\mathrm{Cl} \\
0.02\end{array}$ & Total \\
\hline HT-9_14 & HT-9 & $29 / 06 / 15$ & 69.86 & 0.12 & 12.20 & 0.01 & 1.91 & 0.07 & 0.33 & 4.80 & 4.46 & 0.03 & 0.49 & 94.27 \\
\hline HT-9_16 & HT-9 & $29 / 06 / 15$ & 70.34 & 0.17 & 12.36 & 0.02 & 1.92 & 0.11 & 0.34 & 4.29 & 4.58 & 0.05 & 0.42 & 94.60 \\
\hline HT-9_18 & HT-9 & $29 / 06 / 15$ & 70.58 & 0.10 & 12.08 & 0.00 & 1.94 & 0.03 & 0.31 & 3.35 & 4.72 & 0.03 & 0.45 & 93.60 \\
\hline HT-9_19 & HT-9 & $29 / 06 / 15$ & 69.65 & 0.11 & 12.26 & 0.00 & 1.86 & 0.12 & 0.28 & 4.63 & 4.51 & 0.00 & 0.48 & 93.89 \\
\hline HT-9_20 & HT-9 & $29 / 06 / 15$ & 69.07 & 0.18 & 12.11 & 0.01 & 1.83 & 0.11 & 0.31 & 4.77 & 4.52 & 0.00 & 0.47 & 93.36 \\
\hline HT-10_1 & HT-10 & $29 / 06 / 15$ & 68.29 & 0.15 & 12.54 & 0.05 & 1.80 & 0.01 & 0.34 & 4.47 & 4.64 & 0.00 & 0.49 & 92.78 \\
\hline HT-10_2 & HT-10 & $29 / 06 / 15$ & 68.65 & 0.13 & 12.66 & 0.03 & 1.98 & 0.13 & 0.35 & 4.56 & 4.60 & 0.02 & 0.50 & 93.61 \\
\hline HT-10_5 & HT-10 & $29 / 06 / 15$ & 68.93 & 0.17 & 12.64 & 0.08 & 1.83 & 0.04 & 0.49 & 4.27 & 4.53 & 0.03 & 0.42 & 93.44 \\
\hline HT-10_7 & HT-10 & $29 / 06 / 15$ & 68.67 & 0.15 & 13.02 & 0.03 & 1.69 & 0.07 & 0.34 & 4.31 & 4.59 & 0.00 & 0.46 & 93.34 \\
\hline HT-10_8 & HT-10 & $29 / 06 / 15$ & 69.65 & 0.14 & 12.47 & 0.07 & 1.89 & 0.05 & 0.36 & 4.52 & 4.56 & 0.00 & 0.44 & 94.14 \\
\hline HT-10_10 & HT-10 & $29 / 06 / 15$ & 70.89 & 0.15 & 12.61 & 0.00 & 2.00 & 0.12 & 0.35 & 4.46 & 4.52 & 0.00 & 0.46 & 95.56 \\
\hline HT-10_11 & HT-10 & $/ / 06 / 15$ & 68.49 & 0.09 & 12.57 & 0.00 & 1.94 & 0.09 & 0.35 & 4.30 & 4.55 & 0.00 & 0.49 & 92.87 \\
\hline HT-10_13 & HT-10 & $29 / 06 / 15$ & 68.28 & 0.13 & 12.61 & 0.00 & 1.85 & 0.08 & 0.34 & 4.45 & 4.55 & 0.00 & 0.49 & 92.77 \\
\hline HT-10_14 & HT-10 & $29 / 06 / 15$ & 67.68 & 0.10 & 12.40 & 0.00 & 1.83 & 0.11 & 0.34 & 4.47 & 4.40 & 0.03 & 0.50 & 91.87 \\
\hline HT-10_17 & HT- 10 & $29 / 06 / 15$ & 67.34 & 0.1 & 12.38 & 0.00 & 2.00 & 0.04 & 0.32 & 4.51 & 4.42 & 0.00 & 0.44 & 91.57 \\
\hline HT-10_19 & HT-10 & $29 / 06 / 15$ & 67.53 & 0.13 & 12.05 & 0.05 & 1.86 & 0.00 & 0.31 & 4.52 & 4.47 & 0.00 & 0.55 & 91.48 \\
\hline HT-10_20 & HT-10 & 29/06/15 & 68.89 & 0.14 & 12.60 & 0.08 & 1.81 & 0.11 & 0.41 & 4.43 & 4.47 & 0.03 & 0.48 & 93.46 \\
\hline HT-12_1 & HT-12 & $30 / 06 / 15$ & 71.08 & 0.37 & 10.09 & 0.00 & 4.85 & 0.29 & 0.33 & 5.33 & 4.37 & 0.00 & 0.26 & 96.98 \\
\hline HT-12_2 & HT-12 & $30 / 06 / 15$ & 69.31 & 0.29 & 9.78 & 0.02 & 4.72 & 0.24 & 0.27 & 5.19 & 4.24 & 0.00 & 0.27 & 94.32 \\
\hline HT-12_3 & HT-12 & $30 / 06 / 15$ & 71.29 & 0.32 & 10.25 & 0.06 & 4.99 & 0.23 & 0.33 & 5.31 & 4.42 & 0.00 & 0.24 & 97.44 \\
\hline HT-12_4 & HT-12 & $30 / 06 / 15$ & 72.10 & 0.34 & 10.12 & 0.00 & 5.00 & 0.20 & 0.29 & 5.36 & 4.29 & 0.00 & 0.23 & 97.95 \\
\hline HT- $12 \_5$ & HT-12 & $30 / 06 / 15$ & 70.60 & 0.35 & 10.01 & 0.00 & 4.83 & 0.16 & 0.30 & 5.17 & 4.40 & 0.05 & 0.22 & 96.09 \\
\hline HT-12_6 & HT-12 & $/ 06 / 15$ & 69.36 & 0.29 & 9.78 & 0.00 & 5.04 & 0.06 & 0.30 & 5.00 & 4.41 & 0.02 & 0.24 & 94.49 \\
\hline HT-12_7 & HT- 12 & $/ 06 / 15$ & 71.57 & 0.2 & 9.81 & 0.0 & 4.91 & 0.15 & 0.30 & 5.24 & 4.48 & 0.02 & 0.26 & 97.01 \\
\hline HT-12_8 & HT-12 & $30 / 06 / 15$ & 71.16 & 0.29 & 9.92 & 0.0 & 4.74 & 0.21 & 0.29 & 5.45 & 4.44 & 0.00 & 0.26 & 96.76 \\
\hline HT-12_10 & HT- 12 & $0 / 06 / 15$ & 69.89 & 0.3 & 9.85 & 0.0 & 4.86 & 0.24 & 0.30 & 5.35 & 4.30 & 0.05 & 0.27 & 95.45 \\
\hline HT-12_11 & HT-12 & $30 / 06 / 15$ & 71.11 & 0.37 & 9.89 & 0.00 & 5.08 & 0.10 & 0.29 & 5.21 & 4.51 & 0.00 & 0.27 & 96.82 \\
\hline HT-12_12 & HT-12 & $30 / 06 / 15$ & 70.68 & 0.29 & 9.84 & 0.05 & 5.02 & 0.16 & 0.29 & 5.27 & 4.30 & 0.04 & 0.25 & 96.18 \\
\hline HT-12_13 & HT-12 & $30 / 06 / 15$ & 71.91 & 0.30 & 10.07 & 0.03 & 5.05 & 0.19 & 0.32 & 5.07 & 4.40 & 0.05 & 0.26 & 97.64 \\
\hline HT-12_15 & HT-12 & $30 / 06 / 15$ & 69.14 & 0.34 & 9.72 & 0.00 & 4.92 & 0.15 & 0.26 & 5.23 & 4.35 & 0.02 & 0.25 & 94.38 \\
\hline HT-12_16 & HT-12 & $30 / 06 / 15$ & 70.98 & 0.26 & 9.87 & 0.03 & 4.98 & 0.29 & 0.28 & 5.19 & 4.43 & 0.00 & 0.23 & 96.55 \\
\hline HT-12_17 & HT-12 & $30 / 06 / 15$ & 69.84 & 0.34 & 9.89 & 0.00 & 4.98 & 0.12 & 0.33 & 5.18 & 4.26 & 0.00 & 0.26 & 95.20 \\
\hline HT-12_18 & $\mathrm{H}$ & & 72.09 & 0.3 & 10.09 & 0.00 & 4.97 & 0.12 & 0.32 & 5.18 & 4.27 & 0.00 & 0.26 & 97.66 \\
\hline HT-12_19 & HT-12 & $30 / 06 / 15$ & 70.34 & 0.34 & 9.94 & 0.00 & 4.67 & 0.16 & 0.27 & 5.22 & 4.36 & 0.00 & 0.27 & 95.56 \\
\hline HT-12_20 & HT-12 & $30 / 06 / 15$ & 71.58 & 0.33 & 10.19 & 0.00 & 5.35 & 0.16 & 0.27 & 5.71 & 4.48 & 0.03 & 0.26 & 98.35 \\
\hline
\end{tabular}




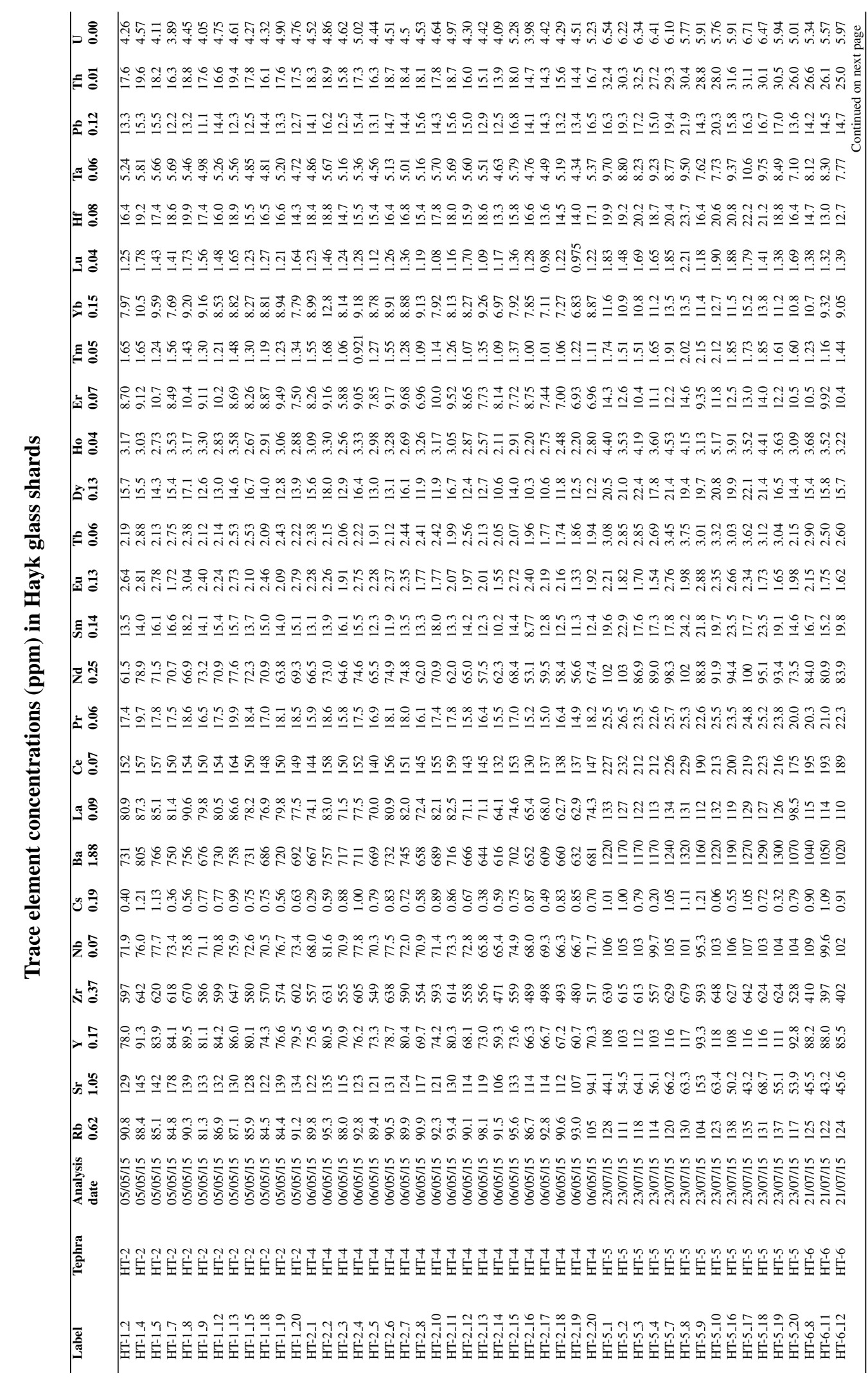




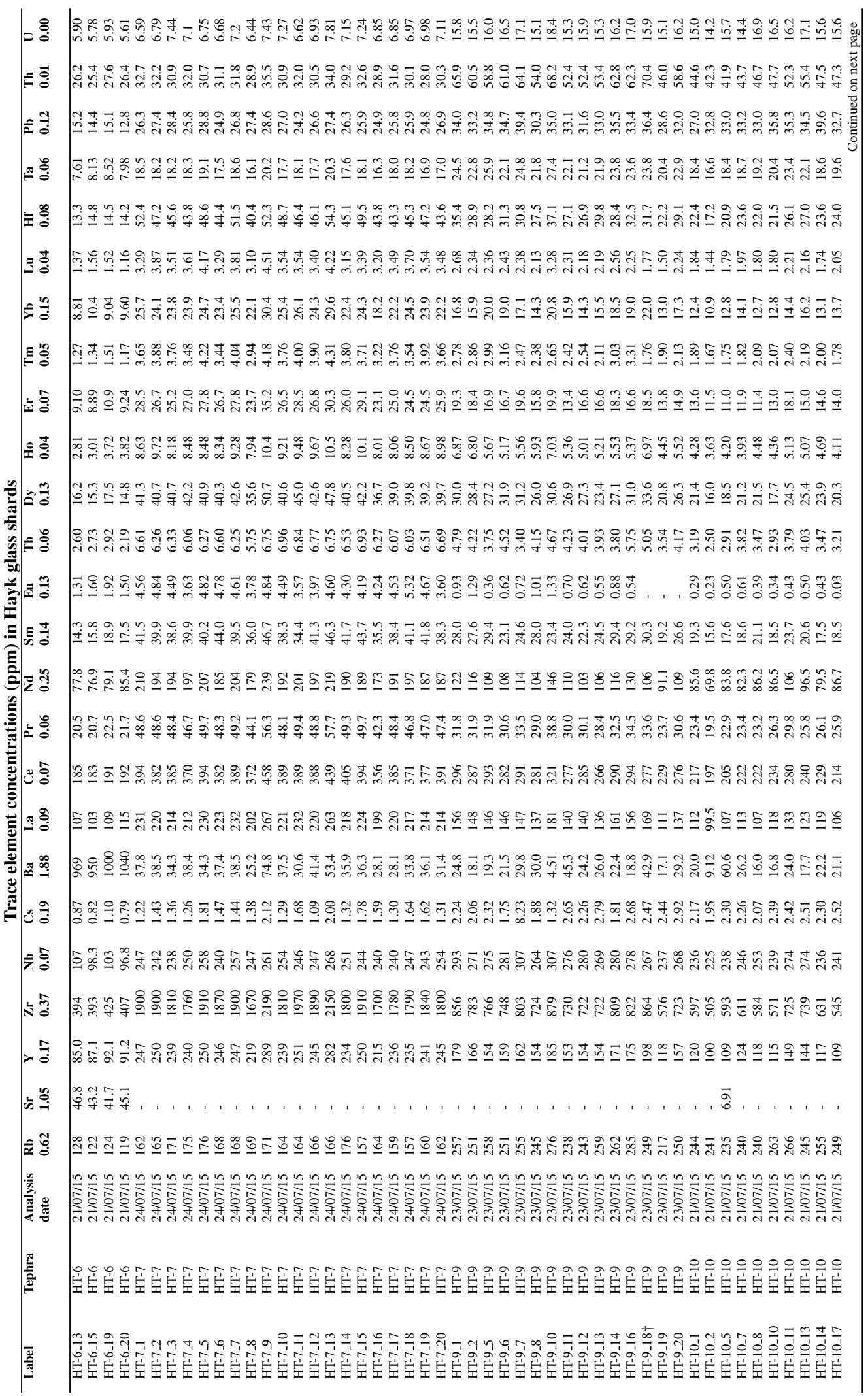




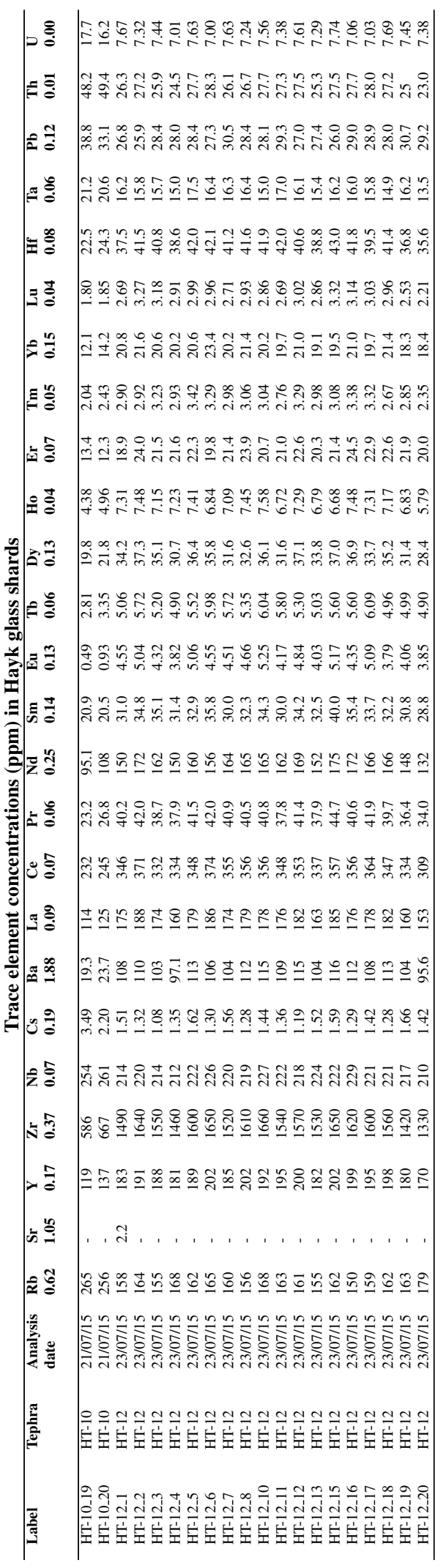


Unnormalised major element concentrations (wt.\%) in Dubbi 1861 tephra glass shards

\begin{tabular}{|c|c|c|c|c|c|c|c|c|c|c|c|c|c|c|}
\hline Label & Tephra & $\begin{array}{l}\text { Analysis } \\
\text { date }\end{array}$ & $\begin{array}{l}\mathrm{SiO}_{2} \\
0.08\end{array}$ & $\begin{array}{l}\mathrm{TiO}_{2} \\
0.05\end{array}$ & $\begin{array}{l}\mathrm{Al}_{2} \mathrm{O}_{3} \\
0.05\end{array}$ & $\begin{array}{l}\text { MgO } \\
\text { 0.04 }\end{array}$ & $\begin{array}{l}\mathrm{FeO}^{T} \\
0.08\end{array}$ & $\begin{array}{l}\text { MnO } \\
0.07\end{array}$ & $\begin{array}{l}\mathrm{CaO} \\
0.04\end{array}$ & $\begin{array}{l}\mathrm{Na}_{2} \mathrm{O} \\
0.08\end{array}$ & $\begin{array}{l}\mathbf{K}_{2} \mathbf{O} \\
\mathbf{0 . 0 3}\end{array}$ & $\begin{array}{l}\mathbf{P}_{2} \mathbf{O}_{5} \\
0.10\end{array}$ & $\begin{array}{l}\mathrm{Cl} \\
0.02\end{array}$ & Total \\
\hline Dubbi_1_1 & Dubbi 1861 & $03 / 07 / 15$ & 68.56 & 0.16 & 11.66 & 0.02 & 2.68 & 0.09 & 0.25 & 5.34 & 4.18 & 0.01 & 0.33 & 93.29 \\
\hline Dubbi_1_4 & Dubbi 1861 & $03 / 07 / 15$ & 67.57 & 0.10 & 11.50 & 0.00 & 3.04 & 0.08 & 0.27 & 5.11 & 4.24 & 0.01 & 0.34 & 92.27 \\
\hline Dubbi_1_5 & Dubbi 1861 & 03/07/15 & 68.56 & 0.21 & 11.88 & 0.00 & 2.91 & 0.09 & 0.27 & 5.34 & 4.09 & 0.00 & 0.32 & 93.67 \\
\hline Dubbi_1_6 & Dubbi 1861 & 03/07/15 & 68.74 & 0.18 & 11.93 & 0.01 & 2.97 & 0.00 & 0.29 & 5.27 & 4.06 & 0.00 & 0.34 & 93.80 \\
\hline Dubbi_1_7 & Dubbi 1861 & $03 / 07 / 15$ & 67.43 & 0.17 & 11.53 & 0.00 & 3.00 & 0.07 & 0.30 & 5.34 & 4.15 & 0.01 & 0.37 & 92.37 \\
\hline Dubbi_1_9 & Dubbi 1861 & $03 / 07 / 15$ & 68.13 & 0.15 & 11.71 & 0.01 & 2.84 & 0.05 & 0.30 & 5.01 & 4.26 & 0.00 & 0.34 & 92.81 \\
\hline Dubbi_1_10 & Dubbi 1861 & $03 / 07 / 15$ & 61.56 & 0.42 & 16.22 & 0.00 & 6.64 & 0.29 & 2.25 & 5.05 & 6.37 & 0.02 & 0.04 & 98.84 \\
\hline Dubbi_1_11 & Dubbi 1861 & $03 / 07 / 15$ & 67.72 & 0.18 & 11.62 & 0.00 & 2.84 & 0.17 & 0.30 & 4.93 & 4.12 & 0.00 & 0.36 & 92.23 \\
\hline Dubbi_1_12 & Dubbi 1861 & $03 / 07 / 15$ & 68.23 & 0.20 & 11.63 & 0.00 & 3.02 & 0.03 & 0.30 & 5.36 & 4.29 & 0.00 & 0.34 & 93.38 \\
\hline Dubbi_1_13 & Dubbi 1861 & $03 / 07 / 15$ & 68.46 & 0.17 & 11.60 & 0.04 & 3.30 & 0.11 & 0.25 & 5.46 & 4.17 & 0.00 & 0.34 & 93.90 \\
\hline Dubbi_1_15 & Dubbi 1861 & $03 / 07 / 15$ & 67.60 & 0.21 & 12.03 & 0.02 & 2.99 & 0.09 & 0.27 & 4.93 & 4.32 & 0.00 & 0.36 & 92.81 \\
\hline Dubbi_1_17 & Dubbi 1861 & $03 / 07 / 15$ & 67.76 & 0.16 & 11.61 & 0.00 & 3.01 & 0.11 & 0.27 & 5.17 & 4.23 & 0.03 & 0.39 & 92.74 \\
\hline Dubbi_1_18 & Dubbi 1861 & $03 / 07 / 15$ & 68.07 & 0.14 & 11.65 & 0.00 & 2.93 & 0.00 & 0.26 & 4.91 & 4.21 & 0.00 & 0.36 & 92.55 \\
\hline Dubbi_1_20 & Dubbi 1861 & $03 / 07 / 15$ & 68.56 & 0.11 & 11.55 & 0.00 & 3.10 & 0.13 & 0.29 & 2.74 & 4.30 & 0.04 & 0.39 & 91.19 \\
\hline Dubbi_1/2_7 & Dubbi 1861 & $03 / 07 / 15$ & 66.49 & 0.15 & 11.71 & 0.00 & 3.05 & 0.05 & 0.39 & 5.35 & 4.08 & 0.01 & 0.31 & 91.58 \\
\hline
\end{tabular}




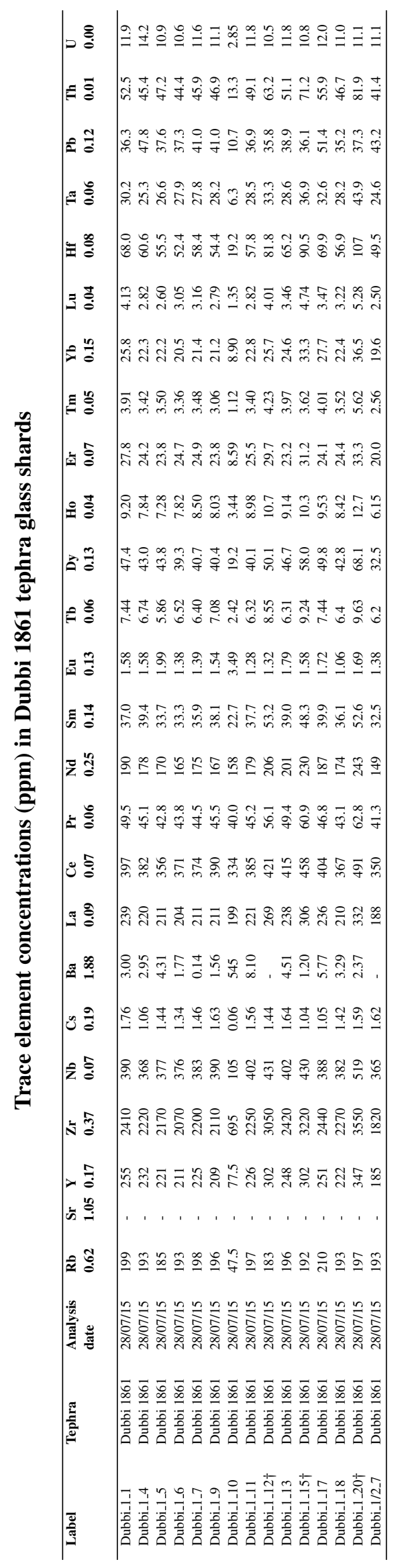




\section{.3.2 Bayesian age models}

The following pages show the OxCal (Bronk Ramsey, 2009b) code used to generate the Ashenge and Hayk Bayesian age models. These P_sequence models allow for more flexible modelling of the data to the IntCal13 calibration curve. Statistical outliers were included in the model, but given less weighting. Two models were run either side of a sedimentary hiatus at $650 \mathrm{~cm}$ depth in the Ashenge archive. The core depths are corrected for the presence of $>0.5 \mathrm{~cm}$ thick tephras, which are assumed to have been deposited instantaneously. Tephra age ranges were then extracted from the age model using the Date function. 


\section{Ashenge}

Ashenge OxCal script

Two P_sequence models, above and below a sedimentary hiatus at $650 \mathrm{~cm}$, with outlier analysis

\section{OxCal output}

Options!
$l$
$B C A D=F A S E$

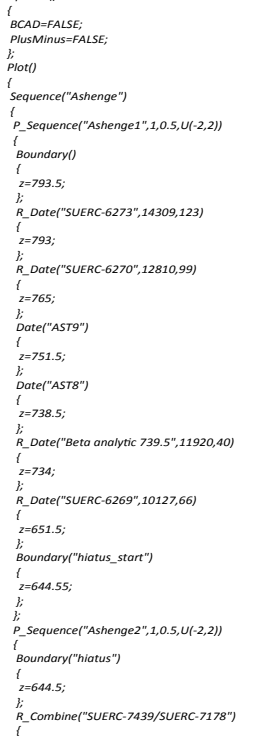

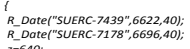

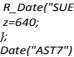

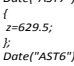

$z=618.5 ;$

$2=618.5 ;$
$j:$
Date("ASTS")
$($ ing

$l_{z=604.5 ;}^{i}$

Rotel"'SUERC-29481",5671,39)

$z=597.5 ;$

RDDAT("SUERC-6268",5063,34)

$z=548.5 ;$
$j ;$

${ }_{\text {Datel "ASTA") }}$

$z=524 ;$
l:
$R$ Date(

Outtier();

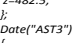

$l_{z=482 ;}$

R_Date("SUERC-29480",4361,38)

$z=437.5 ;$

$l_{z=436 ;}^{\text {Datel"AST2 }}$

R_Date("SUERC-29479",4143,38)

$z=384.5 ;$

R_Date("SUERC-29478",3298,35)

$z=339.5$;

R_Date("SUERC-6265",2865, 28)

$z=298.5 ;$

R_Date("SUERC-29477", 2082,37)

$z=244.5$;

R_Date("SUERC-6264", 1609,22)

$z=173.5 ;$

Rate("SUERC-29476",923,35)

$z=102.5 ;$

Dote("SUERC-6263",618,31

$z=49.5 ;$

Dotel"ASTI"

$z=10 ;$

Datel"SUERC-29473",377,37)

Boundary

AST1

R_Date SUERC-6263

R_Date SUERC-29476

R_Date SUERC-6264

R_Date SUERC-29477

R_Date SUERC-6265

R Date SUERC-29478

R_Date SUERC-29479

AST2

R_Date SUERC-29480

AST3

R_Date SUERC-6266

AST4

R_Date SUERC-6268

R_Date SUERC-29481

ASTS

AST6

AST7

R_Combine SUERC-7439/SUERC-7178

Boundary hiatus

P_Sequence Ashenge2

Boundary hiatus_start

R Date SUERC-

R. Date Beta analytic 739.5

AST8

R_Date SUERC-6270

R_Date SUERC-6273

Boundary

P_Sequence Ashenge1 Unmodelled (BP) Modelled (BP)

$\begin{array}{llll}508 & 316 & 509 & 234 \\ & & 506 & 316 \\ & & 545 & 322\end{array}$

$\begin{array}{llll}658 & 549 & 545 & 322 \\ 958 & 550\end{array}$

$\begin{array}{llll}925 & 762 & 927 & 777\end{array}$

$\begin{array}{llll}1554 & 1415 & 1553 & 1415\end{array}$

$\begin{array}{llll}2146 & 1950 & 2150 & 1951\end{array}$

$\begin{array}{llll}3070 & 2882 & 3069 & 2883\end{array}$

$\begin{array}{llll}3610 & 3450 & 3611 & 3450\end{array}$

$\begin{array}{llll}4826 & 4550 & 4808 & 4527\end{array}$

$\begin{array}{llll}5039 & 4850 & 5039 & 4852\end{array}$

$\begin{array}{lll} & 5627 & 4974 \\ 5581 & 5324 & 5581\end{array}$

$\begin{array}{ll}5581 & 5324 \\ 5878 & 5332\end{array}$

$\begin{array}{llll}5907 & 5735 & 5907 & 5741\end{array}$

$\begin{array}{llll}6560 & 6323 & 6564 & 6324\end{array}$

$\begin{array}{ll}7160 & 6347 \\ 7505 & 6484\end{array}$

\begin{tabular}{lll}
7577 & 6720 \\
\hline 7582 & 7484 & 7581
\end{tabular}

$\begin{array}{rrrr}7582 & 7484 & 7581 & 7478 \\ & & 7725 & 7463\end{array}$

$\begin{array}{lllll}-2 & 2 & -1.52819 & -0.98019\end{array}$

$12018 \quad 10718$

$\begin{array}{llll}12021 & 11404 & 12013 & 11397 \\ 13944 & 13567 & 13961 & 13575\end{array}$

$14593 \quad 13583$

$\begin{array}{lllll}15671 & 14967 & 1535 & 13848\end{array}$

$\begin{array}{llll}17793 & 17070 & 17711 & 16975\end{array}$

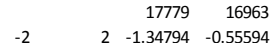

\section{OxCal age model}

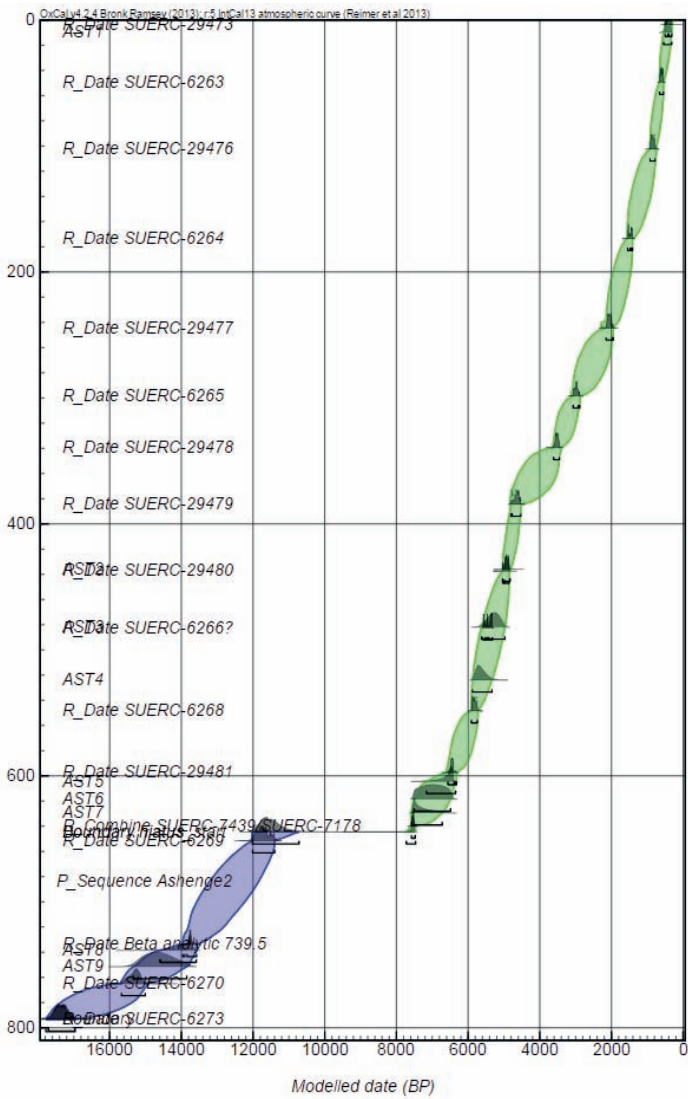




\section{Hayk}

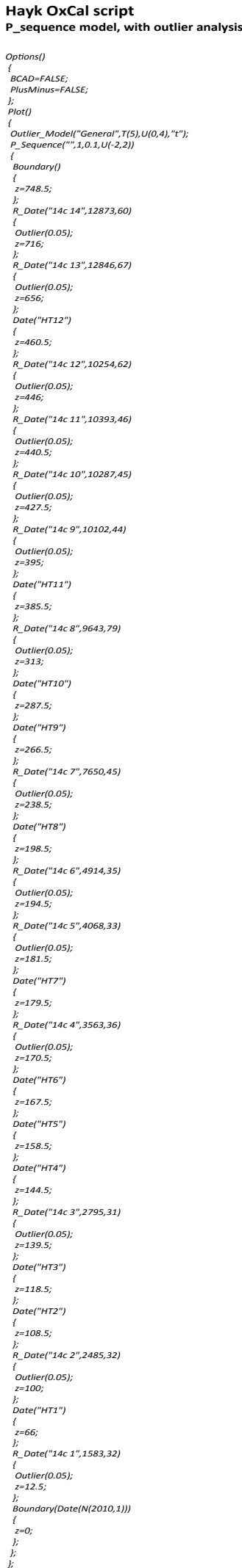

\section{OxCal output}

\begin{tabular}{lrrrr} 
& \multicolumn{3}{c}{ Unmodelled (BP) } & \multicolumn{3}{c}{ Modelled (BP) } \\
\hline & from & to & \multicolumn{2}{c}{ from } \\
Boundary(N(2010,1)) & -57 & -61 & -57 & -61 \\
R_Date 14c 1 & 1545 & 1404 & 1568 & -63 \\
HT1 & & & 2617 & 1607 \\
R_Date 14c 2 & 2729 & 2433 & 2729 & 2432 \\
HT2 & & & 2876 & 2461 \\
HT3 & & & 2930 & 2518 \\
R_Date 14c 3 & 2965 & 2795 & 2973 & 2795 \\
HT4 & & & 3635 & 2793 \\
HT5 & & & 3910 & 2914 \\
HT6 & & & 3983 & 3236 \\
R_Date 14c 4 & 3971 & 3724 & 3973 & 3723 \\
HT7 & & & 4803 & 3834 \\
R_Date 14c 5 & 4802 & 4438 & 4803 & 4436 \\
R_Date 14c 6 & 5716 & 5592 & 5719 & 5590 \\
HT8 & & & 7240 & 5582 \\
R_Date 14c 7 & 8540 & 8385 & 8543 & 8380 \\
HT9 & & & 10510 & 8433 \\
HT10 & & & 11046 & 8906 \\
R_Date 14c 8 & 11205 & 10749 & 11196 & 10717 \\
HT11 & & & 11963 & 11298 \\
R_Date 14c 9 & 11971 & 11404 & 11985 & 11414 \\
R_Date 14c 10 & 12379 & 11829 & 12237 & 11837 \\
R_Date 14c 11 & 12516 & 12060 & 12369 & 12018 \\
R_Date 14c 12 & 12378 & 11757 & 12384 & 12026 \\
HT12 & & & 12954 & 12028 \\
R_Date 14c 13 & 15599 & 15120 & 15468 & 15066 \\
R_Date 14c 14 & 15616 & 15158 & 15728 & 15259 \\
Boundary & & & 17692 & 15349 \\
P_Sequence(1,0.1,U(-2,2)) & -2 & 2 & -1.46283 & -1.21883 \\
U(0,4) & $3.99 E-17$ & 4 & $5.38 E-17$ & 3.68 \\
T(5) & -2.65 & 2.65 & & \\
Outlier_Model General & & & -1577 & 551 \\
& & & &
\end{tabular}

\section{OxCal age model}

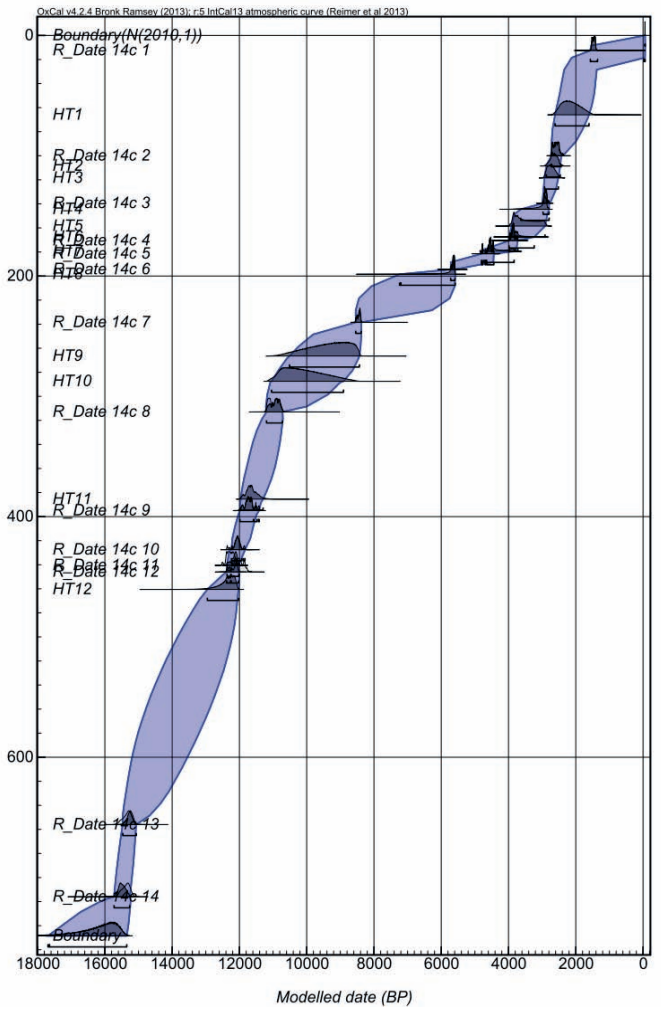




\section{.4 Tephras from the YTVL}

The following Appendix provides the major and trace element glass compositions of glass shards in tephras from the lakes Hora and Dendi sediments. At the end of this Appendix, the age model for the Dendi archive is provided.

\subsection{Major and trace element glass compositions}

Shard specific major and trace element concentrations in the Hora and Dendi tephras are given in the following tables. Major element data is presented to 2 decimal places, and trace element data is presented to 3 significant figures. Major element conncentrations presented are unnormalised.

Some major elements (e.g. Cl) were not analysed on all analytical sessions, and all $\mathrm{Fe}$ is calculated as $\mathrm{FeO}^{T}$. The median LLD for the rhyolitic ATHO-G reference material over all EPMA analytical sessions is given in the following table headings, full details of the limits of detection are on page 401. In some shards $\mathrm{MgO}$ and $\mathrm{P}_{2} \mathrm{O}_{5}$ are below the limit of detection, all other elements are present at concentrations above the LLD.

Most glass shards were analysed for trace elements using $20 \mu \mathrm{m}$ crater diameters, however, †indicates analyses using $10 \mu \mathrm{m}$ crater diameters. LA-ICPMS lower limits of detection (LLD) are given on page 407. For comparison, median LLD concentrations at $20 \mu \mathrm{m}$ crater diameters of all LA-ICP-MS analytical sessions are given in the following table headings. Some low $\mathrm{Sr}$ and Ba sample concentrations, coupled with high concentrations of these analytes in the gas blank, caused negative concentrations to be measured. These negative values are indicated with a dash. Analyses of MPI-DING reference materials 
were used to check EPMA and LA-ICP-MS accuracy. These analyses are given on page 398 , and are ordered by analysis date.

Unnormalised major element concentrations (wt.\%) in Hora tephra glass shards

\begin{tabular}{|c|c|c|c|c|c|c|c|c|c|c|c|c|c|c|}
\hline Label & Tephra & $\begin{array}{l}\text { Analysis } \\
\text { date }\end{array}$ & $\begin{array}{l}\mathrm{SiO}_{2} \\
0.08\end{array}$ & $\begin{array}{l}\mathrm{TiO}_{2} \\
\mathbf{0 . 0 5}\end{array}$ & $\begin{array}{l}\mathrm{Al}_{2} \mathrm{O}_{3} \\
0.05\end{array}$ & $\begin{array}{l}\text { MgO } \\
0.04\end{array}$ & $\begin{array}{l}\mathrm{FeO}^{T} \\
0.08\end{array}$ & $\begin{array}{l}\text { MnO } \\
0.07\end{array}$ & $\begin{array}{l}\mathrm{CaO} \\
0.04\end{array}$ & $\begin{array}{l}\mathrm{Na}_{2} \mathrm{O} \\
0.08\end{array}$ & $\begin{array}{l}\mathrm{K}_{2} \mathrm{O} \\
0.03\end{array}$ & $\begin{array}{l}\mathbf{P}_{2} \mathbf{O}_{5} \\
0.10\end{array}$ & $\begin{array}{l}\mathrm{Cl} \\
0.02\end{array}$ & Total \\
\hline HRT_2_1 & HRT-1 & $29 / 06 / 15$ & 72.62 & 0.18 & 9.31 & 0.00 & 4.31 & 0.28 & 0.17 & 4.91 & 4.17 & 0.00 & 0.18 & 96.14 \\
\hline HRT_2_2 & HRT-1 & $29 / 06 / 15$ & 72.53 & 0.25 & 9.41 & 0.00 & 4.41 & 0.13 & 0.20 & 5.06 & 4.35 & 0.08 & 0.25 & 96.66 \\
\hline HRT_2_3 & HRT-1 & $29 / 06 / 15$ & 71.26 & 0.26 & 9.03 & 0.00 & 4.54 & 0.27 & 0.13 & 4.93 & 4.22 & 0.00 & 0.21 & 94.84 \\
\hline HRT_2_4 & HRT-1 & $29 / 06 / 15$ & 70.48 & 0.29 & 8.97 & 0.00 & 4.42 & 0.17 & 0.17 & 4.89 & 4.21 & 0.00 & 0.20 & 93.79 \\
\hline HRT_2_5 & HRT-1 & $29 / 06 / 15$ & 71.48 & 0.20 & 9.08 & 0.00 & 4.47 & 0.17 & 0.16 & 5.07 & 4.29 & 0.00 & 0.21 & 95.13 \\
\hline HRT_2_6 & HRT-1 & $29 / 06 / 15$ & 73.33 & 0.25 & 9.43 & 0.00 & 4.25 & 0.29 & 0.14 & 5.17 & 4.44 & 0.00 & 0.22 & 97.51 \\
\hline HRT_2_7 & HRT-1 & $29 / 06 / 15$ & 72.56 & 0.25 & 9.28 & 0.02 & 4.52 & 0.21 & 0.15 & 4.88 & 4.38 & 0.00 & 0.23 & 96.46 \\
\hline HRT_2_8 & HRT-1 & $29 / 06 / 15$ & 71.68 & 0.25 & 9.13 & 0.02 & 4.54 & 0.18 & 0.17 & 4.97 & 4.26 & 0.00 & 0.23 & 95.41 \\
\hline HRT_2_10 & HRT-1 & $29 / 06 / 15$ & 69.08 & 0.24 & 8.64 & 0.00 & 4.37 & 0.19 & 0.18 & 5.10 & 4.23 & 0.00 & 0.23 & 92.27 \\
\hline HRT_2_11 & HRT-1 & $29 / 06 / 15$ & 72.56 & 0.22 & 9.40 & 0.01 & 4.53 & 0.13 & 0.16 & 5.04 & 4.43 & 0.00 & 0.19 & 96.67 \\
\hline HRT_2_12 & HRT-1 & $29 / 06 / 15$ & 73.04 & 0.27 & 9.27 & 0.00 & 4.50 & 0.26 & 0.20 & 5.21 & 4.35 & 0.00 & 0.22 & 97.32 \\
\hline HRT_2_13 & HRT-1 & $29 / 06 / 15$ & 71.55 & 0.22 & 9.03 & 0.00 & 4.28 & 0.22 & 0.20 & 5.02 & 4.36 & 0.00 & 0.20 & 95.09 \\
\hline HRT_2_14 & HRT-1 & $29 / 06 / 15$ & 70.48 & 0.24 & 8.91 & 0.00 & 4.25 & 0.14 & 0.15 & 4.64 & 4.31 & 0.00 & 0.22 & 93.34 \\
\hline HRT_2_15 & HRT-1 & $29 / 06 / 15$ & 72.40 & 0.23 & 9.27 & 0.00 & 4.26 & 0.21 & 0.18 & 5.11 & 4.45 & 0.00 & 0.24 & 96.35 \\
\hline HRT_2_16 & HRT-1 & $29 / 06 / 15$ & 72.96 & 0.23 & 9.24 & 0.03 & 4.48 & 0.24 & 0.15 & 4.97 & 4.40 & 0.00 & 0.23 & 96.92 \\
\hline HRT_2_17 & HRT-1 & $29 / 06 / 15$ & 70.34 & 0.23 & 9.07 & 0.05 & 4.36 & 0.17 & 0.18 & 4.93 & 4.28 & 0.02 & 0.22 & 93.87 \\
\hline HRT_2_18 & HRT-1 & $29 / 06 / 15$ & 72.65 & 0.23 & 9.25 & 0.00 & 4.31 & 0.23 & 0.19 & 4.96 & 4.30 & 0.01 & 0.28 & 96.41 \\
\hline HRT_2_19 & HRT-1 & $29 / 06 / 15$ & 68.35 & 0.23 & 10.57 & 0.48 & 4.10 & 0.09 & 0.20 & 4.42 & 4.06 & 0.00 & 0.20 & 92.70 \\
\hline HRT_2_20 & HRT-1 & $29 / 06 / 15$ & 69.14 & 0.23 & 9.25 & 0.00 & 3.75 & 0.21 & 0.18 & 3.89 & 4.30 & 0.00 & 0.19 & 91.14 \\
\hline HRT_2B_1 & HRT-1 & $29 / 06 / 15$ & 71.20 & 0.26 & 12.81 & 0.00 & 3.09 & 0.21 & 0.41 & 5.34 & 4.57 & 0.00 & 0.15 & 98.05 \\
\hline HRT_2B_2 & HRT-1 & $29 / 06 / 15$ & 69.34 & 0.25 & 12.75 & 0.07 & 3.21 & 0.08 & 0.39 & 5.05 & 4.63 & 0.00 & 0.17 & 95.93 \\
\hline HRT_2B_3 & HRT-1 & $29 / 06 / 15$ & 69.29 & 0.28 & 12.57 & 0.09 & 2.96 & 0.09 & 0.41 & 5.09 & 4.60 & 0.00 & 0.18 & 95.55 \\
\hline HRT_2B_4 & HRT-1 & $29 / 06 / 15$ & 67.32 & 0.23 & 15.74 & 0.14 & 2.98 & 0.19 & 0.41 & 4.62 & 4.32 & 0.00 & 0.13 & 96.10 \\
\hline HRT_2B_5 & HRT-1 & $29 / 06 / 15$ & 71.35 & 0.27 & 13.16 & 0.07 & 3.15 & 0.15 & 0.37 & 5.22 & 4.73 & 0.00 & 0.15 & 98.62 \\
\hline HRT_2B_6 & HRT-1 & $29 / 06 / 15$ & 71.35 & 0.26 & 13.07 & 0.06 & 3.28 & 0.11 & 0.40 & 5.26 & 4.74 & 0.00 & 0.15 & 98.67 \\
\hline HRT_2B_7 & HRT-1 & $29 / 06 / 15$ & 69.99 & 0.21 & 12.82 & 0.08 & 2.91 & 0.12 & 0.35 & 5.07 & 4.81 & 0.07 & 0.17 & 96.60 \\
\hline HRT_2B_8 & HRT-1 & $29 / 06 / 15$ & 71.60 & 0.27 & 13.13 & 0.02 & 3.10 & 0.18 & 0.39 & 5.22 & 4.67 & 0.07 & 0.17 & 98.81 \\
\hline HRT_2B_9 & HRT-1 & $29 / 06 / 15$ & 69.32 & 0.27 & 13.71 & 0.03 & 3.03 & 0.10 & 0.40 & 5.04 & 4.56 & 0.02 & 0.19 & 96.68 \\
\hline HRT_2B_10 & HRT-1 & $29 / 06 / 15$ & 70.77 & 0.27 & 13.18 & 0.06 & 2.95 & 0.11 & 0.36 & 5.19 & 4.77 & 0.03 & 0.18 & 97.86 \\
\hline HRT_2B_11 & HRT-1 & $29 / 06 / 15$ & 71.98 & 0.31 & 13.02 & 0.07 & 3.16 & 0.09 & 0.40 & 2.99 & 4.78 & 0.00 & 0.17 & 96.97 \\
\hline HRT_2B_12 & HRT-1 & $29 / 06 / 15$ & 70.68 & 0.21 & 12.99 & 0.07 & 3.09 & 0.20 & 0.36 & 4.96 & 4.66 & 0.01 & 0.18 & 97.40 \\
\hline HRT_2B_13 & HRT-1 & $29 / 06 / 15$ & 71.24 & 0.30 & 13.06 & 0.08 & 3.26 & 0.18 & 0.38 & 5.21 & 4.60 & 0.00 & 0.19 & 98.48 \\
\hline HRT_2B_14 & HRT-1 & $29 / 06 / 15$ & 69.03 & 0.26 & 12.43 & 0.06 & 3.05 & 0.09 & 0.34 & 4.86 & 4.43 & 0.00 & 0.16 & 94.71 \\
\hline HRT_2B_15 & HRT-1 & $29 / 06 / 15$ & 70.95 & 0.23 & 12.95 & 0.07 & 3.05 & 0.11 & 0.37 & 5.47 & 4.57 & 0.00 & 0.15 & 97.90 \\
\hline HRT_2B_16 & HRT-1 & $29 / 06 / 15$ & 69.28 & 0.29 & 12.45 & 0.04 & 2.97 & 0.10 & 0.30 & 5.20 & 4.66 & 0.00 & 0.17 & 95.44 \\
\hline HRT_2B_17 & HRT-1 & $29 / 06 / 15$ & 67.09 & 0.21 & 12.15 & 0.10 & 3.13 & 0.10 & 0.36 & 4.81 & 4.55 & 0.02 & 0.13 & 92.66 \\
\hline HRT_2B_18 & HRT-1 & $29 / 06 / 15$ & 71.16 & 0.25 & 13.16 & 0.0 & 3.27 & 0.09 & 0.42 & 5.07 & 4.74 & 0.03 & 0.15 & 98.46 \\
\hline HRT_2B_19 & HRT-1 & $29 / 06 / 15$ & 70.98 & 0.28 & 13.11 & 0.03 & 3.20 & 0.20 & 0.40 & 5.60 & 4.69 & 0.02 & 0.17 & 98.69 \\
\hline HRT_2B_20 & HRT-1 & $29 / 06 / 15$ & 68.77 & 0.27 & 12.56 & 0.03 & 3.02 & 0.17 & 0.44 & 4.80 & 4.67 & 0.01 & 0.15 & 94.89 \\
\hline HRT-4_1 & HRT-2 & $26 / 08 / 14$ & 71.76 & 0.15 & 8.19 & 0.02 & 6.38 & 0.37 & 0.15 & 6.32 & 4.17 & 0.01 & & 97.52 \\
\hline HRT-4_10 & HRT-2 & $26 / 08 / 14$ & 68.33 & 0.12 & 8.59 & 0.00 & 6.52 & 0.31 & 0.23 & 6.17 & 4.21 & 0.00 & & 94.49 \\
\hline HRT-4_11 & HRT-2 & $26 / 08 / 14$ & 73.67 & 0.25 & 9.72 & 0.01 & 4.19 & 0.21 & 0.21 & 4.87 & 4.38 & 0.00 & & 97.52 \\
\hline HRT-4_13 & HRT-2 & $26 / 08 / 14$ & 71.33 & 0.23 & 9.77 & 0.00 & 3.56 & 0.12 & 0.18 & 1.32 & 4.51 & 0.00 & & 91.01 \\
\hline HRT-4_14 & HRT-2 & $26 / 08 / 14$ & 69.93 & 0.11 & 8.49 & 0.00 & 6.53 & 0.30 & 0.20 & 5.98 & 4.22 & 0.00 & & 95.76 \\
\hline HRT-4_15 & HRT-2 & $26 / 08 / 14$ & 72.06 & 0.15 & 8.42 & 0.00 & 6.43 & 0.38 & 0.23 & 6.24 & 4.04 & 0.02 & & 97.97 \\
\hline HRT-4_16 & HRT-2 & $26 / 08 / 14$ & 71.63 & 0.14 & 8.20 & 0.01 & 6.83 & 0.30 & 0.16 & 6.53 & 4.09 & 0.00 & & 97.88 \\
\hline HRT-4_17 & HRT-2 & $26 / 08 / 14$ & 68.60 & 0.22 & 9.07 & 0.02 & 4.81 & 0.18 & 0.20 & 5.12 & 4.21 & 0.00 & & 92.44 \\
\hline HRT-4_18 & HRT-2 & $26 / 08 / 14$ & 71.38 & 0.21 & 8.23 & 0.00 & 5.92 & 0.27 & 0.22 & 6.09 & 4.11 & 0.00 & & 96.42 \\
\hline HRT-4_19 & HRT-2 & $26 / 08 / 14$ & 73.57 & 0.25 & 9.63 & 0.00 & 4.63 & 0.28 & 0.19 & 5.28 & 4.46 & 0.00 & & 98.28 \\
\hline HRT-4_2 & HRT-2 & $26 / 08 / 14$ & 70.37 & 0.14 & 8.29 & 0.00 & 6.53 & 0.28 & 0.19 & 6.70 & 4.18 & 0.01 & & 96.68 \\
\hline HRT-4_20 & HRT-2 & $26 / 08 / 14$ & 71.62 & 0.19 & 9.35 & 0.01 & 4.54 & 0.17 & 0.24 & 5.11 & 4.27 & 0.02 & & 95.52 \\
\hline HRT-4_3 & HRT-2 & $26 / 08 / 14$ & 70.48 & 0.21 & 10.17 & 0.00 & 3.22 & 0.11 & 0.17 & 4.45 & 4.52 & 0.00 & & 93.32 \\
\hline HRT-4_4 & HRT-2 & $26 / 08 / 14$ & 70.05 & 0.22 & 8.43 & 0.00 & 6.11 & 0.29 & 0.18 & 5.99 & 4.17 & 0.01 & & 95.45 \\
\hline HRT-4_5 & HRT-2 & $26 / 08 / 14$ & 72.92 & 0.23 & 9.57 & 0.00 & 4.61 & 0.10 & 0.19 & 5.04 & 4.40 & 0.00 & & 97.06 \\
\hline HRT-4_6 & HRT-2 & $26 / 08 / 14$ & 70.49 & 0.17 & 8.42 & 0.01 & 6.49 & 0.29 & 0.19 & 6.05 & 4.22 & 0.00 & & 96.33 \\
\hline HRT-4_7 & HRT-2 & $26 / 08 / 14$ & 73.21 & 0.27 & 9.63 & 0.00 & 5.13 & 0.16 & 0.15 & 5.06 & 4.78 & 0.00 & & 98.40 \\
\hline HRT-4_8 & HRT-2 & $26 / 08 / 14$ & 71.93 & 0.18 & 8.24 & 0.00 & 6.67 & 0.33 & 0.20 & 6.46 & 3.99 & 0.01 & & 98.01 \\
\hline HRT-4_9 & HRT-2 & $26 / 08 / 14$ & 67.62 & 0.18 & 8.69 & 0.03 & 4.35 & 0.23 & 0.16 & 4.83 & 4.08 & 0.00 & & 90.16 \\
\hline
\end{tabular}




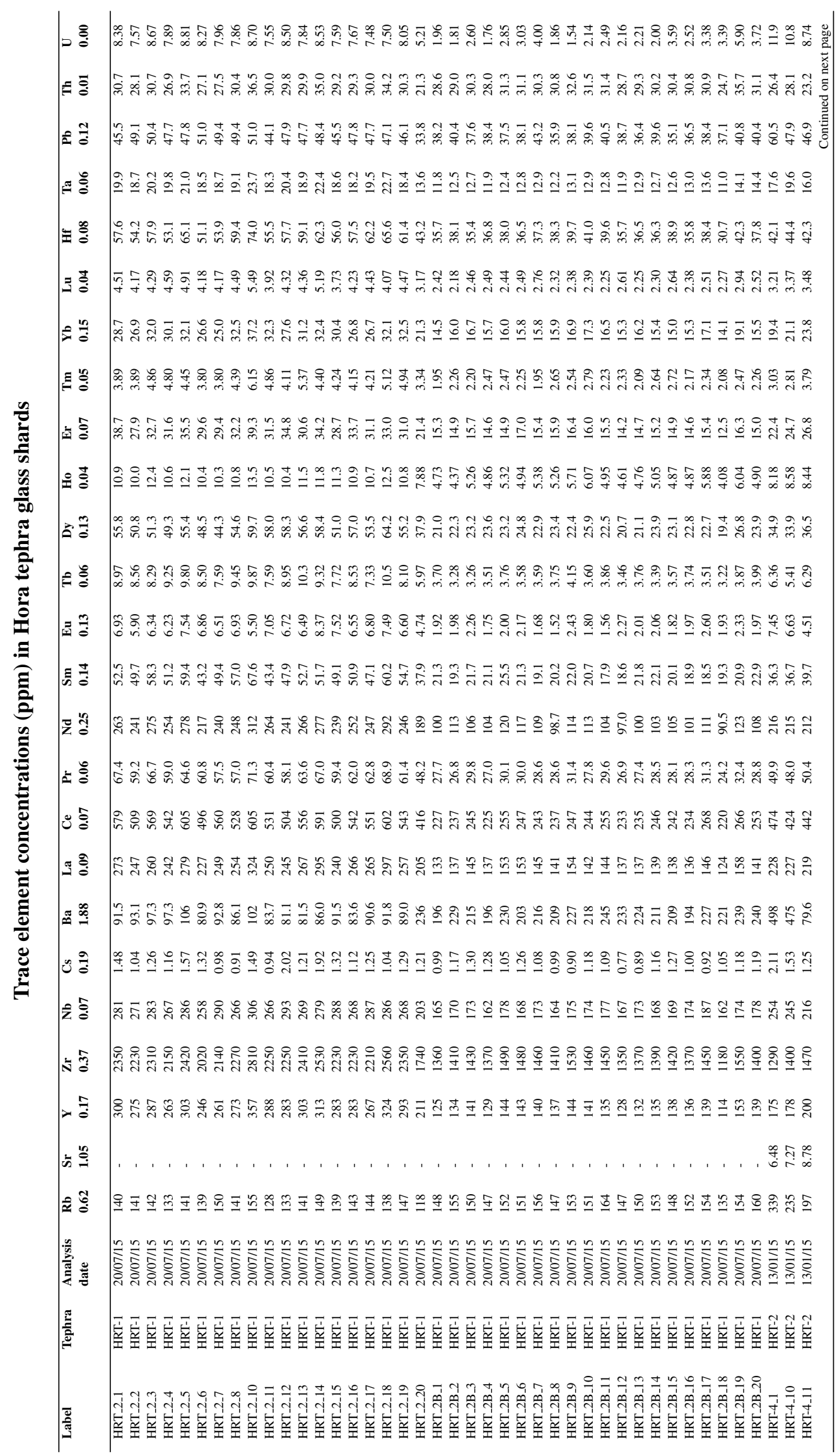




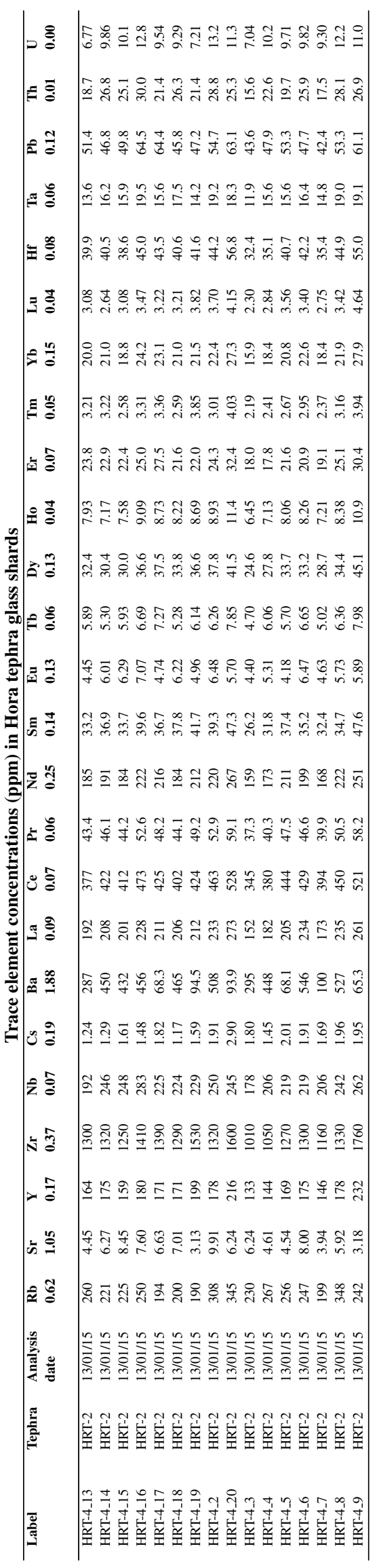


Unnormalised major element concentrations (wt.\%) in Dendi tephra glass shards

\begin{tabular}{|c|c|c|c|c|c|c|c|c|c|c|c|c|c|}
\hline Label & Tephra & $\begin{array}{l}\text { Analysis } \\
\text { date }\end{array}$ & $\begin{array}{l}\mathrm{SiO}_{2} \\
\mathbf{0 . 0 8}\end{array}$ & $\begin{array}{l}\mathrm{TiO}_{2} \\
\mathbf{0 . 0 5}\end{array}$ & $\begin{array}{l}\mathrm{Al}_{2} \mathrm{O}_{3} \\
0.05\end{array}$ & $\begin{array}{l}\text { MgO } \\
0.04\end{array}$ & $\begin{array}{l}\mathrm{FeO}^{T} \\
\mathbf{0 . 0 8}\end{array}$ & $\begin{array}{l}\text { MnO } \\
0.07\end{array}$ & $\begin{array}{l}\mathrm{CaO} \\
0.04\end{array}$ & $\begin{array}{l}\mathrm{Na}_{2} \mathrm{O} \\
0.08\end{array}$ & $\begin{array}{l}\mathrm{K}_{2} \mathbf{O} \\
\mathbf{0 . 0 3}\end{array}$ & $\begin{array}{l}\mathbf{P}_{2} \mathbf{O}_{5} \\
\mathbf{0 . 1 0}\end{array}$ & $\begin{array}{l}\mathrm{Cl} \\
0.02\end{array}$ \\
\hline DT1-1_1 & DT1-1 & $28 / 08 / 14$ & 68.34 & 0.37 & 12.34 & 0.20 & 4.53 & 0.20 & 1.07 & 5.36 & 4.23 & 0.03 & \\
\hline DT1-1_11 & DT1-1 & $28 / 08 / 14$ & 67.14 & 0.30 & 8.31 & 0.01 & 6.85 & 0.23 & 0.29 & 6.16 & 3.95 & 0.03 & \\
\hline DT1-1_12 & DT1-1 & $28 / 08 / 14$ & 68.90 & 0.29 & 8.54 & 0.00 & 6.97 & 0.32 & 0.30 & 6.25 & 3.97 & 0.00 & \\
\hline DT1-1_13 & DT1-1 & $28 / 08 / 14$ & 66.28 & 0.36 & 8.23 & 0.04 & 7.13 & 0.28 & 0.31 & 6.33 & 3.87 & 0.01 & \\
\hline DT1-1_14 & DT1-1 & $28 / 08 / 14$ & 69.27 & 0.20 & 12.91 & 0.08 & 2.98 & 0.19 & 0.42 & 5.23 & 4.78 & 0.01 & \\
\hline DT1-1_15 & DT1-1 & $28 / 08 / 14$ & 70.01 & 0.27 & 8.67 & 0.00 & 6.90 & 0.24 & 0.34 & 6.71 & 4.24 & 0.04 & \\
\hline DT1-1_16 & DT1-1 & $28 / 08 / 14$ & 70.24 & 0.32 & 9.29 & 0.03 & 7.33 & 0.29 & 0.41 & 6.73 & 4.17 & 0.01 & \\
\hline DT1-1_17 & DT1-1 & $28 / 08 / 14$ & 70.37 & 0.30 & 8.75 & 0.01 & 7.65 & 0.25 & 0.38 & 6.95 & 4.16 & 0.06 & \\
\hline DT1-1_18 & DT1-1 & $28 / 08 / 14$ & 70.05 & 0.32 & 8.59 & 0.01 & 7.31 & 0.30 & 0.34 & 6.01 & 4.22 & 0.01 & \\
\hline DT1-1_2 & DT1-1 & $28 / 08 / 14$ & 69.11 & 0.33 & 12.57 & 0.07 & 4.36 & 0.21 & 0.76 & 5.96 & 4.39 & 0.14 & \\
\hline DT1-1_20 & DT1-1 & $28 / 08 / 14$ & 69.18 & 0.25 & 8.66 & 0.00 & 6.88 & 0.30 & 0.34 & 6.72 & 4.07 & 0.04 & \\
\hline DT1-1_3 & DT1-1 & $28 / 08 / 14$ & 70.90 & 0.28 & 8.71 & 0.00 & 7.49 & 0.28 & 0.37 & 6.92 & 4.36 & 0.04 & \\
\hline DT1-1_4 & DT1-1 & $28 / 08 / 14$ & 69.63 & 0.27 & 7.87 & 0.00 & 7.42 & 0.24 & 0.33 & 6.71 & 4.13 & 0.03 & \\
\hline DT1-1_5 & DT1-1 & $28 / 08 / 14$ & 69.56 & 0.35 & 8.47 & 0.00 & 7.40 & 0.23 & 0.31 & 6.85 & 4.19 & 0.06 & \\
\hline DT1-1_7 & DT1-1 & $28 / 08 / 14$ & 67.19 & 0.36 & 8.25 & 0.00 & 6.92 & 0.37 & 0.38 & 6.29 & 4.02 & 0.00 & \\
\hline DT1-1_9 & DT1-1 & $28 / 08 / 14$ & 65.44 & 0.27 & 7.52 & 0.02 & 7.02 & 0.35 & 0.33 & 6.41 & 3.95 & 0.01 & \\
\hline DT1-2_1 & DT1-2 & $28 / 08 / 14$ & 54.67 & 0.45 & 15.83 & 0.19 & 5.14 & 0.23 & 0.76 & 7.72 & 5.17 & 0.02 & \\
\hline DT1-2_10 & DT1-2 & $28 / 08 / 14$ & 60.59 & 0.38 & 16.84 & 0.22 & 5.08 & 0.20 & 0.76 & 8.29 & 5.23 & 0.07 & \\
\hline DT1-2_11 & DT1-2 & $28 / 08 / 14$ & 60.96 & 0.29 & 16.99 & 0.21 & 5.14 & 0.22 & 0.72 & 8.42 & 5.38 & 0.02 & \\
\hline DT1-2_12 & DT1-2 & $28 / 08 / 14$ & 61.14 & 0.37 & 16.78 & 0.17 & 5.10 & 0.26 & 0.70 & 8.34 & 5.18 & 0.08 & \\
\hline DT1-2_13 & DT1-2 & $28 / 08 / 14$ & 60.51 & 0.33 & 16.59 & 0.21 & 4.92 & 0.25 & 0.71 & 8.34 & 5.25 & 0.05 & \\
\hline DT1-2_14 & DT1-2 & $28 / 08 / 14$ & 59.83 & 0.36 & 16.88 & 0.18 & 5.09 & 0.18 & 0.81 & 8.21 & 5.22 & 0.03 & \\
\hline DT1-2_15 & DT1-2 & $28 / 08 / 14$ & 61.33 & 0.39 & 16.78 & 0.18 & 5.03 & 0.24 & 0.78 & 8.38 & 5.40 & 0.03 & \\
\hline DT1-2_16 & DT1-2 & $28 / 08 / 14$ & 62.26 & 0.32 & 17.35 & 0.16 & 4.56 & 0.23 & 0.66 & 8.44 & 5.29 & 0.03 & \\
\hline DT1-2_17 & DT1-2 & $28 / 08 / 14$ & 60.85 & 0.36 & 16.38 & 0.20 & 5.39 & 0.23 & 0.76 & 7.85 & 5.20 & 0.03 & \\
\hline DT1-2_18 & DT1-2 & $28 / 08 / 14$ & 59.48 & 0.39 & 16.77 & 0.18 & 4.82 & 0.23 & 0.74 & 8.22 & 5.32 & 0.06 & \\
\hline DT1-2_19 & DT1-2 & $28 / 08 / 14$ & 56.86 & 0.36 & 16.38 & 0.19 & 5.01 & 0.17 & 0.70 & 7.83 & 5.00 & 0.06 & \\
\hline DT1-2_2 & DT1-2 & $28 / 08 / 14$ & 57.69 & 0.37 & 16.68 & 0.18 & 5.09 & 0.24 & 0.69 & 8.30 & 5.14 & 0.04 & \\
\hline DT1-2_20 & DT1-2 & $28 / 08 / 14$ & 56.46 & 0.38 & 16.32 & 0.16 & 4.94 & 0.24 & 0.77 & 7.89 & 5.11 & 0.04 & \\
\hline DT1-2_3 & DT1-2 & $28 / 08 / 14$ & 58.70 & 0.38 & 16.62 & 0.17 & 4.65 & 0.18 & 0.74 & 7.84 & 5.23 & 0.07 & \\
\hline DT1-2_4 & DT1-2 & $28 / 08 / 14$ & 59.67 & 0.32 & 16.51 & 0.17 & 5.41 & 0.25 & 0.76 & 8.30 & 5.11 & 0.05 & \\
\hline DT1-2_.5 & DT1-2 & $28 / 08 / 14$ & 59.95 & 0.39 & 16.83 & 0.19 & 4.97 & 0.20 & 0.77 & 8.41 & 5.23 & 0.07 & \\
\hline DT1-2_6 & DT1-2 & $28 / 08 / 14$ & 59.71 & 0.36 & 16.70 & 0.22 & 5.02 & 0.24 & 0.77 & 7.84 & 5.18 & 0.04 & \\
\hline DT1-2_7 & DT1-2 & $28 / 08 / 14$ & 59.85 & 0.30 & 16.86 & 0.16 & 4.65 & 0.20 & 0.71 & 8.00 & 5.35 & 0.01 & \\
\hline DT1-2_8 & DT1-2 & $28 / 08 / 14$ & 60.68 & 0.38 & 16.64 & 0.17 & 4.88 & 0.27 & 0.75 & 8.07 & 5.21 & 0.03 & \\
\hline DT1-2_9 & DT1-2 & $28 / 08 / 14$ & 62.39 & 0.19 & 18.10 & 0.09 & 2.54 & 0.12 & 0.59 & 7.73 & 5.56 & 0.03 & \\
\hline DT1-3_1 & DT1-3 & $28 / 08 / 14$ & 63.00 & 0.62 & 17.51 & 0.46 & 3.97 & 0.14 & 1.21 & 7.38 & 5.50 & 0.15 & \\
\hline DT1-3_10 & DT1-3 & $28 / 08 / 14$ & 63.14 & 0.37 & 16.58 & 0.13 & 4.57 & 0.27 & 0.63 & 8.42 & 5.28 & 0.04 & \\
\hline DT1-3_11 & DT1-3 & $28 / 08 / 14$ & 63.18 & 0.32 & 16.56 & 0.12 & 4.89 & 0.23 & 0.61 & 8.29 & 5.31 & 0.03 & \\
\hline DT1-3_12 & DT1-3 & $28 / 08 / 14$ & 64.18 & 0.26 & 17.14 & 0.09 & 3.93 & 0.16 & 0.51 & 8.22 & 5.54 & 0.06 & \\
\hline DT1-3_13 & DT1-3 & $28 / 08 / 14$ & 59.88 & 0.37 & 16.02 & 0.13 & 4.97 & 0.23 & 0.63 & 8.27 & 5.14 & 0.03 & \\
\hline DT1-3_14 & DT1-3 & $28 / 08 / 14$ & 62.97 & 0.65 & 17.82 & 0.44 & 4.18 & 0.13 & 1.26 & 7.13 & 5.59 & 0.15 & \\
\hline DT1-3_15 & DT1-3 & $28 / 08 / 14$ & 62.58 & 0.58 & 17.70 & 0.42 & 3.80 & 0.19 & 1.17 & 7.05 & 5.44 & 0.13 & \\
\hline DT1-3_16 & DT1-3 & $28 / 08 / 14$ & 61.04 & 0.37 & 15.27 & 0.25 & 6.77 & 0.31 & 0.87 & 8.77 & 4.87 & 0.07 & \\
\hline DT1-3_17 & DT1-3 & $28 / 08 / 14$ & 61.44 & 0.33 & 16.39 & 0.13 & 4.93 & 0.24 & 0.67 & 8.40 & 5.00 & 0.04 & \\
\hline DT1-3_18 & DT1-3 & $28 / 08 / 14$ & 60.89 & 0.34 & 16.21 & 0.12 & 5.33 & 0.23 & 0.61 & 8.43 & 5.24 & 0.04 & \\
\hline DT1-3_19 & DT1-3 & $28 / 08 / 14$ & 63.98 & 0.38 & 16.59 & 0.11 & 4.71 & 0.21 & 0.61 & 8.14 & 5.15 & 0.04 & \\
\hline DT1-3_2 & DT1-3 & $28 / 08 / 14$ & 62.97 & 0.29 & 16.52 & 0.15 & 5.19 & 0.22 & 0.69 & 8.65 & 5.20 & 0.03 & \\
\hline DT1-3_20 & DT1-3 & $28 / 08 / 14$ & 62.05 & 0.31 & 16.26 & 0.12 & 5.21 & 0.24 & 0.71 & 8.46 & 4.91 & 0.08 & \\
\hline DT1-3_21 & DT1-3 & $28 / 08 / 14$ & 61.01 & 0.29 & 15.72 & 0.21 & 5.39 & 0.29 & 0.68 & 8.52 & 4.93 & 0.03 & \\
\hline DT1-3_22 & DT1-3 & $28 / 08 / 14$ & 65.28 & 0.24 & 17.91 & 0.08 & 2.91 & 0.08 & 0.61 & 7.69 & 5.56 & 0.04 & \\
\hline DT1-3_3 & DT1-3 & $28 / 08 / 14$ & 62.23 & 0.32 & 16.49 & 0.15 & 4.95 & 0.18 & 0.64 & 8.45 & 5.11 & 0.01 & \\
\hline DT1-3_4 & DT1-3 & $28 / 08 / 14$ & 62.35 & 0.62 & 17.91 & 0.44 & 3.93 & 0.16 & 1.17 & 7.40 & 5.52 & 0.10 & \\
\hline DT1-3_5 & DT1-3 & $28 / 08 / 14$ & 61.51 & 0.35 & 16.32 & 0.14 & 5.91 & 0.16 & 0.70 & 8.55 & 5.03 & 0.05 & \\
\hline DT1-3_6 & DT1-3 & $28 / 08 / 14$ & 61.24 & 0.26 & 16.21 & 0.14 & 4.94 & 0.22 & 0.72 & 7.89 & 4.96 & 0.03 & \\
\hline DT1-3_7 & DT1-3 & $28 / 08 / 14$ & 61.99 & 0.29 & 16.27 & 0.10 & 5.04 & 0.25 & 0.67 & 8.50 & 4.98 & 0.03 & \\
\hline DT1-3_8 & DT1-3 & $28 / 08 / 14$ & 62.71 & 0.62 & 17.50 & 0.42 & 3.92 & 0.20 & 1.17 & 7.12 & 5.52 & 0.12 & \\
\hline DT1-3_9 & DT1-3 & $28 / 08 / 14$ & 63.57 & 0.21 & 16.67 & 0.13 & 4.08 & 0.19 & 0.82 & 8.04 & 4.84 & 0.04 & \\
\hline DEN12A/1 & DT-1 & $21 / 02 / 14$ & 64.11 & 0.13 & 18.62 & 0.05 & 1.78 & 0.07 & 0.79 & 7.47 & 5.58 & 0.03 & \\
\hline DEN12A/10 & DT-1 & $21 / 02 / 14$ & 61.51 & 0.38 & 16.71 & 0.19 & 5.10 & 0.13 & 0.73 & 7.98 & 5.23 & 0.07 & \\
\hline DEN12A/11 & DT-1 & $21 / 02 / 14$ & 61.85 & 0.48 & 16.54 & 0.20 & 5.41 & 0.27 & 0.82 & 8.53 & 5.22 & 0.05 & \\
\hline DEN12A/12 & DT-1 & $21 / 02 / 14$ & 61.22 & 0.27 & 16.40 & 0.12 & 5.28 & 0.19 & 0.68 & 9.22 & 4.91 & 0.03 & \\
\hline DEN12A/13 & DT-1 & $21 / 02 / 14$ & 60.91 & 0.37 & 16.64 & 0.16 & 4.76 & 0.11 & 0.74 & 8.02 & 5.15 & 0.05 & \\
\hline DEN12A/14 & DT-1 & $21 / 02 / 14$ & 61.34 & 0.34 & 16.32 & 0.20 & 5.15 & 0.25 & 0.74 & 8.10 & 5.09 & 0.03 & \\
\hline DEN12A/15 & DT-1 & $21 / 02 / 14$ & 59.02 & 0.32 & 15.69 & 0.18 & 4.71 & 0.24 & 0.75 & 8.13 & 4.92 & 0.08 & \\
\hline DEN12A/16 & DT-1 & $21 / 02 / 14$ & 60.87 & 0.35 & 16.12 & 0.18 & 5.04 & 0.25 & 0.80 & 8.14 & 5.08 & 0.04 & \\
\hline DEN12A/17 & DT-1 & $21 / 02 / 14$ & 64.48 & 0.20 & 18.81 & 0.06 & 1.97 & 0.06 & 0.82 & 8.07 & 4.94 & 0.00 & \\
\hline DEN12A/18 & DT-1 & $21 / 02 / 14$ & 62.06 & 0.36 & 16.65 & 0.21 & 4.98 & 0.22 & 0.76 & 8.20 & 5.11 & 0.03 & \\
\hline DEN12A/19 & DT-1 & $21 / 02 / 14$ & 61.50 & 0.39 & 16.69 & 0.22 & 4.83 & 0.17 & 0.84 & 8.13 & 5.22 & 0.03 & \\
\hline DEN12A/2 & DT-1 & $21 / 02 / 14$ & 60.73 & 0.42 & 16.36 & 0.21 & 4.88 & 0.27 & 0.81 & 8.31 & 5.18 & 0.03 & \\
\hline DEN12A/20 & DT-1 & $21 / 02 / 14$ & 61.68 & 0.37 & 16.44 & 0.19 & 4.94 & 0.18 & 0.72 & 8.28 & 5.28 & 0.04 & \\
\hline DEN12A/3 & DT-1 & $21 / 02 / 14$ & 61.56 & 0.44 & 16.07 & 0.20 & 5.54 & 0.23 & 0.79 & 8.19 & 5.04 & 0.06 & \\
\hline DEN12A/4 & DT-1 & $21 / 02 / 14$ & 61.60 & 0.40 & 16.38 & 0.19 & 4.73 & 0.13 & 0.72 & 8.01 & 5.13 & 0.06 & \\
\hline DEN12A/5 & DT-1 & $21 / 02 / 14$ & 60.96 & 0.48 & 15.98 & 0.24 & 6.28 & 0.33 & 0.85 & 8.93 & 5.06 & 0.07 & \\
\hline DEN12A/6 & DT-1 & $21 / 02 / 14$ & 61.80 & 0.36 & 16.34 & 0.20 & 5.17 & 0.16 & 0.81 & 8.44 & 4.96 & 0.04 & \\
\hline DEN12A/7 & DT-1 & $21 / 02 / 14$ & 60.13 & 0.46 & 15.70 & 0.25 & 6.21 & 0.21 & 0.76 & 8.44 & 5.03 & 0.08 & \\
\hline DEN12A/8 & DT-1 & $21 / 02 / 14$ & 61.34 & 0.35 & 16.52 & 0.19 & 5.08 & 0.17 & 0.73 & 8.24 & 5.16 & 0.02 & \\
\hline DEN12A/9 & DT-1 & $21 / 02 / 14$ & 61.84 & 0.35 & 16.70 & 0.19 & 5.27 & 0.24 & 0.74 & 7.91 & 5.24 & 0.06 & \\
\hline DEN12C/1 & DT-2 & $21 / 02 / 14$ & 58.88 & 0.44 & 14.74 & 0.17 & 5.73 & 0.26 & 0.72 & 8.17 & 4.63 & 0.04 & \\
\hline DEN12C/11 & DT-2 & $21 / 02 / 14$ & 62.20 & 0.16 & 17.46 & 0.00 & 0.80 & 0.00 & 0.07 & 7.46 & 2.69 & 0.03 & \\
\hline DEN12C/12 & DT-2 & $21 / 02 / 14$ & 57.47 & 0.38 & 14.48 & 0.19 & 5.98 & 0.30 & 0.70 & 7.78 & 4.57 & 0.07 & \\
\hline DEN12C/13 & DT-2 & $21 / 02 / 14$ & 61.33 & 0.44 & 15.29 & 0.18 & 6.49 & 0.25 & 0.78 & 8.76 & 4.70 & 0.09 & \\
\hline DEN12C/15 & DT-2 & $21 / 02 / 14$ & 61.15 & 0.37 & 15.46 & 0.12 & 5.51 & 0.27 & 0.71 & 8.46 & 4.86 & 0.05 & \\
\hline & & & & & & & & & & & & & \\
\hline
\end{tabular}


Unnormalised major element concentrations (wt.\%) in Dendi tephra glass shards

\begin{tabular}{|c|c|c|c|c|c|c|c|c|c|c|c|c|c|c|}
\hline Label & Tephra & $\begin{array}{l}\text { Analysis } \\
\text { date }\end{array}$ & $\begin{array}{l}\mathrm{SiO}_{2} \\
\mathbf{0 . 0 8}\end{array}$ & $\begin{array}{l}\mathrm{TiO}_{2} \\
0.05\end{array}$ & $\begin{array}{l}\mathrm{Al}_{2} \mathrm{O}_{3} \\
0.05\end{array}$ & $\begin{array}{l}\text { MgO } \\
0.04\end{array}$ & $\begin{array}{l}\mathrm{FeO}^{T} \\
0.08\end{array}$ & $\begin{array}{l}\text { MnO } \\
0.07\end{array}$ & $\begin{array}{l}\mathrm{CaO} \\
0.04\end{array}$ & $\begin{array}{l}\mathrm{Na}_{2} \mathrm{O} \\
0.08\end{array}$ & $\begin{array}{l}\mathrm{K}_{2} \mathrm{O} \\
\mathbf{0 . 0 3}\end{array}$ & $\begin{array}{l}\mathbf{P}_{2} \mathbf{O}_{5} \\
\mathbf{0 . 1 0}\end{array}$ & $\begin{array}{l}\mathrm{Cl} \\
0.02\end{array}$ & Total \\
\hline DEN12C/16 & DT-2 & $21 / 02 / 14$ & 59.52 & 0.35 & 14.87 & 0.14 & 6.35 & 0.24 & 0.69 & 8.49 & 4.78 & 0.08 & & 95.79 \\
\hline DEN12C/18 & DT-2 & $21 / 02 / 14$ & 59.61 & 0.41 & 14.48 & 0.15 & 5.93 & 0.23 & 0.78 & 4.71 & 4.76 & 0.05 & & 91.40 \\
\hline DEN12C/19 & DT-2 & $21 / 02 / 14$ & 60.43 & 0.38 & 14.78 & 0.16 & 5.94 & 0.24 & 0.72 & 8.81 & 4.62 & 0.03 & & 96.40 \\
\hline DEN12C/2 & DT-2 & $21 / 02 / 14$ & 59.78 & 0.36 & 15.30 & 0.10 & 4.51 & 0.11 & 0.58 & 8.21 & 5.13 & 0.06 & & 94.35 \\
\hline DEN12C/20 & DT-2 & $21 / 02 / 14$ & 61.13 & 0.39 & 15.15 & 0.14 & 6.68 & 0.28 & 0.70 & 8.85 & 4.71 & 0.05 & & 98.38 \\
\hline DEN $12 \mathrm{C} / 20$ & DT-2 & $21 / 02 / 14$ & & & & & & & & & & & & \\
\hline DEN12C/3 & DT-2 & $21 / 02 / 14$ & 56.34 & 0.32 & 15.72 & 0.19 & 4.13 & 0.16 & 0.68 & 7.58 & 4.90 & 0.05 & & 90.43 \\
\hline DEN12C/5 & DT-2 & $21 / 02 / 14$ & 60.39 & 0.42 & 15.10 & 0.16 & 6.23 & 0.13 & 0.81 & 8.37 & 4.75 & 0.04 & & 96.72 \\
\hline DEN12C/6 & DT-2 & $21 / 02 / 14$ & 60.14 & 0.37 & 15.20 & 0.17 & 5.94 & 0.28 & 0.79 & 7.66 & 4.73 & 0.03 & & 95.63 \\
\hline DEN12C/7 & DT-2 & $21 / 02 / 14$ & 61.50 & 0.36 & 15.02 & 0.15 & 6.17 & 0.31 & 0.72 & 8.47 & 4.63 & 0.03 & & 97.64 \\
\hline DEN12C/8 & DT-2 & $21 / 02 / 14$ & 61.82 & 0.37 & 15.23 & 0.14 & 6.72 & 0.32 & 0.71 & 9.02 & 4.80 & 0.05 & & 99.47 \\
\hline DEN12B/1 & DT-3 & $21 / 02 / 14$ & 60.25 & 0.37 & 15.16 & 0.17 & 6.06 & 0.25 & 0.79 & 8.65 & 4.82 & 0.06 & & 96.85 \\
\hline DEN12B/10 & DT-3 & $21 / 02 / 14$ & 59.55 & 0.34 & 16.36 & 0.20 & 4.81 & 0.22 & 0.69 & 8.73 & 4.95 & 0.04 & & 96.19 \\
\hline DEN12B/11 & DT-3 & $21 / 02 / 14$ & 60.52 & 0.47 & 15.10 & 0.13 & 6.19 & 0.21 & 0.75 & 8.86 & 4.83 & 0.03 & & 97.36 \\
\hline DEN12B/12 & DT-3 & $21 / 02 / 14$ & 59.94 & 0.38 & 14.82 & 0.11 & 6.20 & 0.26 & 0.76 & 8.22 & 4.67 & 0.03 & & 95.68 \\
\hline DEN12B/13 & DT-3 & $21 / 02 / 14$ & 61.37 & 0.47 & 15.42 & 0.19 & 5.80 & 0.25 & 0.79 & 8.13 & 4.62 & 0.08 & & 97.37 \\
\hline DEN12B/14 & DT-3 & $21 / 02 / 14$ & 60.13 & 0.58 & 16.92 & 0.30 & 4.37 & 0.28 & 0.98 & 7.29 & 5.51 & 0.13 & & 96.62 \\
\hline DEN12B/15 & DT-3 & $21 / 02 / 14$ & 59.76 & 0.34 & 16.47 & 0.12 & 4.79 & 0.22 & 0.70 & 8.22 & 4.83 & 0.02 & & 95.81 \\
\hline DEN12B/17 & DT-3 & $21 / 02 / 14$ & 59.78 & 0.39 & 14.79 & 0.17 & 5.76 & 0.24 & 0.74 & 8.45 & 4.73 & 0.04 & & 95.33 \\
\hline DEN12B/18 & DT-3 & $21 / 02 / 14$ & 59.80 & 0.49 & 16.47 & 0.31 & 4.15 & 0.17 & 0.87 & 7.61 & 5.09 & 0.10 & & 95.28 \\
\hline DEN12B/19 & DT-3 & $21 / 02 / 14$ & 59.28 & 0.67 & 14.83 & 0.43 & 6.92 & 0.22 & 0.85 & 8.29 & 5.03 & 0.17 & & 96.94 \\
\hline DEN12B/2 & DT-3 & $21 / 02 / 14$ & 56.56 & 0.72 & 14.38 & 0.93 & 6.27 & 0.27 & 2.60 & 7.06 & 4.03 & 0.18 & & 93.15 \\
\hline DEN12B/20 & DT-3 & $21 / 02 / 14$ & 61.22 & 0.39 & 15.11 & 0.14 & 6.35 & 0.23 & 0.74 & 8.17 & 4.76 & 0.08 & & 97.47 \\
\hline DEN12B/3 & DT-3 & $21 / 02 / 14$ & 59.35 & 0.42 & 14.45 & 0.18 & 6.36 & 0.29 & 0.73 & 9.11 & 4.68 & 0.08 & & 95.92 \\
\hline DEN12B/4 & DT-3 & $21 / 02 / 14$ & 60.57 & 0.40 & 14.96 & 0.16 & 6.19 & 0.17 & 0.79 & 8.72 & 4.86 & 0.04 & & 97.11 \\
\hline DEN12B/5 & DT-3 & $21 / 02 / 14$ & 59.30 & 0.45 & 14.94 & 0.20 & 6.33 & 0.27 & 0.74 & 9.22 & 4.64 & 0.06 & & 96.41 \\
\hline DEN12B/6 & DT-3 & $21 / 02 / 14$ & 62.59 & 0.27 & 17.16 & 0.06 & 2.87 & 0.08 & 0.63 & 7.91 & 5.53 & 0.04 & & 97.23 \\
\hline DEN12B/7 & DT-3 & $21 / 02 / 14$ & 56.07 & 0.30 & 16.13 & 0.18 & 3.97 & 0.19 & 0.69 & 7.40 & 4.95 & 0.01 & & 90.23 \\
\hline DEN12B/9 & DT-3 & $21 / 02 / 14$ & 65.93 & 0.33 & 7.54 & 0.01 & 7.36 & 0.33 & 0.34 & 6.13 & 3.78 & 0.05 & & 92.06 \\
\hline
\end{tabular}




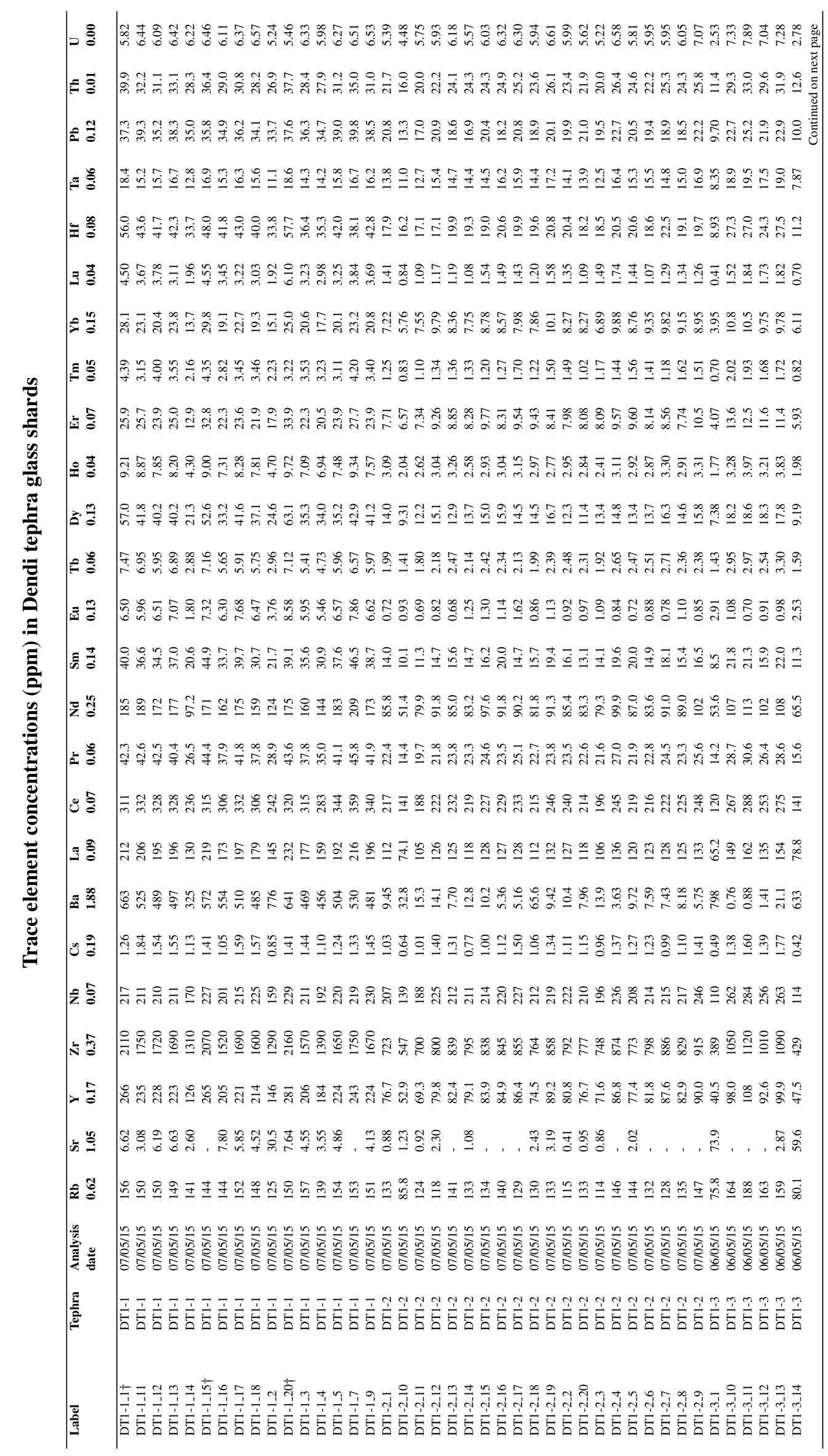




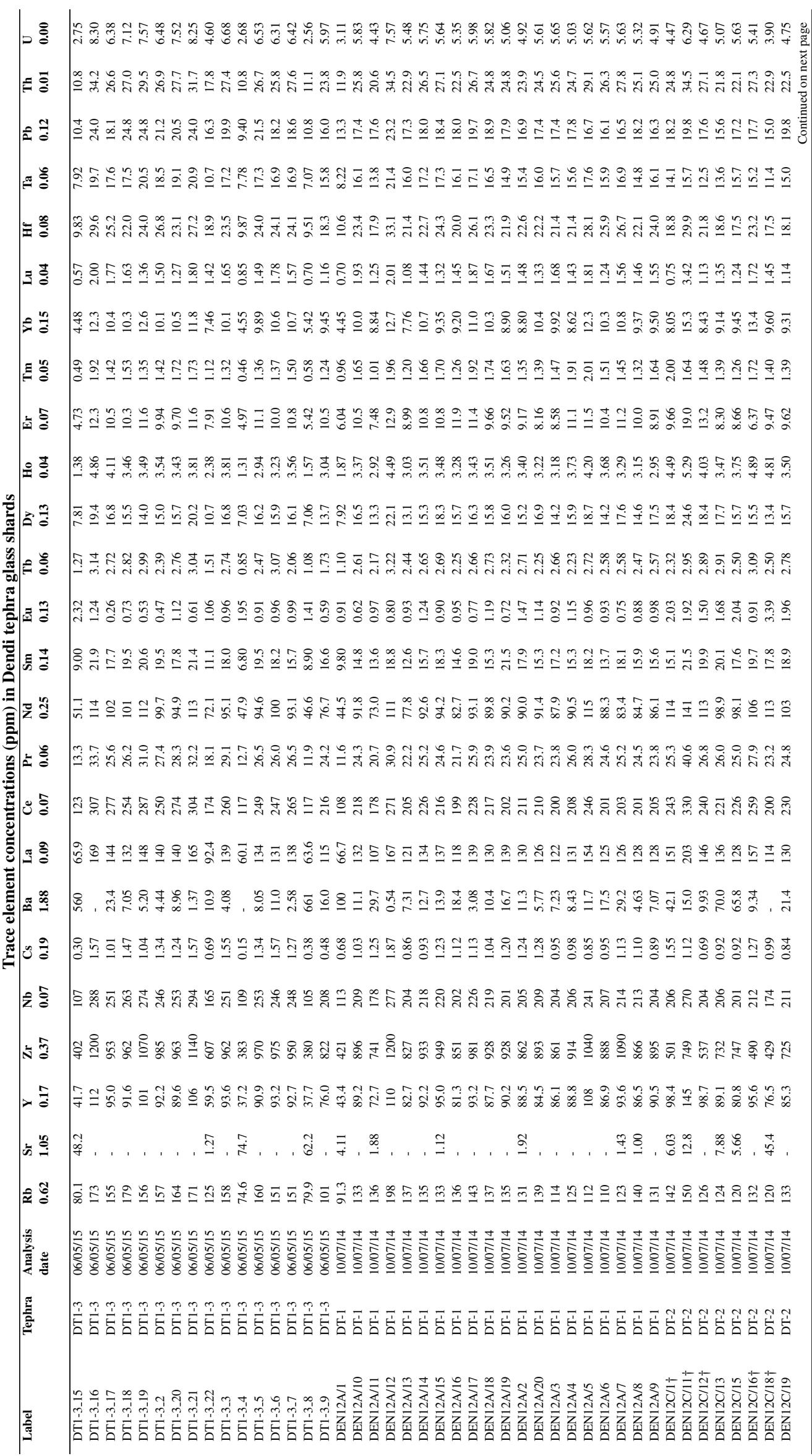




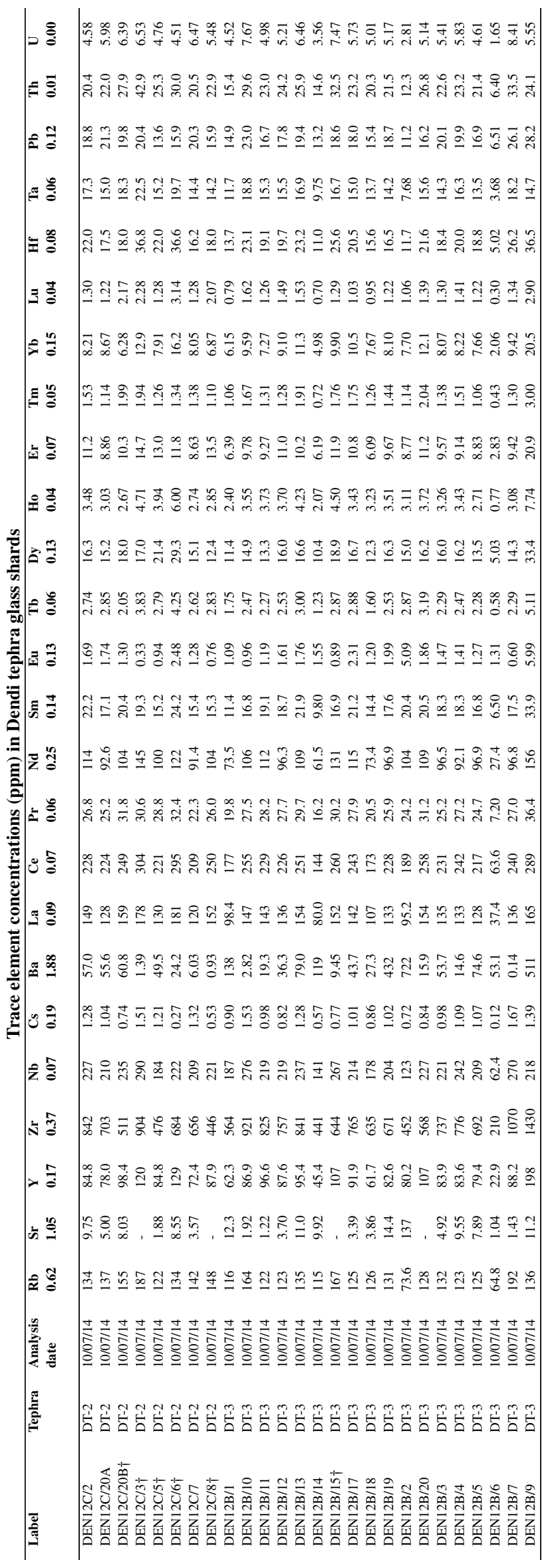




\section{.4.2 Bayesian age models}

Bernd Wagner (University of Cologne) provided the Bayesian age model for the Dendi sediments seen below. The model was generated using Bacon software (Blaauw and Christen, 2011), providing approximate ages for the Dendi tephras. Due to the uncertainities over coring depths and chronology, this study did not produce an age model for the Hora archive.

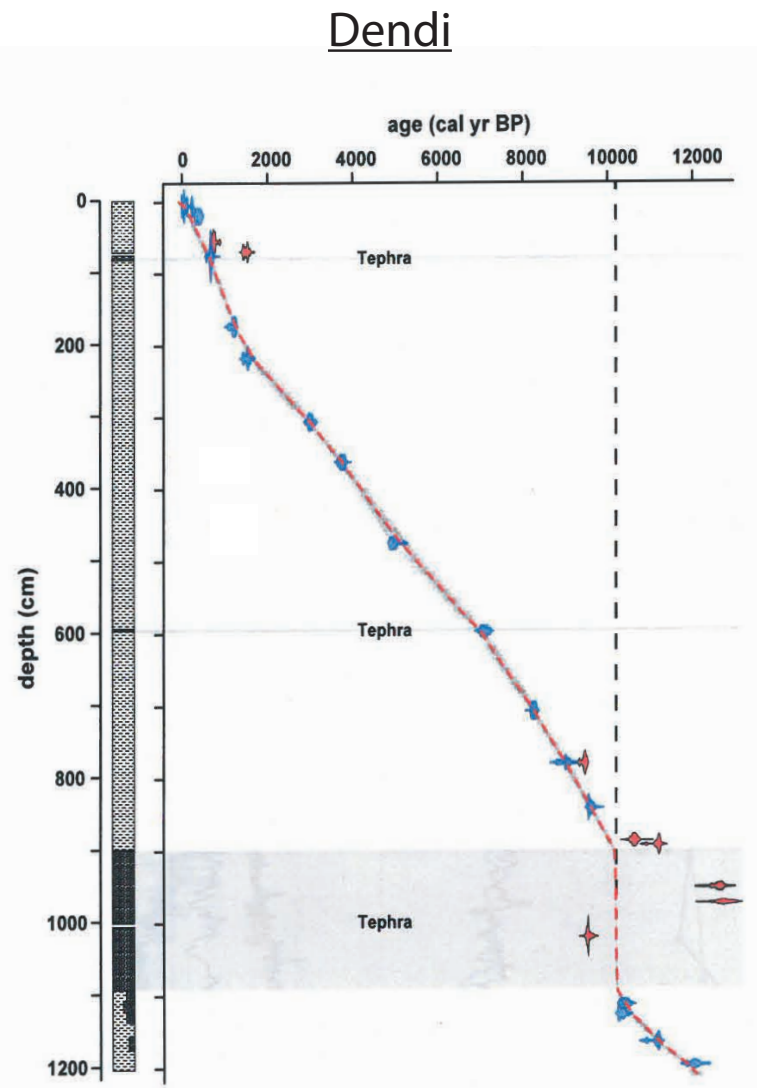

\section{.5 Tephras from the central MER}

This Appendix gives the major and trace element composition of tephras recorded in the central Main Ethiopian Rift lake sediments from Awassa, Tilo and Chamo. The composition of tephra and obsidian samples from the Corbetti caldera are 
also given. The Bayesian age models for Awassa, Tilo and Chamo archives are presented at the end of this section.

\section{.5.1 Major and trace element glass compositions}

The following tables present shard specific major and trace element glass compositions, major elements are presented to 2 decimal places and trace elements are presented to 3 significant figures.

Some major elements (e.g. Cl) were not analysed on all analytical sessions, and all $\mathrm{Fe}$ is calculated as $\mathrm{FeO}^{T}$. Calculated limits of detection for all EPMA sessions are given on page 401. The median LLD for the rhyolitic ATHO-G reference material over all EPMA analytical sessions is given in the following table headings. Most major elements are present at concentrations above these limits of detection, however, concentrations of $\mathrm{MgO}$ and $\mathrm{P}_{2} \mathrm{O}_{5}$ are below the LLD in many shards.

Trace element analyses were typically undertaken using $20 \mu \mathrm{m}$ crater diameters, however, †indicates glass shards were analysed using $10 \mu \mathrm{m}$ crater diameters. Lower limits of detection (LLD) for LA-ICP-MS analyses are given on page 407 . The median LLD concentrations at $20 \mu \mathrm{m}$ crater diameters of all LA-ICP-MS analytical sessions are given beneath each analyte heading in the following tables. Due to high $\mathrm{Sr}$ and Ba concentrations in the gas blanks, coupled with frequent low sample concentrations, some negative concentrations were measured - these are indicated with a dash. Analyses of MPI-DING reference materials were used to check the EPMA and LA-ICP-MS calibrations. These analyses are given on page 398, and are ordered by analysis date.

Unnormalised major element concentrations (wt.\%) in Tilo tephra glass shards

\begin{tabular}{|c|c|c|c|c|c|c|c|c|c|c|c|c|c|c|}
\hline Label & Tephra & $\begin{array}{l}\text { Analysis } \\
\text { date }\end{array}$ & $\begin{array}{l}\mathrm{SiO}_{2} \\
0.08\end{array}$ & $\begin{array}{l}\mathrm{TiO}_{2} \\
0.05\end{array}$ & $\begin{array}{l}\mathrm{Al}_{2} \mathrm{O}_{3} \\
0.05\end{array}$ & $\begin{array}{l}\text { MgO } \\
0.04\end{array}$ & $\begin{array}{l}\mathrm{FeO}^{I} \\
0.08\end{array}$ & $\begin{array}{l}\text { MnO } \\
0.07\end{array}$ & $\begin{array}{l}\mathrm{CaO} \\
0.04\end{array}$ & $\begin{array}{l}\mathrm{Na}_{2} \mathrm{O} \\
0.08\end{array}$ & $\begin{array}{l}\mathrm{K}_{2} \mathrm{O} \\
0.03\end{array}$ & $\begin{array}{l}\mathbf{P}_{2} \mathbf{O}_{5} \\
0.10\end{array}$ & $\begin{array}{l}\mathrm{Cl} \\
0.02\end{array}$ & Total \\
\hline TT97-1_1 & TT-1 & $26 / 08 / 14$ & 73.68 & 0.22 & 9.50 & 0.00 & 4.58 & 0.23 & 0.16 & 5.27 & 4.50 & 0.01 & & 98.16 \\
\hline
\end{tabular}


Unnormalised major element concentrations (wt.\%) in Tilo tephra glass shards

\begin{tabular}{|c|c|c|c|c|c|c|c|c|c|c|c|}
\hline Label & Tephra & $\begin{array}{l}\text { Analysis } \\
\text { date }\end{array}$ & $\begin{array}{l}\mathrm{SiO}_{2} \\
0.08\end{array}$ & $\begin{array}{l}\mathrm{TiO}_{2} \\
0.05\end{array}$ & $\begin{array}{l}\mathrm{Al}_{2} \mathrm{O}_{3} \\
\mathbf{0 . 0 5}\end{array}$ & $\begin{array}{l}\text { MgO } \\
0.04\end{array}$ & $\begin{array}{l}\mathrm{FeO}^{I} \\
\mathbf{0 . 0 8}\end{array}$ & $\begin{array}{l}\text { MnO } \\
0.07\end{array}$ & $\begin{array}{l}\mathrm{CaO} \\
0.04\end{array}$ & $\begin{array}{l}\mathrm{Na}_{2} \mathrm{O} \\
0.08\end{array}$ & $\begin{array}{l}\mathrm{K}_{2} \mathrm{O} \\
\mathbf{0 . 0 3}\end{array}$ \\
\hline TT97-1_10 & TT-1 & $26 / 08 / 14$ & 73.82 & 0.24 & 9.64 & 0.00 & 4.37 & 0.20 & 0.18 & 5.07 & 4.41 \\
\hline TT97-1_12 & TT-1 & $26 / 08 / 14$ & 73.62 & 0.21 & 9.75 & 0.02 & 4.50 & 0.26 & 0.17 & 5.05 & 4.41 \\
\hline TT97-1_13 & TT-1 & $26 / 08 / 14$ & 74.15 & 0.22 & 9.71 & 0.00 & 4.64 & 0.18 & 0.20 & 5.18 & 4.42 \\
\hline TT97-1_14 & TT-1 & $26 / 08 / 14$ & 74.36 & 0.24 & 9.82 & 0.00 & 4.63 & 0.22 & 0.18 & 5.46 & 4.40 \\
\hline TT97-1_15 & TT-1 & $26 / 08 / 14$ & 70.49 & 0.24 & 12.37 & 0.00 & 4.27 & 0.11 & 0.14 & 4.81 & 4.10 \\
\hline TT97-1_16 & TT-1 & $26 / 08 / 14$ & 68.84 & 0.24 & 9.13 & 0.02 & 4.03 & 0.27 & 0.14 & 5.13 & 4.16 \\
\hline TT97-1_17 & TT-1 & $26 / 08 / 14$ & 73.57 & 0.21 & 9.69 & 0.00 & 4.39 & 0.20 & 0.20 & 5.28 & 4.51 \\
\hline TT97-1_18 & TT-1 & $26 / 08 / 14$ & 73.96 & 0.23 & 9.88 & 0.00 & 4.58 & 0.22 & 0.16 & 5.03 & 4.47 \\
\hline TT97-1_19 & TT-1 & $26 / 08 / 14$ & 73.52 & 0.30 & 9.85 & 0.00 & 4.53 & 0.18 & 0.20 & 5.39 & 4.55 \\
\hline TT97-1_2 & TT-1 & $26 / 08 / 14$ & 71.71 & 0.24 & 9.82 & 0.00 & 4.32 & 0.24 & 0.21 & 5.03 & 4.32 \\
\hline TT97-1_20 & TT-1 & $26 / 08 / 14$ & 73.21 & 0.25 & 9.82 & 0.02 & 4.37 & 0.21 & 0.17 & 5.02 & 4.47 \\
\hline TT97-1_4 & TT-1 & $26 / 08 / 14$ & 74.97 & 0.26 & 9.51 & 0.00 & 4.73 & 0.20 & 0.20 & 5.41 & 4.13 \\
\hline TT97-1_5 & TT-1 & $26 / 08 / 14$ & 74.37 & 0.25 & 9.73 & 0.00 & 4.50 & 0.15 & 0.22 & 5.41 & 4.34 \\
\hline TT97-1_6 & TT-1 & $6 / 08 / 14$ & 73.67 & 0.24 & 9.60 & 0.00 & 4.59 & 0.19 & 0.19 & 5.14 & 4.60 \\
\hline TT97-1_8 & TT-1 & $26 / 08 / 14$ & 74.03 & 0.22 & 9.82 & 0.00 & 4.47 & 0.18 & 0.18 & 5.41 & 4.36 \\
\hline TT97-2A_1 & TT-2 & $6 / 08 / 14$ & 73.18 & 0.23 & 9.73 & 0.02 & 4.57 & 0.22 & 0.14 & 5.42 & 4.53 \\
\hline TT97-2A_10 & TT-2 & $26 / 08 / 14$ & 72.30 & 0.23 & 9.15 & 0.00 & 4.49 & 0.21 & 0.16 & 5.30 & 4.31 \\
\hline TT97-2A_13 & TT-2 & $26 / 08 / 14$ & 73.10 & 0.23 & 9.56 & 0.00 & 4.72 & 0.17 & 0.17 & 5.60 & 4.47 \\
\hline TT97-2A_14 & TT-2 & /08/14 & 73.25 & 0.23 & 9.75 & 0.00 & 4.55 & 0.17 & 0.16 & 5.68 & 4.34 \\
\hline TT97-2A_15 & TT-2 & $26 / 08 / 14$ & 73.08 & 0.27 & 9.75 & 0.01 & 4.44 & 0.17 & 0.20 & 5.56 & 4.53 \\
\hline TT97-2A_16 & TT-2 & $26 / 08 / 14$ & 72.20 & 0.23 & 9.59 & 0.00 & 4.49 & 0.13 & 0.20 & 5.31 & 4.38 \\
\hline TT97-2A_18 & TT-2 & $26 / 08 / 14$ & 73.57 & 0.22 & 9.64 & 0.02 & 4.55 & 0.27 & 0.20 & 5.32 & 4.43 \\
\hline TT97-2A_19 & TT-2 & $6 / 08 / 14$ & 71.78 & 0.22 & 9.40 & 0.00 & 4.48 & 0.16 & 0.16 & 5.31 & 4.23 \\
\hline TT97-2A_2 & TT-2 & $26 / 08 / 14$ & 72.70 & 0.19 & 9.46 & 0.00 & 4.53 & 0.20 & 0.16 & 5.37 & 4.16 \\
\hline TT97-2A_3 & TT-2 & $6 / 08 / 14$ & 73.39 & 0.26 & 9.55 & 0.00 & 4.52 & 0.14 & 0.18 & 5.46 & 4.28 \\
\hline TT97-2A_4 & TT-2 & $26 / 08 / 14$ & 74.08 & 0.25 & 9.55 & 0.00 & 4.78 & 0.16 & 0.14 & 5.30 & 4.32 \\
\hline TT97-2A_5 & TT-2 & $6 / 08 / 14$ & 70.01 & 0.22 & 10.31 & 0.03 & 4.11 & 0.22 & 0.18 & 5.05 & 4.05 \\
\hline TT97-2A_6 & TT-2 & $5 / 08 / 14$ & 74.41 & 0.24 & 9.81 & 0.00 & 4.58 & 0.26 & 0.20 & 5.40 & 4.56 \\
\hline TT97-2A_8 & TT-2 & $5 / 08 / 14$ & 72.26 & 0.28 & 10.53 & 0.00 & 4.34 & 0.15 & 0.21 & 5.25 & 4.27 \\
\hline TT97-2A_9 & TT-2 & $5 / 08 / 14$ & 70.47 & 0.29 & 9.17 & 0.01 & 4.37 & 0.17 & 0.16 & 5.26 & 4.16 \\
\hline TT97-2B_1 & TT-2 & $26 / 08 / 14$ & 73.69 & 0.27 & 9.67 & 0.00 & 4.44 & 0.23 & 0.17 & 5.24 & 4.43 \\
\hline TT97-2B_10 & TT-2 & $6 / 08 / 14$ & 67.54 & 0.21 & 8.56 & 0.00 & 4.41 & 0.23 & 0.17 & 5.24 & 4.21 \\
\hline TT97-2B_12 & TT-2 & $26 / 08 / 14$ & 72.51 & 0.20 & 9.60 & 0.00 & 4.23 & 0.15 & 0.18 & 5.36 & 4.14 \\
\hline TT97-2B_13 & TT-2 & $6 / 08 / 14$ & 72.84 & 0.27 & 9.24 & 0.01 & 4.25 & 0.20 & 0.21 & 5.40 & 4.37 \\
\hline TT97-2B_14 & TT-2 & $26 / 08 / 14$ & 71.76 & 0.27 & 10.31 & 0.00 & 4.24 & 0.19 & 0.20 & 5.40 & 4.17 \\
\hline TT97-2B_15 & TT-2 & $6 / 08 / 14$ & 73.46 & 0.23 & 9.15 & 0.00 & 4.29 & 0.19 & 0.15 & 5.22 & 4.42 \\
\hline TT97-2B_16 & TT-2 & $6 / 08 / 14$ & 72.75 & 0.30 & 9.58 & 0.00 & 4.35 & 0.23 & 0.25 & 4.59 & 4.23 \\
\hline TT97-2B_17 & TT-2 & /08/14 & 75.07 & 0.23 & 9.49 & 0.00 & 4.42 & 0.23 & 0.19 & 5.11 & 4.23 \\
\hline TT97-2B_18 & TT-2 & //08/14 & 73.75 & 0.30 & 9.40 & 0.00 & 4.18 & 0.24 & 0.19 & 5.40 & 4.43 \\
\hline TT97-2B_19 & TT-2 & $/ 08 / 14$ & 73.96 & 0.24 & 9.68 & 0.00 & 4.53 & 0.17 & 0.20 & 5.24 & 4.38 \\
\hline TT97-2B_2 & TT-2 & $6 / 08 / 14$ & 74.42 & 0.26 & 9.59 & 0.00 & 4.59 & 0.23 & 0.18 & 5.40 & 4.57 \\
\hline TT97-2B_20 & TT-2 & $6 / 08 / 14$ & 74.10 & 0.23 & 9.65 & 0.02 & 4.59 & 0.27 & 0.19 & 5.56 & 4.48 \\
\hline TT97-2B_3 & TT-2 & $/ 08 / 14$ & 72.96 & 0.23 & 9.22 & 0.01 & 4.31 & 0.15 & 0.20 & 5.25 & 4.40 \\
\hline TT97-2B_4 & TT-2 & $/ 08 / 14$ & 70.43 & 0.22 & 12.08 & 0.00 & 4.10 & 0.19 & 0.18 & 5.08 & 4.25 \\
\hline TT97-2B_7 & TT-2 & $/ 08 / 14$ & 73.19 & 0.26 & 9.15 & 0.00 & 4.25 & 0.17 & 0.16 & 5.34 & 4.45 \\
\hline TT97-2B_8 & TT-2 & $5 / 08 / 14$ & 72.44 & 0.17 & 9.05 & 0.00 & 4.29 & 0.24 & 0.18 & 5.43 & 4.29 \\
\hline TT97-2B_9 & TT-2 & $08 / 14$ & 69.95 & 0.24 & 10.41 & 0.00 & 4.41 & 0.18 & 0.21 & 4.94 & 4.18 \\
\hline TT97-2C_1 & TT-2 & $/ / 08 / 14$ & 71.14 & 0.30 & 11.47 & 0.00 & 4.29 & 0.15 & 0.21 & 4.85 & 4.32 \\
\hline TT97-2C_10 & TT-2 & $/ 08 / 14$ & 70.25 & 0.23 & 8.78 & 0.03 & 4.23 & 0.21 & 0.17 & 5.33 & 4.20 \\
\hline TT97-2C_11 & TT-2 & $7 / 08 / 14$ & 69.91 & 0.21 & 8.88 & 0.00 & 4.31 & 0.21 & 0.16 & 5.24 & 4.15 \\
\hline TT97-2C_13 & TT-2 & $7 / 08 / 14$ & 73.37 & 0.21 & 9.47 & 0.00 & 4.54 & 0.24 & 0.19 & 5.33 & 4.39 \\
\hline TT97-2C_14 & TT-2 & $/ 08 / 14$ & 72.79 & 0.27 & 9.12 & 0.00 & 4.11 & 0.21 & 0.21 & 5.09 & 4.22 \\
\hline TT97-2C_15 & TT-2 & $/ 08 / 14$ & 73.61 & 0.22 & 9.37 & 0.00 & 4.56 & 0.22 & 0.20 & 5.31 & 4.38 \\
\hline TT97-2C_16 & TT-2 & $/ 08 / 14$ & 74.01 & 0.19 & 9.44 & 0.00 & 4.58 & 0.20 & 0.20 & 5.42 & 4.46 \\
\hline TT97-2C_17 & TT-2 & $/ 08 / 14$ & 70.39 & 0.26 & 9.04 & 0.01 & 4.31 & 0.19 & 0.17 & 5.26 & 4.19 \\
\hline TT97-2C_18 & TT-2 & $/ 08 / 14$ & 72.79 & 0.29 & 9.25 & 0.00 & 4.49 & 0.21 & 0.17 & 5.12 & 4.24 \\
\hline TT97-2C_19 & TT-2 & $/ 08 / 14$ & 73.15 & 0.20 & 9.39 & 0.03 & 4.55 & 0.27 & 0.19 & 5.24 & 4.42 \\
\hline TT97-2C_2 & TT-2 & $08 / 14$ & 67.60 & 0.23 & 8.64 & 0.00 & 4.22 & 0.17 & 0.17 & 4.90 & 4.21 \\
\hline TT97-2C_20 & TT-2 & $/ 08 / 14$ & 70.75 & 0.24 & 8.87 & 0.00 & 4.49 & 0.25 & 0.19 & 5.14 & 4.20 \\
\hline TT97-2C_4 & TT-2 & & 67.40 & 0.25 & 10.62 & 0.03 & 4.04 & 0.21 & 0.19 & 4.72 & 3.99 \\
\hline$-2 \mathrm{C}-5$ & TT-2 & 4 & 74.21 & 0.2 & 9.64 & 0.00 & 4.3 & 0.2 & 0.20 & 5.23 & 4.46 \\
\hline & TT-2 & & 72.64 & 0.24 & 9.40 & 0.00 & 4.34 & 0. & 0.17 & 5.24 & 4.30 \\
\hline TTS & $\mathrm{T}$ & & 71.37 & 0.24 & 9.03 & 0.00 & 4.4 & 0.1 & 0.17 & 5.01 & 4.19 \\
\hline TT973/1 & TT-3 & $/ 02 / 14$ & 69.02 & 0.23 & 8.13 & 0.00 & 6.14 & 0.25 & 0.17 & 5.98 & 4.22 \\
\hline ТT973/10 & TT-3 & /02/14 & 7122 & 0.20 & 8.20 & 0.01 & 6.04 & 0.22 & 0.21 & 5.79 & 4.11 \\
\hline TT973/11 & TT-3 & /02/14 & 71.97 & 0.18 & 8.39 & 0.02 & 6.13 & 0.30 & 0.17 & 6.15 & 4.17 \\
\hline TT973/12 & TT-3 & & 72.30 & 0.18 & 8.86 & 0.00 & 5.47 & 0.17 & 0.16 & 6.02 & 4.35 \\
\hline TT973/13 & TT-3 & /02/14 & 70.97 & 0.13 & 7.92 & 0.00 & 6.38 & 0.38 & 0.17 & 6.43 & 4.02 \\
\hline TT973/14 & TT-3 & & 70.88 & 0.18 & 8.03 & 0.00 & 6.24 & 0.31 & 0.20 & 6.40 & 4.27 \\
\hline TT973/15 & TT-3 & 14 & 72.64 & 0.18 & 8.40 & 0.00 & 6.36 & 0.34 & 0.17 & 6.31 & 4.29 \\
\hline TTS & TT-3 & & 70.77 & 0.15 & 8.43 & 0.00 & 6.21 & 0.29 & 0.19 & 5.94 & 4.23 \\
\hline TT973/17 & TT-3 & $02 / 14$ & 71.19 & 0.16 & 7.94 & 0.00 & 6.30 & 0.36 & 0.17 & 6.64 & 4.12 \\
\hline TT973/18 & TT-3 & $1 / 02 / 14$ & 71.04 & 0.13 & 8.21 & 0.00 & 6.06 & 0.27 & 0.20 & 5.95 & 4.11 \\
\hline & & & & 0.1 & 8.10 & 0.00 & 6.64 & 0.31 & 010 & 6.69 & 4.00 \\
\hline TT973/2 & TT-3 & $/ 02 / 14$ & 71.90 & 0.17 & 8.06 & 0.00 & 6.52 & 0.21 & 0.19 & 6.58 & 4.13 \\
\hline ТT973/20 & & & 72.19 & 0.1 & 8.54 & 0.02 & 6. & 0.27 & 0.22 & 6.34 & 4.24 \\
\hline TT973/3 & TT-3 & $/ 02 / 14$ & 73.06 & 0.16 & 8.47 & 0.00 & 6.35 & 0.34 & 0.21 & 6.68 & 4.25 \\
\hline TT973/4 & TT-3 & $/ 02 / 14$ & 68.35 & 0.13 & 7.92 & 0.01 & 6.00 & 0.29 & 0.18 & 5.36 & 4.11 \\
\hline TT973/5 & TT-3 & $02 / 14$ & 69.55 & 0.16 & 9.09 & 0.01 & 6.13 & 0.28 & 0.21 & 6.14 & 4.22 \\
\hline TT973/7 & TT-3 & $/ 02 / 14$ & 71.89 & 0.19 & 8.34 & 0.00 & 6.31 & 0.38 & 0.16 & 5.92 & 4.19 \\
\hline TT973/8 & TT-3 & $/ 02 / 14$ & 71.52 & 0.1 & 8.74 & 0.00 & 6.21 & 0.25 & 0.22 & 6.12 & 4.28 \\
\hline TT974/1 & TT-4 & $/ 02 / 14$ & 74.35 & 0.24 & 9.76 & 0.00 & 4.76 & 0.20 & 0.20 & 5.33 & 4.41 \\
\hline & TT-4 & $/ 02 / 14$ & 73.95 & 0.3 & 9.65 & 0.02 & 4.34 & 0.21 & 0.17 & 4.97 & 4.33 \\
\hline TT974/12 & TT-4 & $21 / 02 / 14$ & 72.13 & 0.26 & 9.54 & 0.00 & 4.37 & 0.24 & 0.18 & 5.16 & 4.28 \\
\hline TT974/13 & TT-4 & $21 / 02 / 14$ & 73.30 & 0.23 & 9.76 & 0.00 & 4.42 & 0.25 & 0.18 & 5.38 & 4.43 \\
\hline & & & & & & & & & & & \\
\hline
\end{tabular}


Unnormalised major element concentrations (wt.\%) in Tilo tephra glass shards

\begin{tabular}{|c|c|c|c|c|c|c|c|c|c|c|c|}
\hline Label & Tephra & $\begin{array}{l}\text { Analysis } \\
\text { date }\end{array}$ & $\begin{array}{l}\mathrm{SiO}_{2} \\
0.08 \\
\end{array}$ & $\begin{array}{l}\mathrm{TiO}_{2} \\
\mathbf{0 . 0 5} \\
\end{array}$ & $\begin{array}{l}\mathrm{Al}_{2} \mathrm{O}_{3} \\
\mathbf{0 . 0 5} \\
\end{array}$ & $\begin{array}{l}\text { MgO } \\
0.04\end{array}$ & $\begin{array}{l}\mathrm{FeO}^{T} \\
0.08\end{array}$ & $\begin{array}{l}\text { MnO } \\
0.07 \\
\end{array}$ & $\begin{array}{l}\mathrm{CaO} \\
0.04 \\
\end{array}$ & $\begin{array}{l}\mathrm{Na}_{2} \mathrm{O} \\
0.08 \\
\end{array}$ & $\begin{array}{l}\mathrm{K}_{2} \mathrm{O} \\
\mathbf{0 . 0 3} \\
\end{array}$ \\
\hline $\begin{array}{l}\text { TT974/14 } \\
\end{array}$ & TT-4 & $21 / 02 / 14$ & 72.33 & 0.21 & 9.42 & 0.02 & 4.47 & 0.18 & 0.21 & 5.10 & 4.30 \\
\hline ТT974/15 & TT-4 & $21 / 02 / 14$ & 73.82 & 0.23 & 9.81 & 0.00 & 4.65 & 0.21 & 0.18 & 5.55 & 4.38 \\
\hline ТT974/16 & TT-4 & $21 / 02 / 14$ & 72.32 & 0.23 & 9.48 & 0.00 & 4.47 & 0.21 & 0.19 & 5.22 & 4.40 \\
\hline ТT974/17 & TT-4 & $21 / 02 / 14$ & 73.66 & 0.28 & 9.86 & 0.01 & 4.34 & 0.18 & 0.21 & 5.41 & 4.54 \\
\hline TT974/18 & TT-4 & $21 / 02 / 14$ & 74.11 & 0.23 & 9.58 & 0.00 & 4.61 & 0.18 & 0.18 & 5.25 & 4.29 \\
\hline TT974/19 & TT-4 & $21 / 02 / 14$ & 73.50 & 0.16 & 9.78 & 0.02 & 4.58 & 0.22 & 0.18 & 4.96 & 4.39 \\
\hline TT974/2 & TT-4 & $21 / 02 / 14$ & 70.99 & 0.24 & 9.24 & 0.01 & 4.39 & 0.27 & 0.15 & 4.96 & 4.21 \\
\hline TT974/20 & TT-4 & $21 / 02 / 14$ & 71.60 & 0.19 & 9.31 & 0.00 & 4.35 & 0.16 & 0.21 & 5.11 & 4.29 \\
\hline TT974/3 & TT-4 & $21 / 02 / 14$ & 71.45 & 0.26 & 9.75 & 0.00 & 4.28 & 0.22 & 0.17 & 5.22 & 4.38 \\
\hline TT974/4 & TT-4 & $21 / 02 / 14$ & 67.34 & 0.23 & 9.27 & 0.00 & 3.98 & 0.24 & 0.20 & 5.03 & 4.03 \\
\hline TT974/5 & TT-4 & $21 / 02 / 14$ & 73.43 & 0.25 & 9.75 & 0.01 & 4.72 & 0.17 & 0.21 & 5.14 & 4.35 \\
\hline TT974/6 & TT-4 & $21 / 02 / 14$ & 73.68 & 0.24 & 9.60 & 0.03 & 4.64 & 0.20 & 0.20 & 5.33 & 4.53 \\
\hline TT974/7 & TT-4 & $21 / 02 / 14$ & 72.79 & 0.26 & 9.60 & 0.02 & 4.44 & 0.22 & 0.19 & 5.24 & 4.38 \\
\hline TT974/8 & TT-4 & $21 / 02 / 14$ & 73.82 & 0.23 & 9.60 & 0.02 & 4.63 & 0.20 & 0.19 & 5.34 & 4.28 \\
\hline TT974/9 & TT-4 & $/ / 02 / 14$ & 73.47 & 0.25 & 9.61 & 0.00 & 4.57 & 0.24 & 0.19 & 5.66 & 4.14 \\
\hline ТT975A/1 & TT-5 & $21 / 02 / 14$ & 72.16 & 0.21 & 9.43 & 0.00 & 4.34 & 0.21 & 0.19 & 5.34 & 4.32 \\
\hline TT975A/10 & TT-5 & $/ 02 / 14$ & 66.75 & 0.20 & 10.20 & 0.00 & 4.25 & 0.15 & 0.16 & 4.66 & 3.96 \\
\hline TT975A/11 & TT-5 & $1 / 02 / 14$ & 73.92 & 0.23 & 9.77 & 0.00 & 4.49 & 0.19 & 0.19 & 5.04 & 4.40 \\
\hline TT975A/12 & TT-5 & 14 & 74.14 & 0.26 & 9.89 & 0.00 & 4.50 & 0.18 & 0.20 & 5.27 & 4.44 \\
\hline TT975A/13 & TT-5 & 14 & 73.94 & 0.26 & 9.74 & 0.02 & 4.33 & 0.15 & 0.15 & 3.43 & 4.22 \\
\hline TT975A/14 & TT-5 & 14 & 73.27 & 0.1 & 9.64 & 0.02 & 4.43 & 0.14 & 18 & 5.12 & 4.32 \\
\hline ТT975A/15 & TT & 14 & 72.32 & 0.22 & 9.45 & 0.01 & 4.54 & 0.10 & 0.17 & 5.29 & 4.36 \\
\hline TT975A/16 & TT-5 & $21 / 02 / 14$ & 72.35 & 0.24 & 9.46 & 0.01 & 4.30 & 0.23 & 0.18 & 5.34 & 4.33 \\
\hline TT975A/17 & TT-5 & & 72.97 & 0.27 & 9.72 & 0.02 & 4.42 & 0.24 & 22 & 5.55 & 4.31 \\
\hline TT975A/18 & TT-5 & 14 & 73.61 & 0.19 & 9.72 & 0.03 & 4.65 & 0.22 & 0.18 & 5.63 & 4.40 \\
\hline TT97 & TT-5 & & 73.44 & 0.24 & 9.55 & 0.02 & 4.61 & 0.20 & 21 & 5.40 & 4.43 \\
\hline TT975A/2 & TT-5 & 14 & 73.10 & 0.20 & 9.50 & 0.00 & 4.65 & 0.15 & 0.17 & 5.37 & 4.44 \\
\hline TT $975 \mathrm{~A} / 20$ & ГТ-5 & 14 & 70.69 & 0.23 & 9.66 & 0.02 & 4.37 & 0.08 & 18 & 5.19 & 4.38 \\
\hline TT975A/3 & TT-5 & & 72.94 & 0.26 & 9.47 & 0.02 & 4.46 & 0.17 & 0.20 & 5.23 & 4.37 \\
\hline TT975A/4 & TT-5 & 14 & 71.24 & 0.25 & 9.29 & 0.00 & 4.54 & 0.21 & 0.20 & 5.44 & 4.13 \\
\hline TT975A/5 & TT- & & 71.73 & 0.25 & 9.38 & 0.00 & 4.68 & 0.17 & 0.19 & 4.96 & 4.34 \\
\hline ТT975A/6 & TT-5 & 14 & 73.49 & 0.23 & 9.65 & 0.00 & 4.57 & 0.20 & 0.18 & 5.09 & 4.34 \\
\hline ТT975A/7 & TT- 5 & & 39 & 0.19 & 9.56 & 0.01 & 4.62 & 0.18 & 0.20 & 5.32 & 4.41 \\
\hline TT975A/8 & TT-5 & 14 & 73.02 & 0.23 & 9.45 & 0.00 & 4.75 & 0.28 & 0.17 & 5.24 & 4.32 \\
\hline TT975A/9 & TT-5 & 14 & 73.20 & 0.22 & 9.62 & 0.03 & 4.59 & 0.18 & 18 & 5.31 & 4.45 \\
\hline TT975AB/1 & TT-5 & $1 / 02 / 14$ & 70.67 & 0.26 & 9.68 & 0.00 & 4.29 & 0.22 & 0.20 & 5.13 & 4.18 \\
\hline TT975AB/10 & [T-5 & 14 & 73.06 & 0.19 & 9.38 & 0.01 & 4.38 & 0.14 & 0.18 & 5.38 & 4.28 \\
\hline $\mathrm{AB} / 11$ & ГT-5 & & 71.03 & 0.25 & 9.60 & 0.00 & 4.75 & 0.13 & 0.15 & 5.14 & 4.36 \\
\hline $\mathrm{AB} / 12$ & TT-5 & 14 & 73.85 & 0.21 & 9.84 & 0.00 & 4.76 & 0.20 & 0.19 & 5.08 & 4.44 \\
\hline $\mathrm{AB} / 13$ & TT-5 & & 74.85 & 0.19 & 9.72 & 0.00 & 4.57 & 0.16 & 0.17 & 3.92 & 4.55 \\
\hline $\mathrm{AB} / 14$ & TT-5 & 4 & 74.09 & 0.27 & 9.75 & 0.02 & 4.46 & 0.15 & 0.18 & 5.13 & 4.38 \\
\hline TT975AB/15 & TT-5 & & 73.53 & 0.2 & 9.62 & 0.01 & 4.69 & 0.16 & 0.1 & 5.21 & 4.19 \\
\hline TT975AB/16 & & & 4 & 0.2 & 968 & 0.0 & 4.4 & 0.21 & 01 & 4.99 & 4.39 \\
\hline TT975AB/17 & $11-$ & & 67.78 & 0.22 & 9.29 & 0.00 & 3.95 & 0.20 & 0.17 & 4.69 & 4.09 \\
\hline TT975AB/18 & TT-5 & 14 & 3.11 & 0.27 & 9.59 & 0.00 & 4.70 & 0.17 & 0.18 & 5.13 & 4.48 \\
\hline TT9 & TT-5 & & .15 & 0.22 & 10.04 & 0.02 & 4.31 & 0.19 & 19 & 5.23 & 4.39 \\
\hline TT97 & TT-5 & 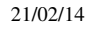 & .37 & 0.21 & 9.81 & $0 . c$ & 4.55 & 0.29 & 0.16 & 5.31 & 4.31 \\
\hline TT97 & TT-5 & & 3.81 & 0.2 & 9.69 & 0.02 & 4.53 & 0.18 & 19 & 5.17 & 4.44 \\
\hline TT9? & TT-5 & & 0.93 & 0.26 & 9.70 & 0. & 4.60 & 0.14 & 16 & 5.04 & 4.22 \\
\hline TT9? & TT-5 & & .68 & 0.21 & 9.80 & 0.00 & 4.80 & 0.24 & 0.17 & 5.28 & 4.22 \\
\hline ТT975AB/5 & TT-5 & & 71.47 & 0.23 & 9.28 & 0.00 & 4.31 & 0.14 & 0.1 & 4.90 & 4.26 \\
\hline TT9? & TT -5 & & .02 & 0.2 & 9.75 & 0.0 & 4.6 & 0.29 & 0.19 & 5.41 & 4.35 \\
\hline TT $975 \mathrm{AB} / 7$ & TT- - & & 72.65 & 0.2 & 9.57 & 0. & 4.54 & 0.19 & 0.19 & 4.91 & 4.35 \\
\hline & & & 7 & 0.2 & 9.65 & & 4.4 & 0.21 & ? & 5.39 & 4.32 \\
\hline TT975AB/ & TT-5 & & 71.76 & 0.23 & 9.32 & 0.00 & 4.34 & 0.15 & 0.19 & 5.40 & 4.25 \\
\hline TT976/1 & TT-6 & 14 & 66.87 & 0.14 & 9.32 & 0.00 & 5.90 & 0.30 & 0.20 & 5.79 & 3.74 \\
\hline TT976/10 & & & .37 & 0.22 & 8.81 & 0.02 & 6.04 & 0.32 & 19 & 6.19 & 3.88 \\
\hline TT976/11 & TT-6 & 17 & 2.74 & 0.17 & 7.27 & 0.00 & 6.29 & 0.41 & 0.17 & 6.12 & 3.88 \\
\hline ТT976/12 & TT-6 & & 70.95 & 0.22 & 8.38 & 0.00 & 6.18 & 0.28 & 20 & 6.23 & 4.29 \\
\hline TT9 & TT-6 & & 4.17 & 0.10 & 8.24 & 0. & 5.73 & 0.18 & 0.08 & 6.38 & 3.72 \\
\hline & & & .66 & 0.1 & 814 & 0. & 6.31 & 0.34 & 0.24 & 6.21 & 4.15 \\
\hline TT9 & $\mathrm{T}$ & & .02 & 0.2 & 7.87 & 0. & 6.19 & 0.3 & 0.19 & 6.07 & 3.96 \\
\hline & & & 2 & 0.1 & 8.20 & 0. & 6.40 & 0.2 & 0.18 & 5.99 & 4.14 \\
\hline ТT976/17 & $\mathrm{T}$ & & 9 & 0.1 & 8.09 & 0. & 6.31 & 0.2 & 0.1 & 6.51 & 4.18 \\
\hline & & & & 0.1 & 8.64 & 0. & 6.10 & 0. & 0. & & 4.28 \\
\hline & & & & & & & & 0. & 0 & 6. & 41 \\
\hline ТT976/20a & $\Gamma-6$ & & .50 & 0.1 & 8.42 & 0.00 & 6.21 & & 0. & 5.89 & 3.89 \\
\hline TT9 & & & 1 & 0.2 & 8.20 & 0.0 & 6.3 & 0. & 02 & 6.57 & 4.11 \\
\hline TT976/4a & TT-6 & 2/14 & 70.96 & 0.20 & 8.07 & 0.00 & 6.61 & 0.34 & 0.16 & 6.66 & 3.93 \\
\hline & & & & 0.21 & & 0.00 & 6.37 & 0.31 & & 6.21 & 4.06 \\
\hline & $\mathrm{T}$ & & & 0. & & & 6.72 & 0.34 & 0.19 & 6.48 & 4.18 \\
\hline & & & & 0. & 8 & 0. & 6.34 & 0.41 & 0.21 & 6.46 & 4.12 \\
\hline & & & 3 & 0.1 & & 0. & 6.16 & 0.23 & 0 & 5.82 & 3.95 \\
\hline & & & & 0. & 9.43 & 0. & 4.20 & 0.20 & 0.17 & 5.21 & 4.21 \\
\hline & & & & 0.2 & 9. & & 4.49 & 0. & 0.22 & 5.19 & 4.19 \\
\hline & & & 0 & 0.2 & 9.49 & & 4.77 & 0. & 0.19 & & 4.30 \\
\hline & & & & & & & & 0. & & & 4.30 \\
\hline TT977/14 & TT-7 & $21 / 02 / 14$ & 71.84 & 0.20 & 9.29 & 0.01 & 4.42 & 0.16 & 0.17 & 5.22 & 4.26 \\
\hline & & & & 0.2 & 9.41 & 0.00 & 4.46 & & 0.21 & 5.06 & 4.31 \\
\hline TT977/16 & TT-7 & /02/14 & 73.08 & 0.1 & 9.63 & 0. & 4.67 & 0.19 & 0.17 & 5.34 & 4.29 \\
\hline & TT-7 & & & 0.3 & 9.57 & 0.00 & 4.63 & 0.12 & 0.19 & 5.07 & 4.45 \\
\hline $\mathrm{TT}$ & TT-7 & $21 / 02 / 14$ & 72.30 & 0.17 & 9.36 & 0.00 & 4.59 & 0.19 & 0.19 & 5.11 & 4.32 \\
\hline ТT977/19 & TT-7 & $21 / 02 / 14$ & 71.68 & 0.21 & 9.33 & 0.02 & 4.66 & 0.25 & 0.19 & 5.00 & 4.32 \\
\hline & TT - & & 72.56 & 0.2 & 9.4 & 0. & 4.4 & 0.22 & 0. & 5.07 & 4.23 \\
\hline TT977/20 & TT-7 & $21 / 02 / 14$ & 71.16 & 0.23 & 9.37 & 0.00 & 4.24 & 0.16 & 0.16 & 5.31 & 4.39 \\
\hline & & & & & & & & & & & \\
\hline
\end{tabular}


Unnormalised major element concentrations (wt.\%) in Tilo tephra glass shards

\begin{tabular}{|c|c|c|c|c|c|c|c|c|c|c|c|}
\hline Label & Tephra & $\begin{array}{l}\text { Analysis } \\
\text { date }\end{array}$ & $\begin{array}{l}\mathrm{SiO}_{2} \\
0.08\end{array}$ & $\begin{array}{l}\mathrm{TiO}_{2} \\
0.05\end{array}$ & $\begin{array}{l}\mathrm{Al}_{2} \mathrm{O}_{3} \\
0.05\end{array}$ & $\begin{array}{l}\text { MgO } \\
0.04\end{array}$ & $\begin{array}{l}\mathrm{FeO}^{T} \\
0.08\end{array}$ & $\begin{array}{l}\text { MnO } \\
0.07\end{array}$ & $\begin{array}{l}\mathrm{CaO} \\
0.04\end{array}$ & $\begin{array}{l}\mathrm{Na}_{2} \mathrm{O} \\
0.08\end{array}$ & $\begin{array}{l}\mathrm{K}_{2} \mathrm{O} \\
\mathbf{0 . 0 3}\end{array}$ \\
\hline TT977/3 & TT-7 & $21 / 02 / 14$ & 72.66 & 0.21 & 9.47 & 0.00 & 4.50 & 0.18 & 0.18 & 5.22 & 4.18 \\
\hline TT977/4 & TT-7 & $21 / 02 / 14$ & 73.30 & 0.23 & 9.63 & 0.03 & 4.58 & 0.15 & 0.17 & 5.22 & 4.36 \\
\hline TT977/5 & TT-7 & $1 / 02 / 14$ & 73.56 & 0.23 & 9.63 & 0.00 & 4.61 & 0.30 & 0.18 & 5.29 & 4.39 \\
\hline TT977/6 & TT-7 & $21 / 02 / 14$ & 70.02 & 0.20 & 9.16 & 0.00 & 4.19 & 0.06 & 0.19 & 4.94 & 4.17 \\
\hline TT977/7 & TT-7 & $21 / 02 / 14$ & 72.98 & 0.27 & 9.94 & 0.00 & 4.52 & 0.23 & 0.16 & 5.29 & 4.26 \\
\hline TT977/8 & TT-7 & $21 / 02 / 14$ & 72.00 & 0.22 & 9.60 & 0.00 & 4.69 & 0.21 & 0.16 & 5.40 & 4.29 \\
\hline TT977/9 & TT-7 & $21 / 02 / 14$ & 72.82 & 0.25 & 9.48 & 0.01 & 4.47 & 0.19 & 0.20 & 5.14 & 4.21 \\
\hline TT97-8_1 & TT- 8 & $27 / 08 / 14$ & 72.81 & 0.26 & 9.71 & 0.00 & 4.57 & 0.23 & 0.16 & 5.19 & 4.54 \\
\hline TT97-8_10 & TT-8 & $27 / 08 / 14$ & 71.99 & 0.28 & 9.27 & 0.01 & 4.39 & 0.19 & 0.21 & 4.98 & 4.16 \\
\hline TT97-8_11 & TT-8 & $27 / 08 / 14$ & 72.09 & 0.22 & 9.27 & 0.01 & 4.47 & 0.16 & 0.16 & 5.07 & 4.30 \\
\hline TT97-8_12 & TT- 8 & $27 / 08 / 14$ & 74.42 & 0.24 & 9.67 & 0.01 & 4.63 & 0.24 & 0.18 & 5.36 & 4.33 \\
\hline TT97-8_13 & TT-8 & $27 / 08 / 14$ & 72.45 & 0.29 & 9.31 & 0.01 & 4.41 & 0.20 & 0.16 & 4.90 & 4.20 \\
\hline TT97-8_14 & TT-8 & $27 / 08 / 14$ & 71.31 & 0.19 & 9.33 & 0.00 & 4.16 & 0.12 & 0.17 & 5.10 & 4.37 \\
\hline TT97-8_15 & TT-8 & $27 / 08 / 14$ & 73.38 & 0.26 & 9.70 & 0.00 & 4.46 & 0.18 & 0.18 & 5.18 & 4.38 \\
\hline TT97-8_16 & TT-8 & $27 / 08 / 14$ & 74.05 & 0.28 & 9.70 & 0.02 & 4.51 & 0.10 & 0.16 & 4.97 & 4.42 \\
\hline TT97-8_17 & TT-8 & $27 / 08 / 14$ & 73.36 & 0.23 & 9.43 & 0.00 & 4.47 & 0.16 & 0.16 & 5.29 & 4.31 \\
\hline TT97-8_18 & TT-8 & $27 / 08 / 14$ & 70.91 & 0.29 & 9.49 & 0.00 & 4.59 & 0.24 & 0.14 & 5.35 & 4.31 \\
\hline TT97-8_19 & TT-8 & $27 / 08 / 14$ & 71.65 & 0.21 & 9.33 & 0.00 & 4.53 & 0.18 & 0.15 & 4.93 & 4.34 \\
\hline TT97-8_2 & TT-8 & /08/14 & 72.33 & 0.34 & 9.16 & 0.00 & 5.63 & 0.22 & 0.41 & 5.06 & 4.26 \\
\hline TT97-8_3 & TT-8 & $27 / 08 / 14$ & 73.60 & 0.30 & 9.79 & 0.00 & 4.61 & 0.25 & 0.19 & 5.25 & 4.20 \\
\hline TT97-8_4 & TT-8 & $/ / 08 / 14$ & 73.59 & 0.30 & 9.68 & 0.00 & 4.60 & 0.23 & 0.15 & 5.40 & 4.41 \\
\hline TT97-8_5 & TT-8 & $27 / 08 / 14$ & 73.00 & 0.28 & 9.32 & 0.00 & 4.89 & 0.22 & 0.18 & 5.10 & 4.27 \\
\hline TT97-8_6 & TT- 8 & $7 / 08 / 14$ & 73.12 & 0.24 & 9.60 & 0.02 & 4.57 & 0.21 & 0.17 & 5.12 & 4.47 \\
\hline TT97-8_7 & TT-8 & $27 / 08 / 14$ & 73.99 & 0.24 & 9.69 & 0.00 & 4.48 & 0.25 & 0.14 & 5.10 & 4.53 \\
\hline TT97-8_8 & TT-8 & $7 / 08 / 14$ & 72.60 & 0.26 & 9.43 & 0.02 & 4.47 & 0.24 & 0.16 & 5.25 & 4.39 \\
\hline TT97-8_9 & TT-8 & $/ 08 / 14$ & 71.77 & 0.28 & 9.10 & 0.00 & 4.47 & 0.26 & 0.16 & 4.98 & 4.30 \\
\hline TT978A/1 & TT-8 & /02/14 & 70.52 & 0.17 & 9.29 & 0.00 & 4.51 & 0.19 & 0.22 & 4.83 & 4.22 \\
\hline TT978A/11 & TT-8 & 14 & 69.06 & 0.19 & 10.55 & 0.00 & 4.05 & 0.16 & 0.20 & 4.94 & 4.17 \\
\hline TT978A/12 & TT-8 & 证 & 72.37 & 0.20 & 9.45 & 0.00 & 4.58 & 0.19 & 0.15 & 5.34 & 4.17 \\
\hline TT978A/13 & TT-8 & 14 & 71.47 & 0.25 & 9.33 & 0.01 & 4.46 & 0.32 & 0.14 & 5.22 & 4.29 \\
\hline TT978A/14 & TT 8 & 4024 & 71.30 & 0.22 & 9.33 & 0.01 & 4.47 & 0.17 & 0.18 & 4.95 & 4.24 \\
\hline TT978A/15 & TT-8 & $1 / 02 / 14$ & 69.92 & 0.23 & 9.11 & 0.00 & 4.58 & 0.21 & 0.21 & 5.17 & 4.18 \\
\hline TT978A/16 & TT-8 & $1 / 02 / 14$ & 72.66 & 0.24 & 9.64 & 0.00 & 4.36 & 0.20 & 0.18 & 5.08 & 4.33 \\
\hline TT978A/17 & TT-8 & 14 & 72.29 & 0.24 & 9.52 & 0.03 & 4.56 & 0.18 & 0.22 & 2.56 & 4.17 \\
\hline TT978A/18 & TT-8 & 14 & 69.79 & 0.24 & 9.04 & 0.00 & 4.37 & 0.21 & 0.21 & 4.87 & 4.11 \\
\hline TT978A/19 & TT-8 & 14 & 70.87 & 0.23 & 9.15 & 0.00 & 4.57 & 0.19 & 0.19 & 5.19 & 4.18 \\
\hline TT978A/2 & TT-8 & 14 & 70.32 & 0.21 & 9.31 & 0.00 & 4.04 & 0.11 & 0.16 & 4.90 & 4.10 \\
\hline TT978A/20 & TT8 & & 72.96 & 0.22 & 9.45 & 0.00 & 4.59 & 0.23 & 0.16 & 5.35 & 4.37 \\
\hline TT978A/3 & TT- 8 & 14 & 71.56 & 0.21 & 9.33 & 0.02 & 4.39 & 0.17 & 0.18 & 5.25 & 4.28 \\
\hline TT978A/4 & TT 8 & 1 & 70.01 & 0.24 & 9.26 & 0.00 & 4.22 & 0.23 & 021 & 4.86 & 4.10 \\
\hline TT978A/5 & TT- 8 & /02/14 & 70.49 & 0.26 & 9.47 & 0.00 & 4.33 & 0.18 & 0.20 & 5.44 & 4.34 \\
\hline TT978A/7 & TT-8 & $/ 02 / 14$ & 71.52 & 0.21 & 9.51 & 0.00 & 4.31 & 0.22 & 0.25 & 3.72 & 4.23 \\
\hline TT978A/8 & TT-8 & & 70.46 & 0.21 & 9.11 & 0.01 & 4.58 & 0.21 & 0.15 & 2.53 & 4.18 \\
\hline TT978A/9 & TT-8 & 14 & 69.81 & 0.30 & 10.00 & 0.03 & 4.63 & 0.25 & 0.19 & 4.73 & 4.26 \\
\hline TT978B/1 & TT-8 & 14 & 70.73 & 0.23 & 9.31 & 0.00 & 4.45 & 0.17 & 0.19 & 5.14 & 4.19 \\
\hline TT978B/10 & TT-8 & 114 & 71.85 & 0.25 & 9.52 & 0.00 & 4.64 & 0.13 & 0.18 & 4.91 & 4.19 \\
\hline TT978B/11 & 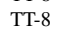 & & 72.51 & 0.24 & 9.56 & 0.02 & 4.50 & 0.26 & 0.18 & 5.24 & 4.44 \\
\hline TT978B/12 & TT-8 & & 72.51 & 0.22 & 9.31 & 0.01 & 4.31 & 0.15 & 0.20 & 4.98 & 4.27 \\
\hline TT978B/13 & TT 8 & & 73.29 & 0.20 & 9.61 & 0.00 & 4.68 & 0.17 & 0.18 & 5.53 & 4.41 \\
\hline TT978B/14 & TT-8 & /02/14 & 73.11 & 0.24 & 9.54 & 0.00 & 4.59 & 0.13 & 0.21 & 5.41 & 4.27 \\
\hline TT978B/15 & TT-8 & . & 73.27 & 0.30 & 9.62 & 0.00 & 4.45 & 0.12 & 0.18 & 5.27 & 4.46 \\
\hline TT978B/16 & TT-8 & & 71.13 & 0.22 & 9.46 & 0.00 & 4.32 & 0.26 & 0.14 & 5.05 & 4.26 \\
\hline TT97 & TT-8 & 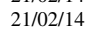 & 72.89 & 0.23 & 9.57 & 0.00 & 4.38 & 0.28 & 0.18 & 5.42 & 4.38 \\
\hline TT978B/18 & $\Gamma-8$ & & 74.08 & 0.24 & 9.83 & 0.04 & 4.42 & 0.20 & .19 & 5.37 & 4.48 \\
\hline TT978B/19 & TT-8 & $02 / 14$ & 72.48 & 0.22 & 9.38 & 0.00 & 4.51 & 0.14 & 0.20 & 5.25 & 4.21 \\
\hline TT978B/2 & TT Q & & 68.59 & 0.22 & 8.99 & 0.03 & 4.08 & 0.22 & 0.16 & 4.76 & 4.04 \\
\hline TT978B/20 & TT- 8 & 14 & 73.19 & 0.23 & 9.94 & 0.00 & 4.44 & 0.28 & 0.19 & 5.25 & 4.33 \\
\hline TT978B/3 & 格 & & 3.04 & 0.24 & 9.61 & 0.00 & 4.65 & 0.31 & 0.21 & 5.33 & 4.43 \\
\hline TT978B/4 & TT- 8 & & 73.27 & 0.28 & 9.78 & 0.00 & 4.28 & 0.12 & 0.16 & 5.18 & 4.46 \\
\hline & & & & 0.23 & 9.54 & 0.00 & 4.49 & 0.17 & 0.16 & & 4.41 \\
\hline TTS & & & 7 & 0. & 9. & 0. & 4. & 0. & 0.16 & 5.56 & 4.33 \\
\hline & & & 1 & 0.1 & 9.59 & 0.03 & 4. & 0. & 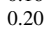 & 5.08 & 4.02 \\
\hline & & & 7 & 0.2 & 9.46 & 0. & 4. & 0. & 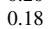 & 5.16 & 4.40 \\
\hline TT978B/9 & TT-8 & /02/14 & 74.35 & 0.22 & 9.77 & 0.00 & 4.76 & 0.26 & 0.20 & 5.05 & 4.51 \\
\hline TT97-9A_1 & & - & 74.07 & 0.23 & 9.55 & 0.00 & 4.79 & 0.24 & . & 5.34 & 30 \\
\hline TT97-9A_10 & TT-9 & 08/14 & 70.80 & 0.16 & 9.04 & 0.00 & 4.53 & 0.18 & 0.17 & 5.09 & 4.15 \\
\hline TT97-9A_11 & & & 22 & 0.25 & 8.94 & 0.03 & 4.37 & 0.15 & 0.21 & 5.13 & 4.15 \\
\hline TT97-9A_12 & TT-9 & /08/14 & 72.72 & 0.21 & 9.45 & 0.02 & 4.66 & 0.22 & 0.21 & 5.12 & 4.27 \\
\hline TT97-9A_13 & TT-9 & & 72.95 & 0.27 & 9.46 & 0.00 & 4.65 & 0.23 & 0.19 & 5.16 & 4.31 \\
\hline TT97-9A_14 & $\mathrm{T}$ & 1 & 70.94 & 0.2 & 9.11 & 0.00 & 4.4 & 0.10 & 20 & 5.01 & 4.17 \\
\hline & 1 & & 72.15 & 0.2 & 9.43 & 0.01 & 4.33 & 0.20 & 0.18 & 4.96 & 4.21 \\
\hline TTS & & 17 & 71.08 & 0.2 & 9.07 & 0.02 & 4.61 & 0.18 & 17 & 4.99 & 4.28 \\
\hline TT97-9A_17 & TT-9 & $7 / 08 / 14$ & 71.47 & 0.20 & 9.47 & 0.00 & 4.74 & 0.18 & 0.18 & 5.11 & 4.32 \\
\hline & & & & 0.2 & 8. & 0.0 & 4. & 0.2 & & 5.00 & 4.20 \\
\hline TT97-9A_19 & TT-9 & $/ 08 / 14$ & 69.78 & 0.22 & 9.44 & 0.03 & 4.37 & 0.19 & 0.19 & 5.35 & 4.26 \\
\hline TT97-9A_2 & & & 72.86 & 0.2 & 9.39 & 0.0 & 4.5 & 0.21 & 0.16 & 5.27 & 4.28 \\
\hline TT97-9A_20 & TT-9 & $/ 08 / 14$ & 70.18 & 0.22 & 9.02 & 0.02 & 4.69 & 0.19 & 0.21 & 4.87 & 4.09 \\
\hline TT97-9A_3 & TT- & & 70.36 & 0.26 & 9.18 & 0.00 & 4.47 & 0.18 & 0.17 & 4.98 & 4.28 \\
\hline 7-9A_4 & $\mathrm{T}$ & 4 & 72.68 & 0.22 & 9.50 & 0.00 & 4.49 & 0.19 & 0.18 & 5.06 & 4.40 \\
\hline TT97-9A_5 & TT-9 & $/ 08 / 14$ & 70.45 & 0.21 & 9.18 & 0.00 & 4.39 & 0.17 & 0.19 & 4.93 & 4.13 \\
\hline TTS & $\mathrm{T}$ & 700 & 73.75 & 0.2 & 9.53 & 0.03 & 4.60 & 0.19 & 0.15 & 5.46 & 4.30 \\
\hline TT97-9A_7 & TT-9 & $/ / 08 / 14$ & 73.25 & 0.23 & 9.57 & 0.00 & 4.43 & 0.17 & 0.17 & 5.33 & 4.27 \\
\hline 9A_8 & & 700 & 71.12 & 0.1 & 9.0 & 0.0 & 4. & 0.22 & 0.18 & 5.11 & 4.15 \\
\hline TT97-9A_9 & TT-9 & $27 / 08 / 14$ & 72.90 & 0.25 & 9.45 & 0.00 & 4.67 & 0.21 & 0.15 & 5.32 & 4.37 \\
\hline TT97-9B_1 & TT-9 & $27 / 08 / 14$ & 71.94 & 0.24 & 8.93 & 0.01 & 4.49 & 0.21 & 0.18 & 4.88 & 4.2 \\
\hline & & & & & & & & & & & \\
\hline
\end{tabular}


Unnormalised major element concentrations (wt.\%) in Tilo tephra glass shards

\begin{tabular}{|c|c|c|c|c|c|c|c|c|c|c|c|}
\hline Label & Tephra & $\begin{array}{l}\text { Analysis } \\
\text { date }\end{array}$ & $\begin{array}{l}\mathrm{SiO}_{2} \\
0.08 \\
\end{array}$ & $\begin{array}{l}\mathrm{TiO}_{2} \\
\mathbf{0 . 0 5} \\
\end{array}$ & $\begin{array}{l}\mathrm{Al}_{2} \mathrm{O}_{3} \\
\mathbf{0 . 0 5} \\
\end{array}$ & $\begin{array}{l}\text { MgO } \\
0.04\end{array}$ & $\begin{array}{l}\mathrm{FeO}^{T} \\
0.08\end{array}$ & $\begin{array}{l}\text { MnO } \\
0.07 \\
\end{array}$ & $\begin{array}{l}\mathrm{CaO} \\
0.04 \\
\end{array}$ & $\begin{array}{l}\mathrm{Na}_{2} \mathrm{O} \\
0.08 \\
\end{array}$ & $\begin{array}{l}\mathrm{K}_{2} \mathrm{O} \\
\mathbf{0 . 0 3} \\
\end{array}$ \\
\hline TT97-9B_10 & TT-9 & $27 / 08 / 14$ & 71.10 & 0.28 & 8.97 & 0.00 & 4.54 & 0.22 & 0.16 & 5.00 & 4.09 \\
\hline TT97-9B_11 & TT-9 & $27 / 08 / 14$ & 72.07 & 0.24 & 9.14 & 0.00 & 4.50 & 0.16 & 0.16 & 5.13 & 4.16 \\
\hline TT97-9B_12 & TT-9 & $27 / 08 / 14$ & 72.88 & 0.24 & 9.14 & 0.00 & 4.56 & 0.09 & 0.16 & 5.29 & 4.25 \\
\hline TT97-9B_13 & TT-9 & $27 / 08 / 14$ & 70.55 & 0.19 & 9.11 & 0.00 & 4.58 & 0.29 & 0.16 & 4.87 & 4.15 \\
\hline TT97-9B_14 & TT-9 & $27 / 08 / 14$ & 74.11 & 0.26 & 9.59 & 0.00 & 4.75 & 0.27 & 0.19 & 5.36 & 4.53 \\
\hline TT97-9B_15 & TT-9 & $27 / 08 / 14$ & 74.21 & 0.22 & 9.57 & 0.00 & 4.53 & 0.24 & 0.16 & 5.36 & 4.41 \\
\hline TT97-9B_16 & TT-9 & $27 / 08 / 14$ & 73.92 & 0.26 & 9.54 & 0.01 & 4.79 & 0.20 & 0.18 & 5.11 & 4.35 \\
\hline TT97-9B_17 & TT-9 & $27 / 08 / 14$ & 73.06 & 0.25 & 9.34 & 0.00 & 4.69 & 0.24 & 0.18 & 5.42 & 4.34 \\
\hline TT97-9B_18 & TT-9 & $27 / 08 / 14$ & 72.97 & 0.24 & 9.36 & 0.02 & 4.34 & 0.20 & 0.14 & 5.23 & 4.31 \\
\hline TT97-9B_19 & TT-9 & $27 / 08 / 14$ & 73.36 & 0.27 & 9.33 & 0.00 & 4.25 & 0.24 & 0.19 & 5.38 & 4.47 \\
\hline TT97-9B_2 & TT-9 & $27 / 08 / 14$ & 73.33 & 0.24 & 9.42 & 0.00 & 4.42 & 0.28 & 0.20 & 5.68 & 4.25 \\
\hline TT97-9B_20 & TT-9 & $27 / 08 / 14$ & 71.28 & 0.23 & 9.19 & 0.03 & 4.35 & 0.28 & 0.17 & 4.94 & 4.27 \\
\hline TT97-9B_3 & TT-9 & $27 / 08 / 14$ & 70.65 & 0.26 & 8.99 & 0.00 & 4.24 & 0.21 & 0.18 & 4.79 & 4.13 \\
\hline TT97-9B_5 & TT-9 & $27 / 08 / 14$ & 73.09 & 0.24 & 9.46 & 0.01 & 4.44 & 0.10 & 0.14 & 5.12 & 4.32 \\
\hline TT97-9B_6 & TT-9 & $27 / 08 / 14$ & 73.20 & 0.22 & 9.39 & 0.00 & 4.74 & 0.21 & 0.17 & 5.50 & 4.52 \\
\hline ТT97-9B_7 & TT-9 & $27 / 08 / 14$ & 73.94 & 0.26 & 9.40 & 0.00 & 4.78 & 0.22 & 0.20 & 5.58 & 4.42 \\
\hline TT97-9B_8 & TT-9 & $27 / 08 / 14$ & 72.92 & 0.25 & 9.41 & 0.00 & 4.19 & 0.25 & 0.18 & 5.29 & 4.30 \\
\hline TT97-9B_9 & TT-9 & $27 / 08 / 14$ & 69.96 & 0.21 & 9.14 & 0.04 & 4.35 & 0.15 & 0.18 & 5.33 & 3.98 \\
\hline TT97-9C_1 & TT-9 & $27 / 08 / 14$ & 73.71 & 0.30 & 9.59 & 0.00 & 4.43 & 0.16 & 0.19 & 5.37 & 4.28 \\
\hline TT97-9C_10 & TT-9 & $27 / 08 / 14$ & 73.82 & 0.22 & 9.80 & 0.01 & 4.30 & 0.24 & 0.18 & 5.21 & 4.33 \\
\hline TT97-9C_11 & TT-9 & $27 / 08 / 14$ & 72.66 & 0.26 & 9.41 & 0.01 & 4.46 & 0.22 & 0.20 & 5.17 & 4.22 \\
\hline TT97-9C_12 & TT-9 & $27 / 08 / 14$ & 74.19 & 0.25 & 9.69 & 0.00 & 4.62 & 0.25 & 0.19 & 4.78 & 4.38 \\
\hline TT97-9C_13 & TT-9 & $27 / 08 / 14$ & 74.69 & 0.24 & 9.67 & 0.00 & 4.54 & 0.21 & 0.20 & 5.30 & 4.51 \\
\hline TT97-9C_14 & TT-9 & $27 / 08 / 14$ & 69.87 & 0.19 & 8.82 & 0.00 & 4.34 & 0.15 & 0.16 & 5.07 & 4.18 \\
\hline TT97-9C_15 & TT-9 & $27 / 08 / 14$ & 73.60 & 0.18 & 9.56 & 0.00 & 4.64 & 0.17 & 0.19 & 5.31 & 4.39 \\
\hline TT97-9C_16 & TT-9 & $27 / 08 / 14$ & 71.72 & 0.24 & 9.10 & 0.04 & 4.24 & 0.17 & 0.16 & 4.91 & 4.39 \\
\hline TT97-9C_17 & TT-9 & $27 / 08 / 14$ & 73.05 & 0.25 & 9.48 & 0.01 & 4.38 & 0.20 & 0.19 & 5.04 & 4.24 \\
\hline TT97-9C_18 & TT-9 & $27 / 08 / 14$ & 73.27 & 0.24 & 9.34 & 0.00 & 4.61 & 0.18 & 0.17 & 5.27 & 4.34 \\
\hline TT97-9C_19 & TT-9 & $27 / 08 / 14$ & 74.16 & 0.18 & 9.51 & 0.00 & 4.43 & 0.20 & 0.22 & 5.47 & 4.18 \\
\hline TT97-9C_2 & TT-9 & $27 / 08 / 14$ & 71.04 & 0.26 & 9.23 & 0.00 & 4.53 & 0.09 & 0.16 & 4.79 & 4.22 \\
\hline TT97-9C_20 & TT-9 & $27 / 08 / 14$ & 73.10 & 0.22 & 9.27 & 0.00 & 4.35 & 0.21 & 0.13 & 5.12 & 4.37 \\
\hline TT97-9C_3 & TT-9 & $27 / 08 / 14$ & 72.34 & 0.22 & 9.29 & 0.00 & 4.55 & 0.16 & 0.17 & 5.03 & 4.41 \\
\hline TT97-9C_4 & TT-9 & $27 / 08 / 14$ & 73.09 & 0.22 & 9.45 & 0.00 & 4.51 & 0.23 & 0.18 & 5.00 & 4.34 \\
\hline TT97-9C_5 & TT-9 & $27 / 08 / 14$ & 71.15 & 0.21 & 9.27 & 0.00 & 4.22 & 0.15 & 0.17 & 5.11 & 4.11 \\
\hline TT97-9C_6 & TT-9 & $27 / 08 / 14$ & 74.06 & 0.22 & 9.55 & 0.01 & 4.39 & 0.23 & 0.16 & 5.37 & 4.22 \\
\hline TT97-9C_7 & TT-9 & $27 / 08 / 14$ & 73.71 & 0.28 & 9.56 & 0.02 & 4.60 & 0.26 & 0.16 & 4.95 & 4.36 \\
\hline TT97-9C_8 & TT-9 & $27 / 08 / 14$ & 72.47 & 0.20 & 9.31 & 0.00 & 4.63 & 0.25 & 0.19 & 5.22 & 4.24 \\
\hline TT97-9C_9 & TT-9 & $27 / 08 / 14$ & 73.21 & 0.26 & 9.48 & 0.00 & 4.71 & 0.15 & 0.19 & 5.01 & 4.39 \\
\hline TT97-10A_1 & TT-10 & $27 / 08 / 14$ & 72.79 & 0.24 & 9.38 & 0.00 & 4.33 & 0.19 & 0.15 & 5.18 & 4.38 \\
\hline TT97-10A_10 & TT-10 & $27 / 08 / 14$ & 71.32 & 0.23 & 8.96 & 0.00 & 4.47 & 0.20 & 0.16 & 5.34 & 4.19 \\
\hline TT97-10A_11 & TT-10 & $27 / 08 / 14$ & 70.34 & 0.24 & 8.99 & 0.00 & 4.26 & 0.14 & 0.15 & 4.96 & 4.12 \\
\hline TT97-10A_12 & TT-10 & $27 / 08 / 14$ & 72.02 & 0.28 & 9.34 & 0.01 & 4.26 & 0.18 & 0.19 & 5.07 & 4.27 \\
\hline TT97-10A_13 & TT-10 & $7 / 08 / 14$ & 73.12 & 0.25 & 9.23 & 0.00 & 4.51 & 0.20 & 0.16 & 5.42 & 4.17 \\
\hline TT97-10A_14 & TT-10 & $7 / 08 / 14$ & 72.52 & 0.18 & 9.03 & 0.01 & 4.68 & 0.22 & 0.19 & 5.43 & 4.47 \\
\hline TT97-10A_15 & TT-10 & $27 / 08 / 14$ & 74.42 & 0.18 & 9.60 & 0.00 & 4.49 & 0.19 & 0.20 & 5.37 & 4.38 \\
\hline TT97-10A_16 & TT-10 & $7 / 08 / 14$ & 71.74 & 0.21 & 8.94 & 0.02 & 4.61 & 0.12 & 0.18 & 5.10 & 4.20 \\
\hline TT97-10A_17 & TT-10 & $7 / 08 / 14$ & 73.91 & 0.27 & 9.28 & 0.01 & 4.88 & 0.18 & 0.19 & 5.30 & 4.33 \\
\hline TT97-10A_18 & TT-10 & $7 / 08 / 14$ & 72.94 & 0.28 & 9.35 & 0.00 & 4.54 & 0.20 & 0.17 & 5.27 & 4.40 \\
\hline TT97-10A_19 & TT-10 & $/ 08 / 14$ & 73.41 & 0.23 & 9.23 & 0.00 & 4.64 & 0.21 & 0.19 & 5.21 & 4.30 \\
\hline TT97-10A_2 & TT-10 & $7 / 08 / 14$ & 71.98 & 0.21 & 9.09 & 0.02 & 4.63 & 0.17 & 0.18 & 5.12 & 4.34 \\
\hline TT97-10A_20 & TT-10 & $27 / 08 / 14$ & 72.94 & 0.24 & 9.38 & 0.01 & 4.44 & 0.25 & 0.15 & 5.28 & 4.48 \\
\hline TT97-10A_3 & TT-10 & $7 / 08 / 14$ & 73.72 & 0.27 & 9.63 & 0.01 & 4.65 & 0.15 & 0.14 & 5.33 & 4.36 \\
\hline TT97-10A_4 & TT-10 & $7 / 08 / 14$ & 73.84 & 0.22 & 9.59 & 0.00 & 4.33 & 0.31 & 0.18 & 5.22 & 4.42 \\
\hline TT97-10A_5 & TT-10 & $7 / 08 / 14$ & 71.07 & 0.26 & 8.87 & 0.00 & 4.53 & 0.19 & 0.15 & 5.30 & 4.35 \\
\hline TT97-10A_6 & TT-10 & $7 / 08 / 14$ & 71.95 & 0.24 & 9.12 & 0.00 & 4.19 & 0.23 & 0.16 & 5.17 & 4.32 \\
\hline TT97-10A_7 & TT-10 & $27 / 08 / 14$ & 71.27 & 0.21 & 9.22 & 0.00 & 4.46 & 0.17 & 0.24 & 5.15 & 4.31 \\
\hline TT97-10A_8 & TT-1 & $7 / 08 / 14$ & 73.12 & 0.15 & 9.37 & 0.00 & 4.57 & 0.29 & 0.16 & 5.22 & 4.26 \\
\hline TT97-10A_9 & TT-10 & $7 / 08 / 14$ & 72.74 & 0.20 & 9.78 & 0.00 & 4.61 & 0.21 & 0.21 & 5.38 & 4.26 \\
\hline TT97-10B_1 & TT-10 & $7 / 08 / 14$ & 73.72 & 0.31 & 9.68 & 0.00 & 4.96 & 0.22 & 0.16 & 5.45 & 4.32 \\
\hline TT97-10B_10 & TT-10 & $7 / 08 / 14$ & 73.51 & 0.24 & 9.37 & 0.00 & 4.75 & 0.29 & 0.19 & 5.36 & 4.48 \\
\hline TT97-10B_11 & TT-10 & $/ / 08 / 14$ & 72.12 & 0.22 & 9.34 & 0.00 & 4.50 & 0.27 & 0.18 & 5.36 & 4.29 \\
\hline TT97-10B_12 & TT- 10 & $/ / 08 / 14$ & 71.47 & 0.19 & 8.91 & 0.02 & 4.39 & 0.19 & 0.18 & 5.17 & 4.37 \\
\hline TT97-10B_13 & TT & $/ / 08 / 14$ & 71.72 & 0.28 & 9.28 & 0.00 & 4.60 & 0.25 & 0.18 & 5.30 & 4.26 \\
\hline TT97-10B_15 & TT- 10 & $7 / 08 / 14$ & 71.12 & 0.21 & 9.10 & 0.00 & 4.32 & 0.24 & 0.17 & 5.37 & 4.17 \\
\hline TT97-10B_16 & TT- & & 73.34 & 0.32 & 9.64 & 0.01 & 4.30 & 0.28 & 0.20 & 5.09 & 4.50 \\
\hline & $T$ & & 5 & 0.1 & 9.15 & 0. & 4.6 & 0.1 & 01 & 5.17 & 4.31 \\
\hline TT97-10B_18 & TT-10 & $7 / 08 / 14$ & 74.07 & 0.22 & 9.61 & 0.00 & 4.56 & 0.20 & 0.20 & 5.41 & 4.51 \\
\hline TT97-10B_19 & TT- & ل > & 73.67 & 0.2 & 9.52 & 0.01 & 4.59 & 0.24 & 0.16 & 5.31 & 4.39 \\
\hline TT97-10B_2 & TT-10 & $27 / 08 / 14$ & 70.78 & 0.22 & 8.96 & 0.00 & 4.40 & 0.15 & 0.15 & 5.37 & 4.25 \\
\hline TT97-10B_20 & TT- 1 & $2708 / 14$ & 71.20 & 0.19 & 9.16 & 0.02 & 4.48 & 0.19 & 0.17 & 5.24 & 4.27 \\
\hline 10B_3 & TT-10 & 14 & 71.33 & 0.1 & 9.79 & 0. & 4.05 & 0.18 & 0.16 & 5.38 & 4.28 \\
\hline TT9 & TT-1 & & 74.22 & 0.26 & 9.41 & 0.00 & 4.41 & 0.20 & 0.20 & 5.42 & 4.41 \\
\hline TT97-10B_5 & TT-10 & //08/14 & 74.91 & 0.27 & 9.60 & 0.02 & 4.64 & 0.21 & 0.21 & 4.04 & 4.61 \\
\hline TT97-10B_6 & TT-1 & 14 & 72.97 & 0.27 & 9.47 & 0.00 & 4.57 & 0.24 & 0.18 & 5.46 & 4.44 \\
\hline & $\mathrm{T}$ & 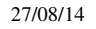 & 73 & 0.1 & 9.55 & 0. & 4.53 & 0.19 & 0.19 & 5.40 & 4.53 \\
\hline TT97-10B_8 & TT-1 & $7 / 08 / 14$ & 72.13 & 0.1 & 9.16 & 0. & 4.67 & 0.18 & 0.21 & 5.41 & 4.37 \\
\hline & & & & 0.2 & 9.5 & 0. & 4.72 & 0.22 & 0.20 & 5.54 & 4.30 \\
\hline TT97-10C_1 & TT-10 & $27 / 08 / 14$ & 72.01 & 0.22 & 9.15 & 0.00 & 4.39 & 0.16 & 0.14 & 5.48 & 4.14 \\
\hline TT97-10C_10 & TT-1 & 2700 & 73.47 & 0.2 & 9.55 & 0.00 & 4.39 & 0.28 & 0.16 & 5.35 & 4.59 \\
\hline TT97-10C_11 & TT-10 & $27 / 08 / 14$ & 74.27 & 0.23 & 9.66 & 0.00 & 4.32 & 0.15 & 0.19 & 5.06 & 4.37 \\
\hline TT97-10C_12 & TT-10 & $27 / 08 / 14$ & 73.34 & 0.21 & 9.58 & 0.00 & 4.68 & 0.24 & 0.16 & 5.22 & 4.50 \\
\hline TT97-10C_13 & TT-10 & $27 / 08 / 14$ & 71.13 & 0.18 & 9.16 & 0.00 & 4.72 & 0.23 & 0.20 & 5.07 & 4.22 \\
\hline TT97-10C_14 & TT-10 & $27 / 08 / 14$ & 74.09 & 0.24 & 9.67 & 0.01 & 4.36 & 0.28 & 0.20 & 5.36 & 4.37 \\
\hline-15 & TT-10 & & 72.19 & 0.18 & 9.25 & 0.00 & 4.49 & 0.27 & 0.18 & 5.41 & 4.27 \\
\hline TT97-10C_16 & TT-10 & $27 / 08 / 14$ & 74.56 & 0.25 & 9.67 & 0.00 & 4.52 & 0.14 & 0.16 & 5.32 & 4.45 \\
\hline & & & & & & & & & & & \\
\hline
\end{tabular}


Unnormalised major element concentrations (wt.\%) in Tilo tephra glass shards

\begin{tabular}{|c|c|c|c|c|c|c|c|c|c|c|c|}
\hline Label & Tephra & $\begin{array}{l}\text { Analysis } \\
\text { date }\end{array}$ & $\begin{array}{l}\mathrm{SiO}_{2} \\
0.08\end{array}$ & $\begin{array}{l}\mathrm{TiO}_{2} \\
0.05\end{array}$ & $\begin{array}{l}\mathrm{Al}_{2} \mathrm{O}_{3} \\
0.05\end{array}$ & $\begin{array}{l}\text { MgO } \\
0.04\end{array}$ & $\begin{array}{l}\mathrm{FeO}^{I} \\
\mathbf{0 . 0 8}\end{array}$ & $\begin{array}{l}\text { MnO } \\
\mathbf{0 . 0 7}\end{array}$ & $\begin{array}{l}\mathrm{CaO} \\
0.04\end{array}$ & $\begin{array}{l}\mathrm{Na}_{2} \mathrm{O} \\
0.08\end{array}$ & $\begin{array}{l}\mathrm{K}_{2} \mathrm{O} \\
\mathbf{0 . 0 3}\end{array}$ \\
\hline TT97-10C_17 & TT-10 & $27 / 08 / 14$ & 73.06 & 0.24 & 9.58 & 0.02 & 4.59 & 0.15 & 0.16 & 5.43 & 4.40 \\
\hline TT97-10C_18 & TT-10 & $27 / 08 / 14$ & 73.82 & 0.26 & 9.60 & 0.00 & 4.64 & 0.25 & 0.16 & 4.88 & 4.39 \\
\hline TT97-10C_19 & TT-10 & $7 / 08 / 14$ & 71.23 & 0.20 & 7.79 & 0.02 & 3.41 & 0.18 & 0.26 & 4.35 & 3.40 \\
\hline TT97-10C_2 & TT-10 & 27/08/14 & 73.74 & 0.28 & 9.67 & 0.00 & 4.44 & 0.18 & 0.16 & 5.45 & 4.44 \\
\hline TT97-10C_20 & TT-10 & $27 / 08 / 14$ & 68.53 & 0.22 & 9.20 & 0.00 & 4.17 & 0.17 & 0.20 & 4.71 & 3.97 \\
\hline TT97-10C_21 & TT-10 & $27 / 08 / 14$ & 74.06 & 0.23 & 9.54 & 0.00 & 4.65 & 0.25 & 0.19 & 5.25 & 4.51 \\
\hline TT97-10C_22 & TT-10 & $27 / 08 / 14$ & 67.70 & 0.20 & 8.76 & 0.00 & 4.40 & 0.19 & 0.20 & 4.83 & 4.11 \\
\hline TT97-10C_3 & TT-10 & $7 / 08 / 14$ & 73.74 & 0.24 & 9.69 & 0.00 & 4.57 & 0.16 & 0.14 & 5.56 & 4.37 \\
\hline TT97-10C_4 & TT-10 & $27 / 08 / 14$ & 73.71 & 0.24 & 9.62 & 0.00 & 4.47 & 0.30 & 0.15 & 5.41 & 4.44 \\
\hline TT97-10C_5 & TT-10 & $7 / 08 / 14$ & 73.40 & 0.30 & 9.53 & 0.00 & 4.75 & 0.29 & 0.20 & 5.32 & 4.53 \\
\hline TT97-10C_66 & TT-10 & $27 / 08 / 14$ & 73.28 & 0.27 & 9.18 & 0.00 & 4.42 & 0.17 & 0.20 & 5.38 & 4.38 \\
\hline TT97-10C_7 & TT-10 & $27 / 08 / 14$ & 71.20 & 0.23 & 9.08 & 0.00 & 4.21 & 0.19 & 0.21 & 5.25 & 4.09 \\
\hline TT97-10C_8 & TT-10 & $27 / 08 / 14$ & 72.84 & 0.26 & 9.15 & 0.02 & 4.72 & 0.22 & 0.17 & 5.43 & 4.48 \\
\hline TT97-10C_9 & TT-10 & $/ / 08 / 14$ & 73.48 & 0.25 & 9.55 & 0.00 & 4.29 & 0.19 & 0.16 & 5.51 & 4.39 \\
\hline TT97-11_1 & TT-11 & $/ / 08 / 14$ & 72.99 & 0.23 & 9.29 & 0.00 & 4.61 & 0.28 & 0.20 & 5.09 & 4.37 \\
\hline TT97-11_10 & TT-11 & $/ / 08 / 14$ & 71.49 & 0.22 & 9.16 & 0.00 & 4.49 & 0.23 & 0.18 & 5.02 & 4.30 \\
\hline TT97-11_11 & TT-11 & $7 / 08 / 14$ & 71.40 & 0.23 & 9.07 & 0.01 & 4.63 & 0.22 & 0.22 & 5.10 & 4.23 \\
\hline TT97-11_12 & TT-11 & $27 / 08 / 14$ & 70.47 & 0.20 & 9.14 & 0.00 & 4.48 & 0.20 & 0.18 & 5.15 & 4.21 \\
\hline TT97-11_13 & TT-1 & $08 / 14$ & 71.91 & 0.21 & 9.06 & 0.01 & 4.49 & 0.13 & 19 & 4.94 & 4.30 \\
\hline TT97-11_14 & TT-11 & & 71.88 & 0.18 & 9.14 & 0.01 & 4.46 & 0.23 & 0.15 & 4.96 & 4.20 \\
\hline TT97-11_15 & TT-11 & $/ 08 / 14$ & 70.68 & 0.28 & 9.04 & 0.00 & 4.30 & 0.28 & 0.19 & 4.93 & 4.13 \\
\hline TT97-11_16 & TT-11 & $/ 08 / 14$ & 73.81 & 0.21 & 9.38 & 0.00 & 4.59 & 0.19 & 0.18 & 5.49 & 4.40 \\
\hline TT97-11_17 & TT-11 & $8 / 14$ & 72.91 & 0.22 & 9.35 & 0.00 & 4.67 & 0.20 & 0.20 & 5.25 & 4.33 \\
\hline$-11 \_18$ & TT-11 & 14 & 71.87 & 0.18 & 8.81 & 0.00 & 4.51 & 0.19 & 0.19 & 5.27 & 4.21 \\
\hline TT97-11_19 & TT-11 & 14 & 71.90 & 0.19 & 9.17 & 0.00 & 4.61 & 0.27 & 0.14 & 3.26 & 4.25 \\
\hline TT9 & TT-1 & & 71.47 & 0.20 & 8.92 & 0.00 & 4.44 & 0.24 & 0.21 & 5.14 & 4.41 \\
\hline TT97-11_20 & TT-1 & $/ 08 / 14$ & 73.52 & 0.19 & 9.46 & 0.00 & 4.70 & 0.17 & 0.18 & 5.43 & 4.48 \\
\hline TT97-11_3 & TT-1 & $/ 08 / 14$ & 72.98 & 0.21 & 9.16 & 0.00 & 4.54 & 0.27 & 0.19 & 5.30 & 4.22 \\
\hline TT97-11_4 & 1 & $/ 08 / 14$ & 71.43 & 0.28 & 9.14 & 0.00 & 4.36 & 0.16 & 0.17 & 5.40 & 4.36 \\
\hline TT97-11_5 & 1-1 & 14 & .25 & 0.22 & 9.21 & 0.00 & 4.51 & 0.19 & 20 & 5.17 & 4.26 \\
\hline TT97-11_6 & T1 & $/ 08 / 14$ & 72.41 & 0.22 & 9.02 & 0.00 & 4.20 & 0.16 & 0.15 & 5.31 & 4.37 \\
\hline$-11 \_7$ & $\Gamma-1$ & $08 / 14$ & 71.56 & 0.19 & 9.10 & 0.00 & 4.59 & 0.23 & 0.16 & 5.34 & 4.36 \\
\hline $11 \_8$ & $\Gamma-11$ & 14 & 73.72 & 0.22 & 9.19 & 0.00 & 4.47 & 0.20 & 0.18 & 5.36 & 4.31 \\
\hline TT97-11_9 & TT-11 & 14 & 72.82 & 0.22 & 9.19 & 0.01 & 4.34 & 0.21 & 0.18 & 3.01 & 4.41 \\
\hline $1 \mathrm{~B} / 1$ & TT-11 & & 72.82 & 0.23 & 9.46 & 0.01 & 4.49 & 0.27 & 0.18 & 5.31 & 4.32 \\
\hline $11 \mathrm{~B} / 10$ & TT-11 & & 70.86 & 0.27 & 9.04 & 0.00 & 4.16 & 0.19 & 0.17 & 5.08 & 4.21 \\
\hline TT9 & TT-1 & & 71.43 & 0.18 & 9.26 & 0.00 & 4.61 & 0.24 & 0.19 & 5.09 & 4.33 \\
\hline TT9 & $T$ & & 0 & 0.2 & 9.23 & 0.0 & 4.3 & 0.10 & 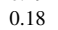 & 5.13 & 4.32 \\
\hline TT9 & {$[-1$} & & 71.09 & 0.20 & 9.23 & 0.00 & 4.5 & 0.25 & 0.2 & 5.45 & 4.27 \\
\hline TT9711 & 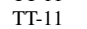 & & 2.63 & 0.22 & 9.40 & 0.00 & 4.6 & 0.24 & 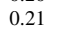 & 5.02 & 4.26 \\
\hline TT9 & T-1 & & 70.07 & 0.11 & 14.64 & 0.00 & 2.72 & 0.06 & 0.08 & 5.98 & 5.99 \\
\hline TT9711B/16 & TT & 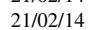 & 70.02 & 0.27 & 9.84 & 0.03 & 4.25 & 0.10 & 0.20 & 4.78 & 4.18 \\
\hline TTS & {$[-1$} & & 73.11 & 0.24 & 9.63 & 0.00 & 4.67 & 0.21 & 0.19 & 5.20 & 4.42 \\
\hline TTS & $\mathrm{T}$ & & 73.01 & 0.22 & 9.38 & 0.00 & 4.62 & 0.16 & 0.20 & 3.46 & 4.25 \\
\hline TTS & {$[-11$} & & 70.54 & 0.22 & 9.15 & 0.02 & 4.21 & 0.23 & 18 & 4.92 & 4.19 \\
\hline TT9? & {$[-1$} & & 73.09 & 0.3 & 9.98 & 0.01 & 4.06 & 0.16 & 0.21 & 4.97 & 4.57 \\
\hline & T & & 0 & 0.1 & 9.36 & 0.00 & 4.9 & 0.23 & 8 & 5.13 & 4.42 \\
\hline TT9711B/3 & {$[-1$} & & 71.21 & 0.19 & 9.20 & 0.00 & 4.5 & 0.09 & 0.21 & 4.58 & 4.19 \\
\hline TT9711B/4 & 11 & & 60 & 0.24 & 9.39 & 0.00 & 4.5 .5 & 0.22 & 8 & 2.64 & 4.18 \\
\hline TT9711B/5 & $T-11$ & & 73.10 & 0.22 & 9.44 & 0.00 & 4.3 & 0.21 & 0.17 & 4.93 & 4.25 \\
\hline TT9711B/7 & (T) & & 72.47 & 0.20 & 043 & 0.00 & 4.6 & 0.18 & 0.16 & 5.13 & 4.24 \\
\hline & T & & .56 & 0.20 & 9.40 & 0.00 & 4.3 & 0.20 & 0 & 5.20 & 4.14 \\
\hline TT & 11 & & .93 & 0.26 & 9.97 & 0.00 & 4.2 & 0.23 & 0.16 & 4.85 & 4.49 \\
\hline TTS & $\mathrm{T}$ & & 73.69 & 0.21 & 9.48 & 0.00 & 4.60 & 0.27 & 16 & 5.48 & 4.24 \\
\hline $\mathrm{A} / 10$ & $-12 \quad-12$ & & 69.51 & 0.24 & 8.97 & 0.01 & 4.38 & 0.28 & 0.20 & 4.99 & 4.22 \\
\hline & T & & 2.59 & 0.19 & 9.46 & 0.02 & 4.65 & 0.29 & 10 & 3.85 & 4.31 \\
\hline TTS & T & & 69.49 & 0.28 & 11.15 & 0.00 & 4.25 & 0.23 & 0.20 & 4.99 & 4.11 \\
\hline & & & 1.84 & 0.17 & 9.18 & 0.00 & 4.5 & 0.21 & 8 & 2.53 & 4.25 \\
\hline $\mathrm{A} / 14$ & $\mathrm{~T}$ & & 71.79 & 0.1 & 9. & 0.00 & 4.44 & 0.21 & 0.17 & 5.40 & 4.21 \\
\hline & & & & 0.20 & & 0.00 & & & & 4.80 & 4.13 \\
\hline & & & & 0. & & 0. & 4. & 0. & 18 & 5.16 & 4.2 \\
\hline & & & & 0. & 9 & 0. & 4. & & & & 4.05 \\
\hline & & & & 0. & 9. & 0. & 4. & 0. & & 2. & 4.2 \\
\hline TT9712A/19 & -1 & & 67.93 & 0.23 & 8.79 & 0.00 & 4.33 & 0.25 & 0.22 & 4.98 & 4.11 \\
\hline TT9 & & & 710 & 018 & 9.26 & 0.03 & 4.22 & 0.20 & .20 & 5.24 & 24 \\
\hline $2 \mathrm{~A} / 20$ & & & 72.66 & 0.14 & 9.62 & 0.00 & 4.72 & 0.23 & 0.21 & 5.43 & 4.31 \\
\hline & & & & 0.2 & 9.43 & & 4.77 & 0.08 & & & 4.26 \\
\hline TTS & & & 71.27 & 0.17 & 9.14 & 0.00 & 4.84 & 0.25 & 0.16 & 5.59 & 4.29 \\
\hline & & & 71.20 & 0.21 & 9.14 & 0.01 & 4.54 & 0.24 & 0.17 & 5.00 & 4.21 \\
\hline TTS & & & 30 & 0.2 & & 0. & 4. & & 19 & 5.62 & 4.26 \\
\hline & & & & 0. & 9. & 0. & 4. & 0 & 0.19 & 5.51 & 4.24 \\
\hline & & & 1 & 0.2 & 9. & 0. & i & 0. & 8 & 5.18 & 4.29 \\
\hline TTS & $\Gamma-12$ & & 71.87 & 0.23 & 9.32 & 0.00 & 4.72 & 0.20 & 0.19 & 5.11 & 4.37 \\
\hline & & & & 0.2 & & 0. & 4. & 0. & & 4.74 & . \\
\hline TTS & $\mathrm{T}$ & & .89 & 0.2 & 9.39 & 0.00 & 4. & 0.17 & 0.20 & 5.23 & 4.19 \\
\hline & & & & & & 0.0 & 4. & 0.2 & & & \\
\hline TT & 1 & & 72.06 & 0.22 & 9.32 & 0.00 & 4.53 & 0.12 & 0.14 & 5.34 & 4.25 \\
\hline & & & & 0.2 & & 0.0 & 4.61 & 0.22 & - & 5.58 & 4.18 \\
\hline $\mathrm{T}$ & & & & 0.18 & 9.50 & 0.00 & 4.67 & & & 5.08 & 4.23 \\
\hline & 1 & & 32 & 0.19 & 9.57 & 0.00 & 4.69 & 0.20 & 0.18 & 4.23 & 4.34 \\
\hline & & & $1-1$ & 0.1 & 9. & 0. & 4. & 0.2 & 0 & 5.05 & 4.25 \\
\hline TTS & $-1-1$ & & 83 & 0.22 & 9.51 & 0.01 & 4.28 & 0.21 & 0.17 & 5.40 & 4.52 \\
\hline & & & & 0.1 & 9. & 0. & 4. & 0.20 & 0.18 & 5.26 & 4.39 \\
\hline TT9 & 11-12 & 14 & 71.57 & 0.24 & 9.22 & 0.01 & 4.41 & 0.16 & 0.15 & 5.28 & 4.29 \\
\hline TT9712B/20 & TT-12 & $1 / 02 / 14$ & 70.94 & 0.20 & 10.54 & 0.00 & 4.71 & 0.27 & 0.15 & 5.29 & 4.17 \\
\hline & & & & & & & & & & & \\
\hline
\end{tabular}


Unnormalised major element concentrations (wt.\%) in Tilo tephra glass shards

\begin{tabular}{|c|c|c|c|c|c|c|c|c|c|c|c|}
\hline Label & Tephra & $\begin{array}{l}\text { Analysis } \\
\text { date }\end{array}$ & $\begin{array}{l}\mathrm{SiO}_{2} \\
0.08 \\
\end{array}$ & $\begin{array}{l}\mathrm{TiO}_{2} \\
\mathbf{0 . 0 5} \\
\end{array}$ & $\begin{array}{l}\mathrm{Al}_{2} \mathrm{O}_{3} \\
\mathbf{0 . 0 5} \\
\end{array}$ & $\begin{array}{l}\text { MgO } \\
\text { 0.04 }\end{array}$ & $\begin{array}{l}\mathrm{FeO}^{T} \\
0.08\end{array}$ & $\begin{array}{l}\text { MnO } \\
0.07 \\
\end{array}$ & $\begin{array}{l}\mathrm{CaO} \\
0.04 \\
\end{array}$ & $\begin{array}{l}\mathrm{Na}_{2} \mathrm{O} \\
0.08 \\
\end{array}$ & $\begin{array}{l}\mathrm{K}_{2} \mathrm{O} \\
\mathbf{0 . 0 3} \\
\end{array}$ \\
\hline TT9712B/3 & TT-12 & $21 / 02 / 14$ & 72.61 & 0.18 & 9.48 & 0.02 & 4.76 & 0.16 & 0.17 & 5.66 & 4.32 \\
\hline TT9712B/4 & TT-12 & $21 / 02 / 14$ & 71.18 & 0.22 & 9.47 & 0.00 & 4.44 & 0.23 & 0.17 & 5.64 & 4.39 \\
\hline TT9712B/5 & TT-12 & $21 / 02 / 14$ & 73.78 & 0.22 & 9.29 & 0.00 & 4.76 & 0.16 & 0.20 & 5.52 & 4.27 \\
\hline ТT9712B/6 & TT-12 & $21 / 02 / 14$ & 72.52 & 0.21 & 9.44 & 0.00 & 4.56 & 0.21 & 0.21 & 5.75 & 4.28 \\
\hline ТT $9712 \mathrm{~B} / 7$ & TT-12 & $21 / 02 / 14$ & 73.49 & 0.21 & 9.38 & 0.01 & 4.77 & 0.25 & 0.21 & 5.71 & 4.35 \\
\hline TT9712B/8 & TT-12 & $21 / 02 / 14$ & 71.80 & 0.18 & 9.30 & 0.00 & 4.63 & 0.18 & 0.21 & 5.41 & 4.35 \\
\hline ТT $9712 \mathrm{~B} / 9$ & TT-12 & $21 / 02 / 14$ & 72.60 & 0.21 & 9.24 & 0.00 & 4.73 & 0.27 & 0.16 & 5.29 & 4.11 \\
\hline TT9712C/10 & TT-12 & $21 / 02 / 14$ & 71.61 & 0.23 & 9.36 & 0.00 & 4.41 & 0.22 & 0.16 & 5.02 & 4.37 \\
\hline ТT9712C/11 & TT-12 & $21 / 02 / 14$ & 69.23 & 0.24 & 9.45 & 0.02 & 4.42 & 0.17 & 0.17 & 4.85 & 4.17 \\
\hline TT9712C/12 & TT-12 & $21 / 02 / 14$ & 73.69 & 0.32 & 9.61 & 0.00 & 4.57 & 0.20 & 0.18 & 5.26 & 4.45 \\
\hline TT9712C/13 & TT-12 & $21 / 02 / 14$ & 73.41 & 0.21 & 9.77 & 0.03 & 4.61 & 0.23 & 0.20 & 5.36 & 4.40 \\
\hline TT9712C/14 & TT-12 & $21 / 02 / 14$ & 71.60 & 0.27 & 9.57 & 0.00 & 4.38 & 0.15 & 0.18 & 5.16 & 4.35 \\
\hline TT9712C/15 & TT-12 & $21 / 02 / 14$ & 69.75 & 0.30 & 9.25 & 0.01 & 4.26 & 0.17 & 0.15 & 3.41 & 4.06 \\
\hline ТT9712C/16 & TT-12 & $21 / 02 / 14$ & 72.43 & 0.24 & 9.45 & 0.02 & 4.21 & 0.20 & 0.21 & 5.17 & 4.31 \\
\hline ТT9712C/17 & TT-12 & $1 / 02 / 14$ & 72.77 & 0.23 & 9.46 & 0.04 & 4.31 & 0.18 & 0.25 & 1.69 & 4.17 \\
\hline ТT9712C/18 & TT-12 & $21 / 02 / 14$ & 74.11 & 0.29 & 9.88 & 0.02 & 4.56 & 0.22 & 0.19 & 5.20 & 4.50 \\
\hline TT9712C/19 & TT-12 & $1 / 02 / 14$ & 73.95 & 0.26 & 9.68 & 0.00 & 4.61 & 0.19 & 0.20 & 4.86 & 4.39 \\
\hline $\mathrm{TT} 9712 \mathrm{C} / 2$ & TT-12 & $1 / 02 / 14$ & 71.63 & 0.22 & 9.47 & 0.00 & 4.23 & 0.15 & 0.25 & 5.30 & 4.31 \\
\hline ТT9712C/20 & TT-12 & $1 / 02 / 14$ & 70.78 & 0.24 & 9.34 & 0.01 & 4.42 & 0.25 & 0.15 & 5.12 & 4.33 \\
\hline TT9712C/3 & TT-12 & 14 & 71.81 & 0.23 & 9.47 & 0.00 & 4.45 & 0.24 & 0.17 & 5.25 & 4.47 \\
\hline TT9712C/4 & TT-12 & 14 & 71.63 & 0.2 & 9.28 & 0.07 & 4.30 & 0.17 & 0.19 & 4.84 & 4.15 \\
\hline TT9712C/5 & $\mathrm{T}$ & $1 / 02 / 14$ & 70.98 & 0.29 & 9.59 & 0.04 & 4.32 & 0.13 & 0.18 & 5.02 & 4.36 \\
\hline ТT $9712 \mathrm{C} / 6$ & TT-12 & $21 / 02 / 14$ & 68.98 & 0.23 & 14.21 & 0.00 & 4.30 & 0.14 & 0.18 & 4.86 & 4.02 \\
\hline TT971 & TT-12 & 4 & 72.96 & 0.23 & 10.65 & 0.00 & 4.20 & 0.20 & 18 & 4.92 & 4.27 \\
\hline TT9712C/8 & TT-12 & 14 & 71.11 & 0.25 & 9.38 & 0.00 & 4.71 & 0.20 & 0.17 & 5.37 & 4.19 \\
\hline TT97 & TT-12 & 4 & 72.84 & 0.20 & 9.59 & 0.00 & 4.54 & 0.21 & 21 & 5.32 & 4.38 \\
\hline TT97-13_1 & TT-1 & 108 & 71.27 & 0.16 & 8.70 & 0.01 & 4.58 & 0.24 & 0.15 & 5.78 & 4.08 \\
\hline TT97-13_10 & T-13 & $/ 08 / 14$ & 68.13 & 0.11 & 8.75 & 0.01 & 4.59 & 0.23 & 0.14 & 5.39 & 4.04 \\
\hline TT97-13_11 & TT-13 & 14 & 71.73 & 0.22 & 8.90 & 0.00 & 4.40 & 0.20 & 0.16 & 3.61 & 4.17 \\
\hline TT97-13_12 & $\Gamma-13$ & 14 & 71.17 & 0.22 & 8.78 & 0.01 & 4.81 & 0.24 & 0.19 & 5.56 & 4.11 \\
\hline TT97-13_13 & TT- 1 & $27 / 08 / 14$ & 73.72 & 0.22 & 9.30 & 0.00 & 4.85 & 0.19 & 0.16 & 5.90 & 4.25 \\
\hline TT97-13_14 & TT-13 & $7 / 08 / 14$ & 66.59 & 0.01 & 18.27 & 0.00 & 0.94 & 0.08 & 0.01 & 5.59 & 8.47 \\
\hline TT97-1 & {$[-13$} & 14 & .52 & 0.18 & 9.05 & 0.04 & 4.69 & 0.17 & 0.18 & 5.77 & 4.09 \\
\hline TT97-13_16 & TT 13 & $7 / 08 / 14$ & 70.92 & 0.21 & 8.74 & 0.00 & 4.60 & 0.24 & 0.18 & 5.26 & 4.36 \\
\hline TT97-13_17 & (15) & //08/14 & 71.96 & 0.17 & 8.90 & 0.01 & 4.53 & 0.21 & 0.15 & 5.41 & 4.38 \\
\hline TT97-13_18 & TT 13 & $7 / 08 / 14$ & 71.50 & 0.15 & 8.92 & 0.00 & 4.74 & 0.21 & 0.15 & 5.46 & 4.09 \\
\hline TT97-13_19 & $\Gamma-13$ & //08/14 & 72.03 & 0.17 & 9.17 & 0.00 & 4.57 & 0.24 & 0.19 & 1.81 & 4.11 \\
\hline TT97-13_2 & -13 & $/ 14$ & 0.79 & 0.18 & 8.98 & 0.00 & 4.78 & 0.23 & 0.22 & 5.38 & 4.14 \\
\hline TT97-13_20 & $\Gamma-1$ & $/ 14$ & 72.15 & 0.23 & 9.08 & 0.03 & 4.54 & 0.22 & 0.17 & 5.63 & 4.67 \\
\hline TT97-13_3 & {$[-13$} & $/ 14$ & 70.34 & 0.15 & 8.79 & 0.00 & 4.41 & 0.15 & 0.16 & 5.39 & 4.24 \\
\hline TT97-13_4 & TT-13 & 4 & 73.00 & 0.2 & 9.20 & 0.00 & 4.65 & 0.21 & 0.15 & 5.59 & 4.47 \\
\hline TT97-13_6 & -13 & 14 & 72.84 & 0.20 & 9.14 & 0.00 & 4.70 & 0.23 & 0.19 & 5.38 & 4.35 \\
\hline TT97-13_7 & & 14 & 1.44 & 0.2 & 8.87 & 0.00 & 4.5 & 0.19 & 01 & 5.56 & 4.12 \\
\hline TT97-13_8 & r-13 & 14 & 71.50 & 0.14 & 8.99 & 0.00 & 4.75 & 0.17 & 0.15 & 5.93 & 4.19 \\
\hline TT97-13_9 & 13 & $7 / 08 / 14$ & 70.90 & 0.19 & 8.94 & 0.01 & 4.44 & 0.18 & 0.21 & 5.58 & 4.13 \\
\hline TT97-14A_1 & 14 & 14 & .09 & 0.23 & 9.08 & 0.0 & 4.27 & 0.20 & 0.17 & 5.38 & 4.21 \\
\hline TT97-14A_10 & 1 & D & 32 & 0.21 & 9.04 & 0. & 4.34 & 0.22 & 0.15 & 5.41 & 4.08 \\
\hline TT97-14A_11 & 14 & 14 & .09 & 0.20 & 9.12 & 0.00 & 4.37 & 0.20 & 0.17 & 5.12 & 4.27 \\
\hline TT97-14A_12 & $\Gamma-14$ & t7 & 64 & 0.21 & 9.22 & 0.02 & 4.49 & 0.22 & 0.16 & 3.33 & 4.22 \\
\hline TT97-14A_13 & TT-14 & 08/14 & 70.15 & 0.13 & 8.94 & 0.00 & 4.26 & 0.25 & 0.21 & 5.44 & 4.11 \\
\hline TT97-14A_14 & TT-14 & 14 & 70.69 & 0.17 & 9.01 & 0.00 & 4.27 & 0.16 & 0.15 & 5.07 & 4.18 \\
\hline TT97-14A_15 & $\Gamma-14$ & & .79 & 0.2 & 9.08 & 0.00 & 4.46 & 0.13 & 01 & 5.35 & 4.12 \\
\hline TT97-14A_16 & $\Gamma-14$ & $8 / 14$ & 71.07 & 0.1 & 9.02 & 0. & 4.46 & 0.25 & 0.1 & 5.32 & 4.21 \\
\hline TT97-14 & $\mathrm{T}$ & & 71.79 & 0.2 & & $0 . c$ & 4.40 & 0.22 & 0.14 & & 3.96 \\
\hline TT97-14A_18 & TT-14 & 14 & 70.81 & 0.19 & 9.32 & 0.01 & 4.42 & 0.19 & 0.20 & 5.41 & 4.12 \\
\hline TT97-14A_19 & TT 14 & $/ 14$ & 70.48 & 0.25 & 9.12 & 0.00 & 4.50 & 0.25 & 0.18 & 5.25 & 4.24 \\
\hline TT97-14A & $\mathrm{T}$ & //08/14 & .94 & 0.1 & 9.40 & 0.02 & 4.37 & 0.18 & 017 & 5.00 & 4.10 \\
\hline TT97-14A_20 & TT-14 & /08/14 & .70 & 0.18 & 9.00 & 0.00 & 4.21 & 0.24 & 0.17 & 5.48 & 4.12 \\
\hline TT97-14A_3 & TT-14 & 7/08/14 & 71.40 & 0.20 & 9.09 & 0.01 & 4.39 & 0.24 & 0.19 & 5.40 & 4.10 \\
\hline TT97-14A_4 & TT-14 & 14 & .12 & 0.21 & 9.03 & 0. & 4.31 & 0.17 & 0.19 & 5.18 & 4.17 \\
\hline TT9 & & & 2 & 0.1 & 8.78 & 0. & 4.47 & 0.20 & 019 & 4.93 & 4.05 \\
\hline TT97-14A_8 & $\mathrm{T}$ & & 7 & 0.2 & 9.14 & 0. & 4.47 & 0.16 & 0.1 & 5.23 & 4.32 \\
\hline & & & 3 & 0.1 & 9.01 & 0. & 4.47 & 0.23 & 0.13 & 4.93 & 4.24 \\
\hline TT97-14B_1 & TT-14 & 14 & 4 & 0.2 & 8.85 & 0. & 4.44 & 0.10 & 0.1 & 5.27 & 4.21 \\
\hline & & & & 0.2 & 9.11 & & 4.43 & 0.26 & & 5.29 & 4.31 \\
\hline & & & & 0. & & & & 0. & & & 4.02 \\
\hline ТT97-14 & -1 & & 8 & 0.2 & 9.10 & & 4.57 & & 0. & & 4.22 \\
\hline TT9 & $\mathrm{T}$ & & & 0.1 & 9. & & 4.5 & 0. & & 4.80 & 4.09 \\
\hline TT97-14B_15 & TT-14 & //08/14 & 71.44 & 0.21 & 8.98 & 0.01 & 4.56 & 0.15 & 0.17 & 5.20 & 4.19 \\
\hline & & & & 0.17 & 9.08 & 0.00 & 4.16 & 0.12 & & 5.53 & 4.12 \\
\hline 14B_18 & & & 5 & 0 . & & & 4.23 & 0.22 & 0.17 & 5.06 & 4.33 \\
\hline & & & & 0. & 8.9 & & 4.28 & 0.25 & 0.17 & 5.24 & 4.15 \\
\hline 14B_2 & & 2 & 55 & 0.2 & & 0. & 4.40 & 0.21 & 0.19 & 5.21 & 4.16 \\
\hline & & & 4 & 0.1 & 8.96 & 0. & 4.24 & 0.20 & 0.16 & 5.27 & 4.15 \\
\hline & & & & 0. & 8. & & 4.43 & 0. & 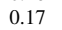 & 5.20 & 4.18 \\
\hline TTS & & & 9 & 0.1 & 9.08 & & 4.54 & & 0. & & 4.20 \\
\hline & & & & 0. & & & & & & & 4.21 \\
\hline TT97-14B_8 & TT-14 & $8 / 08 / 14$ & 71.35 & 0.23 & 9.07 & 0.00 & 4.49 & 0.15 & 0.20 & 5.14 & 4.25 \\
\hline & & & & 0.2 & & 0.0 & 4.36 & & 5,17 & 5.17 & 4.21 \\
\hline TT97-14C_10 & TT-14 & /08/14 & 71.43 & 0.1 & 8.87 & 0.01 & 4.55 & 0.24 & 0.16 & 5.29 & 4.12 \\
\hline & TT-14 & & 70.28 & 0.2 & 8.74 & 0.02 & 4.34 & 0.18 & 0.18 & 5.10 & 4.04 \\
\hline$-14 \mathrm{C} \_12$ & TT- 1 & 4 & 70 & 0.21 & 8.41 & 0.00 & 4.16 & 0.12 & 0.19 & 4.61 & 4.07 \\
\hline TT97-14C_13 & TT-14 & $28 / 08 / 14$ & 71.60 & 0.22 & 9.04 & 0.02 & 4.30 & 0.17 & 0.20 & 5.25 & 4.17 \\
\hline & TT- & & & 0.1 & 9.0 & 0. & 4.3 & 0.20 & 0.15 & 5.12 & 4.21 \\
\hline TT97-14C_15 & TT-14 & $28 / 08 / 14$ & 71.86 & 0.16 & 8.90 & 0.00 & 4.33 & 0.15 & 0.19 & 5.38 & 4.32 \\
\hline & & & & & & & & & & & \\
\hline
\end{tabular}


Unnormalised major element concentrations (wt.\%) in Tilo tephra glass shards

\begin{tabular}{|c|c|c|c|c|c|c|c|c|c|c|c|c|c|c|}
\hline Label & Tephra & $\begin{array}{l}\text { Analysis } \\
\text { date }\end{array}$ & $\begin{array}{l}\mathrm{SiO}_{2} \\
0.08\end{array}$ & $\begin{array}{l}\mathrm{TiO}_{2} \\
0.05\end{array}$ & $\begin{array}{l}\mathrm{Al}_{2} \mathbf{O}_{3} \\
0.05\end{array}$ & $\begin{array}{l}\text { MgO } \\
0.04\end{array}$ & $\begin{array}{l}\mathrm{FeO}^{T} \\
0.08\end{array}$ & $\begin{array}{l}\text { MnO } \\
\text { 0.07 }\end{array}$ & $\begin{array}{l}\mathrm{CaO} \\
0.04\end{array}$ & $\begin{array}{l}\mathrm{Na}_{2} \mathrm{O} \\
0.08\end{array}$ & $\begin{array}{l}\mathrm{K}_{2} \mathrm{O} \\
\mathbf{0 . 0 3}\end{array}$ & $\begin{array}{l}\mathbf{P}_{2} \mathbf{O}_{5} \\
\mathbf{0 . 1 0}\end{array}$ & $\begin{array}{l}\mathrm{Cl} \\
\mathbf{0 . 0 2}\end{array}$ & Total \\
\hline TT97-14C_16 & TT-14 & $28 / 08 / 14$ & 71.08 & 0.20 & 8.71 & 0.00 & 4.50 & 0.20 & 0.16 & 5.41 & 4.22 & 0.01 & & 94.51 \\
\hline TT97- & TT-14 & 28/08/14 & 67.18 & 0.00 & 17.73 & 0.00 & 0.66 & 0.0 & 0.00 & 5.90 & 8.39 & 0.00 & & 99.86 \\
\hline TT97-1 & TT-14 & 28/08/14 & 69.58 & 0.21 & 8.88 & 0.0 & 4.03 & 0.17 & 0.14 & 5.22 & 4.06 & 0.02 & & 92.30 \\
\hline TT97-14C_19 & TT-14 & 8/08/14 & 68.60 & 0.18 & 8.52 & 0.0 & 4.21 & 0.16 & 0.15 & 5.26 & 4.21 & 0.02 & & 91.31 \\
\hline TT9? & TT-14 & & 69.32 & 0.1 & 8.61 & & 4.22 & & 0.18 & 493 & 4.10 & 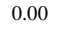 & & 91.76 \\
\hline TT97. & TT-14 & 28/08/14 & 71.20 & 0.20 & 9.15 & 0.00 & 4.59 & 0.17 & 0.16 & 5.27 & 4.19 & 0.03 & & 94.96 \\
\hline TT9 & TT-14 & $08 / 14$ & 71.19 & 0.18 & 8.9 & 0. & 4.41 & 0.1 & 0.20 & 5.20 & 4.17 & 0.02 & & 94.53 \\
\hline TT97-14C_5 & TT-14 & $28 / 08 / 14$ & 66.79 & 0.18 & 11.96 & 0.02 & 4.43 & 0.18 & 0.38 & 4.76 & 3.79 & 0.00 & & 92.50 \\
\hline TT9 & TT-14 & & 70.74 & 0.21 & 8.90 & 0.00 & 4.51 & 0.13 & 0.20 & 5.26 & 4.04 & 0.02 & & 94.01 \\
\hline 4C-7 & TT-14 & $28 / 08$ & 71.09 & 0.21 & 8.98 & $0 . c$ & 4.34 & 0.2 & 0.21 & 5.51 & 4.18 & 0.01 & & 94.74 \\
\hline TT9 & TT-14 & $28 / 08 / 14$ & 71.44 & 0.17 & 8.85 & 0.00 & 4.56 & 0.29 & 0.20 & 5.21 & 4.08 & 0.00 & & 94.81 \\
\hline TT97-14C_9 & TT-14 & $28 / 08 / 14$ & 71.53 & 0.18 & 9.31 & 0.03 & 4.49 & 0.16 & 0.15 & 5.16 & 4.26 & 0.00 & & 95.29 \\
\hline
\end{tabular}




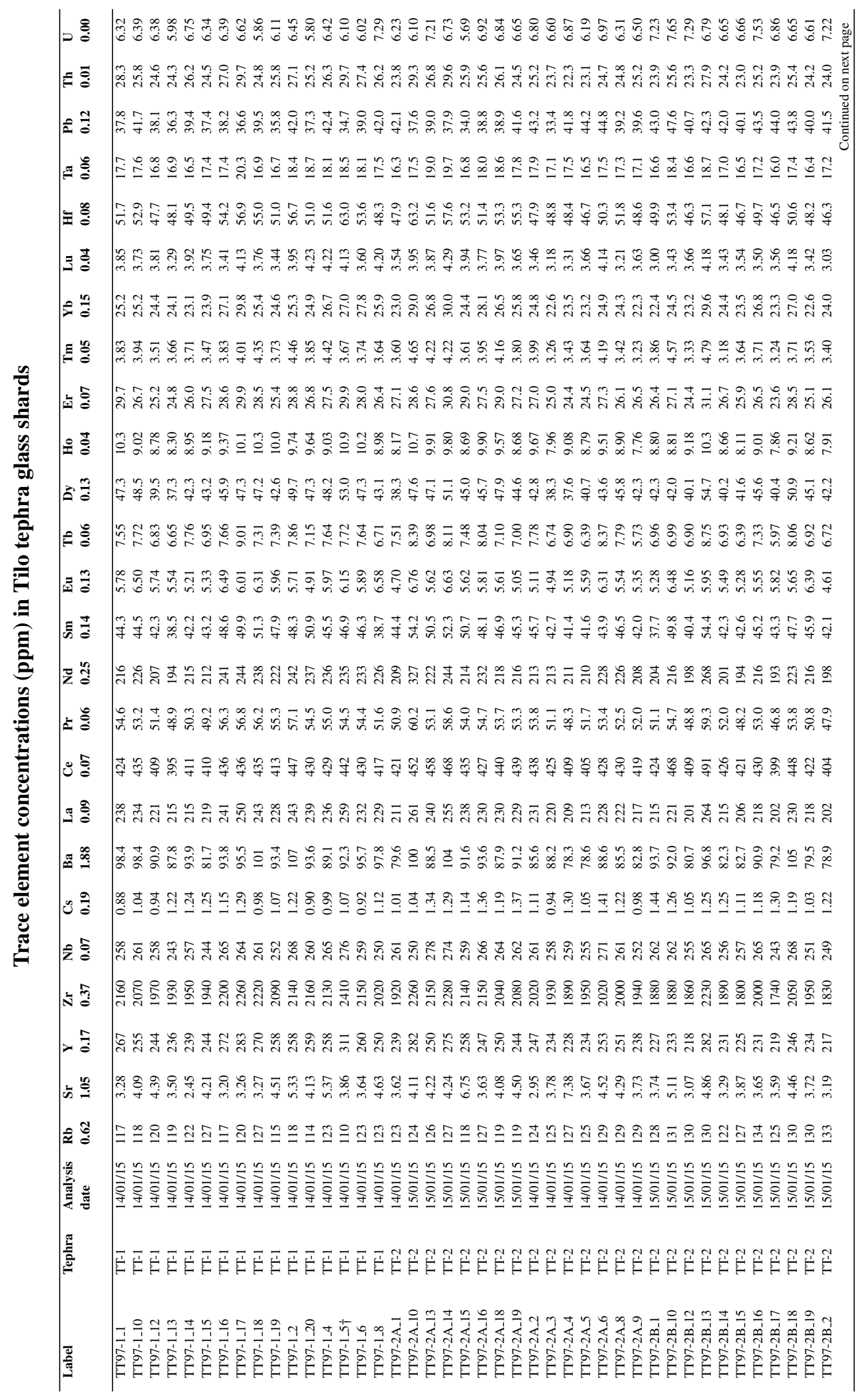




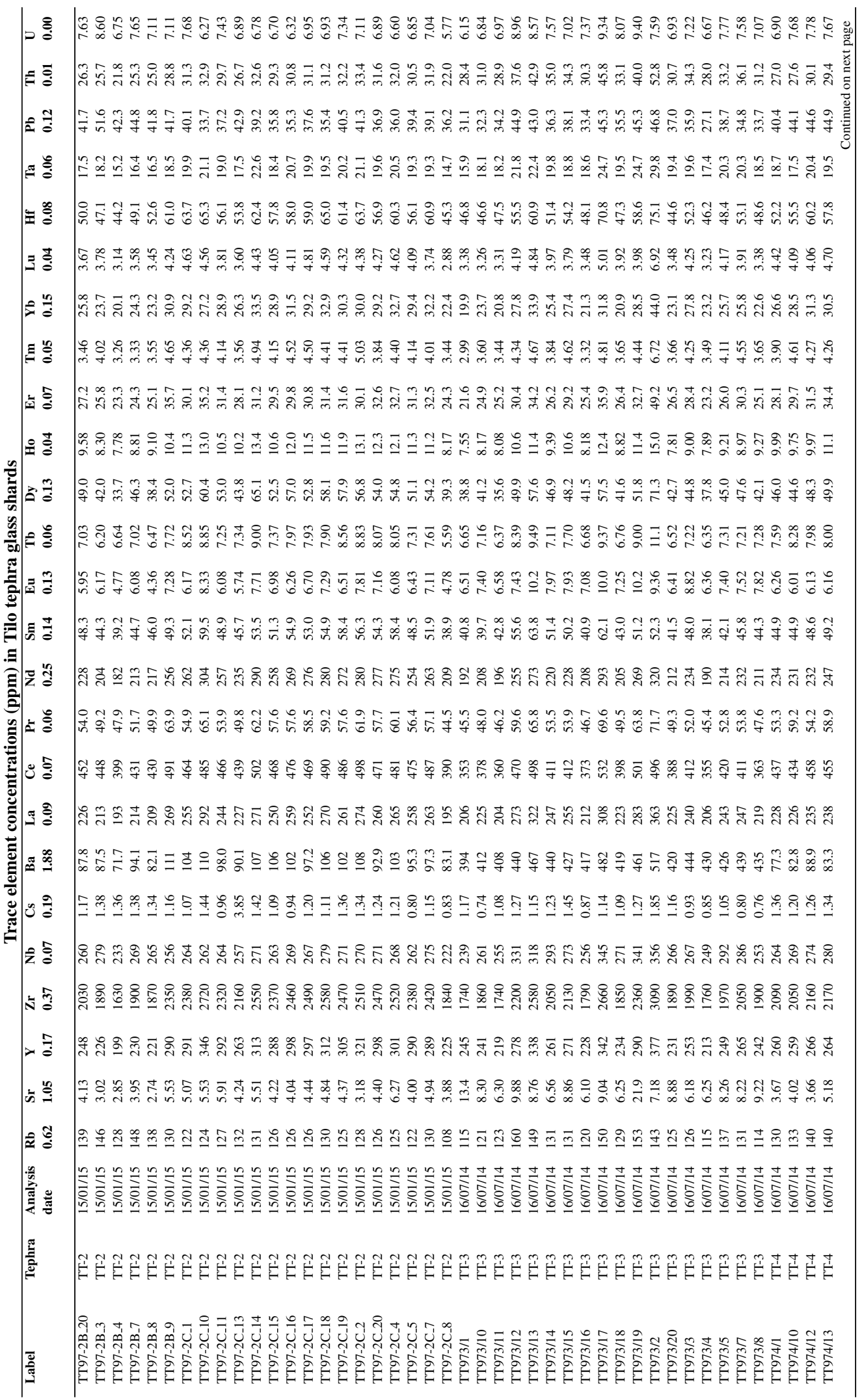




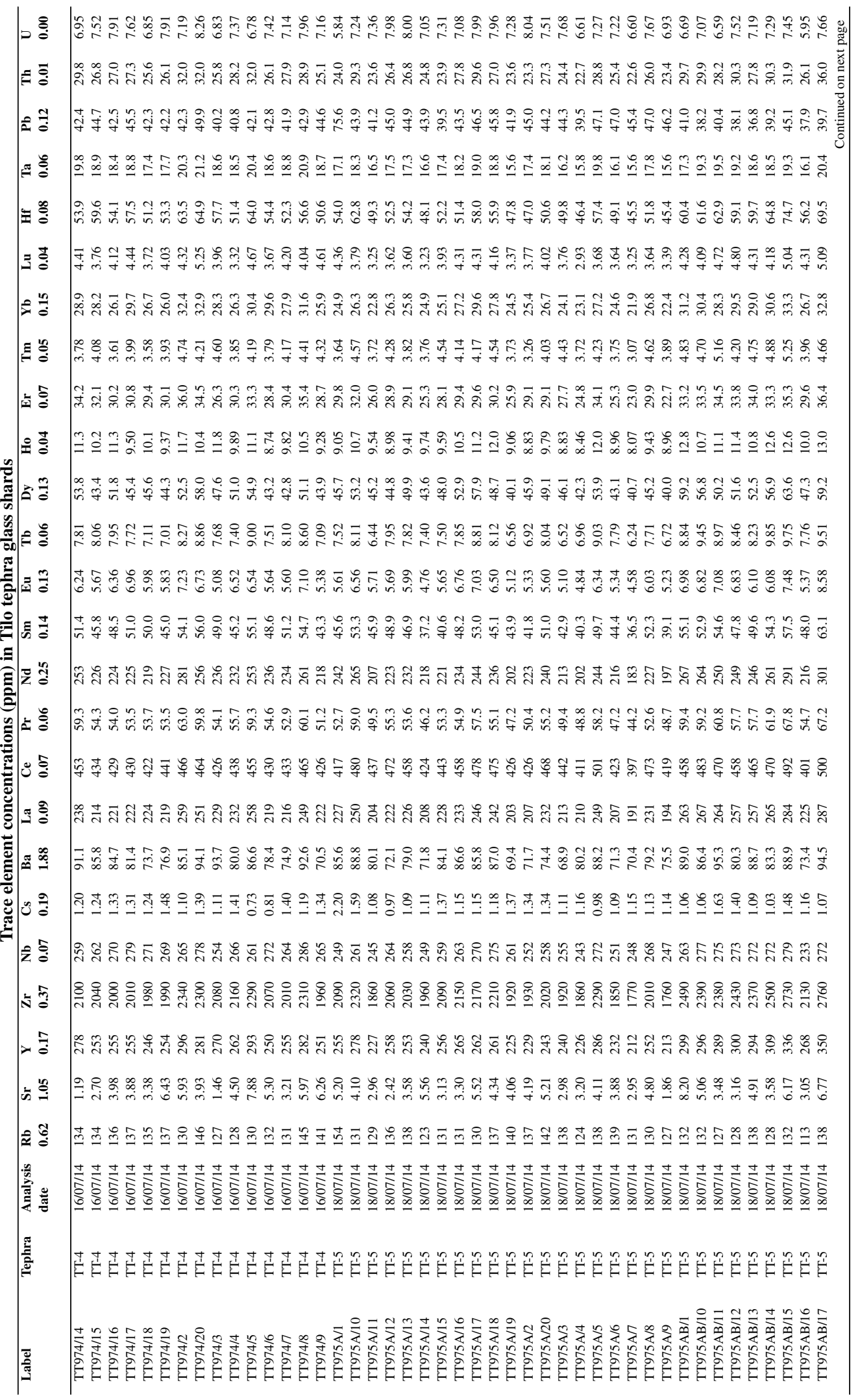




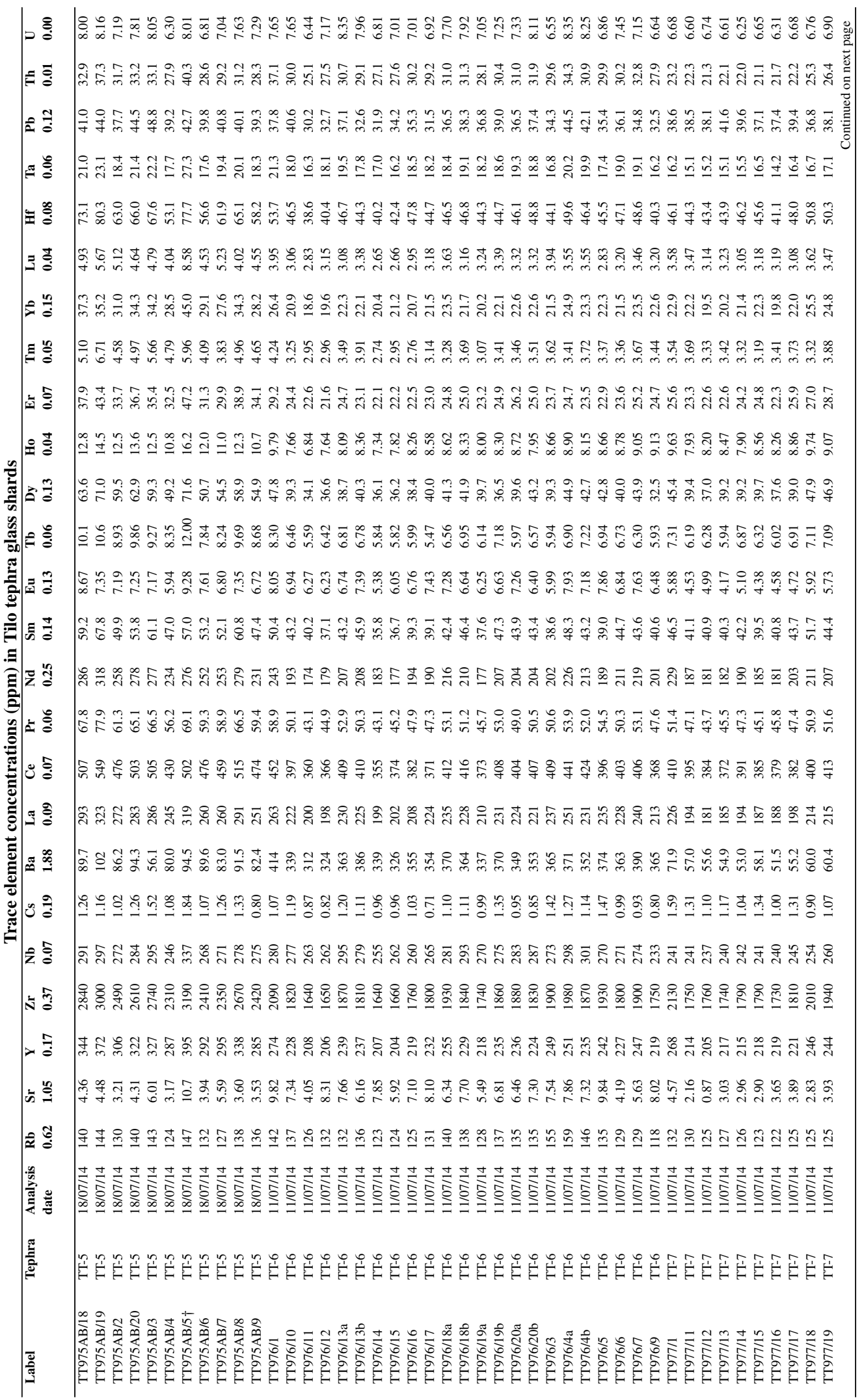




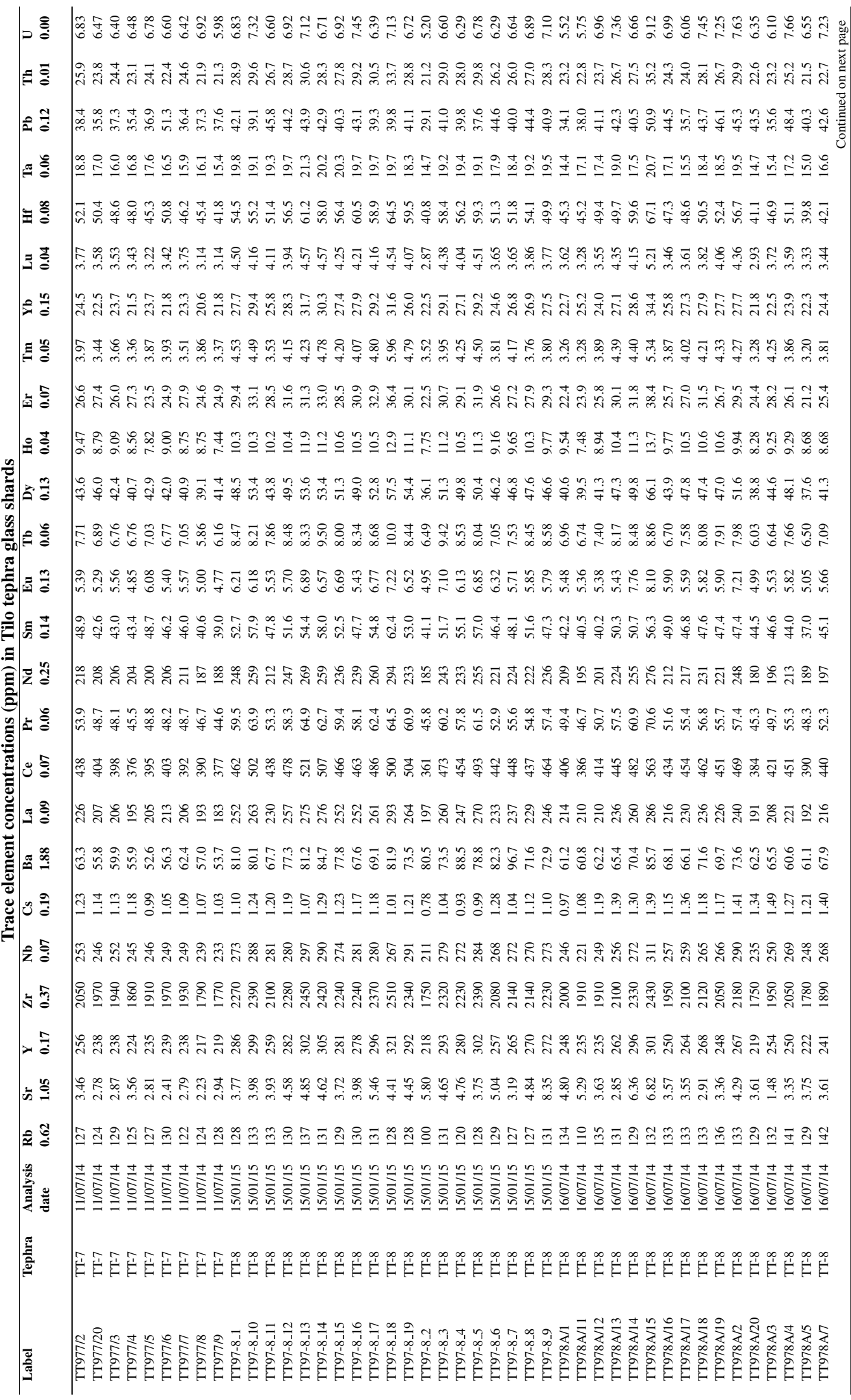




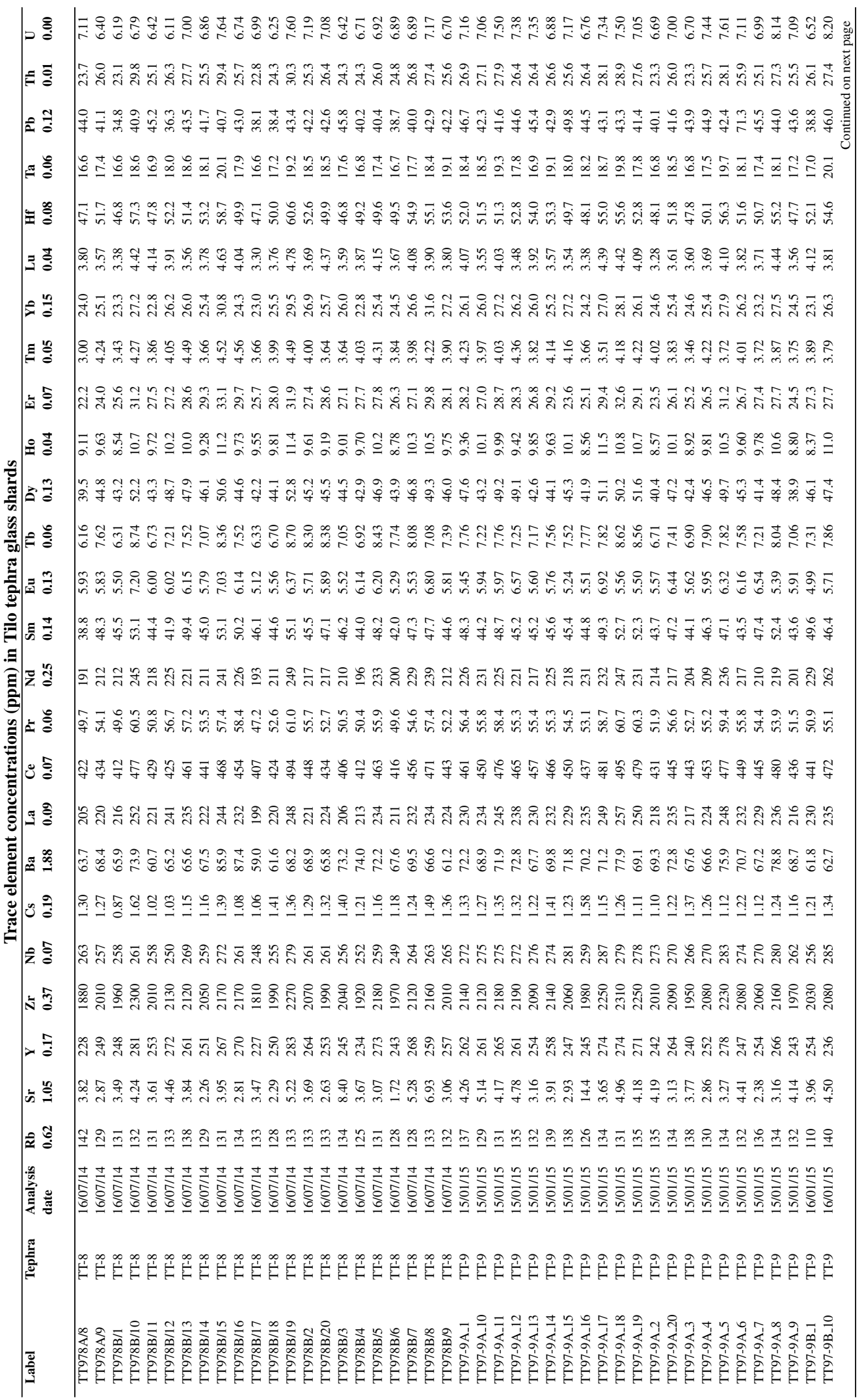




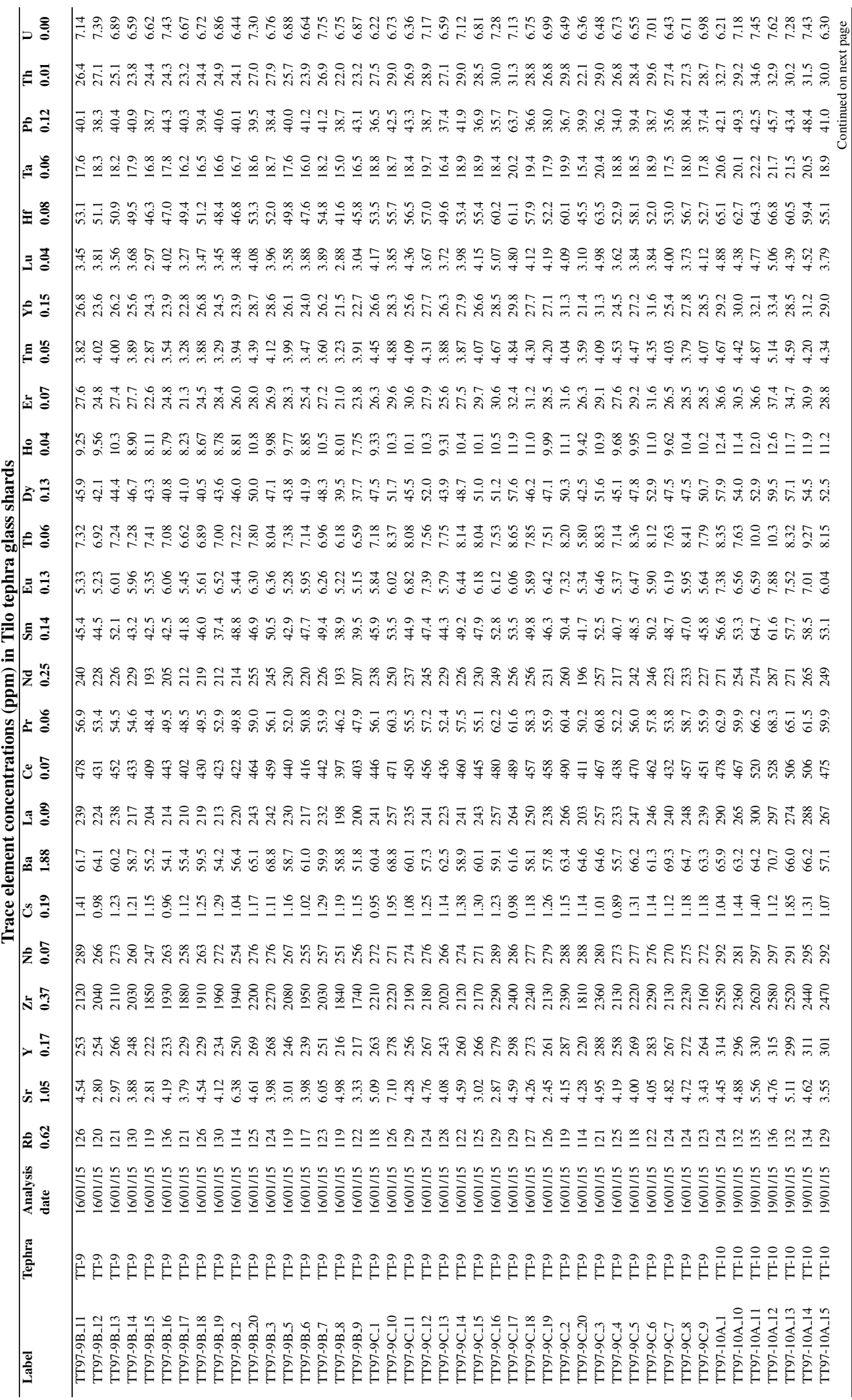




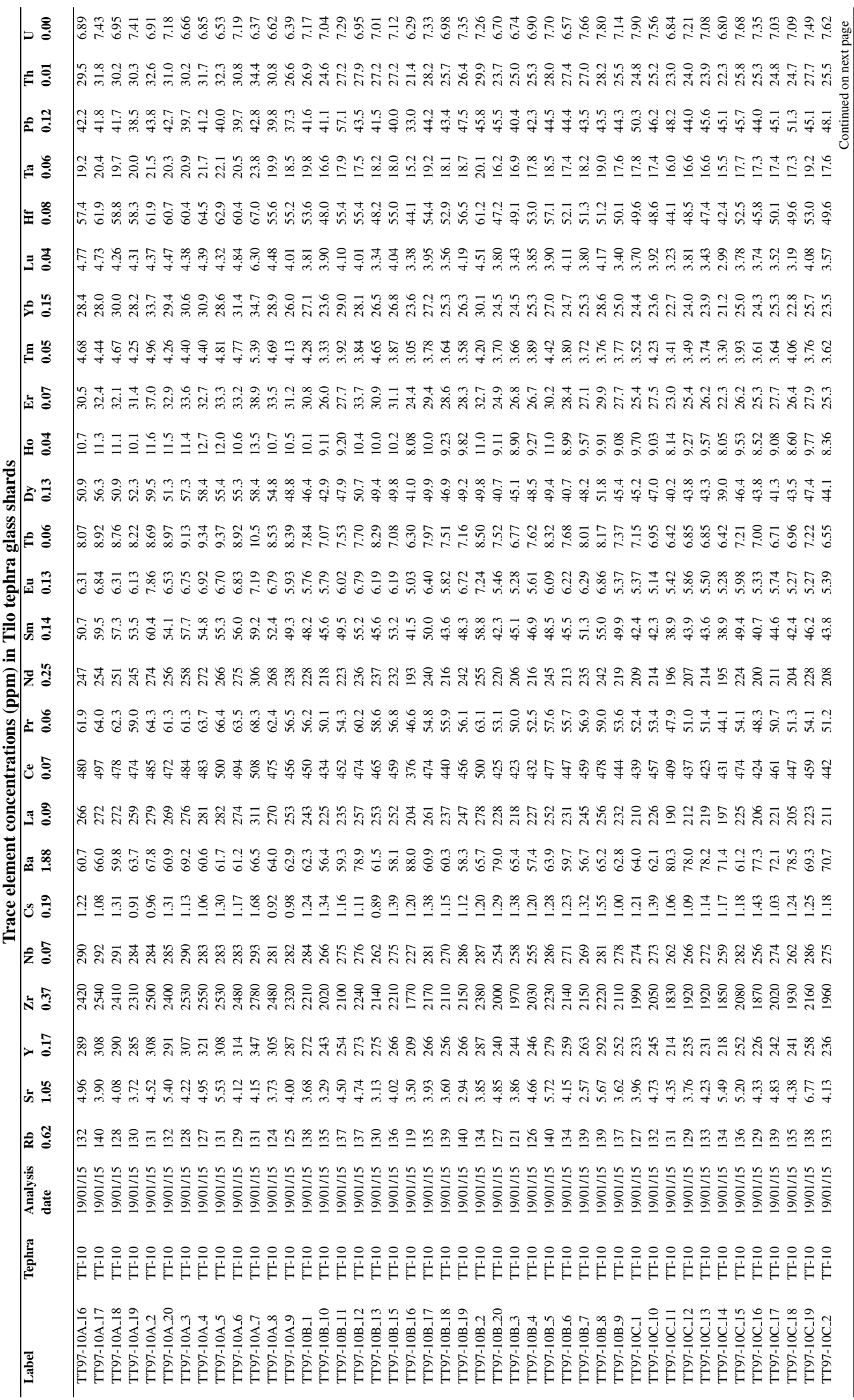




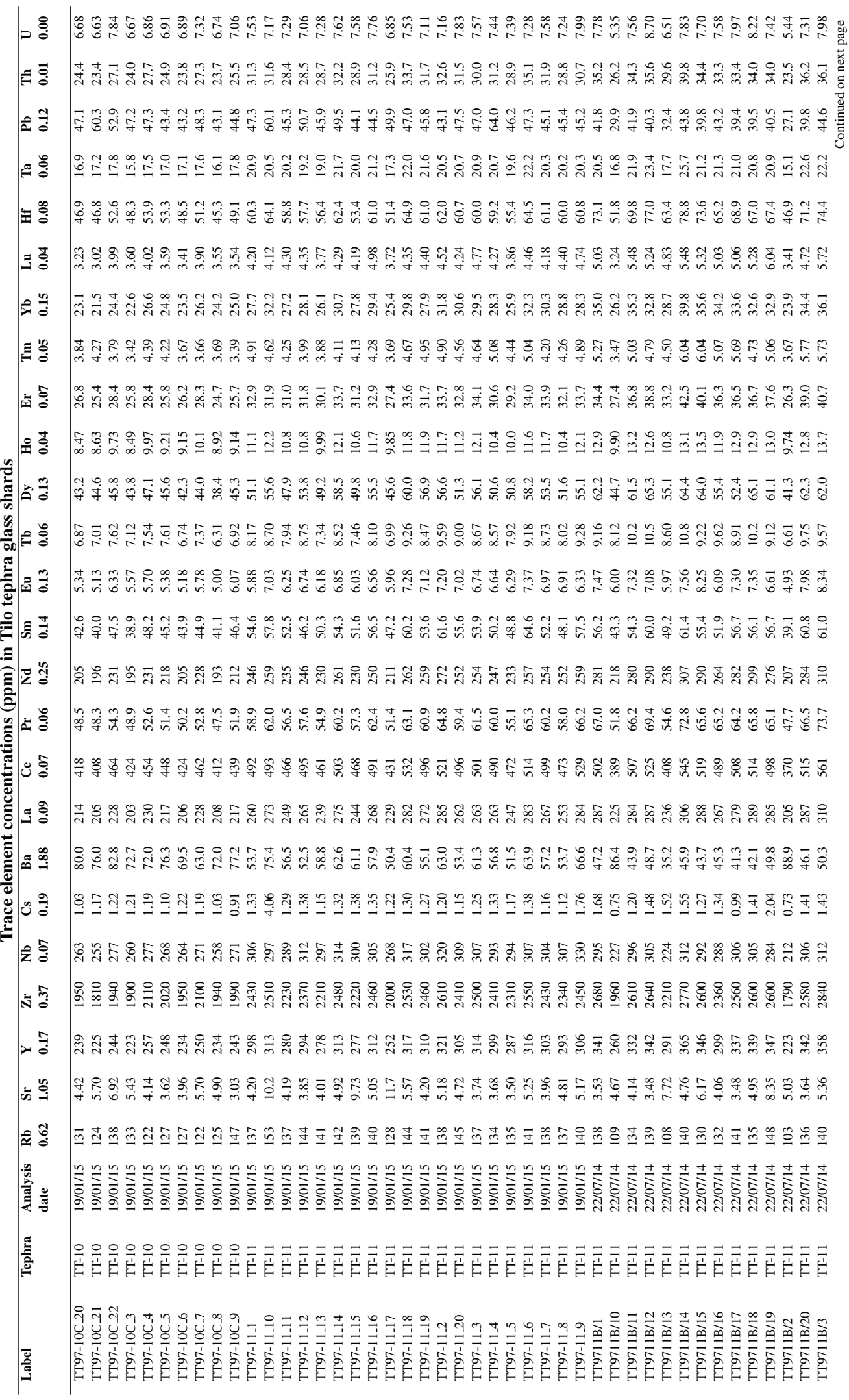




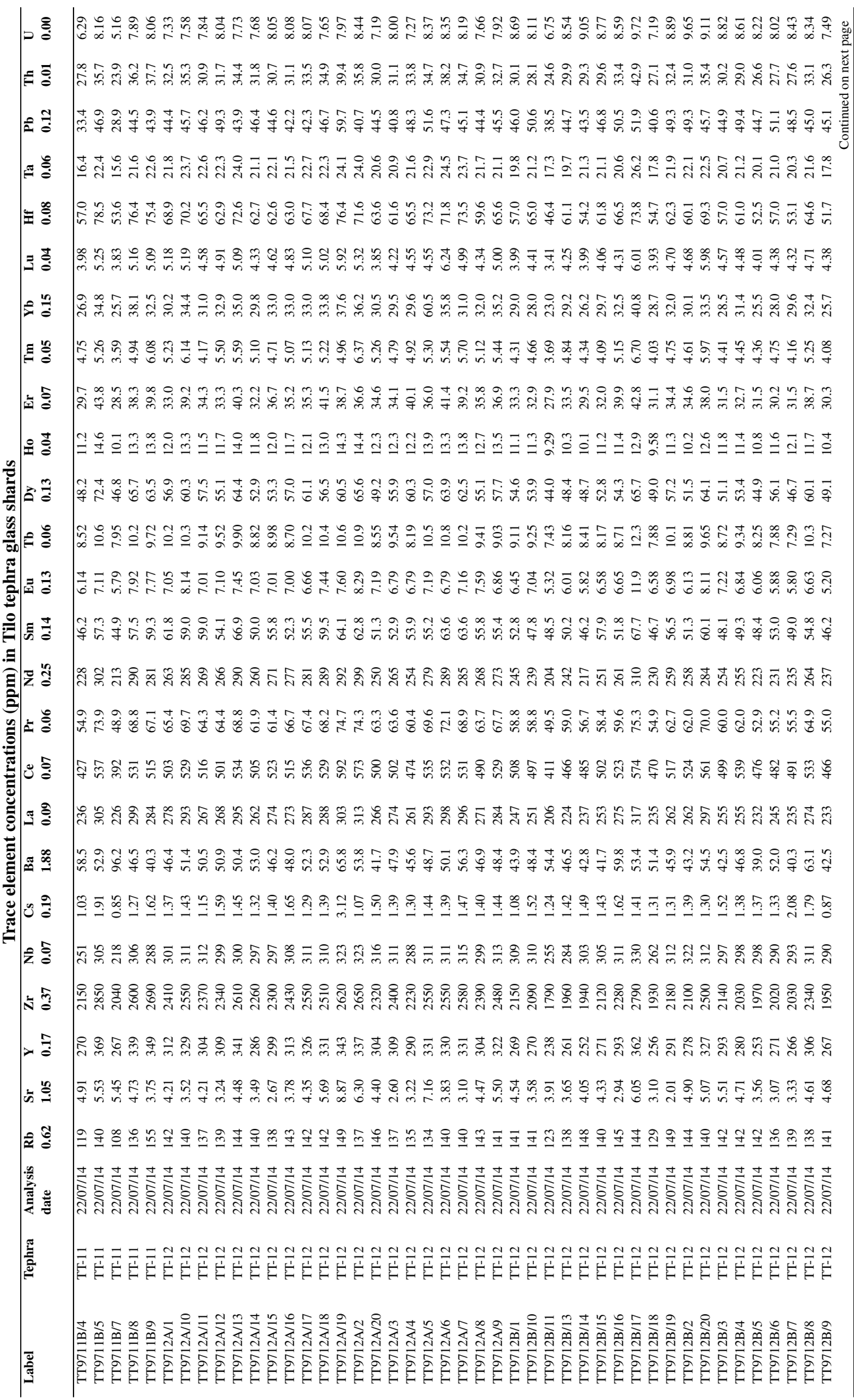




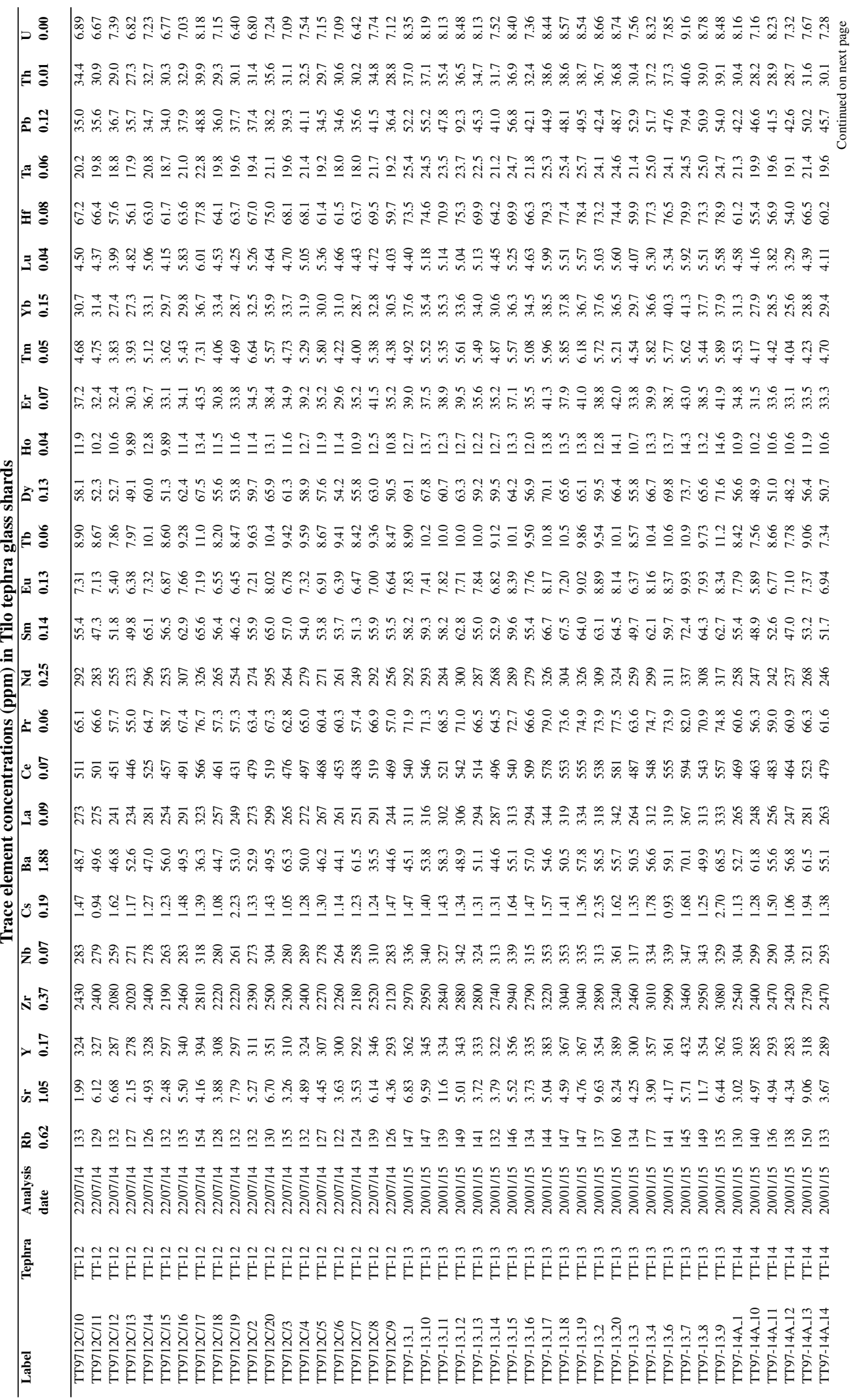




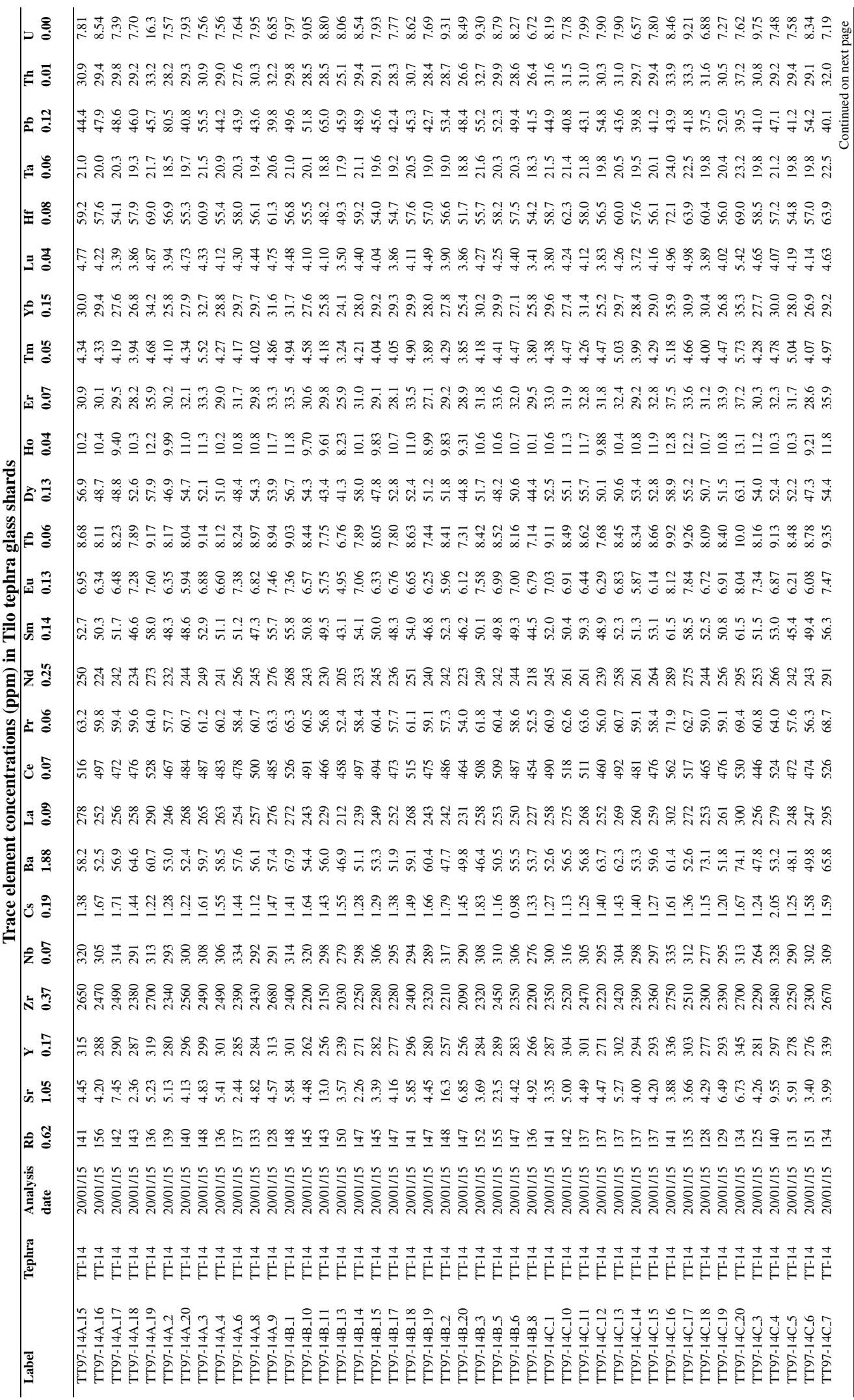




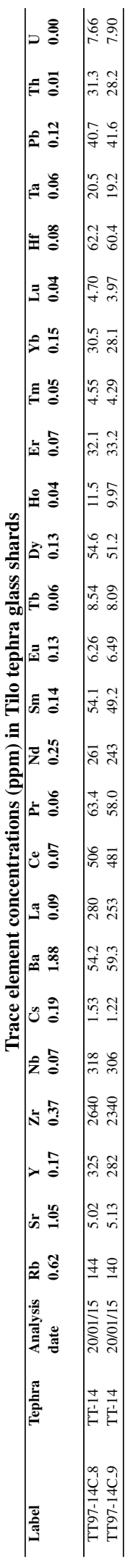


Unnormalised major element concentrations (wt.\%) in Awassa tephra glass shards

\begin{tabular}{|c|c|c|c|c|c|c|c|c|c|c|c|c|c|c|}
\hline Label & Tephra & $\begin{array}{l}\text { Analysis } \\
\text { date }\end{array}$ & $\begin{array}{l}\mathrm{SiO}_{2} \\
\mathbf{0 . 0 8}\end{array}$ & $\begin{array}{l}\mathrm{TiO}_{2} \\
0.05\end{array}$ & $\begin{array}{l}\mathrm{Al}_{2} \mathrm{O}_{3} \\
0.05\end{array}$ & $\begin{array}{l}\text { MgO } \\
0.04\end{array}$ & $\begin{array}{l}\mathrm{FeO}^{T} \\
\mathbf{0 . 0 8}\end{array}$ & $\begin{array}{l}\text { MnO } \\
0.07\end{array}$ & $\begin{array}{l}\mathrm{CaO} \\
0.04\end{array}$ & $\begin{array}{l}\mathrm{Na}_{2} \mathrm{O} \\
0.08\end{array}$ & $\begin{array}{l}\mathrm{K}_{2} \mathrm{O} \\
\mathbf{0 . 0 3}\end{array}$ & $\begin{array}{l}\mathbf{P}_{2} \mathbf{O}_{5} \\
\mathbf{0 . 1 0}\end{array}$ & $\begin{array}{l}\mathrm{Cl} \\
0.02\end{array}$ & Total \\
\hline AT-1_1 & AWT-1 & $26 / 08 / 14$ & 71.52 & 0.24 & 9.95 & 0.00 & 3.50 & 0.14 & 0.23 & 4.21 & 4.56 & 0.00 & & 94.35 \\
\hline AT-1_11 & AWT-1 & $26 / 08 / 14$ & 72.30 & 0.26 & 10.27 & 0.01 & 3.74 & 0.17 & 0.17 & 4.26 & 4.39 & 0.00 & & 95.57 \\
\hline AT-1_12 & AWT-1 & $26 / 08 / 14$ & 71.11 & 0.26 & 10.17 & 0.00 & 3.54 & 0.13 & 0.20 & 4.27 & 4.47 & 0.03 & & 94.18 \\
\hline AT-1_13 & AWT-1 & $26 / 08 / 14$ & 74.66 & 0.26 & 10.42 & 0.02 & 3.72 & 0.15 & 0.19 & 4.70 & 4.46 & 0.00 & & 98.57 \\
\hline AT-1_14 & AWT-1 & $26 / 08 / 14$ & 74.33 & 0.24 & 9.75 & 0.00 & 4.37 & 0.21 & 0.19 & 5.25 & 4.54 & 0.00 & & 98.89 \\
\hline AT-1_15 & AWT-1 & $26 / 08 / 14$ & 71.13 & 0.26 & 8.88 & 0.01 & 5.10 & 0.25 & 0.22 & 4.86 & 4.29 & 0.00 & & 94.99 \\
\hline AT-1_16 & AWT-1 & $26 / 08 / 14$ & 72.00 & 0.22 & 9.82 & 0.00 & 3.79 & 0.20 & 0.22 & 4.90 & 4.35 & 0.00 & & 95.51 \\
\hline AT-1_18 & AWT-1 & $26 / 08 / 14$ & 69.94 & 0.06 & 15.07 & 0.03 & 2.15 & 0.04 & 0.07 & 5.43 & 7.08 & 0.02 & & 99.91 \\
\hline AT-1_3 & AWT-1 & $26 / 08 / 14$ & 69.93 & 0.18 & 9.57 & 0.01 & 3.69 & 0.19 & 0.18 & 4.71 & 4.16 & 0.00 & & 92.63 \\
\hline AT-1_4 & AWT-1 & $26 / 08 / 14$ & 71.57 & 0.30 & 9.41 & 0.01 & 5.83 & 0.31 & 0.29 & 5.76 & 4.31 & 0.00 & & 97.78 \\
\hline AT-1_5 & AWT-1 & $26 / 08 / 14$ & 66.45 & 0.01 & 19.03 & 0.00 & 0.52 & 0.00 & 0.01 & 6.13 & 7.32 & 0.00 & & 99.47 \\
\hline AT-1_6 & AWT-1 & $26 / 08 / 14$ & 67.56 & 0.18 & 8.95 & 0.05 & 5.96 & 0.33 & 0.27 & 5.48 & 3.95 & 0.00 & & 92.72 \\
\hline AT-1_7 & AWT-1 & $26 / 08 / 14$ & 68.73 & 0.22 & 9.64 & 0.02 & 3.81 & 0.12 & 0.21 & 4.29 & 4.56 & 0.02 & & 91.61 \\
\hline AT-1_8 & AWT-1 & $26 / 08 / 14$ & 74.25 & 0.26 & 9.93 & 0.00 & 4.75 & 0.16 & 0.19 & 5.09 & 4.86 & 0.00 & & 99.50 \\
\hline AT-1_9 & AWT-1 & $26 / 08 / 14$ & 69.62 & 0.23 & 9.60 & 0.00 & 3.73 & 0.21 & 0.21 & 3.19 & 5.94 & 0.02 & & 92.76 \\
\hline AT-2_1 & AWT-2 & $26 / 08 / 14$ & 71.66 & 0.17 & 9.16 & 0.00 & 4.47 & 0.27 & 0.18 & 5.09 & 4.19 & 0.03 & & 95.23 \\
\hline AT-2_11 & AWT-2 & $26 / 08 / 14$ & 72.42 & 0.20 & 9.33 & 0.02 & 4.33 & 0.22 & 0.19 & 4.98 & 4.16 & 0.00 & & 95.86 \\
\hline AT-2_12 & AWT-2 & $26 / 08 / 14$ & 71.31 & 0.18 & 9.37 & 0.01 & 4.27 & 0.17 & 0.22 & 4.68 & 4.17 & 0.01 & & 94.37 \\
\hline AT-2_13 & AWT-2 & $26 / 08 / 14$ & 71.15 & 0.19 & 8.92 & 0.01 & 4.42 & 0.26 & 0.20 & 4.91 & 4.28 & 0.04 & & 94.38 \\
\hline AT-2_15 & AWT-2 & $26 / 08 / 14$ & 71.98 & 0.28 & 9.09 & 0.00 & 4.36 & 0.24 & 0.19 & 4.33 & 4.10 & 0.01 & & 94.60 \\
\hline AT-2_16 & AWT-2 & $26 / 08 / 14$ & 71.37 & 0.23 & 9.16 & 0.00 & 4.18 & 0.26 & 0.17 & 5.10 & 4.22 & 0.02 & & 94.70 \\
\hline AT-2_17 & AWT-2 & $26 / 08 / 14$ & 73.09 & 0.23 & 9.31 & 0.01 & 4.32 & 0.24 & 0.17 & 4.73 & 4.21 & 0.00 & & 96.31 \\
\hline AT-2_18 & AWT-2 & $26 / 08 / 14$ & 71.91 & 0.24 & 9.15 & 0.00 & 4.35 & 0.16 & 0.18 & 4.84 & 4.49 & 0.01 & & 95.32 \\
\hline AT-2_19 & AWT-2 & $26 / 08 / 14$ & 71.69 & 0.20 & 9.26 & 0.00 & 4.42 & 0.21 & 0.20 & 4.93 & 4.26 & 0.00 & & 95.18 \\
\hline AT $-2 \_2$ & AWT-2 & $26 / 08 / 14$ & 70.61 & 0.25 & 8.80 & 0.00 & 4.43 & 0.18 & 0.19 & 5.25 & 4.12 & 0.04 & & 93.86 \\
\hline AT $-2 \_3$ & AWT-2 & $26 / 08 / 14$ & 70.05 & 0.22 & 8.89 & 0.01 & 4.14 & 0.27 & 0.17 & 5.02 & 4.27 & 0.02 & & 93.05 \\
\hline AT-2_4 & AWT-2 & $26 / 08 / 14$ & 71.26 & 0.23 & 9.02 & 0.00 & 4.64 & 0.19 & 0.17 & 5.15 & 4.20 & 0.00 & & 94.85 \\
\hline AT-2_8 & AWT-2 & $26 / 08 / 14$ & 70.82 & 0.22 & 9.14 & 0.00 & 4.34 & 0.20 & 0.18 & 4.74 & 4.32 & 0.06 & & 94.02 \\
\hline AT-2_9 & AWT-2 & $26 / 08 / 14$ & 70.02 & 0.23 & 8.87 & 0.00 & 4.24 & 0.23 & 0.20 & 5.17 & 4.27 & 0.02 & & 93.26 \\
\hline AWT_2002_1 & AWT-4 & $29 / 06 / 15$ & 72.31 & 0.20 & 9.55 & 0.00 & 4.59 & 0.18 & 0.15 & 5.09 & 4.29 & 0.05 & 0.24 & 96.65 \\
\hline AWT_2002_2 & AWT-4 & $29 / 06 / 15$ & 73.36 & 0.27 & 9.66 & 0.03 & 4.70 & 0.21 & 0.17 & 5.42 & 4.41 & 0.02 & 0.25 & 98.51 \\
\hline AWT_2002_3 & AWT-4 & $29 / 06 / 15$ & 72.91 & 0.20 & 9.12 & 0.05 & 4.62 & 0.22 & 0.19 & 4.81 & 4.41 & 0.00 & 0.22 & 96.74 \\
\hline AWT_2002_4 & AWT-4 & $29 / 06 / 15$ & 73.26 & 0.28 & 9.38 & 0.02 & 4.67 & 0.21 & 0.20 & 4.93 & 4.42 & 0.02 & 0.24 & 97.63 \\
\hline AWT_2002_5 & AWT-4 & $29 / 06 / 15$ & 72.34 & 0.27 & 9.35 & 0.00 & 4.36 & 0.19 & 0.23 & 5.06 & 4.16 & 0.00 & 0.26 & 96.20 \\
\hline AWT_2002_6 & AWT-4 & $29 / 06 / 15$ & 71.32 & 0.22 & 9.13 & 0.00 & 4.31 & 0.21 & 0.20 & 5.05 & 4.27 & 0.02 & 0.22 & 94.95 \\
\hline AWT_2002_7 & AWT-4 & $29 / 06 / 15$ & 73.32 & 0.22 & 9.39 & 0.06 & 4.54 & 0.23 & 0.28 & 5.05 & 4.09 & 0.03 & 0.22 & 97.42 \\
\hline AWT_2002_8 & AWT-4 & $29 / 06 / 15$ & 72.94 & 0.21 & 9.42 & 0.02 & 4.72 & 0.17 & 0.18 & 5.23 & 4.40 & 0.00 & 0.26 & 97.56 \\
\hline AWT_2002_9 & AWT-4 & $29 / 06 / 15$ & 71.78 & 0.23 & 9.21 & 0.09 & 5.17 & 0.28 & 0.51 & 4.98 & 4.03 & 0.04 & 0.23 & 96.56 \\
\hline AWT_2002_10 & AWT-4 & $29 / 06 / 15$ & 71.67 & 0.24 & 9.20 & 0.00 & 4.57 & 0.23 & 0.18 & 4.96 & 4.35 & 0.00 & 0.21 & 95.60 \\
\hline
\end{tabular}




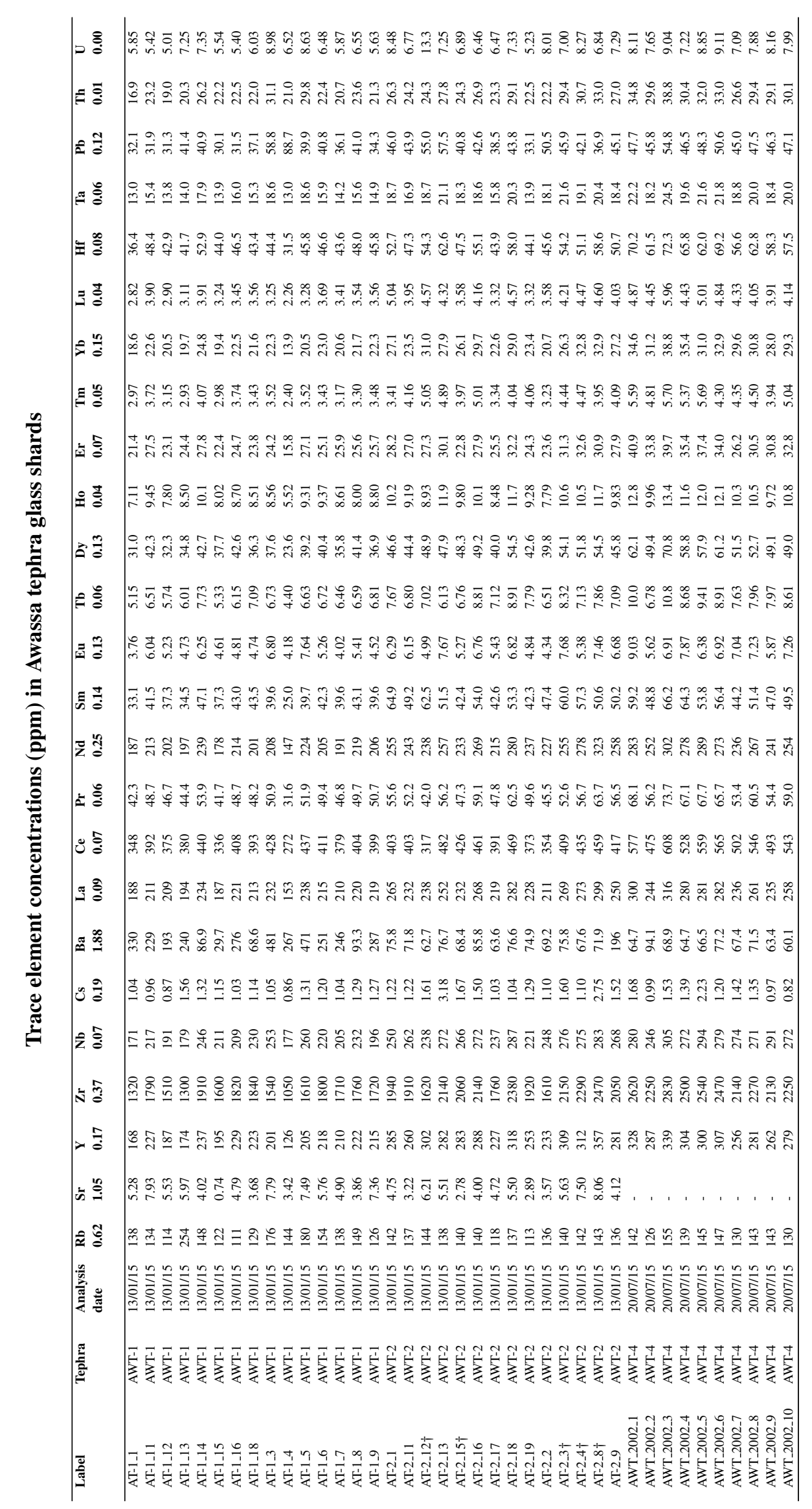


Unnormalised major element concentrations (wt.\%) in Chamo tephra glass shards

\begin{tabular}{|c|c|c|c|c|c|c|c|c|c|c|c|c|c|c|}
\hline Label & Tephra & $\begin{array}{l}\text { Analysis } \\
\text { date }\end{array}$ & $\begin{array}{l}\mathrm{SiO}_{2} \\
\mathbf{0 . 0 8}\end{array}$ & $\begin{array}{l}\mathrm{TiO}_{2} \\
\mathbf{0 . 0 5}\end{array}$ & $\begin{array}{l}\mathrm{Al}_{2} \mathrm{O}_{3} \\
\mathbf{0 . 0 5} \\
\end{array}$ & $\begin{array}{l}\text { MgO } \\
0.04 \\
\end{array}$ & $\begin{array}{l}\mathbf{F e O}^{T} \\
0.08 \\
\end{array}$ & $\begin{array}{l}\text { MnO } \\
0.07 \\
\end{array}$ & $\begin{array}{l}\mathrm{CaO} \\
0.04 \\
\end{array}$ & $\begin{array}{l}\mathrm{Na}_{2} \mathrm{O} \\
0.08 \\
\end{array}$ & $\begin{array}{l}\mathbf{K}_{2} \mathbf{O} \\
\mathbf{0 . 0 3} \\
\end{array}$ & $\begin{array}{l}\mathrm{P}_{2} \mathrm{O}_{5} \\
\mathbf{0 . 1 0}\end{array}$ & $\begin{array}{l}\mathrm{Cl} \\
\mathbf{0 . 0 2}\end{array}$ & Tota \\
\hline CHA_L4_344_10 & CHT-1 & $30 / 06 / 15$ & 70.01 & 0.18 & 9.13 & 0.00 & 4.43 & 0.20 & 0.15 & 5.09 & 4.18 & 0.00 & 0.22 & 93.5 \\
\hline CHA_L4_344_11 & CHT-1 & $30 / 06 / 15$ & 72.67 & 0.20 & 9.55 & 0.00 & 4.40 & 0.24 & 0.15 & 5.26 & 4.27 & 0.00 & 0.19 & 96.95 \\
\hline CHA_L4_344_12 & CHT-1 & /06/15 & 73.72 & 0.21 & 9.53 & 0.00 & 4.53 & 0.13 & 0.19 & 5.21 & 4.25 & 0.00 & 0.21 & 97.99 \\
\hline CHA_L4_344_13 & CHT-1 & /06/15 & 72.19 & 0.21 & 9.27 & 0.00 & 4.34 & 0.27 & 0.14 & 5.02 & 4.29 & 0.00 & 0.24 & 95.98 \\
\hline CHA_L4_344_14 & CHT-1 & $/ 06 / 15$ & 70.39 & 0.24 & 9.12 & 0.01 & 4.55 & 0.20 & 0.17 & 4.98 & 4.14 & 0.00 & 0.25 & 94.05 \\
\hline CHA_L4_344_15 & CHT-1 & /06/15 & 71.82 & 0.26 & 9.44 & 0.01 & 4.57 & 0.24 & 0.21 & 5.09 & 4.24 & 0.04 & 0.19 & 96.12 \\
\hline CHA_L4_344_16 & CHT-1 & $06 / 15$ & 68.72 & 0.21 & 8.86 & 0.00 & 4.07 & 0.21 & 0.17 & 4.95 & 4.11 & 0.01 & 0.35 & 91.66 \\
\hline CHA_L4_344_17 & CHT & 0615 & 72.16 & 0.26 & 9.48 & 0.00 & 4.34 & 0.22 & 0.18 & 5.02 & 4.29 & 0.00 & 0.20 & 96.14 \\
\hline CHA_L4_344_18 & CHT-1 & 15 & 73.53 & 0.20 & 9.39 & 0.03 & 4.19 & 0.17 & 0.16 & 5.29 & 3.98 & 0.00 & 0.17 & 97.12 \\
\hline CHA_L4_344_19 & CHT-1 & $66 / 15$ & 69.09 & 0.29 & 9.06 & 0.04 & 4.50 & 0.17 & 0.17 & 4.73 & 4.18 & 0.06 & 0.27 & 92.55 \\
\hline CHA_L4_344_2 & CHT-1 & $06 / 15$ & 71.85 & 0.22 & 9.19 & 0.00 & 4.52 & 0.20 & 0.18 & 4.91 & 4.10 & 0.01 & 0.24 & 95.42 \\
\hline $344 \_20$ & CHT- 1 & 15 & 72.86 & 0.24 & 9.48 & 0.05 & 4.42 & 0.26 & 0.18 & 5.10 & 4.35 & 0.00 & 0.24 & 97.18 \\
\hline 44_4 & CHT-1 & & 70.84 & 0.19 & 8.99 & 0.06 & 4.60 & 0.17 & 0.18 & 5.10 & 4.32 & 0.00 & 0.23 & 94.69 \\
\hline $344 \_5$ & CHT-1 & $66 / 15$ & 73.04 & 0.25 & 9.55 & 0.00 & 4.41 & 0.15 & 0.17 & 5.36 & 4.16 & 0.00 & 0.22 & 97.31 \\
\hline & CHT-1 & & 71.63 & 0.25 & 9.53 & 0.00 & 4.24 & 0.12 & 0.20 & 4.63 & 4.28 & 0.00 & 0.29 & 95.17 \\
\hline & CHT & 15 & 71.31 & 0.1 & 9.16 & 0. & 4.58 & 0.1 & 0.1 & 4.99 & 4.28 & 0.01 & 0.23 & 95.06 \\
\hline 44_1 & CHT- & & 69.92 & 0.16 & 8.94 & 0.0 & 4.5 & 0.16 & 0.13 & 5.04 & 4.06 & 0.00 & 0.24 & 93.23 \\
\hline 44_11 & CHT- & $6 / 15$ & 68.60 & 0.18 & 859 & 00 & 4.40 & 02 & 0.17 & 5.30 & 3.85 & 0.01 & 0.27 & 91.56 \\
\hline 4.12 & CHT- & & 70.56 & 0.17 & 8.74 & 0.01 & 4.60 & 0.22 & 0.16 & 5.25 & 4.13 & 0.00 & 0.26 & 94.09 \\
\hline -_44_13 & CHT- & $06 / 15$ & 71.61 & 0.17 & 9.01 & 0.01 & 4.35 & 0.23 & 0.17 & 5.32 & 4.23 & 0.07 & 0.27 & 95.45 \\
\hline 4_14 & $\mathrm{CHT}$ & & 72.05 & 0.17 & 004 & 00 & 4.81 & ? & 0.16 & 5.41 & 4.16 & 0 & 029 & 96.39 \\
\hline $44 \_15$ & CHT- & & 70.84 & 0.19 & 8.77 & 0. & 4.66 & 0.28 & 0.21 & 5.50 & 4.25 & 0.00 & 0.28 & 94.99 \\
\hline & CHT & & 70.50 & 0.18 & 885 & 0.00 & 4.39 & 014 & 0.17 & 5.36 & 4.04 & 0.00 & 026 & 93.92 \\
\hline -44_17 & CHT-2 & 15 & 71.79 & 0.17 & 8.93 & 0.02 & 4.58 & 0.17 & 0.14 & 3.82 & 4.14 & 0.00 & 0.24 & 94.00 \\
\hline & CHT & & 70.92 & 0.19 & 9.04 & & & & 0.18 & & 4.01 & & & 95.16 \\
\hline _19 & CHT & & 71.39 & 0. & 8.94 & 0. & 4. & 0. & 0. & 5. & 4.12 & 0.03 & 0.29 & 95.47 \\
\hline & CHT & & 70.39 & 0. & 8.90 & 0. & 4. & 0. & 0.1 & 5. & 4.07 & 0.01 & 0.24 & 93.86 \\
\hline & CHT & & 72.37 & 0.1 & 9.16 & 00 & 4.8 & 0.1 & 0.1 & 5.37 & 4.11 & 0.02 & 0.29 & 96.56 \\
\hline CHA & $\mathrm{CHT}$ & 15 & 71.98 & 0.2 & 9.27 & 0. & 4.67 & 0.24 & 0.1 & 5.32 & 4.29 & 0.00 & 0.27 & 96.45 \\
\hline & & & & & & & & & & 5.6 & 4.03 & & & \\
\hline CHA_L12_44_5 & CHT & 15 & 70.92 & 0.13 & 8.73 & 0. & 4.92 & 0.21 & 0.14 & 5.42 & 4.14 & 0.07 & 0.30 & 94.99 \\
\hline & & & 70.71 & 0.13 & 9.08 & & 4.74 & 0.28 & 0.16 & 5.46 & 4.13 & & & \\
\hline CHA_L12_44_7 & CHT- & 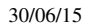 & 71.04 & 0.13 & 9.17 & 0. & 4.81 & 0.17 & 0.13 & 5.68 & 4.17 & 0.00 & 0.28 & 95.58 \\
\hline CHA & CHT-2 & & 71.89 & 0.21 & 9.07 & 0.00 & 4.56 & 0.23 & 0.12 & 5.24 & 4.18 & 0.00 & 0.28 & $0=-7$ \\
\hline CHA_L12_44_9 & CHT-2 & $30 / 06 / 15$ & 71.36 & 0.18 & 8.99 & 0.00 & 4.68 & 0.18 & 0.17 & 5.81 & 4.02 & 0.00 & 0.28 & 95.6 \\
\hline
\end{tabular}




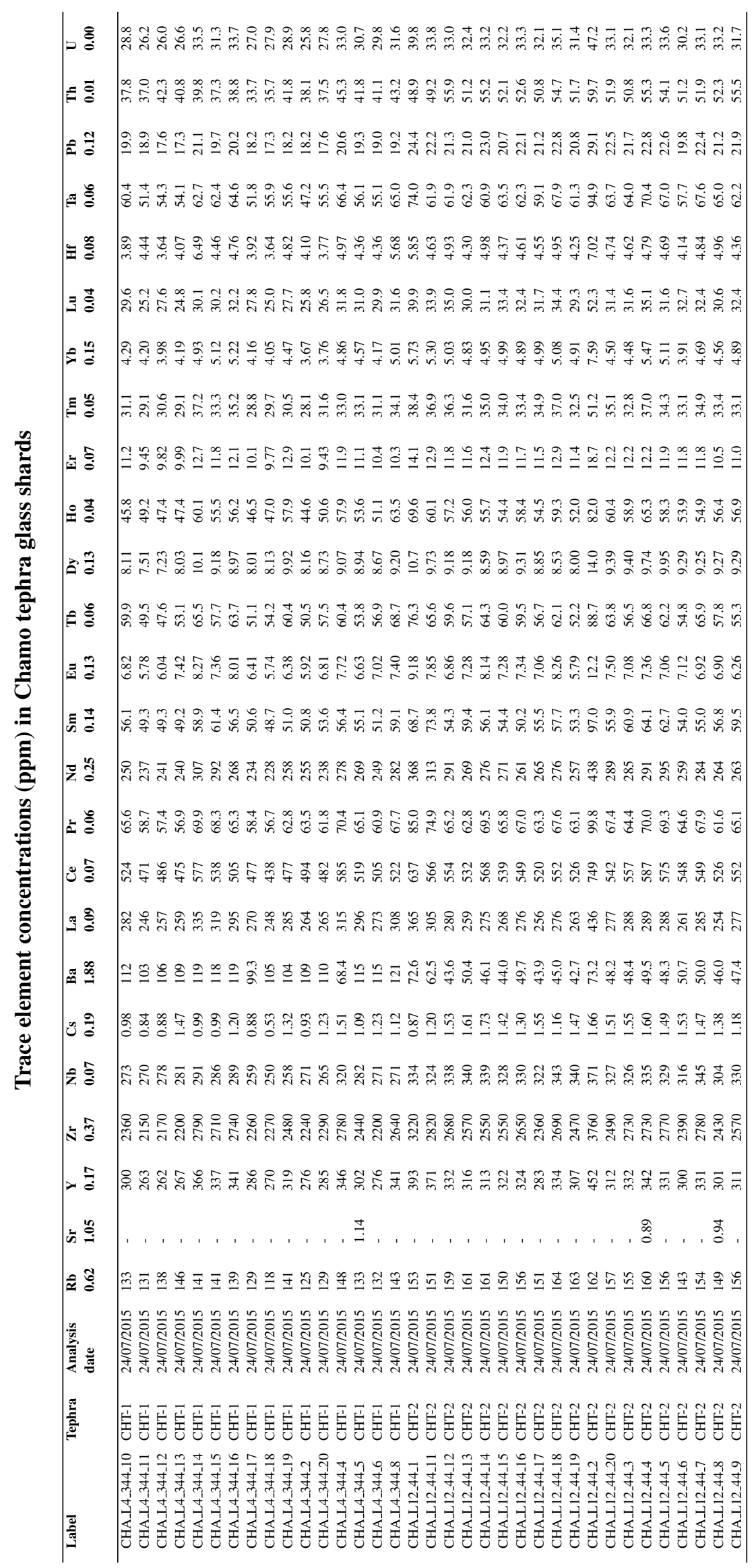


The major and trace element composition of tephras and obsidian samples from the Corbetti caldera are given in the following two tables. Obsidian samples E950010, E950011, E950019 and E950025 were analysed for only trace elements. Average silica concentrations, determined previously by N. Pearce (Aberystwyth University) using EPMA at the University of Toronto, were used as internal standards for LA-ICP-MS analysis.

Limits of detection for all EPMA sessions are given on page 401, the median limits of detection for ATHO-G are given for comparison in the following table headings. Most major elements are present at concentrations above these limits of detection, however, concentrations of $\mathrm{MgO}$ and $\mathrm{P}_{2} \mathrm{O}_{5}$ are below the LLD in many shards.

Trace element analyses were typically undertaken using $20 \mu \mathrm{m}$ crater diameters, however, findicates glass shards were analysed using $10 \mu \mathrm{m}$ crater diameters. Lower limits of detection (LLD) for LA-ICP-MS analyses are given on page 407 . The median LLD concentrations at $20 \mu \mathrm{m}$ crater diameters of all LA-ICP-MS analytical sessions are given beneath each analyte heading in the following tables. Due to high $\mathrm{Sr}$ and Ba concentrations in the gas blanks, coupled with frequent low sample concentrations, some negative concentrations were measured - these are indicated with a dash. Analyses of MPI-DING reference materials were used to check the EPMA and LA-ICP-MS calibrations. These analyses are given on page 398, and are ordered by analysis date.

Unnormalised major element concentrations (wt.\%) in tephra and obsidian samples from Corbetti

\begin{tabular}{|c|c|c|c|c|c|c|c|c|c|c|c|c|c|c|}
\hline Label & Tephra & $\begin{array}{l}\text { Analysis } \\
\text { date }\end{array}$ & $\begin{array}{l}\mathrm{SiO}_{2} \\
0.08\end{array}$ & $\begin{array}{l}\mathrm{TiO}_{2} \\
0.05\end{array}$ & $\begin{array}{l}\mathrm{Al}_{2} \mathrm{O}_{3} \\
0.05\end{array}$ & $\begin{array}{l}\text { MgO } \\
0.04\end{array}$ & $\begin{array}{l}\mathrm{FeO}^{T} \\
0.08\end{array}$ & $\begin{array}{l}\text { MnO } \\
0.07\end{array}$ & $\begin{array}{l}\mathrm{CaO} \\
0.04\end{array}$ & $\begin{array}{l}\mathrm{Na}_{2} \mathrm{O} \\
0.08\end{array}$ & $\begin{array}{l}\mathrm{K}_{2} \mathrm{O} \\
\mathbf{0 . 0 3}\end{array}$ & $\begin{array}{l}\mathbf{P}_{2} \mathbf{O}_{5} \\
0.10\end{array}$ & $\begin{array}{l}\mathrm{Cl} \\
0.02\end{array}$ & Total \\
\hline STNW-1_1 & ST-NW1 & $28 / 08 / 14$ & 74.45 & 0.26 & 9.41 & 0.01 & 4.39 & 0.20 & 0.20 & 5.24 & 4.44 & 0.00 & & 98.60 \\
\hline STNW-1_10 & ST-NW1 & $28 / 08 / 14$ & 73.82 & 0.28 & 9.32 & 0.00 & 4.34 & 0.25 & 0.17 & 5.54 & 4.47 & 0.01 & & 98.21 \\
\hline STNW-1_11 & ST-NW1 & $28 / 08 / 14$ & 74.30 & 0.26 & 9.57 & 0.02 & 4.36 & 0.25 & 0.15 & 5.25 & 4.39 & 0.01 & & 98.56 \\
\hline STNW-1_12 & ST-NW1 & $28 / 08 / 14$ & 73.64 & 0.22 & 9.78 & 0.00 & 4.42 & 0.18 & 0.17 & 5.19 & 4.27 & 0.04 & & 97.91 \\
\hline STNW-1_13 & ST-NW1 & $28 / 08 / 14$ & 73.59 & 0.25 & 9.44 & 0.00 & 4.39 & 0.20 & 0.18 & 5.31 & 4.30 & 0.04 & & 97.70 \\
\hline STNW-1_14 & ST-NW1 & $28 / 08 / 14$ & 71.10 & 0.29 & 10.58 & 0.01 & 4.25 & 0.18 & 0.17 & 5.14 & 4.11 & 0.01 & & 95.84 \\
\hline STNW-1_16 & ST-NW1 & $28 / 08 / 14$ & 73.81 & 0.28 & 9.53 & 0.02 & 4.63 & 0.20 & 0.18 & 5.35 & 4.39 & 0.01 & & 98.42 \\
\hline & & & & & & & & & & & \multicolumn{4}{|c|}{ Continued on next page } \\
\hline
\end{tabular}


Unnormalised major element concentrations (wt.\%) in tephra and obsidian samples from Corbetti

\begin{tabular}{|c|c|c|c|c|c|c|c|c|c|c|c|c|c|c|}
\hline Label & Tephra & $\begin{array}{l}\text { Analysis } \\
\text { date }\end{array}$ & $\begin{array}{l}\mathrm{SiO}_{2} \\
\mathbf{0 . 0 8}\end{array}$ & $\begin{array}{l}\mathrm{TiO}_{2} \\
\mathbf{0 . 0 5} \\
\end{array}$ & $\begin{array}{l}\mathrm{Al}_{2} \mathrm{O}_{3} \\
\mathbf{0 . 0 5} \\
\end{array}$ & $\begin{array}{l}\text { MgO } \\
0.04\end{array}$ & $\begin{array}{l}\mathrm{FeO}^{T} \\
0.08\end{array}$ & $\begin{array}{l}\text { MnO } \\
0.07 \\
\end{array}$ & $\begin{array}{l}\mathrm{CaO} \\
0.04 \\
\end{array}$ & $\begin{array}{l}\mathrm{Na}_{2} \mathrm{O} \\
\mathbf{0 . 0 8} \\
\end{array}$ & $\begin{array}{l}\mathrm{K}_{2} \mathrm{O} \\
0.03 \\
\end{array}$ & $\begin{array}{l}\mathbf{P}_{2} \mathbf{O}_{5} \\
\mathbf{0 . 1 0}\end{array}$ & $\begin{array}{l}\mathrm{Cl} \\
\mathbf{0 . 0 2} \\
\end{array}$ & Total \\
\hline STNW-1_17 & ST-NW1 & $28 / 08 / 14$ & 73.30 & 0.26 & 9.81 & 0.00 & 4.43 & 0.32 & 0.26 & 5.07 & 4.31 & 0.00 & & 97.77 \\
\hline STNW-1_18 & ST-NW1 & $28 / 08 / 14$ & 73.83 & 0.21 & 9.42 & 0.01 & 4.66 & 0.15 & 0.22 & 5.18 & 4.38 & 0.00 & & 98.07 \\
\hline STNW-1_19 & ST-NW1 & $28 / 08 / 14$ & 74.34 & 0.25 & 9.63 & 0.00 & 4.59 & 0.27 & 0.19 & 5.54 & 4.46 & 0.02 & & 99.28 \\
\hline STNW-1_2 & ST-NW1 & $28 / 08 / 14$ & 72.38 & 0.24 & 9.16 & 0.00 & 4.65 & 0.18 & 0.18 & 5.25 & 4.36 & 0.04 & & 96.44 \\
\hline STNW-1_20 & ST-NW1 & $28 / 08 / 14$ & 74.19 & 0.23 & 9.79 & 0.00 & 4.64 & 0.13 & 0.19 & 5.34 & 4.58 & 0.00 & & 99.09 \\
\hline STNW-1_3 & ST-NW1 & $28 / 08 / 14$ & 70.10 & 0.21 & 9.72 & 0.01 & 4.25 & 0.22 & 0.19 & 4.69 & 4.10 & 0.03 & & 93.52 \\
\hline STNW-1_5 & ST-NW1 & $28 / 08 / 14$ & 67.88 & 0.29 & 8.92 & 0.00 & 4.22 & 0.19 & 0.21 & 5.04 & 4.09 & 0.02 & & 90.86 \\
\hline STNW-1_6 & ST-NW1 & $28 / 08 / 14$ & 74.57 & 0.25 & 9.65 & 0.00 & 4.25 & 0.21 & 0.20 & 5.07 & 4.26 & 0.03 & & 98.50 \\
\hline STNW-1_7 & ST-NW1 & $28 / 08 / 14$ & 72.43 & 0.21 & 9.14 & 0.00 & 4.19 & 0.20 & 0.16 & 5.08 & 4.43 & 0.00 & & 95.84 \\
\hline STNW-1_8 & ST-NW1 & $28 / 08 / 14$ & 72.33 & 0.25 & 9.54 & 0.00 & 4.64 & 0.16 & 0.17 & 4.93 & 4.29 & 0.02 & & 96.34 \\
\hline STNW-1_9 & ST-NW1 & $28 / 08 / 14$ & 73.60 & 0.28 & 9.58 & 0.00 & 4.33 & 0.23 & 0.18 & 5.57 & 4.35 & 0.00 & & 98.13 \\
\hline E95007_13 & E95007 & $28 / 08 / 14$ & 69.92 & 0.24 & 10.44 & 0.05 & 3.35 & 0.13 & 0.22 & 4.27 & 4.86 & 0.00 & & 93.49 \\
\hline E95007_3 & E95007 & $28 / 08 / 14$ & 70.31 & 0.32 & 9.10 & 0.02 & 4.96 & 0.20 & 0.21 & 3.35 & 3.96 & 0.01 & & 92.45 \\
\hline E97003_1 & E95003 & $28 / 08 / 14$ & 68.21 & 0.36 & 7.95 & 0.03 & 5.32 & 0.28 & 0.17 & 4.81 & 4.55 & 0.00 & & 91.67 \\
\hline E97003_3 & E95003 & $28 / 08 / 14$ & 71.25 & 0.40 & 8.54 & 0.01 & 5.33 & 0.29 & 0.18 & 5.10 & 4.38 & 0.00 & & 95.47 \\
\hline E97003_9 & E95003 & $28 / 08 / 14$ & 72.20 & 0.24 & 8.72 & 0.05 & 5.51 & 0.24 & 0.17 & 3.84 & 4.39 & 0.02 & & 95.38 \\
\hline
\end{tabular}




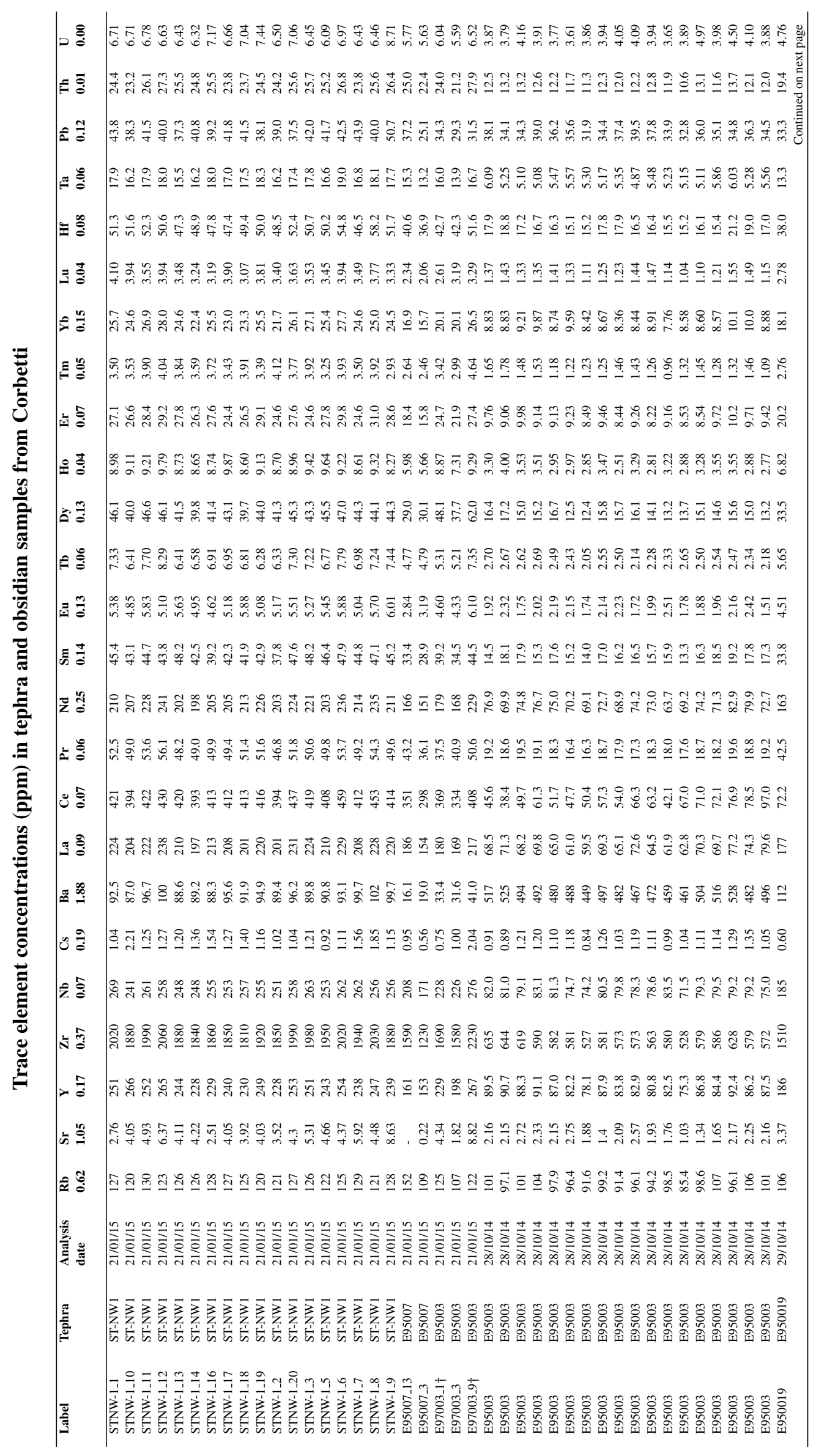




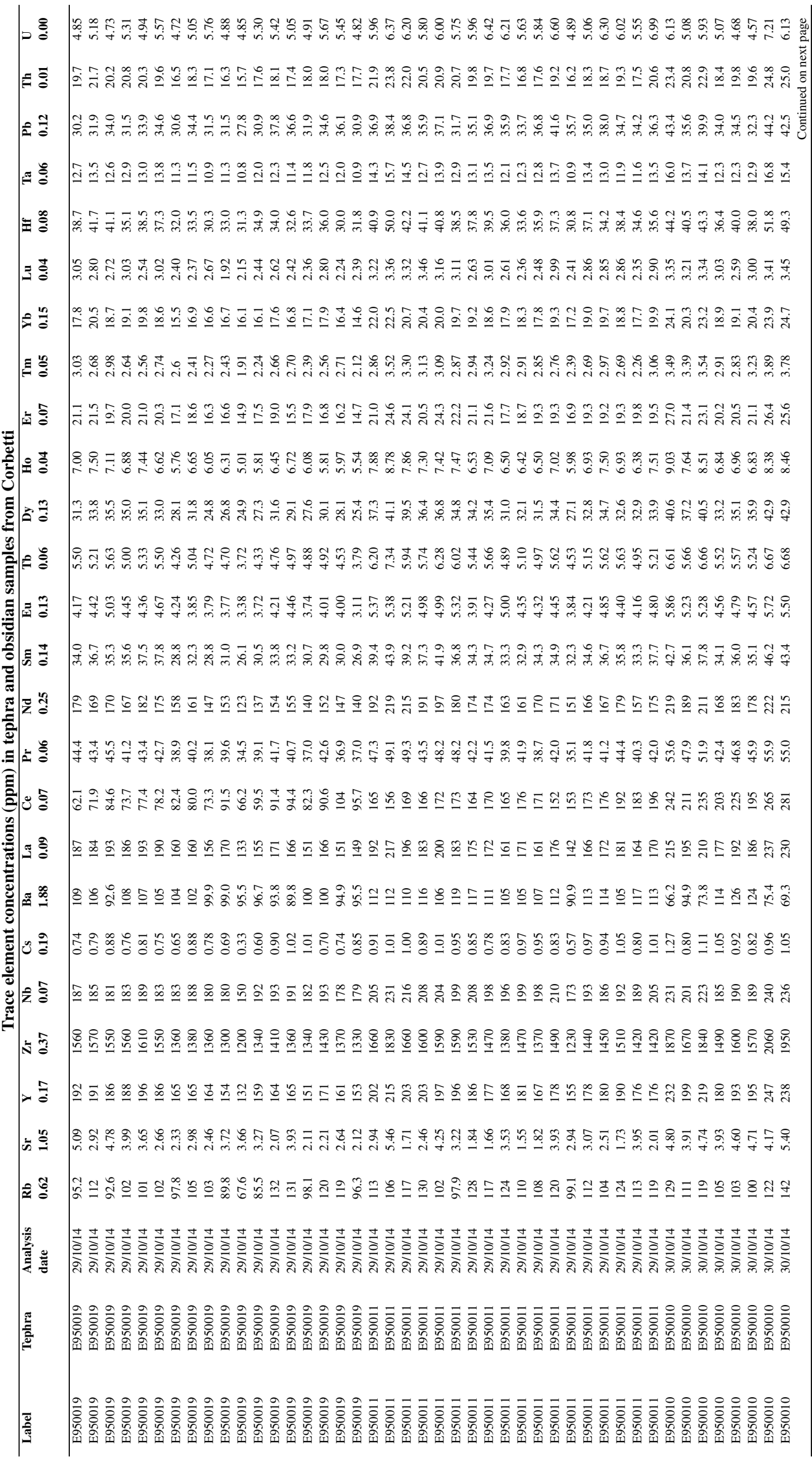




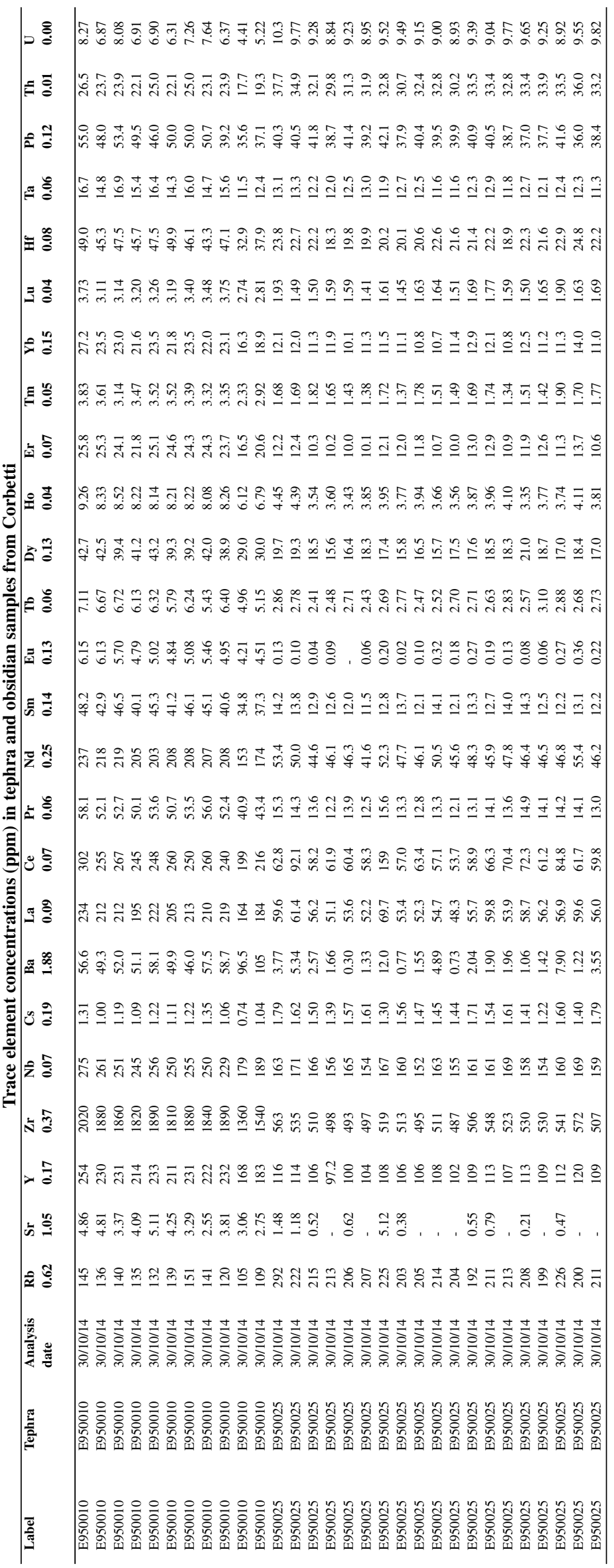




\subsection{Bayesian age models}

The following pages show the OxCal (Bronk Ramsey, 2009b) code and Bayesian age models for the Awassa, Tilo and Chamo sediments. These P_sequences were generated in OxCal using outlier analysis. These models have been corrected for the presence of $<70 \mathrm{~cm}$ thick tephras in the archives, which are assumed to have been deposited instantaneously. The age ranges for these tephras were calculated using the Date function. 


\section{Awassa}

Awassa OxCal Script

P_sequence model with outlier analysis

Options()

BCAD=FALSE;

PlusMinus=FALSE;

(1)

Plot()

Outlier_Model("General",T(5),U(0,4),"t");

P_Sequence("'",1,0.1, U(-2,2))

Boundary()

$z=1068.5$;

Date("14c 4",6270,130)

Outlier(0.05)

$\mathrm{z}=1025.5$

Date("AWT5")

$z=980$

\};

Date("AWT4")

$\mathrm{z}=827$

\};

Date("AWT3")

$z=790$

$\mathrm{z}=79$

R_Date("14c 3",4500,110)

Outlier(0.05)

$\mathrm{z}=669.5$;

Date("AWT2")

$\mathrm{z}=532$

R_te("14c 2", 3180,90)

Outlier(0.05)

$\mathrm{z}=508$

R_Date("14c 1",1450,80)

Outlier(0.05);

$z=245$;

Date("AWT1")

$z=239$;

Boundary()

\{

\}

\section{OxCal output}

\begin{tabular}{lccrr} 
& Unmodelled (BP) & \multicolumn{2}{c}{ Modelled (BP) } \\
\hline Boundary & & & 795 & -1713 \\
AWT1 & & & 1542 & 1119 \\
R_Date 14c 1 & 1535 & 1187 & 1546 & 1190 \\
R_Date 14c 2 & 3609 & 3174 & 3630 & 3215 \\
AWT2 & & & 4089 & 3261 \\
R_Date 14c 3 & \multirow{2}{*}{5463} & \multirow{2}{*}{4855} & 5430 & 4481 \\
AWT3 & & & 6309 & 5524 \\
AWT4 & & & 6563 & 5443 \\
AWT5 & & & 7340 & 6470 \\
R_Date 14c 4 & \multirow{2}{*}{7433} & 6859 & 7496 & 6885 \\
Boundary & & & 8098 & 6972 \\
P_Sequence Tilo1 & -2 & 2 & -2.02 & 1.412
\end{tabular}

\section{OxCal age model}

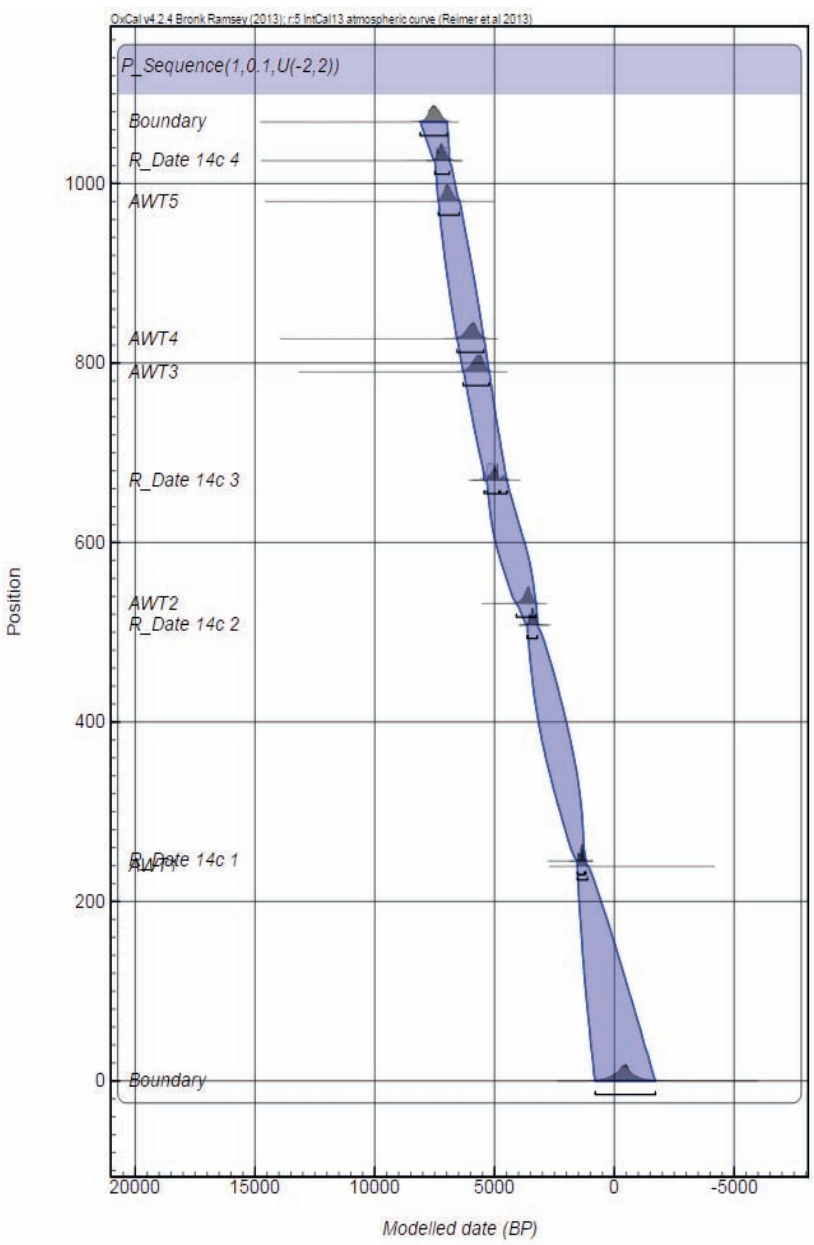


Tilo

Tilo OxCal Script __sequence model with outlier analysis

OxCal output

Options()

BCAD=FALSE;
PlusMinus=FALSE;

Plot()

Outlier_Model|"General",T(T),U(0,4),"t" P_Sequencel"Tilo1", $1,0.0 .05,(-(-2,2)$ )

Boundary()

$z=2117$;

R_Date("14c 7",8840,50)

Outlier(0.05)

z=2083.5;

i=2039;

R_Date("14c 6",7930,90)

Outlier(0.05):

$\mathrm{z}=1579 ;$
li

${ }_{2=1438 ;}$

R_Date("14c 5",6880,50)

Outlier(0.05):

z=1109.5;

$z=735$;

R_Date("14c 4",5520,80)

Outlier(0.05);

$\mathrm{z}=659 ;$
D
Date("Tा11",

i $=618.5$;

Date("דा10", )

$z=571$;

R_Date("14c 3",4140,60)

Outlier(0.05);
$z=485.5 ;$
b;

Datel""TT9",

$z=479$;

Date("TT8",

$z=356$;

Date("TT7",)

$\mathrm{z}=351$;

R_Date("14c 2",2400,50

Outlier(0.05);
$z=314 ;$

bate("Tा6", )

z=288;

Date("TT5",)

$z=260$;

z=260;
Date("TT4",

$z=245.5$

ze245.5;
Date("TT3",

z=213;

Date("TT2", )

\}$_{z=195.5 ;}$

R_Date("14c 1",1390,50

Outlier(0.05):
$\mathrm{z}=175.5$;

bi:
Date("TT1", )

$z=98.5$;

Boundary(Date(N(1995,1)))

$\mathrm{z}=0$;

\begin{tabular}{|c|c|c|c|c|}
\hline & Unmodelle & & Modell & (BP) \\
\hline Boundary & -42 & -46 & -42 & -46 \\
\hline$\pi 1$ & & & 1308 & 52 \\
\hline R_Date $14 \mathrm{c} 1$ & 1390 & 1186 & 1394 & 1185 \\
\hline$\pi 2$ & & & 2066 & 1184 \\
\hline тा3 & & & 2318 & 1243 \\
\hline$\pi 4$ & & & 2480 & 1295 \\
\hline$\pi 5$ & & & 2600 & 1347 \\
\hline тा6 & & & 2699 & 1586 \\
\hline R_Date $14 c 2$ & 2702 & 2342 & 2703 & 2340 \\
\hline$\pi 7$ & & & 3974 & 2346 \\
\hline Тт8 & & & 4081 & 2350 \\
\hline Тт9 & & & 4853 & 3928 \\
\hline R_Date $14 c 3$ & 4836 & 4522 & 4837 & 4451 \\
\hline$\pi 10$ & & & 6280 & 4701 \\
\hline П11 & & & 6432 & 5060 \\
\hline R_Date $14 \mathrm{c} 4$ & 6492 & 6125 & 6480 & 6018 \\
\hline ТT12 & & & 7051 & 6151 \\
\hline R_Date $14 \mathrm{c} 5$ & 7828 & 7617 & 7827 & 7613 \\
\hline Тт13 & & & 7827 & 7613 \\
\hline R_Date $14 c 6$ & 9010 & 8559 & 9011 & 8562 \\
\hline T14 & & & 10175 & 9394 \\
\hline R_Date $14 c 7$ & 10159 & 9705 & 10187 & 9696 \\
\hline Boundary & & & 11086 & 9681 \\
\hline P_Sequence Tilo1 & -2 & 2 & -2.033 & -1.6673 \\
\hline
\end{tabular}

\section{OxCal age model}

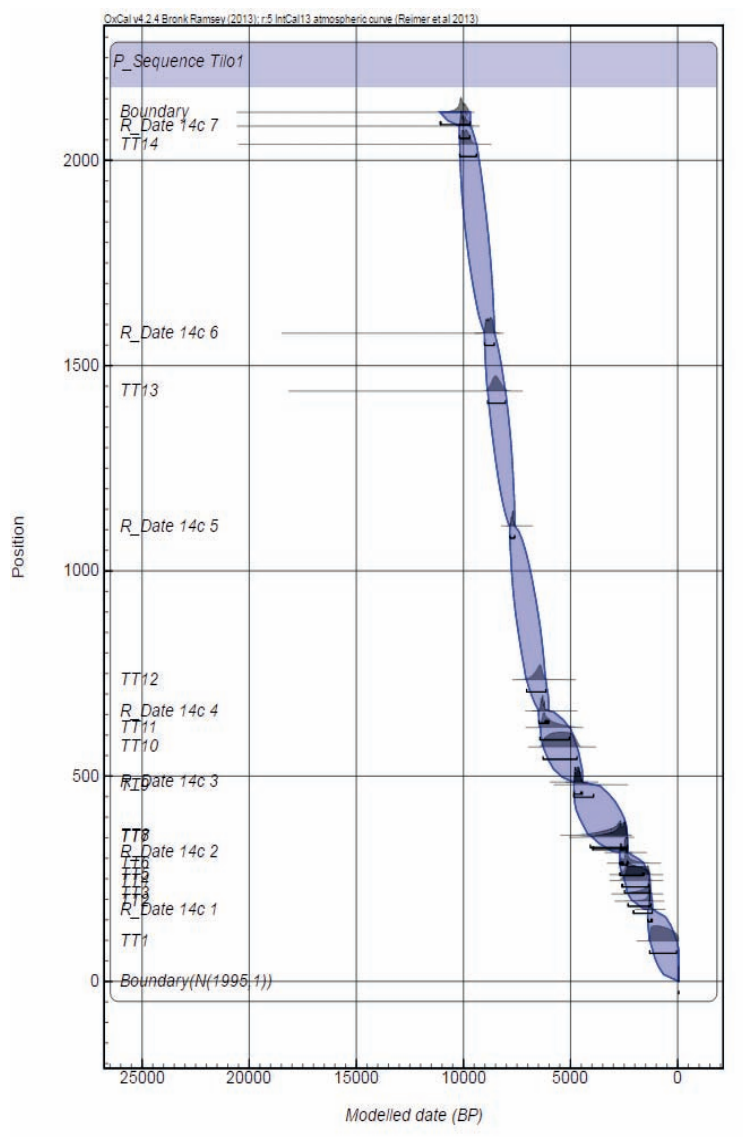




\section{Chamo}

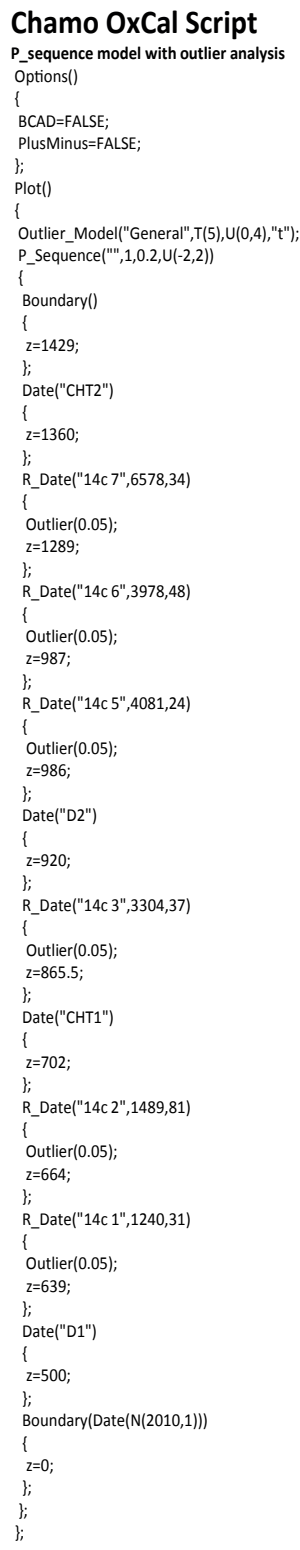

\section{OxCal output}

\begin{tabular}{lcrrr} 
& \multicolumn{3}{c}{ Unmodelled (BP) } & \multicolumn{2}{c}{ Modelled (BP) } \\
\hline Boundary & -57 & -61 & -58 & -62 \\
AWT1 & & & 1542 & 1119 \\
R_Date 14C 1 & 1267 & 1073 & 1280 & 1088 \\
R_Date 14C 2 & 1551 & 1282 & 1540 & 1240 \\
CHT1 & & & 2793 & 1236 \\
R_Date 14C 3 & 3632 & 3450 & 3631 & 3450 \\
R_Date 14C 5 & 4801 & 4447 & 4872 & 4438 \\
R_Date 14C 6 & 4570 & 4260 & 4782 & 4440 \\
R_Date 14C 7 & 7562 & 7427 & 7581 & 5063 \\
CHT2 & & & 9378 & 5356 \\
Boundary & & & 10264 & 5644 \\
P_Sequence Chamc & -2 & 2 & -2.02 & -1.648
\end{tabular}

\section{OxCal age model}

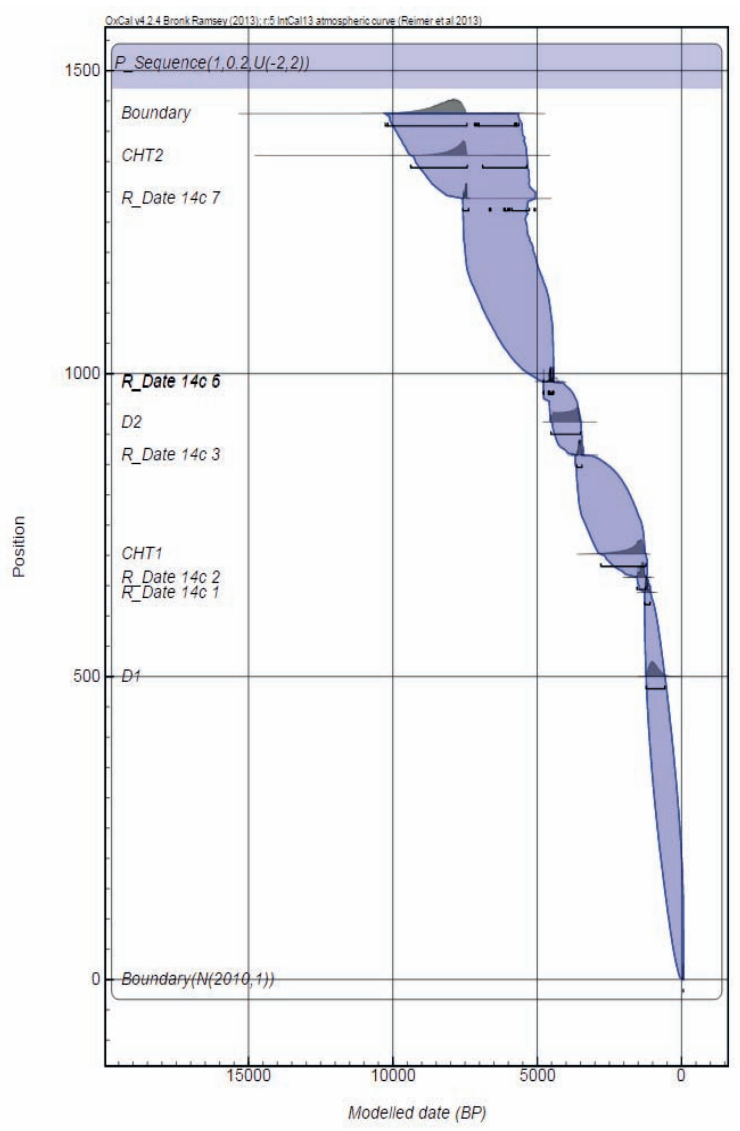




\section{.6 Other outcrop samples}

In order to provide greater potential for correlation to source volcanoes, numerous tephra samples from outcrops throughout Ethiopia have been analyses as part of this work. The majority of these outcrop samples have provided an insight into the possible provenance of tephras in archives. However, samples from the Mochena Borago archaeological site (collected by S. Meyer, University of Cologne) were later found to be unsuitable for comparison with Holocene tephras studied here. This is due to uncertainty over the ages of the Mochena Borago tephras, with ages ranging from $\sim 3$ Ma to Holocene within single tephras. It is possible that these tephras have been reworked, and their stratigraphic integrity compromised. Tephra samples from Ayelu, collected by G. WoldeGabriel (Los Alamos National Laboratory), are late Pleistocene, and significantly older than the Holocene samples identified in this work. Activity from a volcanic centre over this time span would not occur. Nonetheless, these glass analyses are included below, and it is hoped future studies may benefit from these data. Major element glass data are presented to 2 decimal places, trace element data are presented to 3 significant figures. Average silica concentrations in the Ayelu samples, previously determined by G. WoldeGabriel using EPMA, were used as internal standards for LA-ICP-MS analysis.

Limits of detection for all EPMA sessions are given on page 401, the median limits of detection for ATHO-G are given for comparison in the following table headings. Most major elements are present at concentrations above these limits of detection, however, concentrations of $\mathrm{MgO}$ and $\mathrm{P}_{2} \mathrm{O}_{5}$ are below the LLD in many shards.

Trace element analyses were typically undertaken using $20 \mu \mathrm{m}$ crater diameters, however, findicates glass shards were analysed using $10 \mu \mathrm{m}$ crater 
diameters. Lower limits of detection (LLD) for LA-ICP-MS analyses are given on page 407 . The median LLD concentrations at $20 \mu \mathrm{m}$ crater diameters of all LA-ICP-MS analytical sessions are given beneath each analyte heading in the following tables. Due to high $\mathrm{Sr}$ and Ba concentrations in the gas blanks, coupled with frequent low sample concentrations, some negative concentrations were measured - these are indicated with a dash. Analyses of MPI-DING reference materials were used to check the EPMA and LA-ICP-MS calibrations. These analyses are given on page 398 , and are ordered by analysis date.

Unnormalised major element concentrations (wt.\%) in tephra samples from Mochena Borago

\begin{tabular}{|c|c|c|c|c|c|c|c|c|c|c|c|c|c|c|}
\hline Label & Tephra & $\begin{array}{l}\text { Analysis } \\
\text { date }\end{array}$ & $\begin{array}{l}\mathrm{SiO}_{2} \\
0.08\end{array}$ & $\begin{array}{l}\mathrm{TiO}_{2} \\
0.05 \\
\end{array}$ & $\begin{array}{l}\mathrm{Al}_{2} \mathbf{O}_{3} \\
\mathbf{0 . 0 5} \\
\end{array}$ & $\begin{array}{l}\text { MgO } \\
0.04 \\
\end{array}$ & $\begin{array}{l}\mathrm{FeO}^{T} \\
\mathbf{0 . 0 8} \\
\end{array}$ & $\begin{array}{l}\text { MnO } \\
0.07 \\
\end{array}$ & $\begin{array}{l}\mathrm{CaO} \\
0.04 \\
\end{array}$ & $\begin{array}{l}\mathrm{Na}_{2} \mathrm{O} \\
0.08 \\
\end{array}$ & $\begin{array}{l}\mathbf{K}_{2} \mathbf{O} \\
\mathbf{0 . 0 3} \\
\end{array}$ & $\begin{array}{l}\mathbf{P}_{2} \mathbf{O}_{5} \\
0.10\end{array}$ & $\begin{array}{l}\mathrm{Cl} \\
0.02 \\
\end{array}$ & Total \\
\hline MB_3_1 & M14 0.75m SE & $30 / 06 / 15$ & 70.18 & 0.23 & 9.98 & 0.00 & 3.60 & 0.12 & 0.20 & 2.57 & 4.89 & 0.00 & 0.18 & 91.95 \\
\hline MB_3_2 & M14 0.75m SE & $30 / 06 / 15$ & 71.94 & 0.19 & 9.98 & 0.00 & 4.10 & 0.20 & 0.18 & 5.40 & 4.46 & 0.01 & 0.22 & 96.67 \\
\hline MB_3_4 & M14 0.75m SE & $30 / 06 / 15$ & 70.39 & 0.20 & 9.67 & 0.00 & 3.54 & 0.14 & 0.22 & 2.58 & 4.64 & 0.01 & 0.16 & 91.54 \\
\hline MB_3_6 & M14 0.75m SE & $30 / 06 / 15$ & 71.19 & 0.20 & 9.33 & 0.00 & 4.58 & 0.17 & 0.20 & 4.99 & 4.21 & 0.03 & 0.25 & 95.15 \\
\hline MB_2_-1 & M14 $0.47 \mathrm{~m} \mathrm{SW}$ & $30 / 06 / 15$ & 72.52 & 0.16 & 9.10 & 0.00 & 4.71 & 0.20 & 0.15 & 5.45 & 4.15 & 0.04 & 0.26 & 96.72 \\
\hline MB__2_2 & M14 $0.47 \mathrm{~m} \mathrm{SW}$ & $30 / 06 / 15$ & 71.52 & 0.21 & 8.93 & 0.00 & 4.69 & 0.23 & 0.12 & 5.06 & 4.06 & 0.04 & 0.25 & 95.11 \\
\hline MB_2_3 & M14 $0.47 \mathrm{~m} \mathrm{SW}$ & $30 / 06 / 15$ & 72.78 & 0.12 & 9.36 & 0.02 & 4.90 & 0.20 & 0.15 & 5.52 & 4.28 & 0.00 & 0.27 & 97.60 \\
\hline MB_2_4 & M14 $0.47 \mathrm{~m} \mathrm{SW}$ & $30 / 06 / 15$ & 73.01 & 0.17 & 9.20 & 0.00 & 4.95 & 0.24 & 0.19 & 5.59 & 4.23 & 0.00 & 0.27 & 97.87 \\
\hline MB_2_5 & M14 $0.47 \mathrm{~m} \mathrm{SW}$ & $30 / 06 / 15$ & 72.55 & 0.17 & 9.15 & 0.00 & 4.63 & 0.31 & 0.18 & 5.36 & 4.32 & 0.01 & 0.30 & 96.98 \\
\hline MB_2_6 & M14 $0.47 \mathrm{~m} \mathrm{SW}$ & $30 / 06 / 15$ & 72.28 & 0.14 & 8.90 & 0.00 & 5.16 & 0.29 & 0.16 & 5.51 & 4.24 & 0.00 & 0.26 & 96.93 \\
\hline MB_2_-7 & M14 $0.47 \mathrm{~m} \mathrm{SW}$ & $30 / 06 / 15$ & 72.35 & 0.15 & 9.05 & 0.00 & 4.78 & 0.19 & 0.13 & 5.72 & 4.07 & 0.01 & 0.29 & 96.74 \\
\hline MB_2_8 & M14 0.47m SW & $30 / 06 / 15$ & 73.13 & 0.14 & 9.03 & 0.01 & 4.71 & 0.26 & 0.20 & 3.57 & 4.20 & 0.00 & 0.29 & 95.54 \\
\hline MB_2_9 & M14 $0.47 \mathrm{~m} \mathrm{SW}$ & $30 / 06 / 15$ & 71.85 & 0.12 & 8.97 & 0.00 & 5.04 & 0.26 & 0.15 & 5.57 & 4.07 & 0.03 & 0.28 & 96.32 \\
\hline MB_2_10 & M14 $0.47 \mathrm{~m} \mathrm{SW}$ & $30 / 06 / 15$ & 72.17 & 0.19 & 9.05 & 0.00 & 4.72 & 0.14 & 0.20 & 5.36 & 4.28 & 0.00 & 0.25 & 96.37 \\
\hline MB_2_11 & M14 $0.47 \mathrm{~m} \mathrm{SW}$ & $30 / 06 / 15$ & 72.21 & 0.14 & 9.13 & 0.03 & 4.57 & 0.26 & 0.15 & 5.33 & 4.25 & 0.01 & 0.26 & 96.34 \\
\hline MB_2_12 & M14 $0.47 \mathrm{~m} \mathrm{SW}$ & $30 / 06 / 15$ & 70.10 & 0.19 & 8.93 & 0.00 & 4.50 & 0.33 & 0.15 & 5.43 & 4.08 & 0.03 & 0.27 & 94.02 \\
\hline MB_2_13 & M14 $0.47 \mathrm{~m} \mathrm{SW}$ & $30 / 06 / 15$ & 72.82 & 0.15 & 9.11 & 0.00 & 4.84 & 0.21 & 0.16 & 5.59 & 4.06 & 0.00 & 0.27 & 97.21 \\
\hline MB_2_14 & M14 $0.47 \mathrm{~m} \mathrm{SW}$ & $30 / 06 / 15$ & 72.49 & 0.18 & 9.22 & 0.00 & 4.92 & 0.25 & 0.19 & 5.61 & 4.20 & 0.01 & 0.27 & 97.33 \\
\hline MB_2_15 & $77 \mathrm{~m} \mathrm{SW}$ & $30 / 06 / 15$ & 72.65 & 0.19 & 9.42 & 0.00 & 4.84 & 0.22 & 0.24 & 5.52 & 4.32 & 0.03 & 0.25 & 97.70 \\
\hline MB_2_17 & M14 $0.47 \mathrm{~m} \mathrm{SW}$ & $30 / 06 / 15$ & 72.46 & 0.12 & 9.02 & 0.05 & 4.72 & 0.19 & 0.19 & 5.46 & 4.15 & 0.00 & 0.32 & 96.67 \\
\hline MB_2_18 & M14 $0.47 \mathrm{~m} \mathrm{SW}$ & $30 / 06 / 15$ & 70.22 & 0.16 & 8.85 & 0.00 & 4.83 & 0.22 & 0.15 & 5.01 & 4.08 & 0.03 & 0.22 & 93.76 \\
\hline MB_2_19 & M14 $0.47 \mathrm{~m} \mathrm{SW}$ & $30 / 06 / 15$ & 72.37 & 0.14 & 9.21 & 0.00 & 4.97 & 0.21 & 0.18 & 5.64 & 4.12 & 0.02 & 0.26 & 97.12 \\
\hline MB_2_20 & M14 $0.47 \mathrm{~m} \mathrm{SW}$ & $30 / 06 / 15$ & 72.38 & 0.14 & 9.29 & 0.00 & 4.40 & 0.13 & 0.13 & 5.66 & 4.24 & 0.02 & 0.28 & 96.67 \\
\hline TU2_1 & TU2 BWT & 03/07/15 & 68.54 & 0.25 & 9.32 & 0.00 & 4.46 & 0.21 & 0.15 & 4.91 & 4.20 & 0.00 & 0.20 & 92.23 \\
\hline TU2_10 & TU2 BWT & 03/07/15 & 72.34 & 0.20 & 9.44 & 0.00 & 4.91 & 0.24 & 0.14 & 5.14 & 4.13 & 0.00 & 0.23 & 96.77 \\
\hline TU2_11 & TU2 B & 03/07/15 & 69.97 & 0.20 & 8.97 & 0.00 & 4.52 & 0.16 & 0.17 & 4.97 & 4.17 & 0.03 & 0.19 & 93.34 \\
\hline TU2_13 & TU2 BWT & $03 / 07 / 15$ & 71.96 & 0.22 & 9.68 & 0.00 & 4.63 & 0.10 & 0.15 & 5.10 & 4.29 & 0.03 & 0.19 & 96.35 \\
\hline TU2_14 & TU2 I & $03 / 07 / 15$ & 68.65 & 0.17 & 9.03 & 0.00 & 4.42 & 0.22 & 0.23 & 5.23 & 4.24 & 0.01 & 0.25 & 92.45 \\
\hline TU2_15 & TU2 $\mathrm{I}$ & 3/07/15 & 68.75 & 0.18 & 9.03 & 0.01 & 4.29 & 0.20 & 0.19 & 4.94 & 4.16 & 0.00 & 0.21 & 91.97 \\
\hline TU2_17† & TU2 BWT & $03 / 07 / 15$ & 70.23 & 0.20 & 9.19 & 0.03 & 4.33 & 0.27 & 0.15 & 5.34 & 4.24 & 0.09 & 0.19 & 94.27 \\
\hline TU2_19 & TU2 BWT & 3/07/15 & 70.56 & 0.27 & 9.26 & 0.00 & 4.51 & 0.23 & 0.22 & 4.94 & 4.14 & 0.04 & 0.23 & 94.41 \\
\hline TU2_20 & TU2 BWT & $3 / 07 / 15$ & 69.26 & 0.22 & 9.17 & 0.00 & 4.21 & 0.21 & 0.21 & 5.17 & 4.15 & 0.00 & 0.20 & 92.80 \\
\hline TU2_21† & TU2 B & $3 / 07 / 15$ & 71.10 & 0.17 & 9.51 & 0.00 & 4.55 & 0.24 & 0.17 & 5.19 & 4.26 & 0.00 & 0.20 & 95.40 \\
\hline TU2_22 & TU2 BWT & 3/07/15 & 69.75 & 0.14 & 9.54 & 0.00 & 3.71 & 0.04 & 0.09 & 4.86 & 3.95 & 0.00 & 0.15 & 92.23 \\
\hline TU2_23 & TU2 BWT & $3 / 07 / 15$ & 69.70 & 0.29 & 9.34 & 0.00 & 4.63 & 0.17 & 0.15 & 5.38 & 4.35 & 0.00 & 0.24 & 94.24 \\
\hline TU2_6 & $\mathrm{T}$ & 03/07/15 & 70.38 & 0.20 & 8.96 & 0.00 & 4.27 & 0.27 & 0.18 & 5.66 & 4.38 & 0.00 & 0.22 & 94.51 \\
\hline TU2_7 & TU2 BWT & /07/15 & 72.06 & 0.20 & 9.42 & 0.00 & 4.35 & 0.15 & 0.17 & 5.61 & 4.38 & 0.02 & 0.21 & 96.57 \\
\hline TU2_9 & TU2 BWT & $3 / 07 / 15$ & 69.47 & 0.19 & 8.83 & 0.07 & 4.34 & 0.21 & 0.15 & 4.88 & 4.05 & 0.00 & 0.29 & 92.49 \\
\hline M14_0.27_NW_1 & M14 $0.27 \mathrm{~m} \mathrm{NW}$ & $3 / 07 / 15$ & 71.33 & 0.22 & 9.25 & 0.04 & 4.41 & 0.25 & 0.16 & 5.14 & 4.36 & 0.01 & 0.20 & 95.36 \\
\hline M14_0.27_N & M140 & $3 / 07 / 15$ & 71.56 & 0.22 & 9.16 & 0.00 & 4.63 & 0.17 & 0.23 & 5.20 & 4.54 & 0.00 & 0.18 & 95.88 \\
\hline M14_0. & 40. & $03 / 07 / 15$ & 72.65 & 0.28 & 9.52 & 0.01 & 4.83 & 0.17 & 0.21 & 5.25 & 4.39 & 0.04 & 0.19 & 97.55 \\
\hline M14_0. & N & /07/15 & 68.08 & 0.24 & 9.38 & 0.00 & 4.30 & 0.25 & 0.33 & 5.07 & 4.33 & 0.00 & 0.24 & 92.23 \\
\hline M14_C & & /07/15 & 68.86 & 0.25 & 8.84 & 0.04 & 4.46 & 0.19 & 0.35 & 5.04 & 4.30 & 0.02 & 0.20 & 92.55 \\
\hline M14_0.27_NW_24 & M14 $0.27 \mathrm{~m} \mathrm{NW}$ & $03 / 07 / 15$ & 71.17 & 0.23 & 9.05 & 0.00 & 4.68 & 0.16 & 0.19 & 5.23 & 4.54 & 0.03 & 0.22 & 95.51 \\
\hline M14_0.27_NW_3 & 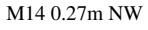 & 03/07/15 & 70.82 & 0.26 & 9.37 & 0.00 & 4.71 & 0.29 & 0.18 & 5.48 & 4.51 & 0.02 & 0.19 & 95.82 \\
\hline M14_0.27_NW_4 & M14 $0.27 \mathrm{~m} \mathrm{NW}$ & 03/07/15 & 67.39 & 0.29 & 9.11 & 0.01 & 4.23 & 0.20 & 0.21 & 4.90 & 4.21 & 0.03 & 0.16 & 90.74 \\
\hline M14_0.27_NW_5 & M14 0.27m NW & 03/07/15 & 71.89 & 0.23 & 9.19 & 0.06 & 4.33 & 0.18 & 0.21 & 5.25 & 4.42 & 0.05 & 0.23 & 96.05 \\
\hline BIS_1_1 & BIS_1_1 & $30 / 06 / 15$ & 72.83 & 0.24 & 9.46 & 0.00 & 4.61 & 0.25 & 0.18 & 5.34 & 4.32 & 0.00 & 0.24 & 97.48 \\
\hline BIS_1_2 & BIS_1_2 & $30 / 06 / 15$ & 73.20 & 0.22 & 9.38 & 0.00 & 4.42 & 0.28 & 0.17 & 4.92 & 4.38 & 0.00 & 0.19 & 97.18 \\
\hline BIS_1_3 & BIS_1_3 & $30 / 06 / 15$ & 72.71 & 0.21 & 9.47 & 0.00 & 4.38 & 0.31 & 0.18 & 4.93 & 4.30 & 0.00 & 0.23 & 96.74 \\
\hline BIS_1_4 & BIS_1_4 & $30 / 06 / 15$ & 73.39 & 0.27 & 9.68 & 0.00 & 4.41 & 0.25 & 0.16 & 4.96 & 4.30 & 0.00 & 0.25 & 97.67 \\
\hline BIS_1_5 & DIC 15 & $30 / 06 / 15$ & 72.89 & 0.26 & 9.35 & 0.00 & 4.48 & 0.26 & 0.18 & 5.17 & 4.31 & 0.01 & 0.21 & 97.13 \\
\hline BIS_1_6 & BIS_1_6 & $30 / 06 / 15$ & 73.05 & 0.26 & 9.53 & 0.00 & 4.63 & 0.16 & 0.20 & 5.08 & 4.24 & 0.00 & 0.20 & 97.34 \\
\hline BIS & & $30 / 06 / 15$ & 71.47 & 0.19 & 9.20 & 0.01 & 4.28 & 0.18 & 0.17 & 5.05 & 4.20 & 0.00 & 0.22 & 94.97 \\
\hline BIS_1_8 & BIS_1_8 & $30 / 06 / 15$ & 72.46 & 0.26 & 9.36 & 0.00 & 4.50 & 0.19 & 0.17 & 4.97 & 4.29 & 0.01 & 0.23 & 96.44 \\
\hline
\end{tabular}


Unnormalised major element concentrations (wt.\%) in tephra samples from Mochena Borago

\begin{tabular}{|c|c|c|c|c|c|c|c|c|c|c|c|c|c|c|}
\hline Label & Tephra & $\begin{array}{l}\text { Analysis } \\
\text { date }\end{array}$ & $\begin{array}{l}\mathrm{SiO}_{2} \\
0.08 \\
\end{array}$ & $\begin{array}{l}\mathrm{TiO}_{2} \\
\mathbf{0 . 0 5} \\
\end{array}$ & $\begin{array}{l}\mathrm{Al}_{2} \mathrm{O}_{3} \\
0.05 \\
\end{array}$ & $\begin{array}{l}\text { MgO } \\
0.04 \\
\end{array}$ & $\begin{array}{l}\mathrm{FeO}^{T} \\
0.08 \\
\end{array}$ & $\begin{array}{l}\text { MnO } \\
0.07 \\
\end{array}$ & $\begin{array}{l}\mathrm{CaO} \\
0.04 \\
\end{array}$ & $\begin{array}{l}\mathrm{Na}_{2} \mathrm{O} \\
0.08 \\
\end{array}$ & $\begin{array}{l}\mathbf{K}_{2} \mathbf{O} \\
0.03 \\
\end{array}$ & $\begin{array}{l}\mathbf{P}_{2} \mathbf{O}_{5} \\
\mathbf{0 . 1 0}\end{array}$ & $\begin{array}{l}\mathrm{Cl} \\
\mathbf{0 . 0 2} \\
\end{array}$ & Total \\
\hline BIS_1_9 & BIS_1_9 & $30 / 06 / 15$ & 72.50 & 0.23 & 9.36 & 0.00 & 4.46 & 0.22 & 0.17 & 5.02 & 4.39 & 0.00 & 0.23 & 96.59 \\
\hline BIS_1_11 & BIS_1_11 & $30 / 06 / 15$ & 73.26 & 0.24 & 9.58 & 0.00 & 4.56 & 0.23 & 0.14 & 4.89 & 4.21 & 0.03 & 0.20 & 97.35 \\
\hline BIS_1_12 & BIS_1_12 & $30 / 06 / 15$ & 72.78 & 0.27 & 9.30 & 0.00 & 4.57 & 0.10 & 0.18 & 5.02 & 4.28 & 0.04 & 0.24 & 96.78 \\
\hline BIS_1_13 & BIS_1_13 & $30 / 06 / 15$ & 73.15 & 0.24 & 9.51 & 0.00 & 4.29 & 0.26 & 0.21 & 5.08 & 4.25 & 0.00 & 0.23 & 97.22 \\
\hline BIS_1_14 & BIS_1_14 & $30 / 06 / 15$ & 73.12 & 0.22 & 9.63 & 0.00 & 4.50 & 0.20 & 0.20 & 5.38 & 4.32 & 0.00 & 0.23 & 97.80 \\
\hline BIS_1_15 & BIS_1_15 & $30 / 06 / 15$ & 73.14 & 0.22 & 9.47 & 0.00 & 4.40 & 0.09 & 0.18 & 5.53 & 4.30 & 0.00 & 0.22 & 97.54 \\
\hline BIS_1_16 & BIS_1_16 & $30 / 06 / 15$ & 74.25 & 0.27 & 9.53 & 0.00 & 4.68 & 0.32 & 0.16 & 2.31 & 4.30 & 0.00 & 0.22 & 96.03 \\
\hline BIS_1_17 & BIS_1_17 & $30 / 06 / 15$ & 73.24 & 0.24 & 9.64 & 0.01 & 4.39 & 0.25 & 0.16 & 5.28 & 4.05 & 0.04 & 0.22 & 97.51 \\
\hline BIS_1_19 & BIS_1_19 & $30 / 06 / 15$ & 73.17 & 0.19 & 9.58 & 0.05 & 4.36 & 0.12 & 0.22 & 5.08 & 4.25 & 0.02 & 0.24 & 97.28 \\
\hline BIS_1_20 & BIS_1_20 & $30 / 06 / 15$ & 73.23 & 0.29 & 9.27 & 0.03 & 4.44 & 0.24 & 0.17 & 4.81 & 4.56 & 0.00 & 0.23 & 97.27 \\
\hline BIS_2_1 & BIS_2_1 & $30 / 06 / 15$ & 72.35 & 0.29 & 9.46 & 0.00 & 4.32 & 0.22 & 0.20 & 4.90 & 4.14 & 0.03 & 0.20 & 96.11 \\
\hline BIS_2_2 & BIS_2_2 & $30 / 06 / 15$ & 74.39 & 0.22 & 9.77 & 0.00 & 4.72 & 0.10 & 0.17 & 5.13 & 4.43 & 0.05 & 0.21 & 99.19 \\
\hline BIS_2_4 & BIS_2_4 & $30 / 06 / 15$ & 69.45 & 0.25 & 8.60 & 0.05 & 5.25 & 0.23 & 0.13 & 5.40 & 4.00 & 0.00 & 0.38 & 93.73 \\
\hline BIS_2_6 & BIS_2_6 & $30 / 06 / 15$ & 70.13 & 0.26 & 9.31 & 0.01 & 4.53 & 0.22 & 0.19 & 4.77 & 4.20 & 0.01 & 0.22 & 93.86 \\
\hline BIS_2_7 & BIS_2 & $30 / 06 / 15$ & 73.38 & 0.25 & 9.45 & 0.00 & 4.49 & 0.28 & 0.15 & 5.02 & 4.33 & 0.00 & 0.23 & 97.58 \\
\hline BIS_2_8 & BIS_2_8 & $30 / 06 / 15$ & 70.82 & 0.27 & 8.87 & 0.00 & 4.47 & 0.22 & 0.21 & 5.15 & 4.02 & 0.00 & 0.23 & 94.25 \\
\hline BIS_2_9 & BIS_2_9 & $30 / 06 / 15$ & 69.65 & 0.25 & 8.77 & 0.02 & 4.27 & 0.19 & 0.17 & 4.79 & 4.13 & 0.00 & 0.25 & 92.48 \\
\hline BIS_2_10 & BIS_2_10 & $30 / 06 / 15$ & 74.22 & 0.21 & 9.43 & 0.00 & 4.72 & 0.15 & 0.17 & 5.16 & 4.48 & 0.00 & 0.23 & 98.76 \\
\hline BIS_2_11 & BIS_2 & $30 / 06 / 15$ & 70.66 & 0.30 & 9.03 & 0.00 & 4.58 & 0.28 & 0.20 & 4.58 & 4.10 & 0.02 & 0.18 & 93.93 \\
\hline BIS_2_12 & $-2 \_12$ & $30 / 06 / 15$ & 73.86 & 0.23 & 9.52 & 0.00 & 4.57 & 0.22 & 0.16 & 4.93 & 4.43 & 0.07 & 0.23 & 98.24 \\
\hline BIS_2_13 & BIS_2_13 & $30 / 06 / 15$ & 73.29 & 0.24 & 9.60 & 0.00 & 4.67 & 0.22 & 0.17 & 5.41 & 4.31 & 0.03 & 0.27 & 98.21 \\
\hline BIS_2_14 & BIS_2_14 & $30 / 06 / 15$ & 73.52 & 0.18 & 10.16 & 0.03 & 3.32 & 0.12 & 0.13 & 4.51 & 4.24 & 0.01 & 0.21 & 96.43 \\
\hline BIS_2_15 & BIS_2_15 & $30 / 06 / 15$ & 69.02 & 0.35 & 8.61 & 0.00 & 5.06 & 0.21 & 0.28 & 4.54 & 4.16 & 0.00 & 0.30 & 92.53 \\
\hline BIS_2_16 & BIS_2_16 & $30 / 06 / 15$ & 72.40 & 0.26 & 9.42 & 0.00 & 4.26 & 0.21 & 0.19 & 4.81 & 4.18 & 0.01 & 0.25 & 95.99 \\
\hline BIS_2_19 & BIS_2_19 & $30 / 06 / 15$ & 72.83 & 0.29 & 9.68 & 0.03 & 4.45 & 0.12 & 0.22 & 5.16 & 4.33 & 0.00 & 0.26 & 97.38 \\
\hline BIS_2_20 & BIS_2_20 & $30 / 06 / 15$ & 70.79 & 0.27 & 9.19 & 0.00 & 4.53 & 0.14 & 0.18 & 4.83 & 4.19 & 0.00 & 0.19 & 94.31 \\
\hline
\end{tabular}




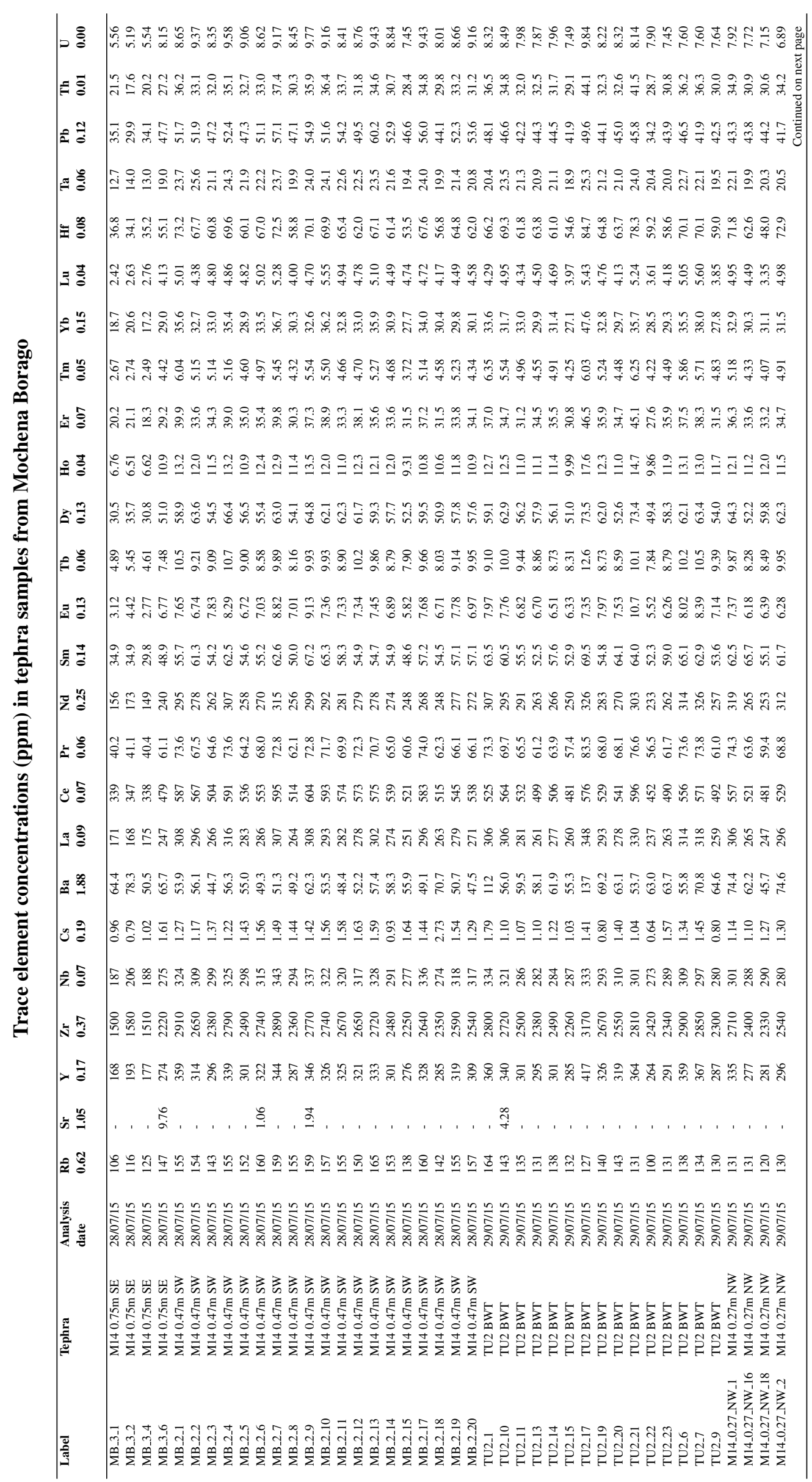




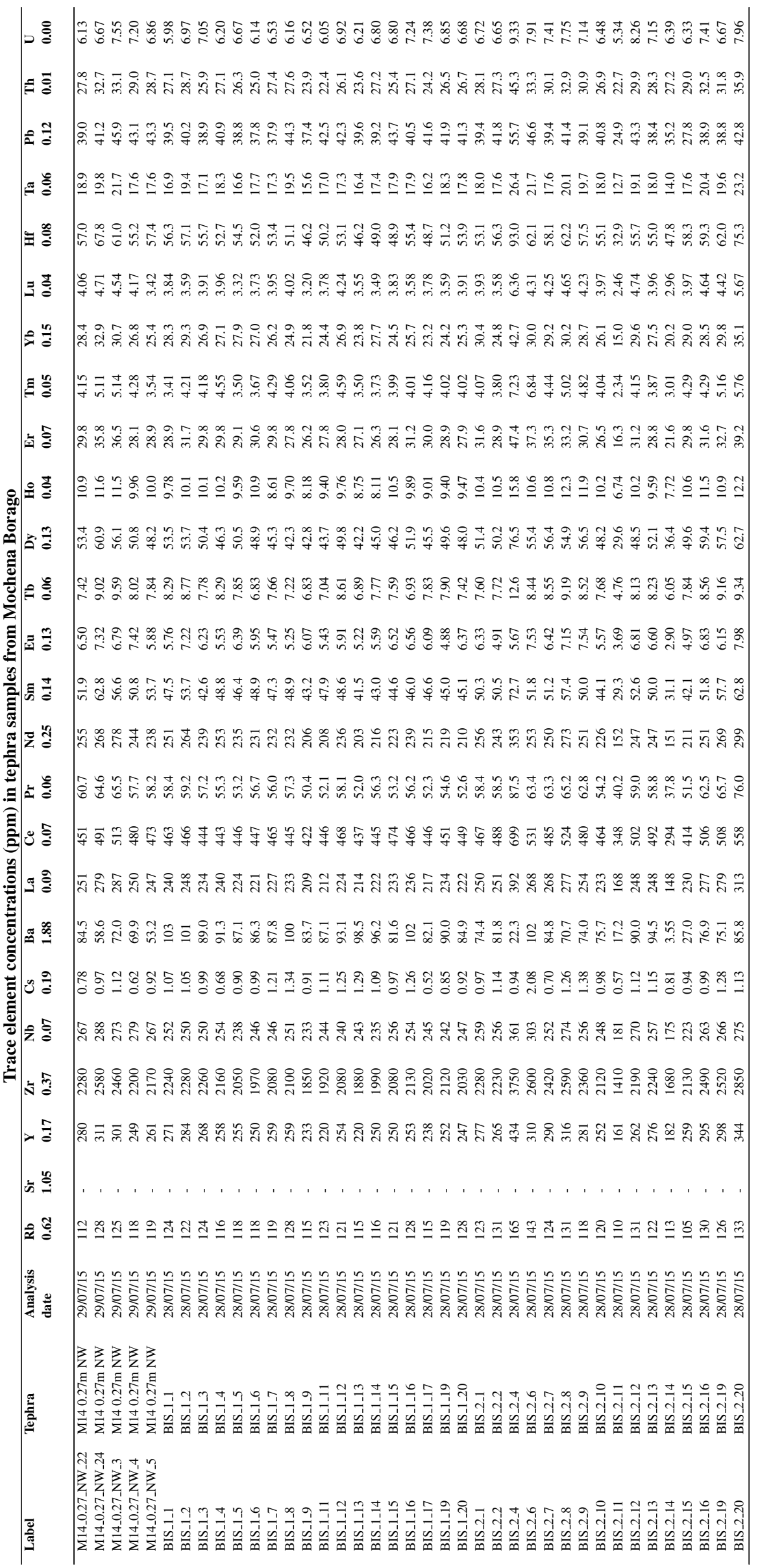




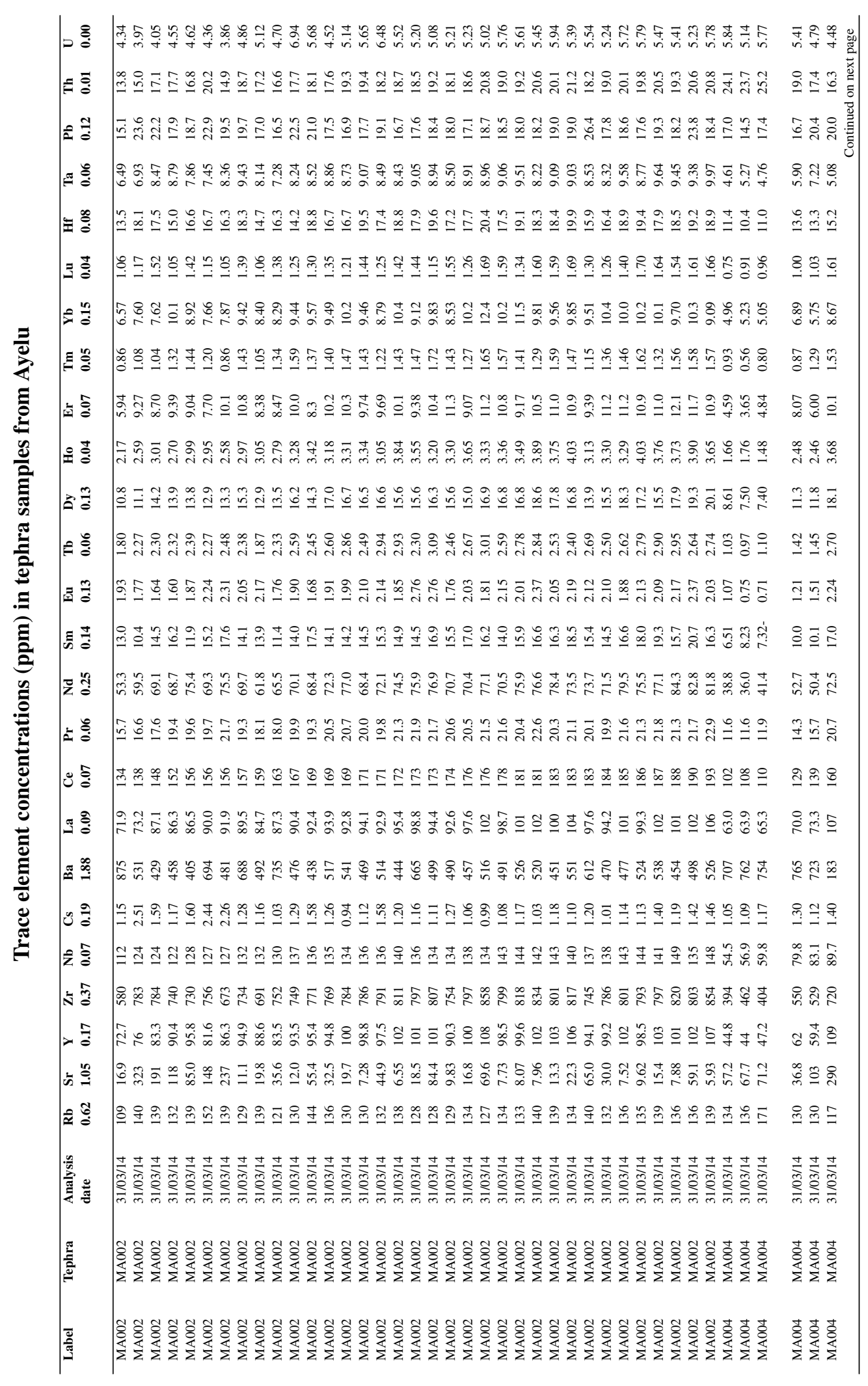




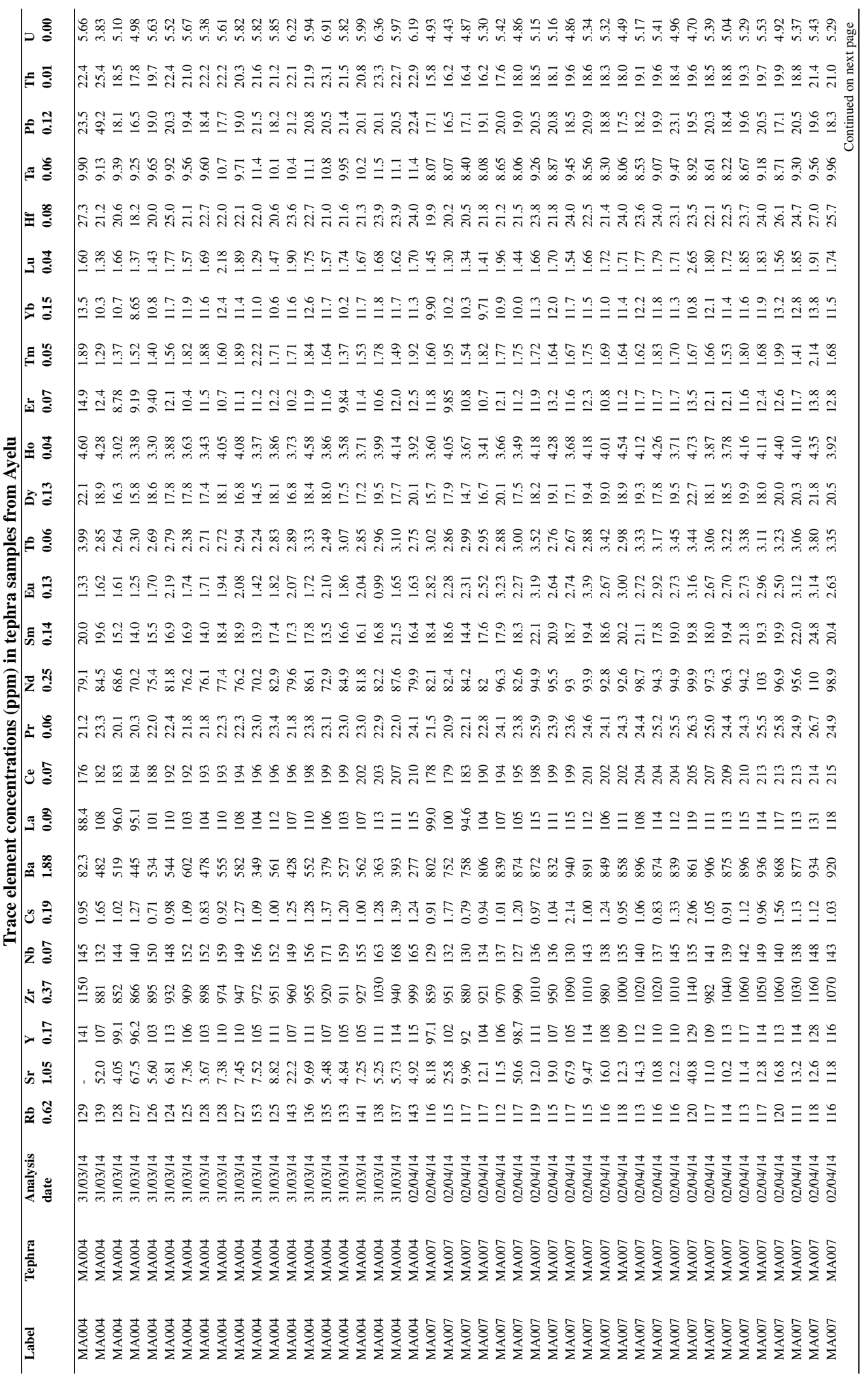




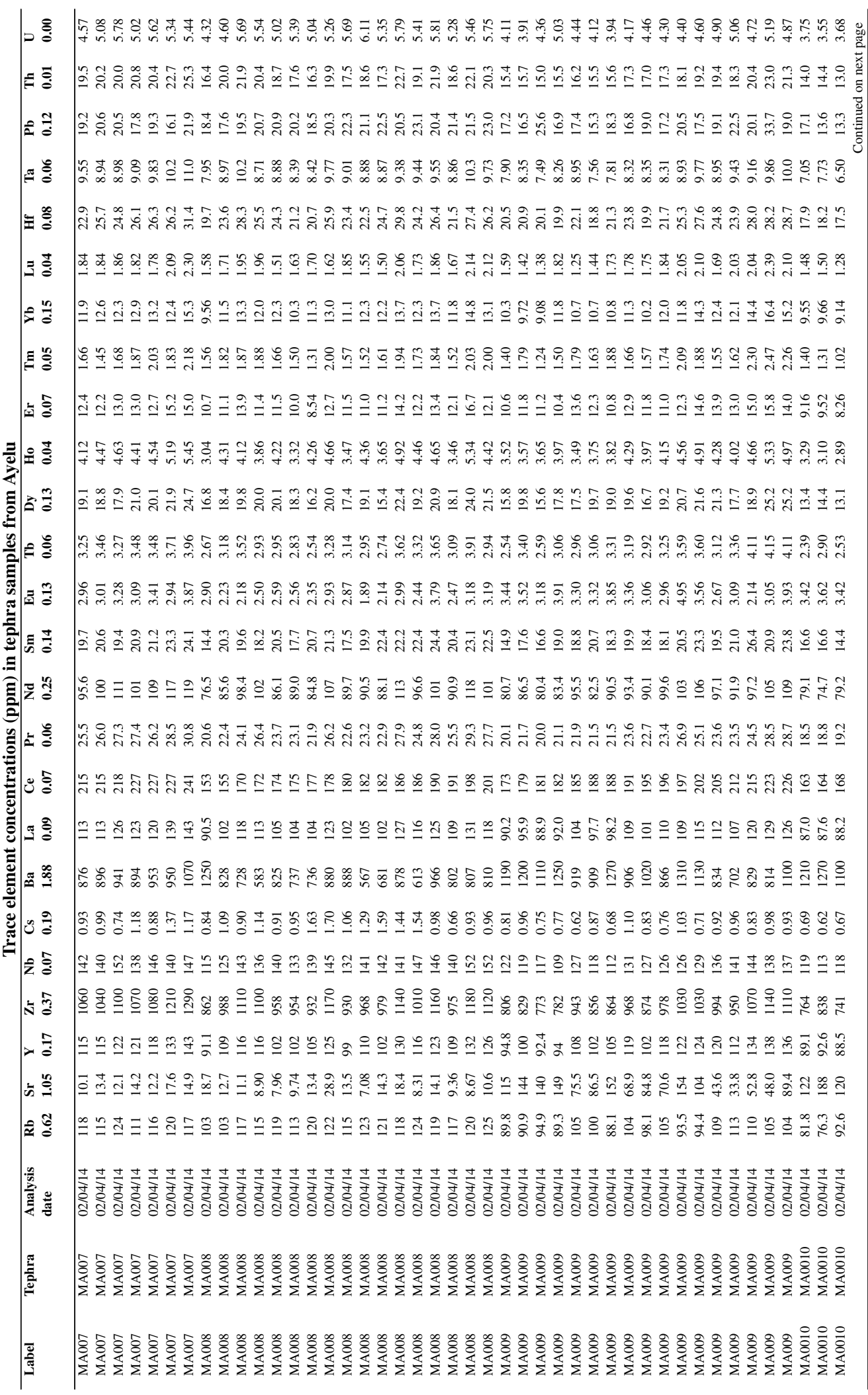




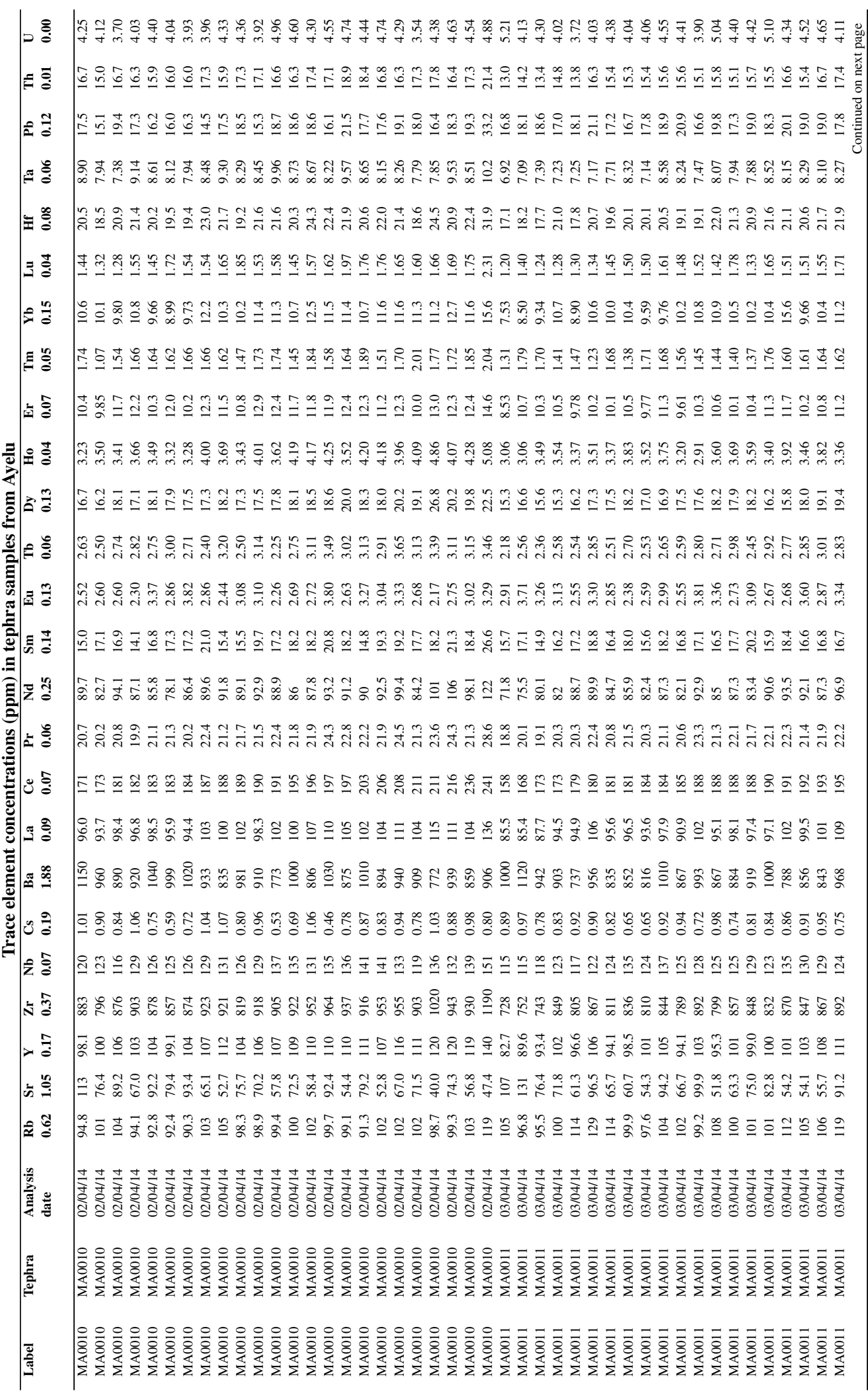




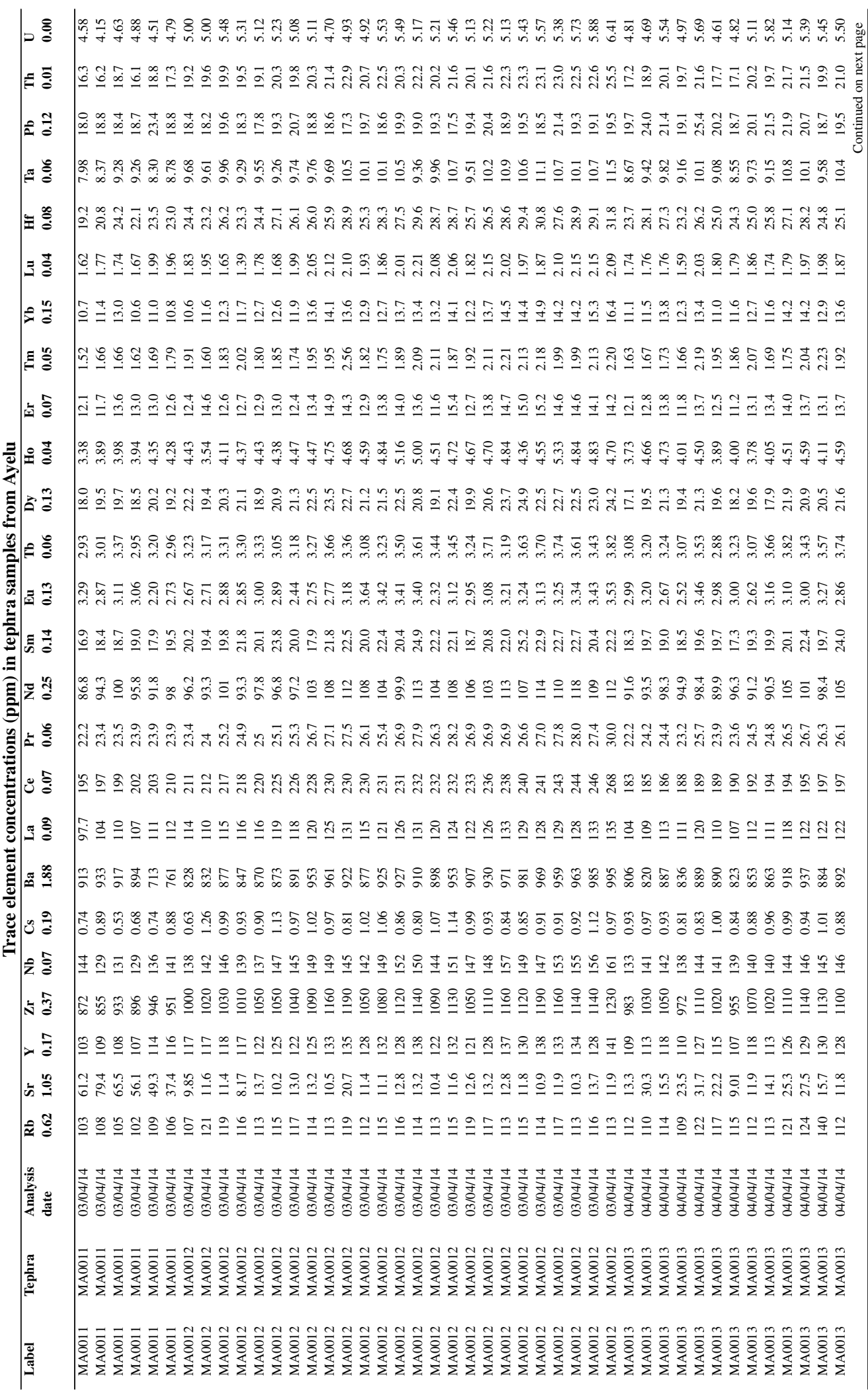




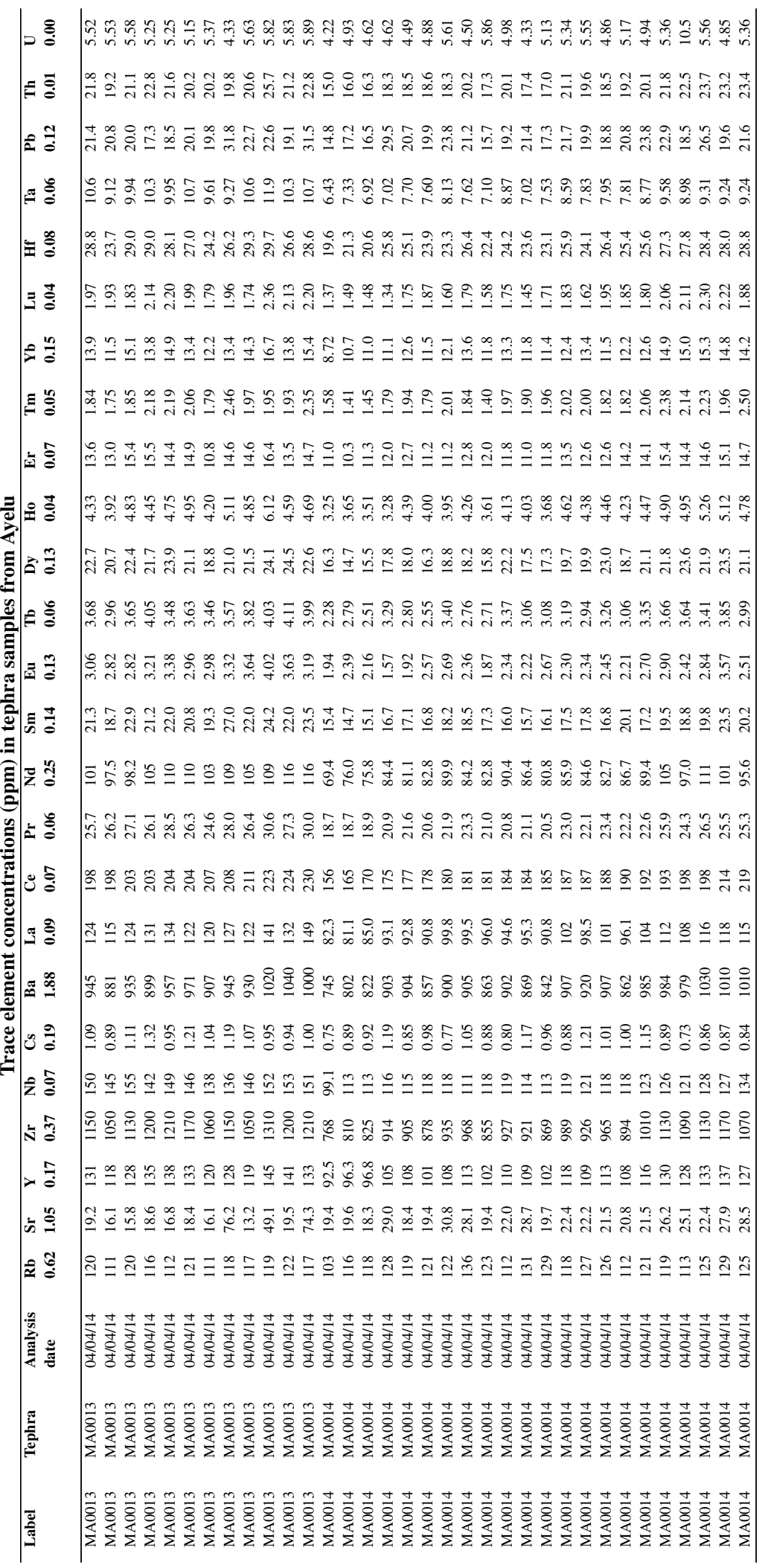




\section{.7 Reference materials}

This Appendix provides analyses of MPI-DING glass reference materials, which were used to check the calibration of the EPMA and LA-ICP-MS.

\section{.7.1 EPMA reference materials}

The MPI-DING reference materials, ATHO-G (rhyolite), St-Hs6/80-G (andesite), GOR128-G (komatiite) and ML3B-G (basalt) were analysed throughout each analytical session. These analyses are given below, and the date of analysis indicated. The average and $2 \sigma$ of these analyses are given alongside published major element concentrations from the GeoReM online database (Jochum et al., 2005).

Normalised major element concentrations (wt.\%) in MPI-DING reference materials

\begin{tabular}{|c|c|c|c|c|c|c|c|c|c|c|c|c|c|}
\hline Label & $\begin{array}{l}\text { MPI- } \\
\text { DING } \\
\text { glass }\end{array}$ & $\begin{array}{l}\text { Analysis } \\
\text { date }\end{array}$ & $\mathrm{SiO}_{2}$ & $\mathrm{TiO}_{2}$ & $\mathbf{A l}_{2} \mathbf{O}_{3}$ & MgO & $\mathbf{F e O}^{T}$ & MnO & $\mathrm{CaO}$ & $\mathrm{Na}_{2} \mathrm{O}$ & $\mathbf{K}_{2} \mathbf{O}$ & $\mathbf{P}_{2} \mathbf{O}_{5}$ & $\mathbf{C l}$ \\
\hline ATH-G/1 & ATHO-G & $20 / 02 / 14$ & 75.29 & 0.22 & 12.45 & 0.12 & 3.35 & 0.14 & 1.75 & 4.04 & 2.76 & 0.02 & 0.05 \\
\hline ATH-G/2 & ATHO-G & $20 / 02 / 14$ & 75.82 & 0.28 & 12.42 & 0.09 & 3.39 & 0.10 & 1.82 & 2.23 & 2.76 & 0.02 & 0.06 \\
\hline ATH-G/3 & ATHO-G & $20 / 02 / 14$ & 74.53 & 0.27 & 12.43 & 0.11 & 3.10 & 0.12 & 1.69 & 4.05 & 2.74 & 0.00 & 0.06 \\
\hline ATH-G/4 & ATHO-G & $20 / 02 / 14$ & 74.83 & 0.28 & 12.45 & 0.09 & 3.15 & 0.12 & 1.66 & 4.17 & 2.72 & 0.00 & 0.06 \\
\hline ATH-G/5 & ATHO-G & $20 / 02 / 14$ & 74.32 & 0.22 & 12.19 & 0.07 & 3.14 & 0.11 & 1.79 & 4.10 & 2.66 & 0.03 & 0.03 \\
\hline ATH-G/6 & ATHO-G & $20 / 02 / 14$ & 75.10 & 0.25 & 12.38 & 0.09 & 3.32 & 0.14 & 1.67 & 4.05 & 2.76 & 0.01 & 0.05 \\
\hline ATH-G/7 & ATHO-G & $20 / 02 / 14$ & 75.28 & 0.28 & 12.38 & 0.10 & 3.19 & 0.10 & 1.73 & 1.98 & 2.75 & 0.00 & 0.06 \\
\hline ATHO-G/3 & ATHO-G & $20 / 02 / 14$ & 75.44 & 0.19 & 12.38 & 0.10 & 3.24 & 0.18 & 1.74 & 3.41 & 2.71 & 0.00 & 0.04 \\
\hline $\mathrm{ATHO} / 1$ & ATHO-G & $21 / 02 / 14$ & 75.05 & 0.28 & 12.33 & 0.09 & 3.00 & 0.01 & 1.80 & 4.22 & 2.69 & 0.00 & 0.05 \\
\hline ATHO/10 & ATHO-G & $21 / 02 / 14$ & 75.53 & 0.22 & 12.52 & 0.12 & 3.20 & 0.12 & 1.75 & 4.09 & 2.66 & 0.04 & 0.06 \\
\hline ATHO/11 & ATHO-G & $21 / 02 / 14$ & 75.26 & 0.28 & 12.55 & 0.10 & 3.09 & 0.10 & 1.73 & 4.20 & 2.68 & 0.04 & 0.04 \\
\hline ATHO/12 & ATHO-G & $21 / 02 / 14$ & 75.63 & 0.24 & 12.39 & 0.10 & 3.26 & 0.09 & 1.71 & 4.13 & 2.73 & 0.02 & 0.06 \\
\hline ATHO/13 & ATHO-G & $21 / 02 / 14$ & 75.03 & 0.23 & 12.38 & 0.08 & 3.26 & 0.04 & 1.76 & 4.10 & 2.74 & 0.04 & 0.06 \\
\hline ATHO/14 & ATHO-G & $21 / 02 / 14$ & 76.24 & 0.24 & 12.50 & 0.11 & 3.40 & 0.07 & 1.70 & 4.25 & 2.72 & 0.05 & 0.05 \\
\hline ATHO/15 & ATHO-G & $21 / 02 / 14$ & 74.88 & 0.28 & 12.29 & 0.07 & 3.28 & 0.08 & 1.75 & 4.15 & 2.85 & 0.01 & 0.11 \\
\hline ATHO/16 & ATHO-G & $21 / 02 / 14$ & 75.07 & 0.25 & 12.16 & 0.13 & 3.28 & 0.07 & 1.76 & 4.07 & 2.79 & 0.02 & 0.06 \\
\hline ATHO/17 & ATHO-G & $21 / 02 / 14$ & 75.18 & 0.26 & 12.31 & 0.10 & 3.26 & 0.17 & 1.74 & 4.44 & 2.75 & 0.04 & 0.06 \\
\hline ATHO/18 & ATHO-G & $21 / 02 / 14$ & 74.86 & 0.28 & 12.18 & 0.08 & 3.25 & 0.06 & 1.68 & 4.14 & 2.68 & 0.01 & 0.06 \\
\hline ATHO/19 & ATHO-G & $21 / 02 / 14$ & 74.85 & 0.24 & 12.28 & 0.09 & 3.30 & 0.11 & 1.72 & 4.22 & 2.69 & 0.02 & 0.06 \\
\hline $\mathrm{ATHO} / 2$ & ATHO-G & $21 / 02 / 14$ & 72.78 & 0.20 & 11.97 & 0.10 & 3.15 & 0.08 & 1.63 & 4.06 & 2.60 & 0.00 & 0.07 \\
\hline ATHO/20 & ATHO-G & $21 / 02 / 14$ & 75.43 & 0.29 & 12.29 & 0.13 & 3.32 & 0.05 & 1.73 & 3.75 & 2.70 & 0.00 & 0.03 \\
\hline $\mathrm{ATHO} / 3$ & ATHO-G & $21 / 02 / 14$ & 73.39 & 0.29 & 12.05 & 0.13 & 3.11 & 0.13 & 1.73 & 4.28 & 2.67 & 0.01 & 0.05 \\
\hline $\mathrm{ATHO} / 4$ & ATHO-G & $21 / 02 / 14$ & 75.29 & 0.27 & 12.39 & 0.11 & 3.17 & 0.12 & 1.73 & 4.27 & 2.74 & 0.00 & 0.05 \\
\hline ATHO/5 & ATHO-G & $21 / 02 / 14$ & 75.46 & 0.24 & 12.49 & 0.10 & 3.39 & 0.14 & 1.71 & 3.31 & 2.67 & 0.00 & 0.03 \\
\hline ATHO/6 & ATHO-G & $21 / 02 / 14$ & 75.08 & 0.21 & 12.49 & 0.12 & 3.26 & 0.12 & 1.73 & 4.27 & 2.63 & 0.02 & 0.05 \\
\hline $\mathrm{ATHO} / 7$ & ATHO-G & $21 / 02 / 14$ & 75.25 & 0.20 & 12.13 & 0.11 & 3.10 & 0.17 & 1.78 & 2.58 & 2.70 & 0.04 & 0.03 \\
\hline ATHO/8 & ATHO-G & $21 / 02 / 14$ & 74.84 & 0.22 & 12.36 & 0.09 & 3.22 & 0.11 & 1.73 & 3.80 & 2.69 & 0.02 & 0.06 \\
\hline ATHO/9 & ATHO-G & $21 / 02 / 14$ & 74.74 & 0.29 & 12.32 & 0.07 & 3.23 & 0.13 & 1.74 & 3.98 & 2.73 & 0.00 & 0.04 \\
\hline ATHO-G/2 & ATHO-G & $21 / 02 / 14$ & 75.04 & 0.28 & 12.41 & 0.12 & 3.44 & 0.05 & 1.75 & 4.15 & 2.74 & 0.01 & 0.03 \\
\hline ATHO-G/2 & ATHO-G & $21 / 02 / 14$ & 75.56 & 0.24 & 12.34 & 0.12 & 3.07 & 0.07 & 1.69 & 4.10 & 2.70 & 0.00 & 0.06 \\
\hline ATHO-G_1 & ATHO-G & $26 / 08 / 14$ & 75.67 & 0.26 & 12.33 & 0.08 & 3.17 & 0.10 & 1.70 & 4.17 & 2.73 & 0.04 & \\
\hline ATHO-G_2 & ATHO-G & $26 / 08 / 14$ & 75.40 & 0.17 & 12.37 & 0.07 & 3.30 & 0.07 & 1.60 & 4.22 & 2.75 & 0.04 & \\
\hline ATHO-G_3 & ATHO-G & $26 / 08 / 14$ & 75.31 & 0.25 & 12.34 & 0.12 & 3.21 & 0.11 & 1.67 & 4.30 & 2.72 & 0.05 & \\
\hline ATHO-G_4 & ATHO-G & $26 / 08 / 14$ & 75.47 & 0.26 & 12.37 & 0.10 & 3.43 & 0.13 & 1.65 & 4.14 & 2.84 & 0.02 & \\
\hline ATHO-G_1 & ATHO-G & $26 / 08 / 14$ & 75.19 & 0.25 & 12.19 & 0.07 & 3.37 & 0.06 & 1.72 & 4.38 & 2.75 & 0.05 & \\
\hline ATHO-G_2 & ATHO-G & $26 / 08 / 14$ & 75.25 & 0.28 & 12.24 & 0.12 & 3.25 & 0.07 & 1.64 & 4.29 & 2.73 & 0.00 & \\
\hline ATHO-G_3 & ATHO-G & $26 / 08 / 14$ & 74.76 & 0.23 & 12.33 & 0.15 & 3.27 & 0.07 & 1.60 & 4.29 & 2.79 & 0.00 & \\
\hline ATHO-G_4 & ATHO-G & $26 / 08 / 14$ & 74.86 & 0.25 & 12.36 & 0.09 & 3.17 & 0.06 & 1.67 & 4.22 & 2.81 & 0.00 & \\
\hline ATHO-G_5 & ATHO-G & $26 / 08 / 14$ & 75.40 & 0.25 & 12.14 & 0.08 & 3.19 & 0.14 & 1.66 & 4.19 & 2.74 & 0.04 & \\
\hline ATHO-G_6 & ATHO-G & $26 / 08 / 14$ & 75.73 & 0.28 & 12.34 & 0.11 & 3.36 & 0.12 & 1.70 & 4.30 & 2.75 & 0.00 & \\
\hline ATHO-G_1 & ATHO-G & $27 / 08 / 14$ & 75.44 & 0.21 & 12.37 & 0.12 & 3.50 & 0.12 & 1.66 & 4.16 & 2.75 & 0.00 & \\
\hline ATHO-G_2 & ATHO-G & $27 / 08 / 14$ & 75.60 & 0.22 & 12.36 & 0.11 & 3.41 & 0.11 & 1.70 & 4.16 & & 0.01 & \\
\hline
\end{tabular}


Normalised major element concentrations (wt.\%) in MPI-DING reference materials

\begin{tabular}{|c|c|c|c|c|c|c|c|c|c|c|c|c|c|}
\hline Label & $\begin{array}{l}\text { MPI- } \\
\text { DING } \\
\text { glass }\end{array}$ & $\begin{array}{l}\text { Analysis } \\
\text { date }\end{array}$ & $\mathrm{SiO}_{2}$ & $\mathrm{TiO}_{2}$ & $\overline{\mathbf{A l}_{2} \mathbf{O}_{3}}$ & MgO & $\mathbf{F e O}^{T}$ & MnO & $\mathrm{CaO}$ & $\mathrm{Na}_{2} \mathrm{O}$ & $\mathbf{K}_{2} \mathbf{O}$ & $\mathbf{P}_{2} \mathbf{O}_{5}$ & Cl \\
\hline ATHO-G_5 & ATHO-G & $27 / 08 / 14$ & 75.27 & 0.26 & 12.07 & 0.09 & 3.26 & 0.16 & 1.67 & 4.20 & 2.76 & 0.03 & \\
\hline ATHO-G_6 & ATHO-G & $27 / 08 / 14$ & 75.29 & 0.27 & 12.17 & 0.11 & 3.24 & 0.13 & 1.64 & 3.93 & 2.66 & 0.02 & \\
\hline ATHO-G_3 & ATHO-G & $27 / 08 / 14$ & 75.34 & 0.29 & 12.16 & 0.10 & 3.38 & 0.09 & 1.66 & 4.47 & 2.71 & 0.06 & \\
\hline ATHO-G_4 & ATHO-G & $27 / 08 / 14$ & 75.51 & 0.17 & 12.29 & 0.09 & 3.38 & 0.12 & 1.63 & 4.30 & 2.86 & 0.00 & \\
\hline ATHO-G_1 & ATHO-G & $28 / 08 / 14$ & 75.19 & 0.25 & 12.19 & 0.07 & 3.37 & 0.06 & 1.72 & 4.38 & 2.75 & 0.05 & \\
\hline ATHO-G_2 & ATHO-G & $28 / 08 / 14$ & 75.25 & 0.28 & 12.24 & 0.12 & 3.25 & 0.07 & 1.64 & 4.29 & 2.73 & 0.00 & \\
\hline ATHO-G_3 & ATHO-G & $28 / 08 / 14$ & 74.76 & 0.23 & 12.33 & 0.15 & 3.27 & 0.07 & 1.60 & 4.29 & 2.79 & 0.00 & \\
\hline ATHO-G_4 & ATHO-G & $28 / 08 / 14$ & 74.86 & 0.25 & 12.36 & 0.09 & 3.17 & 0.06 & 1.67 & 4.22 & 2.81 & 0.00 & \\
\hline ATHO-G_5 & ATHO-G & $28 / 08 / 14$ & 75.40 & 0.25 & 12.14 & 0.08 & 3.19 & 0.14 & 1.66 & 4.19 & 2.74 & 0.04 & \\
\hline ATHO-G_6 & ATHO-G & $28 / 08 / 14$ & 75.73 & 0.28 & 12.34 & 0.11 & 3.36 & 0.12 & 1.70 & 4.30 & 2.75 & 0.00 & \\
\hline ATHO1G_6 & ATHO-G & $29 / 06 / 15$ & 74.54 & 0.28 & 12.32 & 0.09 & 3.06 & 0.09 & 1.70 & 4.23 & 2.69 & 0.02 & 0.05 \\
\hline ATHO1G_1 & ATHO-G & 29/06/15 & 75.01 & 0.16 & 12.31 & 0.12 & 3.25 & 0.11 & 1.60 & 4.45 & 2.70 & 0.00 & 0.04 \\
\hline ATHO1G_2 & ATHO-G & $29 / 06 / 15$ & 74.83 & 0.26 & 12.33 & 0.06 & 3.22 & 0.09 & 1.70 & 3.99 & 2.75 & 0.00 & 0.05 \\
\hline ATHO1G_3 & ATHO-G & $29 / 06 / 15$ & 74.85 & 0.28 & 11.98 & 0.10 & 3.10 & 0.10 & 1.62 & 4.19 & 2.67 & 0.08 & 0.04 \\
\hline ATHO1G_4 & ATHO-G & 29/06/15 & 75.21 & 0.26 & 12.24 & 0.16 & 3.33 & 0.16 & 1.62 & 4.04 & 2.76 & 0.00 & 0.04 \\
\hline ATHO1G_5 & ATHO-G & $29 / 06 / 15$ & 75.02 & 0.25 & 12.24 & 0.06 & 3.22 & 0.10 & 1.73 & 4.11 & 2.71 & 0.02 & 0.03 \\
\hline ATHO1G_10 & ATHO-G & 29/06/15 & 74.99 & 0.23 & 12.18 & 0.07 & 3.19 & 0.17 & 1.70 & 4.05 & 2.72 & 0.05 & 0.06 \\
\hline ATHO-G_6 & ATHO-G & $30 / 06 / 15$ & 74.78 & 0.23 & 12.24 & 0.10 & 3.22 & 0.09 & 1.59 & 4.29 & 2.72 & 0.06 & 0.06 \\
\hline ATHO-G_9 & ATHO-G & $30 / 06 / 15$ & 75.00 & 0.23 & 12.25 & 0.08 & 3.19 & 0.11 & 1.66 & 4.14 & 2.72 & 0.02 & 0.01 \\
\hline ATHO-G_10 & ATHO-G & $30 / 06 / 15$ & 74.92 & 0.28 & 12.35 & 0.09 & 3.11 & 0.16 & 1.70 & 4.04 & 2.64 & 0.01 & 0.05 \\
\hline ATHO-G_1 & ATHO-G & $30 / 06 / 15$ & 75.21 & 0.21 & 12.08 & 0.11 & 3.21 & 0.12 & 1.66 & 3.98 & 2.68 & 0.00 & 0.02 \\
\hline ATHO-G_3 & ATHO-G & $30 / 06 / 15$ & 75.24 & 0.31 & 12.15 & 0.14 & 3.30 & 0.13 & 1.69 & 4.05 & 2.79 & 0.03 & 0.03 \\
\hline ATHO-G_2 & ATHO-G & $30 / 06 / 15$ & 75.44 & 0.28 & 12.23 & 0.09 & 3.21 & 0.10 & 1.64 & 4.23 & 2.73 & 0.00 & 0.04 \\
\hline ATHO-G_4 & ATHO-G & $30 / 06 / 15$ & 74.74 & 0.27 & 12.22 & 0.06 & 3.10 & 0.21 & 1.70 & 4.21 & 2.79 & 0.02 & 0.03 \\
\hline ATHO-G_5 & ATHO-G & $30 / 06 / 15$ & 74.90 & 0.23 & 12.02 & 0.07 & 3.19 & 0.09 & 1.60 & 4.21 & 2.66 & 0.00 & 0.03 \\
\hline ATHO-G_1 & ATHO-G & 03/07/15 & 74.04 & 0.26 & 12.42 & 0.11 & 3.36 & 0.10 & 1.67 & 4.44 & 2.74 & 0.05 & 0.02 \\
\hline ATHO-G_2 & ATHO-G & 03/07/15 & 74.34 & 0.28 & 12.33 & 0.15 & 3.38 & 0.08 & 1.64 & 4.12 & 2.72 & 0.05 & 0.04 \\
\hline ATHO-G_3 & ATHO-G & 03/07/15 & 74.87 & 0.26 & 12.31 & 0.11 & 3.16 & 0.14 & 1.61 & 4.11 & 2.80 & 0.01 & 0.06 \\
\hline ATHO-G_4 & ATHO-G & 03/07/15 & 75.28 & 0.19 & 12.17 & 0.09 & 3.35 & 0.20 & 1.65 & 4.04 & 2.74 & 0.00 & 0.03 \\
\hline ATHO-G_5 & ATHO-G & $03 / 07 / 15$ & 75.20 & 0.28 & 12.26 & 0.08 & 3.41 & 0.10 & 1.55 & 4.36 & 2.67 & 0.04 & 0.03 \\
\hline & & Average & 75.09 & 0.25 & 12.29 & 0.10 & 3.25 & 0.11 & 1.69 & 4.07 & 2.73 & 0.02 & 0.05 \\
\hline & & & 1.01 & 0.06 & 0.25 & 0.04 & 0.21 & 0.08 & 0.11 & 0.86 & 0.10 & 0.04 & 0.03 \\
\hline & & GeoReM & 75.60 & 0.26 & 12.20 & 0.10 & 3.27 & 0.11 & 1.70 & 3.75 & 2.64 & 0.04 & 0.03 \\
\hline $\mathrm{StHs} / 6 / 80-\mathrm{G} / 3$ & StHs6/80-G & $20 / 02 / 14$ & 63.24 & 0.69 & 17.94 & 2.01 & 4.19 & 0.03 & 5.12 & 4.60 & 1.30 & 0.11 & 0.00 \\
\hline StHS6/80-G/1 & StHs $6 / 80-\mathrm{G}$ & $20 / 02 / 14$ & 63.41 & 0.68 & 17.92 & 1.96 & 4.30 & 0.05 & 5.25 & 4.55 & 1.32 & 0.12 & 0.00 \\
\hline StHS6/80-G/2 & StHs $6 / 80-\mathrm{G}$ & $20 / 02 / 14$ & 63.62 & 0.62 & 18.11 & 1.92 & 4.44 & 0.08 & 5.28 & 4.89 & 1.30 & 0.14 & 0.02 \\
\hline StHS6/80-G/3 & StHs6/80-G & $20 / 02 / 14$ & 63.22 & 0.66 & 17.79 & 1.97 & 4.45 & 0.07 & 5.16 & 4.35 & 1.21 & 0.11 & 0.01 \\
\hline StHS6/80-G/4 & StHs6/80-G & $20 / 02 / 14$ & 62.84 & 0.69 & 17.76 & 1.95 & 4.33 & 0.07 & 5.24 & 4.68 & 1.36 & 0.15 & 0.01 \\
\hline StHS6/80-G/5 & StHs6/80-G & $20 / 02 / 14$ & 63.52 & 0.71 & 17.97 & 1.98 & 4.33 & 0.10 & 5.24 & 3.93 & 1.33 & 0.15 & 0.01 \\
\hline StHS6/80-G/6 & StHs6/80-G & $20 / 02 / 14$ & 63.00 & 0.78 & 17.63 & 1.98 & 4.30 & 0.05 & 5.26 & 4.33 & 1.34 & 0.14 & 0.00 \\
\hline StHS6/80-G/7 & StHs $6 / 80-\mathrm{G}$ & $20 / 02 / 14$ & 63.22 & 0.69 & 17.69 & 1.96 & 4.53 & 0.04 & 5.25 & 4.40 & 1.30 & 0.12 & 0.01 \\
\hline StHs6/80-G/2 & StHs6/80-G & $21 / 02 / 14$ & 63.32 & 0.74 & 17.67 & 1.94 & 4.28 & 0.08 & 5.29 & 4.48 & 1.27 & 0.14 & 0.00 \\
\hline $\mathrm{StHs} / 1$ & StHs6/80-G & $21 / 02 / 14$ & 63.06 & 0.70 & 17.58 & 1.91 & 4.54 & 0.07 & 5.19 & 4.43 & 1.27 & 0.15 & 0.00 \\
\hline $\mathrm{StHs} / 9$ & StHs6/80-G & $21 / 02 / 14$ & 63.77 & 0.71 & 17.61 & 1.91 & 4.10 & 0.15 & 5.21 & 3.91 & 1.34 & 0.15 & 0.01 \\
\hline StHs/11 & StHs6/80-G & $21 / 02 / 14$ & 64.46 & 0.69 & 18.27 & 1.91 & 4.50 & 0.02 & 5.35 & 4.08 & 1.29 & 0.11 & 0.00 \\
\hline $\mathrm{StHs} / 12$ & StHs $6 / 80-\mathrm{G}$ & $21 / 02 / 14$ & 64.08 & 0.69 & 17.90 & 1.97 & 4.66 & 0.04 & 5.28 & 3.70 & 1.32 & 0.16 & 0.03 \\
\hline StHs $/ 13$ & StHs $6 / 80-\mathrm{G}$ & $21 / 02 / 14$ & 63.66 & 0.70 & 17.80 & 1.96 & 4.38 & 0.06 & 5.23 & 4.69 & 1.31 & 0.14 & 0.02 \\
\hline StHs/14 & StHs $6 / 80-\mathrm{G}$ & $21 / 02 / 14$ & 63.75 & 0.67 & 17.79 & 2.01 & 4.50 & 0.02 & 5.29 & 4.56 & 1.33 & 0.10 & 0.03 \\
\hline $\mathrm{StHs} / 15$ & StHs6/80-G & $21 / 02 / 14$ & 63.44 & 0.76 & 17.78 & 1.91 & 4.36 & 0.07 & 5.35 & 4.66 & 1.34 & 0.11 & 0.01 \\
\hline StHs/16 & StHs $6 / 80-\mathrm{G}$ & $21 / 02 / 14$ & 63.70 & 0.66 & 17.93 & 1.98 & 4.38 & 0.07 & 5.20 & 4.67 & 1.34 & 0.09 & 0.00 \\
\hline StHs/17 & StHs $6 / 80-\mathrm{G}$ & $21 / 02 / 14$ & 63.68 & 0.70 & 17.86 & 1.89 & 4.31 & 0.11 & 5.13 & 4.67 & 1.33 & 0.14 & 0.00 \\
\hline StHs $/ 18$ & StHs $6 / 80-\mathrm{G}$ & $21 / 02 / 14$ & 63.40 & 0.66 & 17.78 & 1.96 & 4.41 & 0.15 & 5.24 & 4.70 & 1.27 & 0.14 & 0.01 \\
\hline $\mathrm{StHs} / 19$ & StHs6/80-G & $21 / 02 / 14$ & 63.71 & 0.70 & 17.84 & 1.89 & 4.49 & 0.14 & 5.35 & 4.50 & 1.31 & 0.16 & 0.01 \\
\hline $\mathrm{StHs} / 20$ & StHs6/80-G & $21 / 02 / 14$ & 64.07 & 0.77 & 17.75 & 1.97 & 4.44 & 0.09 & 5.31 & 4.47 & 1.35 & 0.14 & 0.00 \\
\hline StHs6/80-G_2 & StHs6/80-G & $26 / 08 / 14$ & 63.60 & 0.67 & 17.52 & 1.94 & 4.27 & 0.04 & 5.32 & 4.59 & 1.33 & 0.14 & \\
\hline StHs6/80-G_1 & StHs6/80-G & $26 / 08 / 14$ & 63.67 & 0.77 & 17.64 & 1.91 & 4.16 & 0.11 & 5.26 & 4.73 & 1.31 & 0.11 & \\
\hline StHs6/80-G_3 & StHs $6 / 80-\mathrm{G}$ & $26 / 08 / 14$ & 63.53 & 0.73 & 17.67 & 1.96 & 4.45 & 0.10 & 5.33 & 4.52 & 1.36 & 0.14 & \\
\hline StHs6/80-G_4 & StHs $6 / 80-\mathrm{G}$ & $26 / 08 / 14$ & 63.88 & 0.76 & 17.50 & 1.95 & 4.35 & 0.12 & 5.17 & 4.83 & 1.34 & 0.19 & \\
\hline StHs6/80-G_1 & StHs6/80-G & $26 / 08 / 14$ & 63.74 & 0.65 & 17.84 & 1.91 & 4.41 & 0.05 & 5.17 & 4.77 & 1.35 & 0.09 & \\
\hline StHs6/80-G_2 & StHs6/80-G & $26 / 08 / 14$ & 63.94 & 0.73 & 17.63 & 1.94 & 4.29 & 0.05 & 5.22 & 4.51 & 1.35 & 0.11 & \\
\hline StHs6/80-G_3 & StHs6/80-G & $26 / 08 / 14$ & 63.89 & 0.71 & 17.47 & 1.94 & 4.25 & 0.05 & 5.30 & 4.63 & 1.35 & 0.12 & \\
\hline StHs6/80-G_4 & StHs6/80-G & $26 / 08 / 14$ & 63.96 & 0.72 & 17.34 & 1.93 & 4.37 & 0.08 & 5.26 & 4.54 & 1.32 & 0.11 & \\
\hline StHs6/80-G_5 & StHs6/80-G & $26 / 08 / 14$ & 63.36 & 0.66 & 17.76 & 1.83 & 4.44 & 0.07 & 5.14 & 4.67 & 1.30 & 0.14 & \\
\hline StHs6/80-G_1 & StHs6/80-G & $27 / 08 / 14$ & 63.87 & 0.70 & 17.70 & 1.83 & 4.31 & 0.05 & 5.22 & 4.61 & 1.29 & 0.14 & \\
\hline StHs6/80-G_2 & StHs6/80-G & $27 / 08 / 14$ & 63.34 & 0.74 & 17.91 & 1.93 & 4.43 & 0.03 & 5.38 & 4.33 & 1.36 & 0.14 & \\
\hline StHs6/80-G_4 & StHs6/80-G & $27 / 08 / 14$ & 63.64 & 0.66 & 17.64 & 1.82 & 4.32 & 0.06 & 5.21 & 4.57 & 1.33 & 0.10 & \\
\hline StHs6/80-G_3 & StHs6/80-G & $27 / 08 / 14$ & 63.79 & 0.75 & 17.74 & 1.91 & 4.33 & 0.08 & 5.30 & 4.64 & 1.28 & 0.17 & \\
\hline StHs6/80-G_5 & StHs6/80-G & $27 / 08 / 14$ & 63.59 & 0.70 & 17.52 & 1.92 & 4.55 & 0.04 & 5.26 & 4.72 & 1.33 & 0.13 & \\
\hline StHs6/80-G_6 & StHs6/80-G & $27 / 08 / 14$ & 63.78 & 0.75 & 17.55 & 1.95 & 4.36 & 0.07 & 5.28 & 4.73 & 1.34 & 0.13 & \\
\hline StHs6/80-G_1 & StHs6/80-G & $28 / 08 / 14$ & 63.74 & 0.65 & 17.84 & 1.91 & 4.41 & 0.05 & 5.17 & 4.77 & 1.35 & 0.09 & \\
\hline StHs6/80-G_2 & StHs6/80-G & $28 / 08 / 14$ & 63.94 & 0.73 & 17.63 & 1.94 & 4.29 & 0.05 & 5.22 & 4.51 & 1.35 & 0.11 & \\
\hline StHs6/80-G_3 & StHs6/80-G & $28 / 08 / 14$ & 63.89 & 0.71 & 17.47 & 1.94 & 4.25 & 0.05 & 5.30 & 4.63 & 1.35 & 0.12 & \\
\hline StHs6/80-G_4 & StHs6/80-G & $28 / 08 / 14$ & 63.96 & 0.72 & 17.34 & 1.93 & 4.37 & 0.08 & 5.26 & 4.54 & 1.32 & 0.11 & \\
\hline StHs6/80-G_5 & StHs6/80-G & 28/08/14 & 63.36 & 0.66 & 17.76 & 1.83 & 4.44 & 0.07 & 5.14 & 4.67 & 1.30 & 0.14 & \\
\hline StHs_5 & StHs6/80-G & 29/06/15 & 63.53 & 0.69 & 17.43 & 1.88 & 4.36 & 0.09 & 5.33 & 4.64 & 1.29 & 0.26 & 0.03 \\
\hline StHs_1 & StHs6/80-G & 29/06/15 & 63.73 & 0.73 & 17.70 & 2.03 & 4.50 & 0.15 & 5.33 & 4.25 & 1.25 & 0.19 & 0.02 \\
\hline StHs_2 & StHs6/80-G & 29/06/15 & 63.50 & 0.69 & 17.56 & 1.83 & 4.46 & 0.01 & 5.22 & 4.72 & 1.32 & 0.20 & 0.00 \\
\hline StHs_4 & StHs6/80-G & 29/06/15 & 63.48 & 0.74 & 17.63 & 2.00 & 4.39 & 0.04 & 5.23 & 4.66 & 1.34 & 0.18 & 0.00 \\
\hline StHs_7 & StHs $6 / 80-\mathrm{G}$ & $29 / 06 / 15$ & 63.08 & 0.75 & 17.74 & 2.01 & 4.55 & 0.04 & 5.29 & 4.71 & 1.35 & 0.20 & 0.01 \\
\hline StHs_10 & StHs $6 / 80-\mathrm{G}$ & $29 / 06 / 15$ & 63.84 & 0.73 & 17.55 & 1.92 & 4.29 & 0.03 & 5.22 & 4.78 & 1.36 & 0.13 & 0.02 \\
\hline StHS6/80-G_8 & StHs $6 / 80-\mathrm{G}$ & $30 / 06 / 15$ & 63.42 & 0.76 & 17.44 & 1.92 & 4.34 & 0.02 & 5.38 & 4.62 & 1.32 & 0.15 & 0.01 \\
\hline StHS6/80-G_9 & StHs $6 / 80-\mathrm{G}$ & $30 / 06 / 15$ & 63.62 & 0.72 & 17.48 & 2.06 & 4.51 & 0.05 & 5.20 & 4.67 & 1.24 & 0.20 & 0.01 \\
\hline StHS6/80-G_10 & StHs6/80-G & $30 / 06 / 15$ & 63.49 & 0.72 & 17.73 & 1.97 & 4.46 & 0.04 & 5.26 & 4.07 & 1.36 & 0.10 & 0.00 \\
\hline & & & & & & & & & & & Contir & d on 1 & page \\
\hline
\end{tabular}


Normalised major element concentrations (wt.\%) in MPI-DING reference materials

\begin{tabular}{|c|c|c|c|c|c|c|c|c|c|c|c|c|c|}
\hline Label & $\begin{array}{l}\text { MPI- } \\
\text { DING } \\
\text { glass }\end{array}$ & $\begin{array}{l}\text { Analysis } \\
\text { date }\end{array}$ & $\mathrm{SiO}_{2}$ & $\mathrm{TiO}_{2}$ & $\mathbf{A l}_{2} \mathbf{O}_{3}$ & MgO & $\mathbf{F e O}^{T}$ & MnO & $\mathrm{CaO}$ & $\mathrm{Na}_{2} \mathrm{O}$ & $\mathbf{K}_{2} \mathbf{O}$ & $\mathbf{P}_{2} \mathbf{O}_{5}$ & Cl \\
\hline $\begin{array}{l}\text { StHS6/80-G_5 } \\
\end{array}$ & StHs6/80-G & $30 / 06 / 15$ & 63.64 & 0.64 & 17.47 & 1.96 & 4.38 & 0.10 & 5.15 & 4.37 & 1.25 & 0.12 & 0.03 \\
\hline StHS6/80-G_2 & StHs6/80-G & $30 / 06 / 15$ & 63.45 & 0.70 & 17.54 & 1.97 & 4.36 & 0.17 & 5.24 & 4.51 & 1.31 & 0.21 & 0.02 \\
\hline StHS6/80-G_4 & StHs6/80-G & $30 / 06 / 15$ & 63.52 & 0.70 & 17.70 & 1.92 & 4.38 & 0.09 & 5.12 & 4.41 & 1.31 & 0.17 & 0.01 \\
\hline StHS6/80-G_3 & StHs6/80-G & $30 / 06 / 15$ & 63.43 & 0.78 & 17.56 & 1.93 & 4.56 & 0.05 & 5.28 & 4.84 & 1.30 & 0.12 & 0.01 \\
\hline StHS6/80-G_6 & StHs6/80-G & $30 / 06 / 15$ & 62.94 & 0.72 & 17.52 & 2.02 & 4.62 & 0.17 & 5.17 & 4.54 & 1.29 & 0.22 & 0.02 \\
\hline StHS6/80-G_7 & StHs6/80-G & $30 / 06 / 15$ & 62.93 & 0.69 & 17.39 & 1.99 & 4.40 & 0.10 & 5.22 & 4.54 & 1.21 & 0.21 & 0.03 \\
\hline StHs6/80-G_1 & StHs6/80-G & $03 / 07 / 15$ & 63.55 & 0.66 & 17.90 & 1.90 & 4.51 & 0.04 & 5.16 & 4.78 & 1.31 & 0.06 & 0.02 \\
\hline StHs6/80-G_2 & StHs6/80-G & 03/07/15 & 63.26 & 0.68 & 17.44 & 1.90 & 4.34 & 0.08 & 5.24 & 4.31 & 1.28 & 0.08 & 0.01 \\
\hline StHs6/80-G_3 & StHs6/80-G & $03 / 07 / 15$ & 63.75 & 0.66 & 17.50 & 1.90 & 4.60 & 0.02 & 5.30 & 4.52 & 1.30 & 0.02 & 0.01 \\
\hline StHs6/80-G_4 & StHs6/80-G & $03 / 07 / 15$ & 63.42 & 0.70 & 17.52 & 1.96 & 4.30 & 0.04 & 5.35 & 4.55 & 1.30 & 0.10 & 0.02 \\
\hline StHs6/80-G_5 & StHs6/80-G & $03 / 07 / 15$ & 63.57 & 0.74 & 17.27 & 1.95 & 4.41 & 0.06 & 5.20 & 4.35 & 1.28 & 0.09 & 0.00 \\
\hline \multirow[t]{4}{*}{ StHs6/80-G_6 } & StHs6/80-G & 03/07/15 & 63.37 & 0.66 & 17.63 & 1.88 & 4.37 & 0.04 & 5.28 & 4.61 & 1.31 & 0.04 & 0.01 \\
\hline & & Average & 63.57 & 0.70 & 17.67 & 1.94 & 4.39 & 0.07 & 5.25 & 4.54 & 1.31 & 0.14 & 0.01 \\
\hline & & & 0.61 & 0.07 & 0.39 & 0.10 & 0.22 & 0.08 & 0.13 & 0.46 & 0.07 & 0.08 & 0.02 \\
\hline & & GeoReM & 63.70 & 0.70 & 17.80 & 1.97 & 4.37 & 0.08 & 5.28 & 4.44 & 1.29 & 0.16 & 0.01 \\
\hline GO128-G/1 & GOR128-G & $20 / 02 / 14$ & 45.64 & 0.23 & 10.01 & 25.75 & 9.85 & 0.22 & 6.16 & 0.63 & 0.03 & 0.03 & 0.01 \\
\hline GO128-G/2 & GOR128-G & $20 / 02 / 14$ & 45.90 & 0.32 & 9.92 & 25.89 & 10.20 & 0.17 & 6.16 & 0.52 & 0.02 & 0.01 & 0.02 \\
\hline GO128-G/3 & GOR128-G & $20 / 02 / 14$ & 45.40 & 0.29 & 9.72 & 25.54 & 9.87 & 0.07 & 6.15 & 0.50 & 0.04 & 0.01 & 0.00 \\
\hline $\mathrm{GO} 128-\mathrm{G} / 4$ & GOR128-G & $20 / 02 / 14$ & 45.52 & 0.31 & 10.09 & 25.95 & 10.16 & 0.26 & 6.23 & 0.54 & 0.04 & 0.04 & 0.01 \\
\hline $\mathrm{GO} 28-\mathrm{G} / 5$ & GOR128-G & $20 / 02 / 14$ & 45.83 & 0.30 & 10.22 & 25.32 & 9.33 & 0.20 & 6.25 & 0.67 & 0.02 & 0.04 & 0.00 \\
\hline GO128-G/6 & GOR128-G & $20 / 02 / 14$ & 45.60 & 0.30 & 10.13 & 25.65 & 9.56 & 0.20 & 6.44 & 0.52 & 0.04 & 0.01 & 0.00 \\
\hline GO128-G/7 & GOR128-G & $20 / 02 / 14$ & 45.48 & 0.31 & 10.17 & 26.02 & 9.59 & 0.24 & 6.03 & 0.59 & 0.03 & 0.04 & 0.01 \\
\hline GOR128-G/3 & GOR128-G & $20 / 02 / 14$ & 46.20 & 0.31 & 10.13 & 25.60 & 9.84 & 0.25 & 6.21 & 0.56 & 0.03 & 0.03 & 0.00 \\
\hline GOR128/1 & GOR128-G & $21 / 02 / 14$ & 46.28 & 0.31 & 9.98 & 25.39 & 9.58 & 0.17 & 6.18 & 0.50 & 0.03 & 0.00 & 0.00 \\
\hline GOR128/10 & GOR128-G & $21 / 02 / 14$ & 46.43 & 0.34 & 10.10 & 25.52 & 9.72 & 0.23 & 6.33 & 0.56 & 0.01 & 0.02 & 0.01 \\
\hline GOR128/11 & GOR128-G & $21 / 02 / 14$ & 46.49 & 0.29 & 10.05 & 25.64 & 9.74 & 0.14 & 6.10 & 0.61 & 0.06 & 0.00 & 0.00 \\
\hline GOR128/2 & GOR128-G & $21 / 02 / 14$ & 46.46 & 0.31 & 9.95 & 25.53 & 9.56 & 0.15 & 6.15 & 0.51 & 0.06 & 0.01 & 0.02 \\
\hline GOR128/3 & GOR128-G & $21 / 02 / 14$ & 46.32 & 0.30 & 10.10 & 25.54 & 9.34 & 0.18 & 6.20 & 0.53 & 0.02 & 0.05 & 0.01 \\
\hline GOR128/4 & GOR128-G & $21 / 02 / 14$ & 46.39 & 0.29 & 9.88 & 25.39 & 9.69 & 0.22 & 6.33 & 0.53 & 0.06 & 0.04 & 0.00 \\
\hline GOR128/5 & GOR128-G & $21 / 02 / 14$ & 46.48 & 0.32 & 10.05 & 25.58 & 10.14 & 0.20 & 6.25 & 0.46 & 0.04 & 0.04 & 0.00 \\
\hline GOR128/6 & GOR128-G & $21 / 02 / 14$ & 46.76 & 0.25 & 10.15 & 25.81 & 9.53 & 0.18 & 6.29 & 0.48 & 0.03 & 0.00 & 0.00 \\
\hline GOR128/7 & GOR128-G & $21 / 02 / 14$ & 46.38 & 0.28 & 10.12 & 25.45 & 9.93 & 0.26 & 6.30 & 0.57 & 0.06 & 0.02 & 0.01 \\
\hline GOR128/8 & GOR128-G & $21 / 02 / 14$ & 46.53 & 0.32 & 10.02 & 25.61 & 9.77 & 0.24 & 6.07 & 0.61 & 0.01 & 0.03 & 0.00 \\
\hline GOR128/9 & GOR128-G & $21 / 02 / 14$ & 46.07 & 0.26 & 10.10 & 25.55 & 9.77 & 0.27 & 6.35 & 0.50 & 0.02 & 0.02 & 0.00 \\
\hline GOR128-G/1 & GOR128-G & $21 / 02 / 14$ & 46.00 & 0.24 & 10.11 & 25.57 & 9.64 & 0.21 & 6.27 & 0.65 & 0.03 & 0.02 & 0.00 \\
\hline GOR128-G/2 & GOR128-G & $21 / 02 / 14$ & 46.23 & 0.29 & 10.08 & 25.41 & 9.79 & 0.18 & 6.18 & 0.58 & 0.02 & 0.03 & 0.00 \\
\hline GOR128/1 & GOR128-G & $21 / 02 / 14$ & 46.40 & 0.26 & 9.92 & 25.78 & 9.77 & 0.12 & 6.23 & 0.58 & 0.02 & 0.00 & 0.00 \\
\hline GOR128/10 & GOR128-G & $21 / 02 / 14$ & 46.55 & 0.29 & 10.20 & 25.62 & 9.73 & 0.08 & 6.35 & 0.49 & 0.06 & 0.01 & 0.01 \\
\hline GOR128/11 & GOR128-G & $21 / 02 / 14$ & 46.24 & 0.21 & 10.02 & 25.70 & 9.81 & 0.15 & 6.19 & 0.54 & 0.07 & 0.02 & 0.01 \\
\hline GOR128/2 & GOR128-G & $21 / 02 / 14$ & 45.14 & 0.26 & 9.98 & 24.69 & 9.33 & 0.16 & 6.05 & 0.77 & 0.05 & 0.04 & 0.10 \\
\hline GOR128/3 & GOR128-G & $21 / 02 / 14$ & 46.38 & 0.30 & 9.99 & 25.75 & 10.07 & 0.16 & 6.20 & 0.57 & 0.04 & 0.01 & 0.01 \\
\hline GOR128/4 & GOR128-G & $21 / 02 / 14$ & 45.91 & 0.21 & 10.06 & 25.84 & 10.01 & 0.15 & 6.14 & 0.53 & 0.04 & 0.02 & 0.00 \\
\hline GOR128/5 & GOR128-G & $21 / 02 / 14$ & 46.06 & 0.24 & 9.86 & 25.63 & 9.81 & 0.18 & 6.24 & 0.63 & 0.07 & 0.04 & 0.00 \\
\hline GOR128/6 & GOR128-G & $21 / 02 / 14$ & 46.53 & 0.27 & 10.10 & 25.73 & 9.78 & 0.20 & 6.17 & 0.55 & 0.02 & 0.01 & 0.02 \\
\hline GOR132_6 & GOR128-G & $29 / 06 / 15$ & 45.27 & 0.38 & 10.87 & 21.93 & 10.51 & 0.12 & 8.36 & 0.85 & 0.03 & 0.05 & 0.00 \\
\hline GOR132_1 & GOR128-G & 29/06/15 & 45.28 & 0.29 & 10.81 & 22.33 & 10.11 & 0.19 & 8.33 & 0.83 & 0.04 & 0.00 & 0.01 \\
\hline GOR132_2 & GOR128-G & 29/06/15 & 45.30 & 0.32 & 10.80 & 22.05 & 10.17 & 0.20 & 8.49 & 0.85 & 0.01 & 0.07 & 0.00 \\
\hline GOR132_3 & GOR128-G & 29/06/15 & 45.38 & 0.27 & 10.91 & 22.39 & 10.05 & 0.11 & 8.39 & 0.75 & 0.05 & 0.02 & 0.02 \\
\hline GOR132_4 & GOR128-G & 29/06/15 & 45.58 & 0.32 & 10.86 & 22.21 & 10.40 & 0.11 & 8.46 & 0.86 & 0.00 & 0.06 & 0.02 \\
\hline GOR132_5 & GOR128-G & 29/06/15 & 45.21 & 0.34 & 10.77 & 22.18 & 10.29 & 0.18 & 8.43 & 0.72 & 0.04 & 0.05 & 0.01 \\
\hline GOR132_10 & GOR128-G & $29 / 06 / 15$ & 45.28 & 0.30 & 10.99 & 22.32 & 10.33 & 0.20 & 8.53 & 0.88 & 0.02 & 0.05 & 0.02 \\
\hline GOR132-G_7 & GOR128-G & $30 / 06 / 15$ & 45.58 & 0.35 & 10.83 & 22.23 & 10.10 & 0.19 & 8.31 & 0.74 & 0.03 & 0.04 & 0.04 \\
\hline GOR132-G_8 & GOR128-G & $30 / 06 / 15$ & 45.18 & 0.29 & 10.72 & 22.21 & 10.56 & 0.13 & 8.48 & 0.86 & 0.02 & 0.00 & 0.00 \\
\hline GOR132-G_9 & GOR128-G & $30 / 06 / 15$ & 45.49 & 0.27 & 10.85 & 22.38 & 10.41 & 0.10 & 8.44 & 0.72 & 0.05 & 0.01 & 0.02 \\
\hline GOR132-G_10 & GOR128-G & $30 / 06 / 15$ & 45.74 & 0.24 & 10.78 & 22.31 & 10.20 & 0.20 & 8.50 & 0.74 & 0.04 & 0.07 & 0.00 \\
\hline GOR132-G_6 & GOR128-G & $30 / 06 / 15$ & 45.28 & 0.25 & 10.87 & 22.11 & 10.47 & 0.13 & 8.35 & 0.79 & 0.03 & 0.04 & 0.00 \\
\hline GOR132-G_3 & GOR128-G & $30 / 06 / 15$ & 45.38 & 0.30 & 10.79 & 22.41 & 10.38 & 0.21 & 8.32 & 0.75 & 0.02 & 0.02 & 0.00 \\
\hline GOR132-G_2 & GOR128-G & $30 / 06 / 15$ & 45.40 & 0.34 & 10.77 & 22.27 & 10.62 & 0.16 & 8.40 & 0.72 & 0.03 & 0.02 & 0.00 \\
\hline GOR132-G_4 & GOR128-G & $30 / 06 / 15$ & 45.58 & 0.33 & 10.83 & 22.26 & 10.67 & 0.13 & 8.48 & 0.77 & 0.04 & 0.08 & 0.01 \\
\hline GOR132-G_5 & GOR128-G & $30 / 06 / 15$ & 45.54 & 0.30 & 10.84 & 22.18 & 10.29 & 0.16 & 8.70 & 0.79 & 0.04 & 0.03 & 0.00 \\
\hline GOR132-G_1 & GOR128-G & $03 / 07 / 15$ & 44.98 & 0.31 & 10.92 & 22.46 & 10.35 & 0.23 & 8.51 & 0.84 & 0.04 & 0.07 & 0.00 \\
\hline GOR132-G_2 & GOR128-G & $03 / 07 / 15$ & 45.07 & 0.33 & 10.84 & 22.31 & 9.99 & 0.11 & 8.61 & 0.83 & 0.04 & 0.05 & 0.02 \\
\hline GOR132-G_3 & GOR128-G & $03 / 07 / 15$ & 45.26 & 0.37 & 10.99 & 22.23 & 10.37 & 0.05 & 8.62 & 0.80 & 0.04 & 0.04 & 0.01 \\
\hline GOR132-G_4 & GOR128-G & $03 / 07 / 15$ & 45.15 & 0.24 & 11.04 & 22.35 & 9.93 & 0.09 & 8.43 & 0.76 & 0.01 & 0.04 & 0.01 \\
\hline GOR132-G_5 & GOR128-G & $03 / 07 / 15$ & 45.81 & 0.27 & 11.11 & 22.47 & 10.32 & 0.16 & 8.36 & 0.76 & 0.04 & 0.05 & 0.00 \\
\hline GOR132-G_6 & GOR128-G & 03/07/15 & 45.72 & 0.28 & 10.89 & 22.32 & 10.00 & 0.10 & 8.49 & 0.76 & 0.04 & 0.00 & 0.00 \\
\hline & & Average & 45.81 & 0.29 & 10.40 & 24.16 & 9.99 & 0.17 & 7.18 & 0.66 & 0.03 & 0.03 & 0.01 \\
\hline & & & 1.00 & 0.07 & 0.85 & 3.36 & 0.70 & 0.10 & 2.25 & 0.26 & 0.03 & 0.04 & 0.03 \\
\hline & & GeoReM & 45.39 & 0.30 & 10.87 & 22.27 & 10.30 & 0.15 & 8.45 & 0.79 & 0.03 & 0.04 & 0.01 \\
\hline ML3B-G_1 & ML3B-G & $26 / 08 / 14$ & 51.54 & 2.12 & 13.86 & 6.57 & 11.10 & 0.19 & 10.33 & 2.26 & 0.39 & 0.22 & \\
\hline ML3B-G_2 & ML3B-G & $26 / 08 / 14$ & 51.69 & 2.10 & 13.81 & 6.55 & 10.76 & 0.23 & 10.56 & 2.09 & 0.36 & 0.27 & \\
\hline ML3B-G_3 & ML3B-G & $26 / 08 / 14$ & 51.84 & 2.04 & 13.89 & 6.60 & 11.22 & 0.20 & 10.26 & 2.35 & 0.38 & 0.25 & \\
\hline ML3B-G_4 & ML3B-G & $26 / 08 / 14$ & 51.90 & 2.02 & 13.84 & 6.49 & 10.84 & 0.18 & 10.32 & 2.37 & 0.38 & 0.20 & \\
\hline ML3B-G_1 & ML3B-G & $27 / 08 / 14$ & 51.76 & 2.14 & 13.87 & 6.51 & 11.39 & 0.25 & 10.44 & 2.41 & 0.39 & 0.22 & \\
\hline ML3B-G_2 & ML3B-G & $27 / 08 / 14$ & 52.12 & 2.08 & 13.75 & 6.37 & 10.86 & 0.20 & 10.52 & 2.42 & 0.39 & 0.24 & \\
\hline ML3B-G_4 & ML3B-G & $27 / 08 / 14$ & 51.93 & 2.13 & 13.93 & 6.51 & 11.34 & 0.20 & 10.60 & 2.42 & 0.33 & 0.21 & \\
\hline ML3B-G_3 & ML3B-G & $27 / 08 / 14$ & 51.94 & 2.13 & 13.55 & 6.55 & 11.02 & 0.22 & 10.50 & 2.23 & 0.41 & 0.25 & \\
\hline ML3B-G_6 & ML3B-G & $27 / 08 / 14$ & 52.01 & 2.17 & 13.74 & 6.44 & 10.97 & 0.17 & 10.44 & 2.37 & 0.39 & 0.23 & \\
\hline ML3B-G_5 & ML3B-G & $27 / 08 / 14$ & 51.57 & 2.18 & 13.79 & 6.36 & 10.77 & 0.19 & 10.47 & 2.34 & 0.39 & 0.23 & \\
\hline ML3B-G_1 & ML3B-G & $28 / 08 / 14$ & 52.06 & 2.11 & 13.46 & 6.70 & 11.33 & 0.21 & 10.46 & 2.15 & 0.39 & 0.24 & \\
\hline ML3B-G_2 & ML3B-G & $28 / 08 / 14$ & 52.18 & 2.10 & 13.71 & 6.55 & 11.00 & 0.21 & 10.36 & 2.41 & 0.38 & 0.26 & \\
\hline & & & & & & & & & & & Cont & $d$ on 1 & \\
\hline
\end{tabular}




\begin{tabular}{|c|c|c|c|c|c|c|c|c|c|c|c|c|c|}
\hline Label & $\begin{array}{l}\text { MPI- } \\
\text { DING } \\
\text { glass }\end{array}$ & $\begin{array}{l}\text { Analysis } \\
\text { date }\end{array}$ & $\mathrm{SiO}_{2}$ & $\mathrm{TiO}_{2}$ & $\overline{\mathbf{A l}_{2} \mathbf{O}_{3}}$ & MgO & $\mathrm{FeO}^{T}$ & MnO & $\mathrm{CaO}$ & $\mathrm{Na}_{2} \mathrm{O}$ & $\mathbf{K}_{2} \mathbf{O}$ & $\mathbf{P}_{2} \mathbf{O}_{5}$ & Cl \\
\hline ML3B-G_3 & ML3B-G & $28 / 08 / 14$ & 51.46 & 2.18 & 13.64 & 6.62 & 11.41 & 0.19 & 10.63 & 2.45 & 0.45 & 0.25 & \\
\hline ML3B-G_4 & ML3B-G & $28 / 08 / 14$ & 52.06 & 2.06 & 13.62 & 6.57 & 10.81 & 0.16 & 10.51 & 2.17 & 0.40 & 0.24 & \\
\hline ML3B-G_5 & ML3B-G & $28 / 08 / 14$ & 52.04 & 2.14 & 13.62 & 6.56 & 10.93 & 0.16 & 10.60 & 2.52 & 0.39 & 0.26 & \\
\hline \multirow[t]{4}{*}{ ML3B-G_6 } & ML3B-G & $28 / 08 / 14$ & 51.77 & 2.08 & 13.67 & 6.53 & 11.53 & 0.23 & 10.64 & 2.31 & 0.39 & 0.24 & \\
\hline & & Average & 51.87 & 2.11 & 13.74 & 6.53 & 11.08 & 0.20 & 10.48 & 2.33 & 0.39 & 0.24 & \\
\hline & & & 0.44 & 0.09 & 0.27 & 0.17 & 0.51 & 0.05 & 0.23 & 0.24 & 0.05 & 0.04 & \\
\hline & & GeoReM & 51.87 & 2.11 & 13.74 & 6.53 & 11.08 & 0.20 & 10.48 & 2.33 & 0.39 & 0.24 & \\
\hline
\end{tabular}

\subsection{EPMA lower limits of detection}

Lower limits of detection (LLD) for EPMA analyses are given in the Table below. The LLD is defined as the concentration at which an element is detected above the instrument back ground noise (Perkins and Pearce, 1995), and is calculated using Equation 1. These limits of detection are calculated from repeat analyses of three different MPI-DING glass standards, analysed during each analytical session. The median limit of detection for ATHO-G over all analytical sessions is given, this has the most similar composition to samples analysed in this study.

$$
L L D=3 \times \sigma \text { of gas blanks } \times(\text { concentrations } / \text { avg. sample cps })
$$

where cps is counts per second

EPMA lower limits of detection, concentrations are in wt. \%

\begin{tabular}{lllllllllllll}
\hline Analysis date & MPI-DING glass & $\mathbf{S i O}_{2}$ & $\mathbf{T i O}_{2}$ & $\mathbf{A l}_{2} \mathbf{O}_{3}$ & $\mathbf{M g O}$ & $\mathbf{F e O}$ & $\mathbf{M n O}$ & $\mathbf{C a O}$ & $\mathbf{N a}_{2} \mathbf{O}$ & $\mathbf{K}_{2} \mathbf{O}$ & $\mathbf{P}_{2} \mathbf{O}_{5}$ & $\mathbf{C l}$ \\
& & & & & & & & & & & & \\
& ATHO-G & 0.06 & 0.02 & 0.04 & 0.02 & 0.07 & 0.02 & 0.03 & 0.05 & 0.04 & 0.10 & 0.02 \\
$20 / 02 / 14$ & GOR 128-G & 0.06 & 0.03 & 0.04 & 0.05 & 0.12 & 0.08 & 0.04 & 0.09 & 0.02 & 0.04 & 0.15 \\
$20 / 02 / 14$ & StHs6/80-G & 0.03 & 0.04 & 0.04 & 0.04 & 0.10 & 0.07 & 0.02 & 0.06 & 0.04 & 0.04 & 0.02 \\
$21 / 02 / 14$ & ATHO-G & 0.07 & 0.05 & 0.03 & 0.03 & 0.08 & 0.10 & 0.04 & 0.07 & 0.03 & 0.04 & 0.02 \\
$21 / 02 / 14$ & GOR 128-G & 0.06 & 0.05 & 0.04 & 0.04 & 0.11 & 0.08 & 0.04 & 0.06 & 0.01 & 0.05 & 1.80 \\
$21 / 02 / 14$ & StHs6/80-G & 0.05 & 0.05 & 0.03 & 0.03 & 0.10 & 0.06 & 0.04 & 0.07 & 0.04 & 0.05 & 0.04 \\
$28 / 08 / 14$ & ATHO-G & 0.05 & 0.05 & 0.03 & 0.04 & 0.09 & 0.08 & 0.03 & 0.07 & 0.03 & 0.12 & \\
$28 / 08 / 14$ & ML3B-G & 0.03 & 0.08 & 0.05 & 0.04 & 0.07 & 0.09 & 0.05 & 0.05 & 0.03 & 0.05 & \\
$28 / 08 / 14$ & StHs6/80-G & 0.04 & 0.04 & 0.04 & 0.04 & 0.08 & 0.05 & 0.01 & 0.07 & 0.02 & 0.05 & \\
$27 / 08 / 14$ & ATHO-G & 0.04 & 0.03 & 0.03 & 0.02 & 0.06 & 0.05 & 0.05 & 0.06 & 0.03 & 0.08 & \\
$27 / 08 / 14$ & ML3B-G & 0.05 & 0.02 & 0.02 & 0.02 & 0.14 & 0.09 & 0.04 & 0.07 & 0.05 & 0.05 & \\
$27 / 08 / 14$ & StHs6/80-G & 0.03 & 0.06 & 0.03 & 0.06 & 0.08 & 0.10 & 0.02 & 0.03 & 0.03 & 0.05 & \\
$26 / 08 / 14$ & ATHO-G & 0.03 & 0.04 & 0.04 & 0.03 & 0.04 & 0.04 & 0.03 & 0.01 & 0.03 & 0.01 & \\
$26 / 08 / 14$ & ML3B-G & 0.04 & 0.06 & 0.03 & 0.04 & 0.15 & 0.08 & 0.04 & 0.07 & 0.03 & 0.06 & \\
$26 / 08 / 14$ & StHs6/80-G & 0.06 & 0.03 & 0.04 & 0.01 & 0.13 & 0.05 & 0.03 & 0.04 & 0.02 & 0.05 & \\
$29 / 06 / 15$ & ATHO-G & 0.10 & 0.06 & 0.09 & 0.03 & 0.08 & 0.06 & 0.03 & 0.11 & 0.02 & 0.24 & 0.02 \\
$29 / 06 / 15$ & GOR 128-G & 0.09 & 0.05 & 0.06 & 0.10 & 0.03 & 0.08 & 0.04 & 0.07 & 0.04 & 0.05 & 0.02 \\
$29 / 06 / 15$ & StHs6/80-G & 0.12 & 0.05 & 0.06 & 0.11 & 0.09 & 0.12 & 0.02 & 0.14 & 0.03 & 0.04 & 0.02 \\
30/06/15 & ATHO-G & 0.15 & 0.05 & 0.10 & 0.06 & 0.07 & 0.07 & 0.05 & 0.20 & 0.03 & 0.18 & 0.03 \\
& & & & & & & & & & & Continued on next page \\
\hline
\end{tabular}


EPMA lower limits of detection, concentrations are in wt. \%

\begin{tabular}{lllllllllllllll}
\multicolumn{10}{c}{ EPMA lower limits of detection, concentrations are in wt. \% } \\
\hline Analysis date & MPI-DING glass & $\mathbf{S i O}_{2}$ & $\mathbf{T i O}_{2}$ & $\mathbf{A l}_{2} \mathbf{O}_{3}$ & $\mathbf{M g O}$ & $\mathbf{F e O}$ & $\mathbf{M n O}$ & $\mathbf{C a O}$ & $\mathbf{N a}_{2} \mathbf{O}$ & $\mathbf{K}_{2} \mathbf{O}$ & $\mathbf{P}_{2} \mathbf{O}_{5}$ & $\mathbf{C l}$ \\
& & & & & & & & & & & & & & \\
\hline $30 / 06 / 15$ & GOR 128-G & 0.15 & 0.05 & 0.07 & 0.09 & 0.10 & 0.05 & 0.03 & 0.11 & 0.01 & 0.09 & 0.02 \\
$30 / 06 / 15$ & StHs6/80-G & 0.09 & 0.03 & 0.09 & 0.02 & 0.09 & 0.05 & 0.03 & 0.14 & 0.03 & 0.10 & 0.02 \\
$03 / 07 / 15$ & ATHO-G & 0.13 & 0.08 & 0.05 & 0.06 & 0.15 & 0.13 & 0.04 & 0.05 & 0.03 & 0.03 & 0.03 \\
$03 / 07 / 15$ & GOR 128-G & 0.15 & 0.06 & 0.07 & 0.09 & 0.05 & 0.11 & 0.02 & 0.09 & 0.02 & 0.07 & 0.05 \\
$03 / 07 / 15$ & StHs6/80-G & 0.17 & 0.01 & 0.09 & 0.07 & 0.12 & 0.11 & 0.03 & 0.14 & 0.03 & 0.20 & 0.03 \\
& & & & & & & & & & & & & & \\
& Median ATHO-G & 0.08 & 0.05 & 0.05 & 0.04 & 0.08 & 0.07 & 0.04 & 0.08 & 0.03 & 0.10 & 0.02 \\
\hline
\end{tabular}

\section{.7.3 LA-ICP-MS reference materials}

During each LA-ICP-MS analytical run, the MPI-DING reference material, ATHO-G, was analysed five times using a $20 \mu \mathrm{m}$ crater diameter to check the calibration. These analyses are given below and are ordered according to analysis date. The average and $2 \sigma$ of these analyses are given alongside published trace element concentrations from the GeoReM online database (Jochum et al., 2005). 


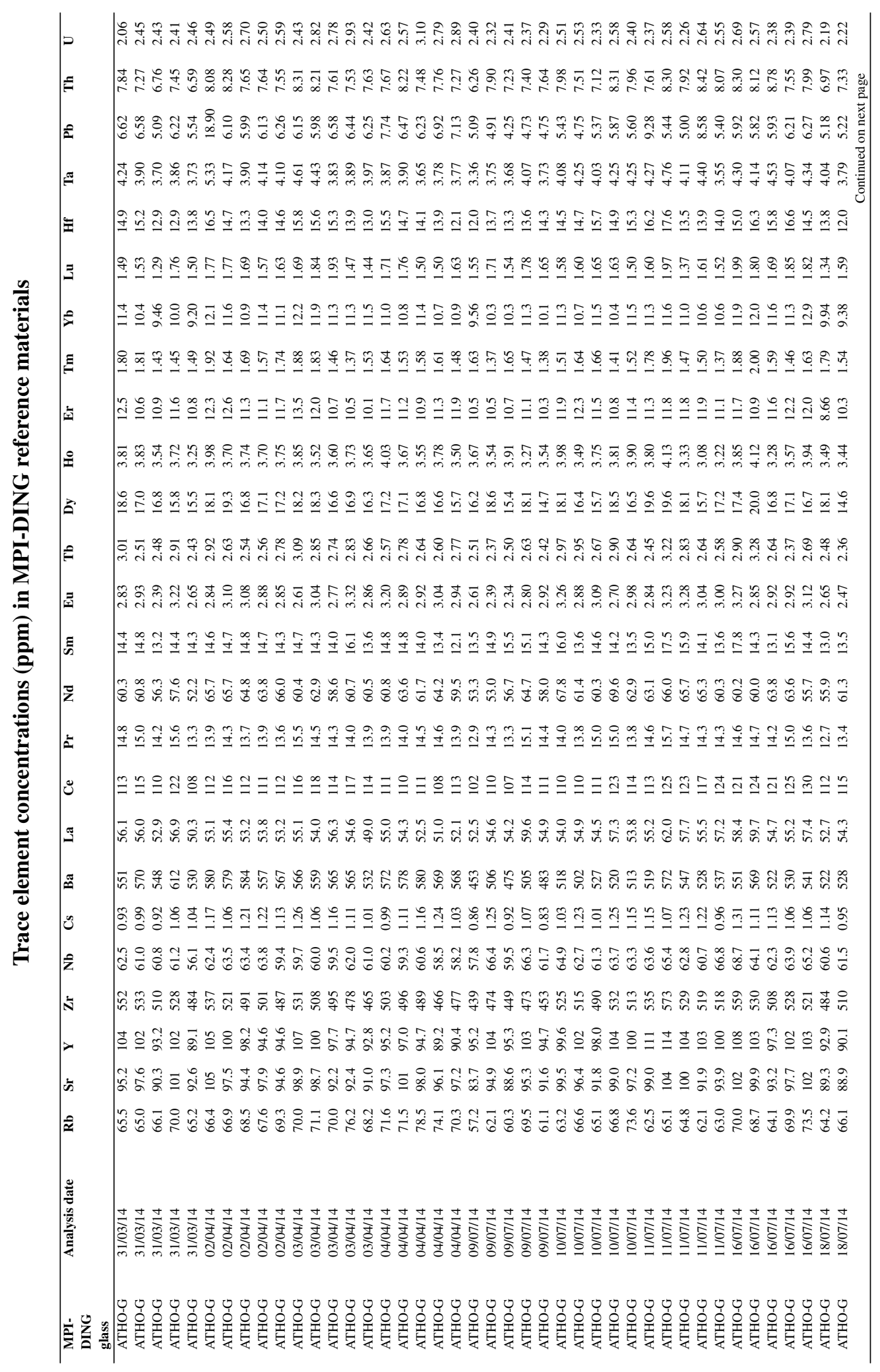




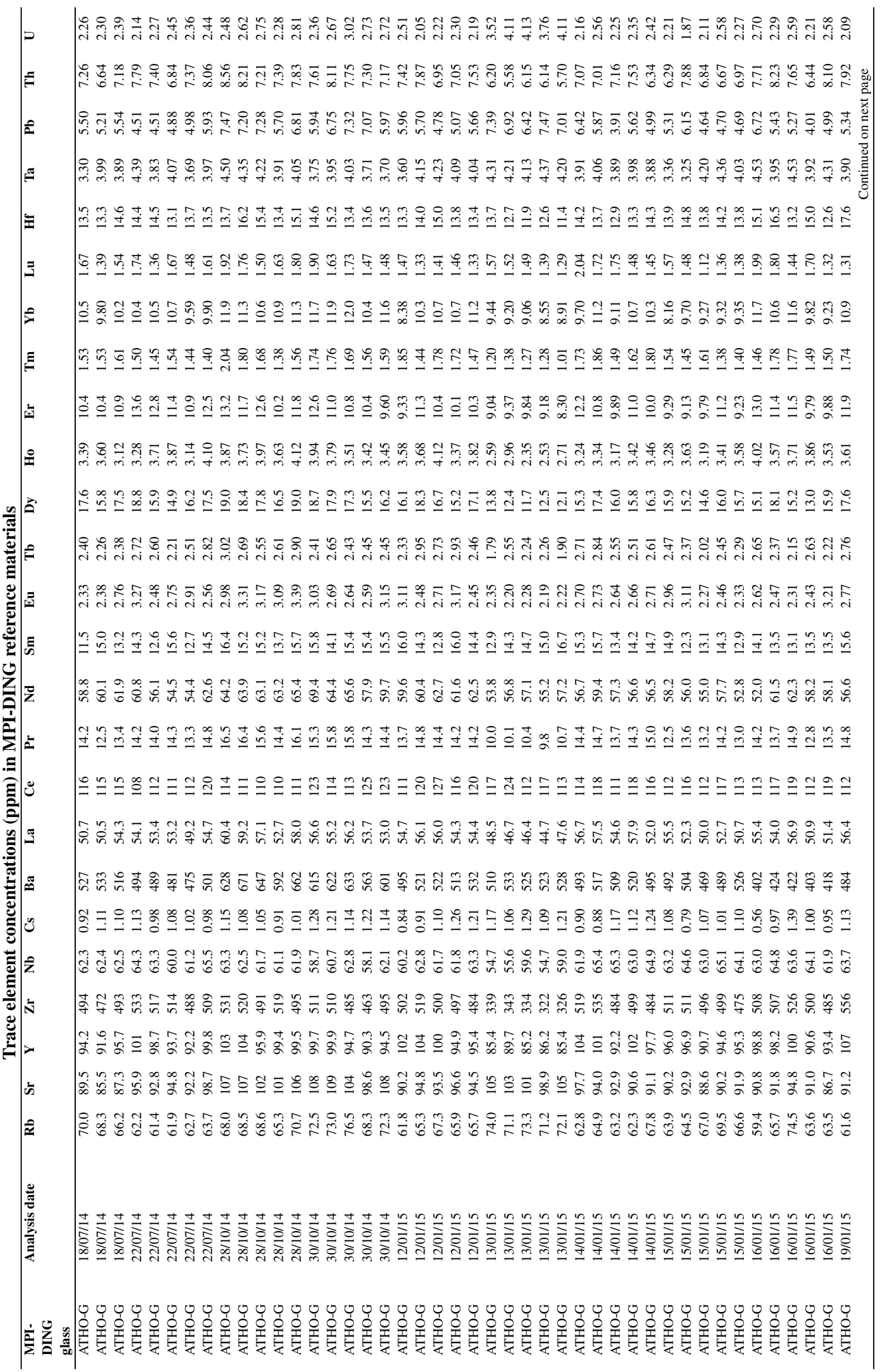




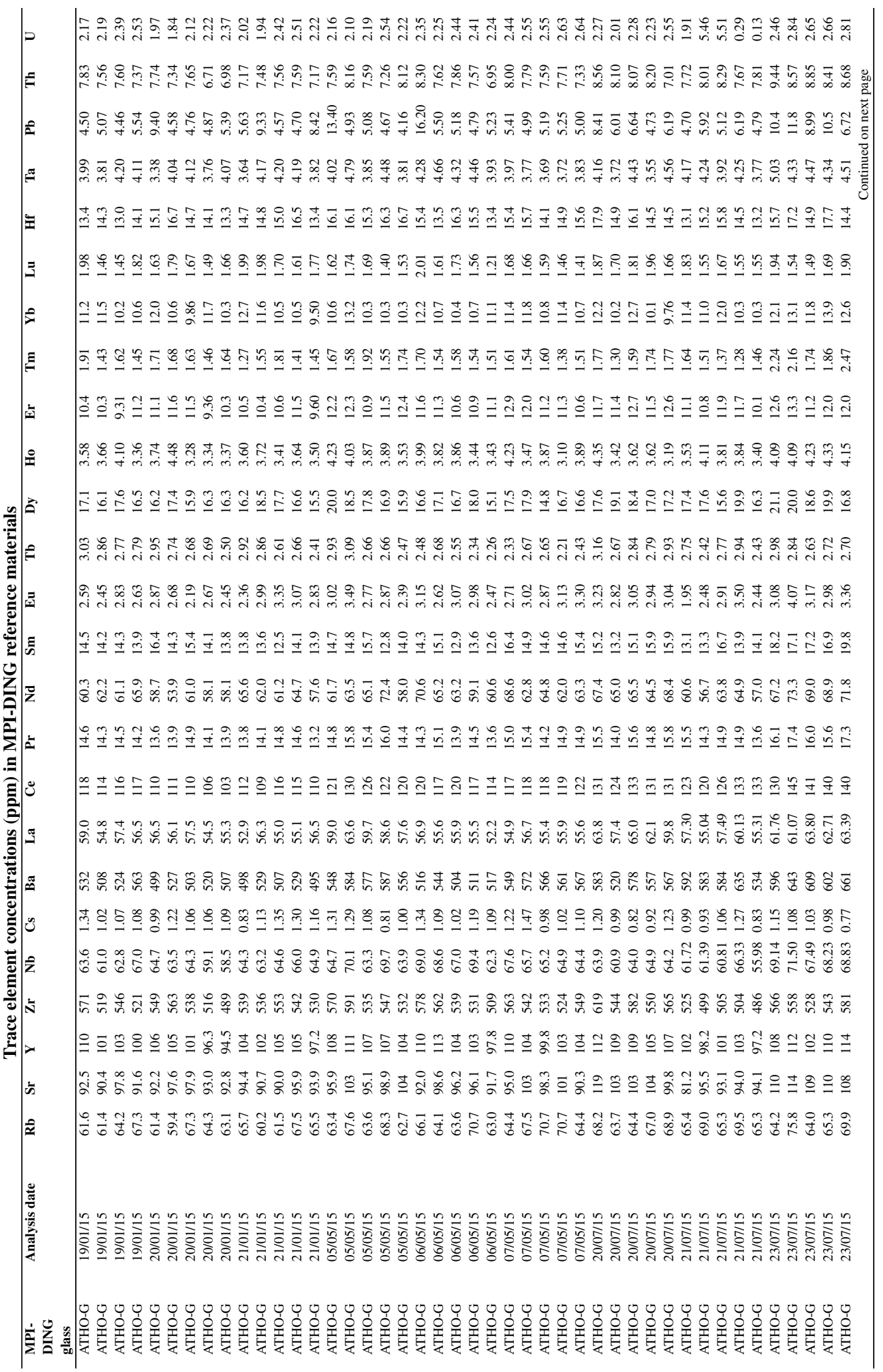




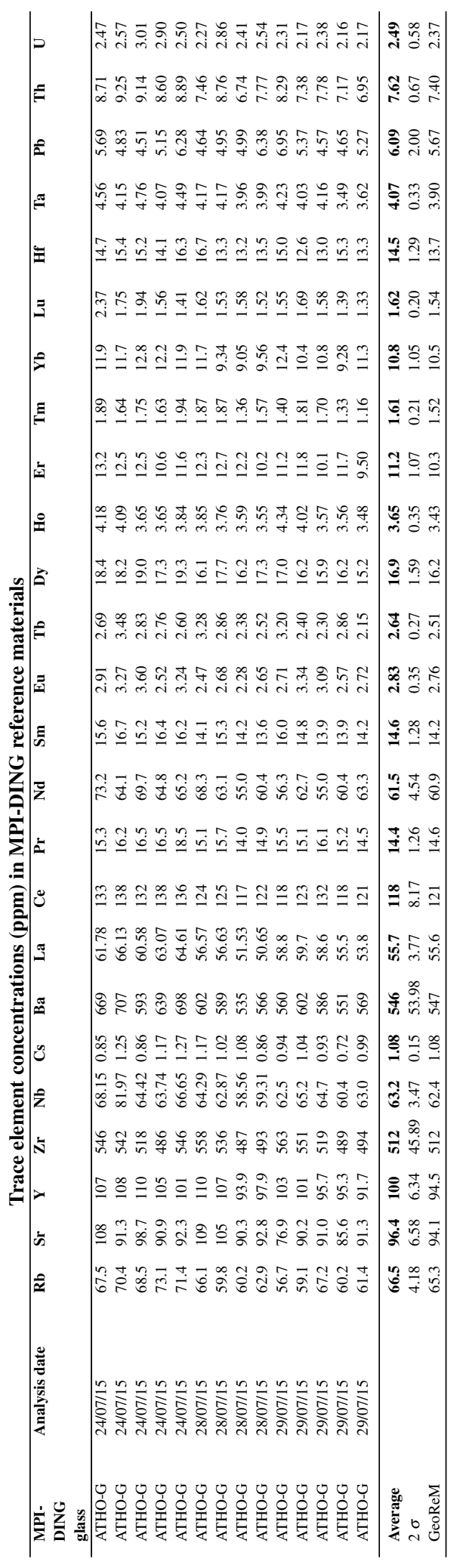




\subsection{LA-ICP-MS lower limits of detection}

Lower limits of detection (LLD) for all LA-ICP-MS analytical sessions are given in the following table.

Limits of detection are low for most analytes, particularly using $20 \mu \mathrm{m}$ crater diameters. Using $10 \mu \mathrm{m}$ crater diameters, the ${ }^{29} \mathrm{Si}$ signal to background ratio decreases, causing LLD concentrations to increase. Glass shards analysed in this study are highly evolved, containing incompatible elements typically exceeding these limits of detections when using $20 \mu \mathrm{m}$ diameter craters. Limits of detection are sensitive to instrumental variations, associated with tuning and gas blanks (Pearce et al., 2011). Background counts for $\mathrm{Sr}, \mathrm{Rb}, \mathrm{Cs}$ and $\mathrm{Ba}$ increase over time, due to their 'sticky' nature causing them to adhere to the glassware and interface cones of the ICP-MS (Pearce et al., 2011). This behaviour, coupled with low Sr concentrations in these fractionated glass compositions, causes their higher LLD concentrations. Barium was found to be useful for discrimminating the Tilo tephras, however, concentrations in the glass shards fall well above the LLD for this analyte. 


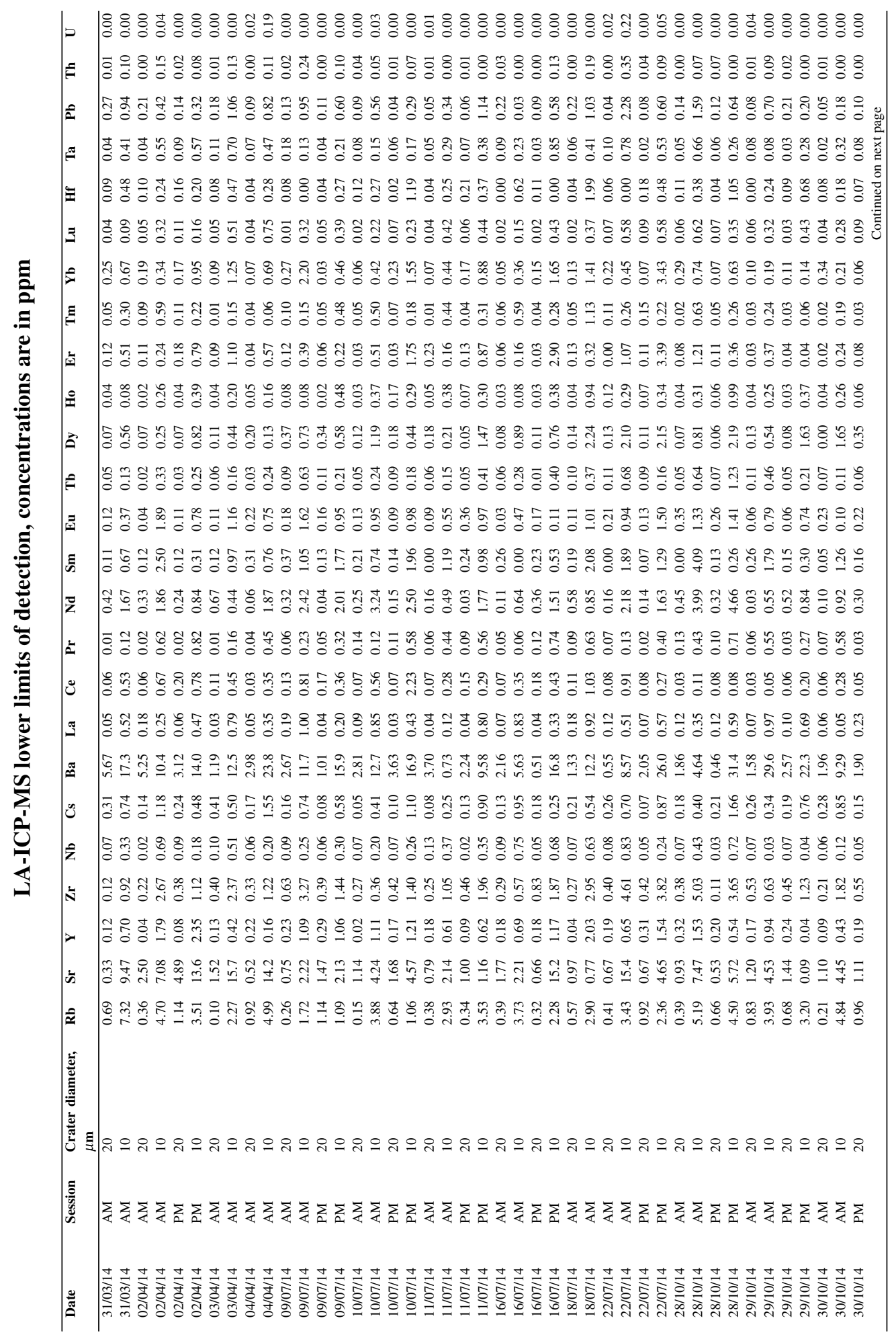




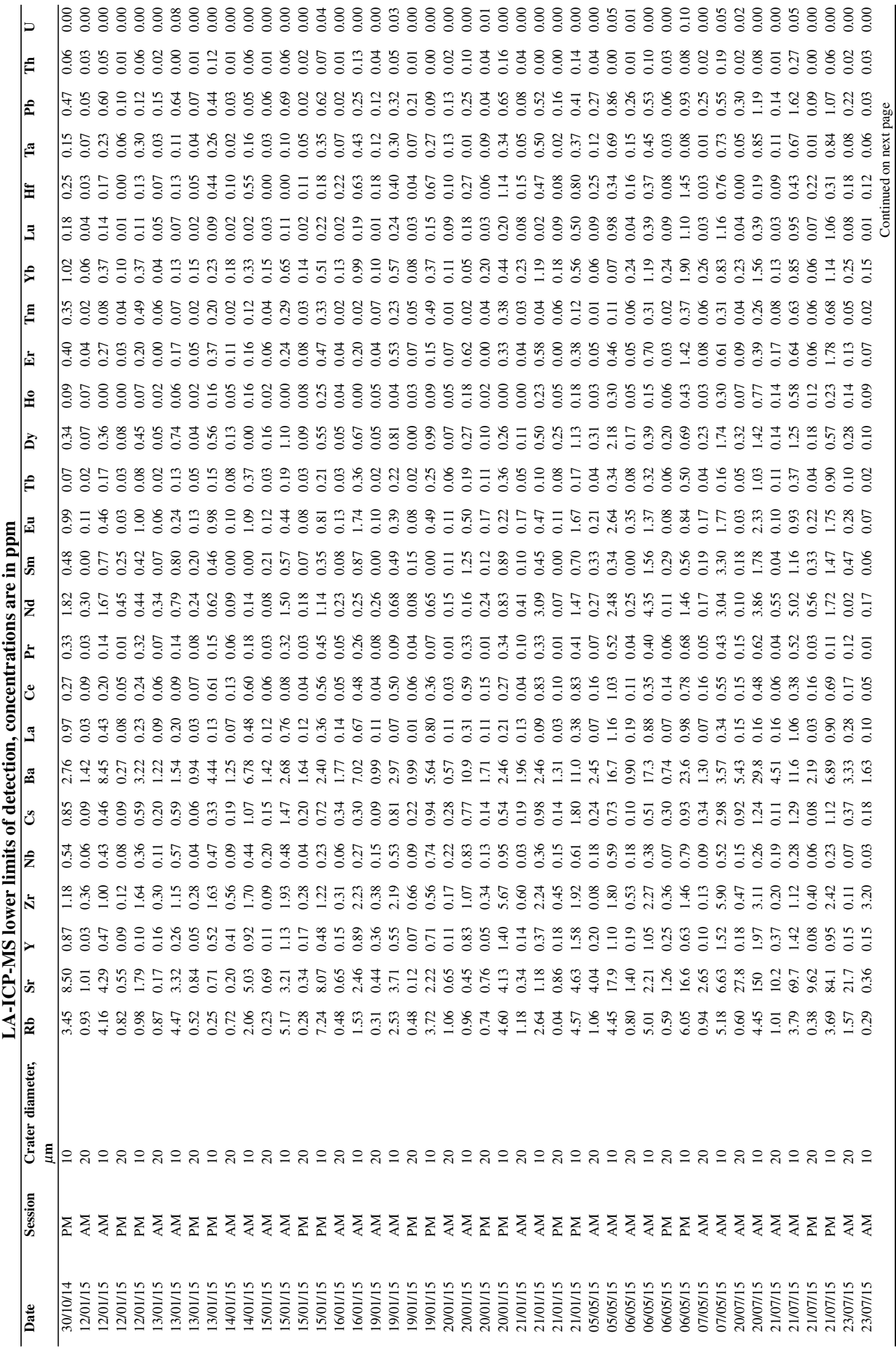




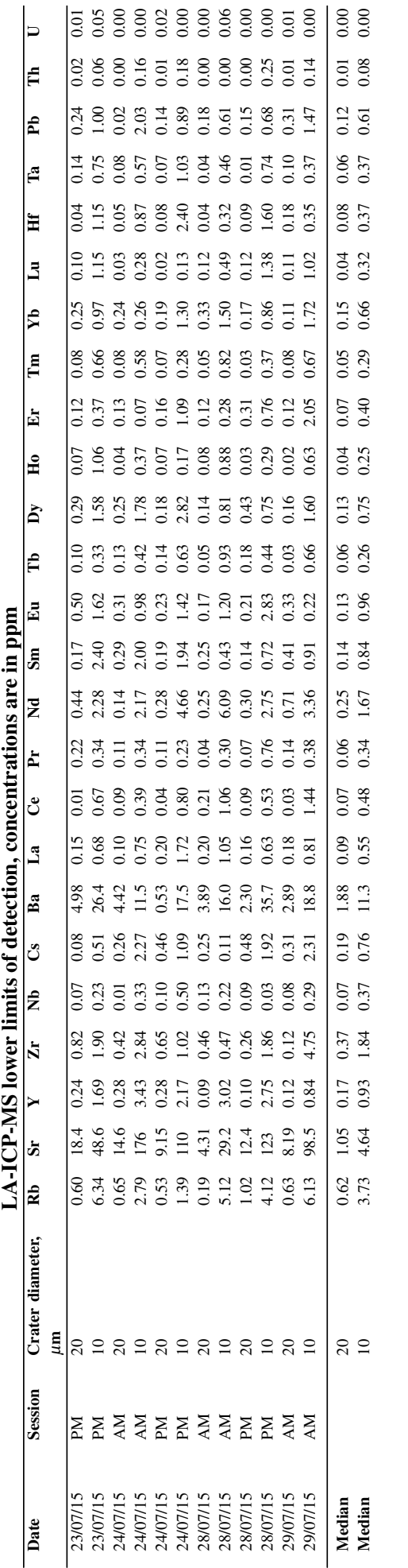




\section{.8 Calculations}

\subsection{Calculation of Q Ab Or normative positions in the Hap- logranite System}

Equations 2 to 4, from Blundy and Cashman (2001), were used to calculate the quartz, albite and orthoclase normative positions of rhyolitic tephras. These calculations compensate for the effect of anorthite, which displaces the quartzfeldspar cotectic to higher quartz contents. None of the samples contained normative kalisiite, or normative leucite, but if they had these would have to be included in the calculation for Ks'. The new normative positions could then be plotted on the haplogranite (Q-Ab-Or) system.

$$
\begin{gathered}
Q z^{\prime}=Q z_{n} \times\left(1-0.03 A n+6 \times 10^{-5}\left[O r_{n} \times A n\right]+10^{-5}\left[A b_{n} \times O r_{n} \times A n\right]\right. \\
O r^{\prime}=O r_{n} \times\left(1-0.07 A n+10^{-3}\left[Q z_{n} \times A_{n}\right]\right) \\
A b^{\prime}=100-Q z^{\prime}-O r^{\prime}
\end{gathered}
$$

where $Q z^{\prime}$ is the position of quartz on the haplogranite system, and $Q z_{n}$ is normative quartz normalised to an anorthite free basis. 


\subsection{Calculation of $Q$ Ne Ks normative positions in Petrogeny's Residua Sytem}

The CIPW norms of quartz, nepheline and kalsilite in trachytic-phonolitic tephras were recast to an an alkali feldspar free basis (i.e. converting alkali feldspar end-members to their equivalent contents of $\mathrm{Ne}, \mathrm{Ks}$ and Q) using Equations 5 to 7. These normative positions could then be plotted on Petrogeny's Residua System.

$$
\begin{gathered}
Q z^{\prime}=Q+O r \times\left(\left[4 \times Q_{m w}\right] /\left[2 \times O r_{m w}\right]\right)+A b \times\left(\left[4 \times Q_{m w}\right] /\left[2 \times A b_{m w}\right]\right) \\
N e^{\prime}=A b \times\left(\left[2 \times N e_{m w}\right] /\left[2 \times A b_{m w}\right]\right)+N e \\
K s^{\prime}=O r \times\left(\left[2 \times K s_{m w}\right] /\left[2 \times O r_{m w}\right]\right)
\end{gathered}
$$

where $Q_{m w}$ is the molecular weight of quartz. 
